
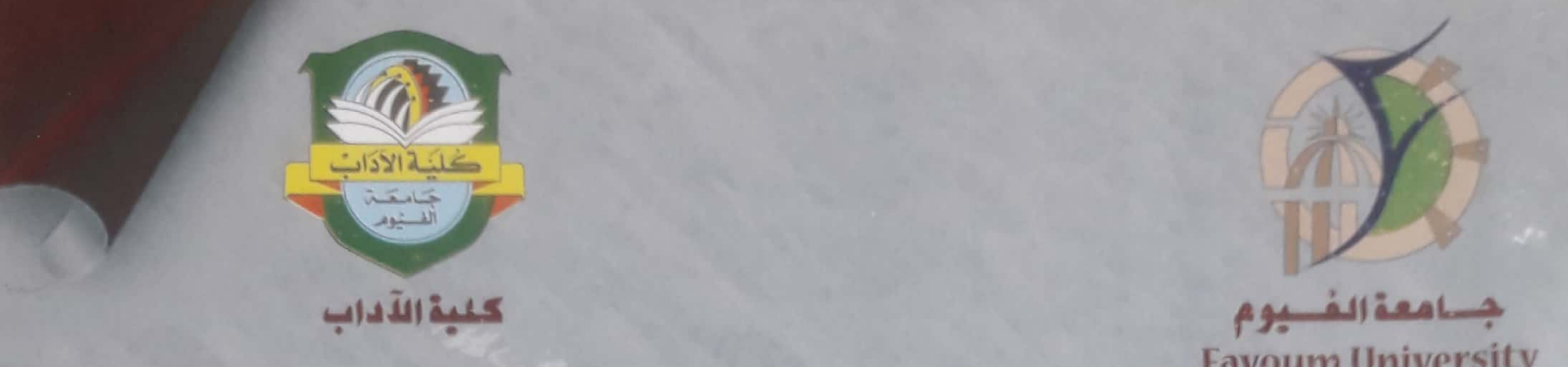

A

Fayoum University
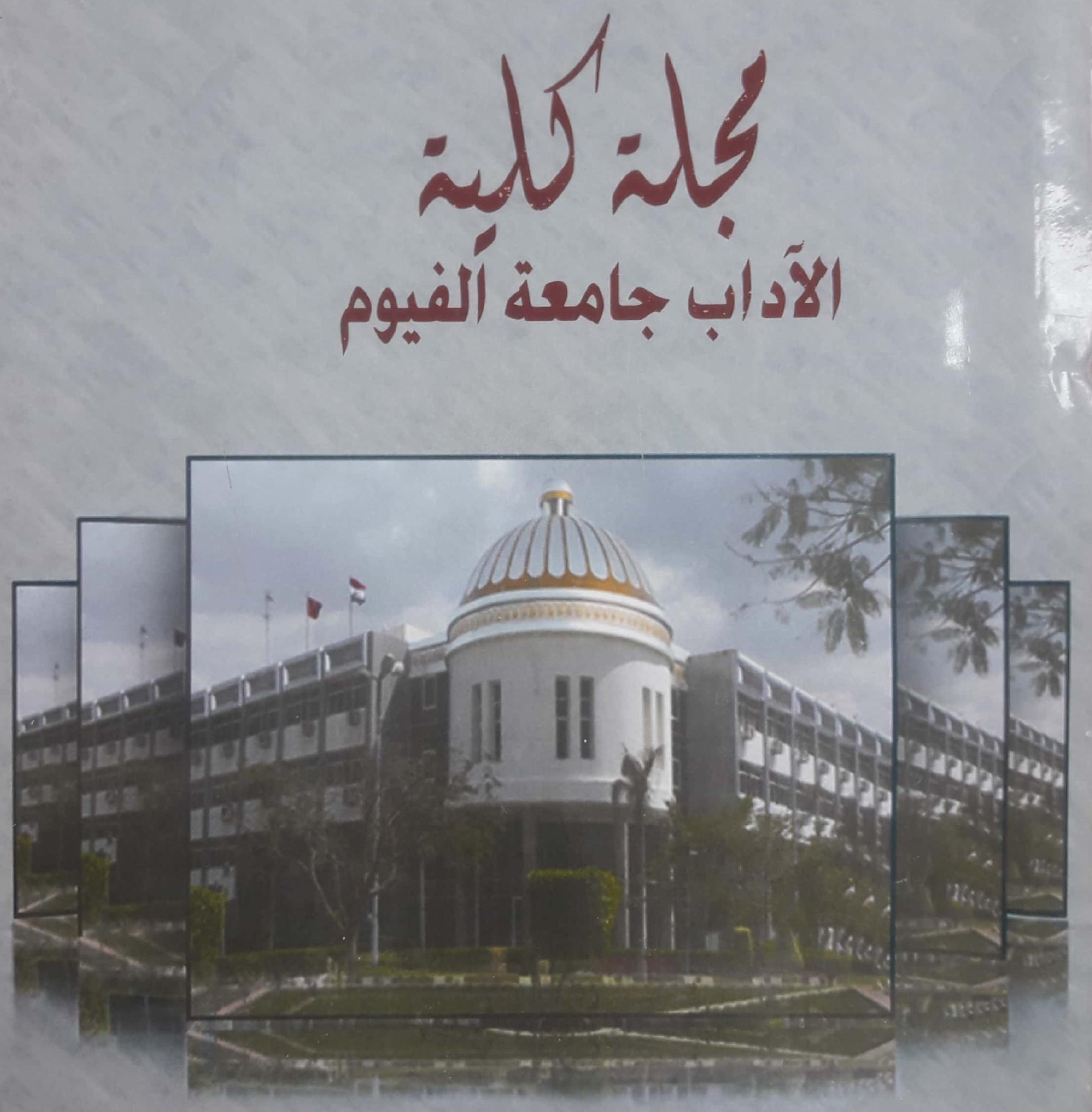

Scanned by CamScanner 
مجلة كلية الآداب. جامعة الفيوم

دورية علمية نصف سنوية محكمة

رقم الإيداع 2014/18953

الترقيم الدولي 235N-0709 2357

$$
\text { يونيو 2015 - العدد الثاني عشر الأول }
$$




\section{مجلس إدارة الـمجلة}

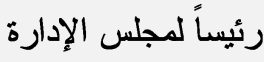

أ.د/ عبد الحميد حسين حمودة (عميد الكلية)

رئيساً للتحرير

أ.د/ مجدي أحمد توفيث (وكيل الكلية لشئون الدراسات العليا)

عضواً

أ.د/ محمد الخزامى عزيز (الأستاذ بقسم الجغرافيا)

عضواً

أ.د/ إبر اهيم محمد صقر (الأستاذ بقسم الفلسفة)

عضواً

أ.د/ حامد أمين شعبان (الأستاذ بقسم اللغة العربية)

عضواً

أ.د/ عادل عبد العزيز (الأستاذ بقسم التاريخ)

عضواً

أ.د/ إيمان محمد صبري (الأستاذ بقسم علم النفس) هـــــة الـتـحريـر

رئيساً لمجلس الإدارة

أ.د/ عبد الحميد حسين حمودة

رئيساً للتحرير

أ.د / مجدي أحمد توفيق

مديراً للتحرير

د/ سيد أحمد محمد الوكيل

محرراً للنص

د/ محمد عيد سعيد

العربي

محرراً للنص

الإنجليزي

سكرثيراً

أر أحمد شمبولية

د/ على عبد التواب

للتحريز 
الهيئة الاستثارية

الرتبة الأكاديمية

أستاذ بقسم الفلسفة كلية الآداب جامعة الفيوم

أستاذ بقسم علم النفس كلية الآداب جامعة الإسكندرية أستاذ بقسم اللغة الفارسية كلية الآداب جامعة الفيوم أستاذ بقسم علم الاجتماع كلية الآداب جامعة الإسكندرية أستاذ بقسم علم الاجتماع كلية الآداب جامعة طنطا أستاذ بقسم علم النفس كلية الآداب جامعة القاهرة أستاذ بقسم علم النفس كلية الآداب جامعة البحرين أستاذ بقسم علم النفس كلية الآداب جامعة الكويت أستاذ بقسم علم الاجتماع كلية الآداب جامعة بنها أستاذ بقسم علم النفس كلية الآداب جامعة القاهرة أستاذ بقسم التاريخ كلية الآداب جامعة الفيوم أستاذ بقسم التاريخ كلية الآداب جامعة الفيوم أستاذ بقسم اللغة العربية كلية الآداب جامعة الفيوم

أستاذ بقسم علم النفس كلية الآداب جامعة بنها أستاذ بقسم علم النفس كلية الآداب جامعة الفيوم أستاذ بقسم الجغر افيا كلية الآداب جامعة الفيوم أستاذ بقسم الجغر افيا كلية الآداب جامعة الفيوم أستاذ بقسم الفلسفة كلية الآداب جامعة الفيوم أستاذ بقسم اللغة الإنجليزية كلية الآداب جامعة القاهرة

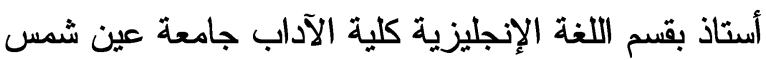
أستاذ بقسم اللغة العربية كلية الآداب جامعة الفيوم أستاذ بقسم علم النفس كلية الآداب جامعة حلوان
الاسم

أد. إبر اهيم محمد صقر

أد/ أحمد محمد عبد الخالق أد/ أحمد محمد بقوش أ.د/ سامية محمد جابر أ.د/ سيد جاب الله السيد أ.د/شعبان جاب الله رضوان أ.دد/ توفيق محمد عبد المنعم أ.د/ بدر سليمان الأنصاري أ.د/ عزة أحمد صيام أ.د// معتز سيد عبد الله. أد/ عبد الحميد حمودة

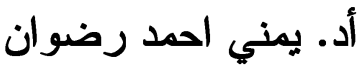
أد/ مجدي أحمد توفيق أ.د/ عادل كمال خضر

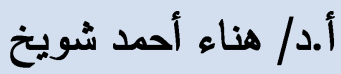

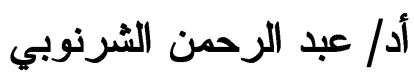
أد. محمد الخز امي عزيز الرحن الدريز أد. صبري عبد الله شُندي أد. محمد محمد عناني أد. مصطفى رياض أد. محمد دياب أ.د/ محمد حسن غانم 
1- مجلة كلية الآداب بجامعة الفيوم دورية علمية محكمة تعني بنشر الأبحاث

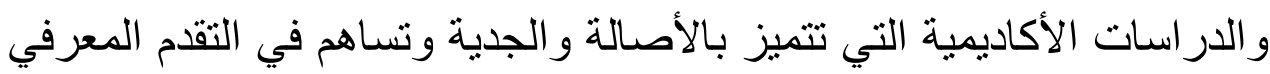

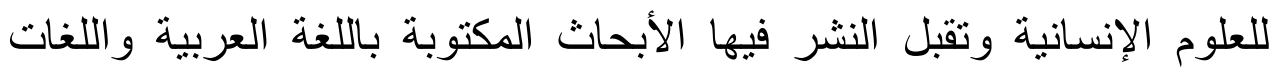
الأخرى شريطة ألا يكون البحث منشورًا من قبل.

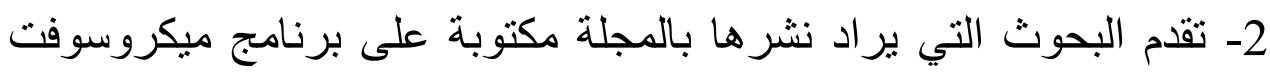

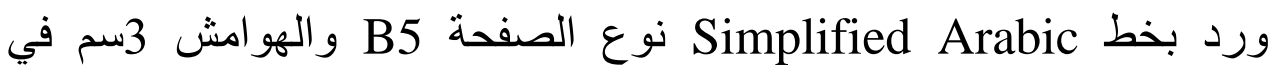
الأربعة جو انب ببنط 14 للمتن و الهو امش بنط 12 و العناوين الجانبية بنط 16.

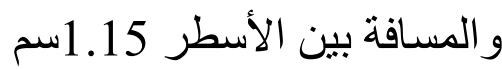
3- في حالة رغبة الباحث نشر الصور أو الخرائط أو الأشكال البيانية ملونة يلتزم دفع تكاليفها. 4- يقدم الباحث إقرارًا كتابيًا ممهورًا بتوقيعه بأن البحث المقدم لم يسبق نشره في أي مجلة علمية أو غير ها.

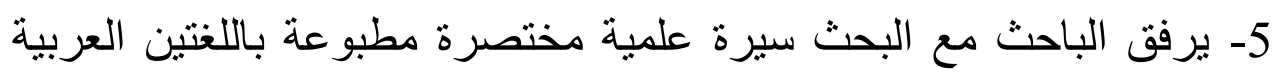
و الإنجليزية تشمل أهم مؤلفاته و أعماله.

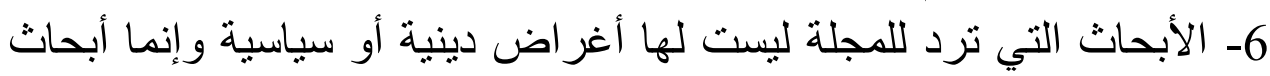

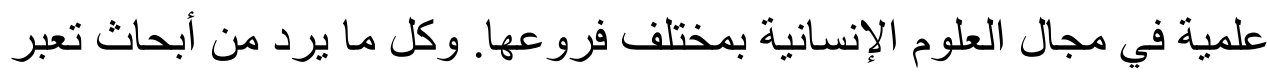
عن وجهة نظر الباحث وتحت مسؤوليتها. 7- يشترط عمل ملخص للبحث باللغة العربية والبه والإنجليزية.

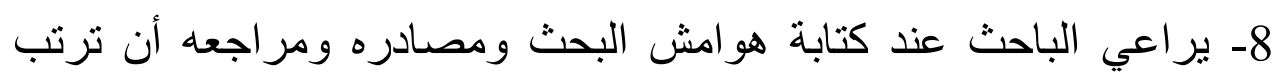

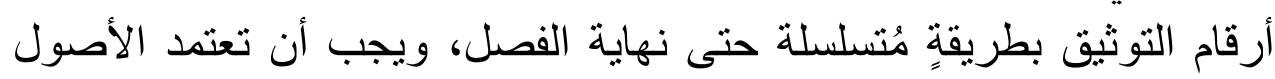
العلمية المتعارفة في التوثيق و الإثـارة. 9- تقدم ثلاث نسخ من البحث إلى الأستاذ الأنداذ الدكتور رئيس التحرير مع سي ي CD

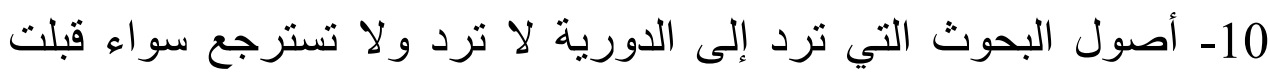
للنشر أو لم تُقبل. 11- يحصل صاحب البحث على 10 مستلات من بحثة بالإضافة إلى نسخة من

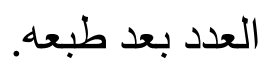


تُرسل البحوث بريدياً على العنوان التالي:

جمهورية مصر العربية، الفيوم، كلية الآداب - جامعة الفيوم، رمز بريدي:

63514

\author{
ت: 0846379326

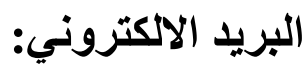 \\ mat03@fayoum.edu.eg \\ sae11@ fayoum.edu.eg
}




\begin{tabular}{|c|c|c|}
\hline الصفحات & الموضوع & \\
\hline $74-1$ & 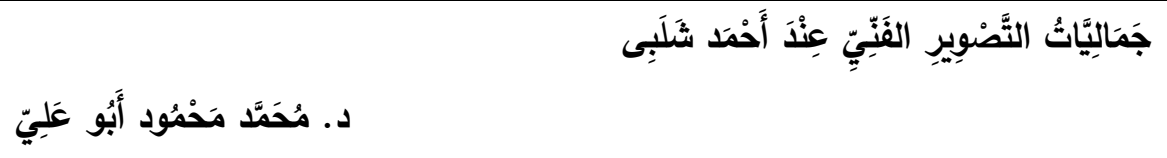 & 1 \\
\hline $111-9 \varepsilon$ & 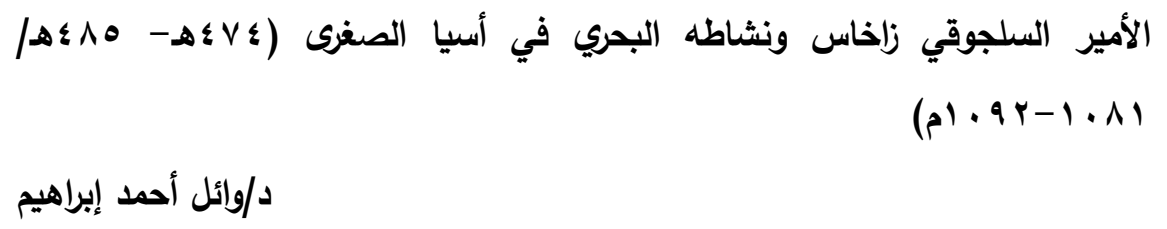 & r \\
\hline $1 r q-11 r$ & 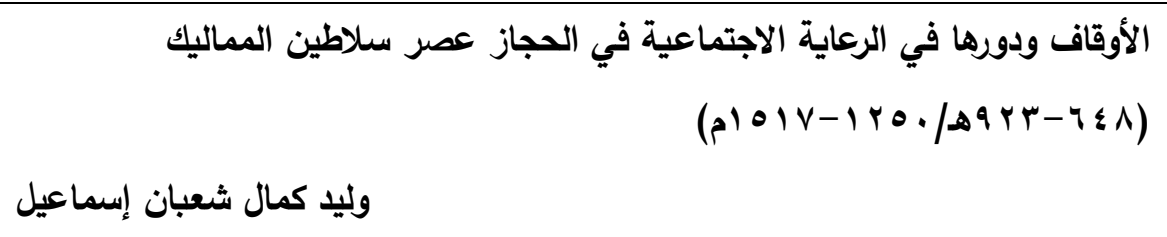 & r \\
\hline$r \cdot q-1 \leq$. & الخريطة المورفولوجية لمنطقة حلايب كأداة أساسية للتنمية في جنوب شرق لمصر. & $\varepsilon$ \\
\hline$r r V-r \cdot V$ & سكوت النبي- صلى الله عليه وسلم- عند الحاجة إلى البيان ودلالته. & ○ \\
\hline$r \otimes \Lambda-Y r \Lambda$ & الماركسية الجديدة ولانهائية التاريخ عند جاك دريدا & 7 \\
\hline$r r r-r \diamond q$ & دور الإعلانات التلفزيونية في نشر الخرافات الطبية & $v$ \\
\hline$r 0 \leq-r r \leq$ & $\begin{array}{l}\text { Clinton's Political Speeches about the Arab Spring } \\
\text { Mai Ashraf Hussein Sayed }\end{array}$ & $\wedge$ \\
\hline$\varepsilon-r \Delta \theta$ & زوراج القاصرات "الأسباب والأثار المترتبة عليه": دراسة حالة بقرية & 9 \\
\hline$\varepsilon Y_{1}-\varepsilon \cdot 1$ & 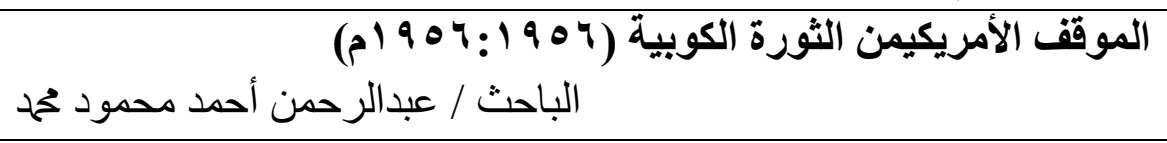 & 1 . \\
\hline$\varepsilon \Delta r-\varepsilon r r$ & موقف بونافنتورا من الميتافيزيقا & 11 \\
\hline $01 \mu-\varepsilon 0 \leqslant$ & 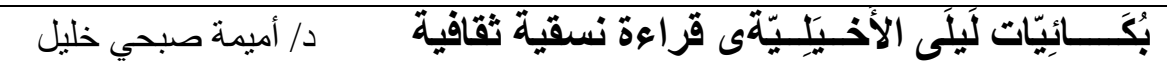 & Ir \\
\hline
\end{tabular}




\begin{tabular}{|c|c|c|}
\hline $0 \curlyvee \wedge-01 \leq$ & تحصين الشباب ضد الفكر الإرهابي ضرورة مقاصدية & ir \\
\hline $7.7-079$ & أنماط الإفادة من مواقع القرآن الكريم كمصدر من مصادر المعلومات & $1 \leqslant$ \\
\hline$\neg r q-q \cdot V$ & 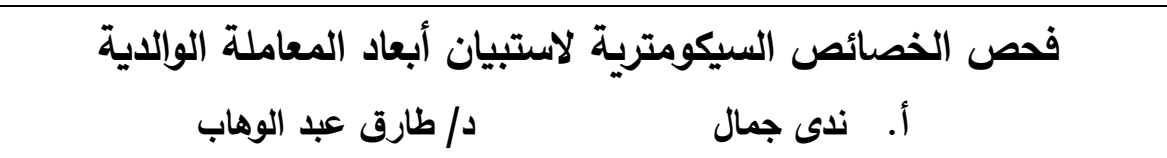 & 10 \\
\hline $7 V I-7 r V$ & 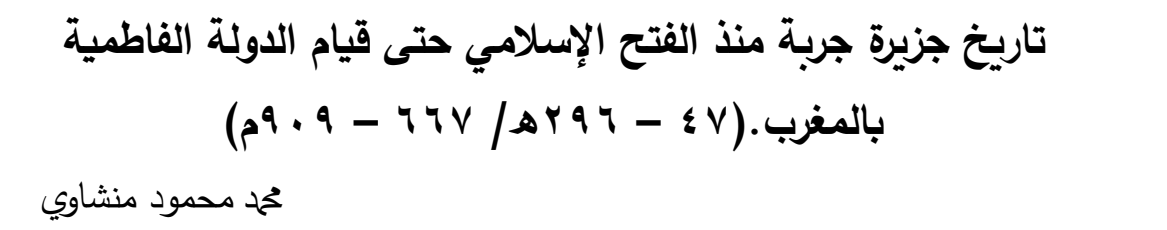 & 17 \\
\hline$\neg \wedge 1-T \vee r$ & 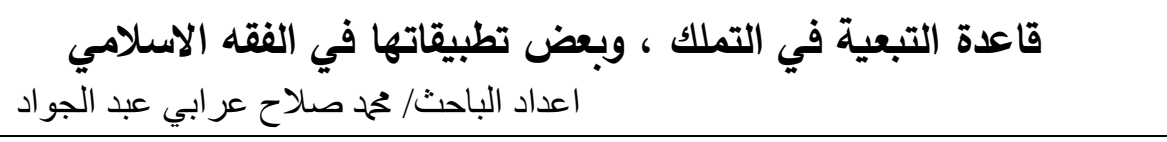 & IV \\
\hline$\vee \cdot q-9 \wedge r$ & " موقف الزمخشري من الاحتجاج بالحديث الثريف اسماء ماهر حسين & 11 \\
\hline$v \leq 1-V_{1}$. & $\begin{array}{l}\text { Im/politeness Strategies in the Story of Moses in the } \\
\text { Holy Quran } \\
\text { Hebat-Allah Mahmoud Zaky }\end{array}$ & 19 \\
\hline
\end{tabular}




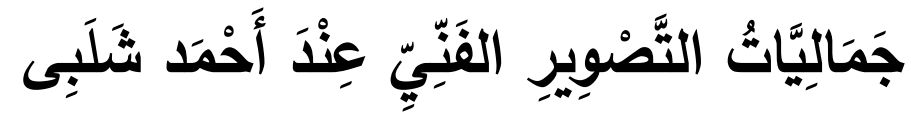

$$
\begin{aligned}
& \text { د. مُحَمَّد مَحْمُود أَبُو عَلِيّ } \\
& \text { أستاذ مساعد النقد والبلاغة } \\
& \text { قسم اللغة العربية وآدابها } \\
& \text { كلية الآداب - دمنهور }
\end{aligned}
$$




\section{المُلَخَّص}

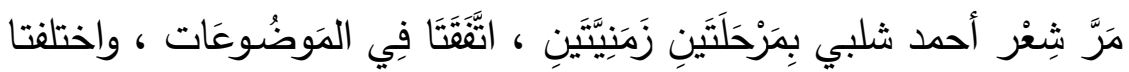

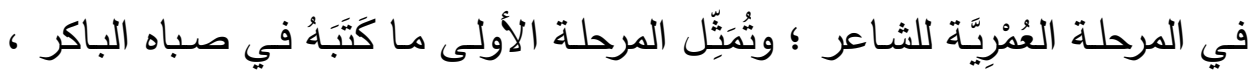
وثمانينيات القَرْن العِشْرِين ، وتَثْنَل المرحلة الثانية القصـائد التي كتبها في بداية الألفيَّة الثانية . النمالية

ويَهْدِفُ هذا البحث إلىى دراسة تفاصيل هاتين المَرْحَلَتَينِ ، ومِنْ ثَمَّ تَطَوُرْ

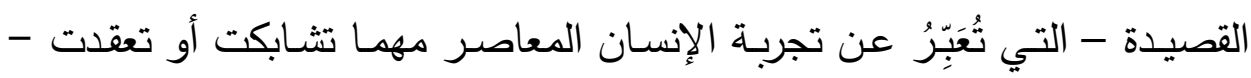
عنده

وقد جاء البحثُ في تمهيدٍ وثلاثة مباحث وخاتمة ، تتاول المبحث الأول :

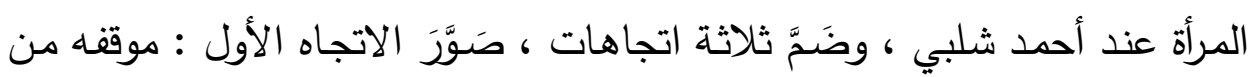

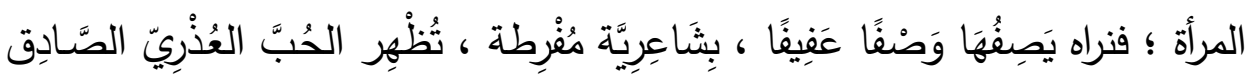

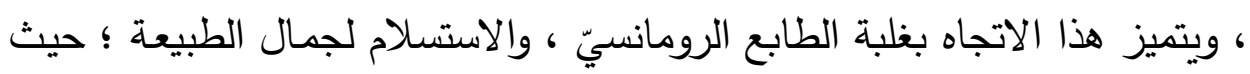

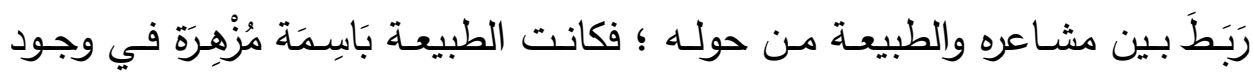

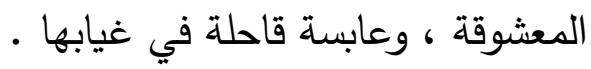

وعَرَضَ الاتجاه الثاني : الحب الثقافيّ للمرأة ؛ فلم تكن المرأة مجرد أنثى فئى

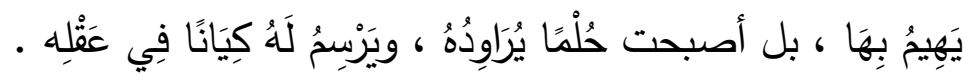

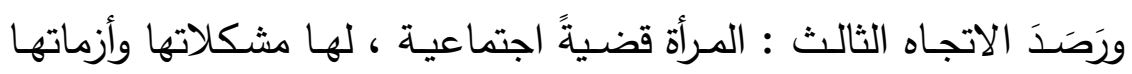
وأحلامها صعبة المنال في مجتمع ذكوري يَجْحَدُ فضلها ويتناساها .

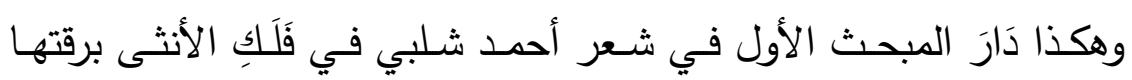
وعذوبتها وكينونتها وكيانها .

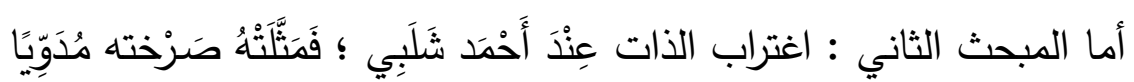

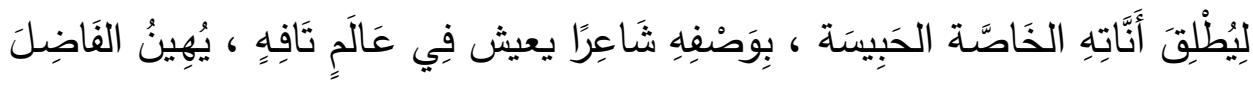




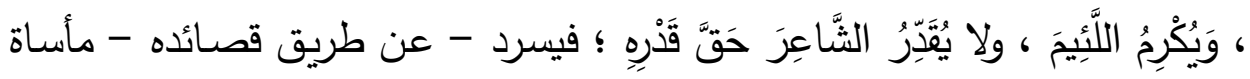

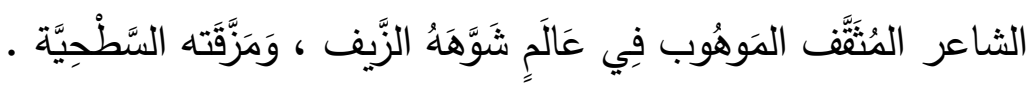

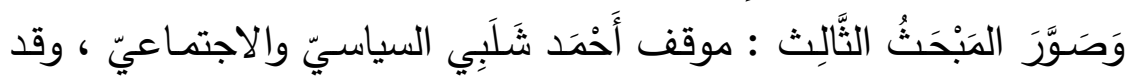

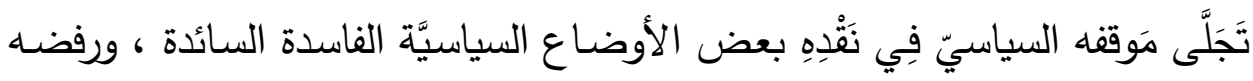

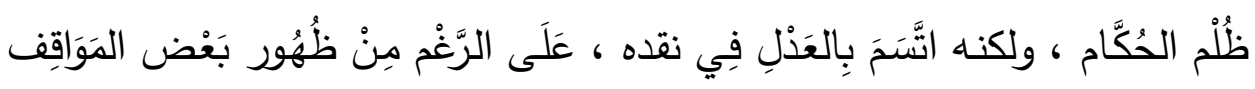

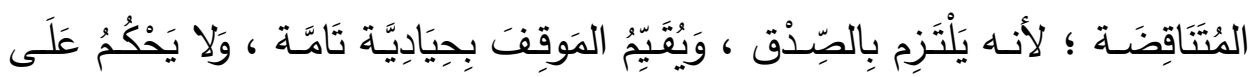
الثَّخْص نَفْسه .

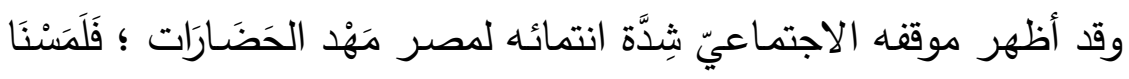

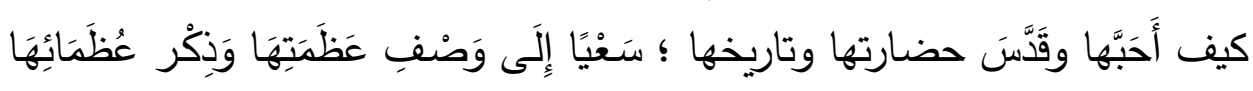

وقد اقتضت طبيعة البحث الاستعانة بالدنهج التاريخي و التحليليّ ؛ لأنه

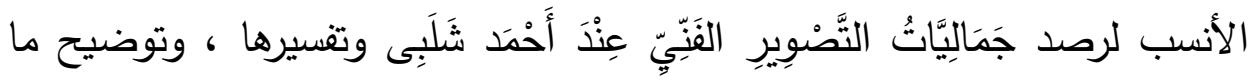
فيها مِنْ قيم جماليَّة . 


\section{مُعَقِّمَة}

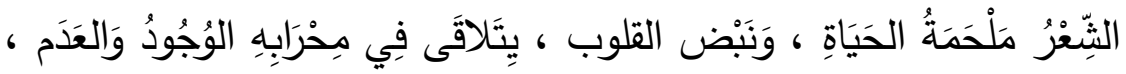

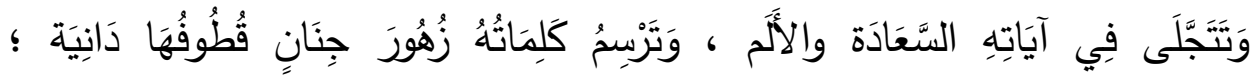

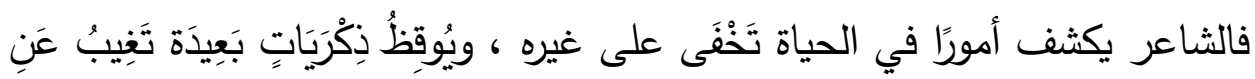

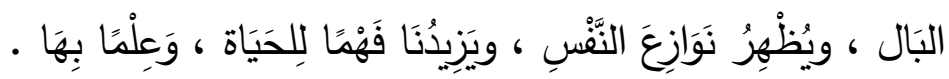

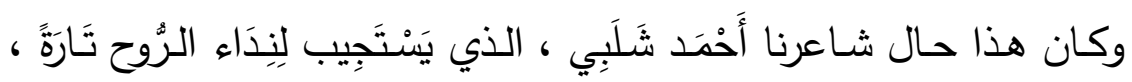

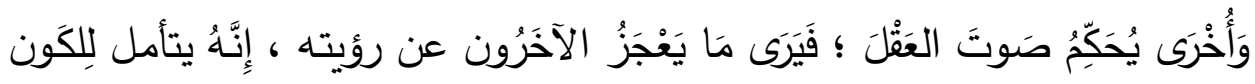

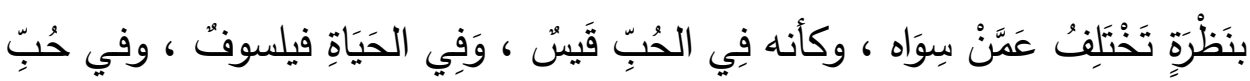

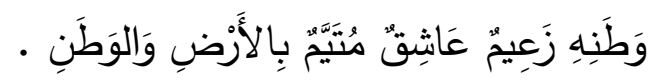

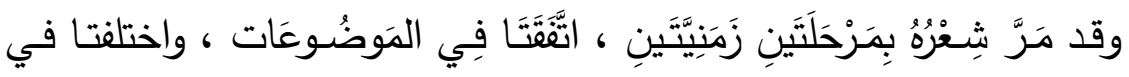

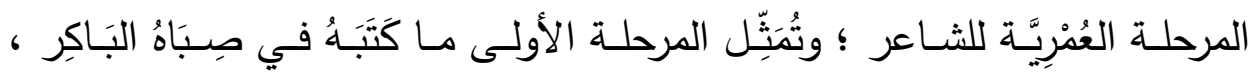

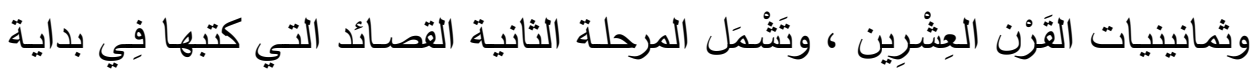

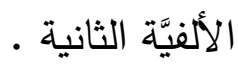

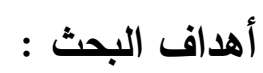

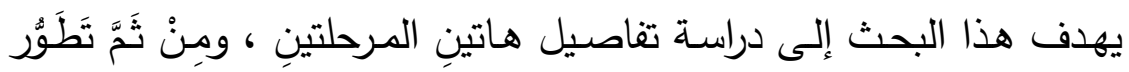
القصيدة - التي تُعَبِّر عن تجربة الإنسان المعاصر مهما تثابكت أو تعقدت - عند ولند

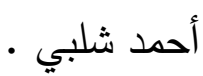

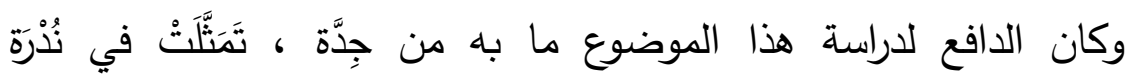

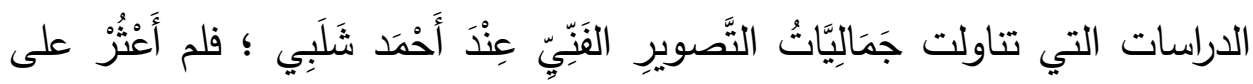

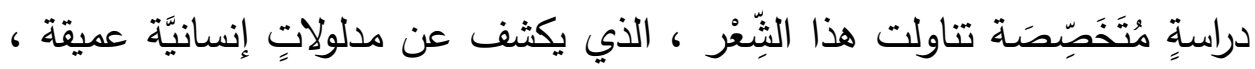

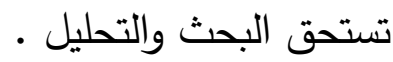
مَنْهَج البَحْثَ :

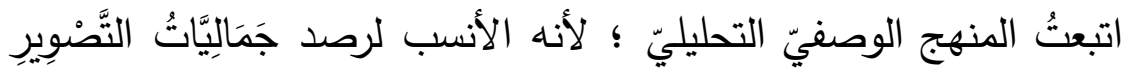

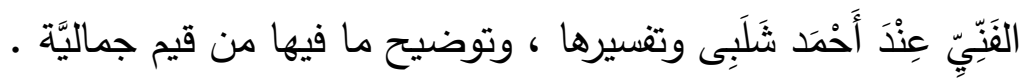


وقد جاء البحثُ في تميٍٍٍ وثلاثة مباحث وخاتمة ، وتناول المبحث الأول :

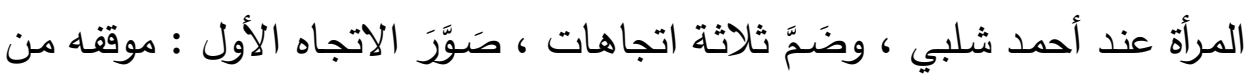

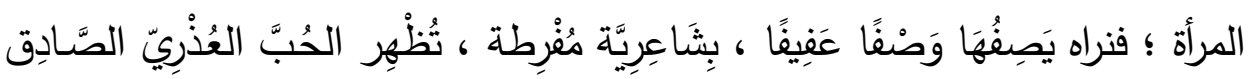
، ويتميز هذا الاتجاه بغلبة الطابع الرومانسيّ ، والاستسلام لجمال الطبيعة ؛ حيث الطيّة

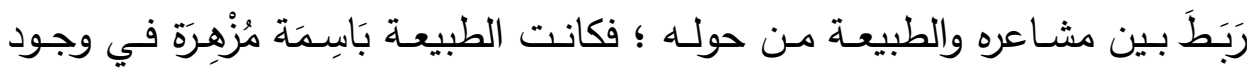

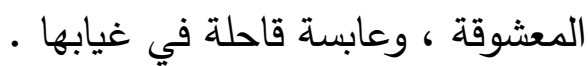

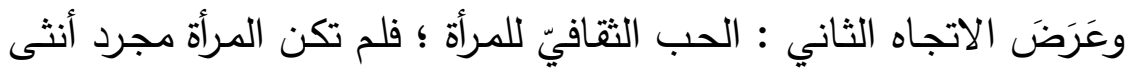

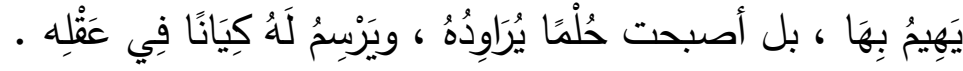

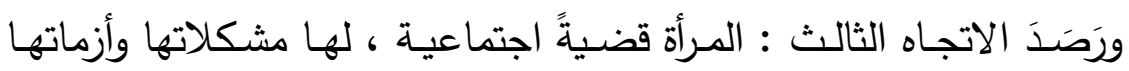

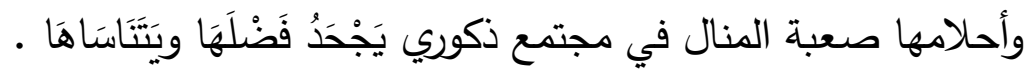

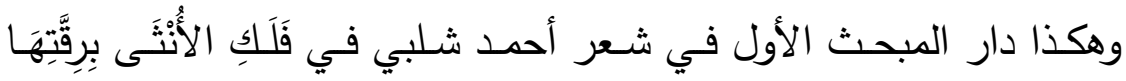

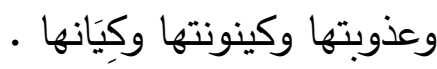

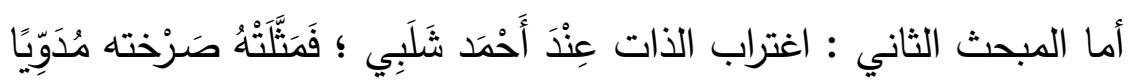

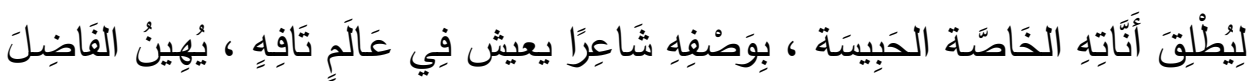

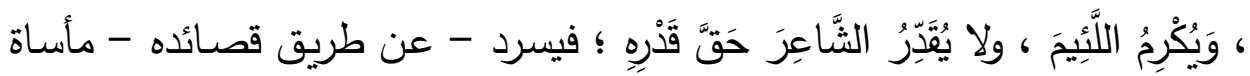

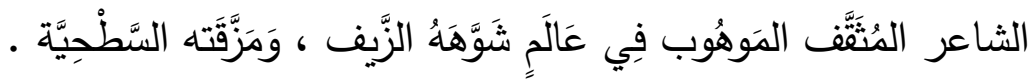

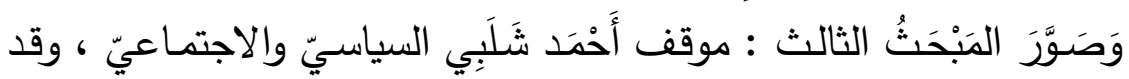

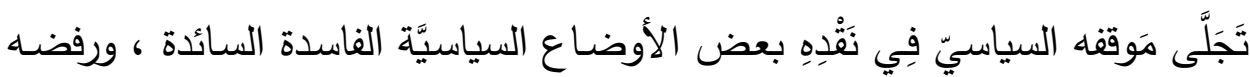

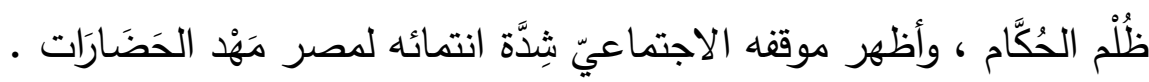

\section{تمهيل :}

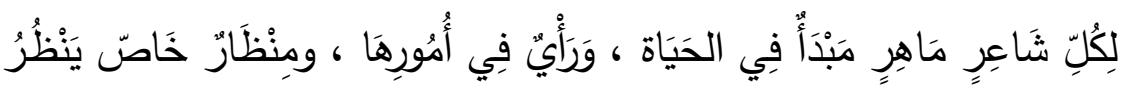

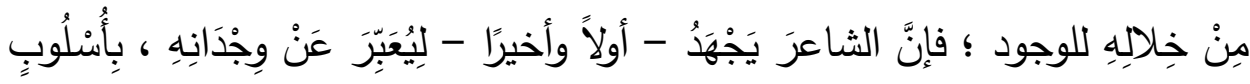

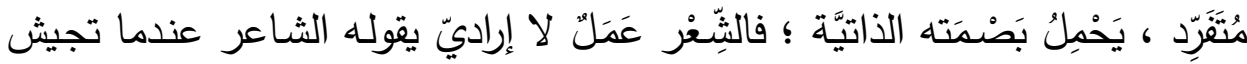


الخواطر في صدره ، ويلتمس لها مَخْرَجَا ؛ فتتطلق زفرات قلبه شعرًا غنائيًَا ؛

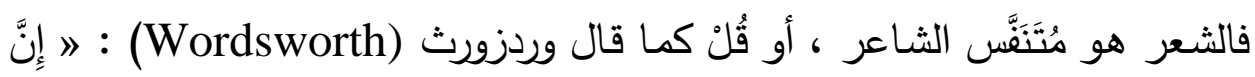

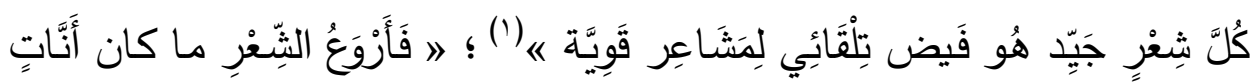

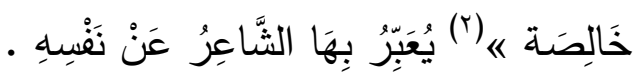

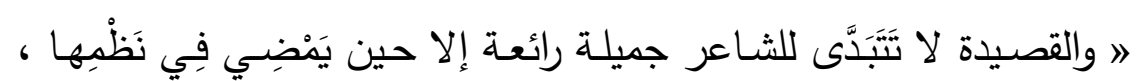

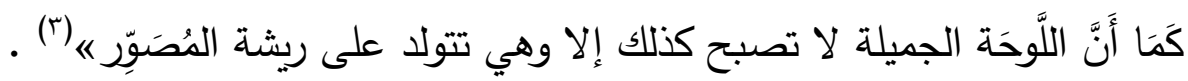

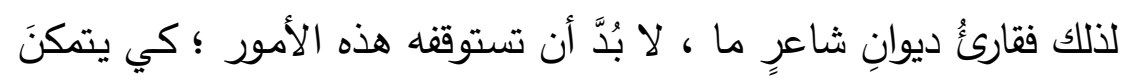

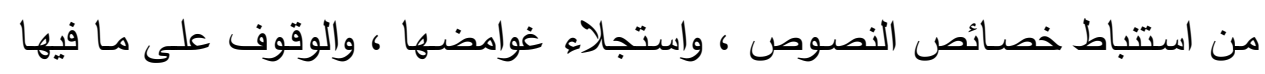

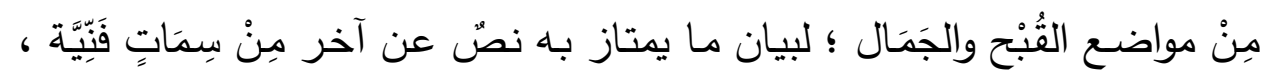

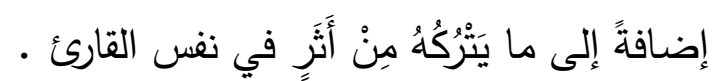

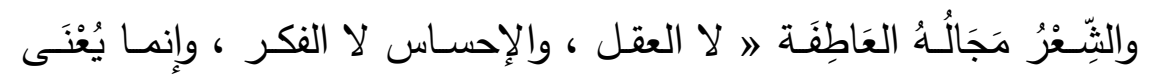

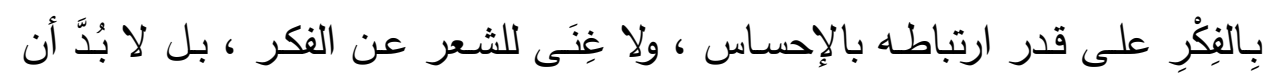

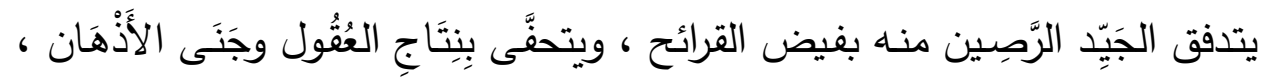

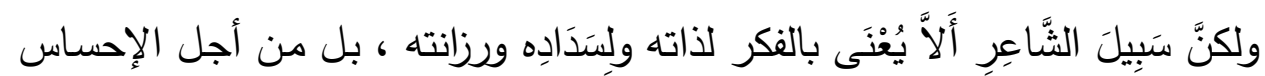

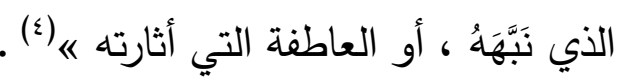

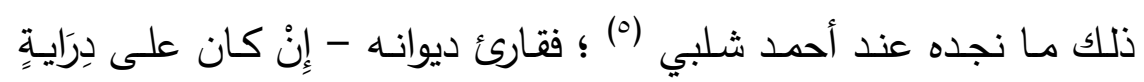

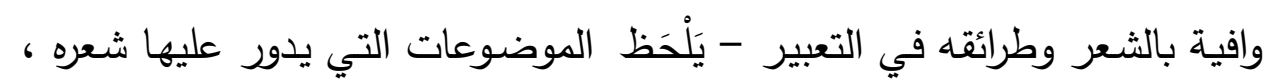

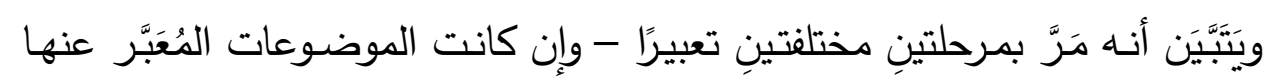

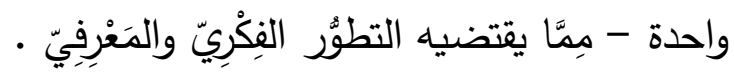

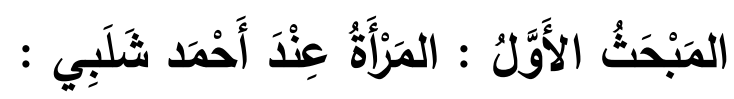

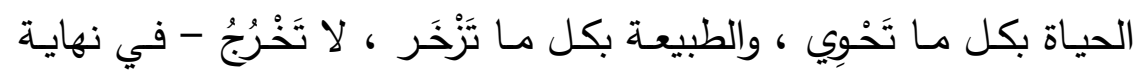

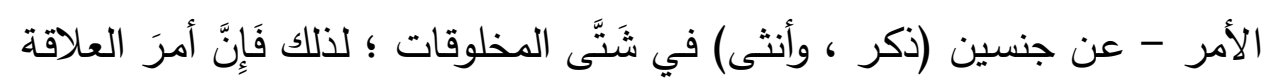

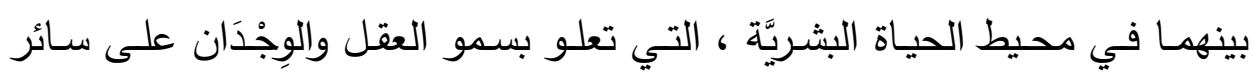




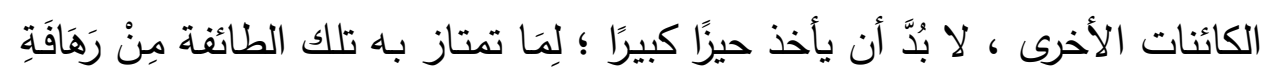

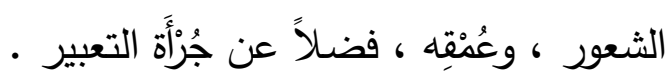

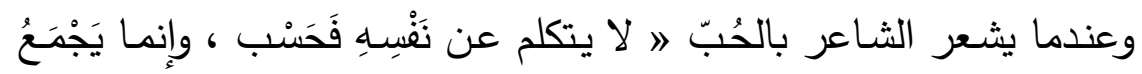

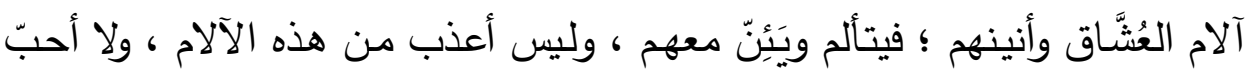

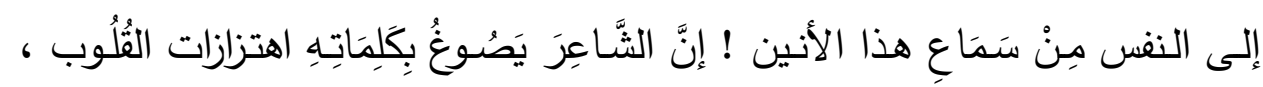

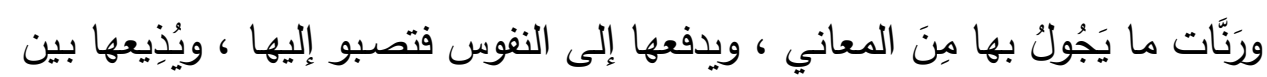

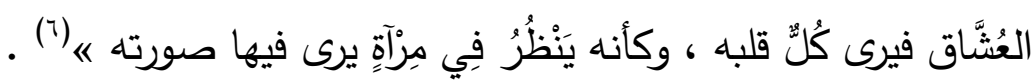

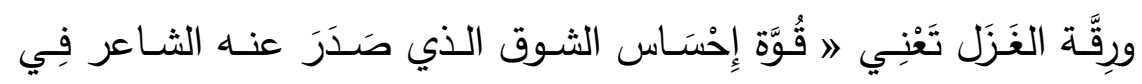

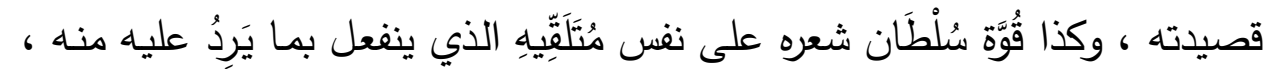

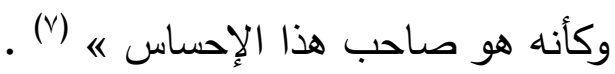

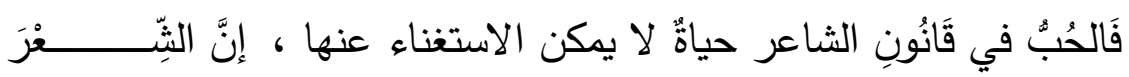

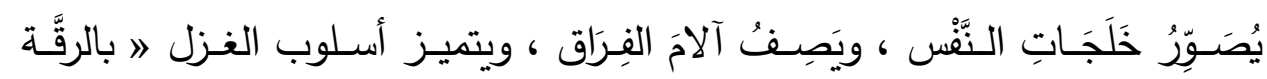

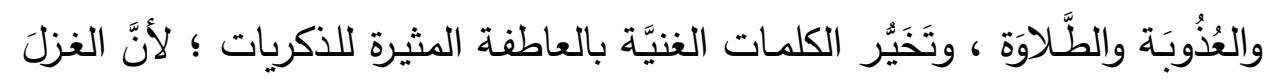

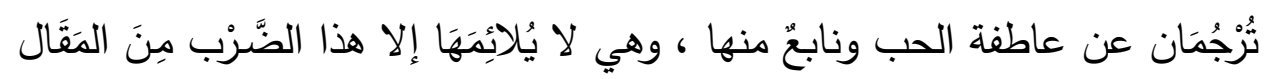
(^) «

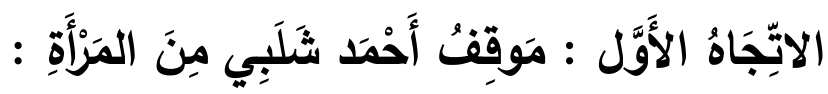

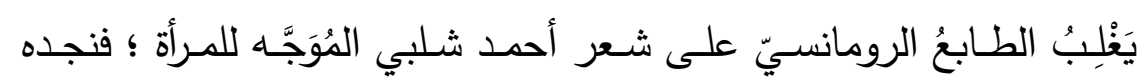

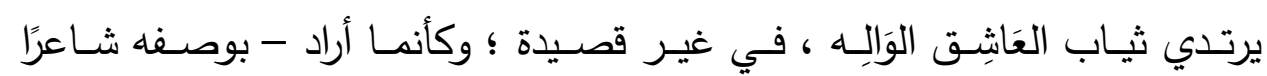

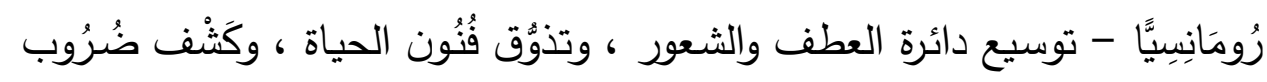

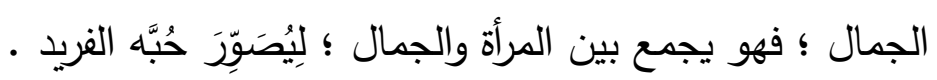

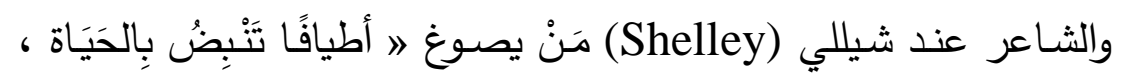

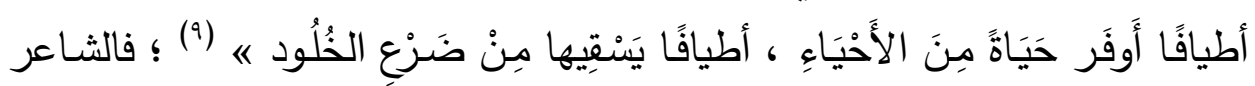

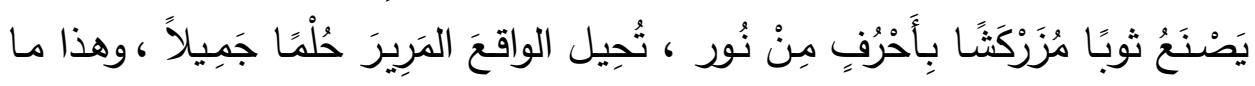


نستشعره مـع أحمد شلبي حين جَعَل الحَبِيََََ مـلاذًا لـه ووطنًا ، يقول في قصيدة : (لَقََاء)

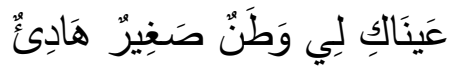

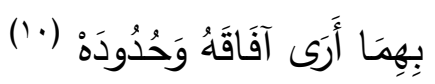

وتُعَرَّف الرومانسيَّة بأنها » انتصسار الخيال والعاطفة الفرديَّة على النظـام

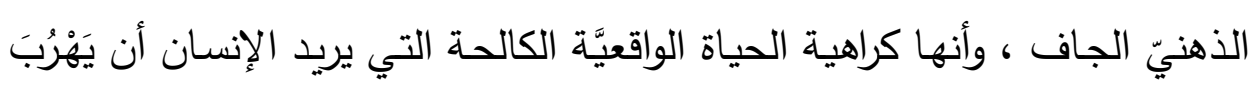

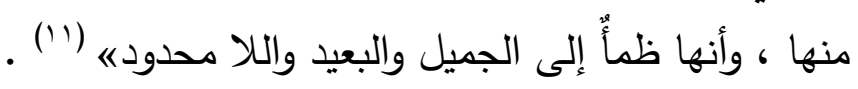

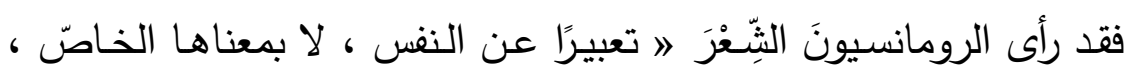

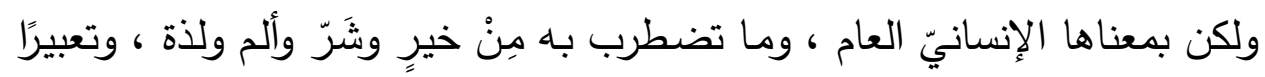

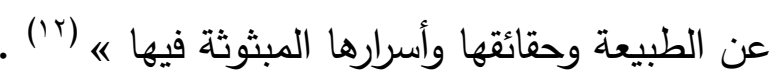

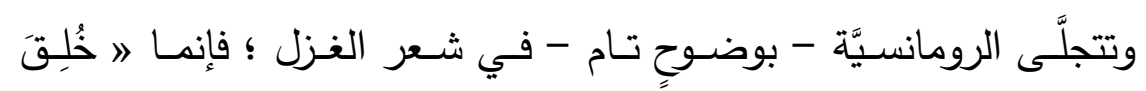

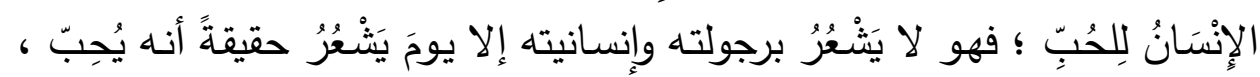

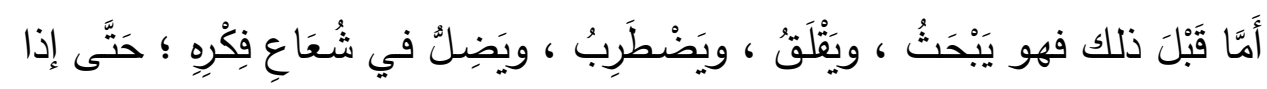

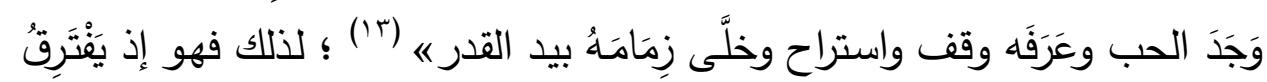

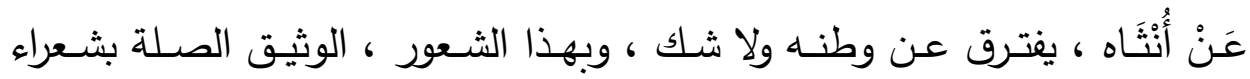
الرومانسيَّة ، يَمْضِي أحمد شلبي في خطابـه للمرأة في ديوانـه ، يقول في قصيدة : (خَوف)

\section{لَمْ يَبْقَ بَعْدَكِ إِلَّ}

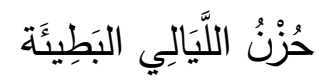

وَهَزْلُ قَوْمِ سُكَارَى

فِي الأُمْنِيَاتِ البَذَيَّة

تَثَابَة الحُسنُُ وَالَقُبْحُ 


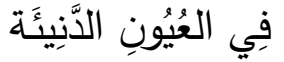

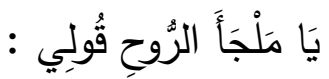

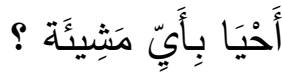 \\ وَخَلْفَ بَابِي جِيَّاعٌ

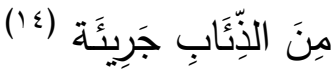

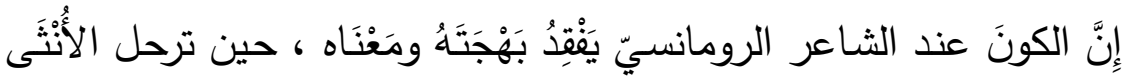

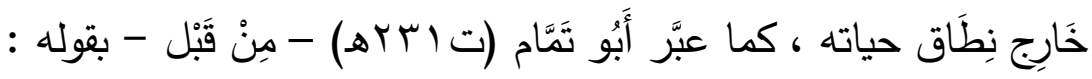

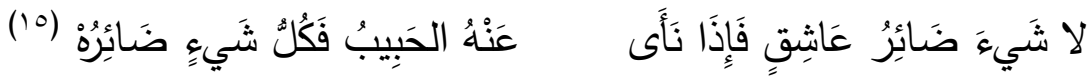

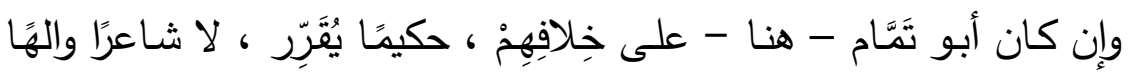

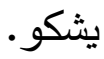

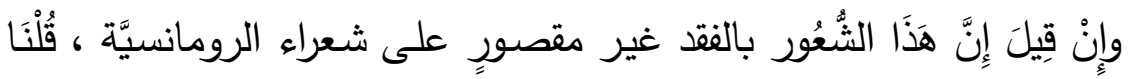

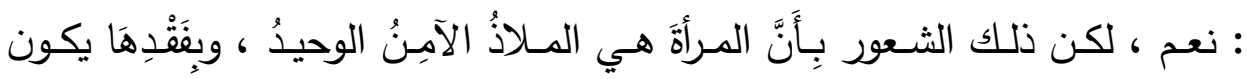

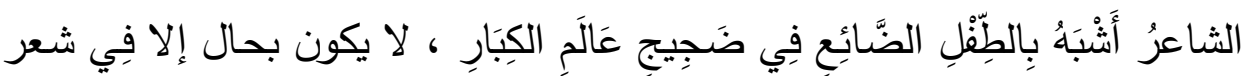

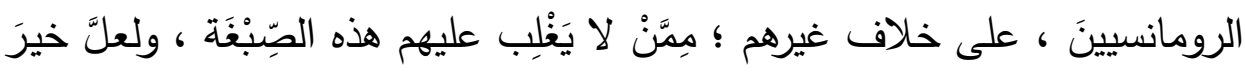

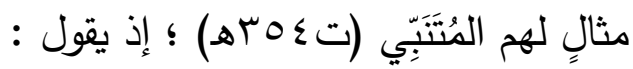

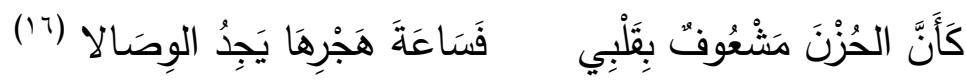

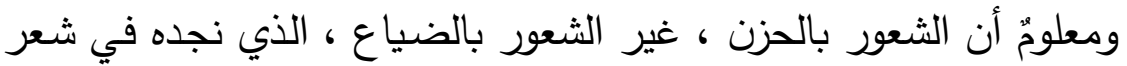
أحمد شلبي ؛ إذ يقول في قصيدة (إلى لُؤلُؤة) :

مَا سِوَى وَجْهِكِ عَنَّي يَدْراً

كَهَبَ الحُزْنِ الِذِي لا يُطْفَاُ

يَا عُيُونًَا لَمْ أَزَلْ أَتْنُوْ لَهَّا 


\section{مُنْيَتِي أَنْ يَحْتَوِينِي الُْوَعْبُوُ}

فَالَأَسَى بَعْدَلكِ صَحْوُ دَائعِّ

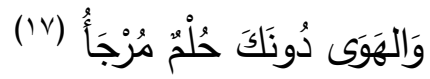

$$
\text { ويقول في قصيدة (وَيَبَقَى الحُبّ) : }
$$

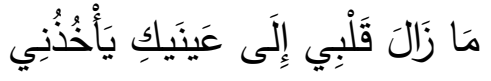

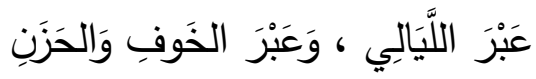

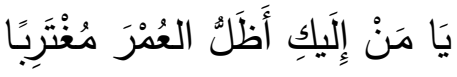

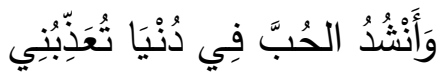

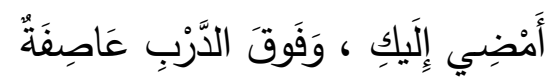

تَُوحُ فِي عَالَمِ الآلامِ وَالِْحَنِ

أَبَسيرُ خَلْفَ بَرِيقِ لَنَنْ أُدْرِكُهُ

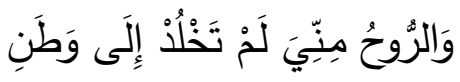

أَدُورُ فِي جَنَبَاتِ الكَونِ أَبْحَتُ عَنْ

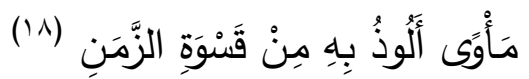

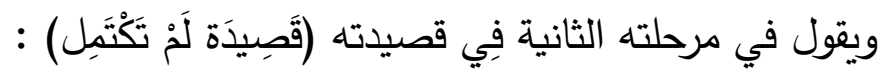

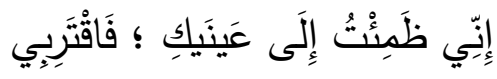

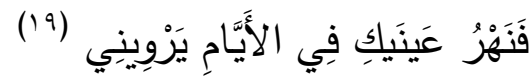

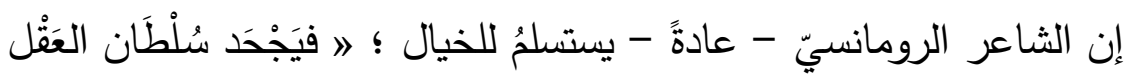

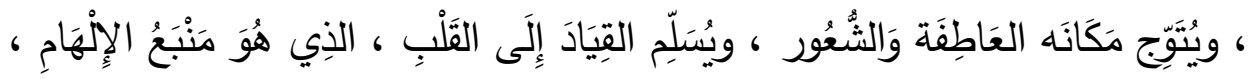




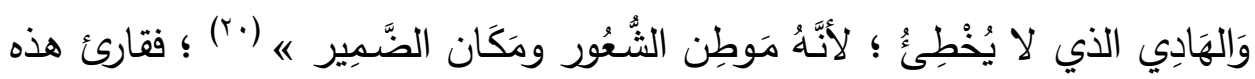

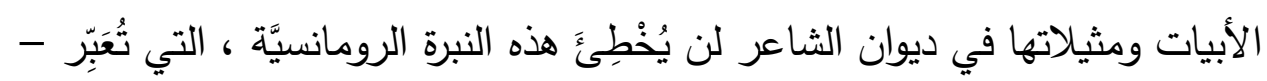

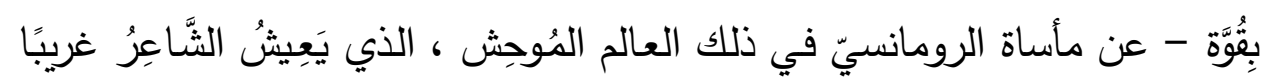
فيه .

والحياة عند الثاعر الرومانسيّ موقوفة على وجود المرأة ؛ حَتَّى إنَّ مظاهر

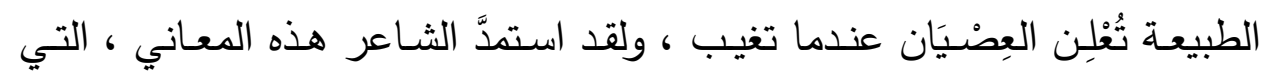

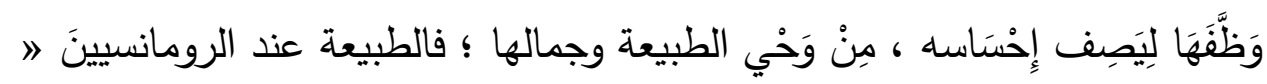

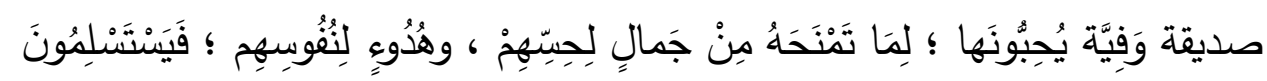

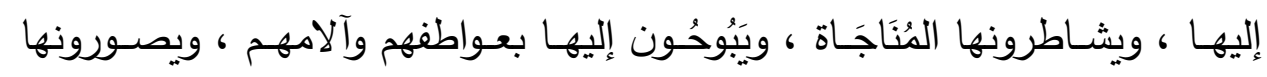

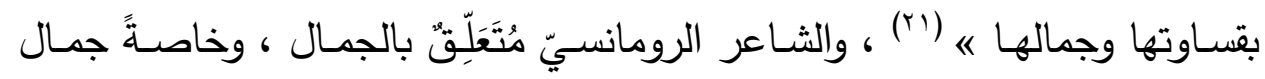

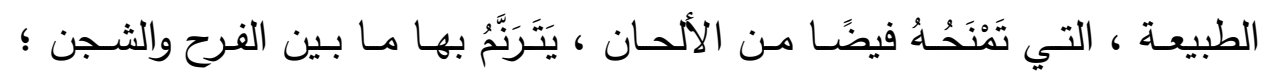

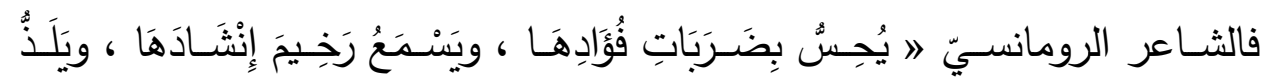

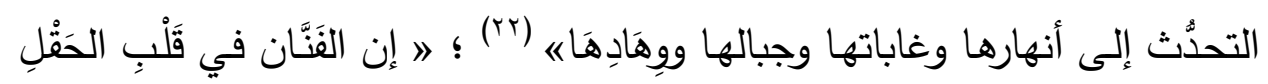

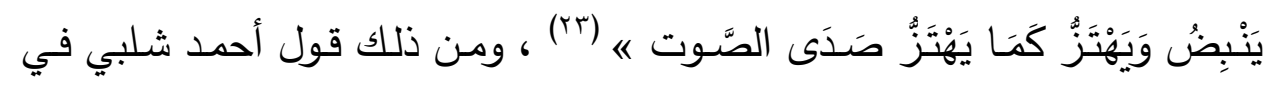

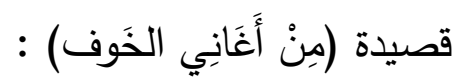

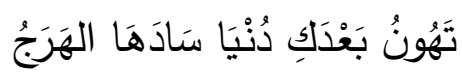

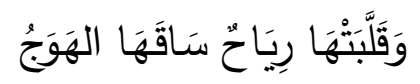

الطَّيُر فِيَها عَلَى الأَعْشَاشِ ذَاهِلَةُ

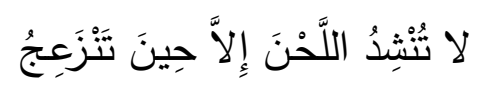

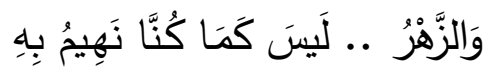

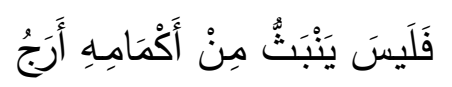




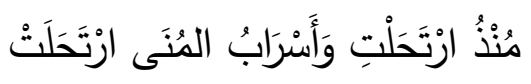

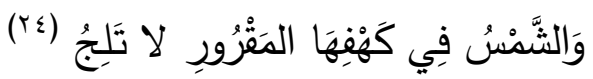

وقوله في قصيدة (أُغْنِيَّة إِلَى غَائبَّة) :

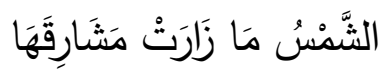

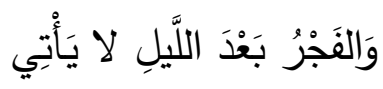

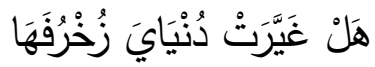

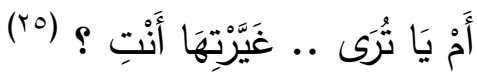

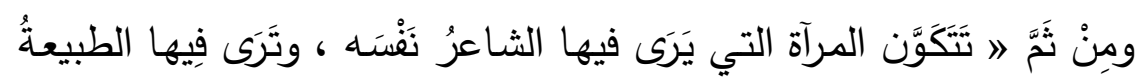

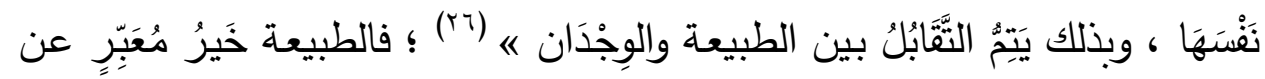

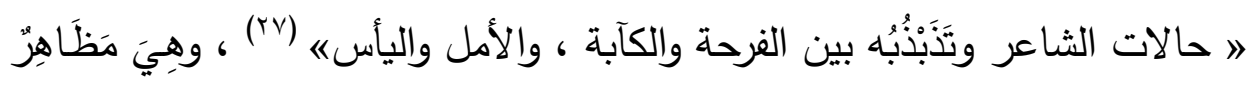

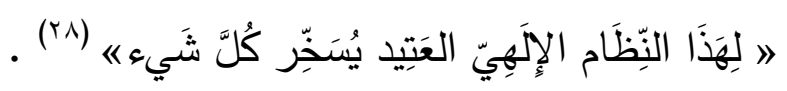

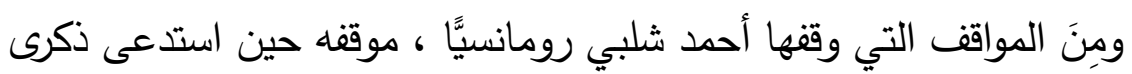

الحبيبة ، يظهر ذلك في قوله في قصيدته (قصيدة لم تكتمل) :

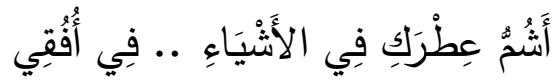

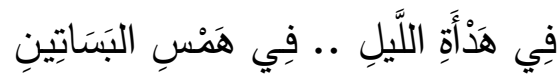

فِي دَفََْرِ الثِِّعْرِ فِي اللَّوحَاتِ فِي كُتُبِي

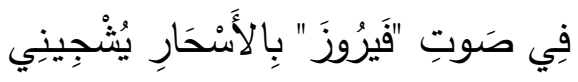

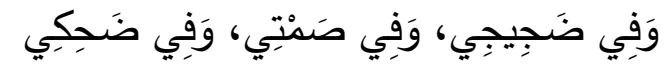

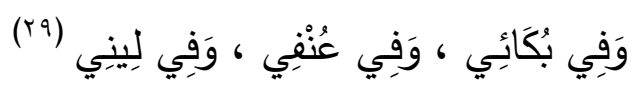

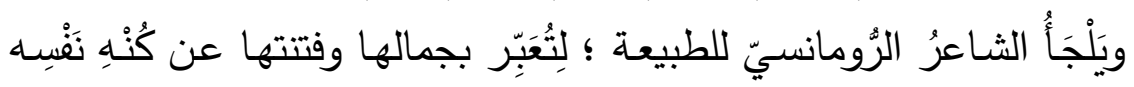

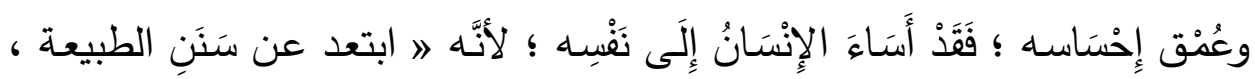




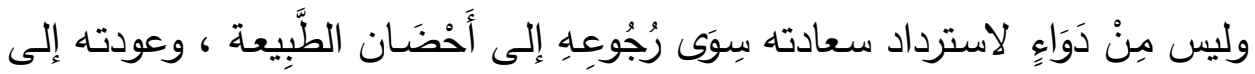

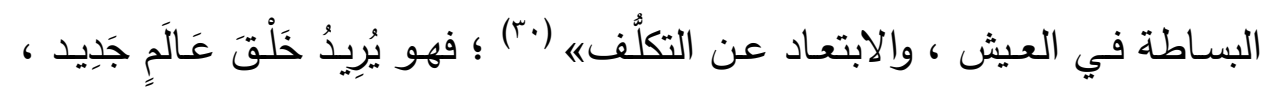

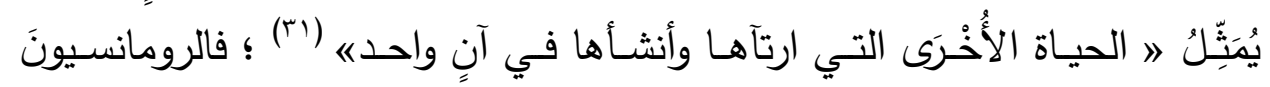

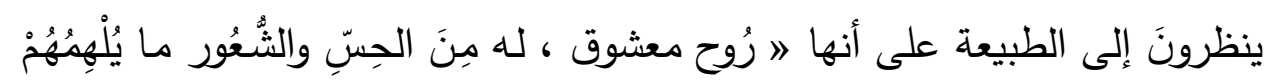

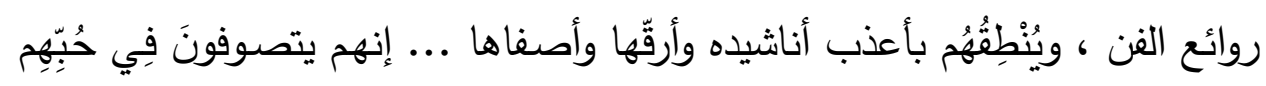

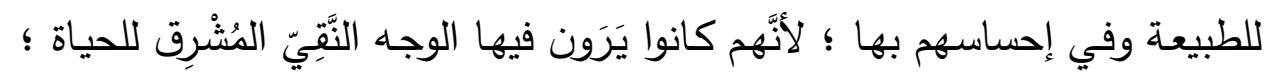

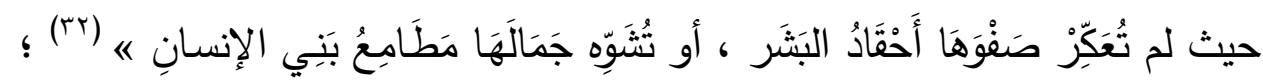

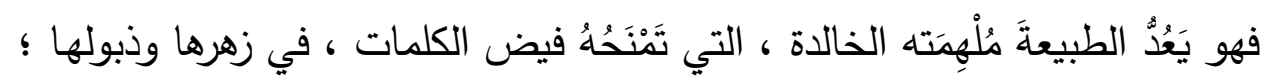

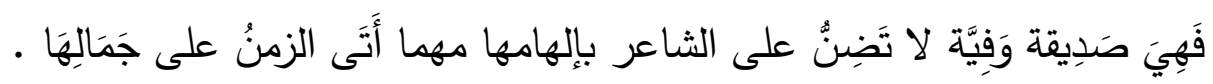

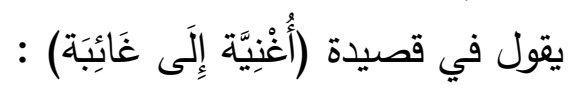

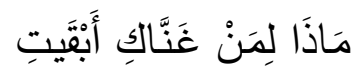

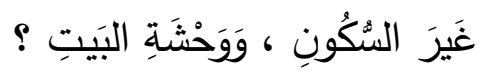

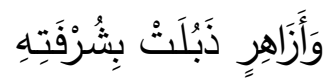

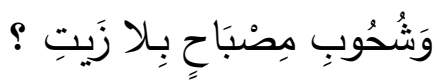

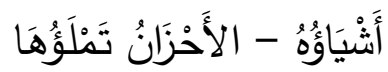

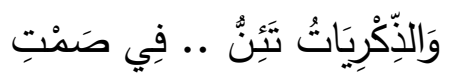

$$
\begin{aligned}
& \text { صُوَرْ عَلَى الجُدْرَانِ نَازفَفْة }
\end{aligned}
$$

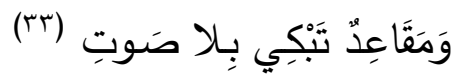

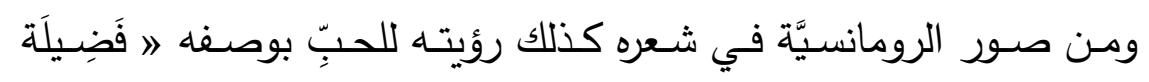

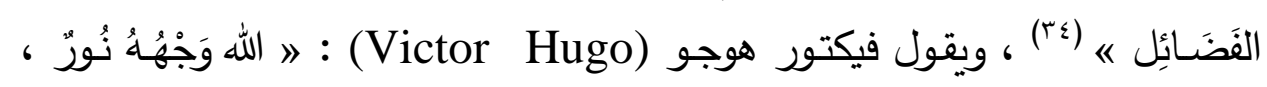

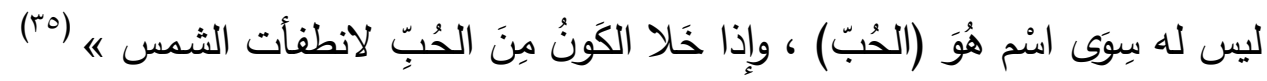


؛ فهو يراه شقاءً جميلاً ، الأمر الذي نجده عند أغلب قصائد شعراء تلك النزعة ؛

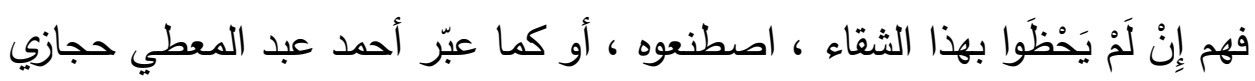

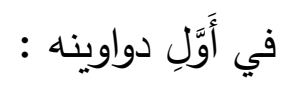

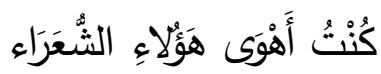

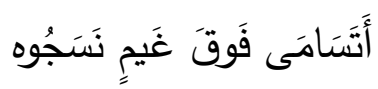

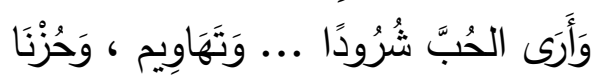

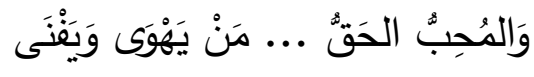

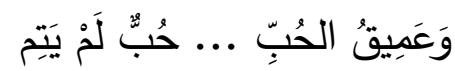

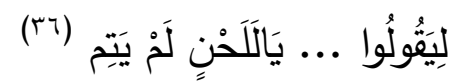

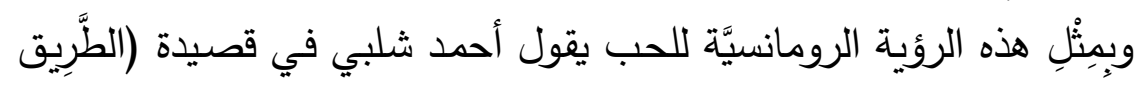

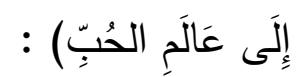

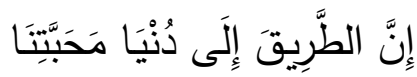

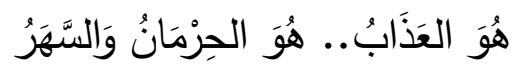

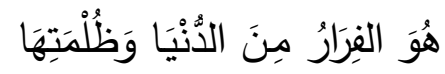

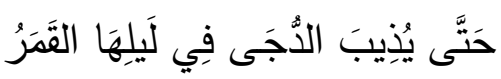
هَذَا طَرِيقِيَ .. مَا أَحْلَى الثََََّاءَ بِهِ

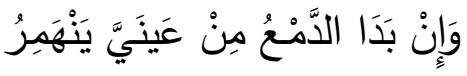

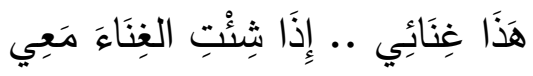

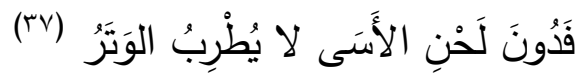

ويقول في قصيدة (إلَىى فَاء) :

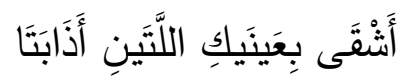




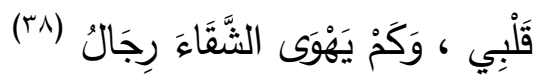

فنحن إزاء ذلك الشعر نرى موقف شاعر رومانسيّ تجاه المرأة ؛ فهو تارةً

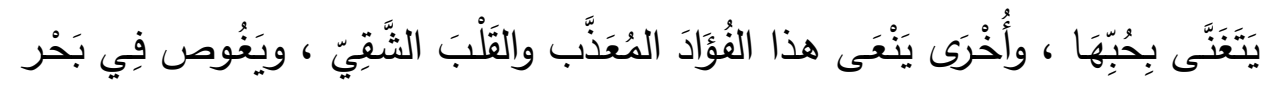

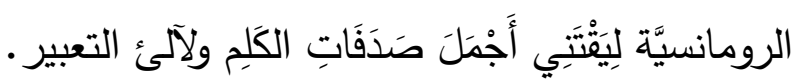

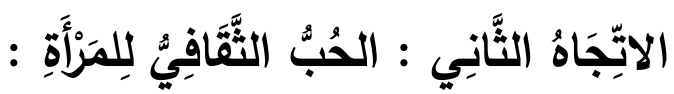

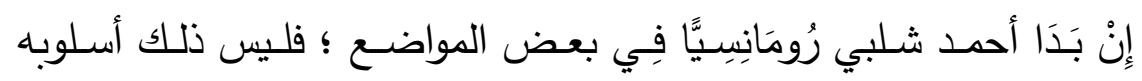
الأوحد في موقفه من المرأة ؛ ففي مواضع أخرى نرى خطابه لها يأخذ منحًى مختلفًا

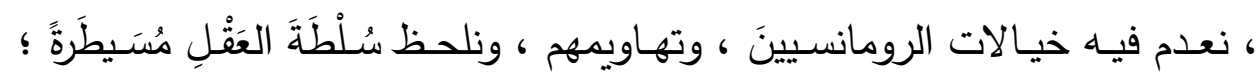

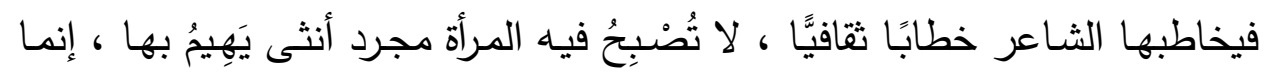
صورة لحُلْم مَا فِي خاطره ؛ فالصورة في الثعر ״ ليست إلا تعبيرًا عن حالة نفسيَّة

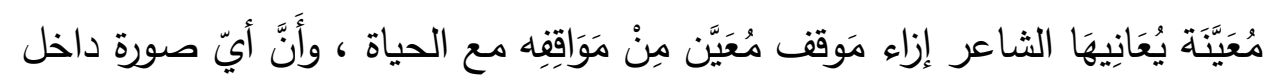

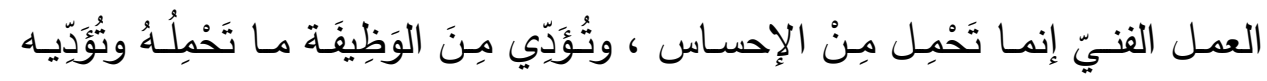

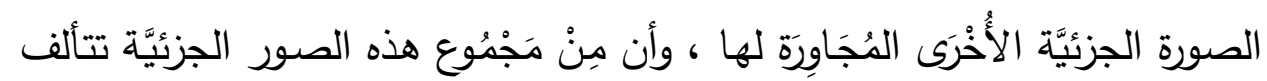

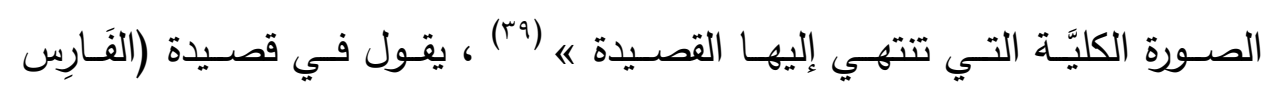

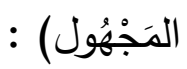

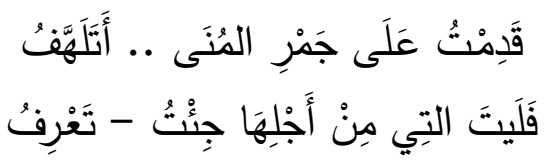

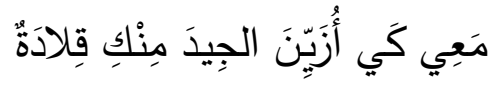

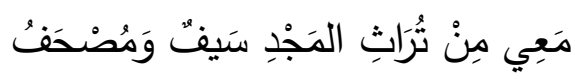

وَفَوقَ جَبْبِ الكبر .... مَا انْفَكََّّ آيَةً

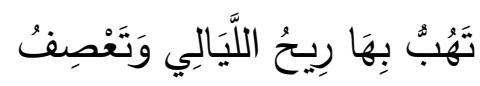


وَبَيَنَ يَدَيَّ الحُبُُ يَحْمِلُ شُعْلَتِّي

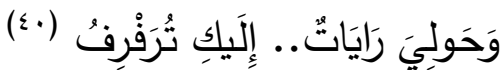

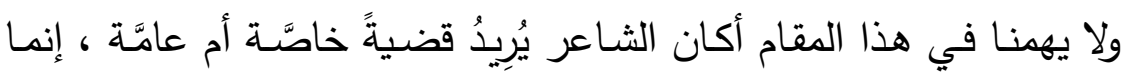

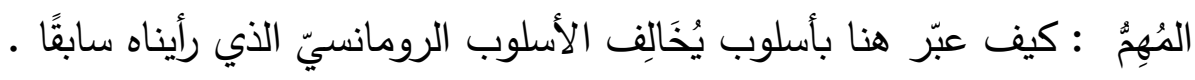

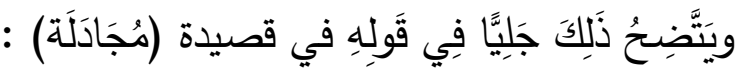

$$
\text { : قَالَتْتُ }
$$

وَكَيفَ تَكُونُ قِصَّتُنَا ؟

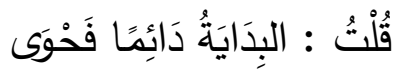

$$
\text { : قَالَتْ }
$$

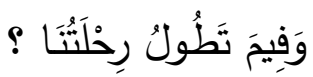

وَالنََّّاسُ مَرَرُوا حَولَلَنَا عَدْوَا

$$
\text { : قُقلتُ }
$$

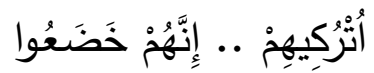

لِسَرَابِ زِيفِهِهُ الذِي أَغْوَى

لَكَنَّ لِي فِي الحُبّ مَنْزَلَةَّة

هِيَ مِنْ وُجُودِي

غَايَةُ قُصْوَى

$$
\text { قََالَتْ : }
$$

فَقُلْ لِي : هَلْ لَنَا أَمَلْ 


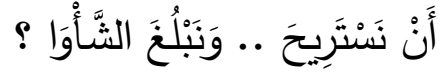

$$
\begin{aligned}
& \text { قُقلْتُ : } \\
& \text { اسنتَرِيحِي .. فَالَهَوى أَمَلُّ }
\end{aligned}
$$

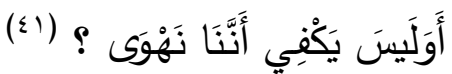

فبمثل هذه الأبيات ومثيلاتها يَنْفِي أحمد شلبي موقفه الرومانسيّ السابق ، فنحن هنا نرى سلطة العقل الحِوَاري الحِجَاجِيّ - إن جاز التعبير - هي السلطة الأقوى ، على خِلاف أسلوبه السابق الذي كان فيهه عاشقًا ولِهًا ، ليس عليه من

وَأَنْتِ آَفَاقُهُهُ ، وَعَالَمَهُهُ

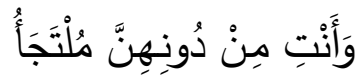

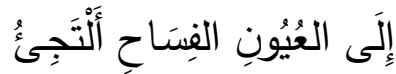

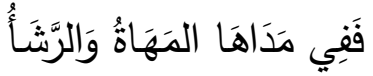

وَزَورَقِي بَيَنَهُنَّ مُرْنَحَلُ

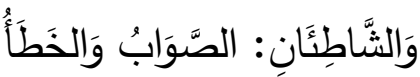

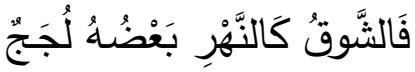

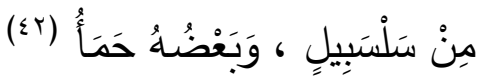




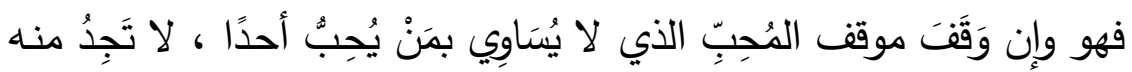

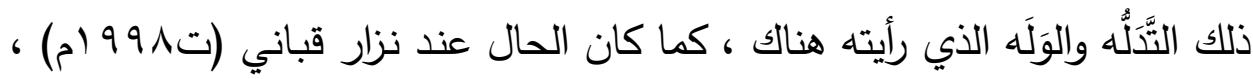

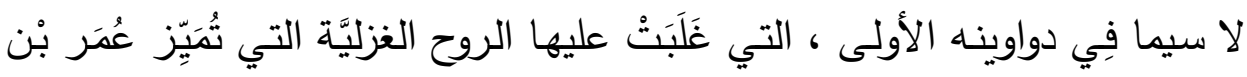

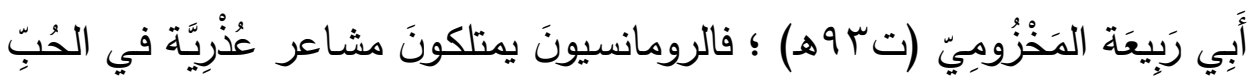

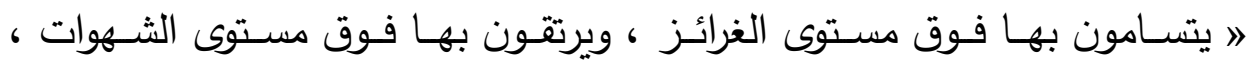

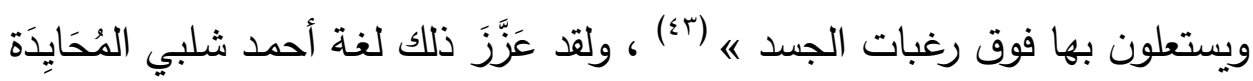

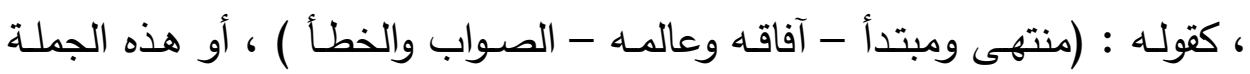

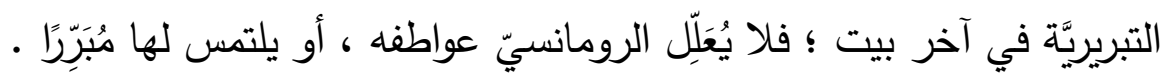

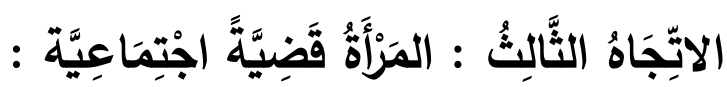

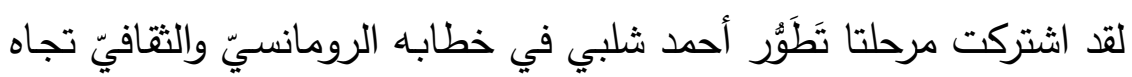

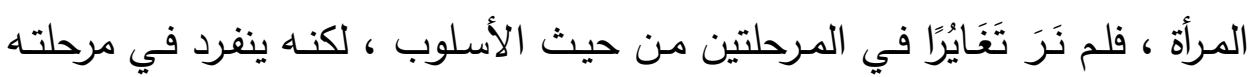

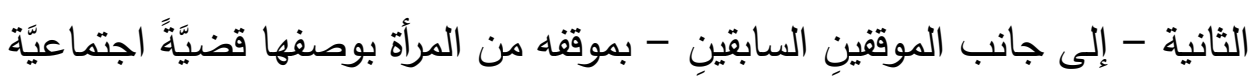

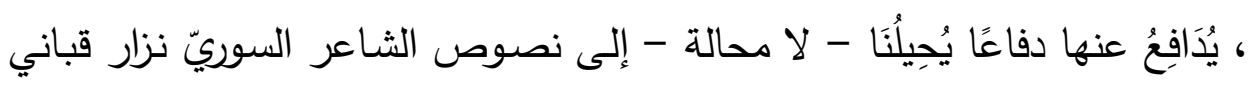

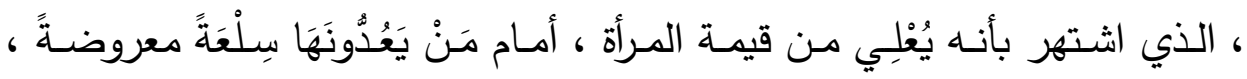

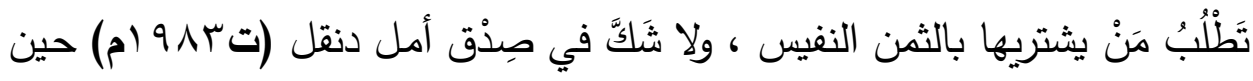

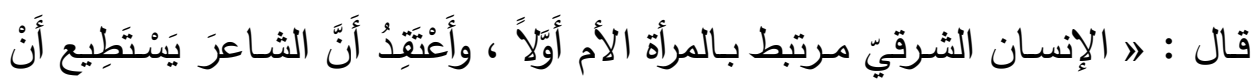

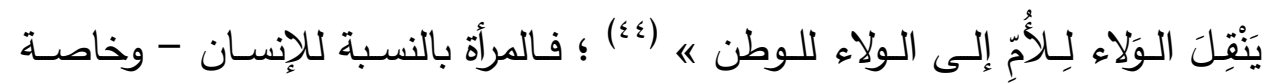

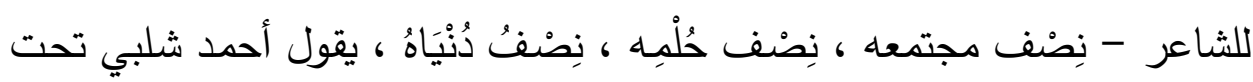
عنوان (جُمُوح) :

$$
\begin{aligned}
& \text { كُونِي - كَكَا أَحْبَبْتِ - مُفْتَرِسَةْ }
\end{aligned}
$$

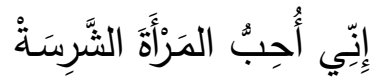

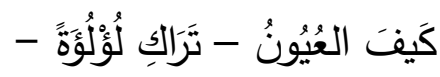

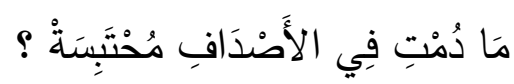




$$
\begin{aligned}
& \text { وَالمُشْتَتَهِي للِلَُّرِ - يُنْكِرْهُ }
\end{aligned}
$$

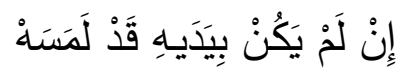

$$
\begin{aligned}
& \text { فَتَفَفَّقِي مَاءً ... وَعَينَ هَوَىى } \\
& \text { مِنْ بَينِ صَخْرِ العُمْرِ مُنْبَجِنَةْ }
\end{aligned}
$$

$$
\begin{aligned}
& \text { كُونِي - كَمَا أَهْوَالكِ - جَامِحَةً } \\
& \text { كُونِي لِبَعْضِ الوَقْتِ مُخْتَلَِنَة }
\end{aligned}
$$

$$
\begin{aligned}
& \text { إِنْ كَانَ حِصْنْلَكِ مَانِعًا - فَدَعِي }
\end{aligned}
$$

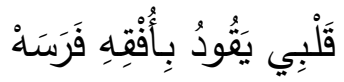

$$
\text { لا تَعْبَيَي بِدَبِيبِ أَرْجُلهِهْ }
$$

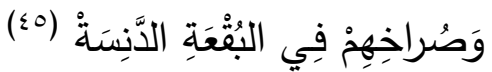

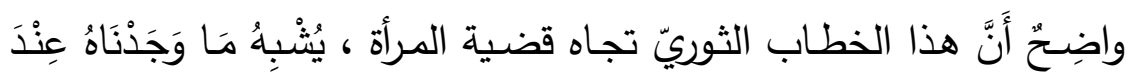

$$
\begin{aligned}
& \text { نزار قبانى في قوله : } \\
& \text { أَحِبِينِي وَقُولِيهَا }
\end{aligned}
$$

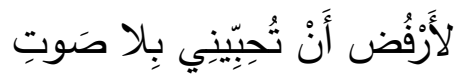

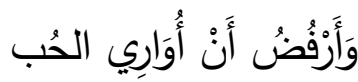

$$
\begin{aligned}
& \text { في قَبْرِ مِنَ الصَّمْتِ } \\
& \text { أَحِيّنِيْي بَعِيدًا عَنْ بِلادِ القَهْرِ وَالكَبْتِ }
\end{aligned}
$$

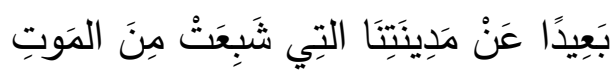

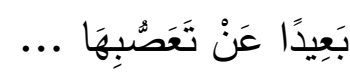




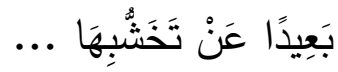

$$
\begin{aligned}
& \text { بَعِيدًا عَنْ مَدِينَتِنَا } \\
& \text { التِي مِنْ يَوَمِ أَنْ كَانَتْ }
\end{aligned}
$$

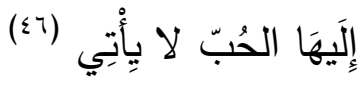

فعلى الرغم مـن اختلاف الثـاعرين في مدى الجُرَأَة في الطـرح ، وشكل

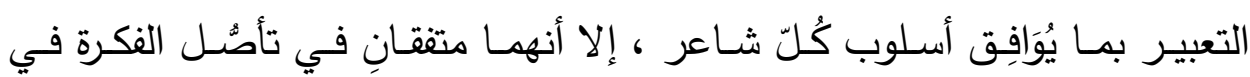

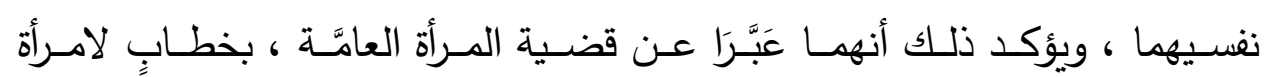
مخصوصة ؛ مِمَّا يُضْفِي على النص أُلْفَة ، لا نجدها في الخطاب المُبَاشِر ، مِنْ

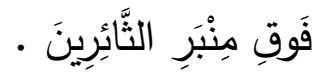

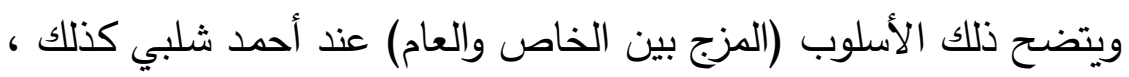
في قصيدته (الوَجْهَ الغَائب) ؛ إذ يقول : بُوجِي بِِِرِّكِ مِنْ خَلْفِ الثََّبَابِيكِ وَأَمْطِرِي قَطَرَاتِ البَوحِح مِنْ فِيكِ

تِلْكَ الثََّوَارِعُ وَالحَارَاتُ أََْْنأَلَهَا بأَيْيّ كَهْفِ يَِ النَََّّاسِ تُخْفِيكِ ؟

$$
\begin{aligned}
& \text { وَهَلْ رَحَلْتِ مَعَ الأَعْرَابٍ } \\
& \text { بَادِيَةً } \\
& \text { أَمِ ازْتَمَيتِ }
\end{aligned}
$$




\title{
بِأَحْضَانِ المَمَالِيكِ؟
}

\author{
وَهَلْ سَفَطْتِ \\ -

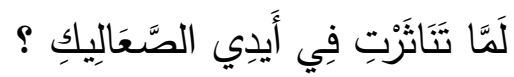

$$
\begin{aligned}
& \text { بُوحِي بِِِرِّلِ : }
\end{aligned}
$$

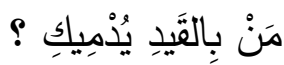

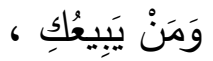

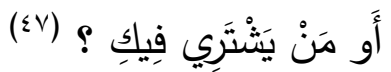

إِنَّ المرأة عند أحمد شلبي ليست مجرد حبيبة ومعشوقة ، إنما هي قضيّية اجتماعية ، بوصفها إنسانًا له أزماته ومشكلاته داخل مجتمع ذكوريّ بحت ، ويَتَّنَُّْ

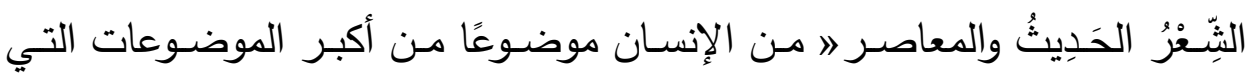

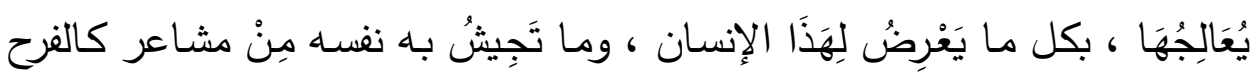

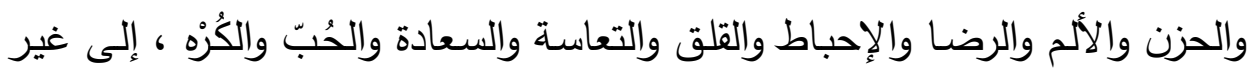

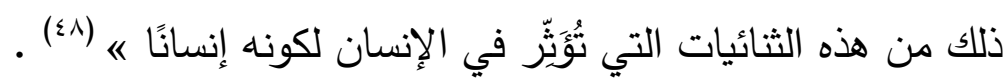

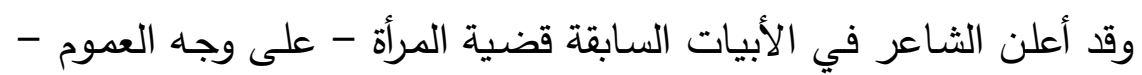

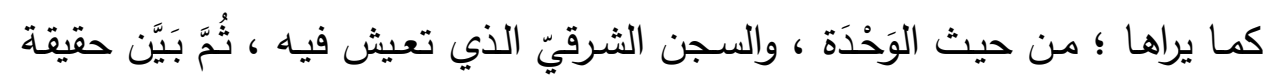
هؤلاء السَّجَّانِينَ ، وهُوَيَّتهم ؛ فهم نَخَّاسُون ، مماليك - في إشارة تجعل قضية المرأة

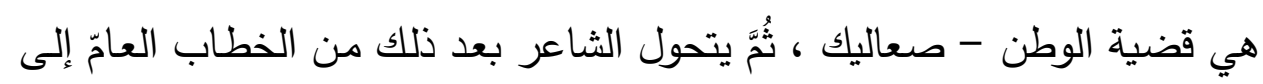
الخاصٌ ، مُكَمِلاً قصيدته ، يقولن

كُلُّ الأُجُوهِ

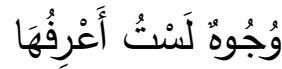

وَلَيَسَ حَولِيَ مَوَلَى مِنْ مَوَالِيكِ 


$$
\begin{aligned}
& \text { فَأَيَنَ وجْهُكِكِ ؟ } \\
& \text { فَالَأَضْوَاءُ خَافِنَّة }
\end{aligned}
$$

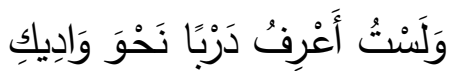

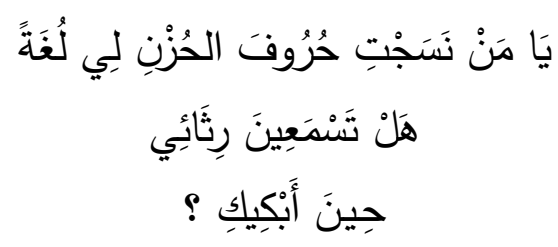

$$
\begin{aligned}
& \text { - هَذَا أَنَا }
\end{aligned}
$$

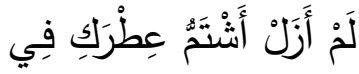

$$
\begin{aligned}
& \text { تَنْكَارِ عَينَيكِ } \\
& \text { فِي أَورَاقِ مَاضِيكِ عَيكِ } \\
& \text { وَقَلَبِي صَارَ أَجْنِحَةً }
\end{aligned}
$$

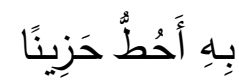

$$
\begin{aligned}
& \text { فِي الَيَالِيكا } \\
& \text { وَأُغْنَيَاتِي } \\
& \text { سَحَابَاتُ أَطُونُ بِّهَ } \\
& \text { سَمَاءَ غَيَهَبَكِ الََّامِي } \\
& \text { أُنَادِيكِ }
\end{aligned}
$$


ومثل نزار قباني ، يُعَبِّر أحمد شلبي - في هذا الإطار - عن مشاعر المرأة

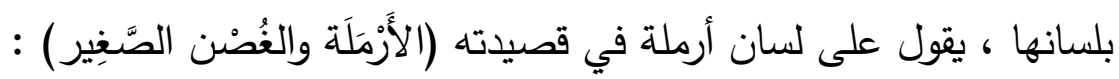

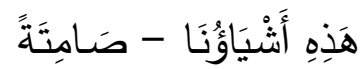

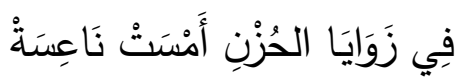

$$
\begin{aligned}
& \text { بَيُتَنَا- النَّْْرُ - الطُّيُوِرِ - المُنْحَنَى }
\end{aligned}
$$

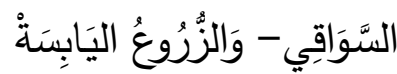

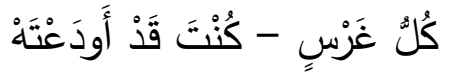

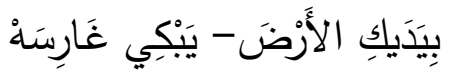

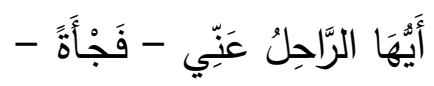

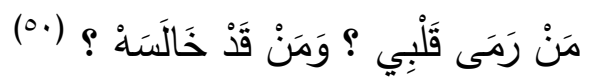

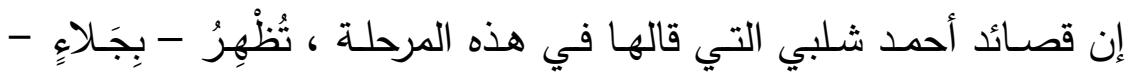

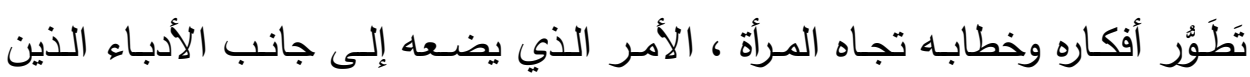

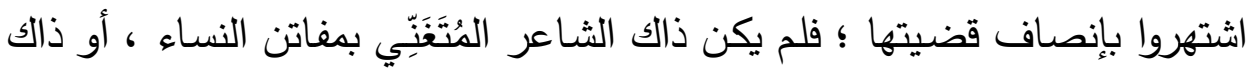

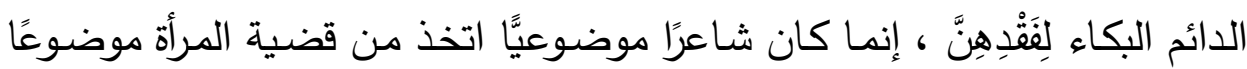

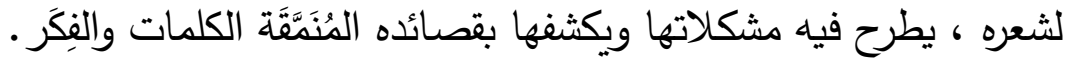

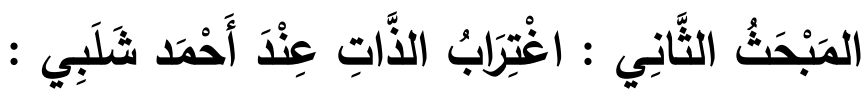

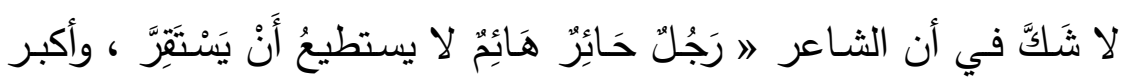

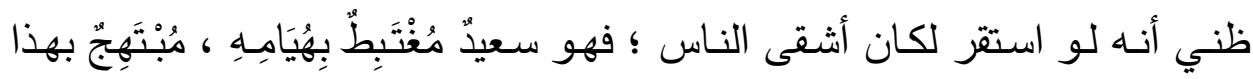

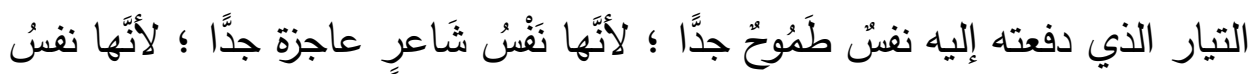

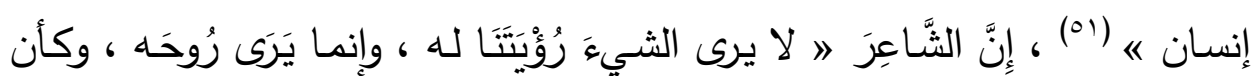

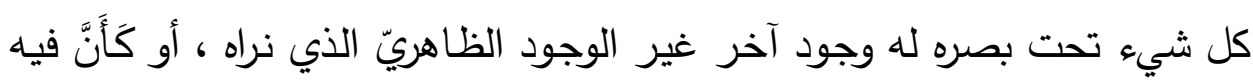




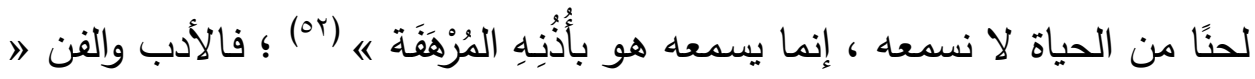

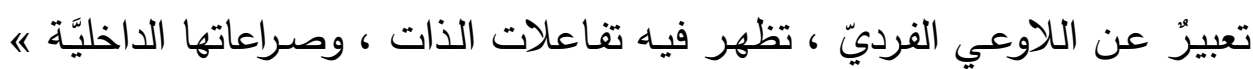

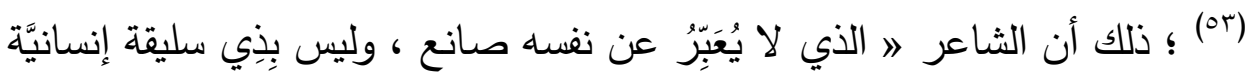

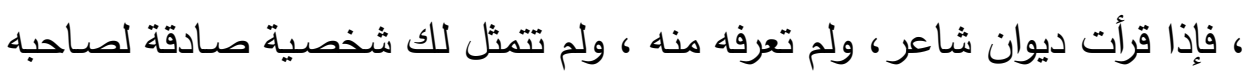

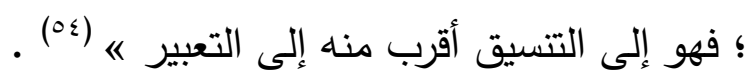

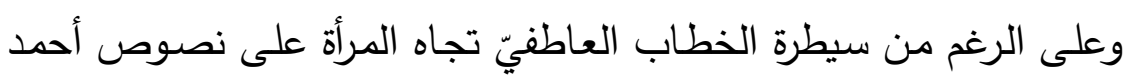
شلبي في مرحلته الأولى ؛ فلا نعدم صوته الغنائيّ الفرديّ ؛ » فالرومانسيَّة ليست مدرسة أدبيَّة فحسب ، بل هي موقف ثقافيّ عام ... يَتَبََّى فِي كُلِّ صُوَر الثقافة

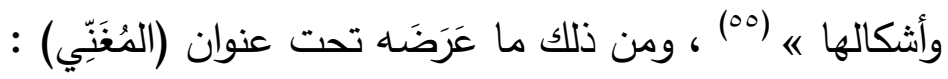
عِنْدَا يَذْخُلُ المَسَاءُ عَلَيهِ

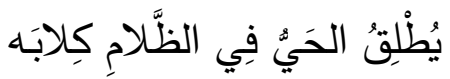

تَأَكُلُ الثِِّعْرُ وَالَرَبَبابَتُهُ مِنْهُ وَيُعَانِي الفَنَى العَنِيدُ اغْتِرَبَبَه

$$
\text { يَا ذَوِي الحَيٍّ : }
$$
إِنَّ هَذَا المُغَنَبِي لَيَنَ يَتْنِيهِه عَنْ هَوَاهُ عِصَابَة كَيفَ يَخْشَى كِلابَكُمْ فِي اللََّّالِي

$$
\begin{aligned}
& \text { مَنْ يَعِي }
\end{aligned}
$$

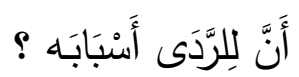

إِنَّ مَنْ عَاقَرَ الغِنَاءَ سَيَيَنْدُو 


\section{حِينَ يَبْدُو..

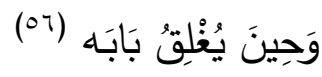

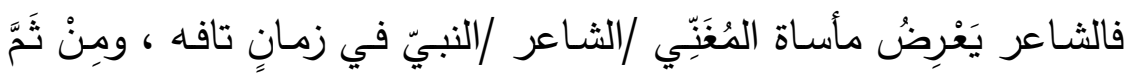

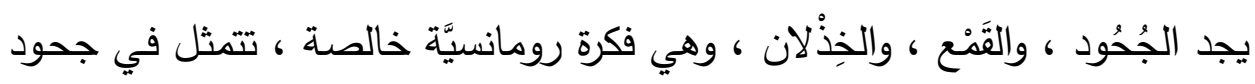

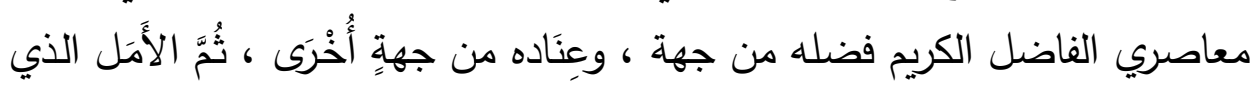
يَحْمِلُهُ بين جنبيها ، بأنه سينتصر أخيرًا .

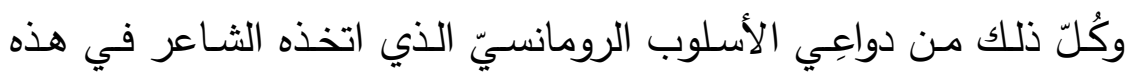
المرحلة ، ويظهر ذلك في زفراته الفرديَّة الوجدانيَّة ، وهو في سياق خطابه للمرأة ، في غير قصيدة ، كأن يقول عازفًا على النغمة نفسها في قصيدة (إلى لُؤْلُؤة) : مَا عَسَى يُرْجَى مِنَ الثَّْْْرِ إِذَا

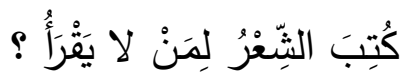

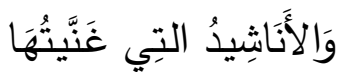
كُلَّ حِينٍ .. فِي شِفَاهِيَ تَظْمَأُ

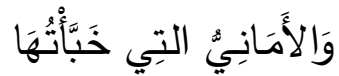

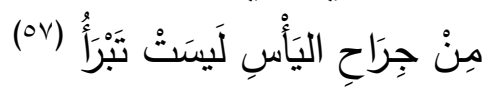

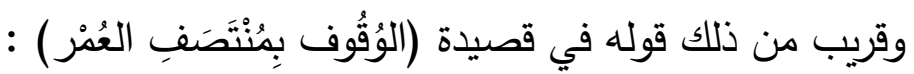$$
\text { بِمُنْتَصَفِ الطَّرِيقِ نَزَفْتُ عُمْرِي }
$$

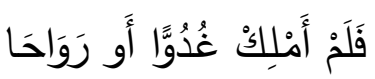

وَكَيفَ يَرُوقُ لِِلََطْيَارِ أُفْقُق

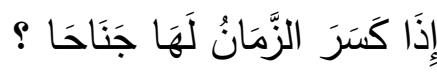




\section{وَكَيفَ لْزَورَقِ الأَحْلامِ يَجْرِي}

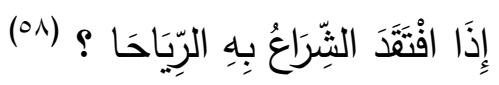

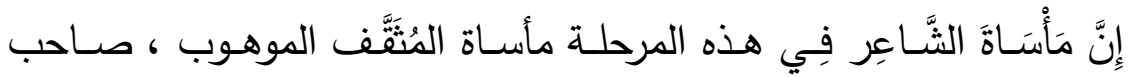

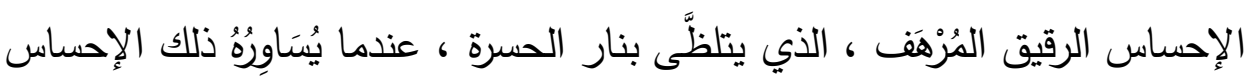

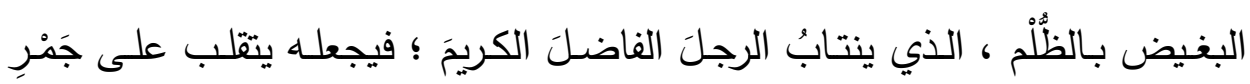

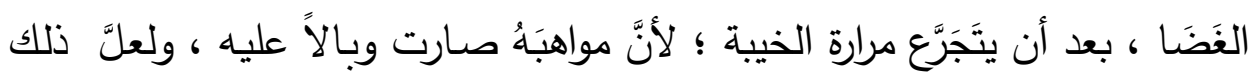

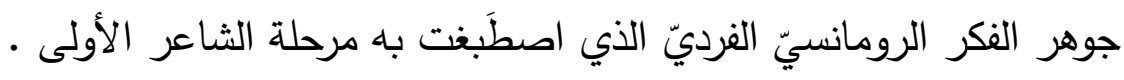

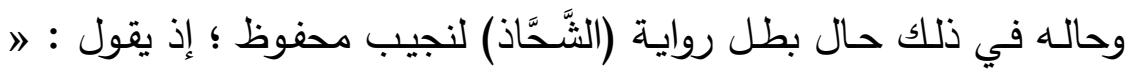

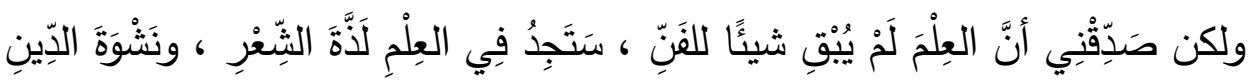

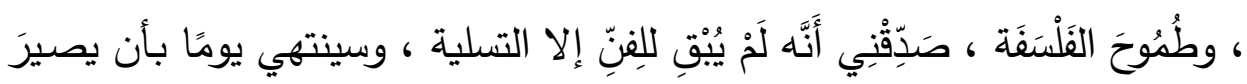

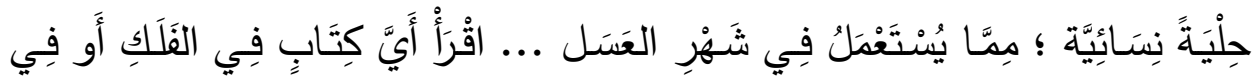

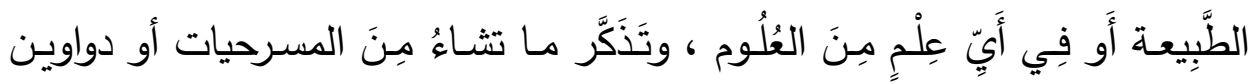

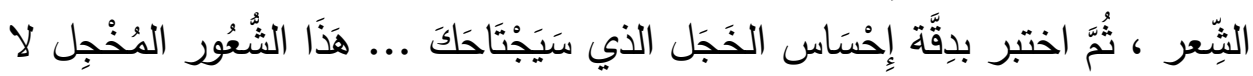

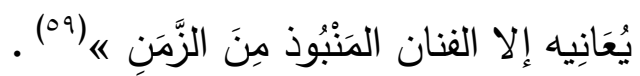

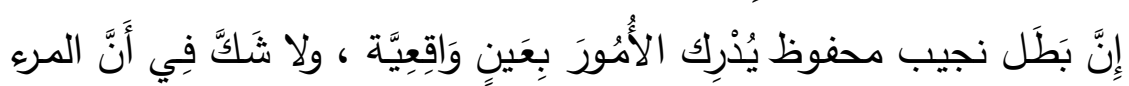

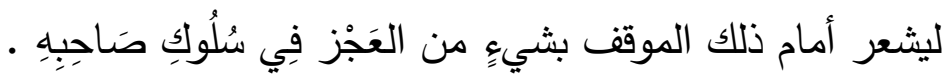

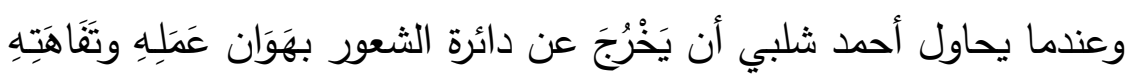

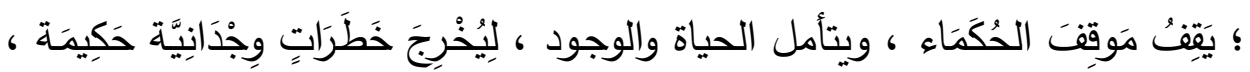

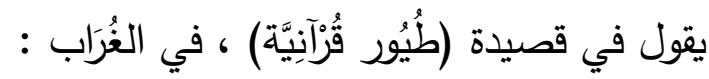

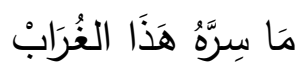

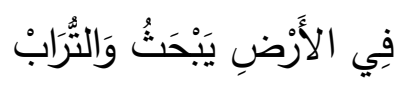

وَعَلَيهِ رِيشُ أَمْوَدُّ

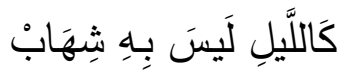


مَا سِرِهُهُ هَذَا الغُرَابْ ؟

بنَعِيِِِهِ الَبَاكِي شَجَنْ

وَعَلَيهِ أَلْوَانُ الحَرَزْنْ

أَتَرَاهُه يَنْعَى رَاحِلاً

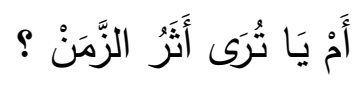

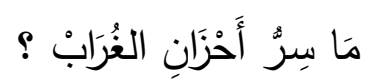

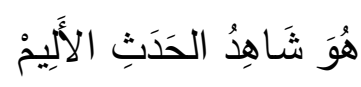

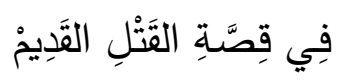

لَمَّا ابْنُ آدَمَ قَادَهُ

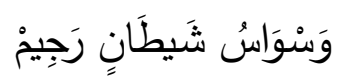

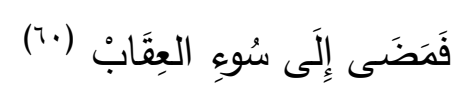

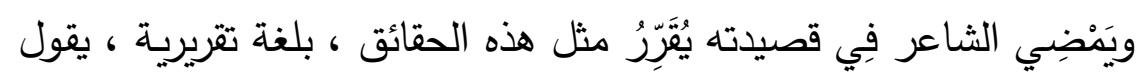

في (الهُدْهُدُ) :

أَنَا أُحِبُّ الهُدْهُدَا

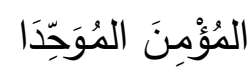

الطَّائرَ المُغَرَدَا 


$$
\text { يَذْعُو إلََلى الإِيمَانْ }
$$

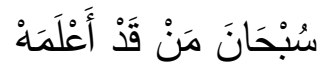

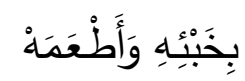

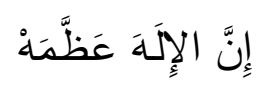

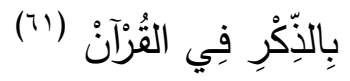

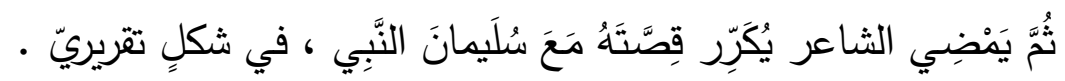

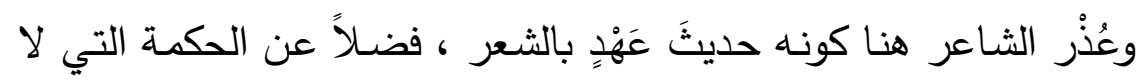

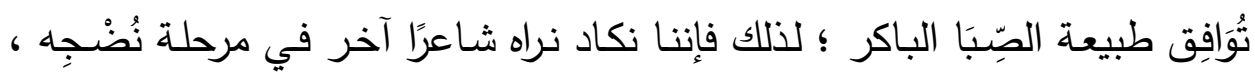

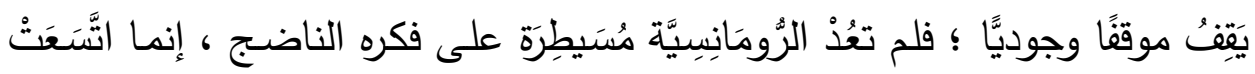

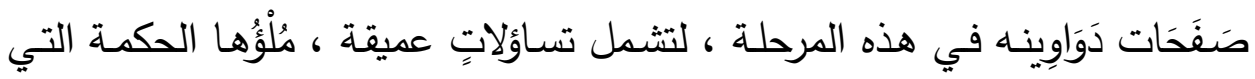

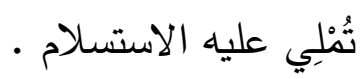

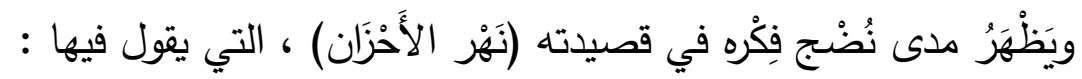

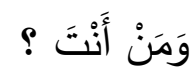

مَا عُدْتَ أَنْتَ الذِّي

$$
\begin{aligned}
& \text { هَوَاهُ }
\end{aligned}
$$

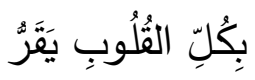

سَرَابًَا

تَرَاءَيتَ لِلِظَّامِيَيْنَ

وَحُلْمًا

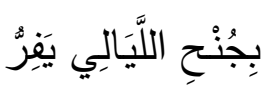


وَكَيفَ

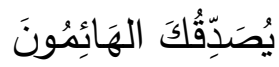

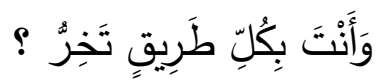

فَيًَا نَهْرَ حُزْنِ

سَرَى فِي الإدمَاءِ

كَفَالكَ ،

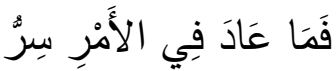

$$
\begin{aligned}
& \text { فَمَرْ بِوَقَتِتَكَ مِنْ أَيّ بَابٍ } \\
& \text { وَكُنْ }
\end{aligned}
$$

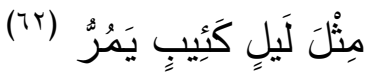

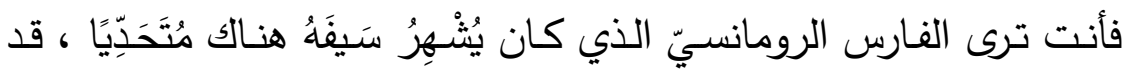
ترجَّل أخيرًا ، وأغمـد السيف ، وأتىى باللائمسة على نفسـهـ ، حين أدرك أن الأمسور

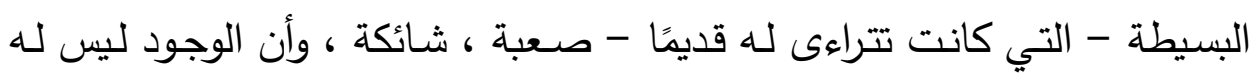

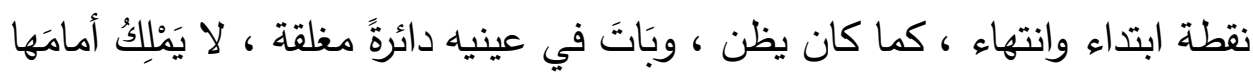

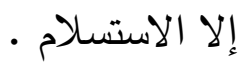

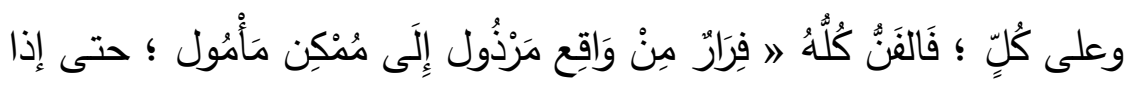

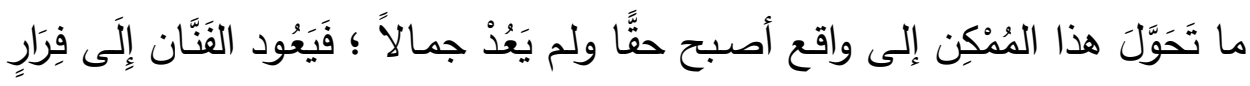

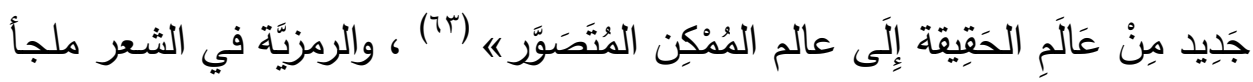

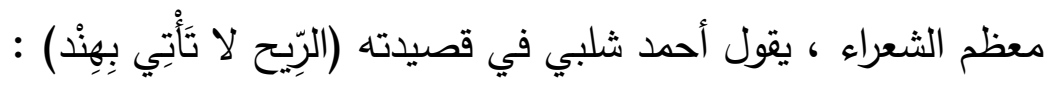

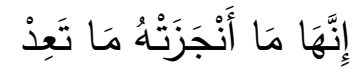

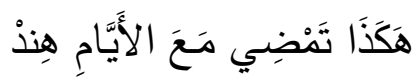




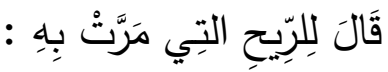

$$
\begin{aligned}
& \text { بَلِّنِي: }
\end{aligned}
$$

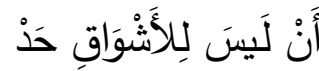

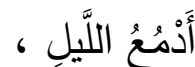

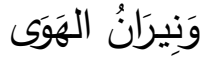

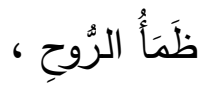

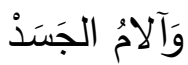

\section{تَعَبْ حُبَلْتَتُهُ مِنْ أَجْلِهَا

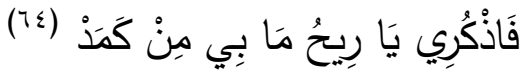

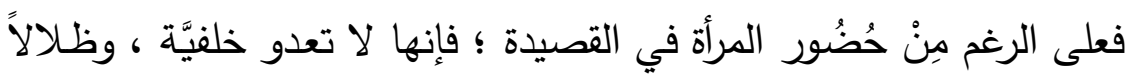

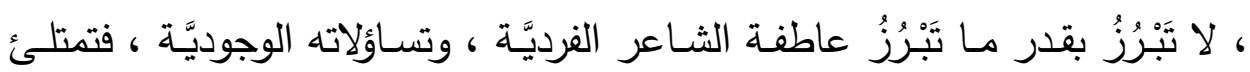

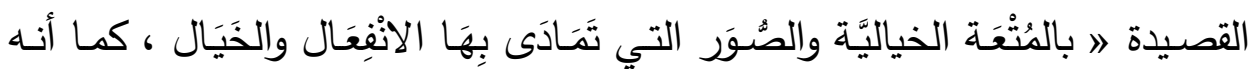

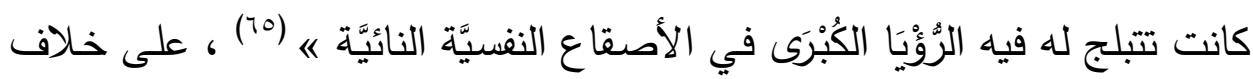

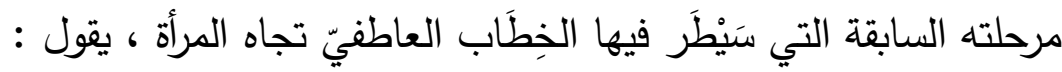

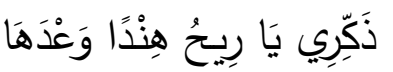

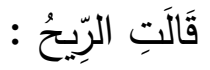

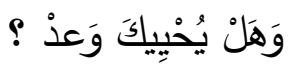

قَالَ :

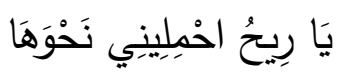

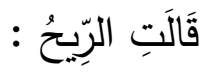

وَهَنْ 


$$
\begin{aligned}
& \text { أَو } \\
& \text { أَينَ هِنْْ ؟ } \\
& \text { قَالَ : } \\
& \text { ، يَا رِيِحُ قِفِي : }
\end{aligned}
$$

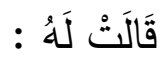

$$
\begin{aligned}
& \text { هِيَ نَجْمُ } \\
& \text { لَمْ يَلْحْ - فِي الَلَّلِِ- بَعْْ }
\end{aligned}
$$

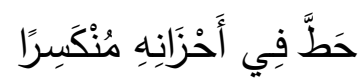

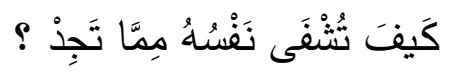

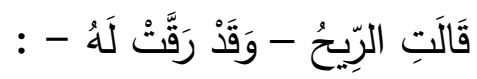

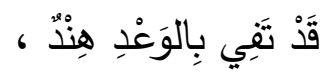

$$
\begin{aligned}
& \text { قَالَ : } \\
& \text { قَدَ }
\end{aligned}
$$

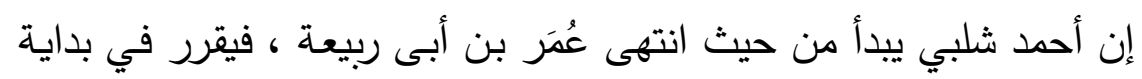

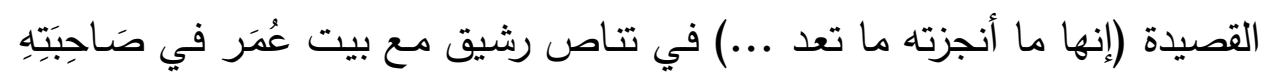

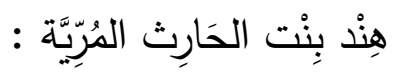

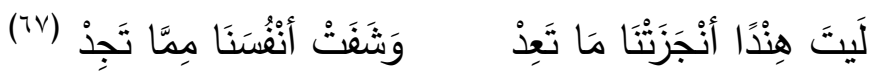

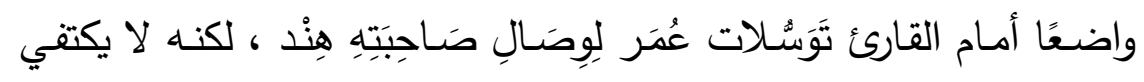

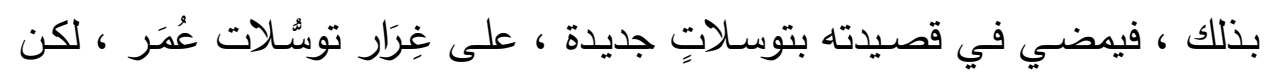

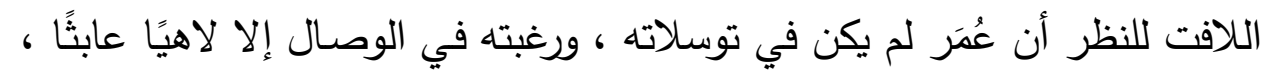
يقول : 


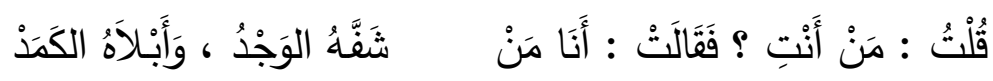

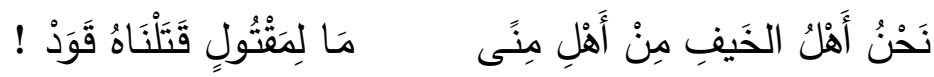

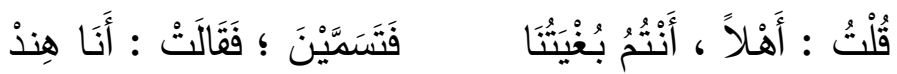

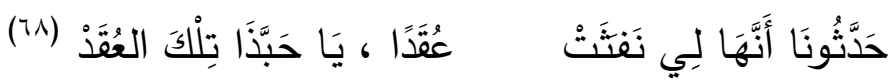

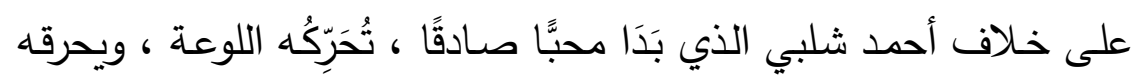

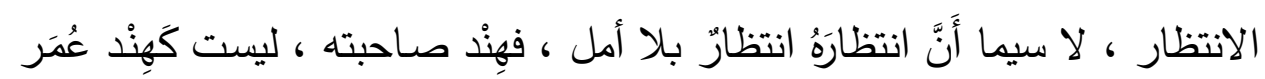

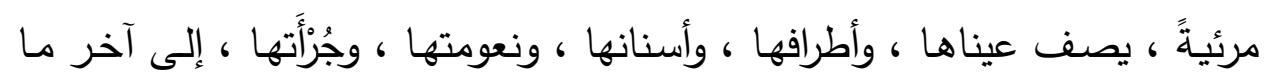

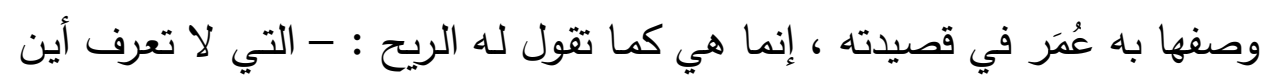

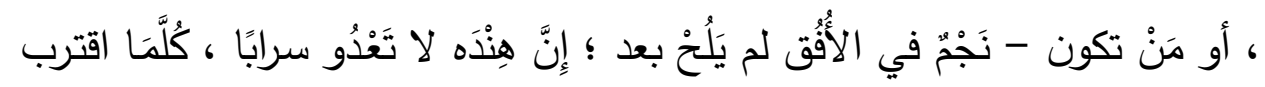
منه الثاعر ابتعد . من لكرن

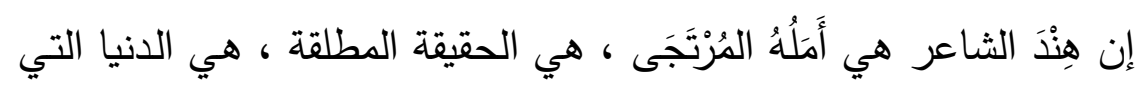

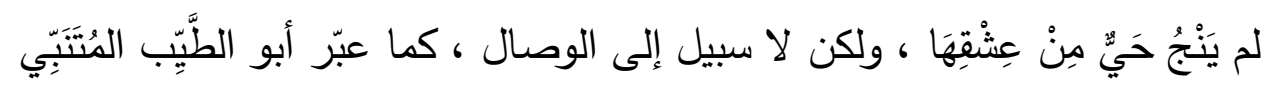

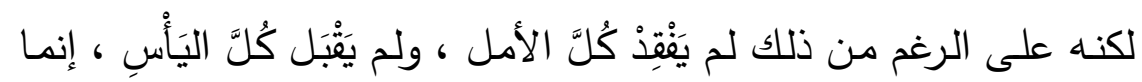

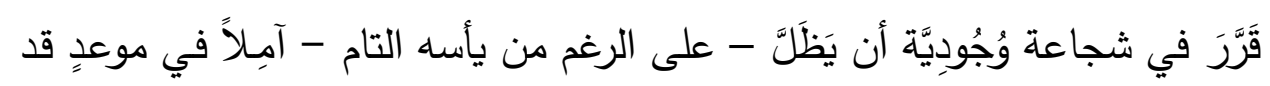
يجيء.

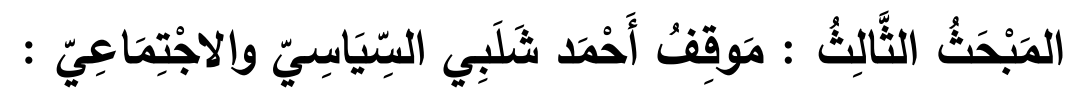

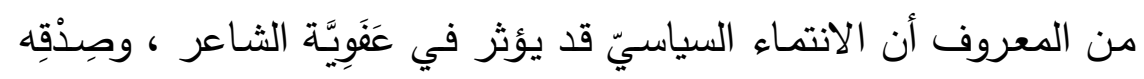

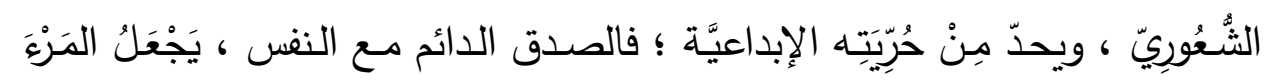

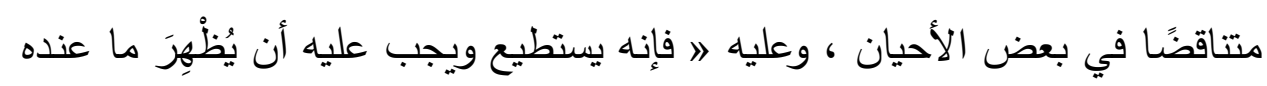

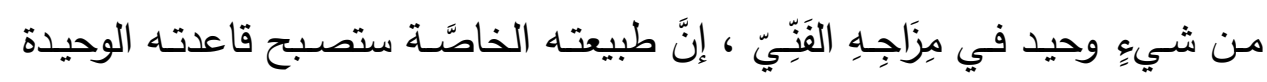

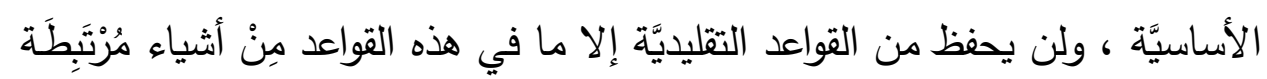

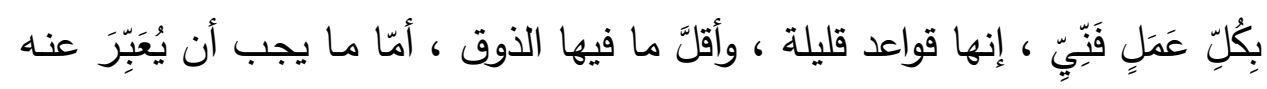

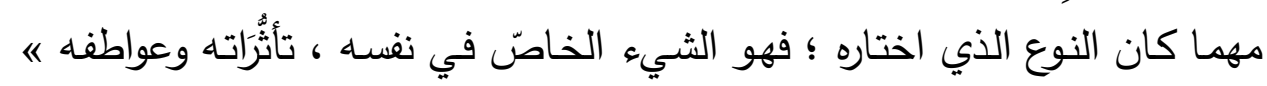


(19) ؛ لذلك فحين يتعاطى الثـاعر أمور السياسـة ، يجب أن يكون حَذِرًا ؛ لأنَّهـ

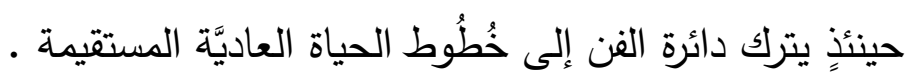

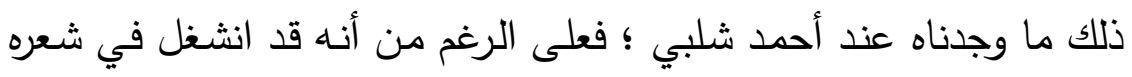

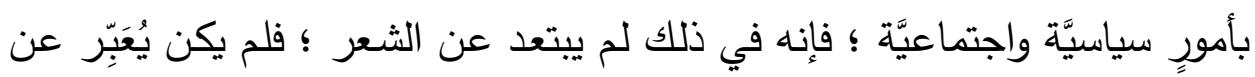

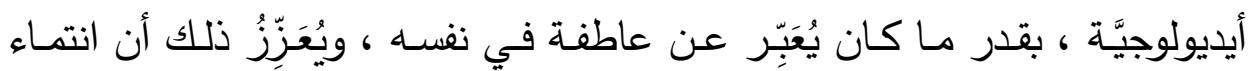

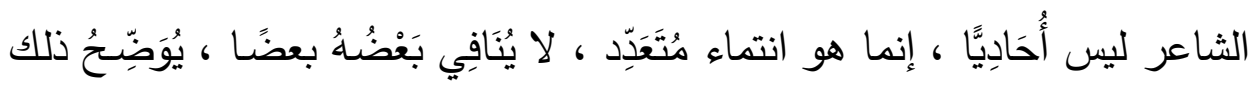

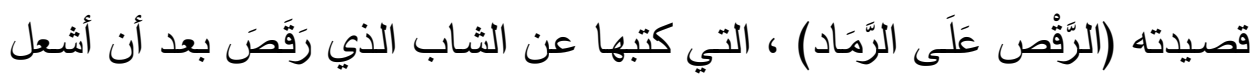

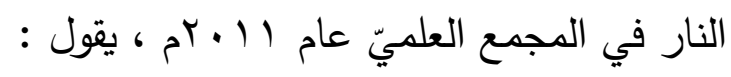

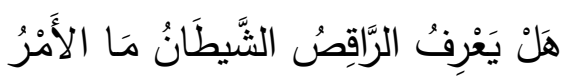

$$
\begin{aligned}
& \text { مَا الثََّعْبُ .. } \\
& \text { مَا نَبْتُ هَذِي الأَرْضِ . . } \\
& \text { مَا مِصْرُ }
\end{aligned}
$$

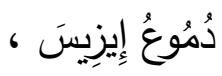

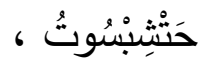

$$
\begin{aligned}
& \text { حُورَس ، رَعْ حَّن } \\
& \text { حَابِي ... } \\
& \text { وَمْمُسَى ... } \\
& \text { أَخْنَاتُون ... } \\
& \text { وَالخِضْرُ }
\end{aligned}
$$




\section{رِحْلَتَهُها}

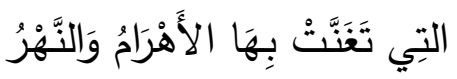

$$
\begin{aligned}
& \text { نَثِثَيُُ آمُونَ ... } \\
& \text { مَارِي جِرْجٍِ ... } \\
& \text { عَنَبَاتُ جَرْ } \\
& \text { الجَامِيعُ الأَزْهَرِ }
\end{aligned}
$$

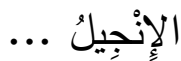

$$
\begin{aligned}
& \text { وَالأنِّكُرُ }
\end{aligned}
$$

$$
\text { مَا الثَّافِعِيُّ ... }
$$

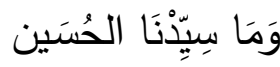

$$
\text { وَمَا }
$$

هَذِي المَتآذِنُ - إذذْ يَنْدَى بِهَّا الفَجْرُ

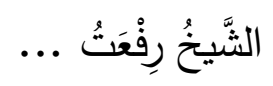

قُقَّاسُ الكَنَائس ..

$$
\text { شَدْوُ }
$$

أُمِْ كُلْثُوَ .....

إِذْ يُصْنِي لَهَا الطَّيرُ

$$
\text { شَوَِيَ ... }
$$


وَالعقَّاد ....

طَهَ حُسَين

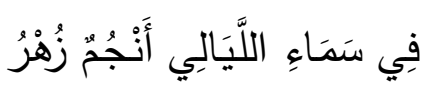

$$
\begin{aligned}
& \text { نَجِيٌُ مَحْفُوظ .... } \\
& \text { تَوفِيقُ الحَكِيم .... } \\
& \text { ومَنْ }
\end{aligned}
$$

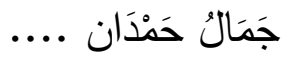

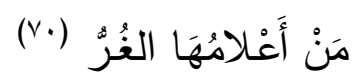

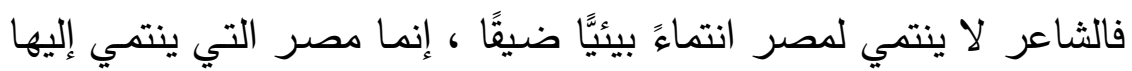

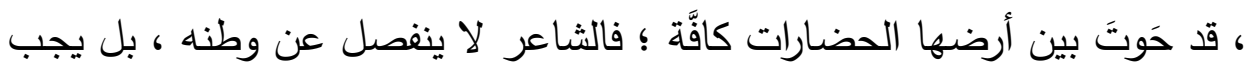

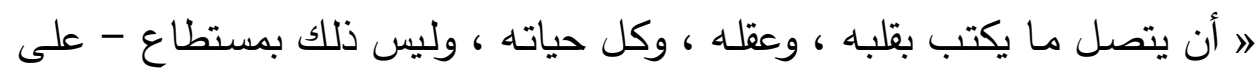

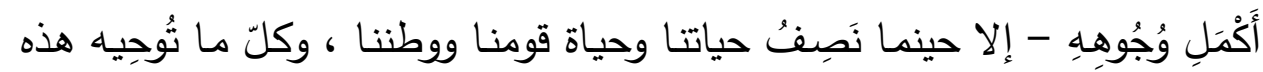

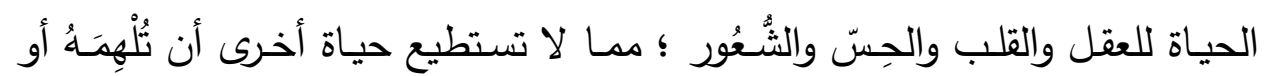

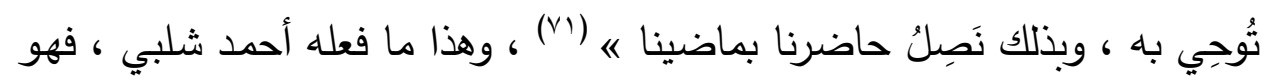

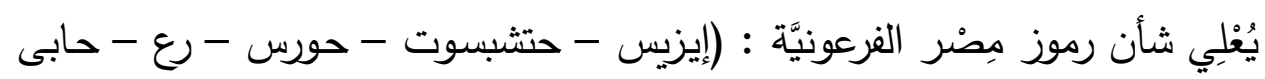

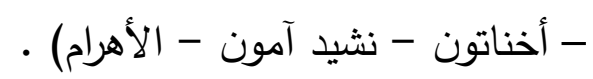

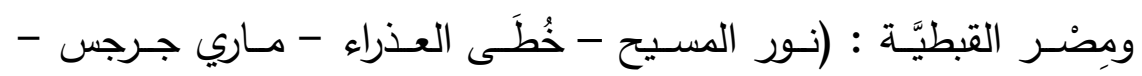
• (الإنجيل)

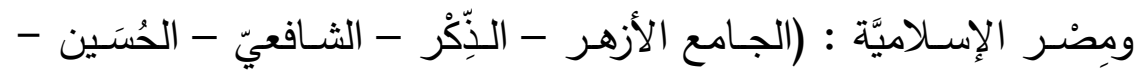

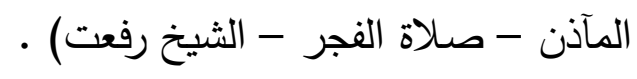

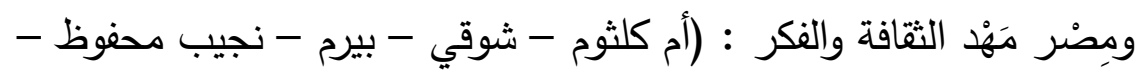

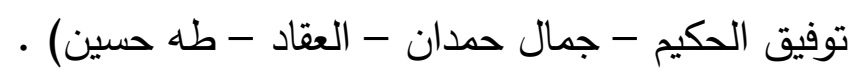




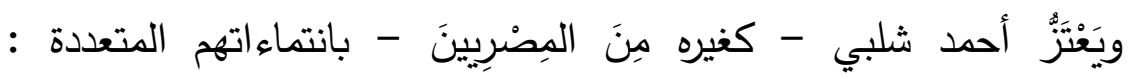

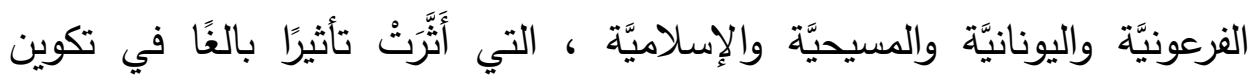

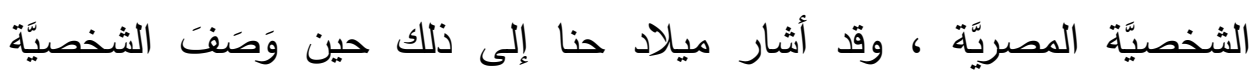

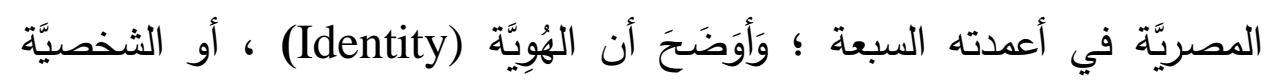

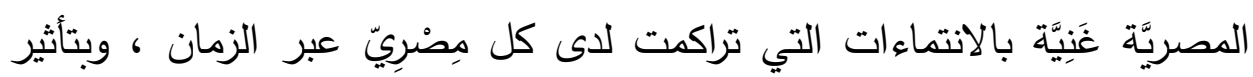

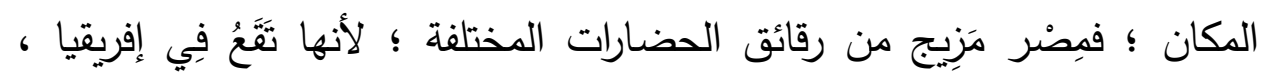

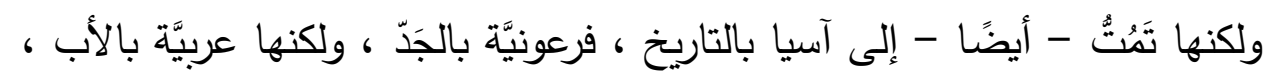

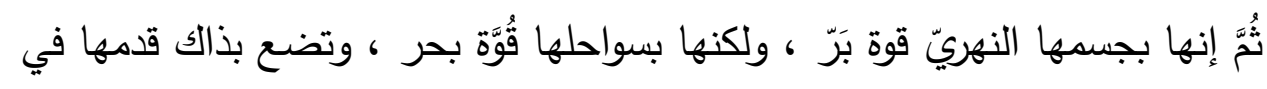

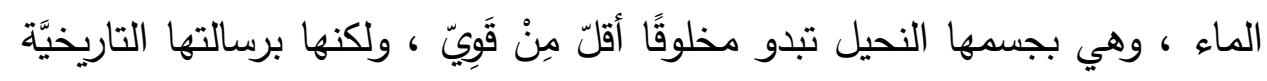

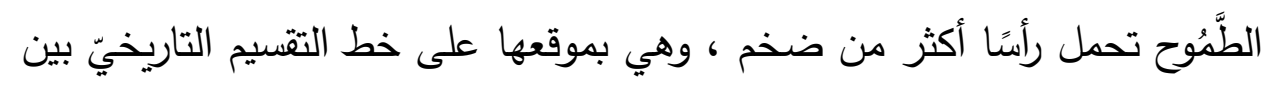

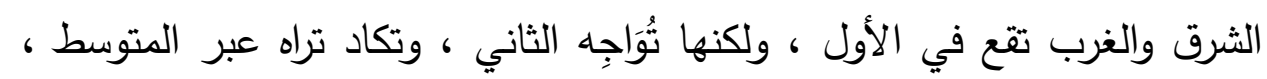

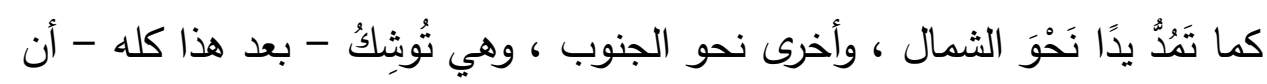

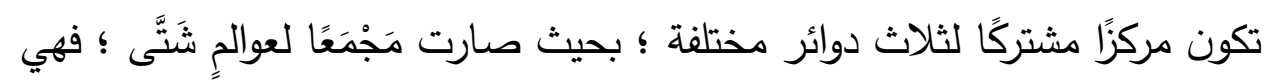

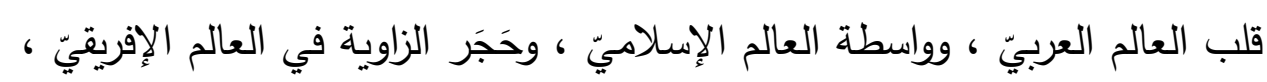

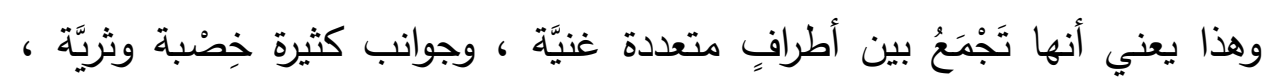

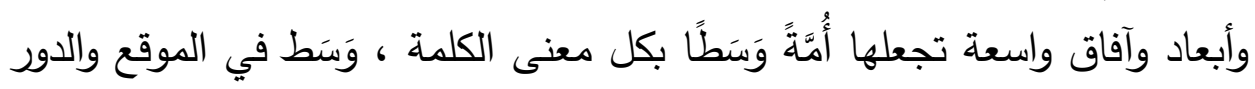

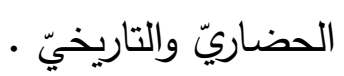
وعلى الرغم مِنْ 》 أن هذه الأعمدة داخلة في التركيبة الإنسانيَّة لِكُلِّ

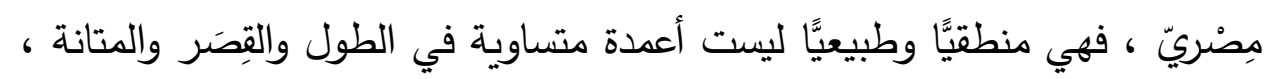

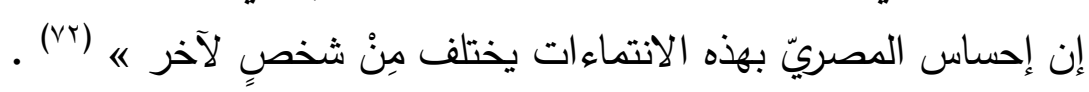

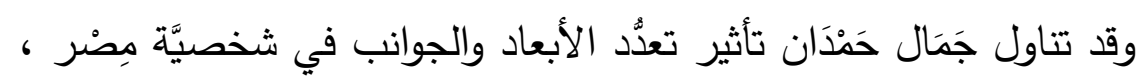

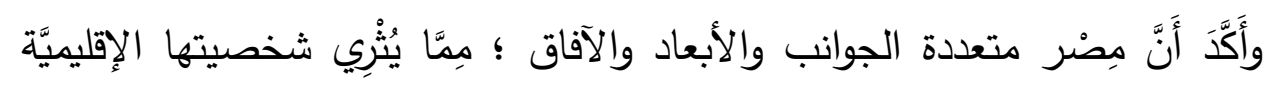

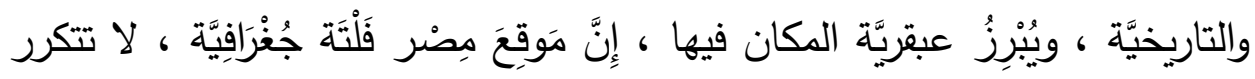

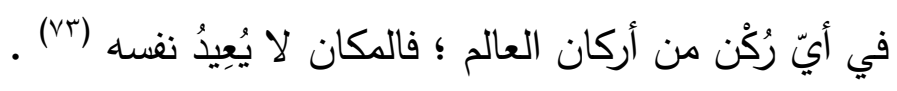




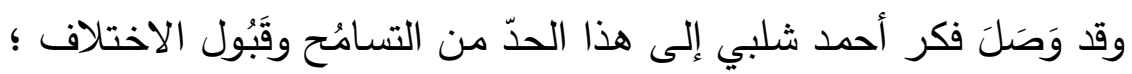

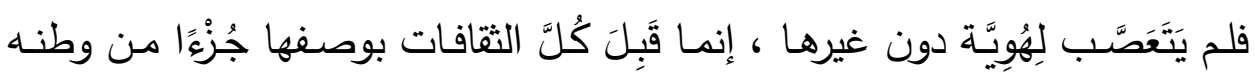
الكبير ، ذي التراث الحضاري الهائل .

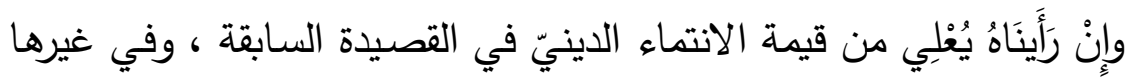
، كأن يقول في قصيدة (المَنَارة) :

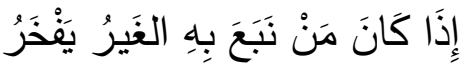

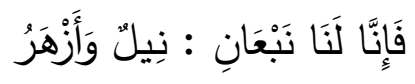

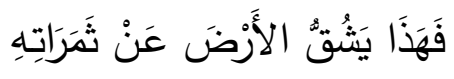

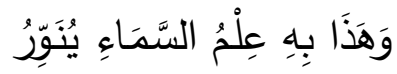

وَهَذَا عَلَى شَطَّيَهِ قَامَتَتْ حَضَارَةٌ

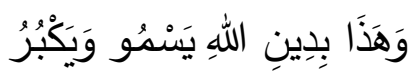

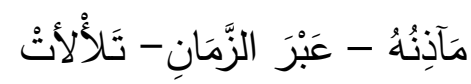

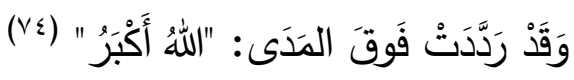

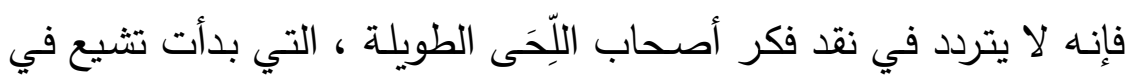

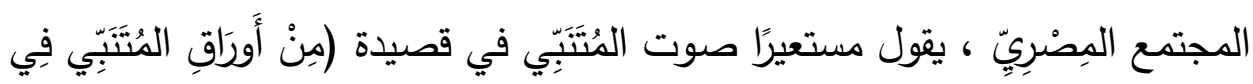
مَنْ للِمَجَازِرِ فِي زِيِّ الأَعَارِيبٍ ؟

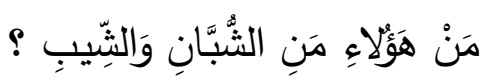
مِصْر) :

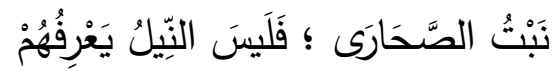

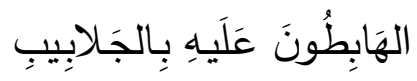




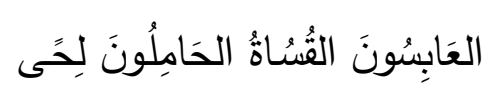

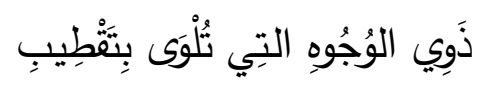

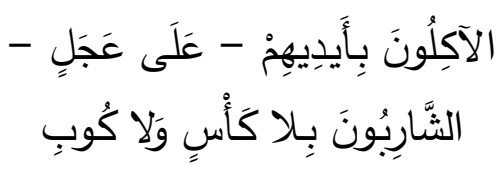

- النَّاكِحْونَ رِبَابعًا - دُونَمَا خَجَلٍ

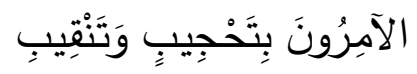

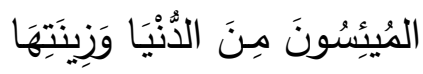

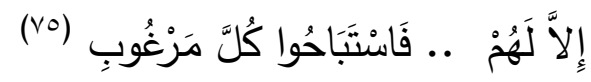

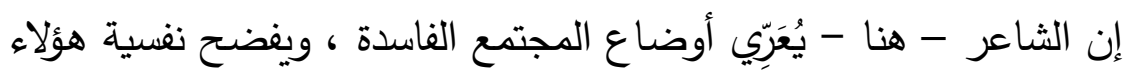

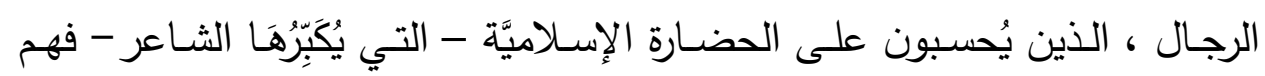

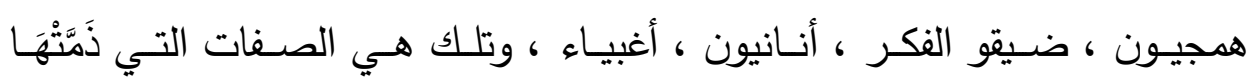

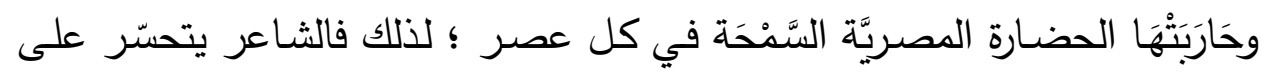
شيوع هذه الظواهر ، يقول في قصيدة (مَرْبنيَّة فِي حَفْلِ غِنَّاء) :

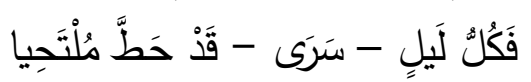

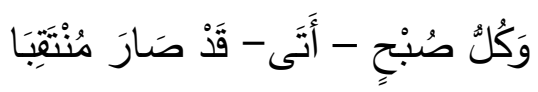

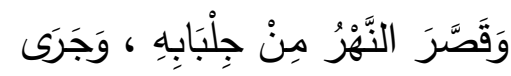

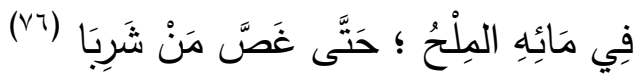

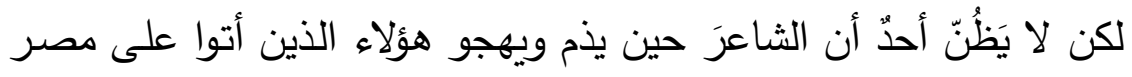

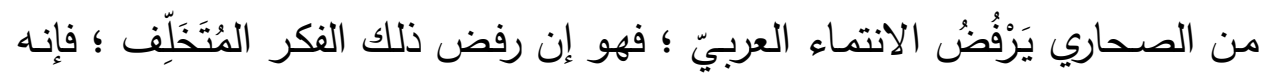




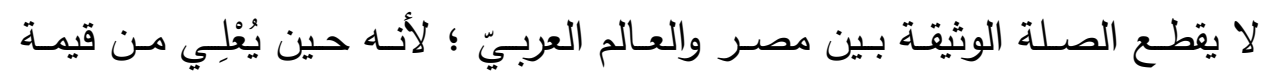

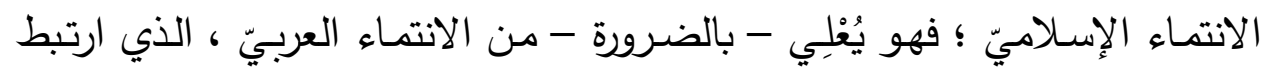

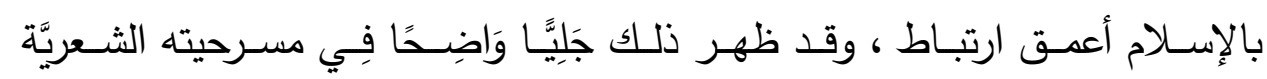

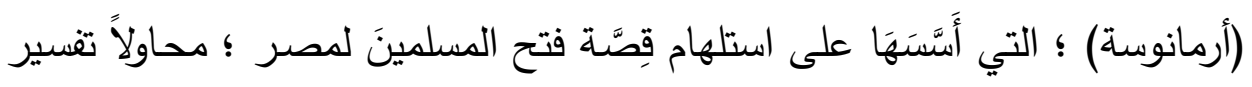

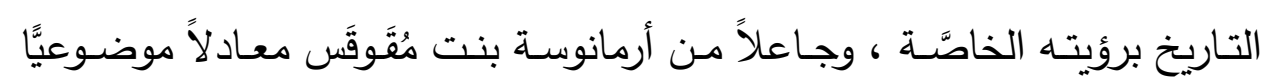

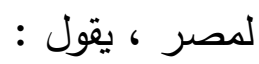
أََْمَانُوسَنة

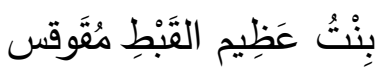

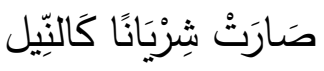

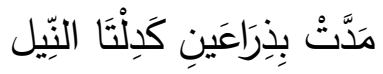

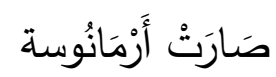
نَنْعًا يُنْبِقِي

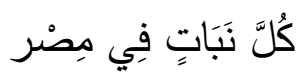
وَكُكلَ نَخِيل

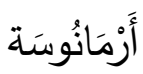
صَارَتْ وَطنًَا صَارَتْت زَمَنَا صَارَتْت مَهْدًا أَبَِِيَّا لِضِيَّاءِ الحَقِّ بوَادِي النِيّل

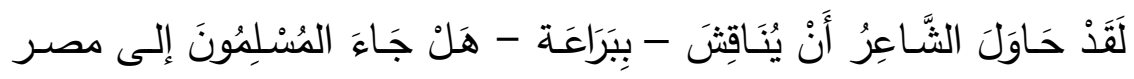

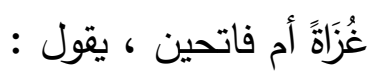

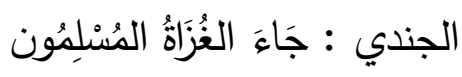

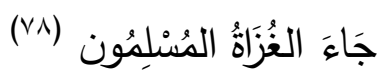




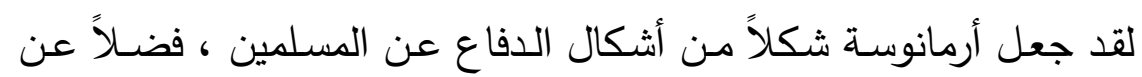

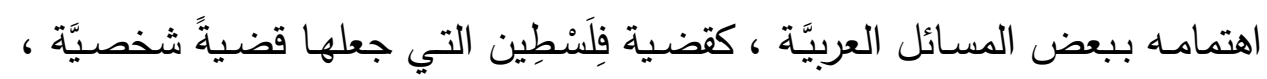

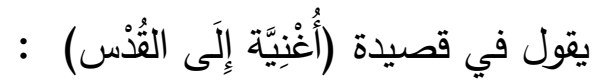

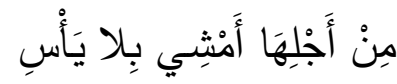

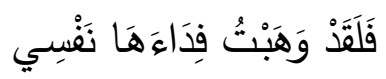

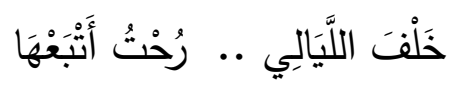

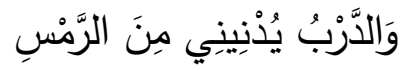

لا شَيََ مِنْ زَادِ الحَيَاةِ مَعِيِ

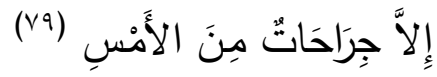

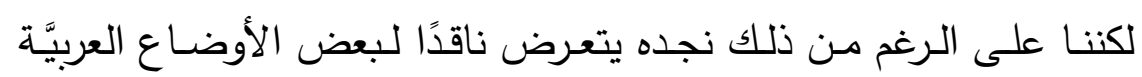

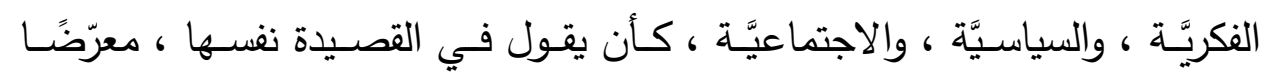

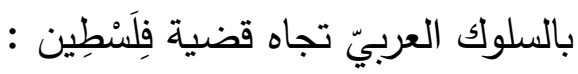

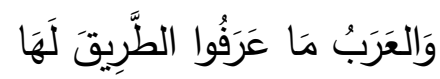
مِنْ خَزْرَجِ كَانوا .. وَمَنْ أَوسِ يَا مَنْ مَكَتْنُمْ فِي مَقََابِرِكُمْ

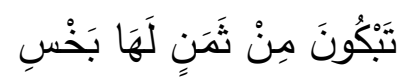

يَا مَنْ حَمَلْتُمْ عَارَكُمْ عَلَنَا

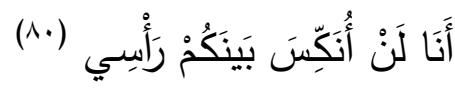

ويقول في قصيدة (الَّنوم عَلَى خَارِطَة الطََِّيق) : عَبَاءَاتُ خَوَاءُ مِنْ رِجَالِ 


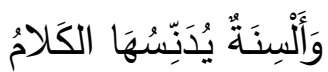

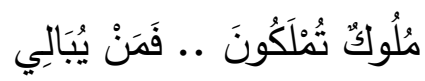

بِمَا يُلْقِيهِهِ فِي الوَطَنِ الحِمَامُ

سَلامُ أَيَهُها العَرَبُ الكِرَاُم

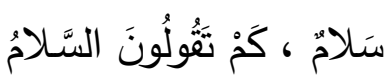

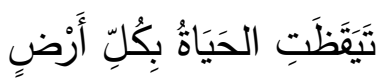

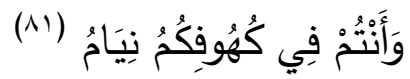

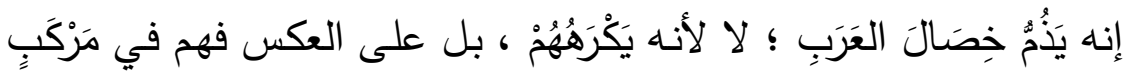

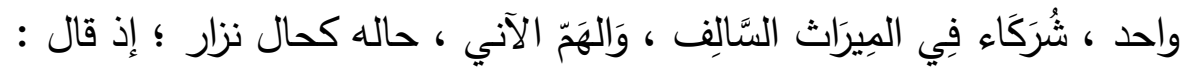

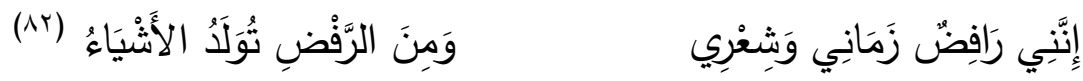

وَقَّال :

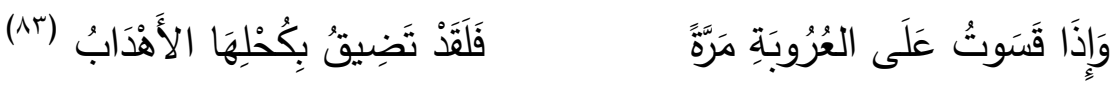

لكن الثاعر وإن بََا نقده مباشرًا في هذه القصائد التي تتنمي إلى مرحلته

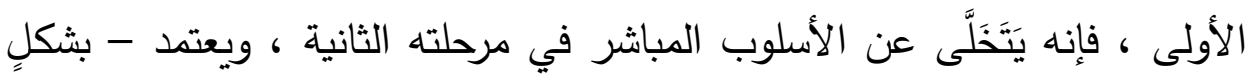

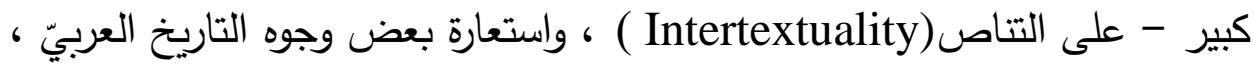

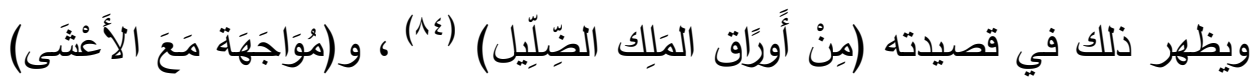

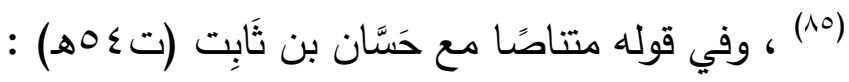

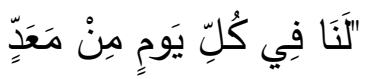

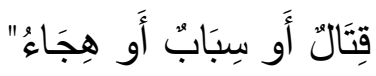

فَلا كُنَّا ... وَلا كَانتْ مَعَدْ

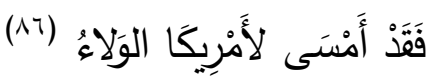

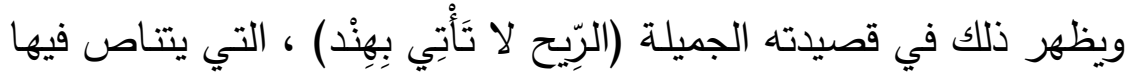

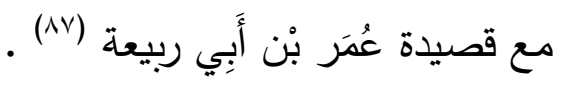




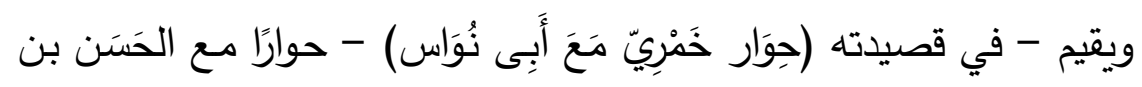

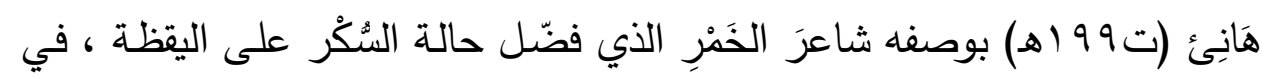

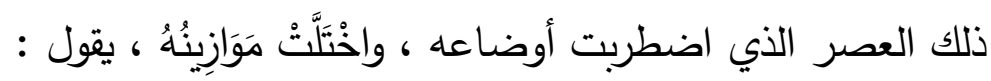

قَالَ :

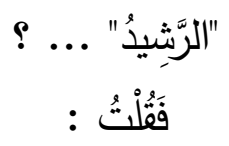

الرُرَتُنْ فَارَقَهُ

عَلَى جَنَاحِ الَهَوى فِي بِرْبِ مَنْ جَنَحُوا

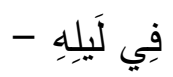

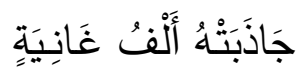

وَتَحْتَ أَقَقَمَامِهِ

وَاشٍِ وَمْنْنَتَحُح

فَفَّالَ :

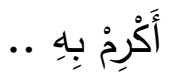

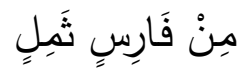

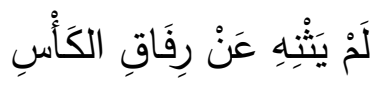

مَنْ جَمَحُوا لِقِ

: فَفُلْتُ

لَمْ تَنْْهِه فِي القُدْسِ فَاجِعَةُ

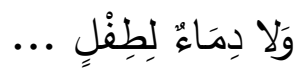

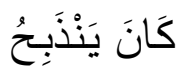




$$
\begin{aligned}
& \text { قَالَ : } \\
& \text { الأَثَنَاوُِ .. ؟ ؟ }
\end{aligned}
$$

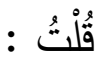

$$
\begin{aligned}
& \text { الرُرعْبُ أَنْكَكَهُهُم } \\
& \text { فَلا يُبُوخُونَ }
\end{aligned}
$$

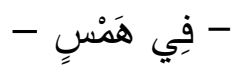

$$
\begin{aligned}
& \text { بِمَا لَمَحُوا } \\
& \text { *** } \\
& \text { قَالَ : } \\
& \text { القَبَائلِلُ .. ؟ ؟ } \\
& \text { : } \\
& \text { النِنْطُطُ أَغْرَََهَا } \\
& \text { وَإِنَّ أَعْرَابَهَا فِي مَوجِهِ سَبَحُوا }
\end{aligned}
$$

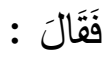

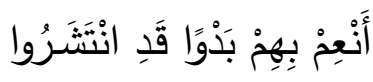

خَلَفْتَ الغَوَانِي ..

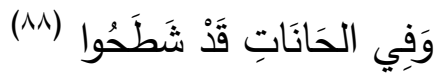

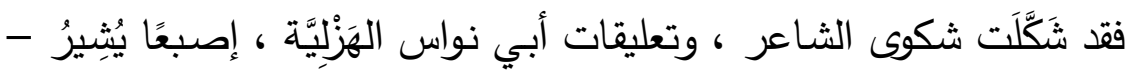

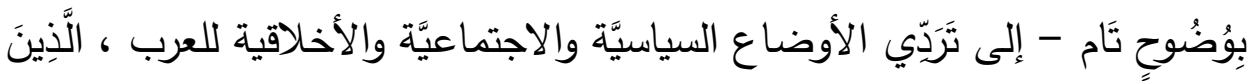

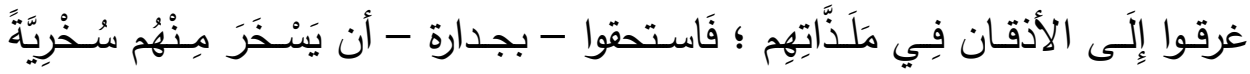

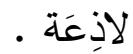

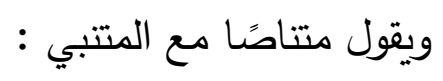




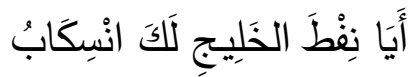

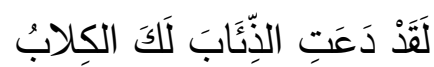

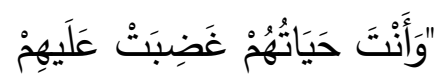

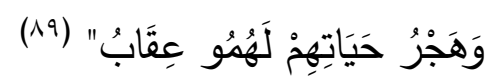

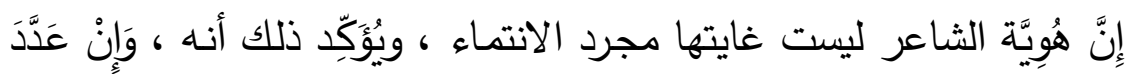

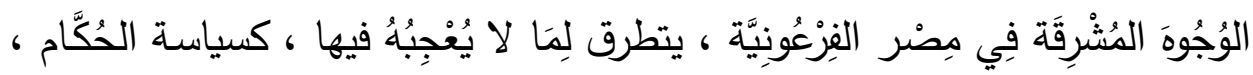

يقول في قصيدته (بَرْدِيَّات) :

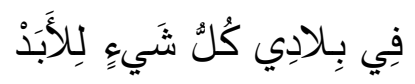

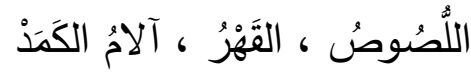

قَبَنَةُةُ الحَاكِمِ فِي سَطْوَتِهِ

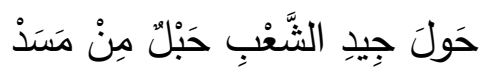

فِي بِلادِ البَجْرِ وَالنَّْْرِ

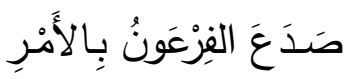

قََالَ : إِنَّ النَّهْرَ لِي

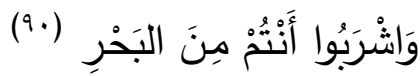

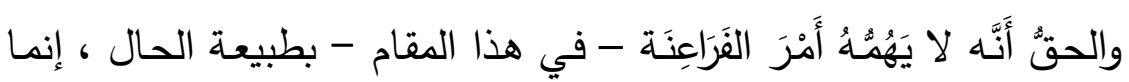

هو يُعَرِض بالحاكم العصريّ لمصر ، وسياسته .

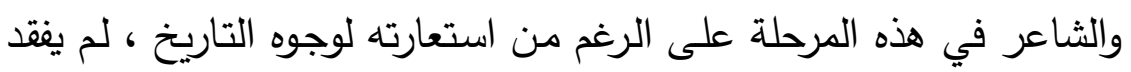

الوضوح اللازم ، الذي يتطلبه الخطاب التثويري . 


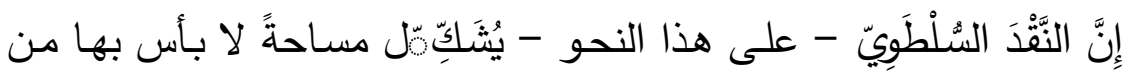

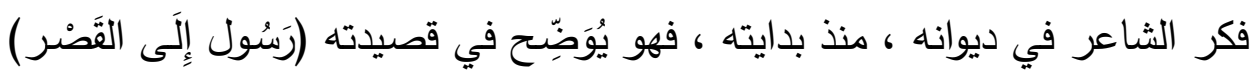

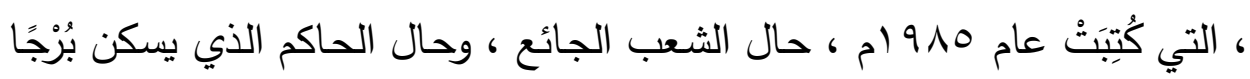
عَاجِيًا كما يقولون ، يقول :

$$
\begin{aligned}
& \text { دَعْنِي إِلَيكَ - مَرَّةً - أَدْخُلُ }
\end{aligned}
$$

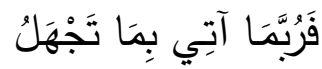

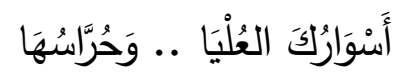

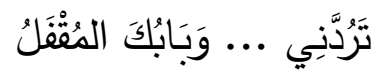

وَأَلْنُ حَاجٍِ شَدِيدُ الُْوَى

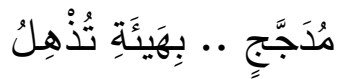

وَأَنَنَ مِنْ بُرْجِكَ لا تَنْزْلُ

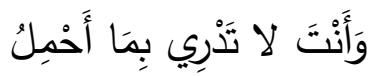

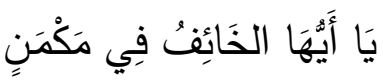

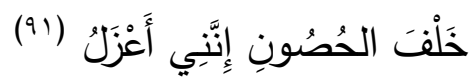

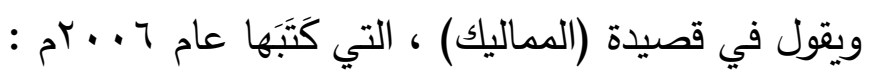

المَتَّالِيكُ

وَالَمَتَالِيكُ كُتُرُ

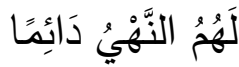

وَالأمنْ 


$$
\begin{aligned}
& \text { لَكَهُمُ الحَبُّ } \\
& \text { وَالنََّّى } \\
& \text { وَالَبَرَارِي } \\
& \text { لَهَهُمُ الَبرَّ } \\
& \text { وَالرُربّا } \\
& \text { وَالَبَحْرُ } \\
& \text { وَقِلاعُ حَصِينَةُ ... } \\
& \text { وَخْيُولْ } \\
& \text { وَسَيُوْنَ وَنَ } \\
& \text { وَعَنْنْوَانْ }
\end{aligned}
$$

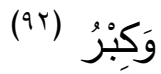

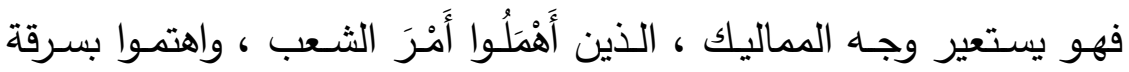

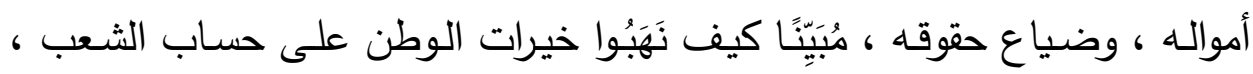

$$
\begin{aligned}
& \text { الذي وصفه - في نهاية القصيدة - بقوله : } \\
& \text { الرََّعَايًا } \\
& \text { تَهَبابُهُمْ فِي بِلادٍ }
\end{aligned}
$$

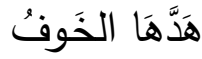

$$
\begin{aligned}
& \text { وَالطَّوَى } \\
& \text { وَالَْفْرُ }
\end{aligned}
$$$$
\text { فَيَتَّتَى }
$$

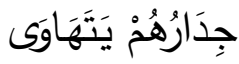$$
\text { وَكُنْوٌ }
$$ 


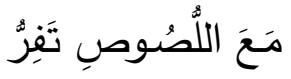

\author{
وَالمَتَاكِينَ فِي المَنَفِينَةِ

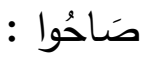 \\ أَيَنَ يَا مُوسَى فِي الزَّمَانِ الخِضْرُ ؟
}

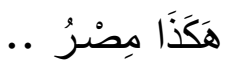

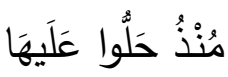

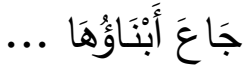

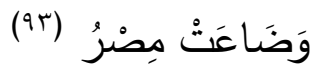

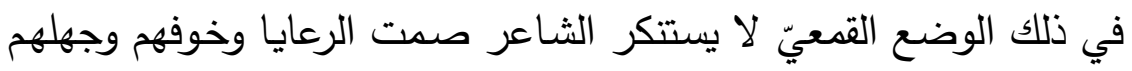

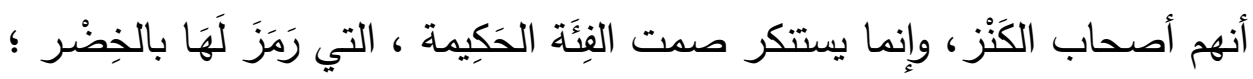

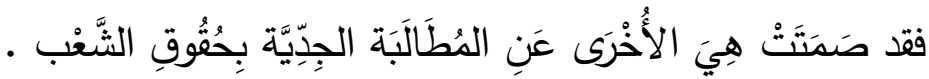

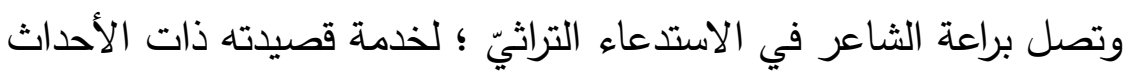

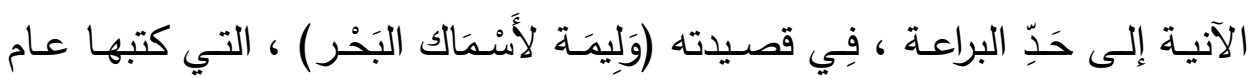

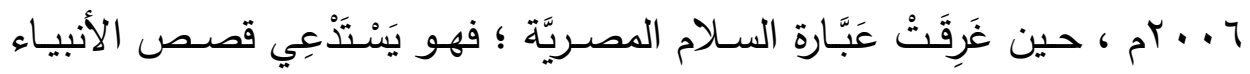

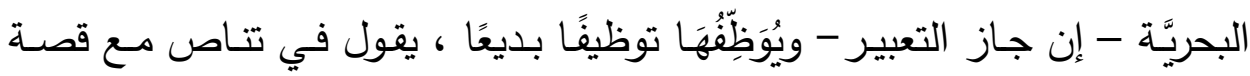

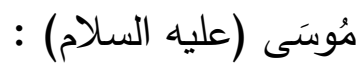

أَنَا لَسْتُ مُوسنَى ، تَثْقُقُ عَصَاهُ

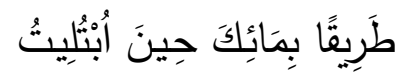

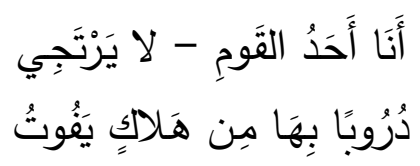




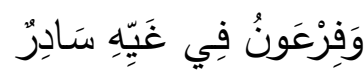

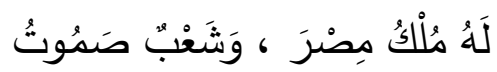

وَأَرَنسى لَهُ بَغْيَه المُرْجِفُونَ

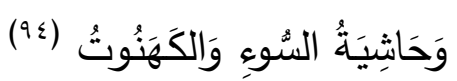

ويقول في تتاص مع قصة يُونُس (عليه السلام) في القصيدة نفسها :

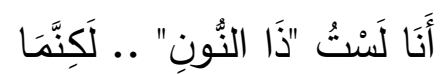

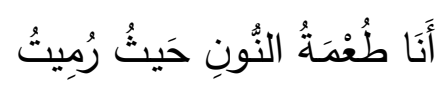

$$
\begin{aligned}
& \text { وَمَا عُدْتُ أَدْرِي . . بَأَيَّةِ بَطْنِ }
\end{aligned}
$$

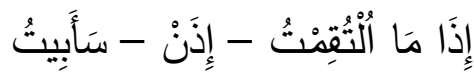

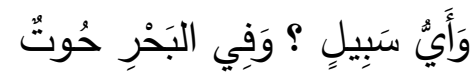

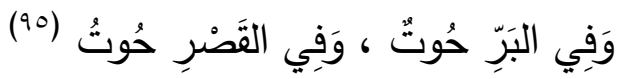

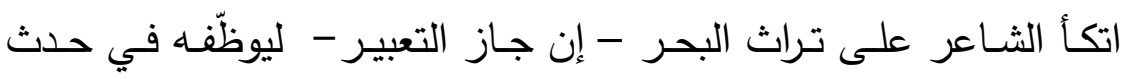

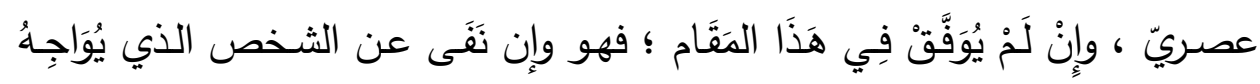

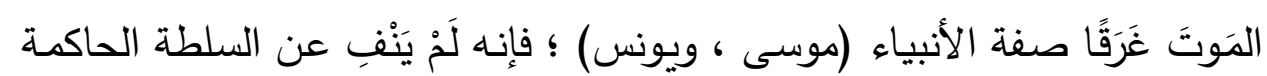
صفة الفرعون ، والحوت .

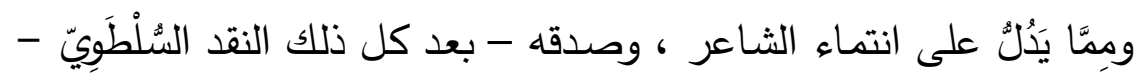

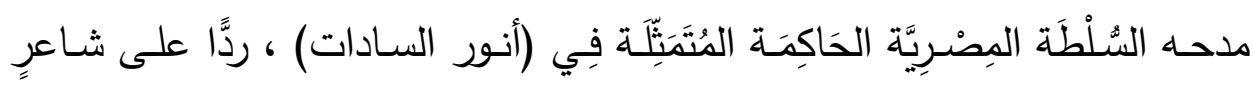

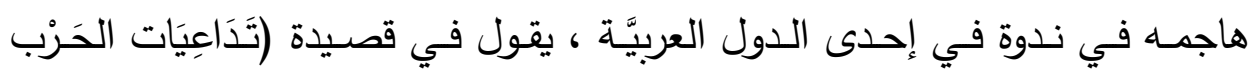
والسَّلام) :

أَيَهْها الفَارِسُ الجَلِيلُ

سَتَنْفَّى 


$$
\begin{aligned}
& \text { مِِفْلَا - كُنْتَ } \\
& \text { فَارِسَا وَجَلِيلا }
\end{aligned}
$$

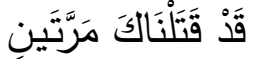

$$
\text { وَلَكَكْن }
$$

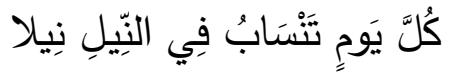

$$
\text { سَتِيَّ الحَرْبِ وَالَسَّلامِ }
$$

$$
\begin{aligned}
& \text { فَلكَّْ } \\
& \text { - زَيفًا - } \\
& \text { اتَّبَعْنَا غَوِيَّا } \\
& \text { وَلَكَّْ } \\
& \text { - جَهْلاً - }
\end{aligned}
$$

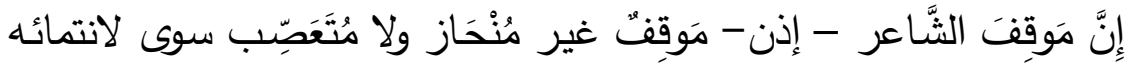

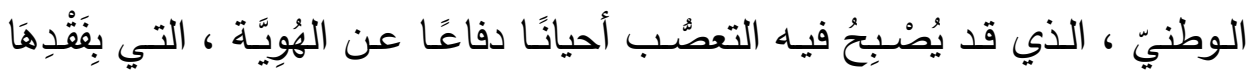

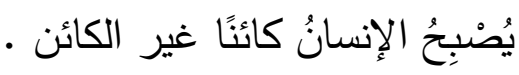

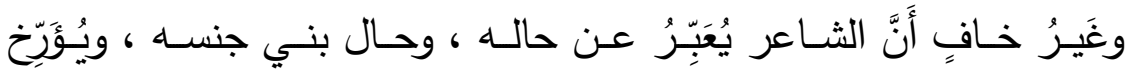

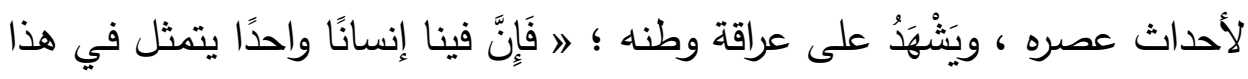

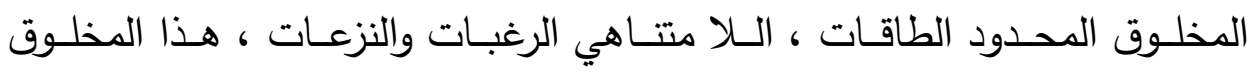

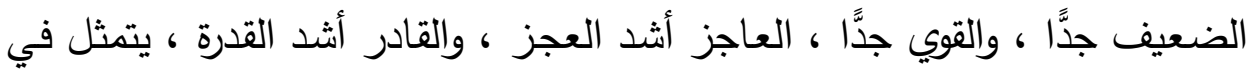


هذه الذات الإنسانيَّة التي تفرح وتحزن ، تخاف وتقلق ، تنتصر وتنهزم ، تحب

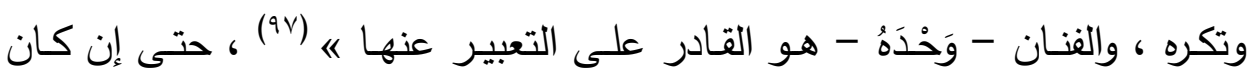

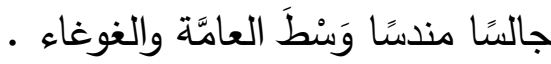

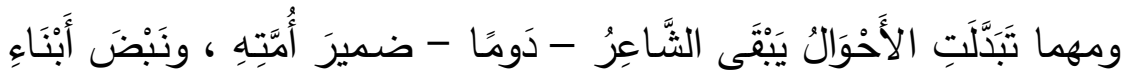

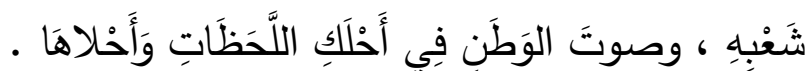

\section{الخَاتمة وَنَتَائعجُ الَبَحْثِ}

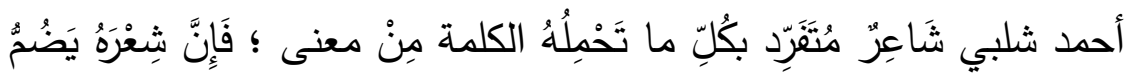

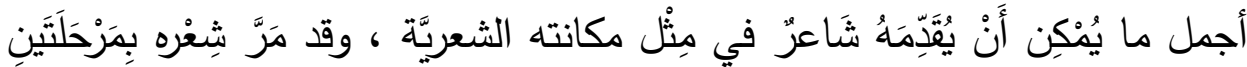

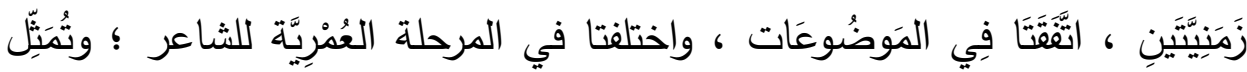

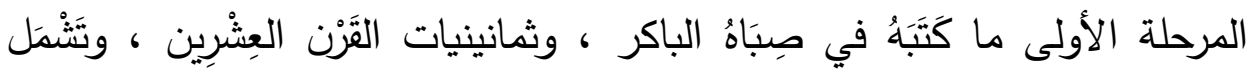
المرحلة الثانية القصائد التي كَبَّها في بداية الألفيَّة الثانية .

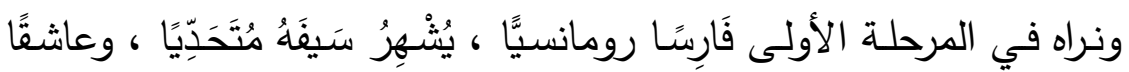
ولِيًَا ، ليس عليه من سلطان غير الوِ مِجْدَان ، وقد سيطر الخطاب العاطفيّ تجاه

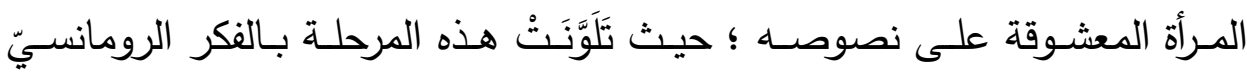

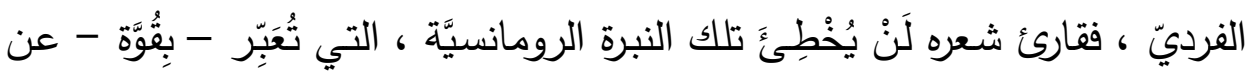

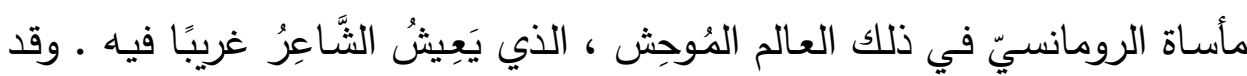

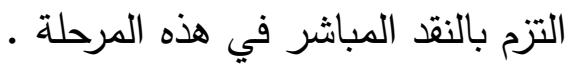

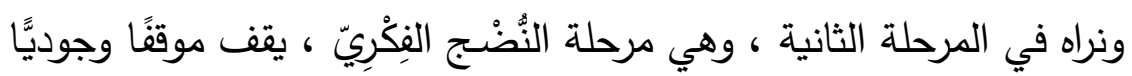

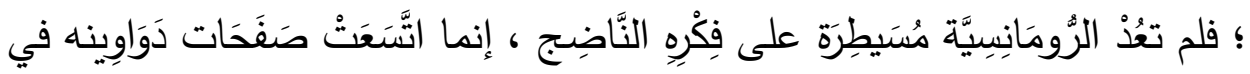


هذه المرحلـة ، لتشمل تسـاؤلاتٍ وجوديـة عميقة ، مُلْؤهـا الحِكْمَة التي تُمْلِي عليـه

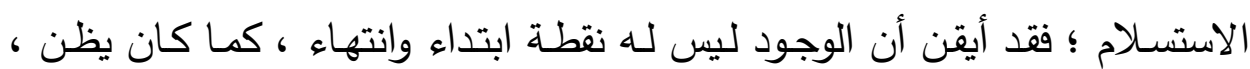

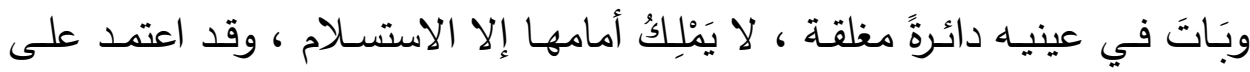
التتاص ، واستدعاء الحوادث التاريخيَّة في هذه المرحلة ، وعلى الرغم من ذلك لم لم يفقد الوضوح اللازم الذي يتطلبه الخطاب التثويريّ ـ وقد استوعبت هاتين المـرحلتين ثلاثة مباحث ، وتتاول المبحث الأول :

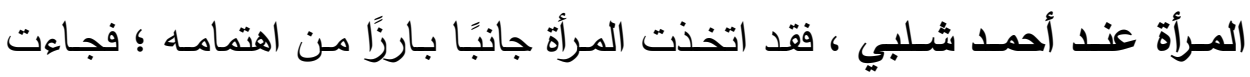
قصائده عنها في ثلاثة اتجاهات ، صَوََّ الاتجاه الأول : موقفهـ من المرأة ؛ فنراه

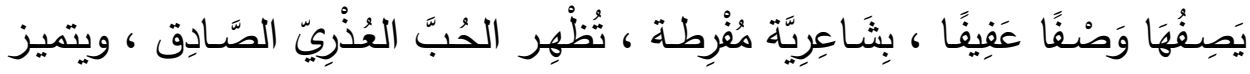

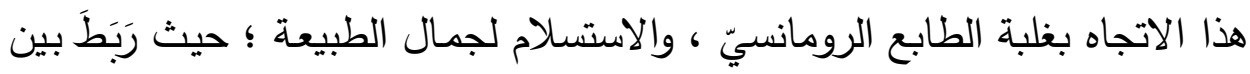

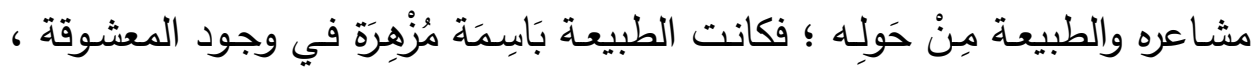
وعابسة قاحلة في غيابها . وعَرَضَ الاتجاه الثاني : الحُبّ الثقافيّ للمرأة ؛ فلم تقتصر نظرته للمرأة

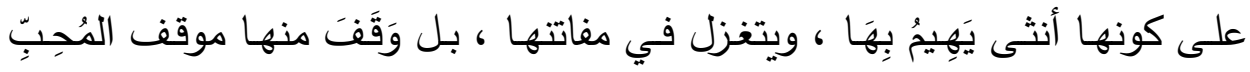

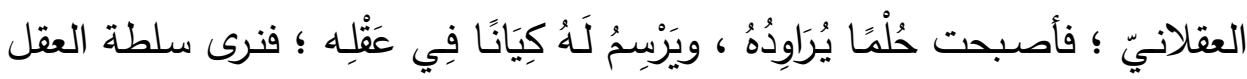

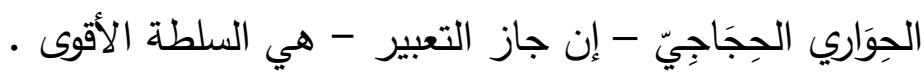

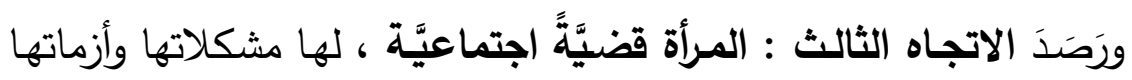
وأحلامها صعبة المنال في مجتمع ذكوري يَجْحَدُ فضلها ويتتاساها ، لقد استوقفته قضايا المرأة ؛ فجاءت بعض أشعاره على لسان حال المرأة في المجتمع المصريّ ،

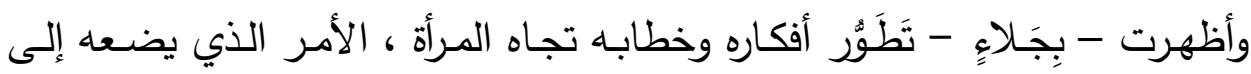
جانبـ الأدبـاء الذين اشتهروا بإنصـاف قَضِيَّتها ، والـدفاع عنهـا ؛ فلم يكن ذاك

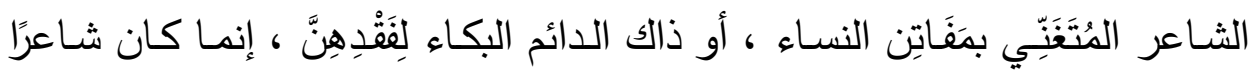

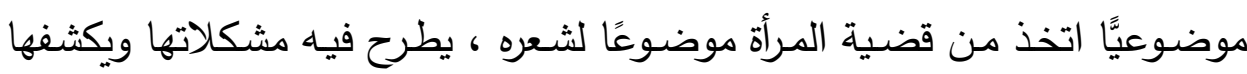
بقصائده المُنَمَّقَة الكلمات والفِكَر . موصن. 
وهكذا دار المبحث الأول في شعر أحمد شلبي في فَلَكِ الأنثى بِرِقِتَهَـا

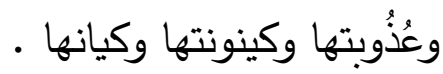

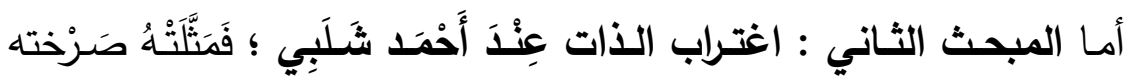

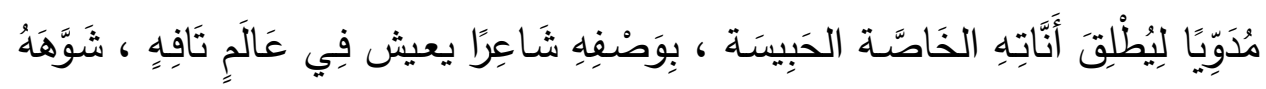

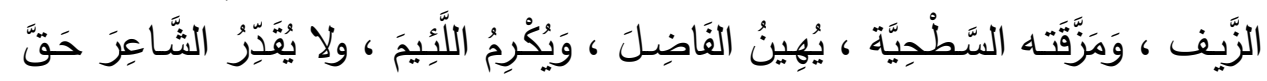

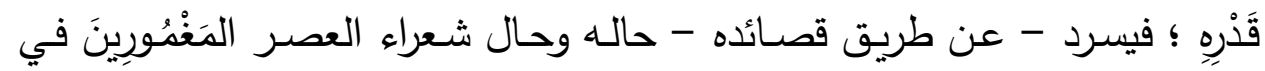

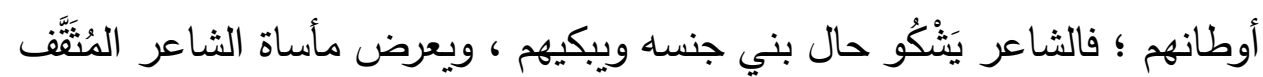

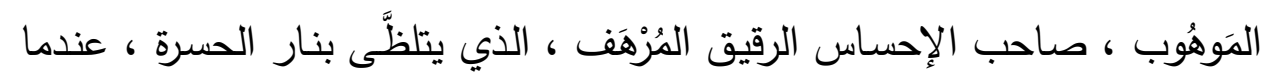

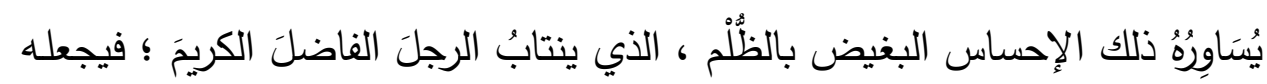

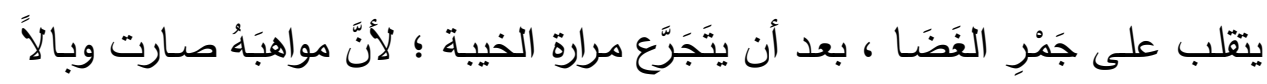

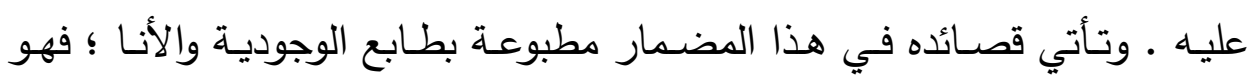
يتحدث عن نفسه بلسان حاله .

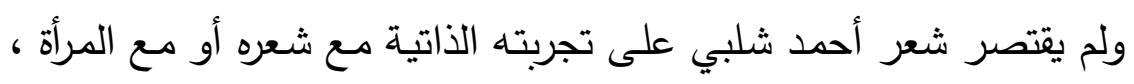

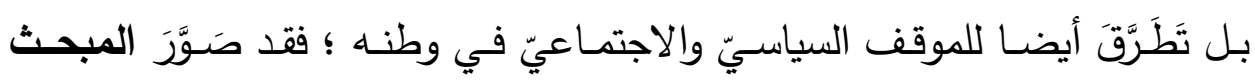

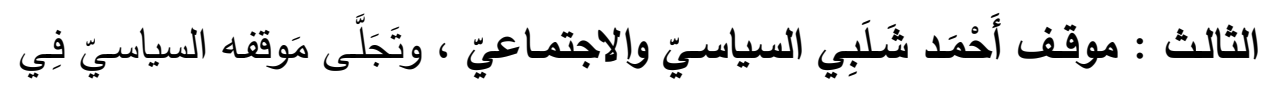

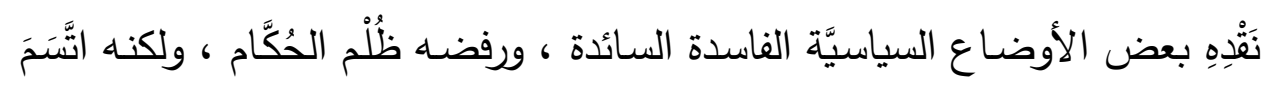

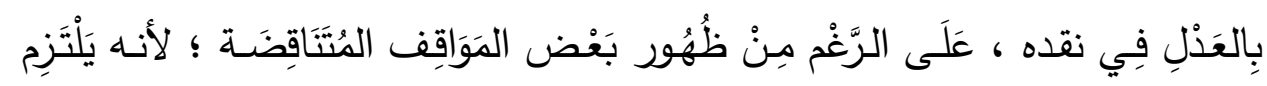

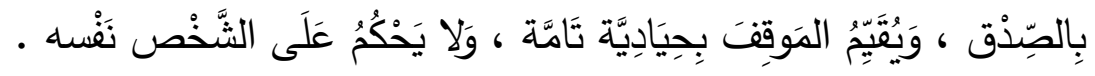

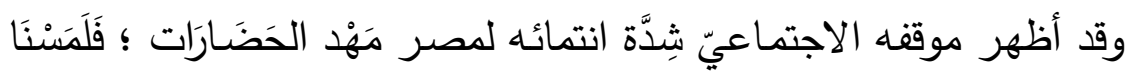

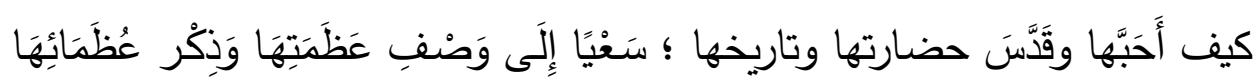

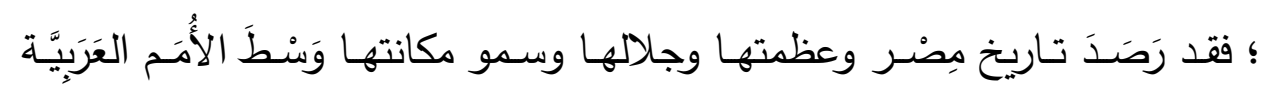

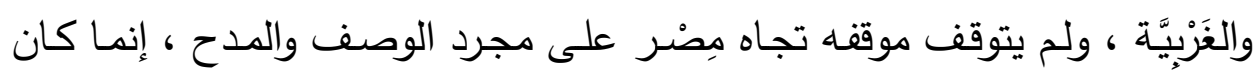

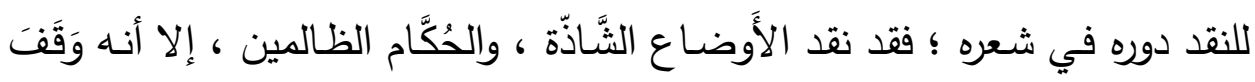




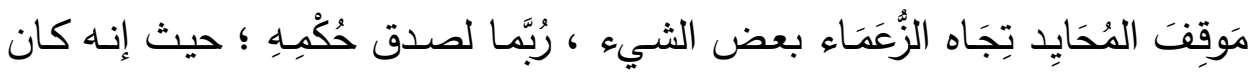

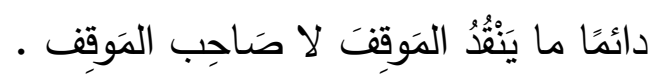

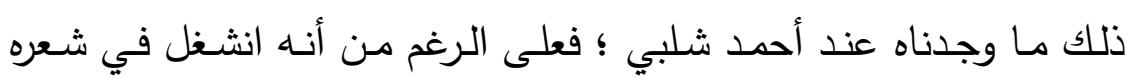

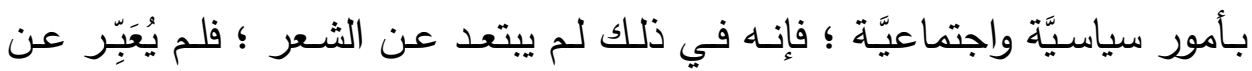

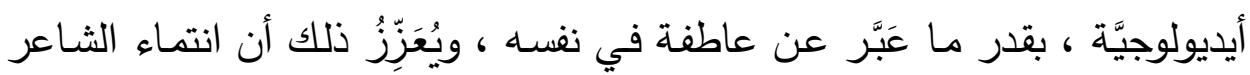

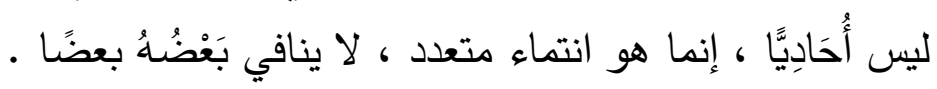

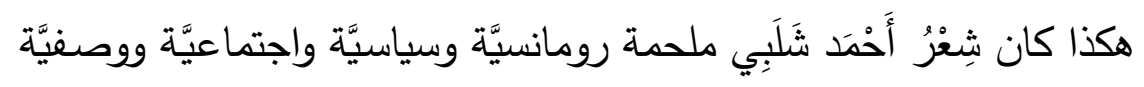

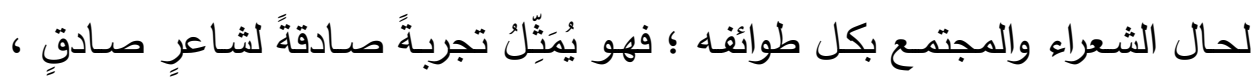

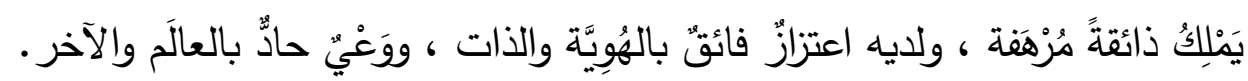
الحَوَاشِيسي

(1) شكري عزيز الماضي : في نظرية الأدب ، دار الحداثة للطباعة والنشر ، بيروت ، طا ، 919 ام ، ص ص Do pon

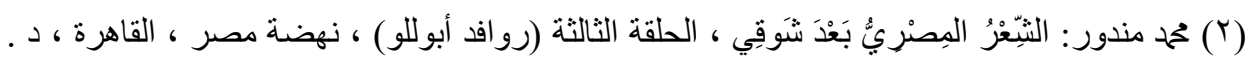

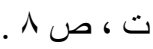

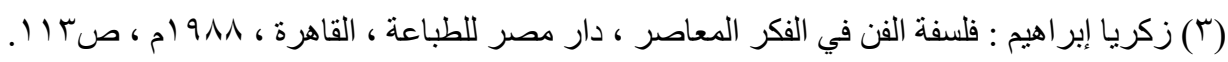

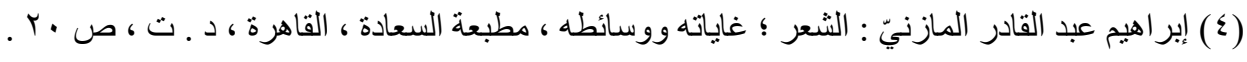
(0) أحمد معروف شلبي : عضو اتحاد كُنَّاب مِصنر ، له مجموعة من المسرحيات الثُعريَّة ، ومجموعة من الدواوين الشعريَّة ، وله ديوان (بُسنتًان الحياة) للاطفلال ، وقد قامت الهيئة العامة لقصور الثقافة بطبع

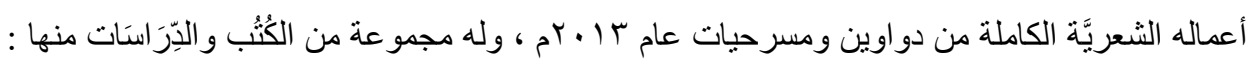
(النص والنص الزائف في الثعر العربيّ المعاصر) ، و(أغرب القصائد في الشعر العربيّ) ، و(قصائد

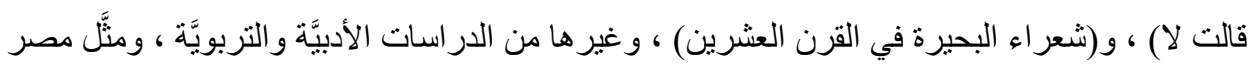
في عدد من المؤتمرات ، ودُرِّستَْْ نصوصه الثعريَّة والمسرحيَّة وأدب الطفل في عدد من الجامعات

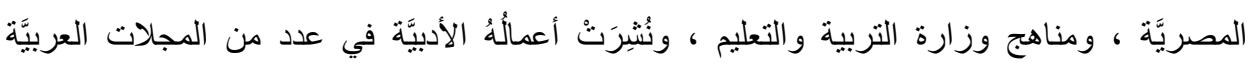

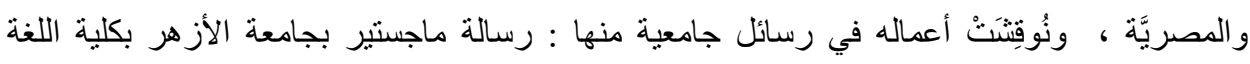
العربية بإيتابي البارود بعنوان (التجديد في الإطار المحافظ ـ أحمد شلبي نموذجًا) ، وحَصَلَ عَلَى عِدَّة جَوَائز ، منها : جائزة أحسن قصيدة في محافظة البحيرة عام ، 99 ام ، وجائزة أحسن ديوان شعر عن بعن 
ديوان (من أغاني الخوف) من الهيئة العامة لقصور الثقافة عام (99 ام ، وجائزة حسن عبد الله القرشي

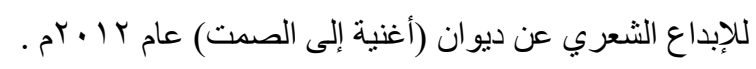

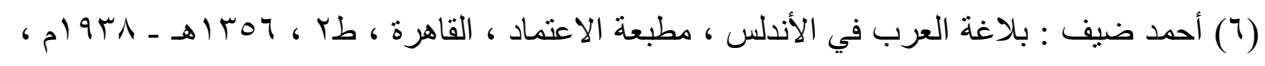

$$
\text { . }
$$

(V) عيسى علي العاكوب : العاطفة والإبداع الثعري ؛ دراسة في التراث النقدي عند العرب إلى نهاية

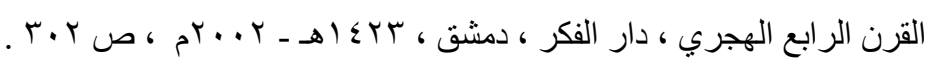

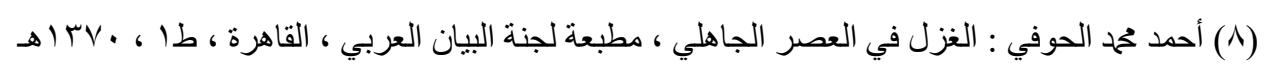

$$
\text { . با }
$$

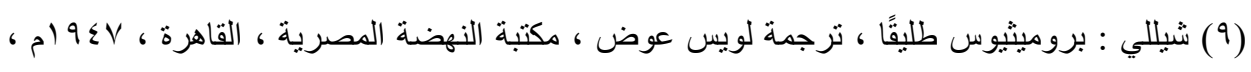
ص

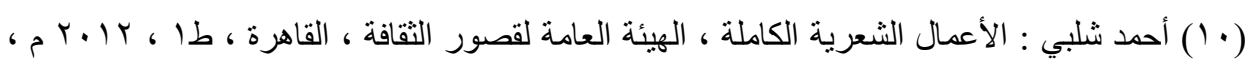
$.1 .0 / 4$

(11) يانكو لافرين : الرومانتيكية والو اقعية ، نرجمة حلمى راغب البنا ، سلسلة الألف كتاب الثاني

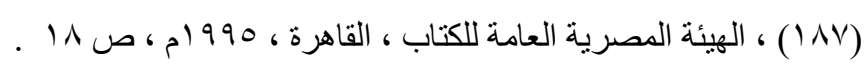

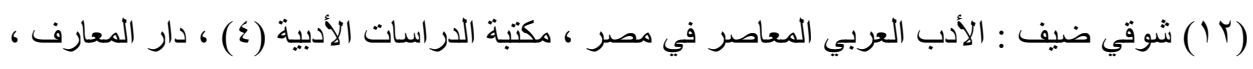

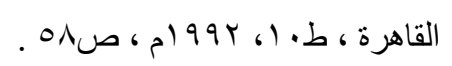

(T (1) لامرتين : رفائيل ، ترجمة أحمد حسن الزيات ، مطبعة لجنة التأليف و الترجمة والنشر ، القاهرة ،

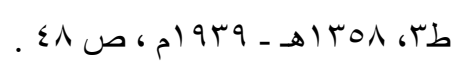

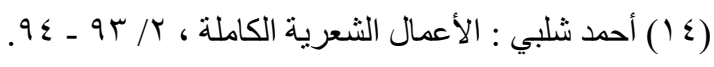

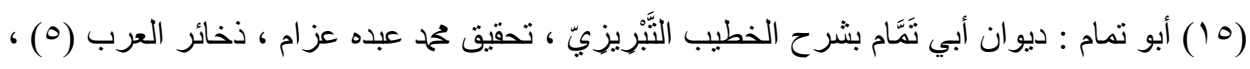

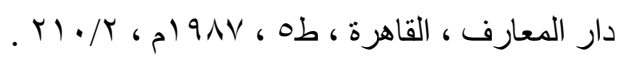

(7 (1) المتنبي : ديوان أبي الطيب المتببي ؛ بشرح أبي البقاء العكبري ، المسمى بالتبيان في شرح الديوان ، ضبطه وصححه ووضع فهارسه مصطفى السقا وإبر اهيم الإبياري و عبد الحفيظ شلبي ، دار المعرفة ،

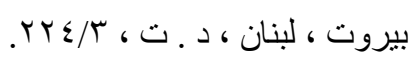

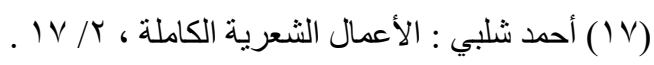

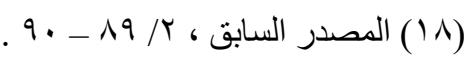

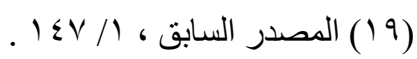




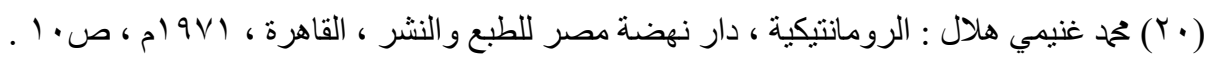

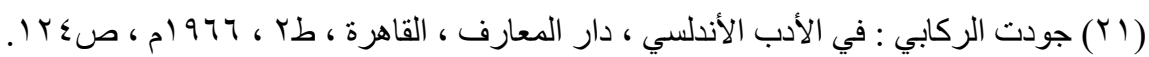

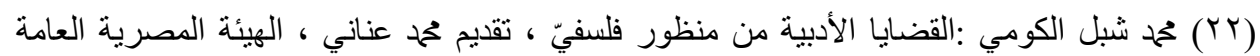

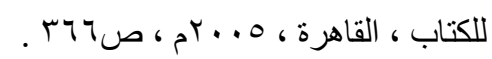

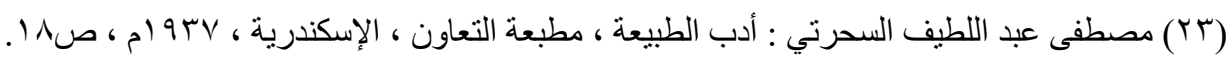

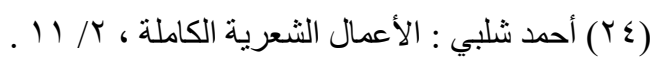

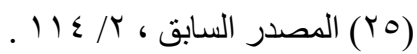
(T) محمد مندور : فن الثعر ، المكتبة الثقافية ، وزارة الثقافة والإرشاد القومي ، دار القلم ، القاهرة $.1 \cdot 1-1 \cdots \cdot$ - 197. (YV) عبد القادر القط : الاتجاه الوجدانيّ في الثعر العربي المعاصر ، دار النهضة العربية ، بيروت ، (Y)

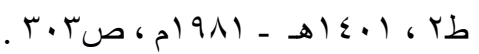
، أبو القاسم الثابي : الخيال الثعريّ عند العرب ، إعداد وتقديم أبو القاسم محمد كرّو ، دار صادر (Y) بيروت ، طا،

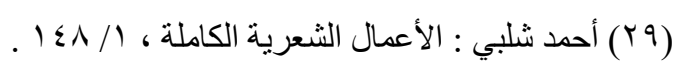

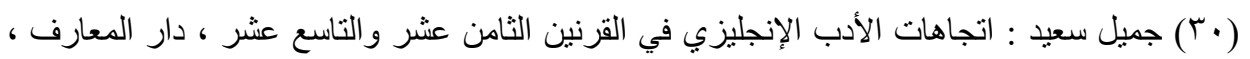

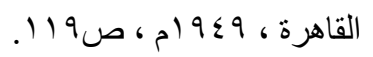

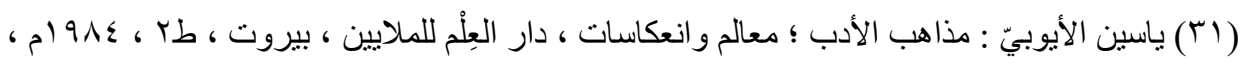
ص صivin

(r (T) عبد الحكيم بلبع : التجديد الثعري في المهر بين النظرية والتطبيق ، مكتبة الثباب ، القاهرة ،

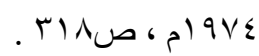

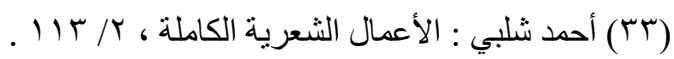

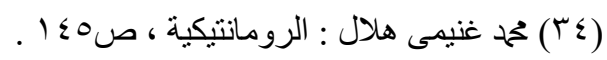

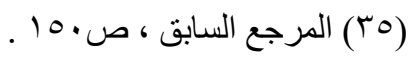

(דץ) أحمد عبد المعطى حجازي : ديوان أحمد عبد المعطى حجازي ، دار العودة ، بيروت ، طب ، $.1 \cdot r-1.10$ ص م 19r

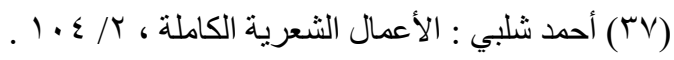

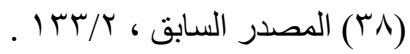


(Y) محمد زكي العشماوي : قضايا النقد الأدبي بين القديم و الحديث ، دار المعرفة الجامعية ، الإسكندرية ،

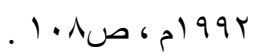

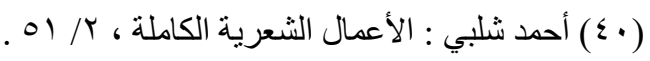

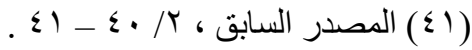

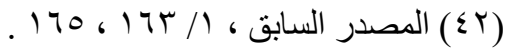

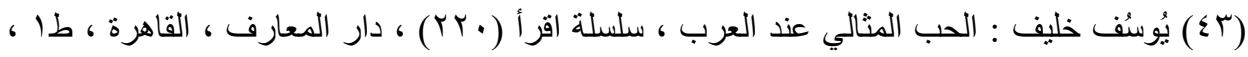

$$
\text { . }
$$

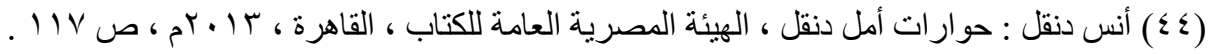

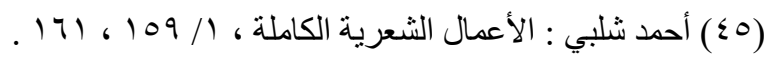

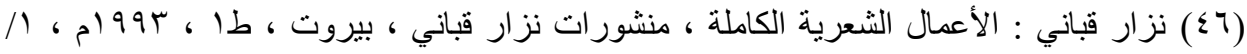

$$
.700
$$

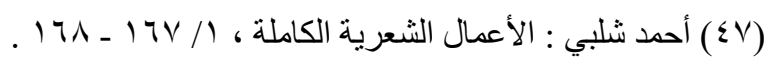

(^^) فاروق عبد الحكيم دربالة : الموضوع الثعري ؛ دراسة تحليلية في الرؤيا والتشكيل عند (أمل دنقل ، حمح عفيفي مطر ، محم مهران السيد ، محم إبراهيم أبو سنة ، فاروق شوشة ، أحمد سويلم) ، إيتر الك

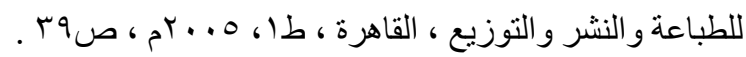

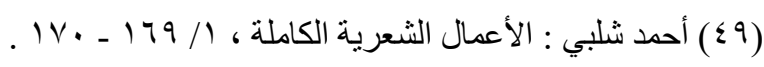

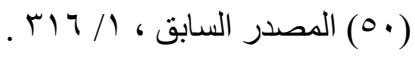

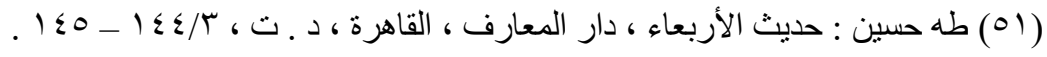

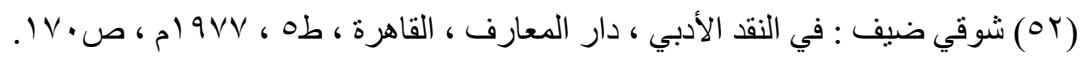

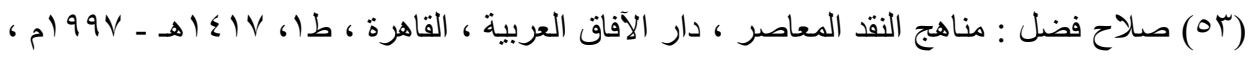
ص

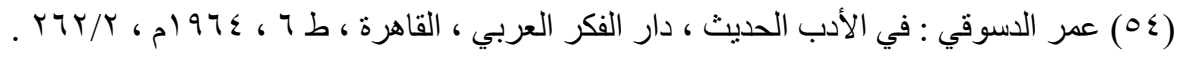
(00) عبد المنعم تليمة : مقدمة في نظرية الأدب ، دار الثقافة للطباعة والنشر، القاهرة ، بل7 ام ،

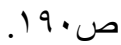

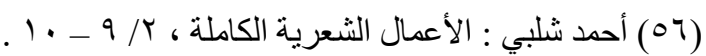

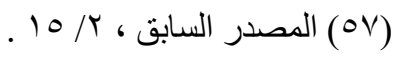

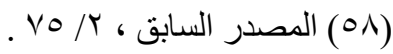




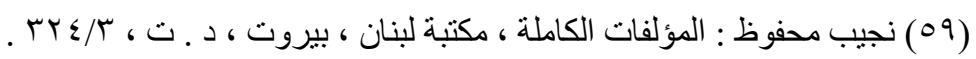

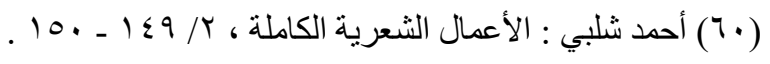

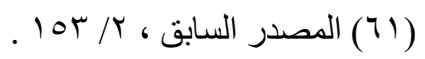

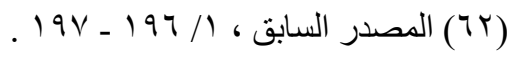

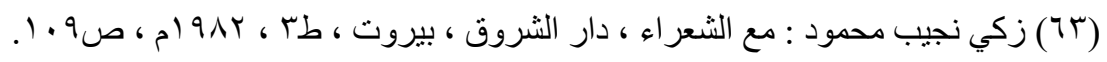

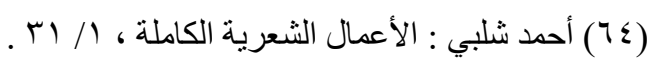

(07) إيليا الحاوي : الرومانسية في الثعر الغربي والعربي ، دار الثقافة ، بيروت ، لبنان ، طا، ، ـ19 ام

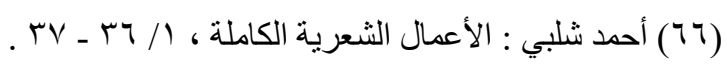

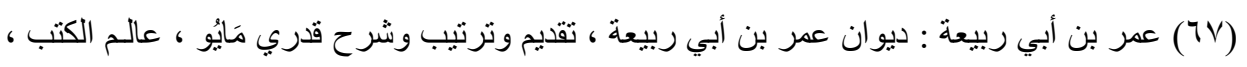

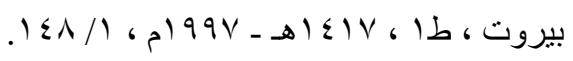

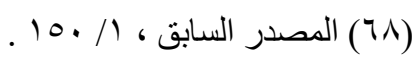

(997) بول ثان تيجم : المذاهب الأدبية ؛ الرومنطيقية ، نرجمة بهيج شعبان ، دار بيروت للطباعة والنشر،

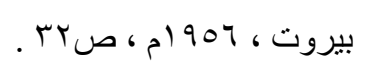

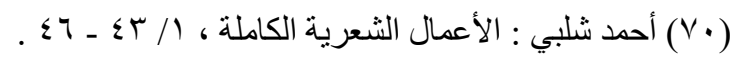

(VI)

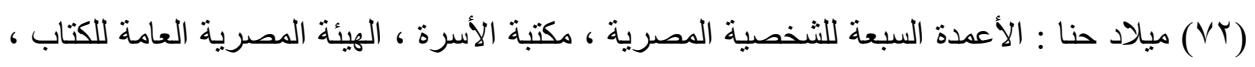

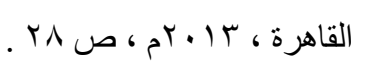

انظر : جمال حمدان : شخصية مصر وتعدُّد الأبعاد والجوانب ، مكتبة مدبولي ، القاهرة ، ع 99 (VT)

أحمد شلبي : الأعمال الثعرية الكاملة ، / (V ع (Y)

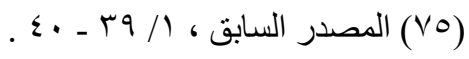

$$
\begin{aligned}
& \text { (VT) }
\end{aligned}
$$

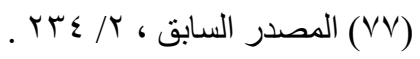

$$
\begin{aligned}
& \text { (VA) } \\
& \text { ( المصدر السابق ، Y / T9) }
\end{aligned}
$$

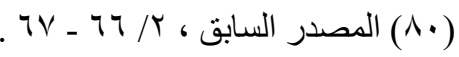




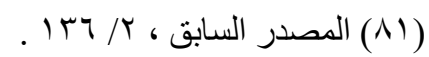

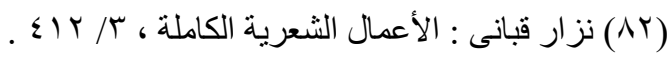

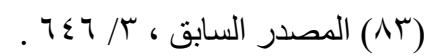

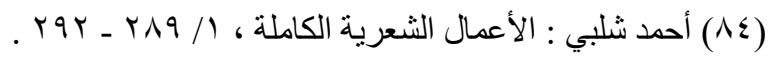

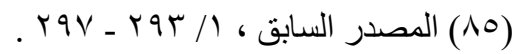

(1) أحمد شلبي : الأعمال الشعرية الكاملة ، / / / ا ـ ـ و انظر : حسان بن ثابت : ديوان حسان بن ثابت

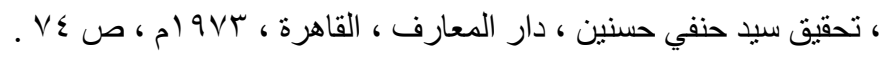

(AV)

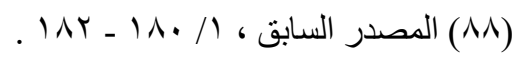

(19) أحمد شلبي : الأعمال الثعرية الكاملة ، // عـا ـ و انظر : المتنبي : ديوان أبي الطيب المتنبي ،

. $1 / 1$

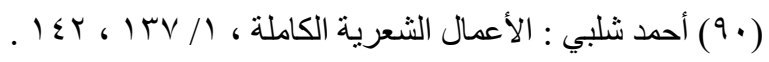

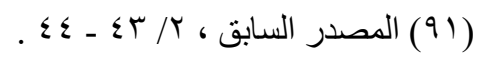

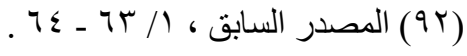

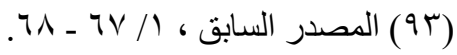

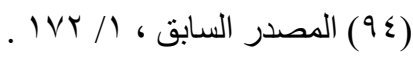

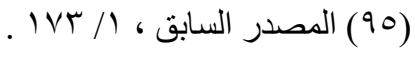

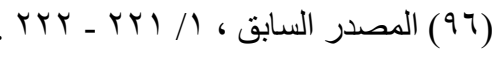

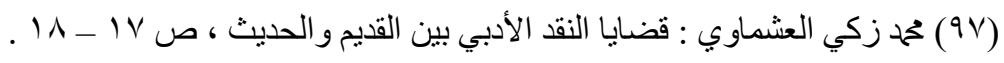




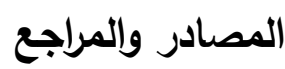

\section{أولا : المصادر :}

: أحمد شلبي :

1- الأعمال الثعرية الكاملة ، وزارة الثقافة ، الهيئة العامة لقصور الثقافة ، القاهرة ، طا ، $\cdot 5 r+14$ : أحمد عبد المعطى حجازي :

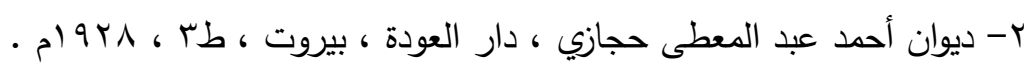

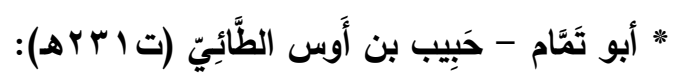

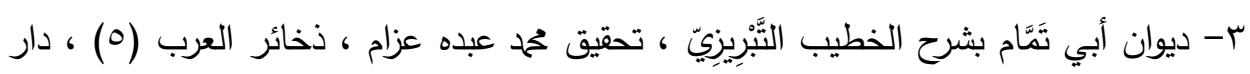

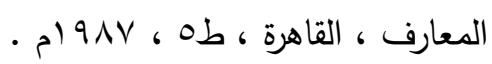

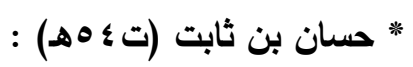

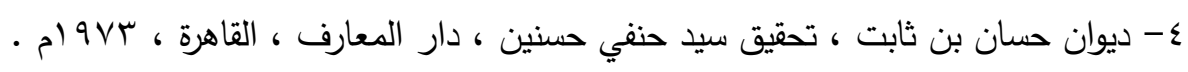

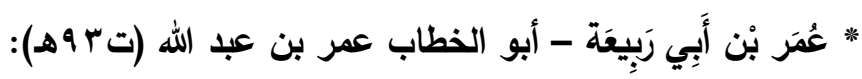

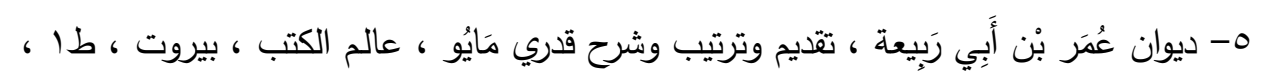
. $199 \mathrm{~V}-ه \mid \mathrm{s} / \mathrm{V}$

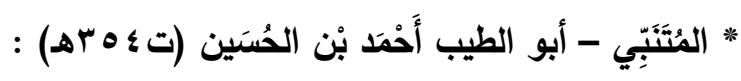

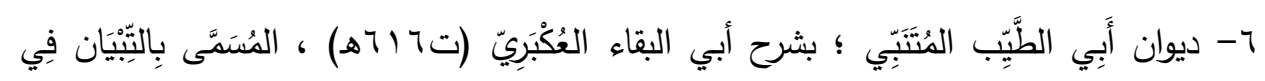

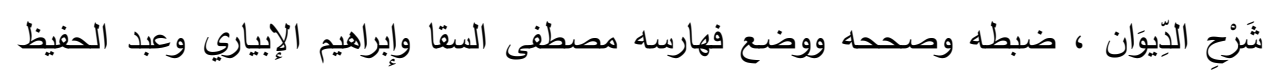

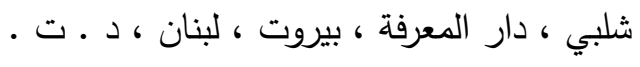
: نزار قباني :

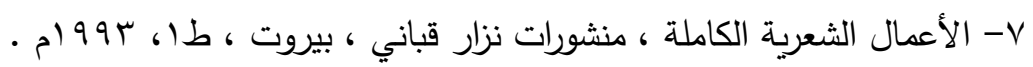
ثانيًا : المراجع العربية :

* إبراهيم عبد القادر المازني : 1- الثعر ؛ غاياته ووسائطه ، مطبعة السعادة ، القاهرة ، د ـ ت . . 


$$
\text { : أبو القاسم الثابي : }
$$

9- الخيال الثعريّ عند العرب ، إعداد وتقديم أبو القاسم ححم كرّو ، دار صادر ، بيروت ، طا،

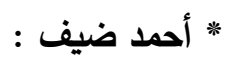

• 1 - بلاغة العرب في الأندلس ، مطبعة الاعتماد ، القاهرة ، طץ ، 7ه اهـ - 19 ام . : أحمد عحم الحوفي :

Iا- الغزل في العصر الجاهلي ، مطبعة لجنة البيان العربي ، القاهرة ، طا ، . •Vا اهـ - 190 .

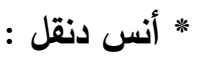
r ا - حوارات أمل دنقل ، الهيئة المصرية العامة للكتاب ، القاهرة ، با • rم • : إيليا الحاوي : ب ا- الرومانسية في الثعر الغربي والعربي ، دار الثقافة ، بيروت ، لبنان ، طا، ، 91 ام . : جمال حمدان * ع ا - شخصية مصر وتعدُّد الأبعاد والجوانب ، مكتبة مدبولي ، القاهرة ، ؛99 ام . : جميل سعيد * ه - اتجاهات الأدب الإنجليزي في القرنين الثامن عشر والتاسع عشر ، دار المعارف ، القاهرة - م) $9 \leqslant 9$.

$$
\text { : جودت الركابي : }
$$

7 ا- في الأدب الأندلسيّ ، دار المعارف ، القاهرة ، طب ، 977 ام •

$$
\text { : زكربا إبراهيم * }
$$

V I - فلسفة الفن في الفكر المعاصر ، دار مصر للطباعة ، القاهرة ، 91 ام .

$$
\text { : زكي نجيب محمود * }
$$

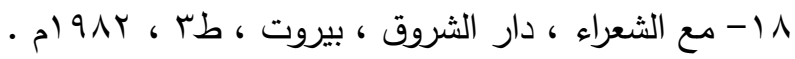
: شكري عزيز الماضي : 
9 19- في نظرية الأدب ، دار الحداثة للطباعة والنشر ، بيروت ، ط1 ، 919 ام .

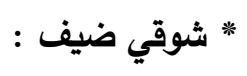

• ץ- الأدب العربي المعاصر في مصر ، مكتبة الدراسات الأدبية (ع) ، دار المعارف ، القاهرة

، ط.1،

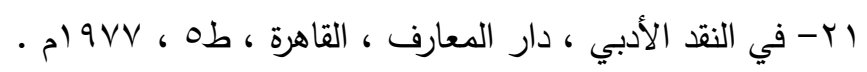

: صلاح فضل :

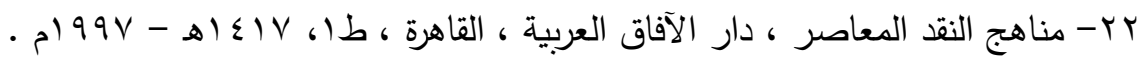

* طه حسين :

ب ب- حديث الأربعاء ، دار المعارف ، القاهرة ، د ـ ت . .

: عبد الحكيم بلبع :

ع ؟- التجديد الثعريّ في المهجر بين النظرية والتطبيق ، مكتبة الثباب ، القاهرة ، ع أم .

* عبد القادر القط :

هץ- الاتجاه الوجدانيّ في الشعر العربي المعاصر ، دار النهضة العببية ، بيروت ، طץ ،

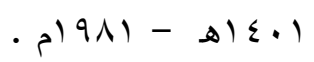

* عبد المنعم تليمة : (2)

ج ب- مقدمة في نظرية الأدب ، دار الثقافة للطباعة والنشر ، القاهرة ، 9 ام •

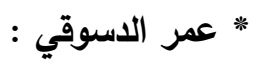

ه ع في الأدب الحديث ، دار الفكر العربيّ ، القاهرة ، ط 7 ، ع 97 ام .

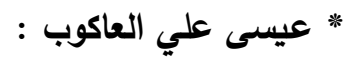

^ץ- العاطفة والإبداع الثعريّ ؛ دراسة في التراث النقديّ عند العرب إلى نهاية القرن الرابع

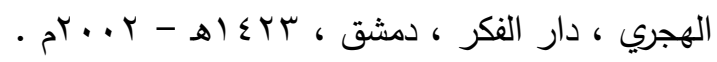
* فاروق عبد الحكيم دربالة : 
9 - الموضوع الثعري ؛ دراسة تحليلية في الرؤيا والتشكيل عند (أمل دنقل ، محم عفيفي مطر ،

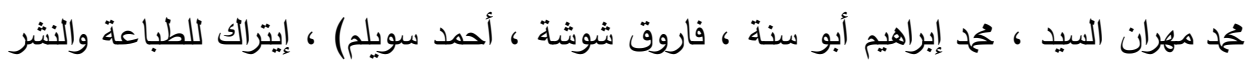

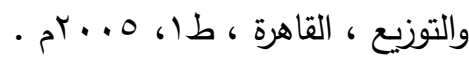

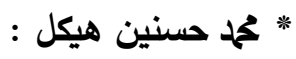

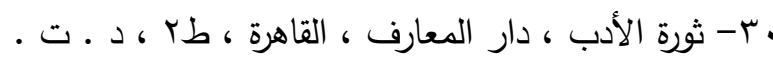

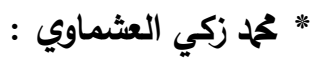
اب- قضايا النقد الأدبي بين القديم والحديث ، دار المعرفة الجامعية ، الإسكندرية ، ب99 ام. : محم شبل الكومي : r ب- القضايا الأدبية من منظور فلسفي ، تقديم محمد عناني ، الهيئة المصرية العامة للكتاب ،

$$
\begin{aligned}
& \text { القاهرة ، 0...بم . } \\
& \text { " محمد غنيمي هلال : }
\end{aligned}
$$

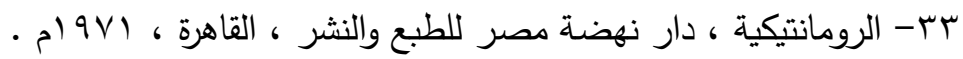
* محمد مندور:

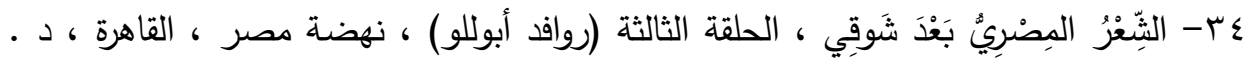

هـ- فن الثعر ، المكتبة الثقافية ، وزارة الثقافة والإرشاد القومي ، دار القلم ، القاهرة ، ـ97ام : مصطفى عبد اللطيف السحرتي :

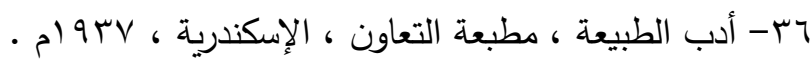
: ميلاد حنا :

V V- الأعمدة السبعة للشخصية المصرية ، مكتبة الأسرة ، الهيئة المصرية العامة للكتاب ،

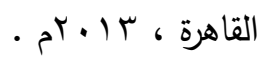
: نجيب محفوظ : ^ץ- المؤلفات الكاملة ، مكتبة لبنان ، بيروت ، د ـ ت . 
* ياسين الأيوبيّ :

qr- مذاهب الأدب ؛ معالم وانعكاسات ، دار العِلم للملايين ، بيروت ، طب ، ع 9 ام .

* يُوسُف خليف :

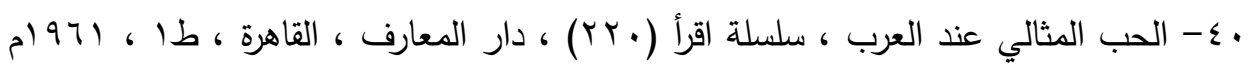

\section{ثالثًا : المراجع الأجنبية المترجمة :}

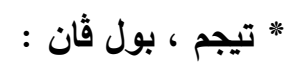

1 - المذاهب الأدبية ؛ الرومنطيقية ، ترجمة بهيج شعبان ، دار بيروت للطباعة والنشر ، بيروت

. م) 907 ،

: شيللي *

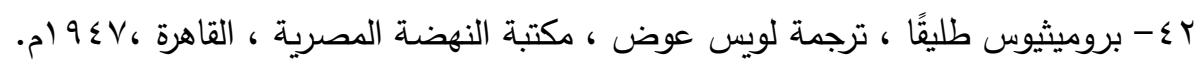

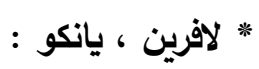

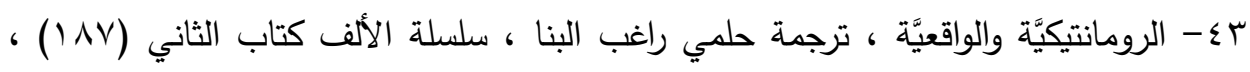

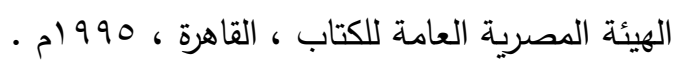
: لامرتين *

؟ ؟- رفائيل ، ترجمة أحمد حسن الزيات ، مطبعة لجنة التأليف والترجمة والنشر ، القاهرة ،

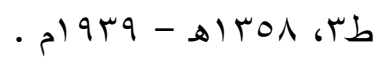




\title{
الأمير السلجوقي زاخاس \\ ونشاطه البحري في أسيا الصغرى

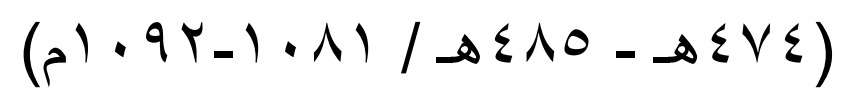

\author{
دكتور \\ و ائل أحمد إبر اهيم \\ مدرس التاريخ الإسلامي والحضارة الإسلامية \\ كلية دار العلوم - جامعة الفيوم
}

$$
\text { بونيو } 10
$$




\section{مقدمــة}

الحمد لله الذي أنزل القرآن وفصل الفرقان وأحكم البرهان وهو رب العالمين

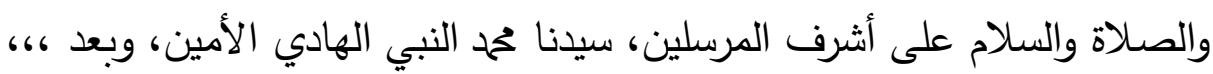
تزخر الفترة الأولى من استقرار الأتراك السلاجقة في منطقة أسيا الصغرى

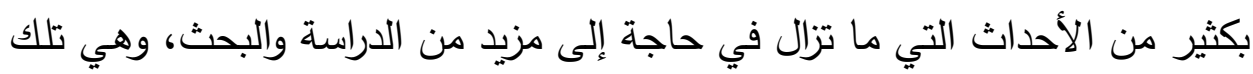

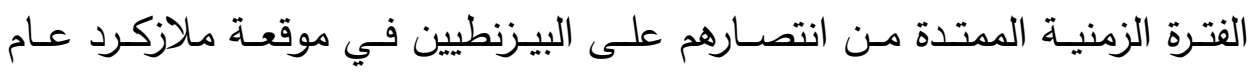

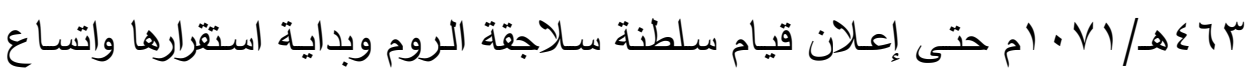

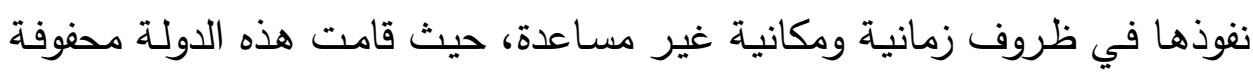
بالمخاطر من عدة جوانب، فهناك قوة الدولة البيزنطية، وهناك القوات الصليبية

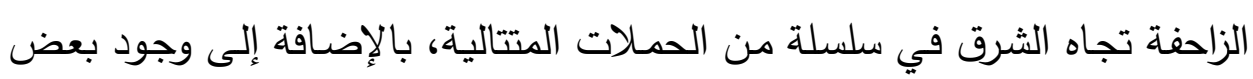
الإمارات التركمانية المنافسة في المنطقة.

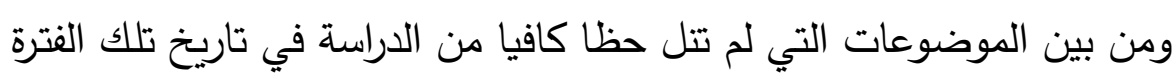

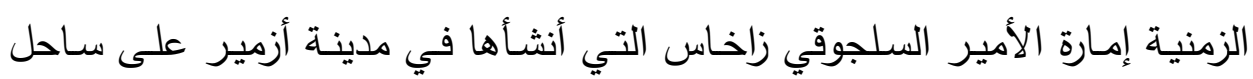

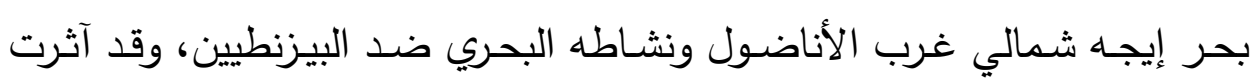

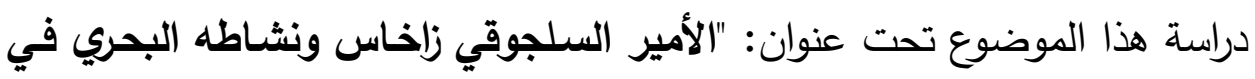

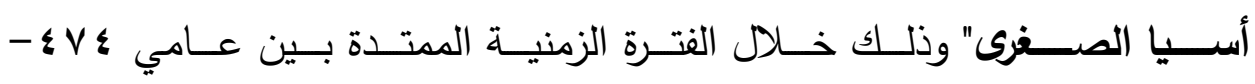

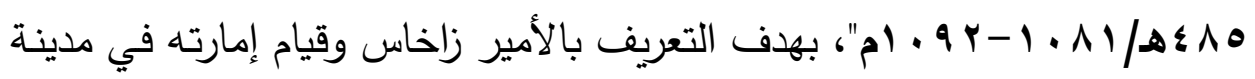

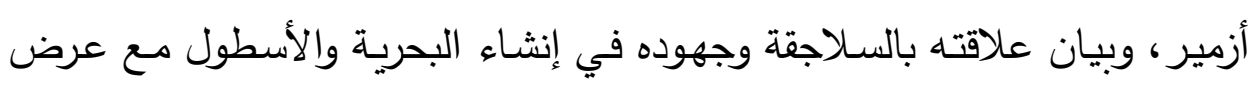
مفصل لنشاطه البحري وصراعه مع البيزنطيين، ثم نهايته وسقوط إمارته على أيدي البيزنطيين.

وقد كان زاخـاس أحد الأمـراء الذين شـاركوا السـلاجقة في انتصـارهم الخالد

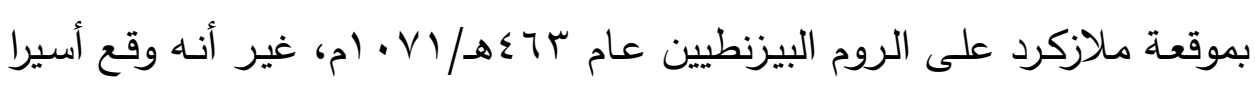

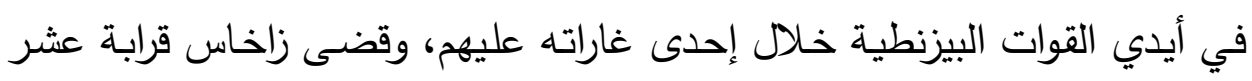


سـوات (ع القسطنطينية تعلم خلالها اللغة اليونانية وتعرف على أساليب البيزنطيين السياسية

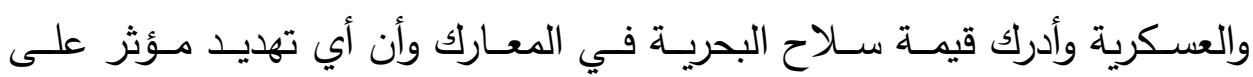
القسطنطينية لا بد أن يكون عن طريق البحر .

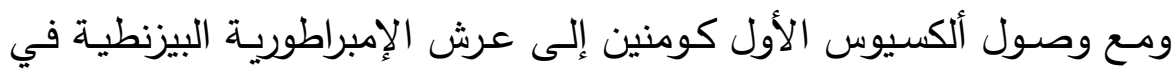

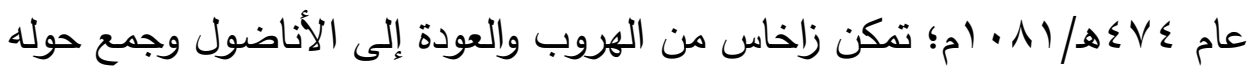
مجموعة من الجند المرتزقة من الأتراك واليونانيين والبيزنطيين الساخطين على حكم

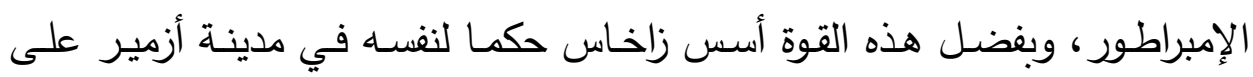
ساحل بحر إيجه منذ ذلك الحين، كما ركز جهده في بناء أسطول قوي أخذ يشن به الغارات على المدن والجزر القريبة، بل إنه هدد القسطنطينية نفسها، ودخل في

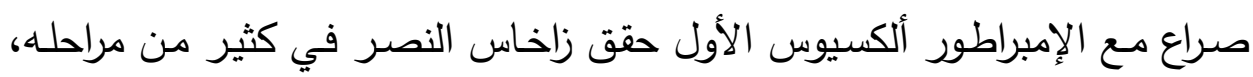
واستمر صراعه مع البيزنطيين حول السيطرة على بعض المدن والجزر ببحر إيجه

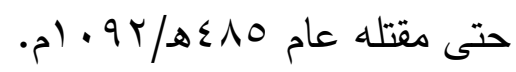
ولا يمكن بداهة القول بأن القوة الناشئة للبحريـة السلجوقية التي بناهـا الأمير زاخاس في أزمير كانت تضاهي أو تكافئ سلاح البحريـة عند البيزنطيين، ورغم أن لن لان

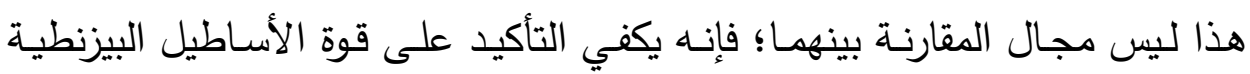
وخبرتها العريضة في الحروب منذ فترة زمنية تعود إلى ما قبل ظهور السلاجقة في

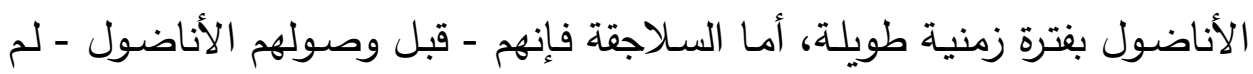
يكونوا يعرفون ركوب البحر، ولم تكن لديهم الخبرة في الحروب البحريـة، ولم يكونوا يعرفون شيئا عن الأسـاطيل، وإنما كان تفوقهم في حروب البر كفرسـان خفيفي لإني الحركة، حيث كانت طبيعة الأرض التي يتحركون فيها في إيران والعراق تقتصر على الحروب البرية، ولم يفكر السلاجقة في إنشاء أسطول بحري حربي إلا عندما

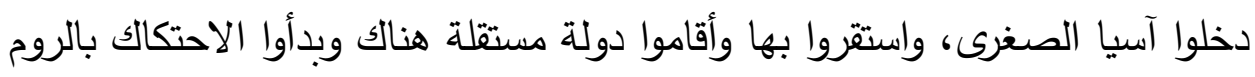
البيزنطيين والقوات الصليبية. 
وتبقى محاولات الأمير زاخاس لإنشاء البحرية وبناء الأسطول بمدينة أزمير

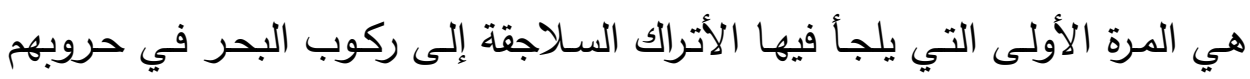

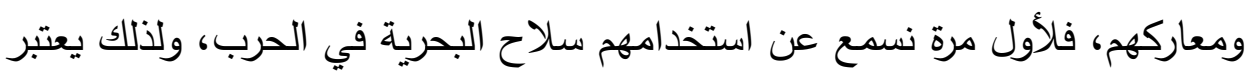
الأمير زاخاس أول "أميرال" تركي، وأول من أسس لسلاح البحرية عند الأتراك.

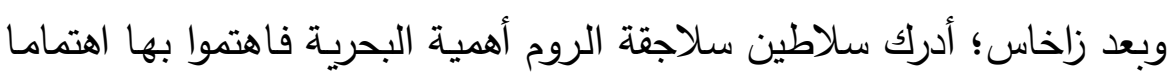

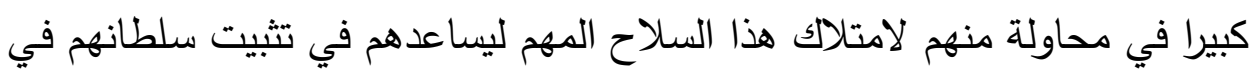

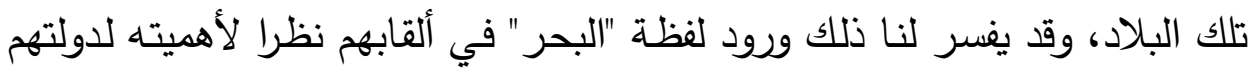

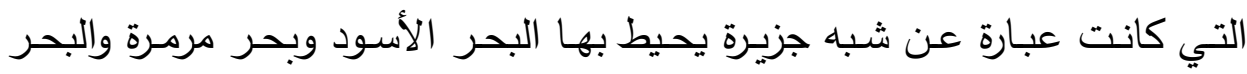
المتوسط.

ولا شك أن محاولات الأمير زاخاس لبناء البحرية والأسطول قد وجهت أنظار سلاطين سلاجقة الروم خلال السنوات التالية نحو مدن الساحل في الثمال والثمال

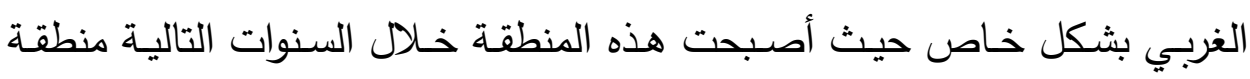

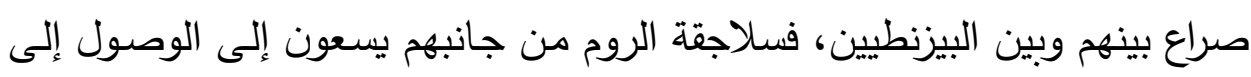

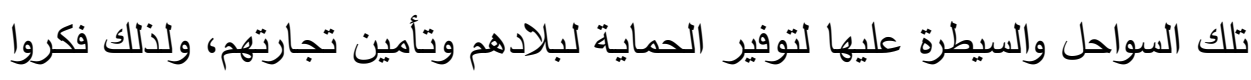

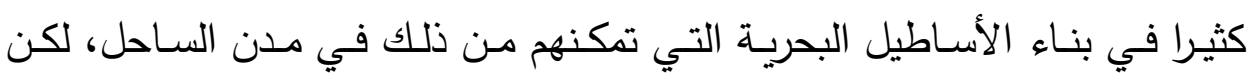

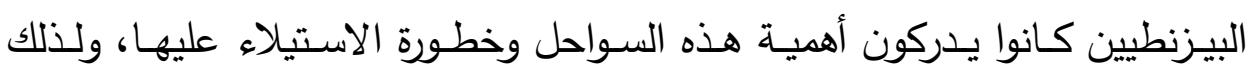

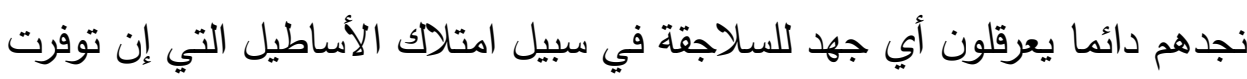

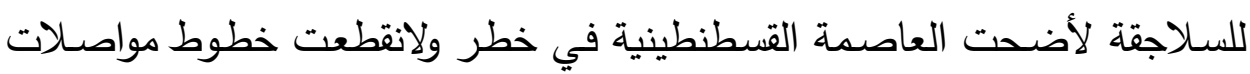

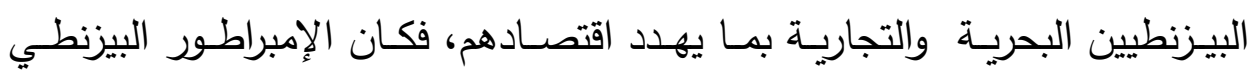

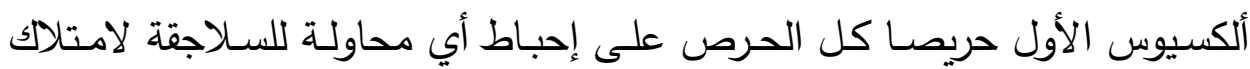

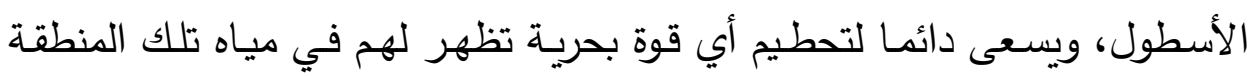

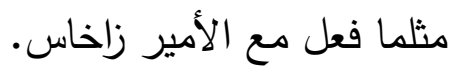


أما عن تخطيط البحث، فلقد اقتضت طبيعة هذا الموضوع وما أتاحته المادة العلميـة تقسيمه إلى مقدمـة وخمسـة مباحث ثم خاتمـة وثبت بالمصــادر والمراجع وملحق واحد يتعلق بالموضوع. أمـا المقدمـة فقد اشتملت على التعريف بالموضوع وأهميته وتخطيطه ومنهج البحث وأهم مصـادره، وجـاء المبحث الأول بعنـوان: ترجمـة الأميـر زاخـاس، أمـا المبحث الثاني فكان بعنوان: قيام إمـارة زاخـاس في أزميـر، والمبحث الثالث بعنوان: جهود الأمير زاخاس في إنثاء البحريـة وبناء الأسطول، والمبحث الرابع بعنوان: النشاط البحري للأمير زاخاس، والمبحث الخامس والأخير بعنوان: نهاية زاخاس وسقوط أزمير، ثم خاتمة تعرض لنتائج البحث. وقد اتبع البحث المنهج التاريخي القائم على الوصف والتحليل والنقد معتمدا على مجموعـة مـن المصـادر والمراجـع المهــة منهـا مـا سـجله الرحالـة اليهودي

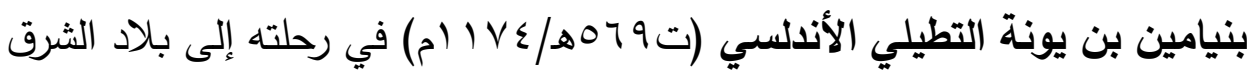
الإسـامي حيث زار كثيرا من المدن والجزر في المنطقة وعرف بها بمعلومات لم تتوفر في كتب الجغرافيا والرحلات الأخرى، على أن أهم مصدر استند إليه البحث

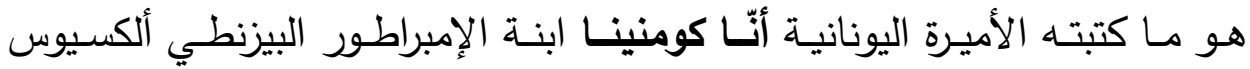
كومنين في كتابها "ألكسياد"، حيث اشتمل هذا الكتاب على معلومات وفيرة عن الإن الأميـر زاخـاس وبداياتـهـ وعلاقتـهـ بالسـلاجقة وصـراعه مـع الإمبراطـور ألكسيوس كومنين حتى نهايته، كما اعتمد البحث على مجموعة من المراجع الحديثة مثل ما كتبه الدكتور سعيد عاثور في كتابه "الحركة الصليبية - الجزه الأول"، والدكتورة زبيدة عطا في كتابها "بـلاد الترك في العصور الوسطى"، وما كتبه الدكتور محمد سهيل طقوش في كتابه "تاريخ سـلاجقة الروم في أسيا الصغرى"، واستتد البحث كذلك إلى مجموعة من المراجع المترجمة من أهمها ما كتبه ستيفن رنسيمان عن

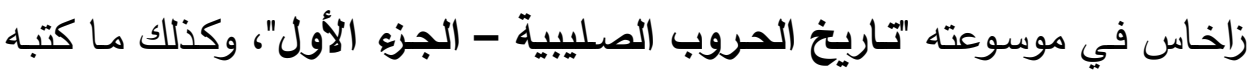
أرشيبالد لويس في كتابه "القوى البحريـة والتجاريـة في حوض البحر المتوسط"، 
بالإضـافة إلى بعض المعلومـات التي وفرتها الدراسـات الأكاديميـة مثل رســالة

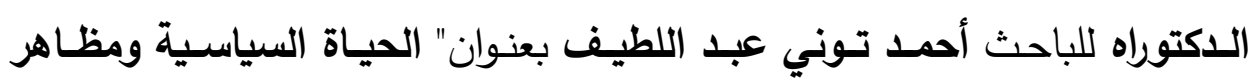

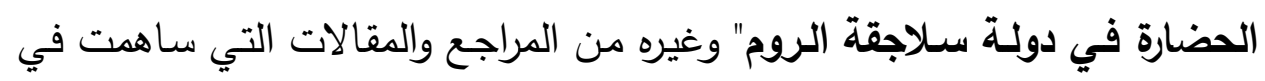
إخراج البحث على صورته الحالية.

وأخيرا فإن دراسة النثاط البحري لدولة سلاجقة الروم بأسيا الصغرى ما زال

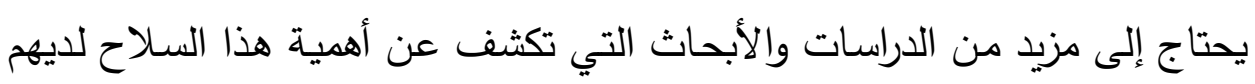

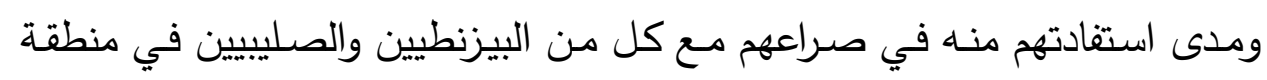
الثرق الإسلامي. وأرجو أن أكون بما كتبت في هذه الورقات قد فتحت بابا لمزيد من الدراسة عن هذا الموضوع المهم في تلك الفترة الزمنية. سائلا المولى تعالى السداد

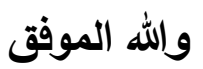
الباحث 


\section{المبحث: الأول : ترجمة الأمبر السلجوقي زاخاس}

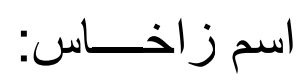

تختلف الروايات الواردة حول حقيقـة اسم زاخـاس وكيفيـة نطقـه ورسمه، فقد ذكرته بعض تلك الروايات باسـم "جاقا" أو "جاغا بيـه" أو "شكا" أو "جكا بكـ"(') وذكره مورتمان J.H.Mordtmann في دائرة المعارف الإسـلامية باسم "زركش" أو

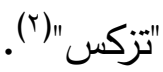

ولعل أقرب تلك الروايات إلى الصواب هي رواية المؤرخة اليونانية الأميرة آنا كومنينا بصفتها أقدم من أرخ لأحداث تلك الفترة الزمنية، فهي لم تذكر اسم "جاقا" Caka على روايتها هذه معظم المراجع الحديثة في كتاباتها عن السـلاجقة بمنطقة أسيا

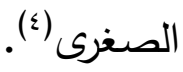

(1) ستيفن رنسيمان: تاريخ الحروب الصليبية جا (الحرب الأولى وقيام مملكة بيت المقدس)، ترجمة

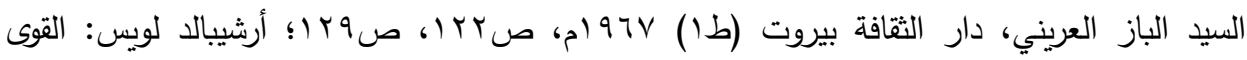

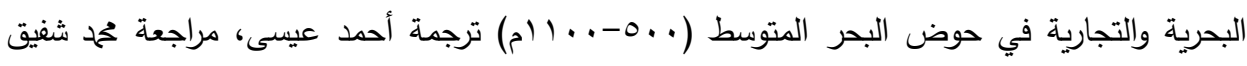

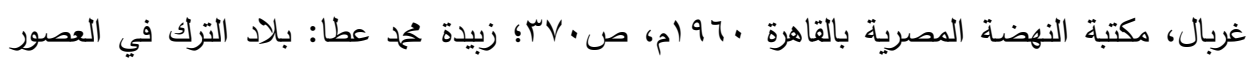

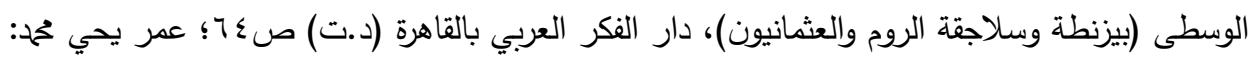

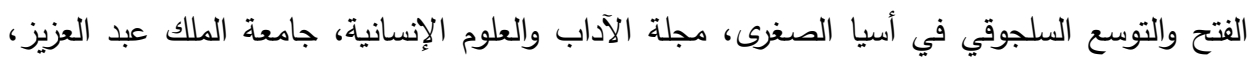

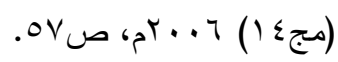
(Y) انظر دائرة المعارف الإسلامية، تعريب إبراهيم زكي خوشيد وآخرين، دار الشعب بالقاهرة (د.ت)

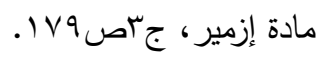

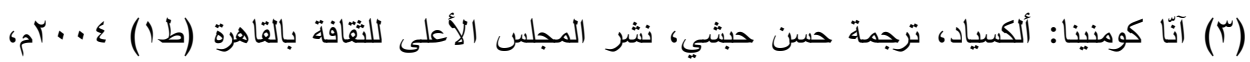

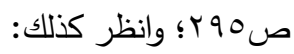
Ostrogorsky "George": History of Byzantine state, translated from the German by Hussey with a fore by Peter Charanis, New Jersey, 1957, p: 319.

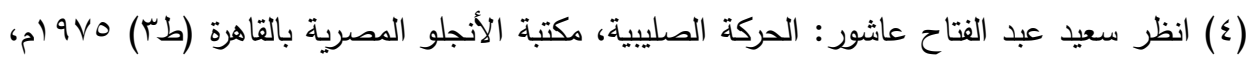

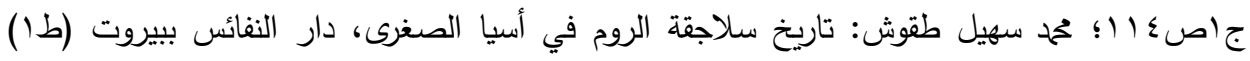
$=$ 


\section{ظهور الأمير زاخاس وعلاقته بالسلاجقة :}

تتفق رواية المصادر والمراجع المتاحة على أن زاخاس أمير تركي ينتمي إلى الى الدي

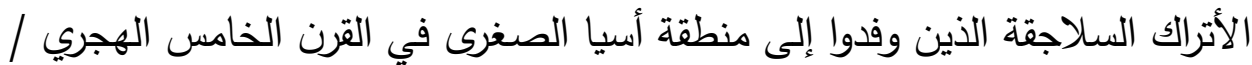

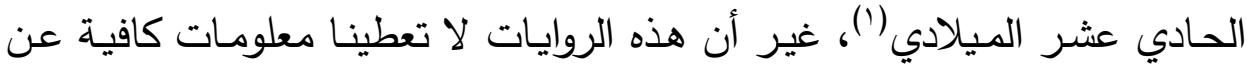

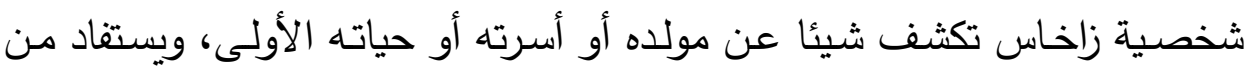

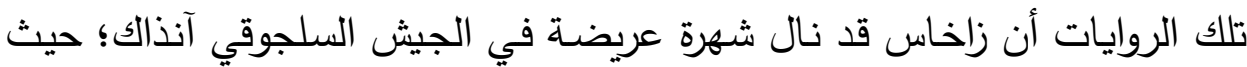

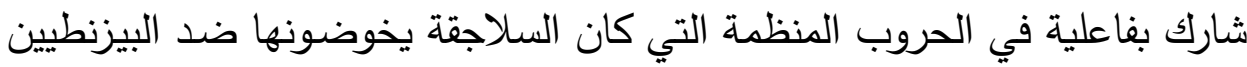
خلال المرحلة الأولى من استقرارهم بمنطقة أسيا الصغرى.

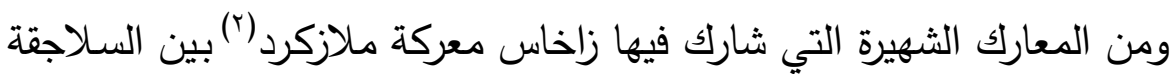
والبيزنطيين عام بآـه/ (V • ام والتي انتهت بانتصار السلاجقة ووقوع الإمبراطور

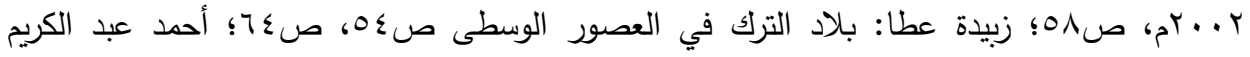

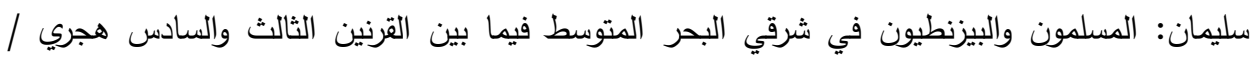

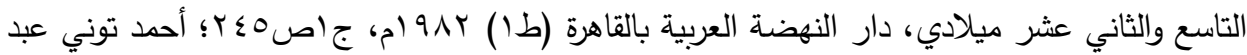

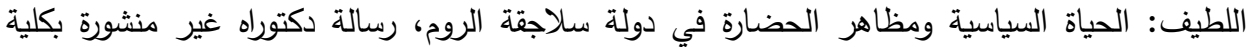

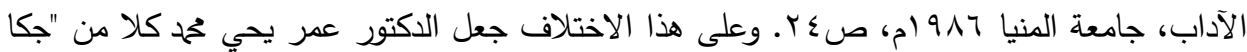

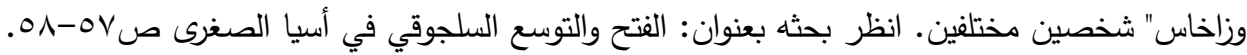

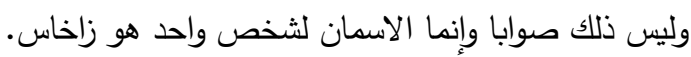

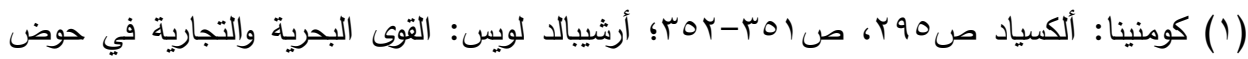

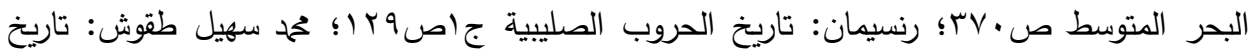

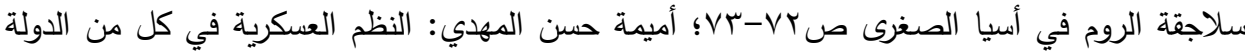

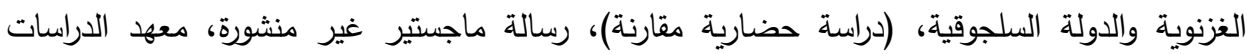

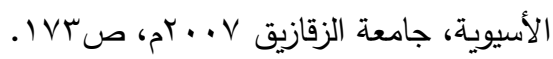

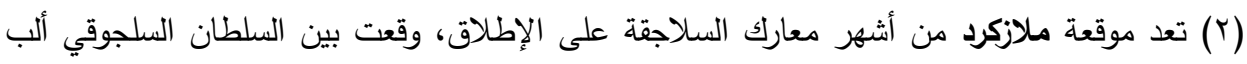

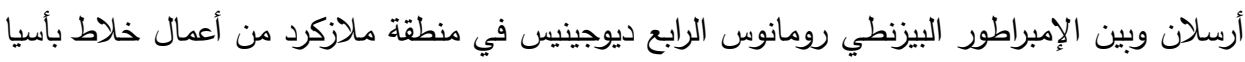

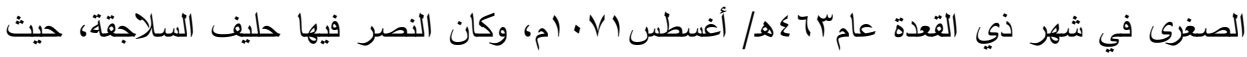

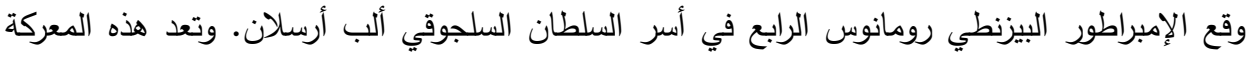
$=$ 
البيزنطي في الأسر ، فلقد أتاح هذا الانتصار للأتراك السلاجقة فرصة الانسياح في

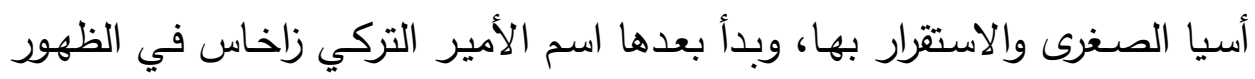

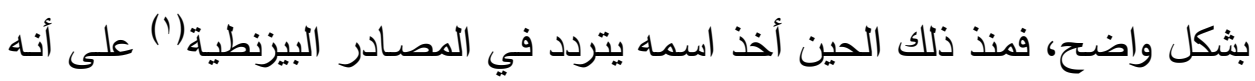

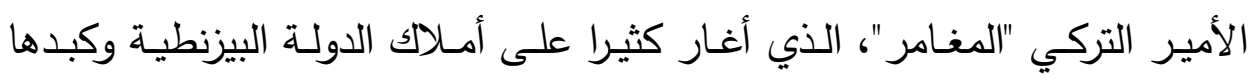
الخسائر ، واستولى على ساحل بحر إيجه (r).

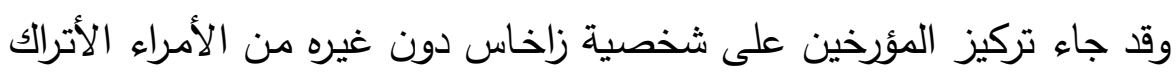

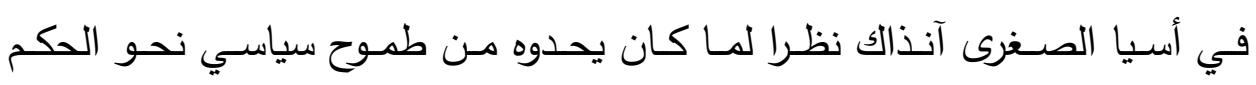

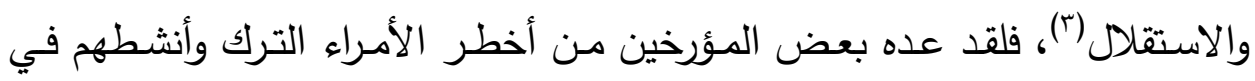

البداية الحقيقية لانهيار الإمبراطورية البيزنطية في أسيا الصغرى والتمكين للأتراك السلاجقة فيها، كما

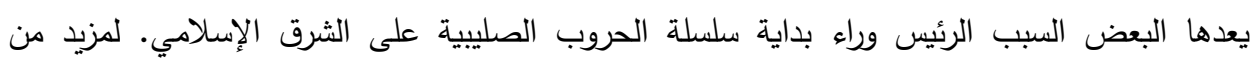

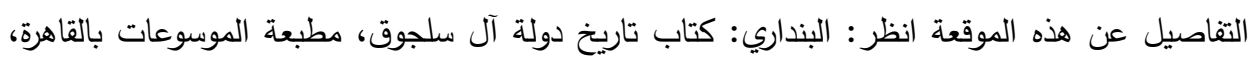

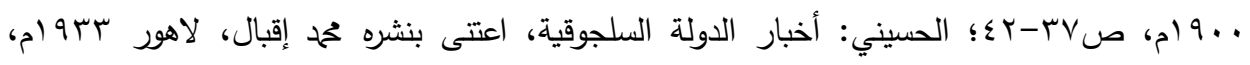

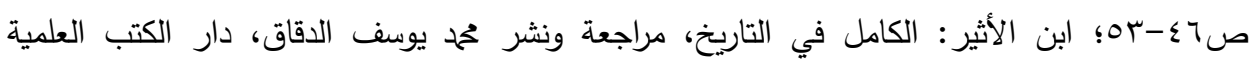

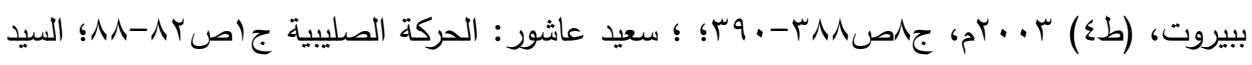

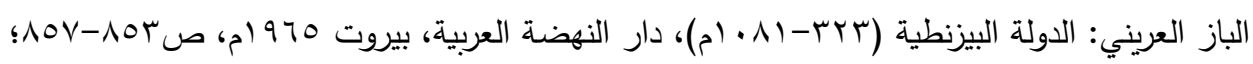
محم نايف العمايرة، ومحمود محم الرويضي: معركة ملازكرد (جانب من العلاقات السلجوقية البيزنطية)،

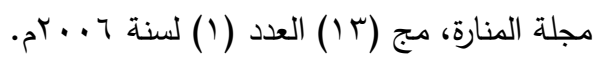

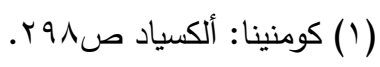

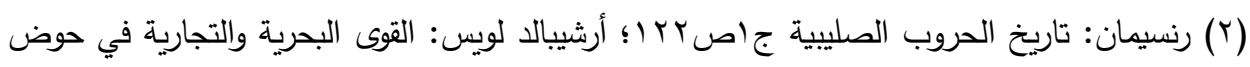

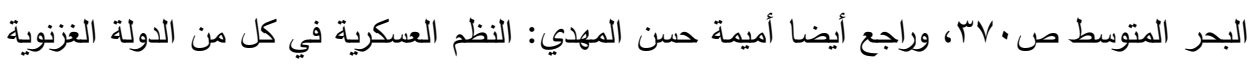

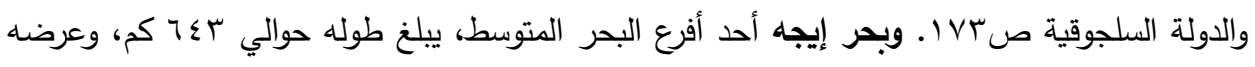

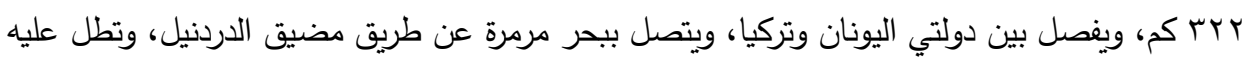

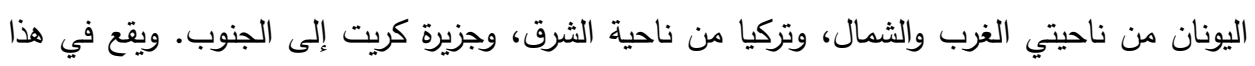

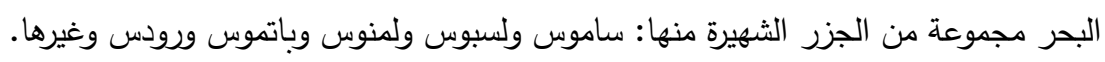

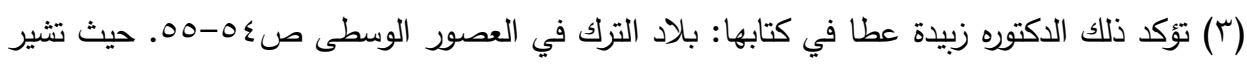

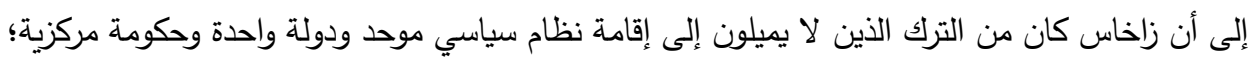
$=$ 
غربي أسيا الصـغرى(')، حيث شكل وجوده في هذه المنطقـة خطرا كبيرا على الإمبراطورية البيزنطية نفها فاعتبره البعض (r) أحد أهم أعداء الإمبراطور البيزنطي

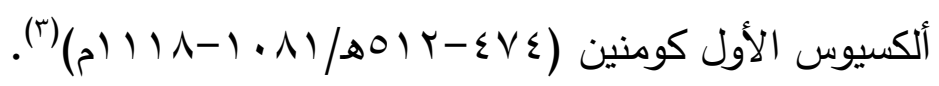

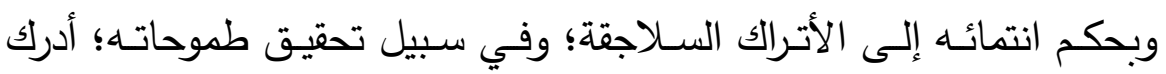

زاخاس أهمية أن يكون هناك حليف له فهي أسيا الصغرى يساعده في الظهور من جانـب، ويكـون عونـا لـه في ذات الوقت على مواجهـة البيزنطيين وإمبراطـورهم

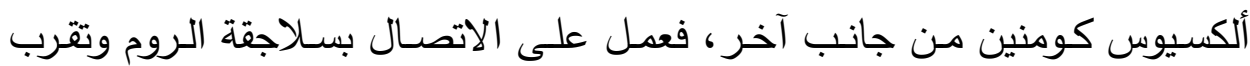

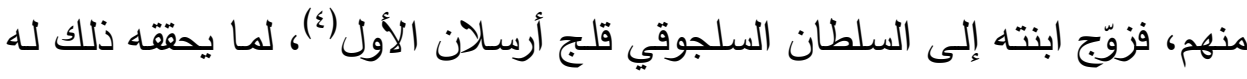
من مكسب سياسي وعسكري في المنطقة بالتحالف مع قوة سلاجقة الروم.

بل كان من الذين يميلون إلى الاستقلال وتكوين الحكم الخاص بهم تحقيقا لها كان يحدوه من طموح

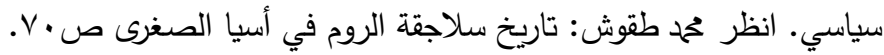

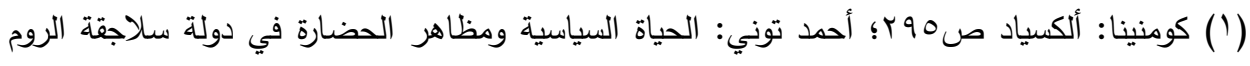

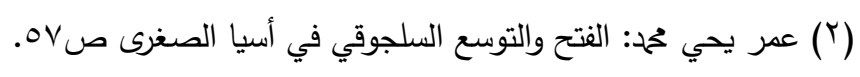

(r) أكسيوس الأول كومنين: الإمبراطور البيزنطي مؤسس الأسرة الكومنينية الحاكمة في القسطنطينية،

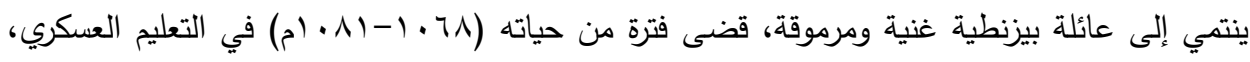

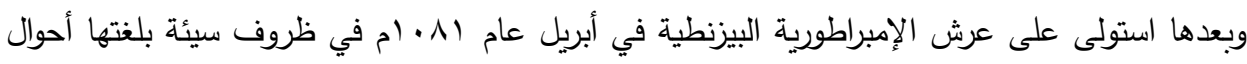

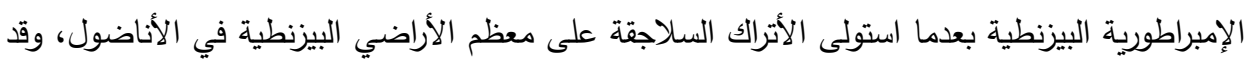

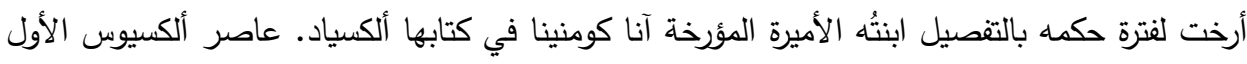

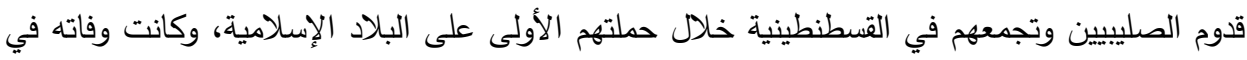

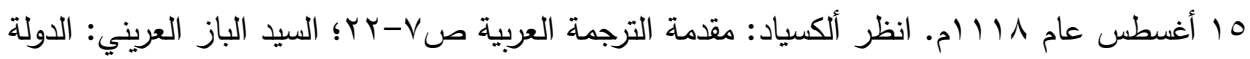

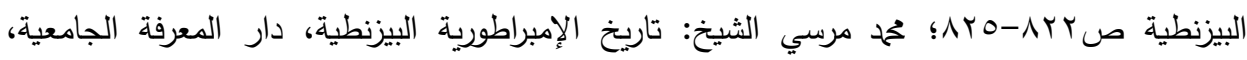

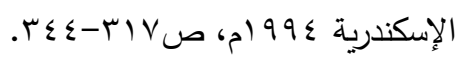

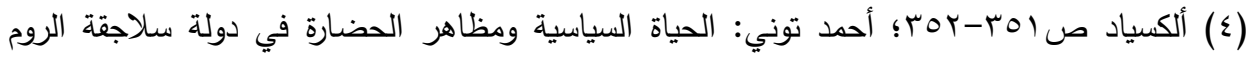

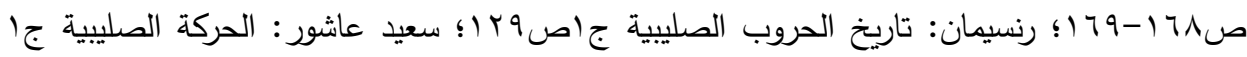

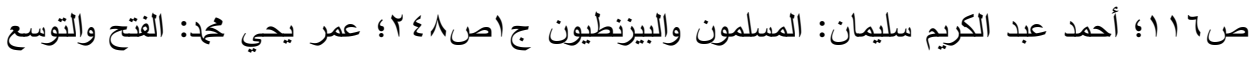
$=$ 


\section{زاخاس أسير ا في القسطنطينية:}

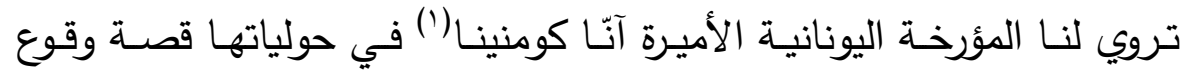
الأمير السلجوقي زاخاس في أسر البيزنطيين، فهي تذكر أنه في إحدى غاراته؛ وقع

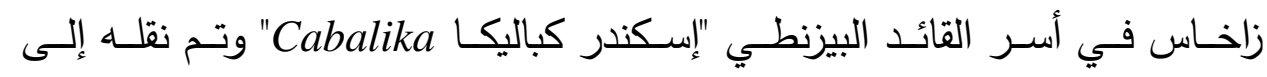

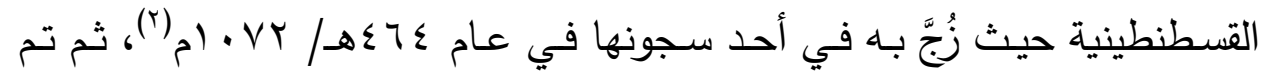

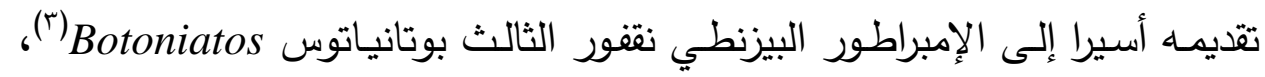

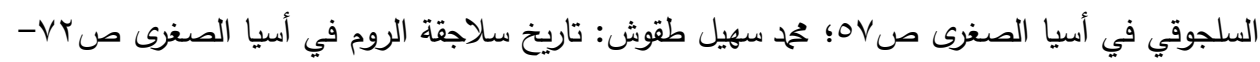

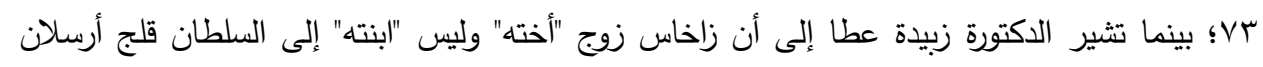

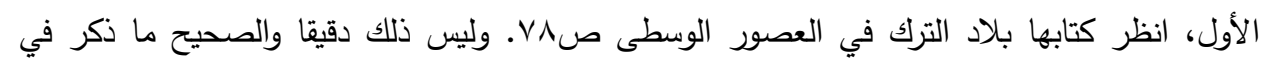

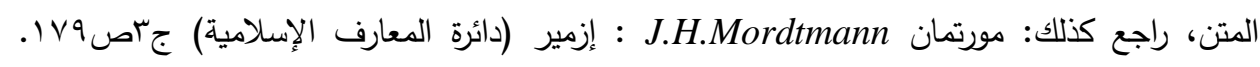

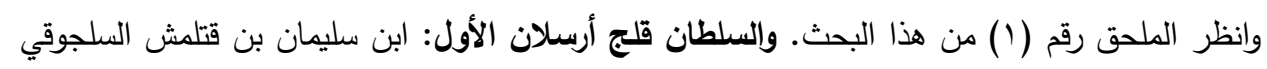

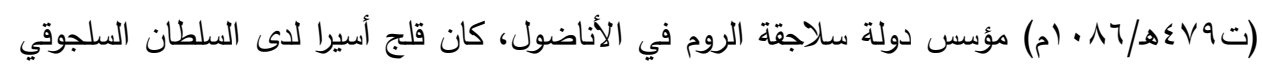

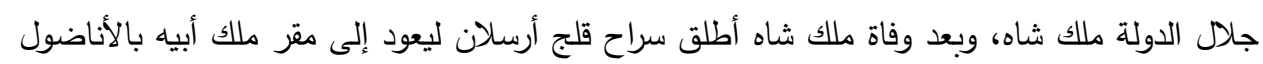

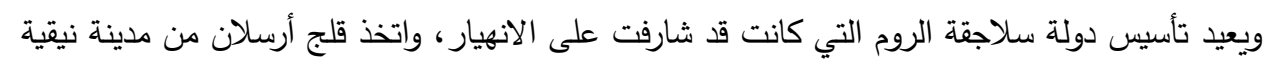

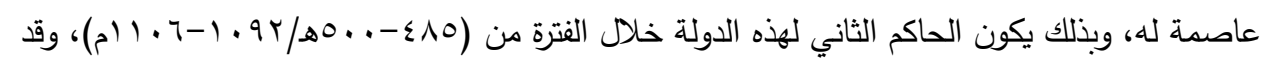

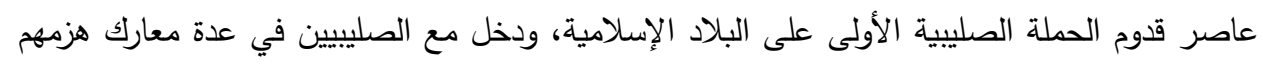

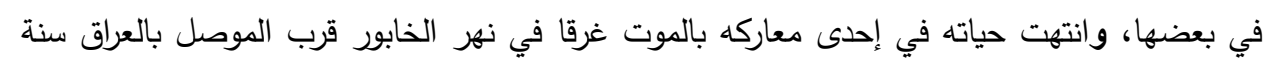

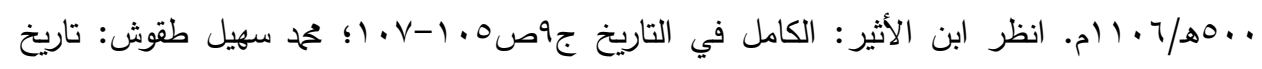

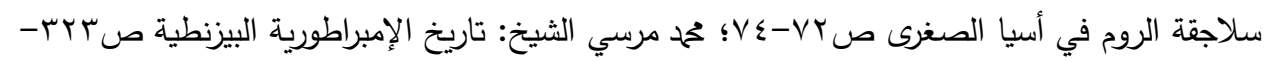

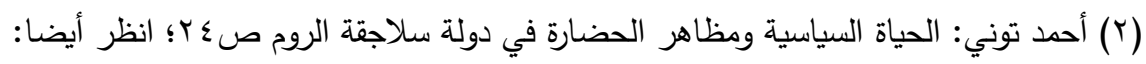
The Cambridge History of Islam, Cambridge at the University press, 1970, vol ,1, $p: 237$.

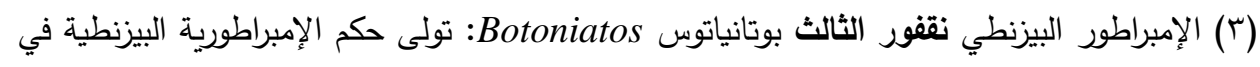

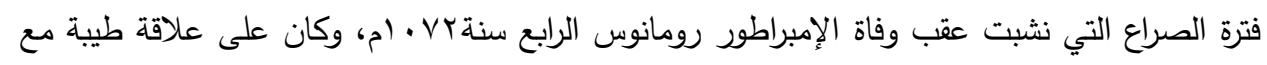

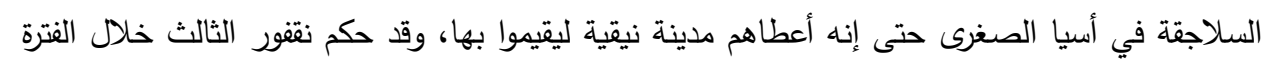

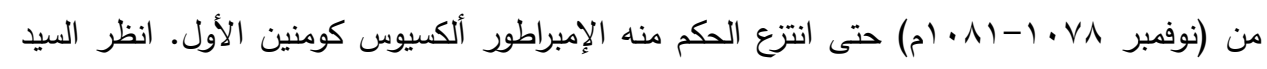
$=$ 
غير أن الإمبراطور أعجب بثجاعة الأمير التركي وفطنته، فأطلق سراحه من

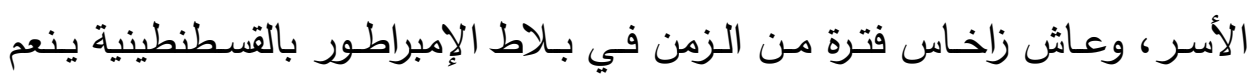

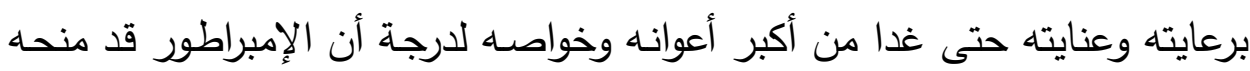

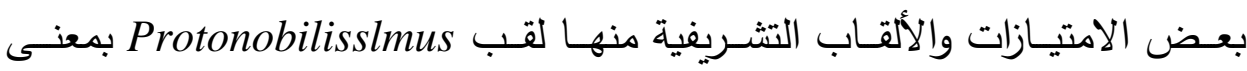
"النبيل" أو "الثريف" لما لمسه فيه من وفاء وإخلاص (")

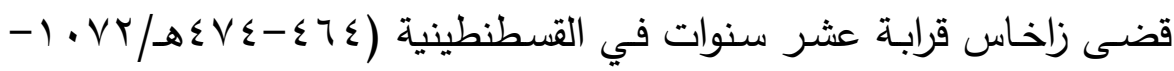

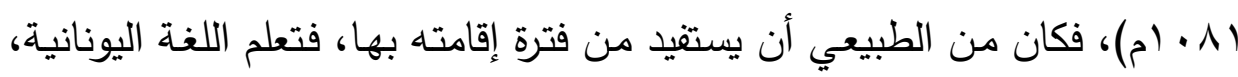

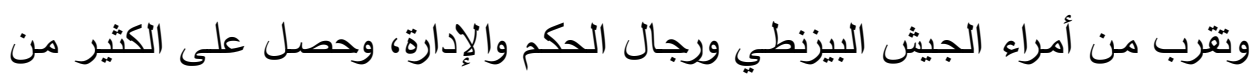
الامتيازات، وكوّن ثروة ضخمة، كما تعرف خلال تلك الفترة على طرق البيزنطيين

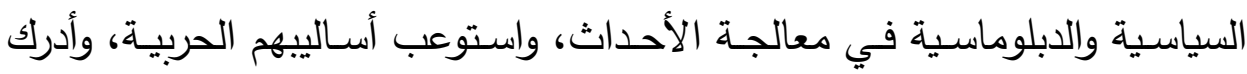

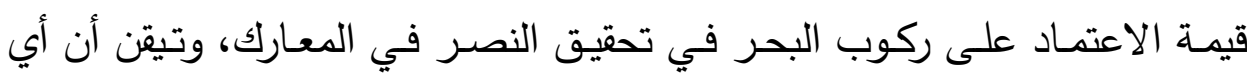

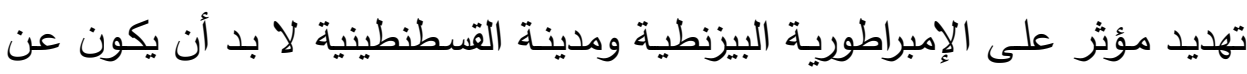

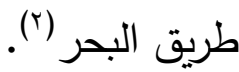

$$
\begin{aligned}
& \text { المبحث الثاني : قيام إمارة زاخاس في أزمير (أمار ) }
\end{aligned}
$$

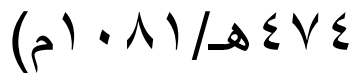

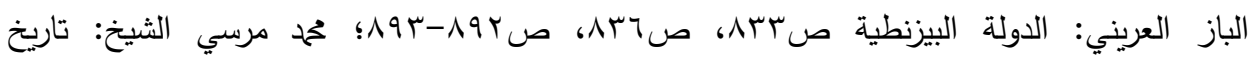

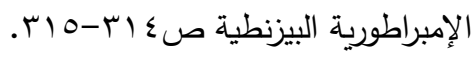

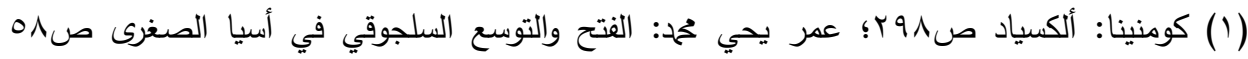

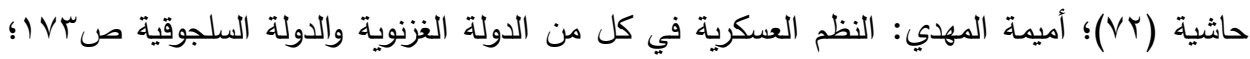

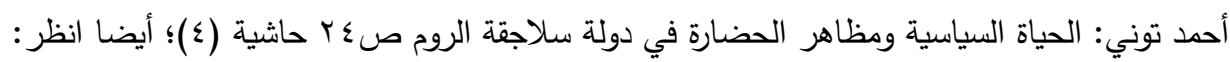
Ostrogorsky: History of the Byzantine state, p: 319.

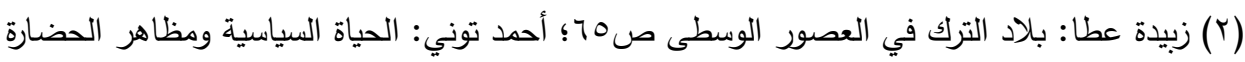

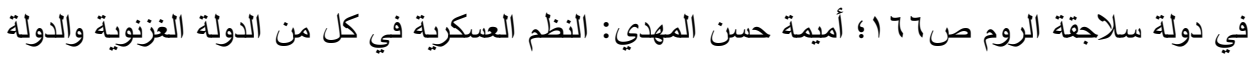

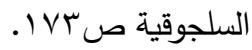


عنــما تـولى ألكسيوس الأول كـومنين عـرش الإمبراطوريـة البيزنطيـة عـام

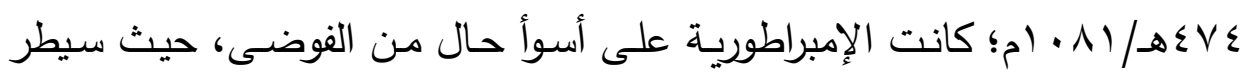

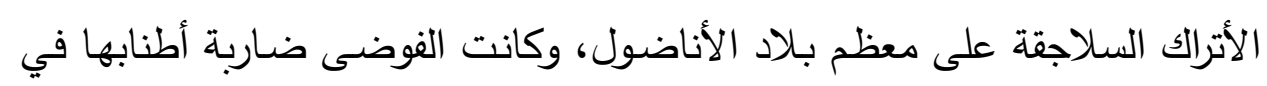
قوات الجيش والأسطول البيزنطي (1).

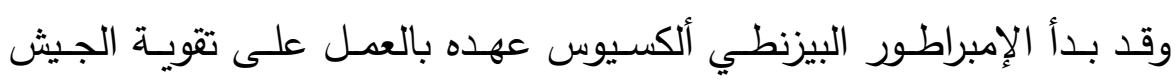

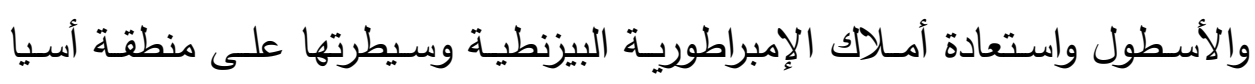

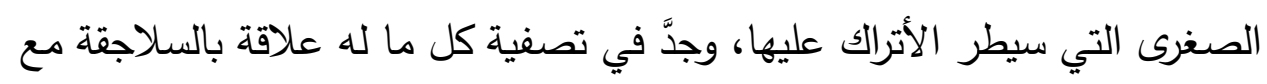

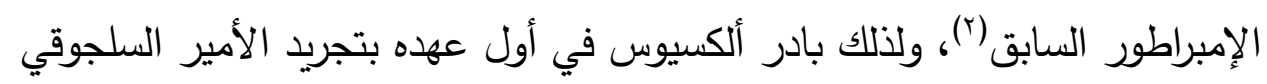

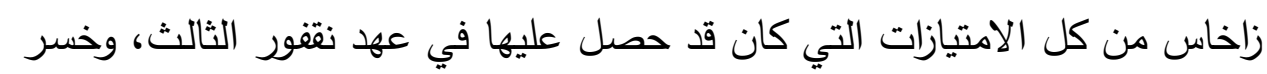

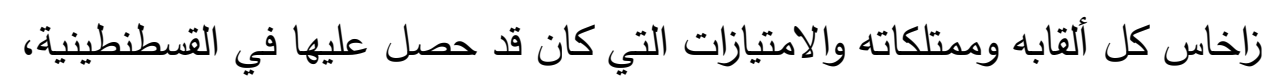

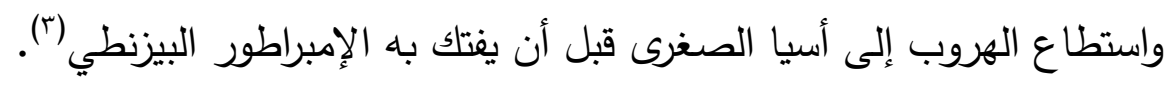

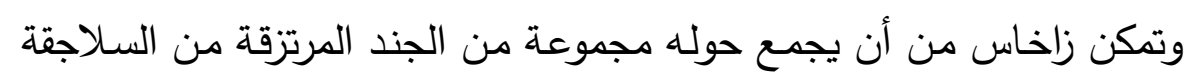

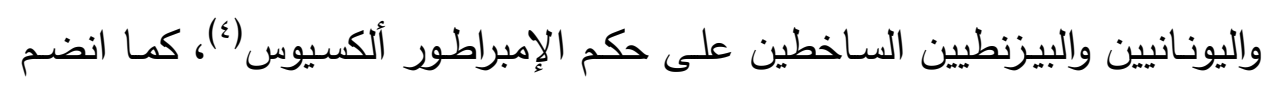

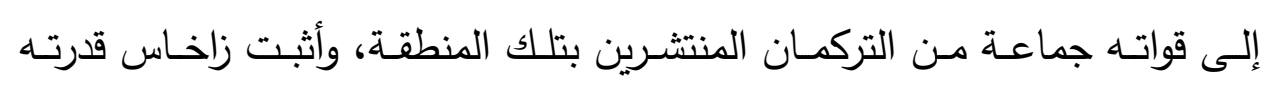

(1) أرشيبالد لويس: القوى البحرية والتجارية في حوض البحر المتوسط ص. لrr؛ السيد الباز العريني:

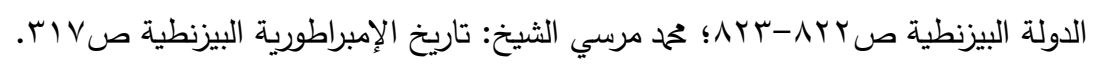

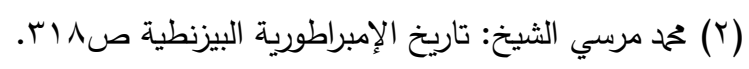

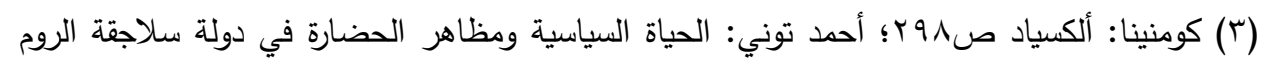

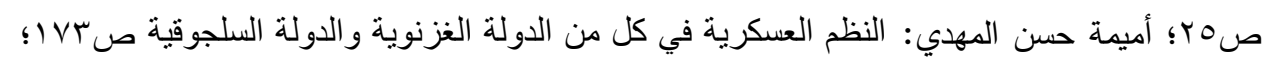

Ostrogorsky: History of the Byzantine state, p: 319.

كذلك:

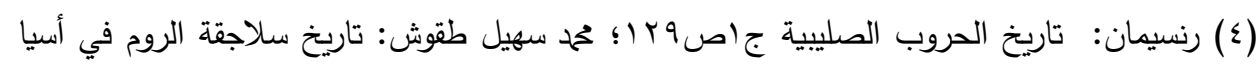

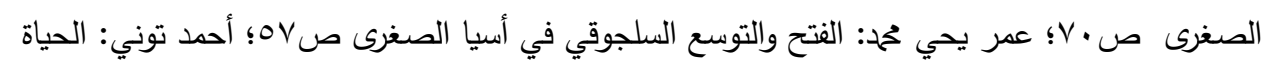

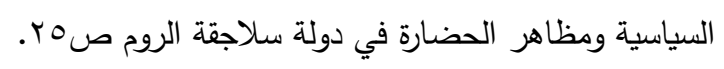




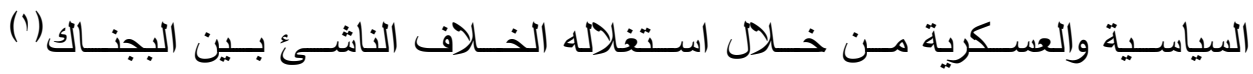

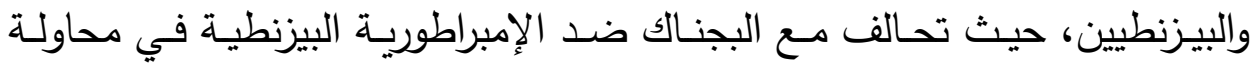
لتشتيت قواتها بينما انصرفت أنظاره إلى السيطرة على المدن الساحلية على بحر

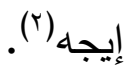

سعى زاخاس نحو تحقيق طموحاته وأحلامه في أسيا الصغرى، ومع أول قدوم

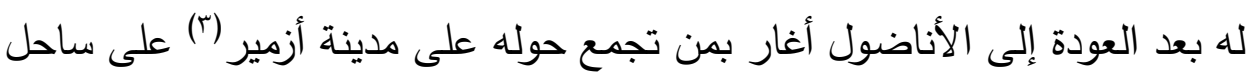

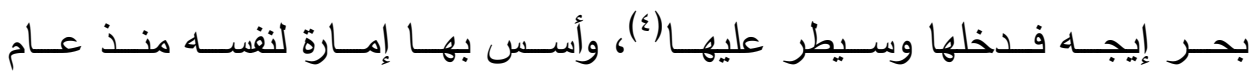

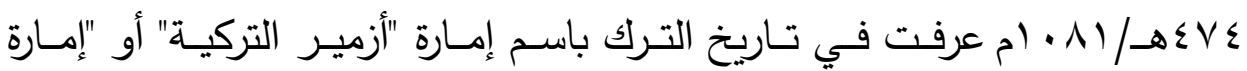

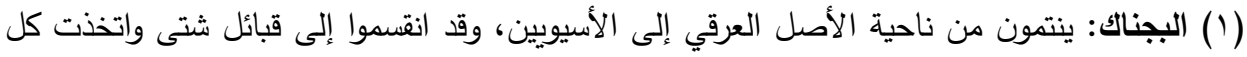

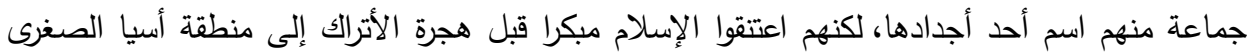

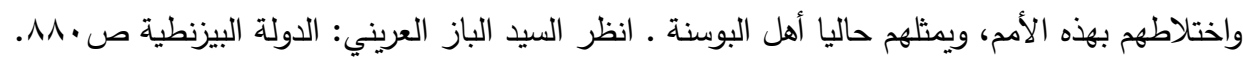

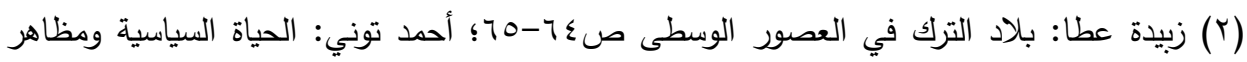

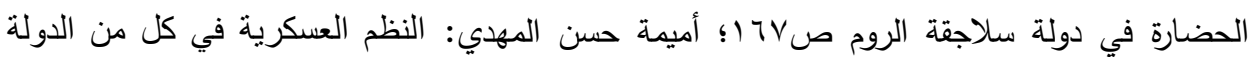

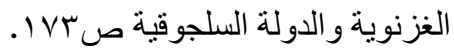

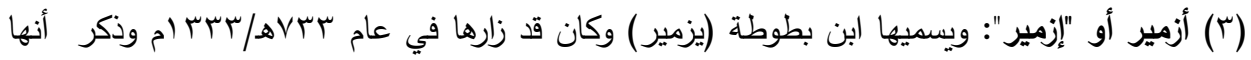

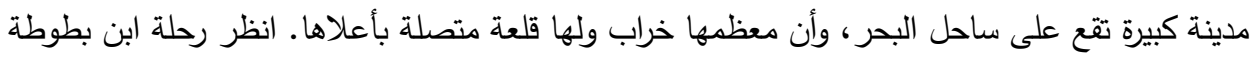

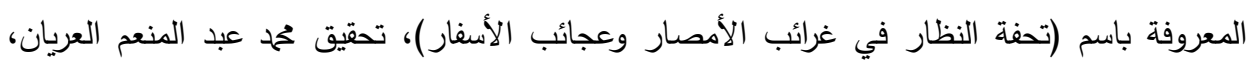

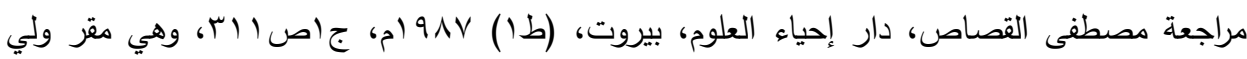

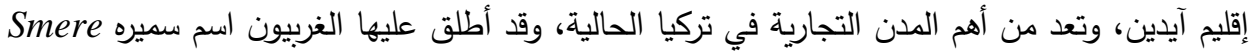

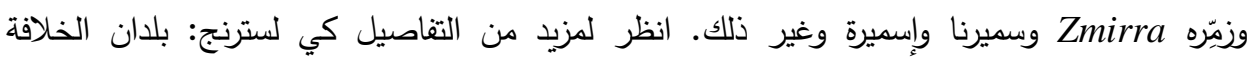

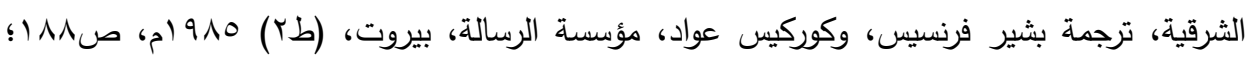

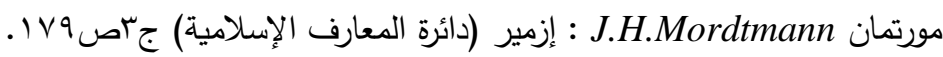

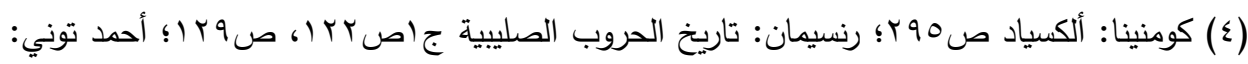

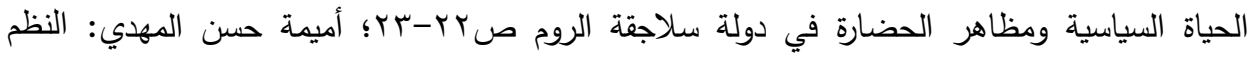

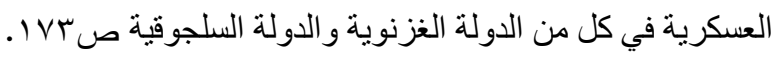


زاخاس"، كما عرفت أيضا باسم "إمارة سامرانا أو سميرنا"(")، وكلها مسميات لمدينة

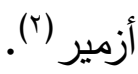

كان دخول زاخاس أزمير والسيطرة عليها هو المرة الأولى التي تخضع فيها هذه الدينة للسيطرة التركية من قبل السلاجقة، وقد اتخذها زاخاس منذ ذلك الحين الحين قاعدة ثابتة يغير من خلالها على أملاك البيزنطيين على ساحل بحر إيجه من أجل

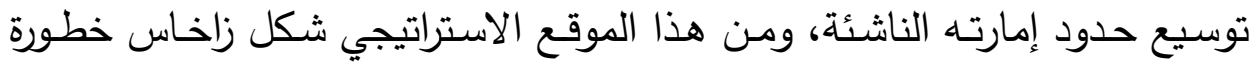

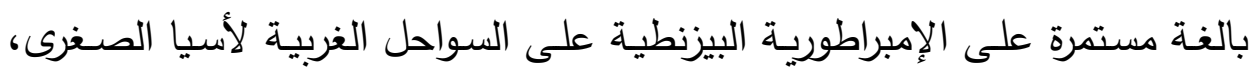
وقد نجح في ذلك نجاحا كبيرا مستغلا ضسف الإمبراطورية البيزنطية من ناحية، وعدم تعرض سلطنة سلاجقة الروم له من ناحية أخرى ().

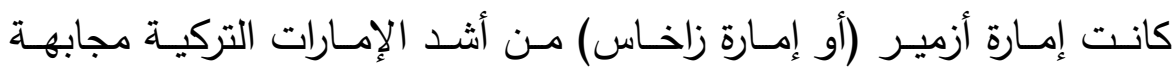

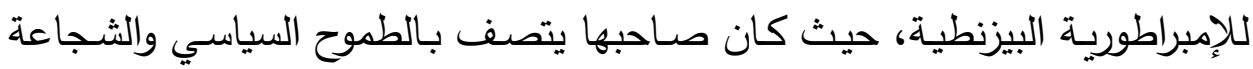

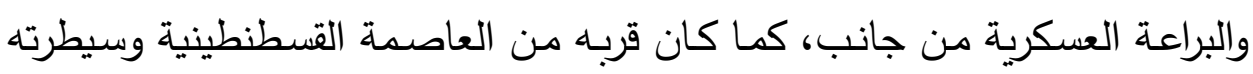

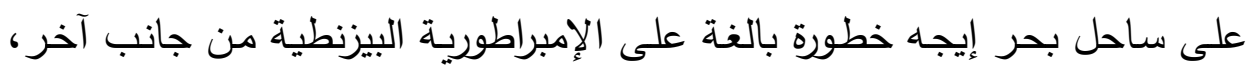

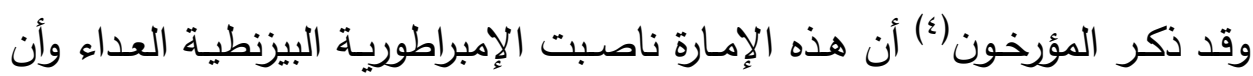

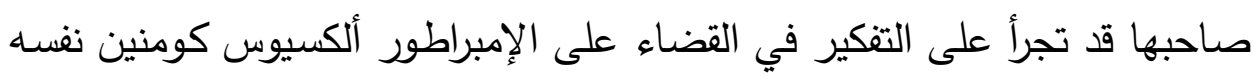

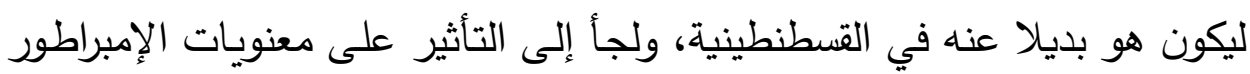
فاتخذ لنفسه لقب الإمبراطور في أزمير ، واستخدم شارات الإمبراطورية ورتبها (ه).

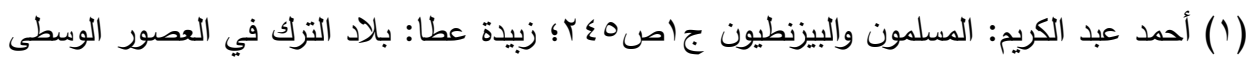

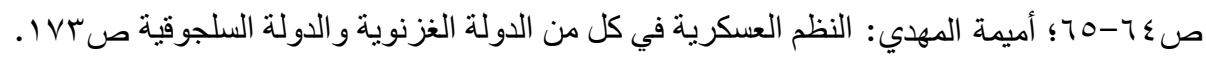

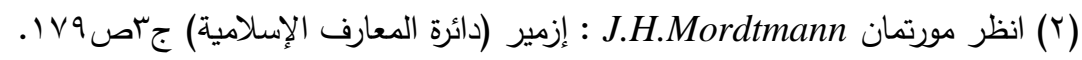

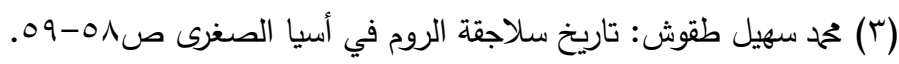

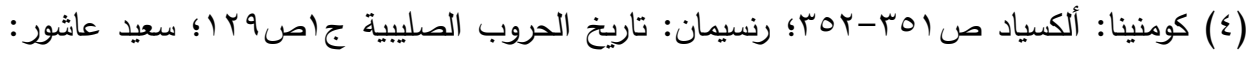

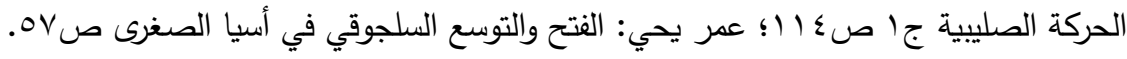

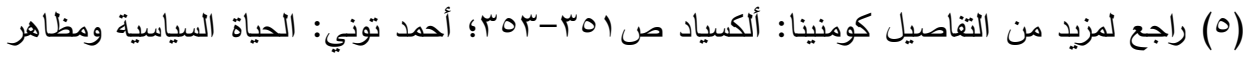
$=$ 
ومنذ ذلك الحين بـأت مرحلـة جديدة مـن الصـراع بين زاخـاس والإمبراطور

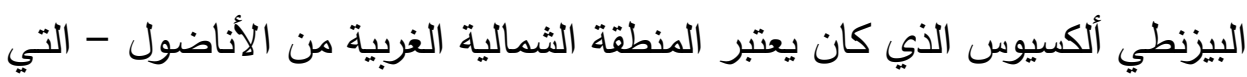
يقيم فيها زاخـاس حكمـه - تشكل خطرا كبيـرا على الإمبراطوريـة البيزنطيـة، فلقد غدت أزمير قاعدة ثابتة أخذ الأتراك يغيرون من خلالها على ساحل بحل بحر إيجـا بأكمله، وركزت بعض المصـادر على وصف أزمير آنذاك بأنها "قاعدة لأعمال القرصنة" البحرية التي كان يقوم بها زاخاس ومن معـه ضد أمسلاك الدولة البيزنطية

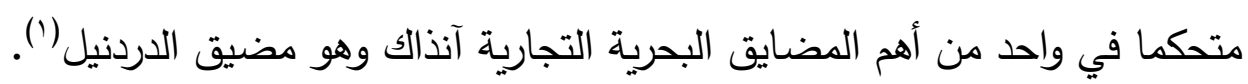

\section{$* * * * * * * * * * * * * * * * * * * * * * * * * * *$}

\section{المبحث الثالث : جهود الأمير زاخاس في إنثاء البحرية وبناء الأسطول}

يشير المستشرق أرشيبالد لويس(؟) إلى أن السلاجقة كانوا قد بلغوا البحر في أسيا الصغرى منذ عام V7

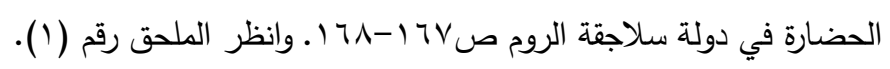

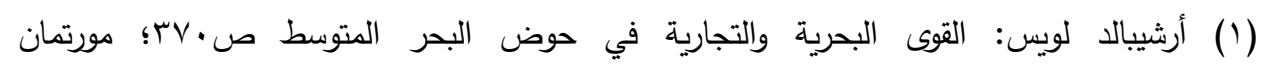
J.H.Mordtmann

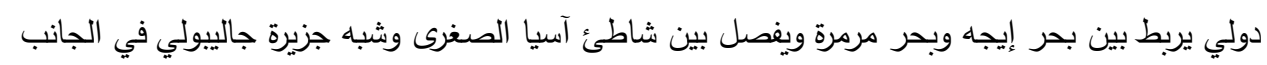

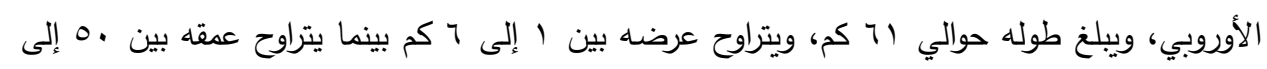

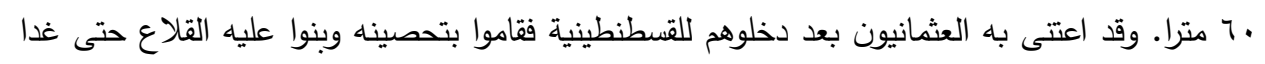
منيعا يصعب على الأساطيل الحربية والتجارية اجتيازه بسهولة، وبذلك أصبح التحكم في المضيق للفئل للسيادة

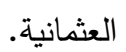

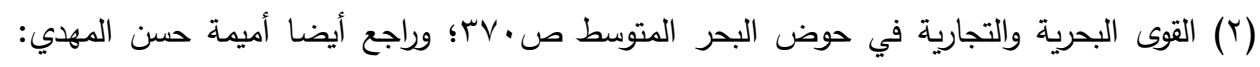

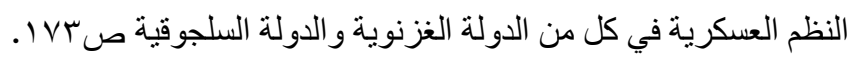


مدن الساحل آنذاك، غير أنهم لم يكونوا قد امتلكوا قوة بحرية أو أسطولا يساعدهم

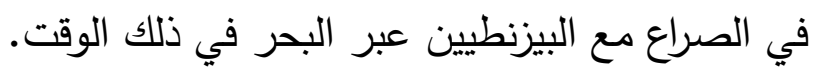

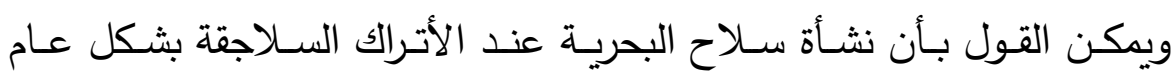

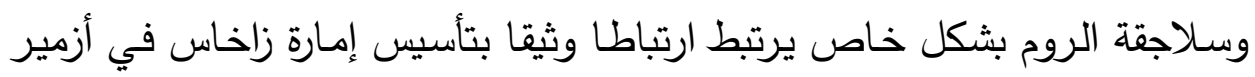

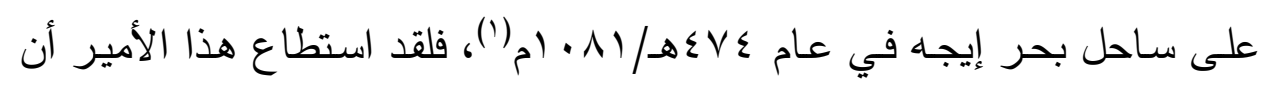

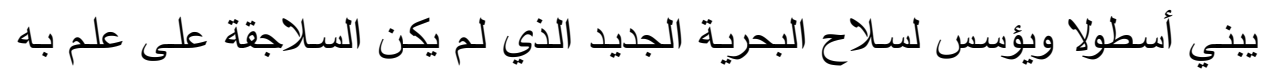

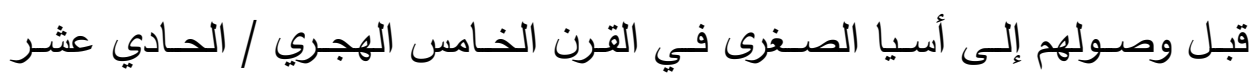

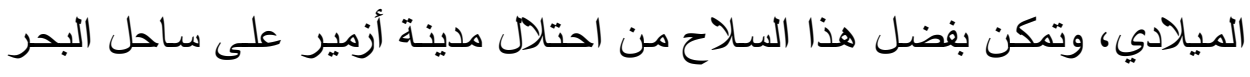

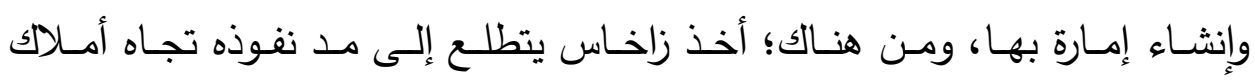
الإمبراطورية البيزنطية فسيطر بقوته البحرية على مدن الساحل وكثير من الجزر

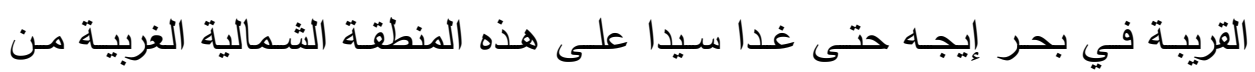
الأناضول (؟) كما سيرد بعد قليل.

( (1) يعتبر الأتراك في العصر الحديث أن الأمير زاخاس أول "أميرال تركي"، ويعدونه أول من أنشأ سلاح

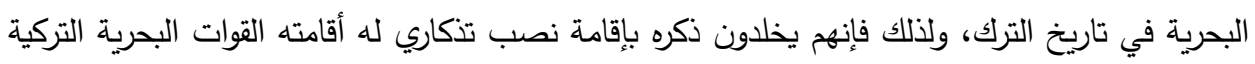

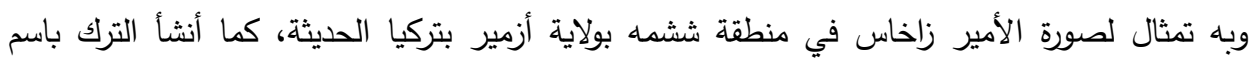

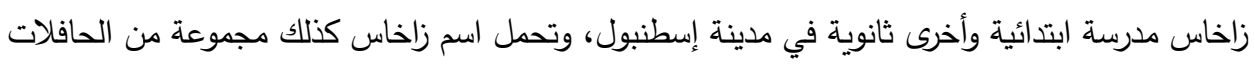

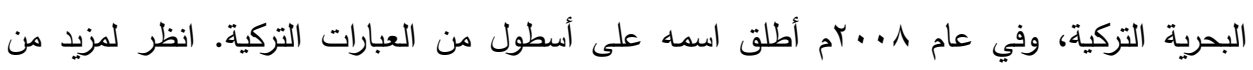
https://ar.wikipedia.org

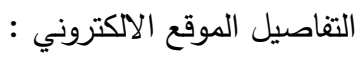

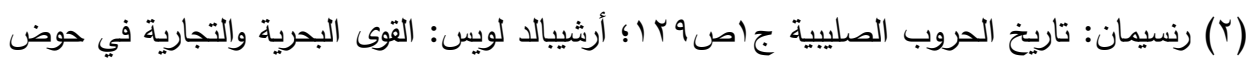

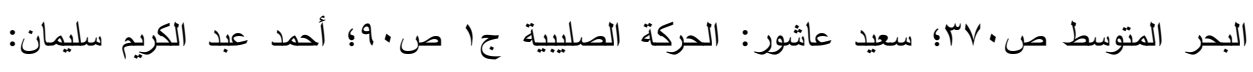

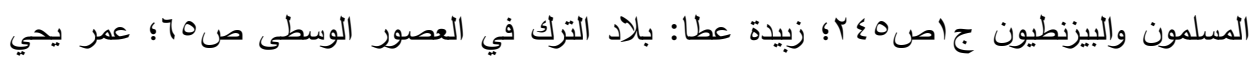

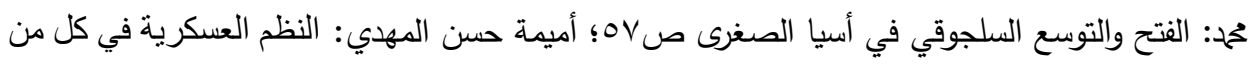

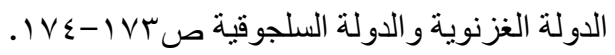




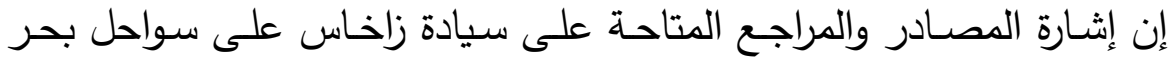

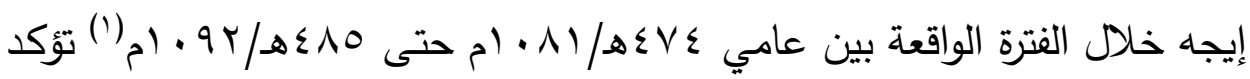

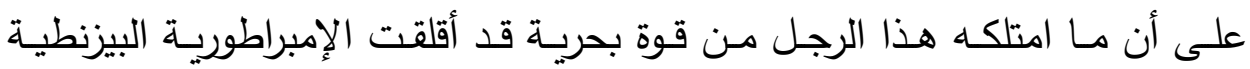

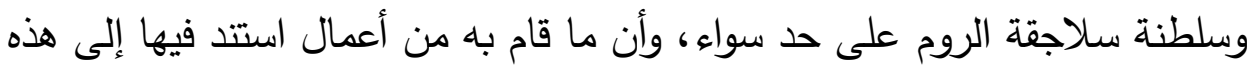

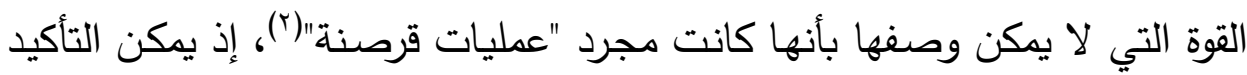
أن هذه القوة البحريـة كانت الدرع الأساسي الذي أثبت زاخاس وجوده من خلالهـ وجعله يعلن الاستقلال بحكم أزمير وما تحت يده من بلاد.

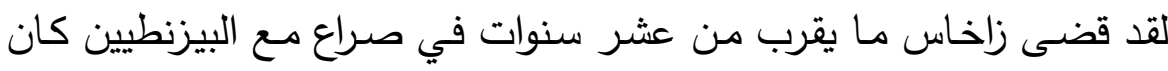
للبحرية السلجوقية خلالها نشاط واضح في زعزعة استقرار البيزنطيين في منطقة أسيا الصغرى وبخاصة على سواحل بحر إيجه، فلقد دخل زاخاس معهم خلال هذه فئه الفترة في عدة معارك، خسر في بعضها وتمكن من إحراز النصر في كثير منها،

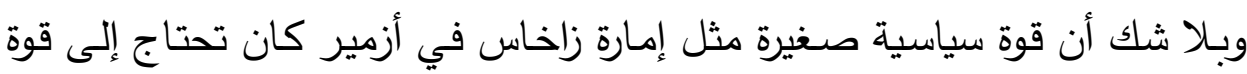

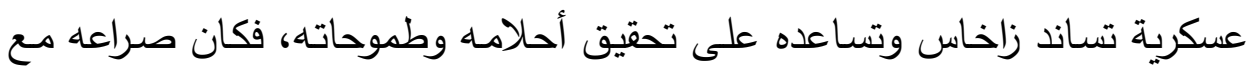

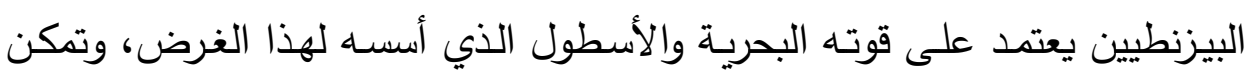

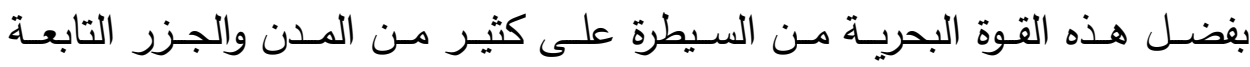
للإمبراطورية البيزنطية في أسيا الصغرى. لقد أدرك زاخاس خلال الفترة التي قضاها في البلاط البيزنطي أسير ووصيفا

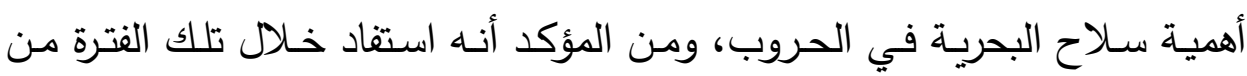

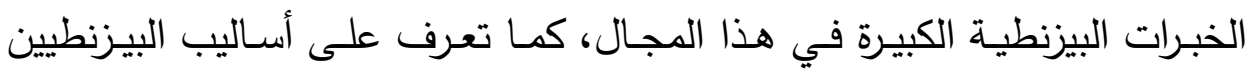

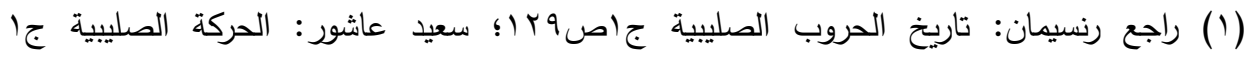

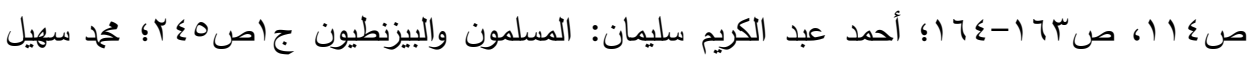

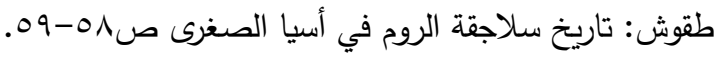

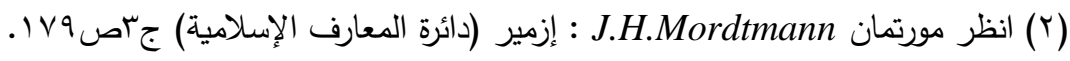


العسكرية والدبلوماسية، وتيقن زاخاس - كما سبق القول - من أن أي تهديد مؤثر

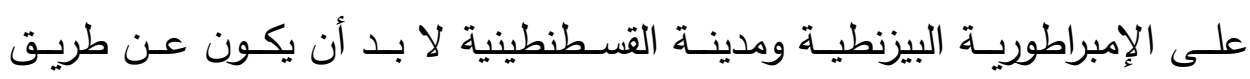

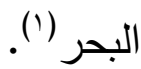

وقد يؤكد على هذا الرأي عدم وجود خبرات بحريـة لاى السلاجقة، ولذلك نرى زاخاس يستعين بخبرة الجنود البيزنطيين واليونانيين والإيطاليين في بناء الأسطول

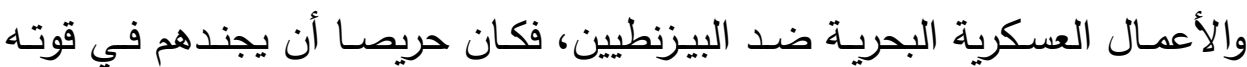

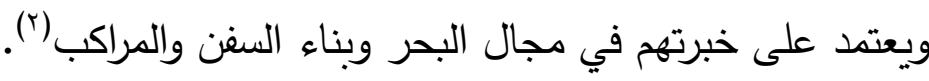

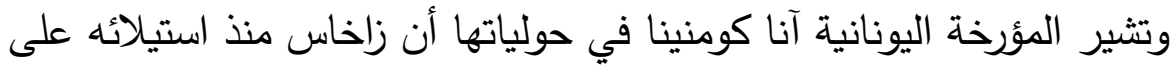

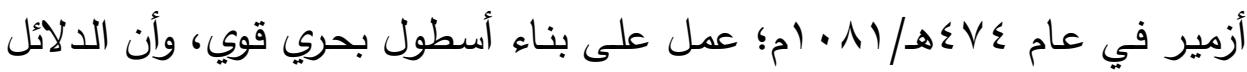

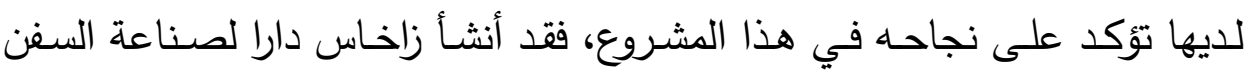

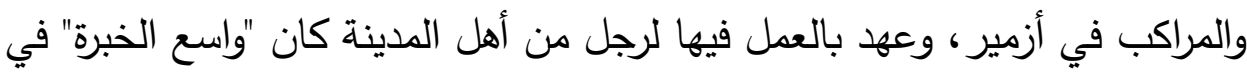

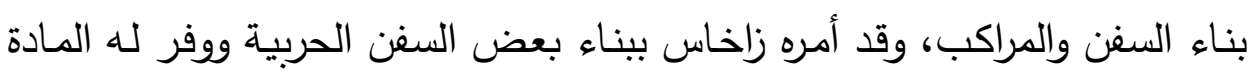

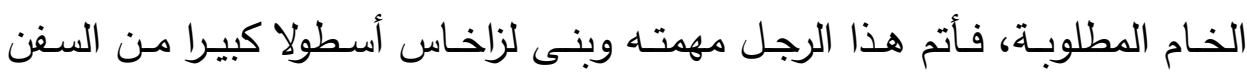
الحربية، كما ساعده على توفير ما يقرب من أربعين مركبا صغيرا بملاحيها كانوا

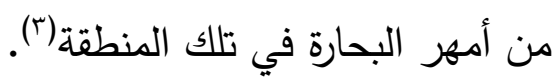
ولا يمكن قبول أن زاخاس الذي قضى فترة من الوقت في الأسر البيزنطي وتم

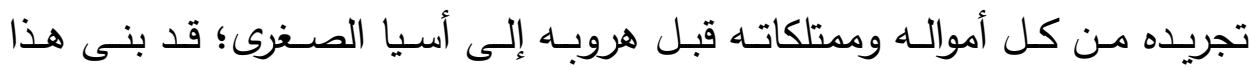

(1) زبيدة عطا: بلاد الترك في العصور الوسطى صهو؟؛ أحمد توني: الحياة السياسية ومظاهر الحضارة

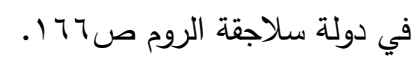

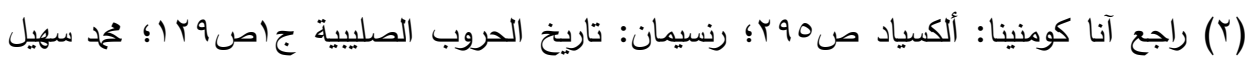

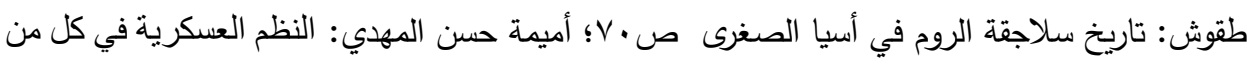

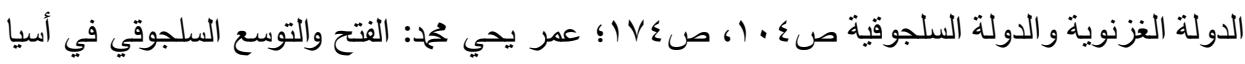


الأسطول في نفس عام تأسيس الإمارة، ولذلك نرجح تلك الروايات التي تثير إلى الى التى

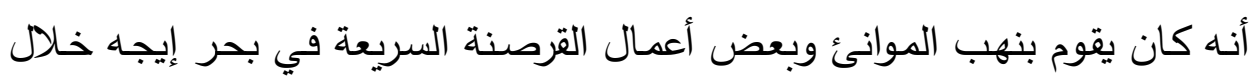

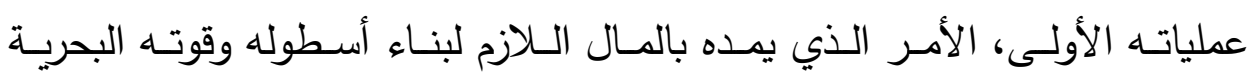
ويساعده على تحقيق مطالبه السياسية ('). وبلا شك كان زاخاس على اتصال وثيق بقوة سلاجقة الروم وحميه السلطان

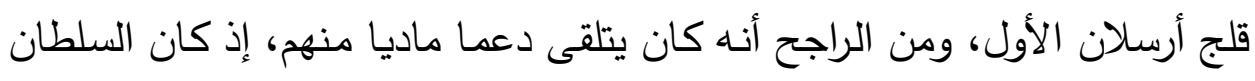

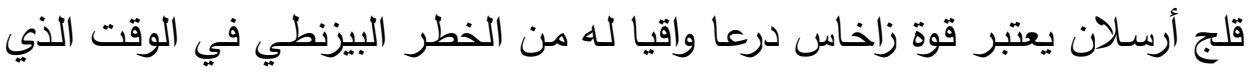

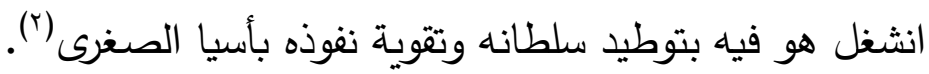

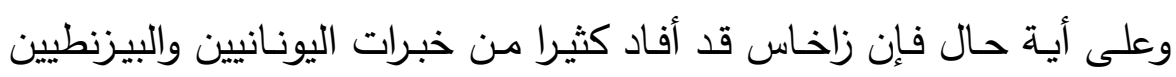

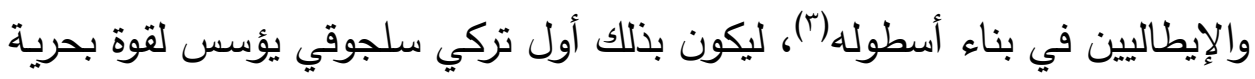

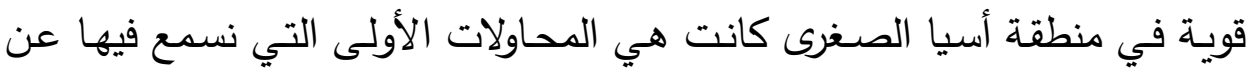

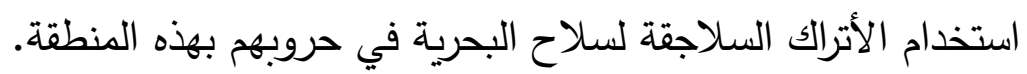

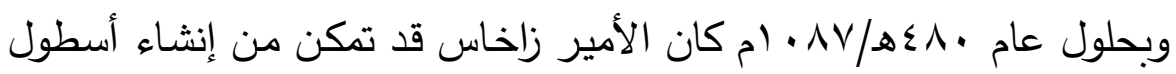

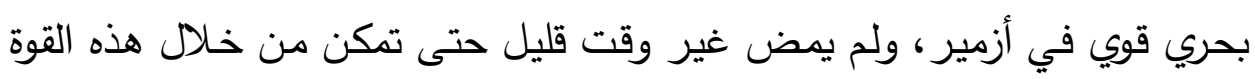
البحرية ان يكون سيدا على بحر إيجه (iٔ).

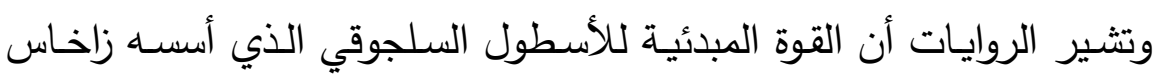

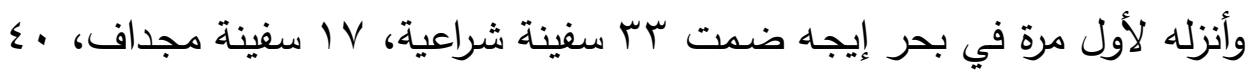

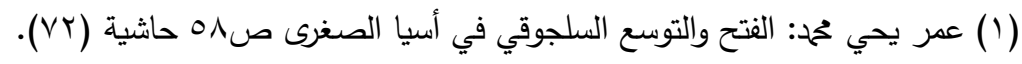

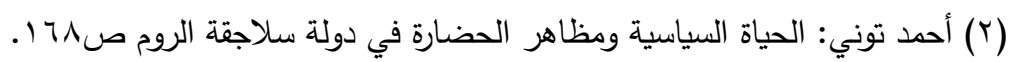

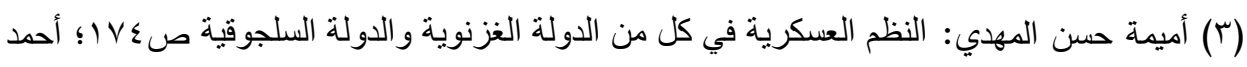

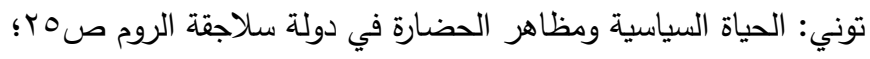
Ostrogorsky: History of the Byzantine state, p: 319.

(§) سوف يعرض البحث بالتفصيل في المبحث التالي للنشاط البحري للأمير زاخاس. 


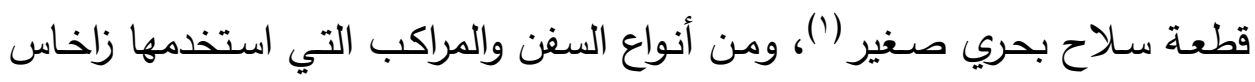

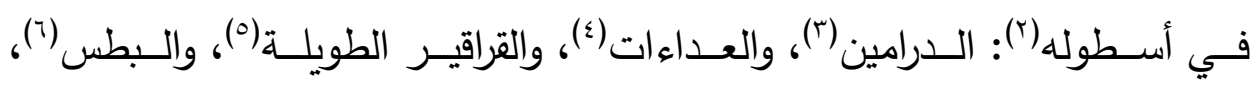

$$
\begin{aligned}
& \text { (1) انظر كومنينا: ألكسياد ص90. }
\end{aligned}
$$

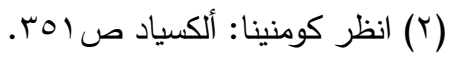

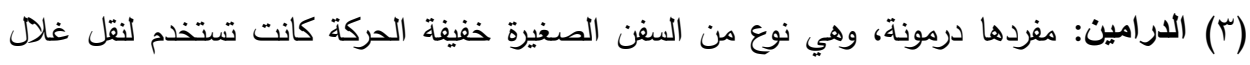

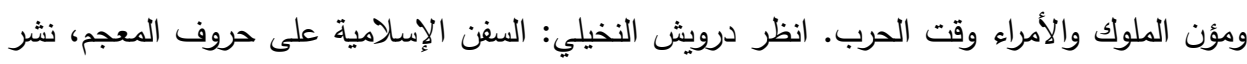

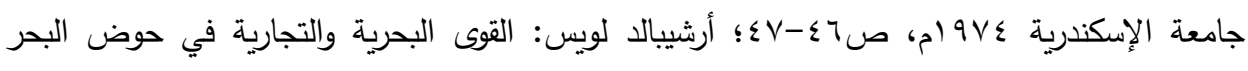
الكتوسط، ص1إئ.

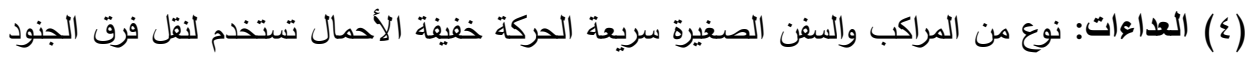
محدودة العدد من وإلى السفن الكبيرة داخل البحر . درويش النخيلي: السفن الإسلامية على حروف المعنم ص 9 . 9

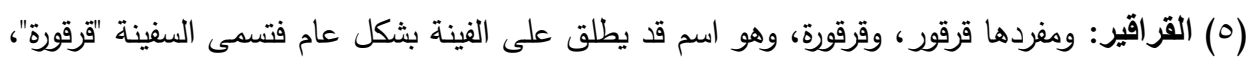

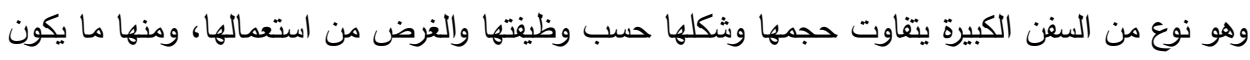

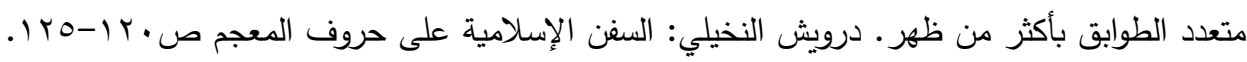

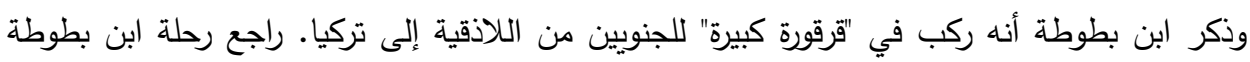

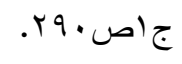

(ا) البطس: نوع من السفن الضخمة المستخدمة في الحروب بشكل كبير وقت الحروب الصليبية،

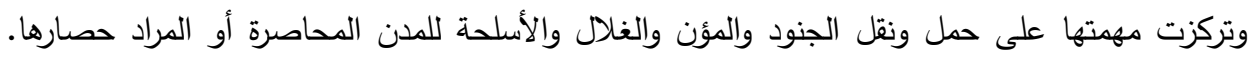

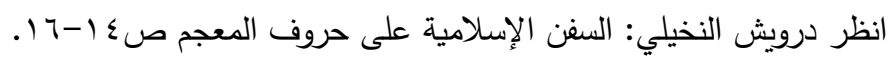


والثـــاني (')، والمزاريب الطويلة ثلاثية المجـاديف(؟)، ونوع آخر من السفن يسمى

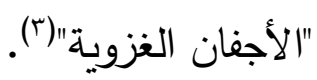

(1) الثواني: ومغردها شينية أو شونة، وهي السفينة الحربية الضخمة الكبيرة، وهي أهم قطع الأنسول

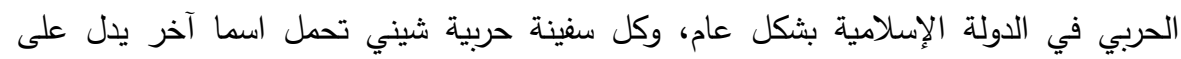

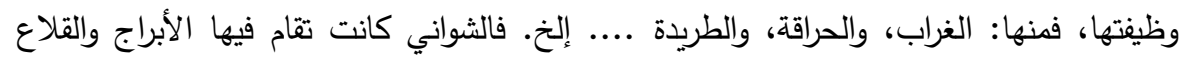

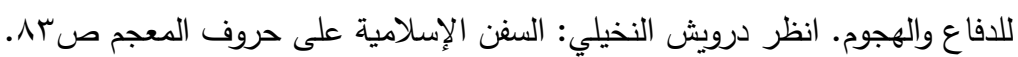

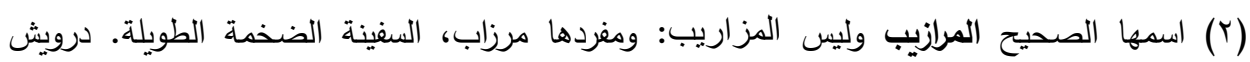

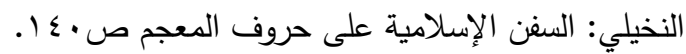

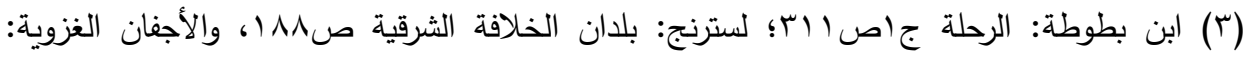

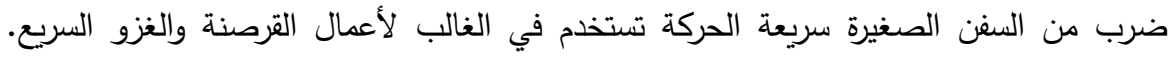

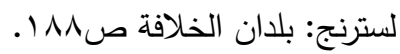




\section{المبحث الر ابع : النشاط البحري للأمير زاخاس في أسيا

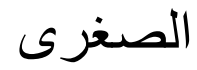

على الرغم من إثارة الروايات إلى أن قوة زاخاس البحرية بدأت في الظهور

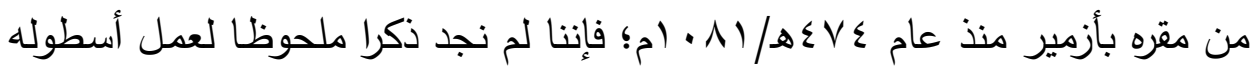

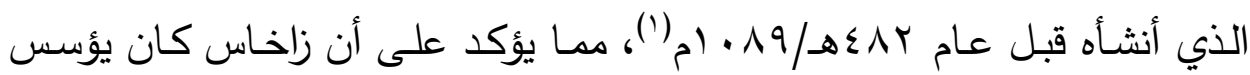
أسطوله ويبنيه طوال تلك الفترة الزمنية.

وبعد بناء الأسطول وتجهيزه؛ بدأ زاخاس في محاربـة الإمبراطور البيزنطي البني

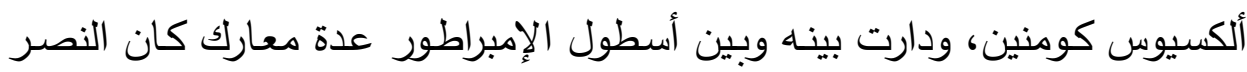
في معظمها حليف الأمير السلجوقي زاخاس. تشير كومنينا في حولياتها أن أول عمل عسكري بحري لزاخاس كان الان موجها

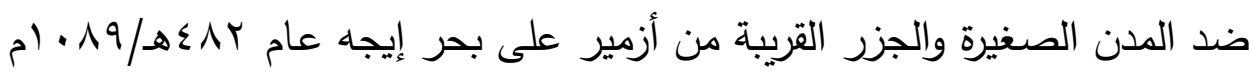

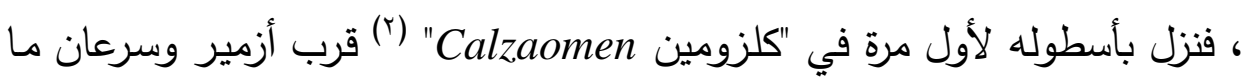

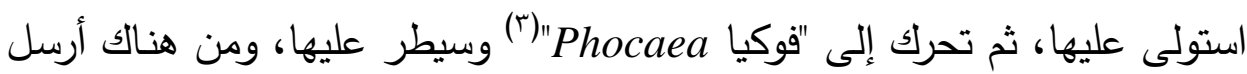
رسالة إلى "ألوباس Alopus" حاكم جزيرة ميتيلين (\&) على ساحل بحر إيجها، وأمام

(1) انظر عمر يحي محح: الفتح والتوسع السلجوقي في أسيا الصغرى صلهماه.

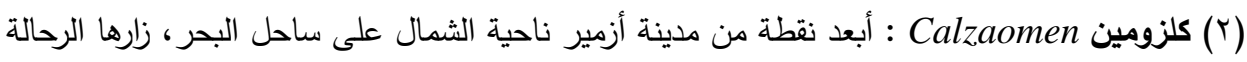

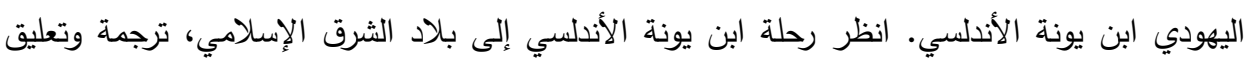

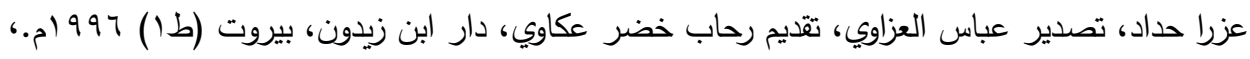

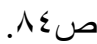

(T) فوكيا: وتعرف حديثا "ني فوكيا" مدينة يونانية تقع حاليا في هالكيديكي في مقاطعة فوريا إلادا.

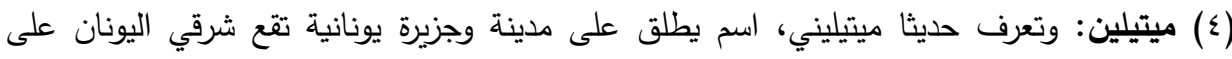

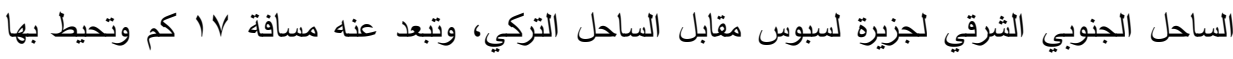
التلال من الغرب والثمال ولها ميناء يربطها بجزيرتي خيوس وليمنوس في بحر إيجه. انظر رحلة ابن النابل

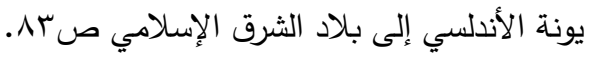


تهديد زاخاس؛ أبحر حاكم الجزيرة سرا في الليل هاربا إلى القسطنطينية، واستولى

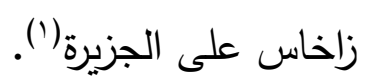

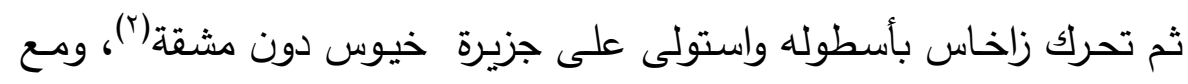

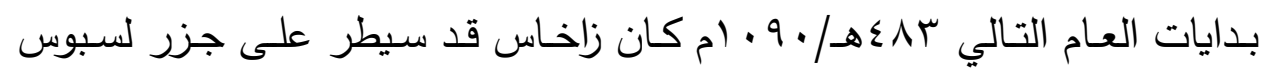

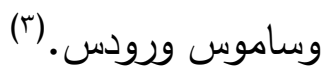

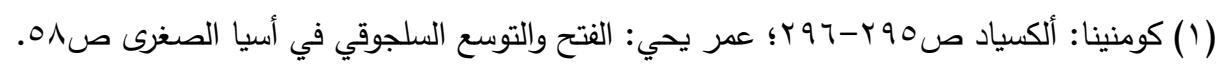

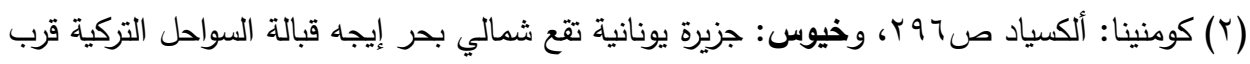

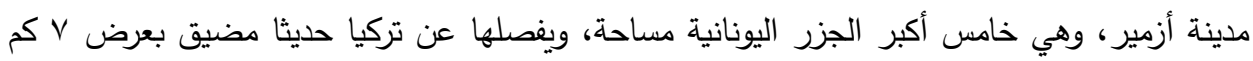

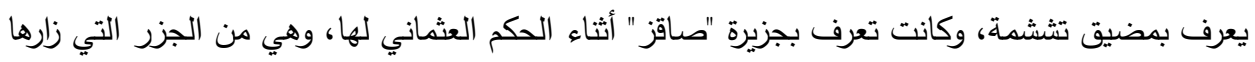

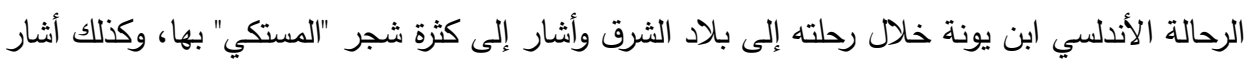

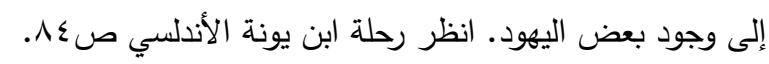

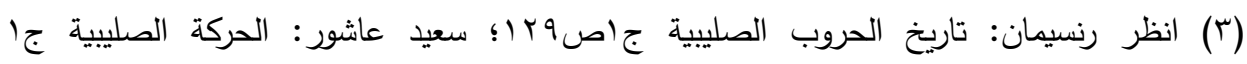

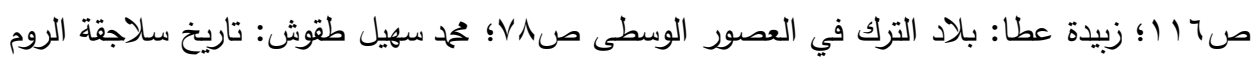

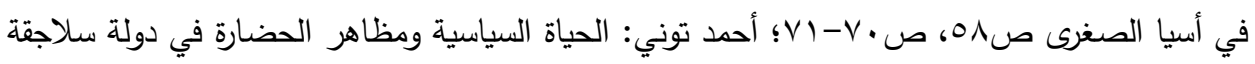

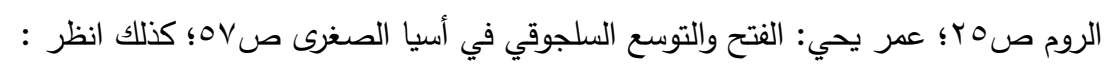
Cambridge History of Islam, vol , 1, p: 239.

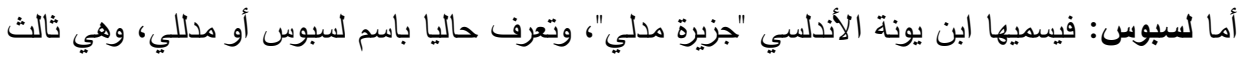

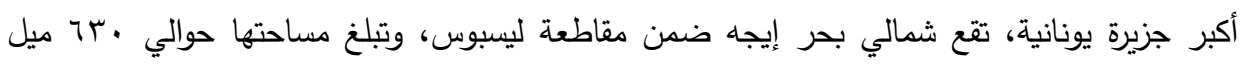

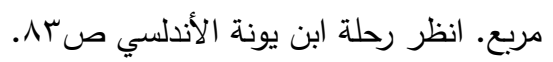

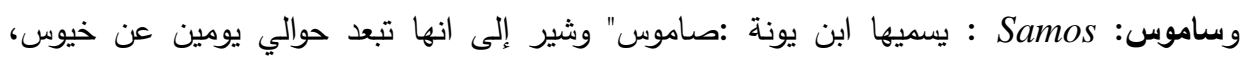

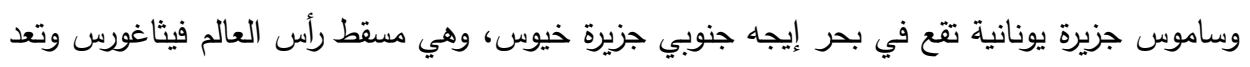

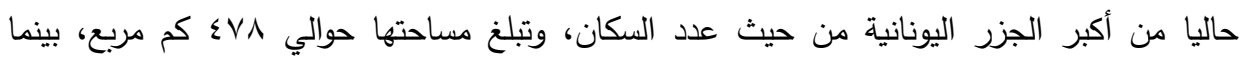

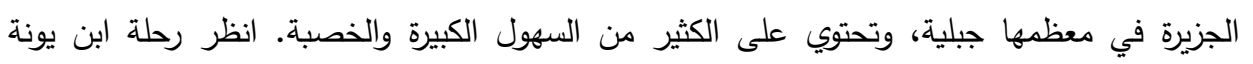

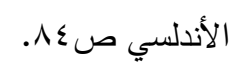

ورودس: تبعد حوالي ثلاثة أيام من جزيرة ساموس وعلى بعد أربعة أيام من جزيرة قبرص، وروس

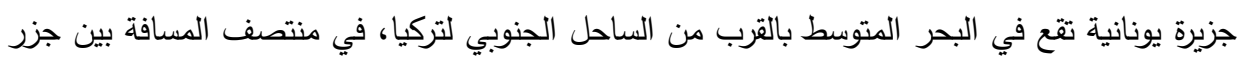

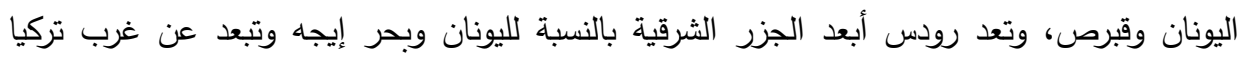

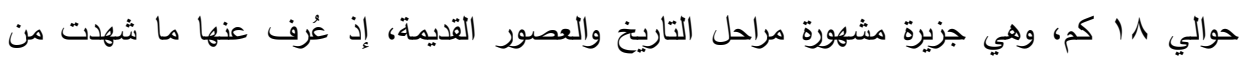
$=$ 
وهكذا غدا زاخاس خلال مدة زمنية بسيطة لم تتجاوز العامين سيدا على بحر

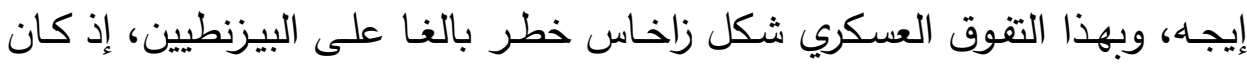

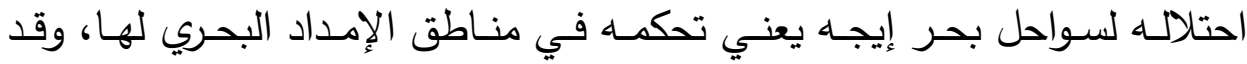
أزعجت انتصـاراته المتتالية الإمبراطور البيزنطي ألكسيوس كومنين، فأرسل على الئى

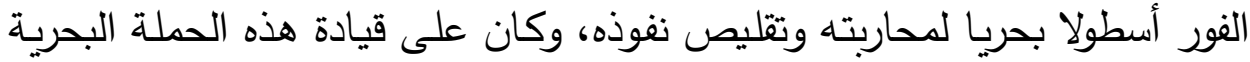
القائد نيكتاس كاستامونيتس Nicetas Castamonites، وبادر القائد البيزنطي بالتوجه أولا إلى جزيرة لسبوس لاستعادتها من زاخاس، لكن هذا الأسطول عاد خائبا وتمكن زاخاس من إحراز النصر على القوات البيزنطية وأسر عدد كبير من لأنس السفن والمراكب البيزنطية(')، وظلت الجزيرة تحت يدي زاخاس مما يشير إلى مدى الئى

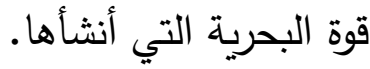

ومن جانبه أرسل الإمبراطور البيزنطي ألكسيوس كومنين أسطولا بحريا أخر

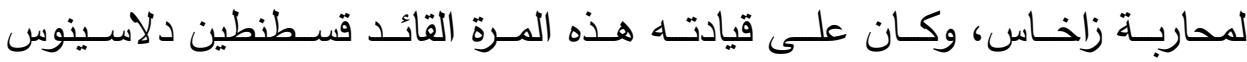
Constantine Dalassenus البيزنطية، وتحركت القوات البيزنطية يرافقها القائد "ألوباس Alopus" حاكم ميتيلين

صراعات ونزاعات من قبل أغلب الإمبراطوريات والقوى القديمة، ويعود هذا الصراع الذي كان دائرا حولها

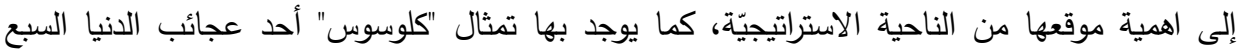

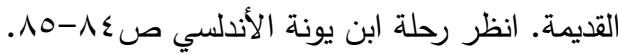

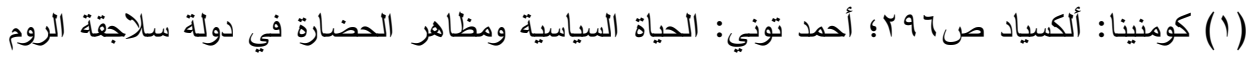

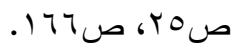
(ץ) قسطنطين دلاسينوس Constantine Dalassenus: كان يتصل بصلة القربى بالإمبراطور

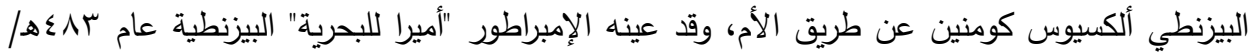

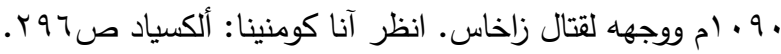


الذي هرب سابقا، غير أن هذا الأسطول البيزنطي مني هو الآخر بالهزيمة قرب

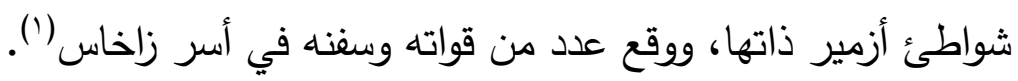
وعلى الرغم من انتصـار زاخاس كما أوضحنا، واعتراف الأميرة آنا كومنينا

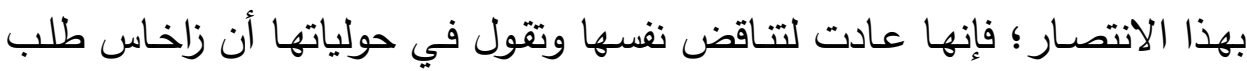

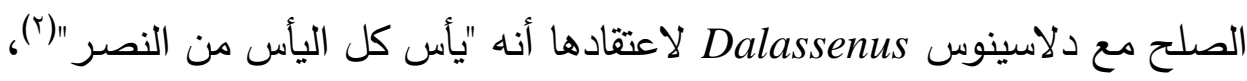

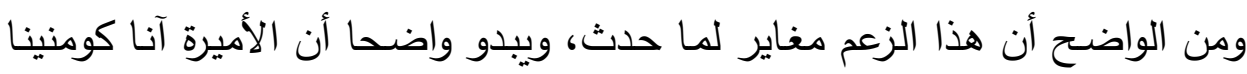
قصدت به إعلاء شأن القوات البيزنطية في شأن المعارك التي خاضتها ضد التد الأمير السلجوقي زاخاس (־).

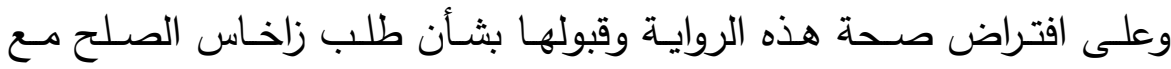

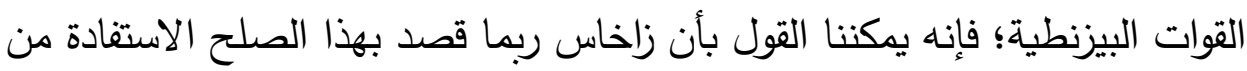

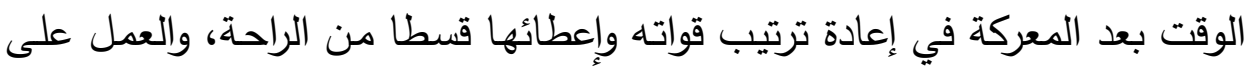

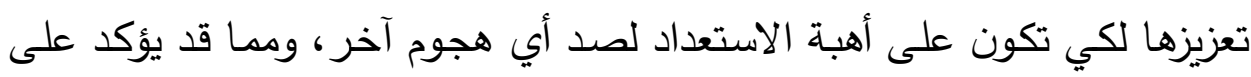

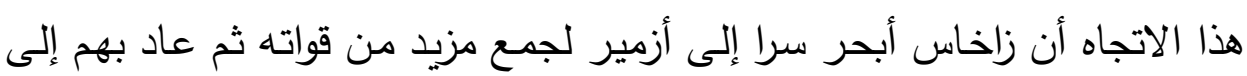

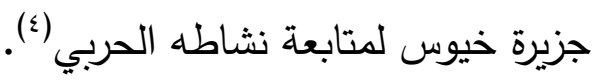

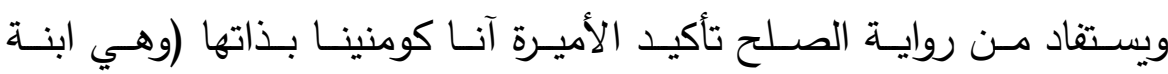

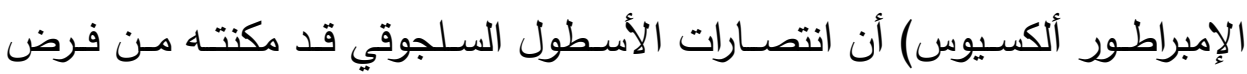
سيطرته على بحر إيجه، ولذلك أبدى زاخاس رغبته في الجلوس للتنفاهم مع القائد

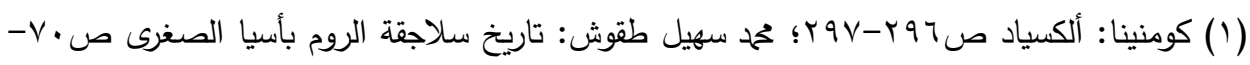

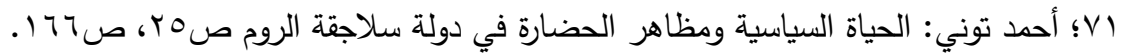

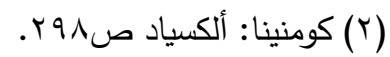

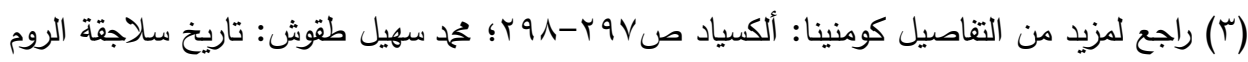

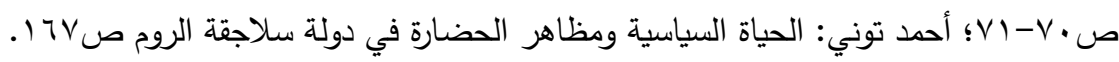

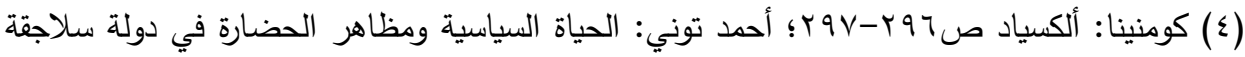

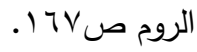


قسطنطين دلاسينوس Constantine Dalassenus، كما أبدى استعداده لإعـادة الجزر التي احتلها للبيزنطيين ولكن بشرط أن يعيد إليه الإمبراطور البيزنطي كل أموالهه وممتلكاته التي سلبها منهـ وقت وجوده في القسطنطينية، وأن يوافق القائد

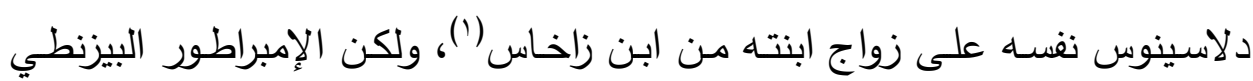

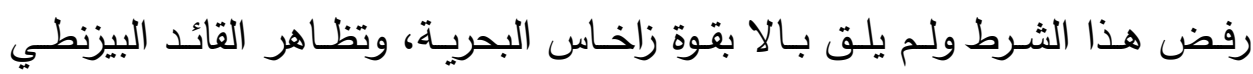
دلاسينوس بالموافقة على شروط زاخاس حتى انقضى اليوم ودخل الليل فذهب كل منهما في الاستعداد للحرب دون الوقوف على شروط الصلح السابقة(؟). ولم يجد الإمبراطور البيزنطي بدا من مضـاعفة الجهد للقضـاء على خطر زاخـاس وقوتـه البحريـة، حيث كان ذلك يحتل مكانـة كبيرة في فكرة واستراتيجيته باعتبار أن السـيادة في البحر بهذه المنطقـة ينبغـي أن تظل بأيدي البيزنطيين

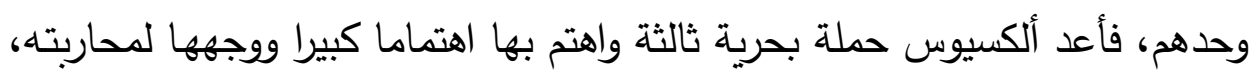
وكان قائد القوات البحريـة البيزنطية هذه المرة القائد حنـا دوكاس Ducas، والتقىى الأسطول البيزنطي بالأسطول السلجوقي بالقرب من جزر كويون في بحر مرمرة

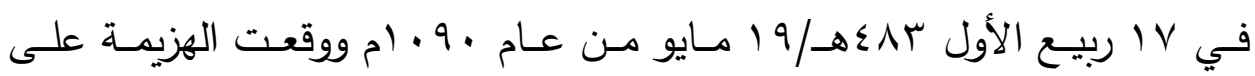
أسطول السـلاجقة، وركزت القوات البيزنطية على استخلاص جزيرة خيوس، حيث حاصروها وأخذوا في قذف الحامية التركية بها بالمجانيق، وخسر زاخاس السيطرة على جزيرة خيوس التي دخلتها القوات البيزنطية بأمر الإمبراطور ().

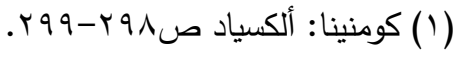

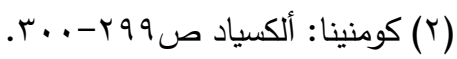

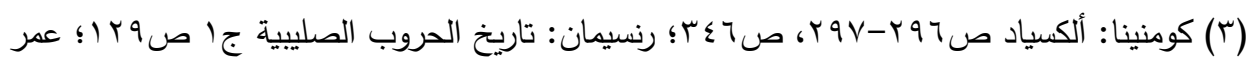

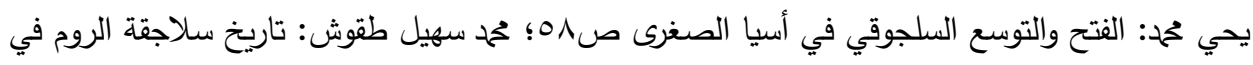
أسيا الصغرى ص •V-VI؛ أحمد توني: الحياة السياسية ومظاهر الحضارة في دولة سلاجقة الروم 
وقد رأى زاخـاس بعدما خسر جزيرة خيوس أن يعود بقواتـه إلى قاعدتـه في

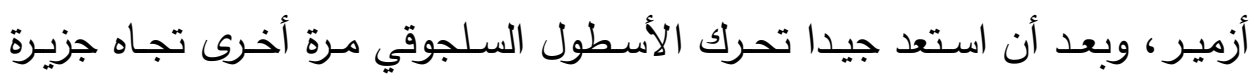
خيوس، وكانت تعداد رجاله هذه المرة وفق رواية كومنينا ثمانية آلاف جندي من

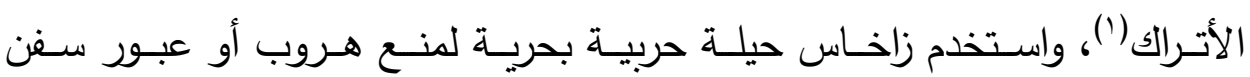

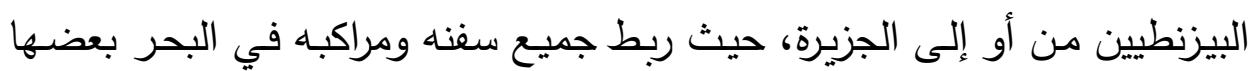

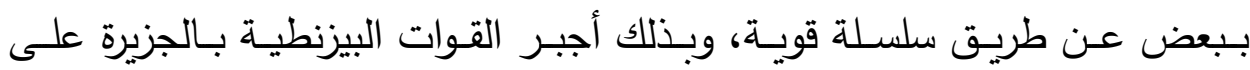

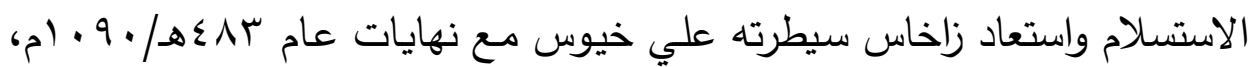
كما بادر باتخاذ خطوة في غاية الأهمية حيث تحرك صوب مدينة أبيدوس مفتاح

مضيق الدردنيل وسيطر عليها، وأغلق المضيق أمام الملاحة البيزنطية(؟).

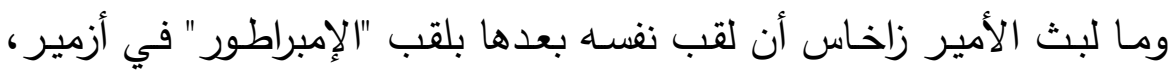

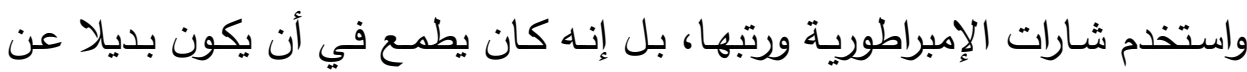

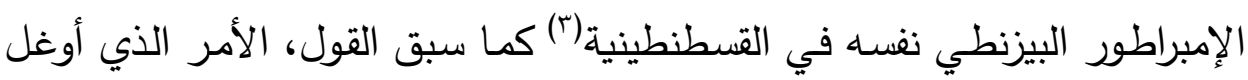
صدر الإمبراطور ألكسيوس كومنين وجعله يقرر إخراج زاخاس من مقره بأزمير حتى يمكن القضاء عليه. وفي سبيل ذلك؛ أعد الإمبراطور البيزنطي قوة كبيرة لمحاربة زاخاس والقضـاء على نفوذه وقوته البحرية، وقد تولى قيادة هذه الحملة القائد دوكاس John Ducas،

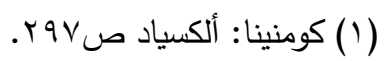

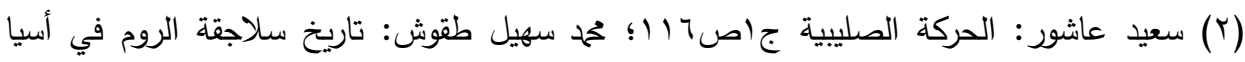

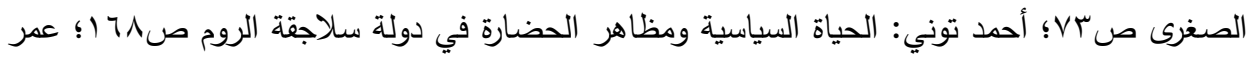

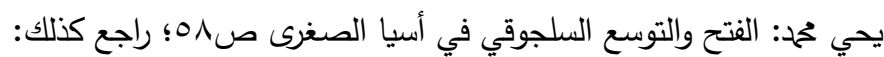

Cambridge History of Islam, vol ,1, p: 238,

Ostrogorsky: History of the Byzantine state, p: 320.

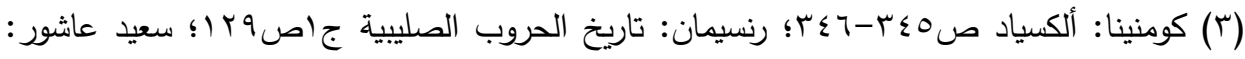

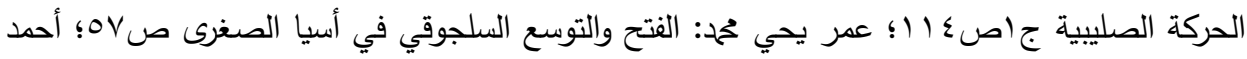

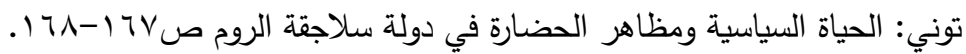




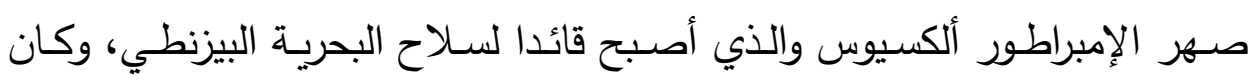

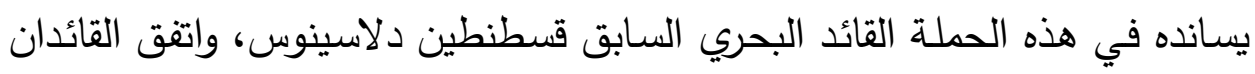

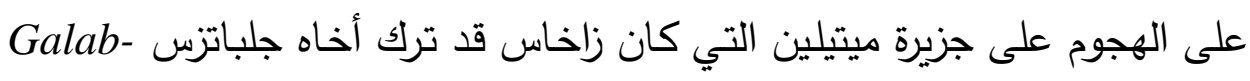
atzes

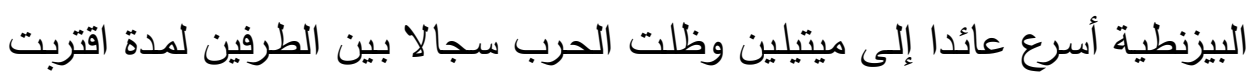

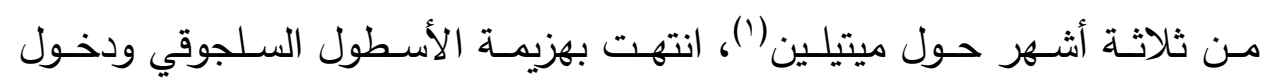

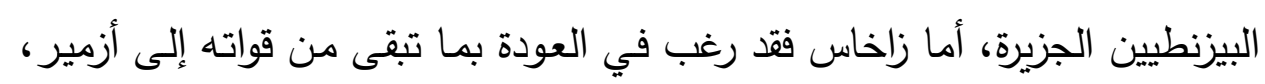

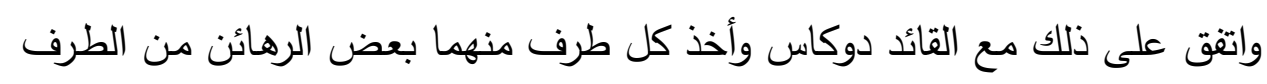

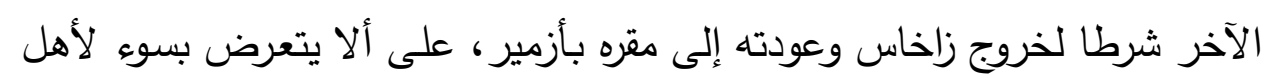

ميتيلين (؟).

غير أن القائد دلاسينوس - الذي لم يكن حاضرا اتفاق دوكاس مع زاخاس -

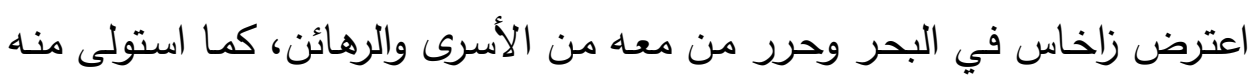

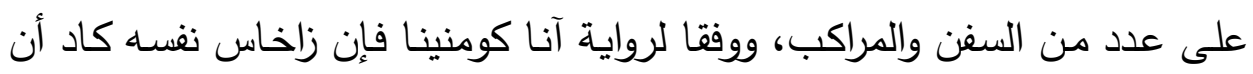

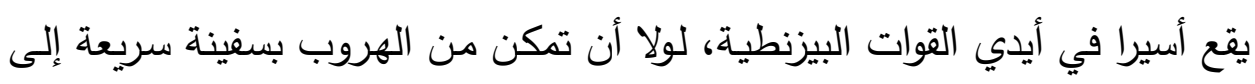

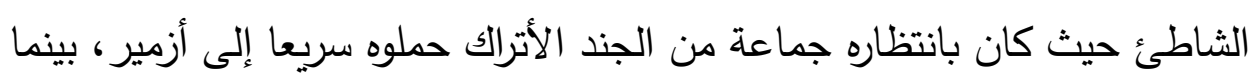

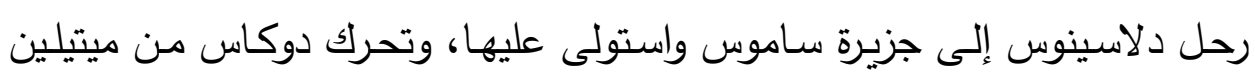
عائدا إلى القسطنطينية (). ولما لم تكن سيطرة الأسطول السلجوقي على "جزر متناثرة" - على حد تعبير

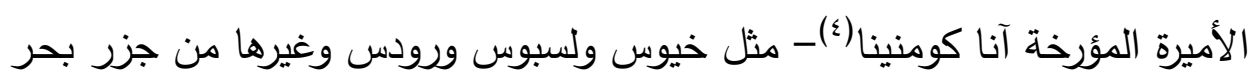

$$
\begin{aligned}
& \text { (1) كومنينا: ألكسياد صه ك }
\end{aligned}
$$

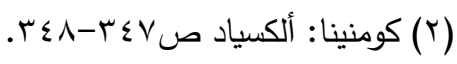

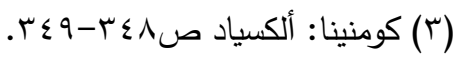

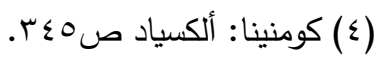


إيجه تثكل خطورة كبيرة على الدولة البيزنطية كونها جزر غير ذات أهمية كبرى -

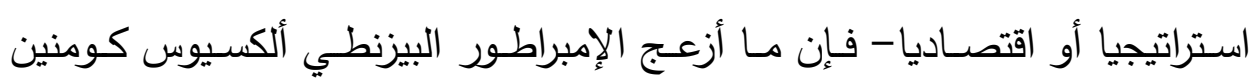

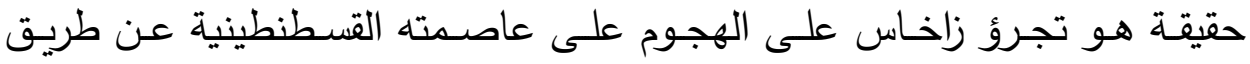

\section{أسطول الأمير زاخاس بيهاجم القسطنطينية :}

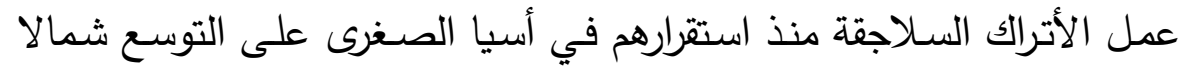
على حساب الدولة البيزنطية، وقد لجأوا إلى استخدام الحيل السياسية والدبلوماسية،

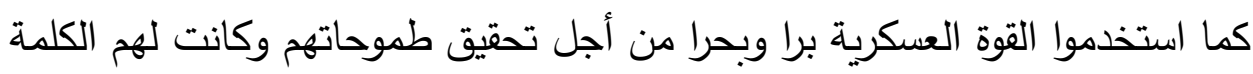

$$
\text { العليا في كل بلاد أسيا الصغرى ('). }
$$

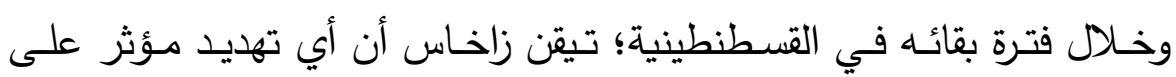

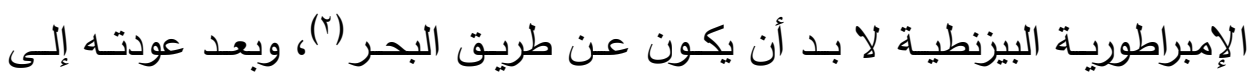

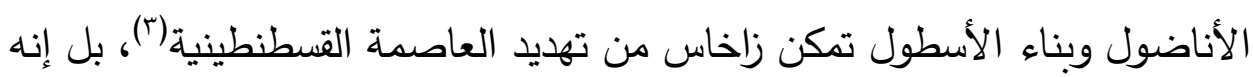

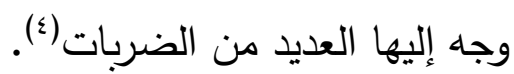

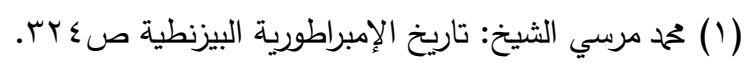

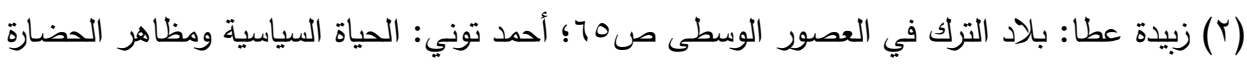

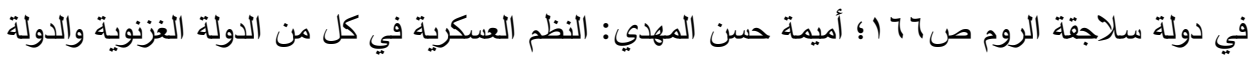

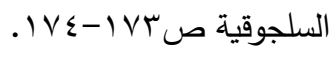
(r) أرشيبالد لويس: القوى البحرية والتجارية في حوض البحر المتوسط ص • لrا؟ سعيد عاشور : الحركة

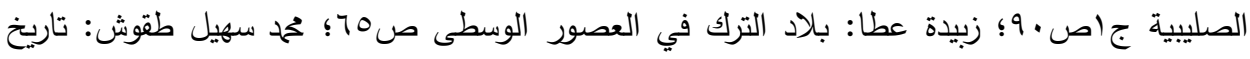

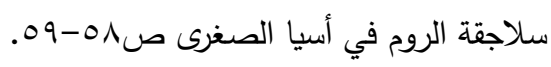

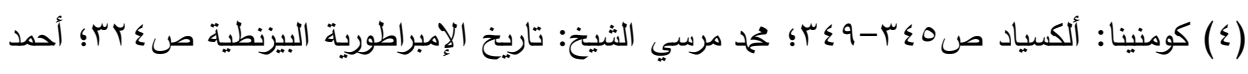

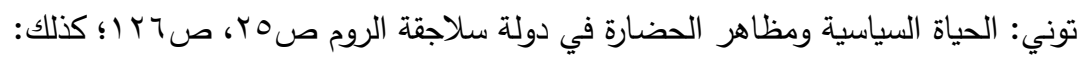
Ostrogorsky: History of the Byzantine state, p: 319. 
وقد عمل زاخاس على الإفادة من الخلاف الواقع بين البيزنطيين والبجناك،

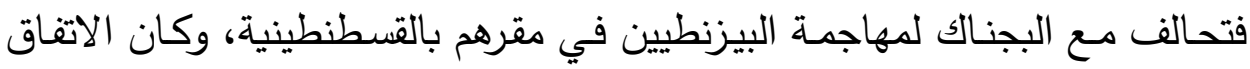
قائما على أن يهاجم البجناك المدينة بجيش بري، بينما يهاجمها زاخاس بأسطوله عن طريق البحر (')، وبذلك تكون القوات البيزنطية وقعت بين شقي البئل الرحى.

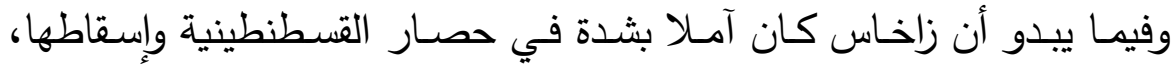

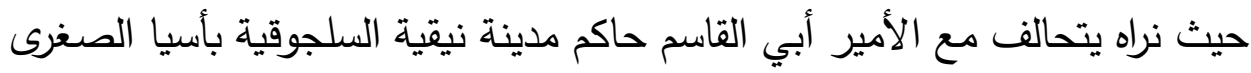

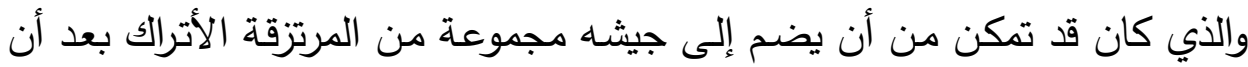

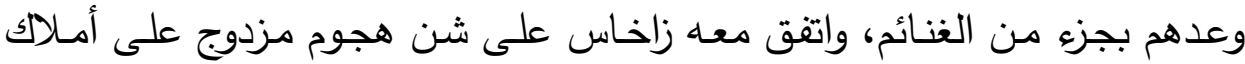
البيزنطيين، فبينما يهاجم البجناك القسطنطينية برا ويحاصرها زاخاس بحرا؛ يهاجم أبو القاسم البيزنطيين في نيقوميديا فتتثت قواتهم في الدفاع عن أملاكهم (r). وتحركت الجيوش الثلاثتة كل في طريقه، فتحرك جيش البجنـاك محاصـرا القسطنطينية برا ومنع اتصـال المدينة بولاياتها الغربية، بينما تحركت الأسطول

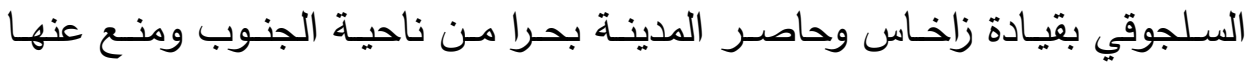
الإمدادات من هذا الاتجاه، وعلى ما يبدو أن سلطان سلاجقة الروم كان على علم المان

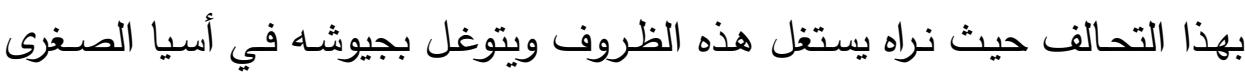
مستوليا على الكثير من الددن والقلاع البيزنطية(؟).

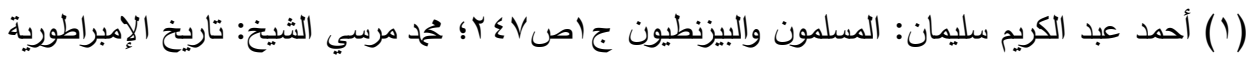

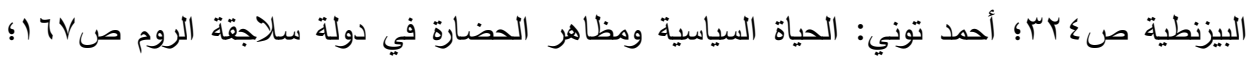

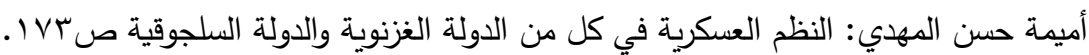

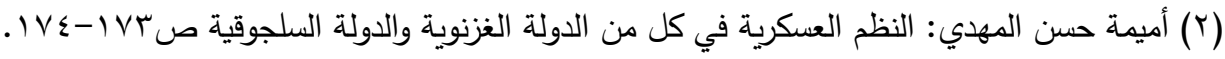

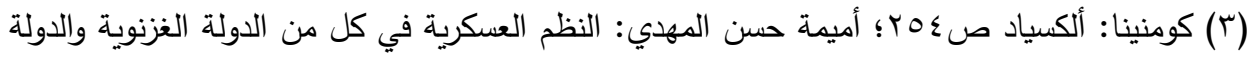

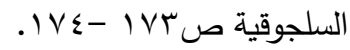




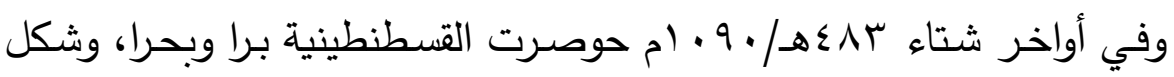

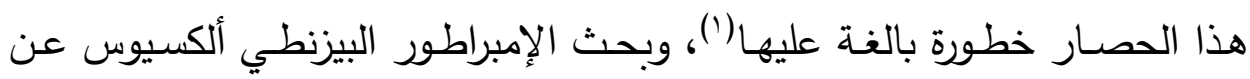

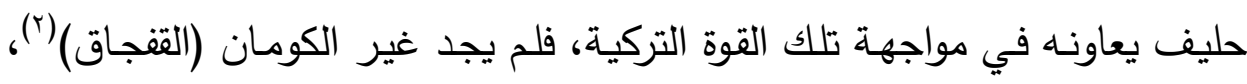

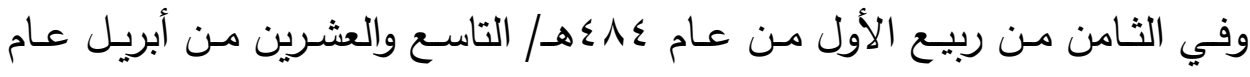

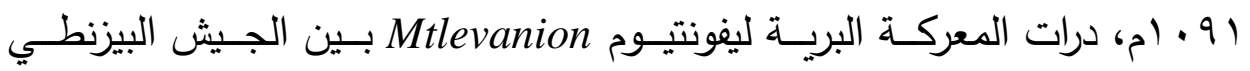

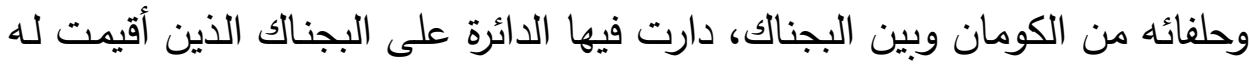

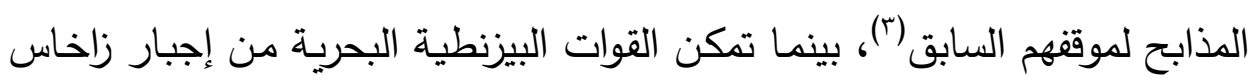

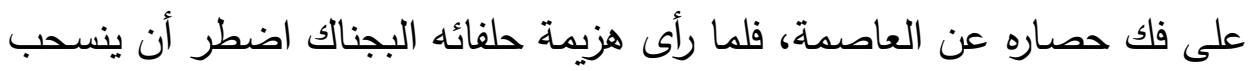
بقواته عائدا إلى أزمير (๕).

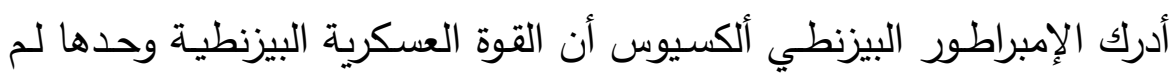

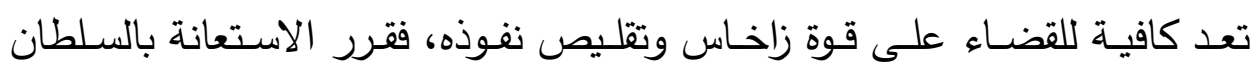

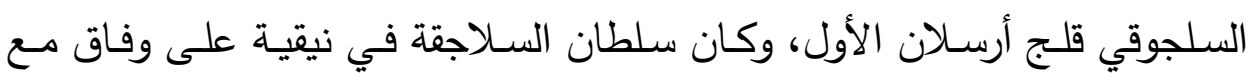

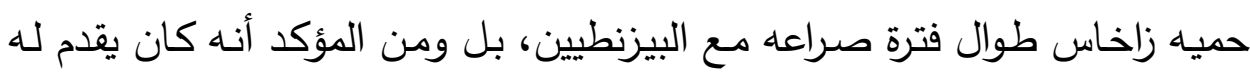

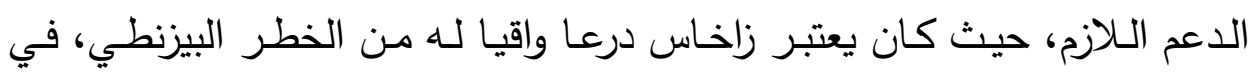

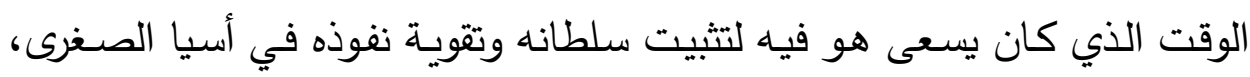

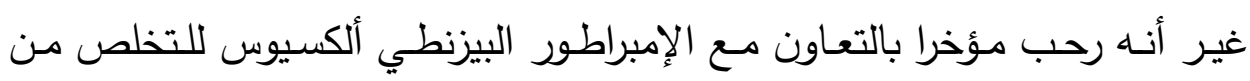

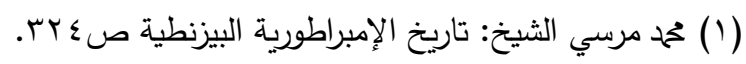

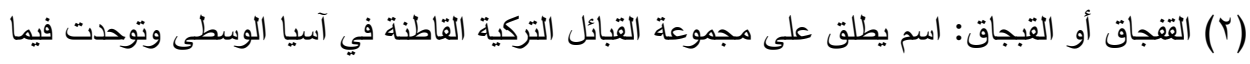

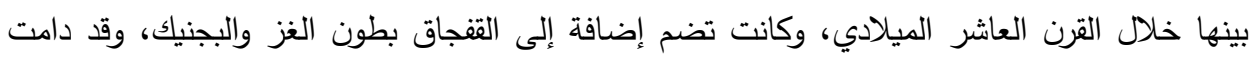

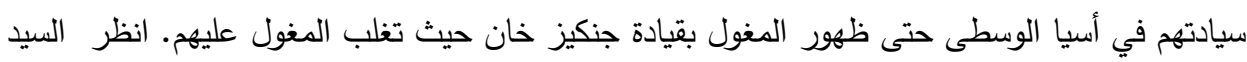

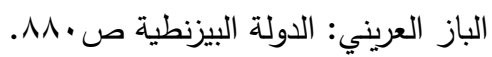

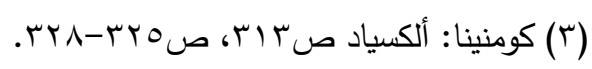

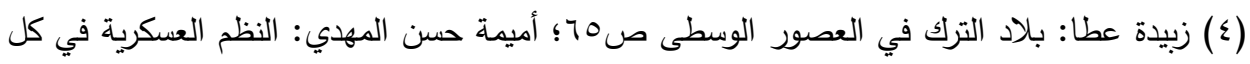

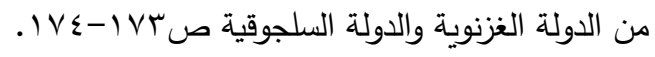


زاخاس لما تأكد أن قوة زاخاس أصبحت تثكل خطر عليه هو ذاته، حيث كانت

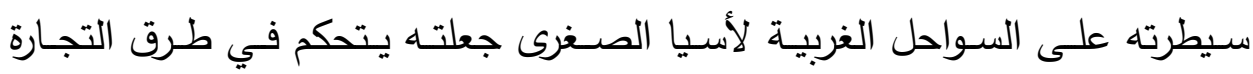

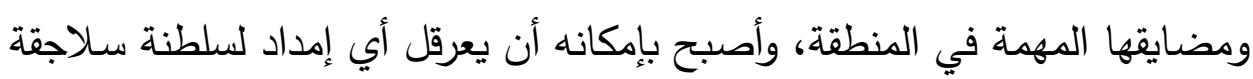

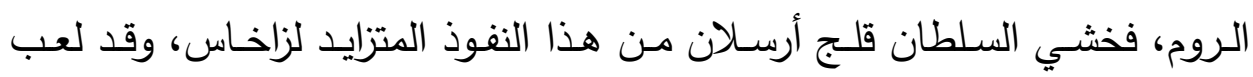

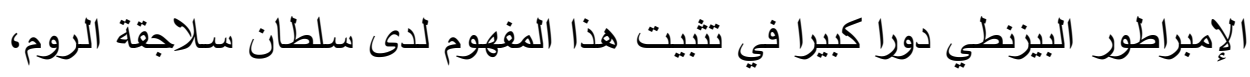
فقرا العمل سويا للتخلص من زاخاس وقوته. 


\section{المبحث الخامس : نهاية الأمير زاخاس وسقوط إمارة أزمير}

كان لاتصال زاخاس بالبيت السلجوقي ومصاهرة السلطان قلج أرسلان الأول

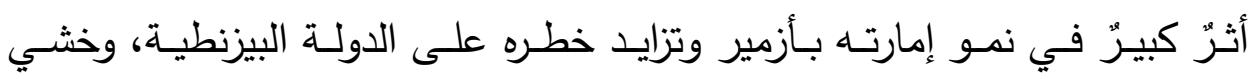

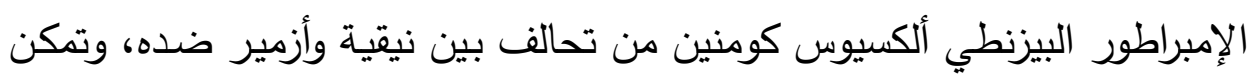

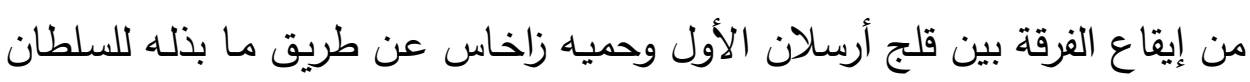

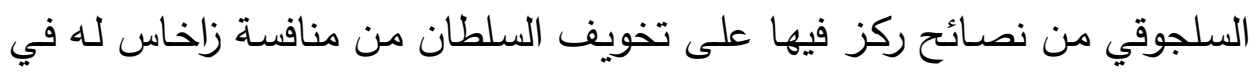

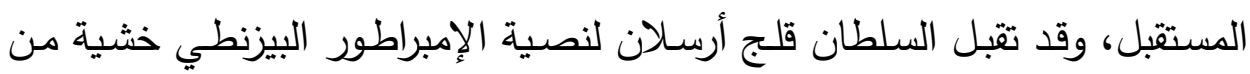
ظهور أمير تركي آخر يطغى على شخصيته وينافسه على الزعامة في منطقة أسيا الصغرى (').

ولا شك في أن الإمبراطور البيزنطي ألكسيوس كومنين كان يخشى قوة زاخاس

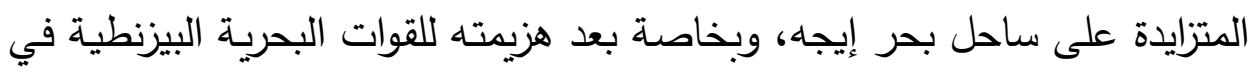

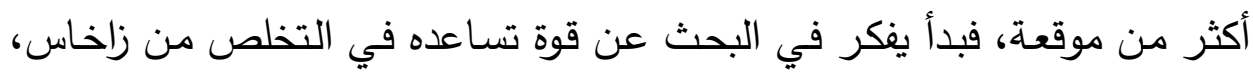

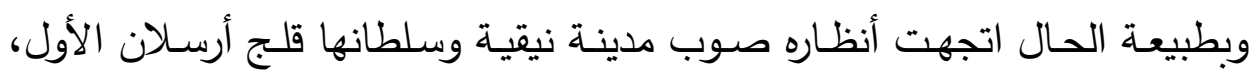

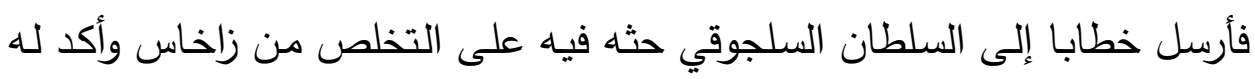

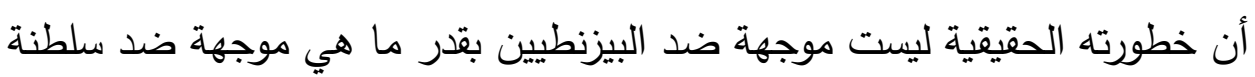

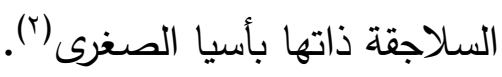

(') رنسيمان: تاريخ الحروب الصليبية جاصوج با؛ أحمد عبد الكريم سليمان: المسلمون والبيزنطيون

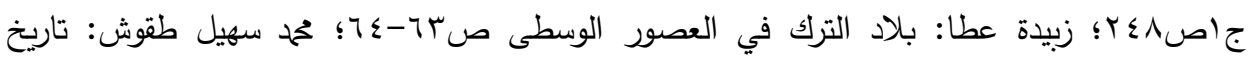

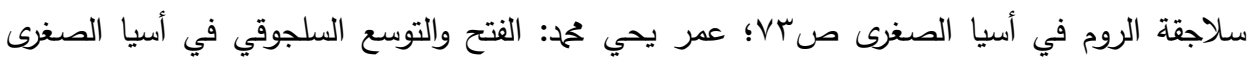
صن-OV

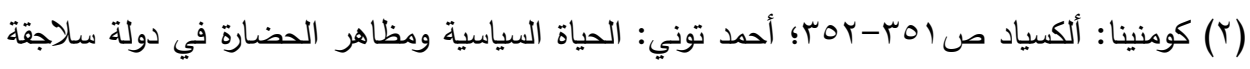

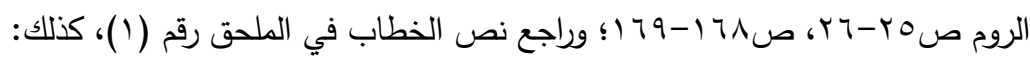
Cambridge History of Islam, vol , 1, p: 238. 


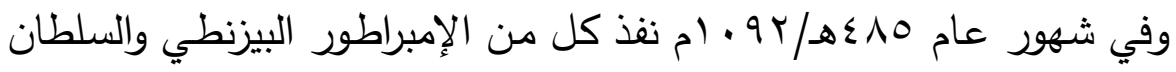

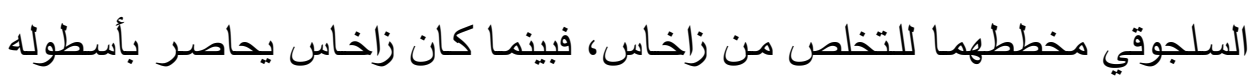

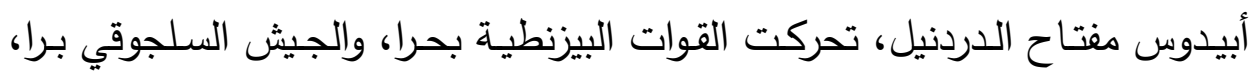

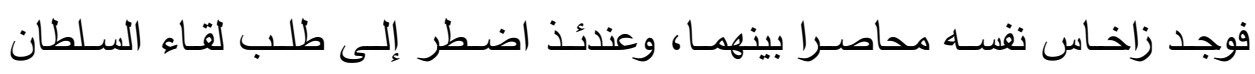

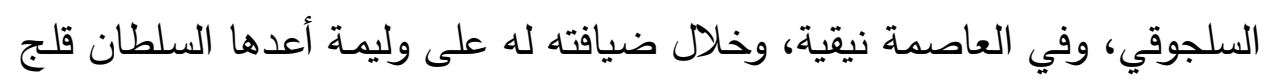

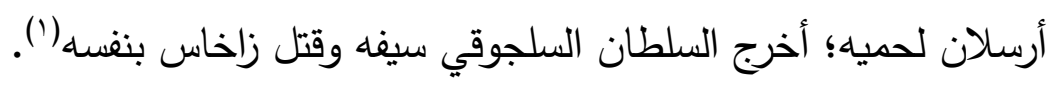

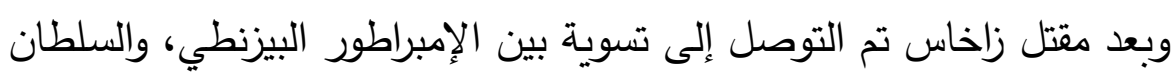

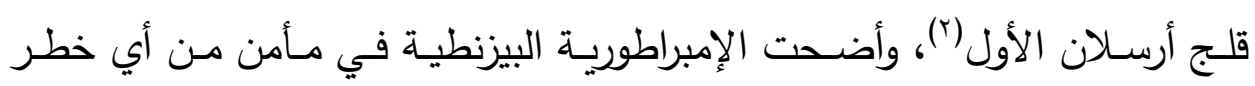

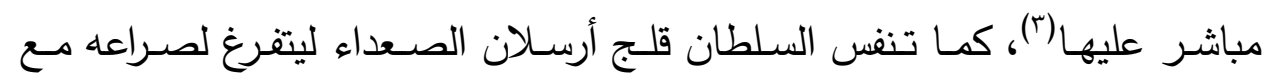

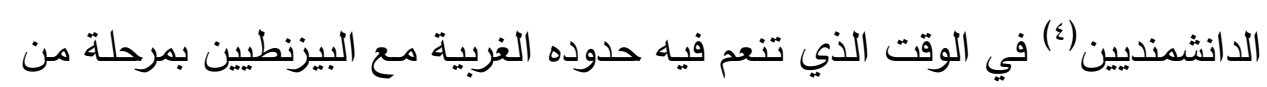
الهدوء بعد تقارب وجهات النظر بينه وبينه ألكسيوس كومنين (').

(1) كومنينا: ألكسياد ص (1)

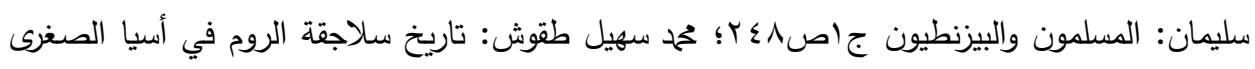

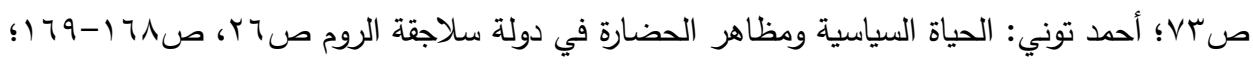

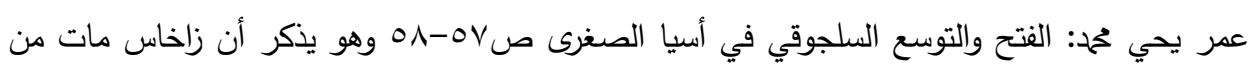

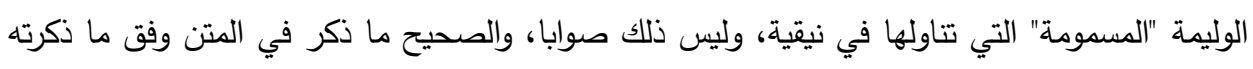

Cambridge History of Islam, vol , 1, p: 238,

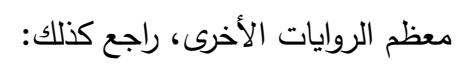

Ostrogorsky: History of the Byzantine state, p: 320.

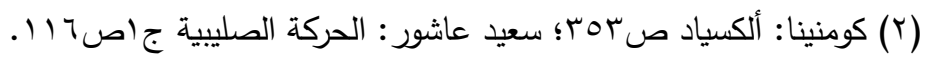

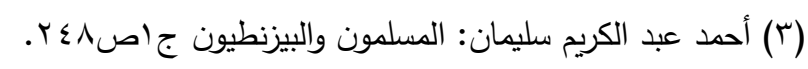

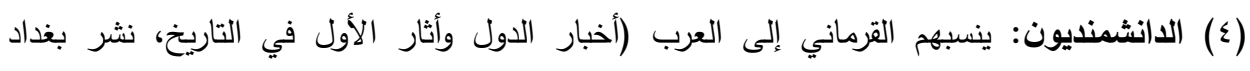

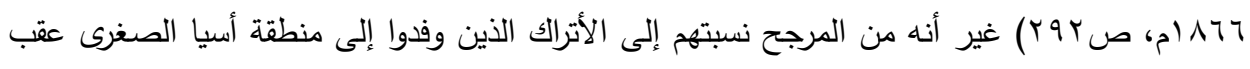

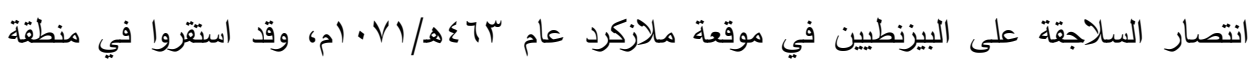

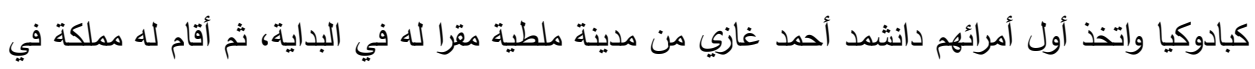

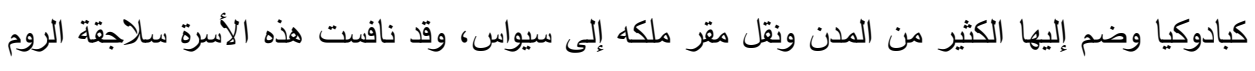
$=$ 
على أن الإمبراطور البيزنطي ألكسيوس بعد أن اطمـأن إلى نجاح مسـعاه

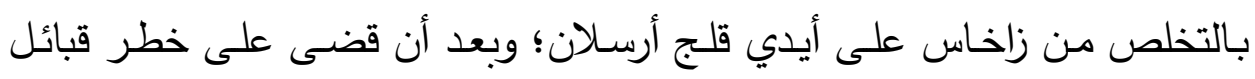

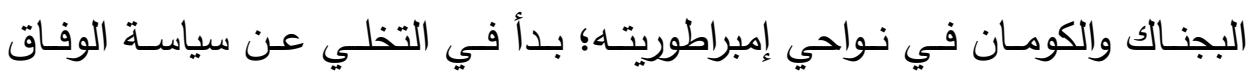
والتقارب التي كان قد اتبعها مع سلاجقة الروم خلال الفترة السابقة من حكمها، وبدأ

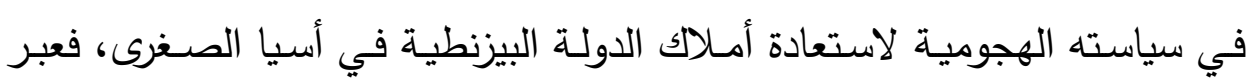
البسفور إلى إقليم بيثينيا، وأشرف بنفسه على إقامة التحصينات هناك، كم اهتم

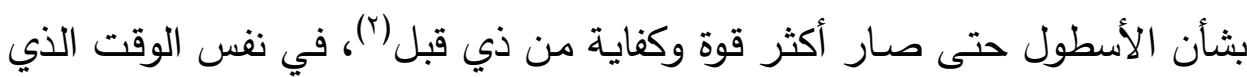

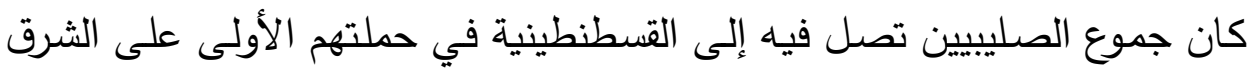

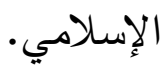

$$
\text { استسلام أزمير ( }
$$

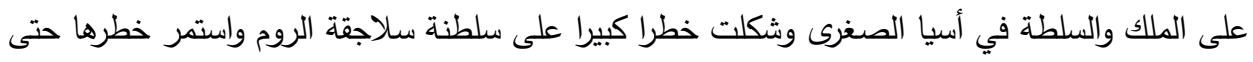

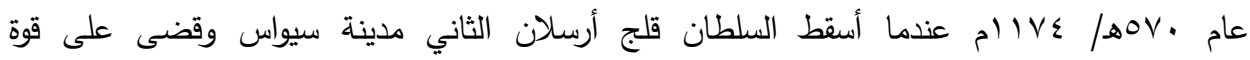

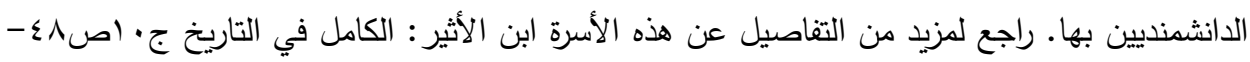

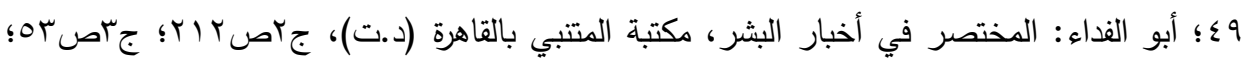

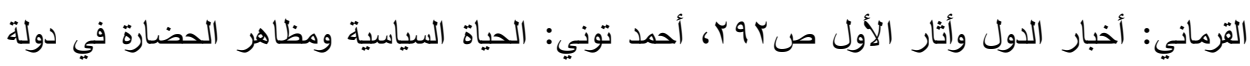

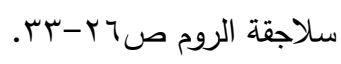

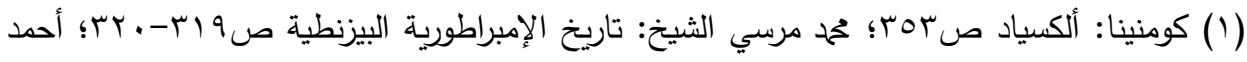

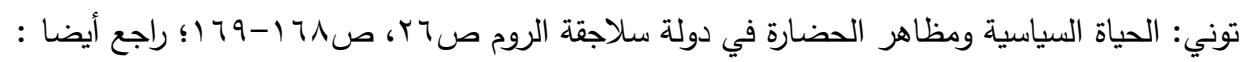
Ostrogorsky: History of the Byzantine state, p: 320.

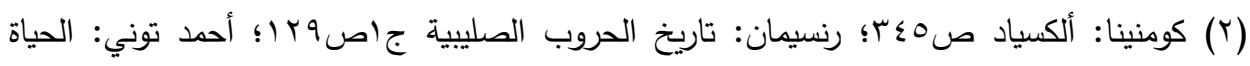

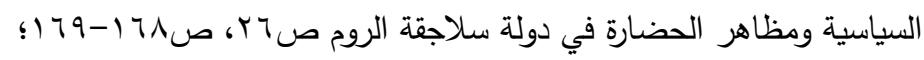

Ostrogorsky: History of the Byzantine state, p: 320. 
بعد جهود ضخمة بذلها زاخاس في بناء إمارته بأزمير وتدعيم قوتها البحرية

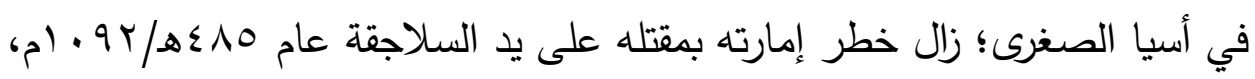
وتدمرت قوته البحرية وأسطوله.

وبعد سقوط مدينة نيقية في أيدي البيزنطيين في 17 رجب .9 ؛ هـ/9 19 يونيو

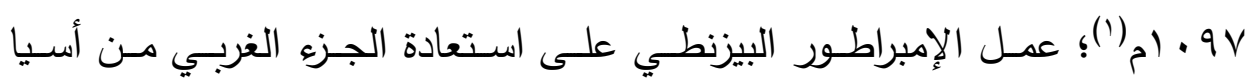

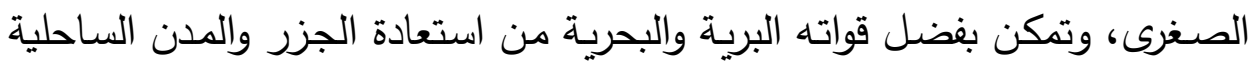

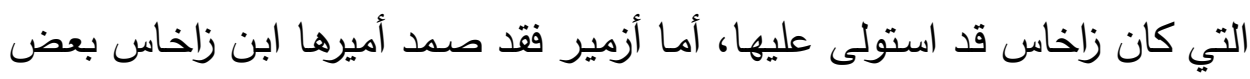
الوقت حتى وجلت نفسها منعزلة عن الدولة السلجوقية وبخاصة بعد سقوط نيقية،

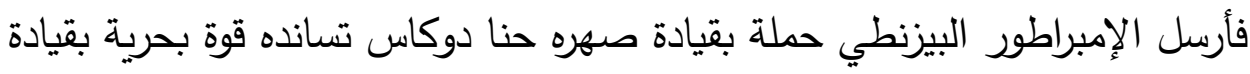

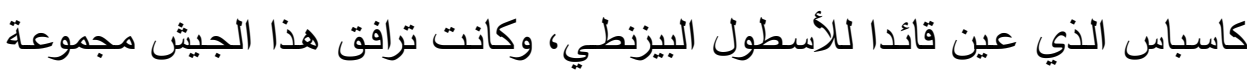

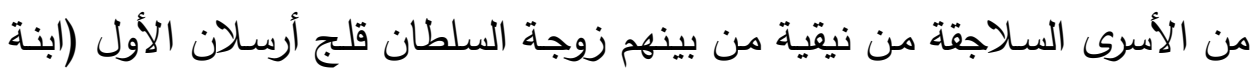

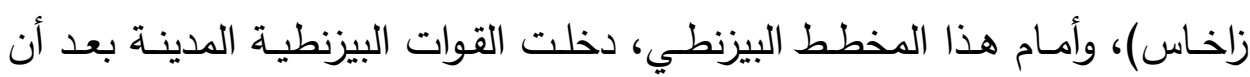

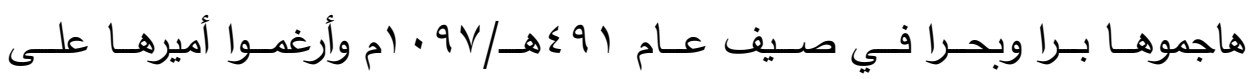

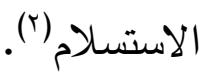
وجدير بالذكر أن الدولة البيزنطية والإمبراطور ألكسيوس كومنين نفسه قد أفاد

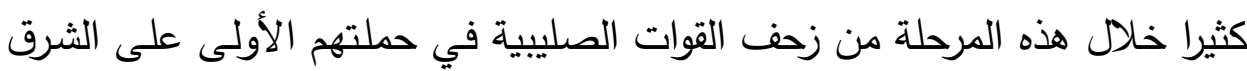

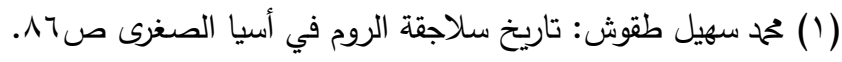

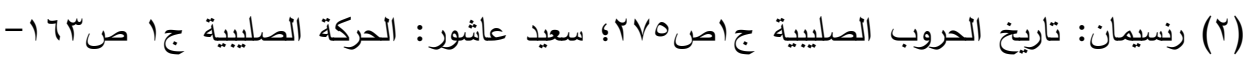

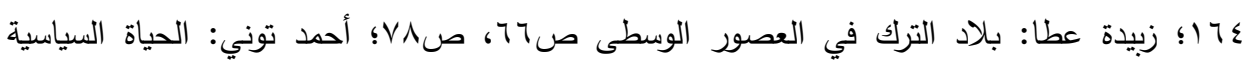

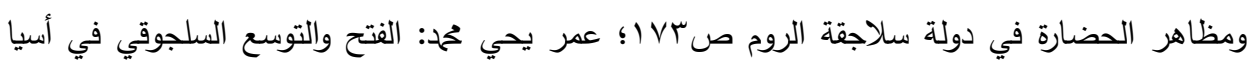
Cambridge History of Islam, vol ,1, p: 239.

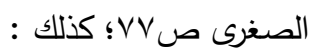


الإســلامي، حيـث سـاندته تلـك القـوى الصـليبية في وضـع حــ لنفـوذ السـلاجقة وخطورتهم في منطقة أسيا الصغرى ('). ورغم سقوط مدينة أزمير في يد القوات البيزنطية فإنها بحكم موقعها الجغرافي

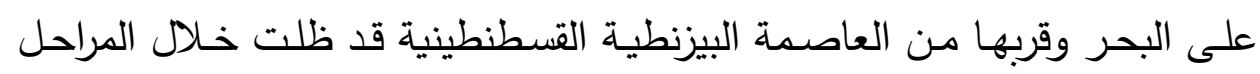
المقبلة خطرا على الدولة البيزنطية على الدوام حيث استولى عليها وعلى إقليم

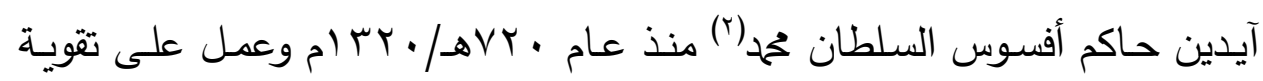

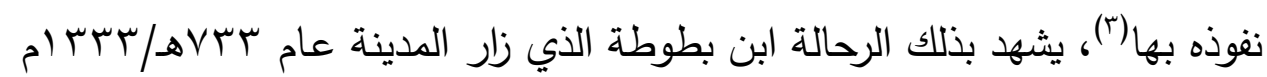

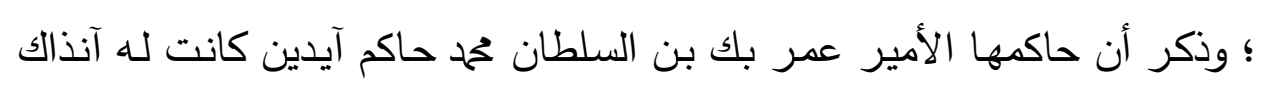
سفن يطلق عليها "أجفان غزويـة"، يغير بها على القسطنطينية والمدن السـاحلية على ساحل البحر فيسبي ويغنم ثم يعود إلى مقره(؛ُ).

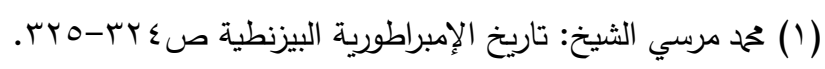

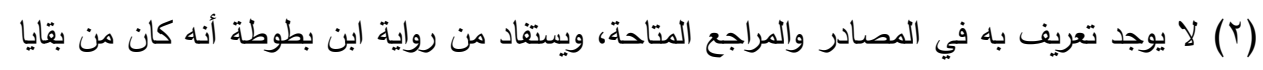

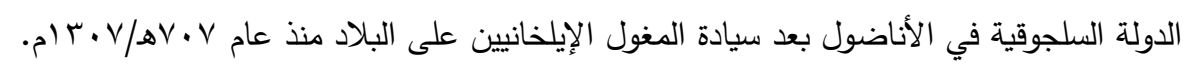

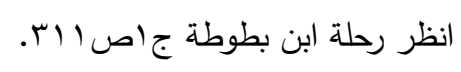

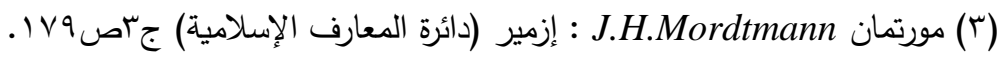

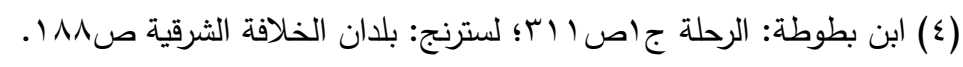




\section{ملحق رقم (1)}

\section{خطاب الإمبر اطور ألكسيوس كومنين إلى السلطان السلجوقى قلج أرسلان الأول بشأن زاخاس}

"إلى السلطان المعظم قلج أرسـلان: إنك لتعرف أن السلطنة ملك خاص لك بحق الوراثة، ولا ينازعك فيها منازع، ولكن ها هو ذا ابن جلدتك تزاخاس على الرغم

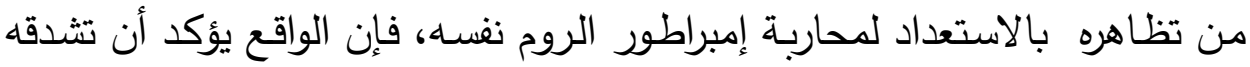
بمحاربتنا ليس إلا ذرًا للرماد في العيون، وما هذا الكلام سوى ذريعة مفضوحة لا تجوز على أحد، لأنه - وهو الخبير المجرب - يعرف تمام المعرفة أن إمبراطوريـة الروم يستحيل أن تكون لـه، ولكن طويته الثريرة وخطته اللئيمة موجهـة بأكملها

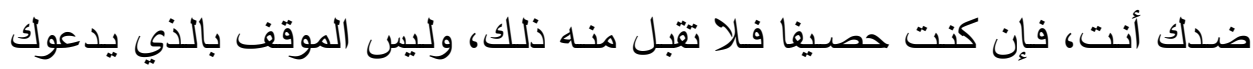
لليأس بل يحتم عليك اليقظة والحذر منه، وإلا سلبك سلطانك وانتزعه منك، أما آنا يأس فإني سأبذل جهدي وعامل على إخراجه بعون الرب من الأراضي الرومية، كما أن

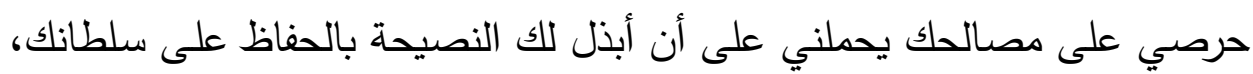

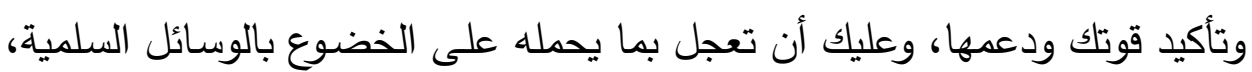

فإن جادلك فيما لا حق له فيه، فلا جواب عليه سوى السيف فهو خير معلم"(').

(1) آنا كومنينا: ألكسياد صاOب-r-ror؛ أحمد توني: الحياة السياسية ومظاهر الحضارة في دولة سلاجقة الروم ص1414 1-179. 


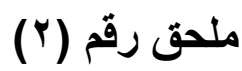

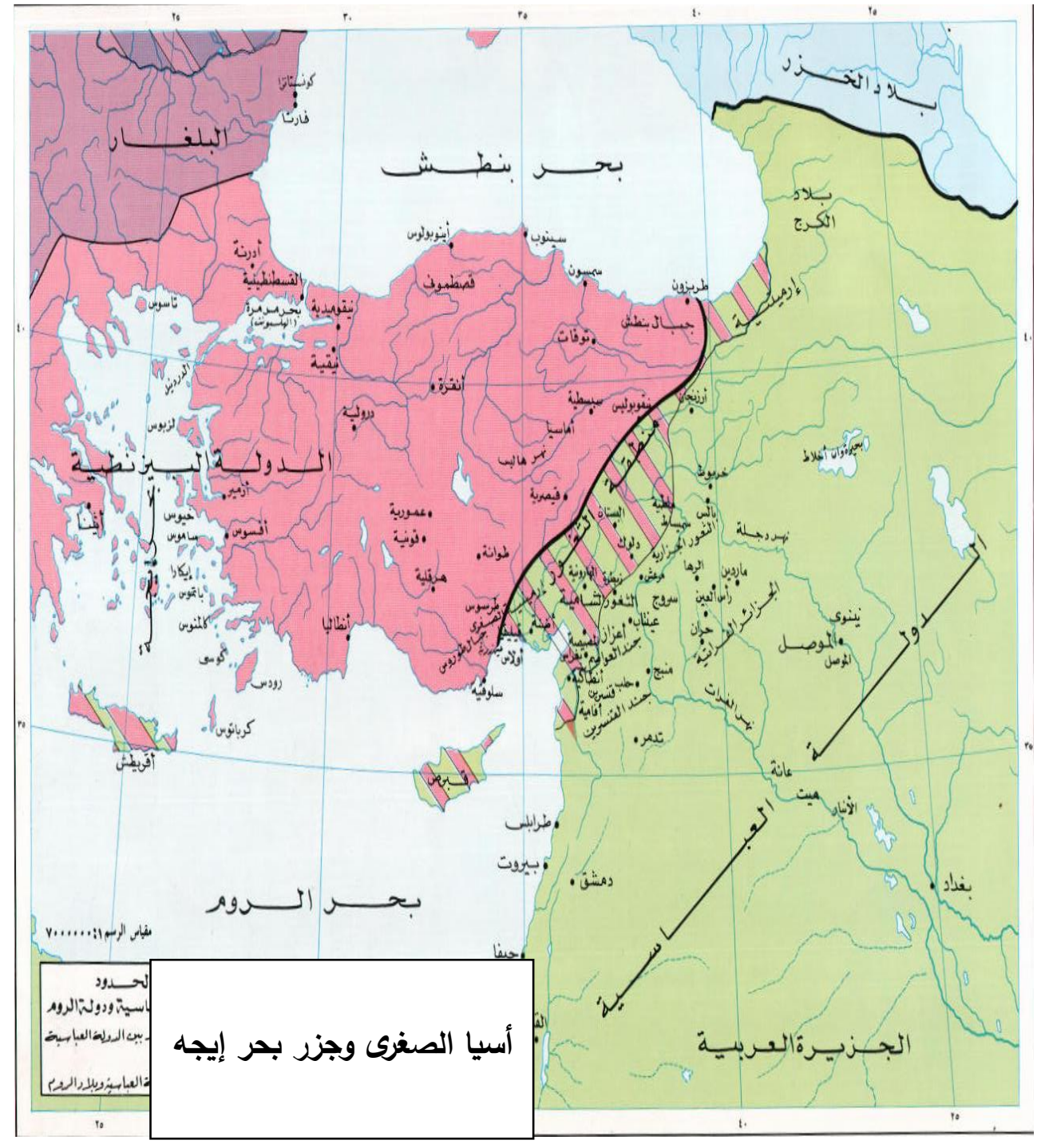

\section{خريطة أسيا الصغرى}

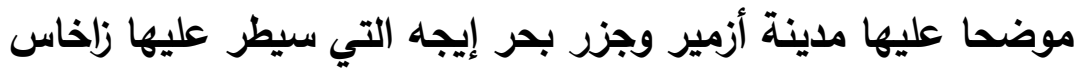
نقلا عن حسين مؤنس: أطلس تاريخ الإسلام ص ـ10 10 


\section{الخاتمة ونتائج البحث}

تنـاول البحث بالدراسـة شخصية الأمير السلجوقي زاخساس وعلاقته بسلطنة

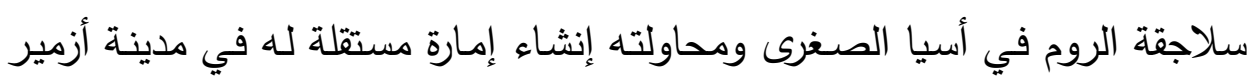
على ساحل بحر إيجها، كما عرض البحث بالتفصيل لجهوده زاخاس في إنشاء البحرية والأسطول ونشاطه البحري وصراعه مـع الإمبراطور البيزنطي ألكسيوس

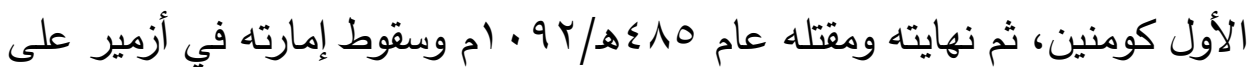
أيدي البيزنطيين.

\section{ويمكن الإثارة في النقاط التالية إلى أهم ما توصل البحث إليه من نتائج:}

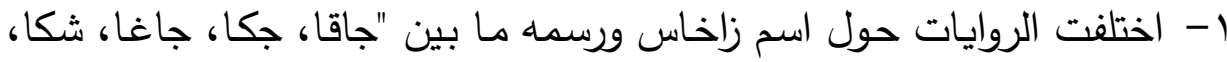
زركش، تزكس، تزخاس، زاخاس"، ورجح البحث صحة الاسم الأخير ورسمه كونه الأثهر لثخصية الأمير السلجوقي وفق رواية المؤرخة اليونانية الأميرة آنّا كومنينا أقدم مصدر كتب بالتفصيل عن زاخاس.

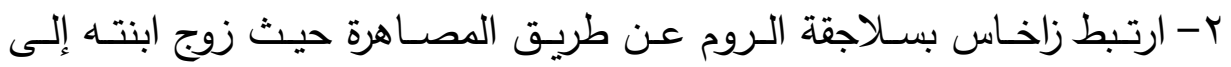
السلطان السلجوقي قلج أرسلان الأول.

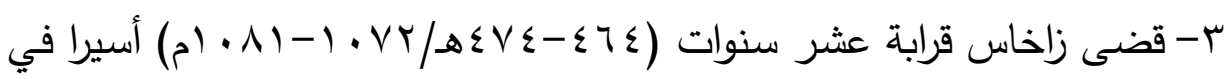

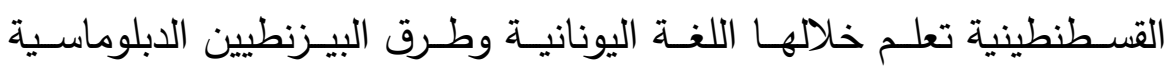

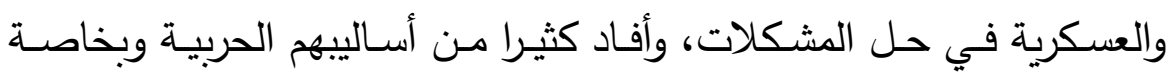
السلاح البحري وأهميته وخطورته في الحرب.

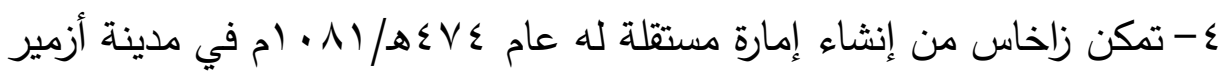
على ساحل بحر إيجه شمالي غرب الأناضول. 0- شكلت إمارة زاخاس في أزمير خطورة بالغة على الإلى الإمبراطورية البيزنطية في

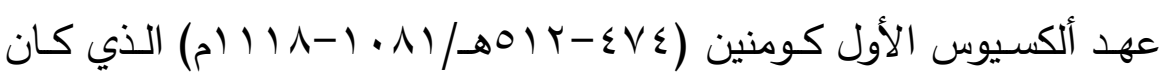

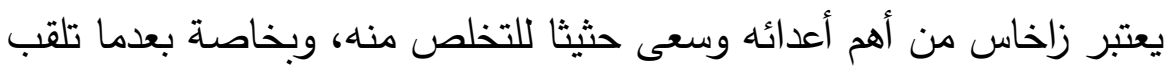
زاخاس بلقب "الإمبراطور" واتخذ لنفسه رتب الإمبراطورية وشاراتها في أزمير . 
4- يعتبر الأمير زاخـاس أول من أسس سـلاح البحريـة عند الأتراك السـلاجقة

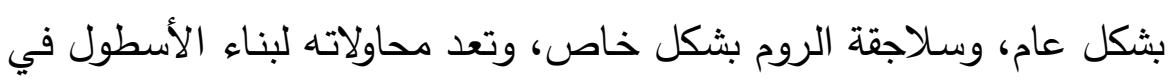

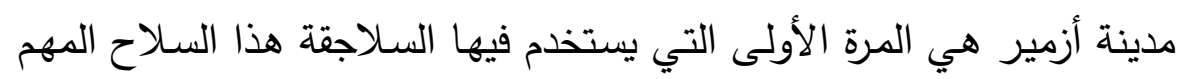
في معاركهم وصراعهم مع القوات البيزنطية.

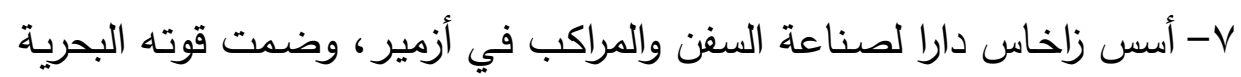

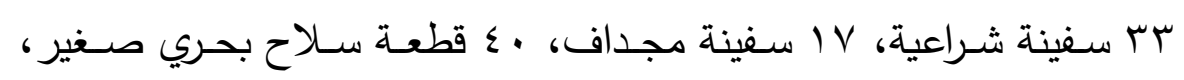

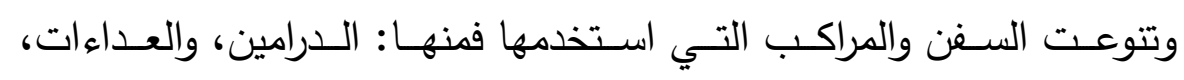
والقراقير ، والبطس، والثواني، والمزاريب، والأجفان الغزوية.

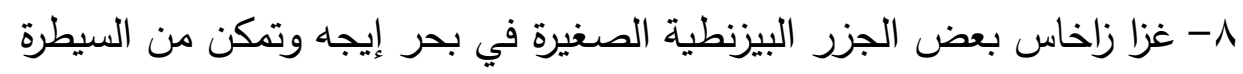

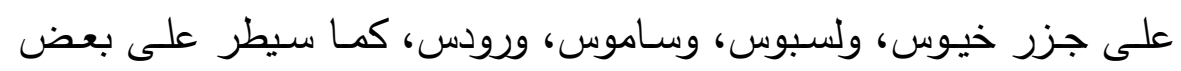

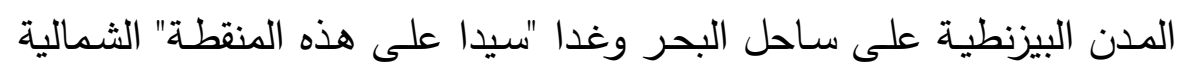

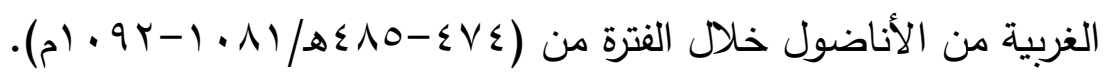

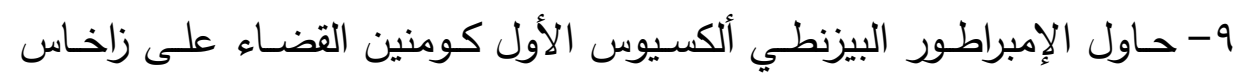

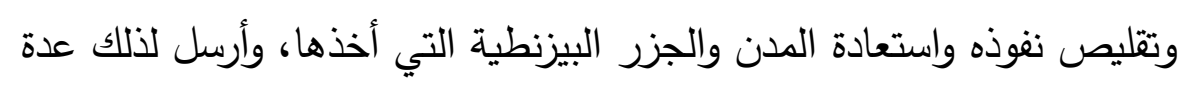

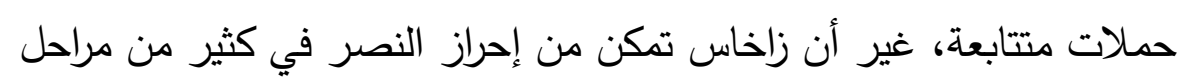

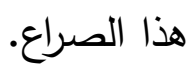
• 1- هددت القوة البحريـة للأمير زاخـاس العاصمة البيزنطية القسطنطينية في البي

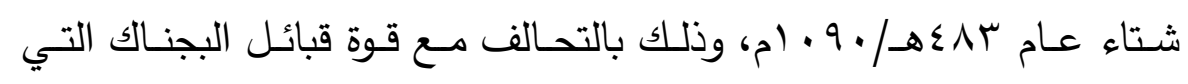
هاجمت الدينة برا بينما هاجمها زاخاس بحرا. 11- نجح تحريض الإمبراطور البيزنطي ألكسيوس الأول كومنين للسلطان

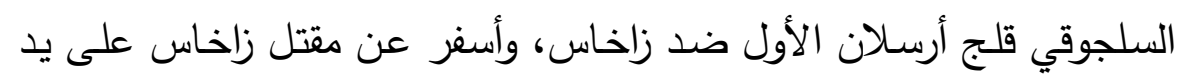

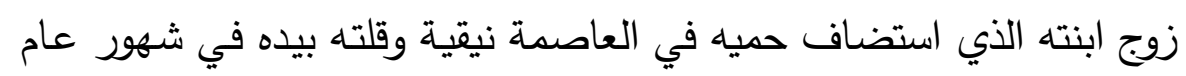
. $94 / 8 \leqslant 10$ 


$$
\text { r ا - سقطت إمارة أزمير تماما في أيدي القوات البيزنطية في صيف عام في }
$$




\section{ملخص البحث}

جاء البحث تحت عنوان: الأمير السلجوقي زاخاس ونشاطه البحري في

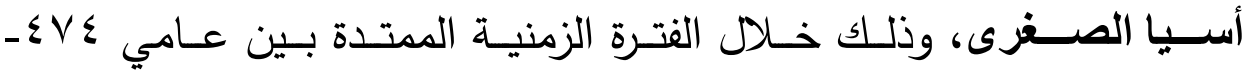

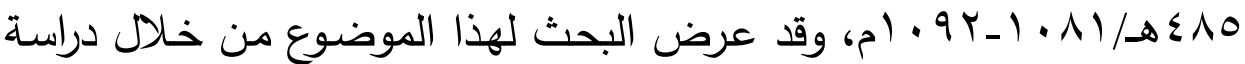
مفصلة عن شخصية الأمير زاخاس وبيان علاقته بالسلاجقة ومحاولته إنشاء إمارة مستقلة في مدينة أزمير على ساحل بحر إيجه شمالي غرب الأناضول

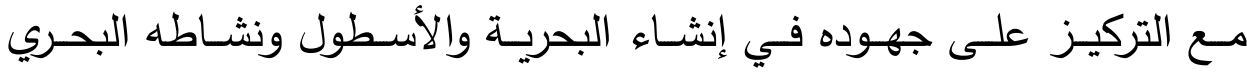

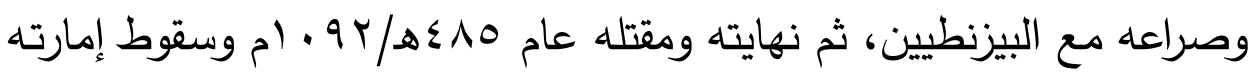
في أزمير على أيدي البيزنطيين.

\section{Abstract}

The current research is entitled, "The Seljuk Prince Zachas and his maritime activity in Minor Asia" in the period from 474-485 AH/ 1081-1092 AC. The research presents a detailed study of the character of the prince Zachas in addition to a statement of his relationship with Saljuks and his attempt to establish an independent emirate in the city of Azmir which is situated on the Aegean coast of the Aegean Sea, north-west of Anatolia, with particular emphasis on his efforts in the creation of marine, the fleet, his maritime activity, and his conflict with the Byzantines, and finally his death as being murdered in 485 $\mathrm{AH} / 1092 \mathrm{AC}$ and consequently the fall of his emirate in Izmir at the hands of the Byzantines 


\section{مصادر البحث ومر اجعه}

أولا: المصادر العربية

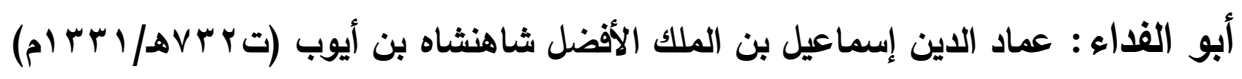

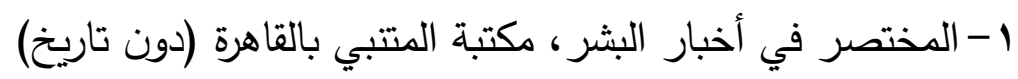

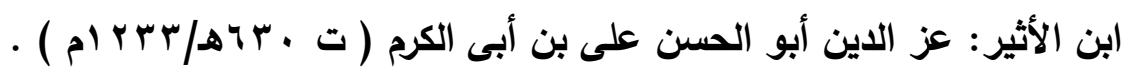

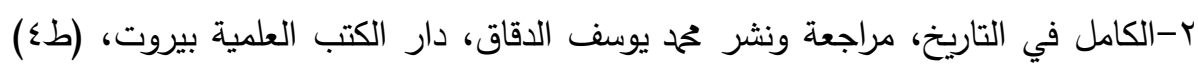

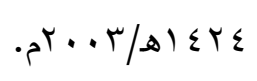

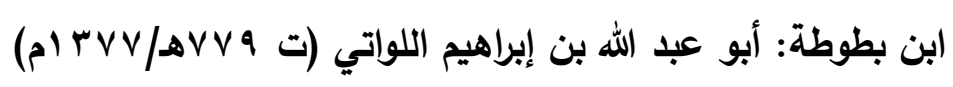
r-رحلة ابن بطوطة المعروفة باسم (تحفة النظار في غرائب الأمصار

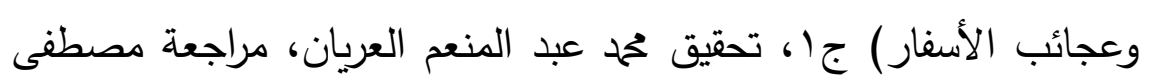

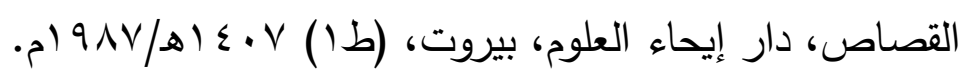

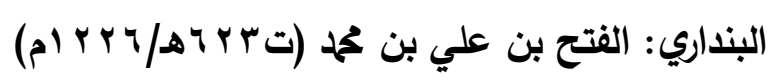

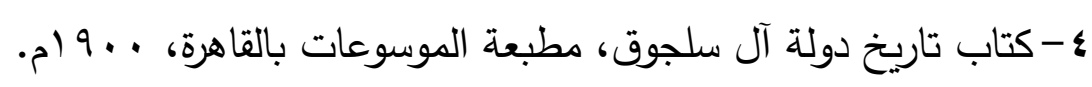

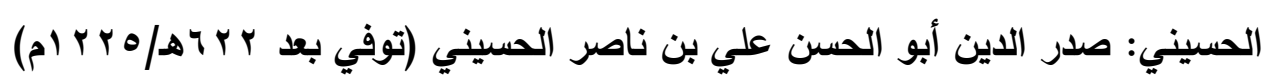

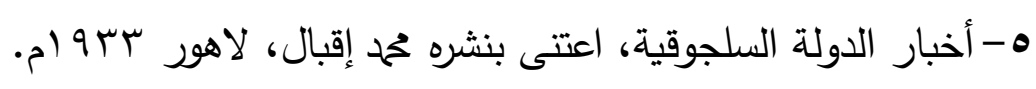

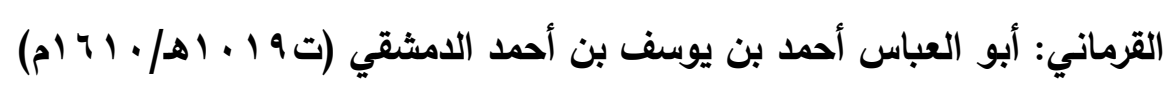

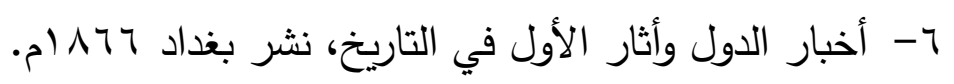

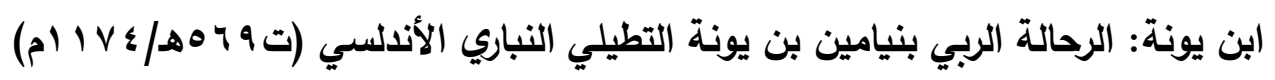

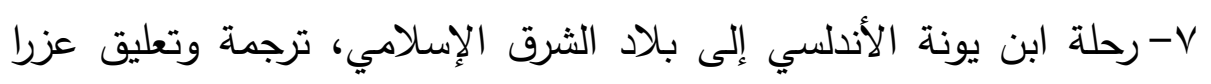

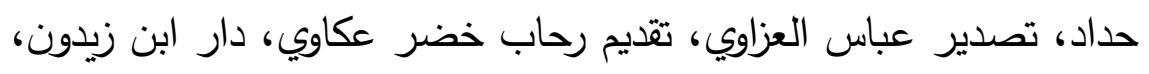

$$
\begin{aligned}
& \text { بيروت (ط ا) } 999 \text { ام. } \\
& \text { ثانيا: المراجع العربية } \\
& \text { سليمان: أحمد عبد الكريم (دكتور) }
\end{aligned}
$$

^- المسلمون والبيزنطيون في شرقي البحر المتوسط فيما بين القرنين الثالث

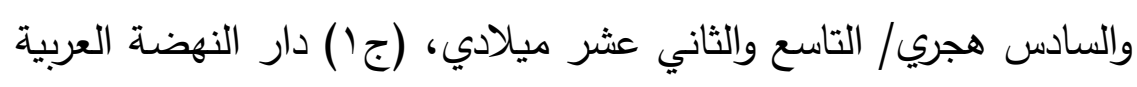




$$
\begin{aligned}
& \text { بالقاهرة (ط (1) ra ام. } \\
& \text { الشيخ: محمد مرسي (دكتور) }
\end{aligned}
$$

9-تاريخ الإمبراطورية البيزنطية، دار المعرفة الجامعية، الإسكندرية، ؟99 ام.

طقوش: محمد سهيل (دكتور)

•

$$
\cdot r \cdot r
$$

عاشور: سعيد عبد الفتاح (دكتور)

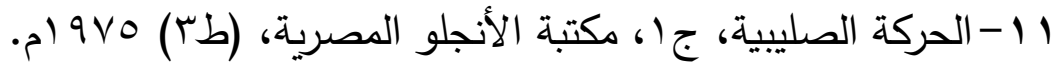

العربني: السيد الباز (دكتور)

ץ ا - الدولة البيزنطية (بrس-1 (1) • (م)، دار النهضة العربية، بيروت 970 ام.

$$
\text { عطا: زبيدة تحمد (دكتور) }
$$

ب ا -بلاد الترك في العصور الوسطى (بيزنطة وسلاجقة الروم والعثمانيون)، دار الفكر العربي، القاهرة (دون تاريخ).

النخيلي: درويش (دكتور)

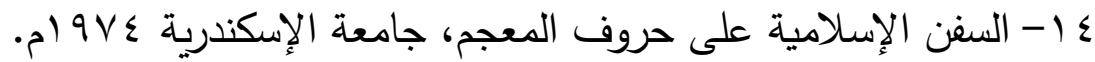

ثالثا: المراجع الأجنبية المترجمة الإنية علية

رنسيمان: ستيفن (دكتور)

10-تاريخ الحروب الصليبية، (جا الحرب الأولى وقيام مملكة بيت المقدس)

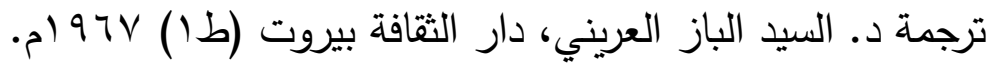

كومنينا: آنـا (الأميرة اليونانية ابنة الإمبراطور البيزنطي ألكسيوس الأول كومنين) 7 ا 1 ألكسياد، ترجمة حسن حبشي، نشر المجلس الأعلى للثقافة، القاهرة، (ط ا)،

$$
\begin{aligned}
& \text { ع . . ז } \\
& \text { لسترنج: كى }
\end{aligned}
$$

V ا - بلدان الخلافة الثرقية، ترجمة بشير فرنسي، وكوركيس عواد، مؤسسة 


$$
\begin{aligned}
& \text { الرسالة، بيروت، (طץ) 0م أم. } \\
& \text { لويس: أرشيبالا. ر: }
\end{aligned}
$$

1 1 - القوى البحرية والتجارية في حوض البحر المتوسط ( . .0- .. 1 (م)، ترجمة احمد عيسى، مراجعة وتقديم محمد شفيق غربال، مكتبة النهضة المصرية

$$
\begin{aligned}
& \text { بالقاهرة، • } 97 \text { (م. } \\
& \text { رابعا: الدوريات والمجلات العربية } \\
& \text { عحمد: عمر يحي (دكتور) }
\end{aligned}
$$

9 1 - الفتح والتوسع السلجوقي في أسيا الصغرى، مجلة الآداب والعلوم الإنسانية،

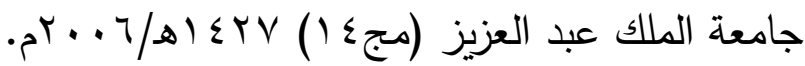

$$
\begin{aligned}
& \text { العمايرة ، الرويضي: محمد نايف ، ومحمود محهد: (دكتور) }
\end{aligned}
$$

•r- معركة ملازكرد (جانب من العلاقات السلجوقية البيزنطية)، مجلة المنارة، مج

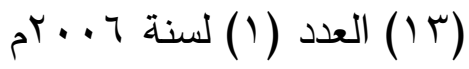

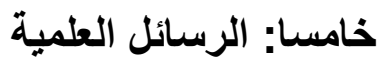

$$
\begin{aligned}
& \text { عبد اللطيف: أحمد توني (دكتور) }
\end{aligned}
$$

ا ץ- الحياة السياسية ومظاهر الحضارة في دولة سلاجقة الروم، رسالة دكتوراه غير

منشورة بكلية الآداب، جامعة المنيا 919 (م.

$$
\text { المهدي: أميمة حسن: }
$$

r r- النظم العسكرية في كل من الدولة الغزنوية والدولة السلجوقية (دراسة حضارية مقارنة)، رسالة ماجستير غير منشورة، معهد الدراسات الأسيوية، جامعة الزقازيق

$$
\text { ب...V }
$$

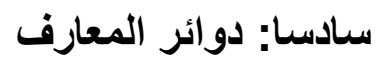
المستشرقون : مجموعة مستشرقين

ץY- دائرة المعارف الإسلامية، تعريب إبراهيم زكى خورشيد، د. عبد الحميد يونس، د. حسن عثمان، نشر دار الثعب بالقاهرة (دون تاريخ). 
Cambridge

Ostrogorsky,

George
24- The Cambridge History of Islam, vol ,1, Cambridge at the University press, 1970.

25- History of Byzantine state, translated from the German by Hussey with a fore by Peter Charanis , New Jersey, 1957.

الموقع الإلكتروني:

26- https://ar.wikipedia.org 
الأوقاف ودورها في الرعاية الاجتماعية في الحجاز

عصر سلاطين المماليك

$$
(\text { (م) } 01 V-140 . / \Delta q r r-4 \leq \Lambda)
$$

وليد كمال شعبان إسماعيل

باحث دكتوراه

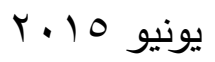




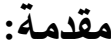

لا يمكن إنكار الدوافع الاجتماعية التي جعلت المماليك يولون الحرمين اهتماههم، فقد كانوا حريصين على تدعيم روابط التكافل الاجتماعي، والأوقاف باعتبارها صـدقة جارية، قامت بدور كبير في مجال الرعاية الاجتماعية في المجتمع الإسلامي بصفة عامة، وفي مجتمع المدينتين المقدستين بصفة خاصة .

ويرى البحث في الوقف(') لونا من ألوان التكافل الاجتماعي لم يسبق إليه نظام، بل ولم يدانه نظام كذلك؛ وذلك أن هذه الشريعة السمحة، قد جاءت لتحقيق مصالح الناس في دينهم ودنياهم، لأنها بنيت على أصل عظيم وهو: جلب المصالح ودرو المفاسد، ومن شأن هذه الشريعة كذلك تحصيل المصالح وتكميلها، وتقليل المفاسد وتعطيلها؛ لأن مبناها وأساسها على الحكم ومصالح العباد .

ومما لا شك فيه أن الوقف الإسلامي كان له دوره الكبير في خدمة الدعوة الإسلامية، ورعاية العلم وطلابه، وصيانة المؤسسات الدينية والإنسانية، ومواساة الأرامل والأيتام والفقراء، فقد أضفت الأوقاف والصدقات على المجتمع روح الإسلام وهديه، ونشرت فيه مظلة التكافل الاجتماعي، حيث أسهمت في تأليف القلوب، وتوحيد الصفوف بخطى ثابتة وموفقة على طريق الخير والرقي •

ولقد أحاط سلاطين المماليك وأمرائهح أهالي الحرمين عظيم عنايتهم، فكثرت أوقافهم عليهم، وعلى مجاوريهم وفقرائهج، حتى إن هذه الأوقاف وسعت المساكين والأيتام والمحتاجين والمعدمين ووفرت لهم جميعا المأوى والطعام . 
والملفت للنظر أن سلاطين المماليك أنفقا الأوقاف على أهالي الحرمين، ولم

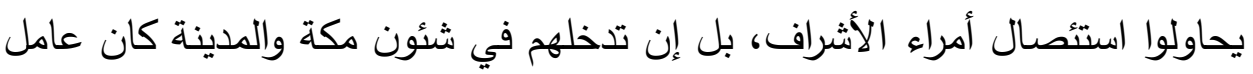

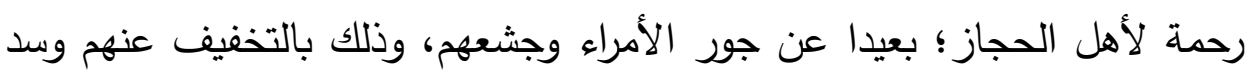

$$
\text { جوعهم وحاجتهم. }
$$

ولقد بلغ مقدار الأوقاف في أيام سلطين المماليك مبلغا كبيرا، فما من سلطان أو أمير مملوكي إلا وله وقف في جهة من جهات البر ، ويعود ذلك في المقام الأول؛ لعمل الخير واكتساب الأجر من الله هذا إلى جانب تحصين أموالهم

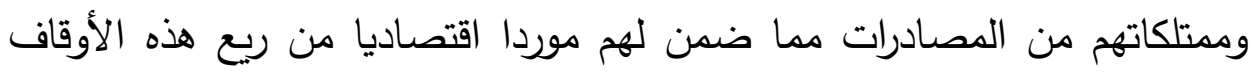

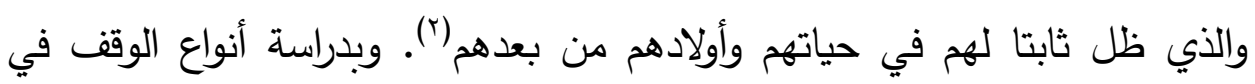

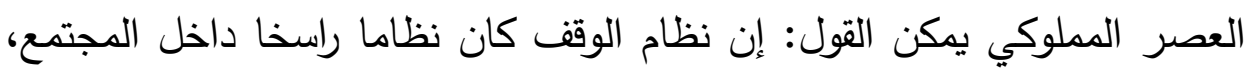

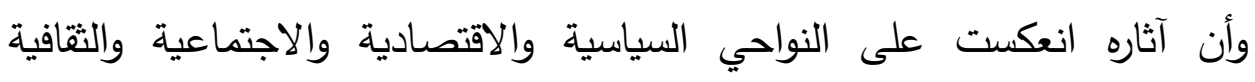

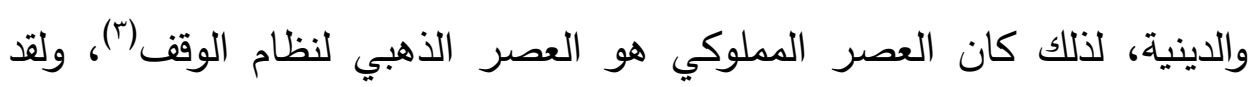
شهدت هذه الحقبة أنواع ثلاثة من الوقف:

\section{الأول: الأوقاف الخيرية:}

وتختص بالوقف على جهات البر التي لا تنقطع كالوقف على العلماء، وطلاب

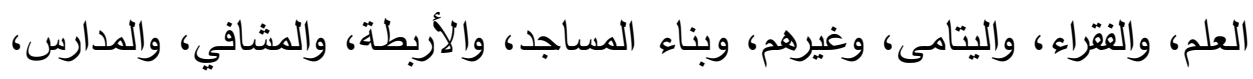

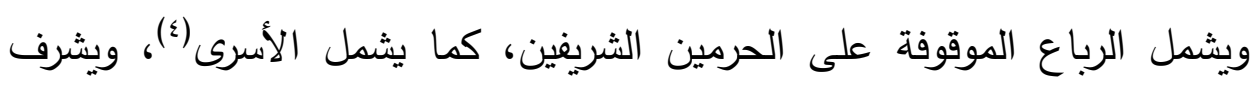

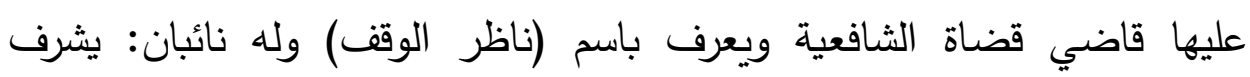
أحدهما على أوقاف القاهرة، والثاني على أوقاف مصر ، ويعين كل منهما نائبا عنه؛ يكون مباشرا لأوقاف الحرمين في مكة والمدينة (ه). 


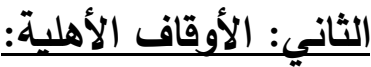

وهذا النوع من الأوقاف خاص بالأسرة؛ لكونه مصدرا للرزق والعيش حتى ينتهي نسل الأسرة تماما وينقطع، وعندئذ يتحول إلى وقف خيري؛ للصرف على جهات البر الأخرى(1)، ويقوم على أساس حبس العين والتصدق بريعها وثمارها في وجوه الخير في الحال أو المآل، فإنه يذهب أولا إلى ذريته أو غيرهم - طبقا للشروط

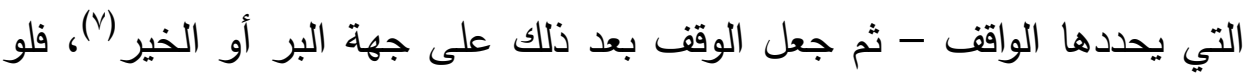
جعل أرضه المعينة وقفا على أولاده، ثم من بعدهم على مسجد كذا أو جمعية حفظ القرآن - مثلا - كان وقفا أهليا .

\section{الثالث: الوقف المثترك:}

كما يكون الوقف كله خيريا فقط أو أهليا فقط، كذلك يكون منوعا: بعضه خيري، وبعضه أهلي، وهو ما يسمى بالوقف المشترك.

فالوقف المشترك هو الذي يجمع بين الوقفين وهو الذي تم ابتداءا على الذرية وعلى جهة من جهات البر في وقت واحد بمعنى أن الواقف قد جمعهما في وقفه، فجعل

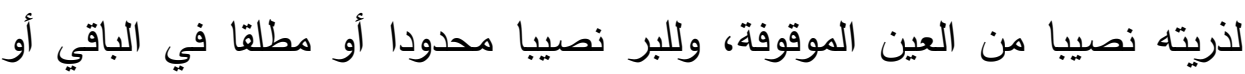

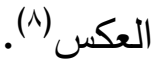

والأوقاف في العصر المملوكي يشرف عليها ديوان يسى ديوان الأحباس(9)

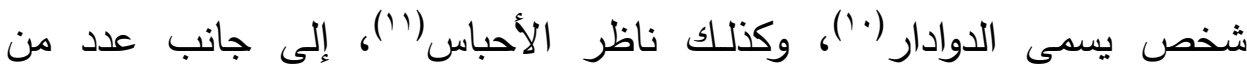
المباشرين والكتبة، ويتولى صاحب ديوان الأحباس توزيع الصدقات من ريع الأرض الموقوفة على المؤسسات الدينية، ويختص أيضا بالإثراف عليها إلي جانب 
الإحسان إلى المحتاجين، ونؤكد ذلك بنص المقريزي " أنه حين فوض الناصر محم

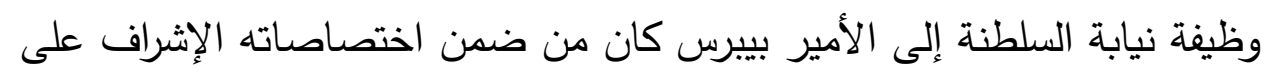

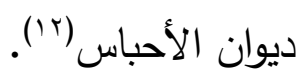

وتسمى الأوقاف الخاصة بالبر على الحرمين الأوقاف الحكمية، ولا يدخل منها أي وقف أهلي، فهي أوقاف خيرية خالصة؛ لأهل البيت الحرام، ولطلبة العلم

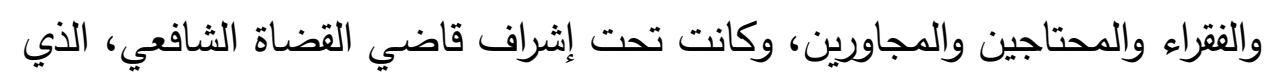

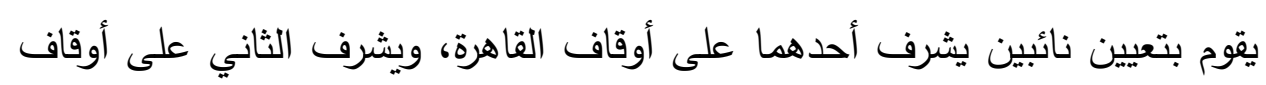

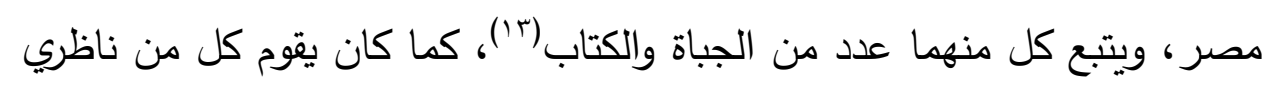

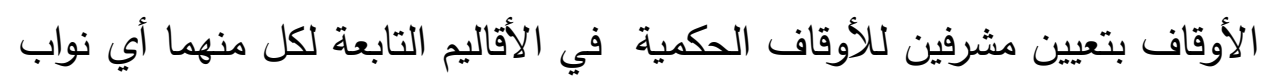
صغار ، كما كان يحدث في كل بلد إسلامي بتعيين مباشر لأوقاف الحرمين (؛ (1). ومن الجدير بالذكر أنه مع تعاقب الفترات التاريخية المختلفة للحكم الإسلامي عمل هؤلاء الواقفين على كتابة نصوص واضحة تتضمن العمل الموقوف في مواد مفصلة؛ رغبة منهم في تثبيت الوقف وإعطائه صبغة شرعية، وإدراج وثيقته مع لع سجلات ديوان الأحباس؛ فيحققون له بذلك إثراف الدولة من ناحية، واستمرار عمل الوقف في تحقـيق المنافع الخيرية من جهة أخرى (10).

\section{أولاً: الأوقاف ودورها في مساعدة الفقراء والمحتاجين ونشر الرخاء بمكة:}

لم تكن الأوقاف الموقوفة على أهل الحرمين الثريفين قاصرة فقط على سلاطين

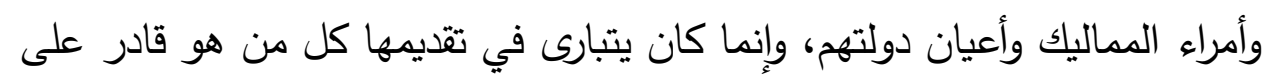

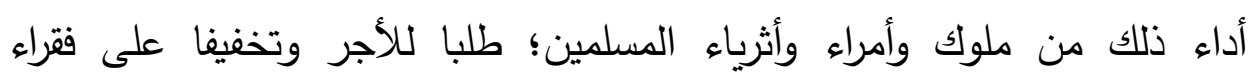


المجتمع شظف العيش، ولا سيما في أوقات الأزمات والجفاف، والأوقات التي تعز

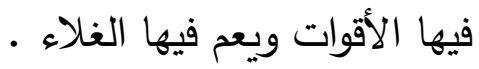

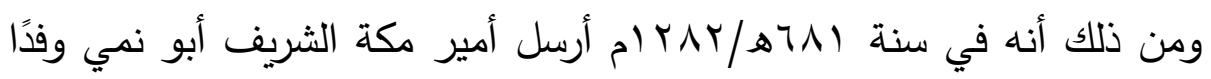
إلى القاهرة، مصحوبا بعدد من أشراف وزعماء الحجاز يرافقهم ابنه؛ لـقابلة

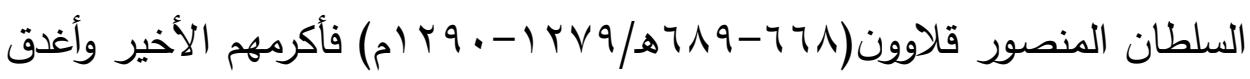
عليهم العطايا، بل وأجرى ما كان موقوفا من أوقافهم وأرسل الكثير من الصدقات والأموال؛ لتفريقها على أهـل الحرمين، وكذا العلماء وأصحاب الزوايا('1).

وتبين حجة وقف سيف الدين بكتمر الجوكنداروالمؤرخة سنة V•Vه/V•r ام أن من أوجه صرفها تخصيص ما تبقى من ريع الربع من الأراضي الزراعية

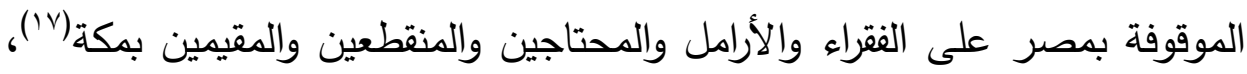

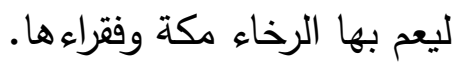

وتأتي حجة الأمير سيف الدين أرغون الدوادار الناصري(^)( نائب السلطنة

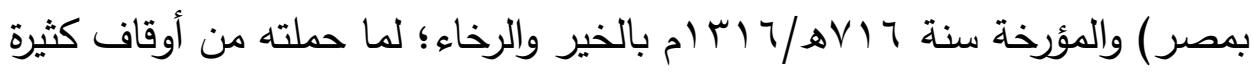
بمكة والمدينة (19).

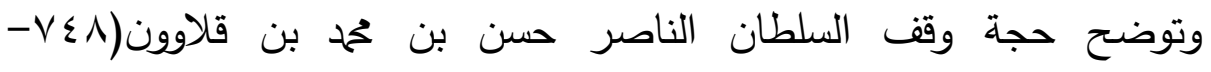

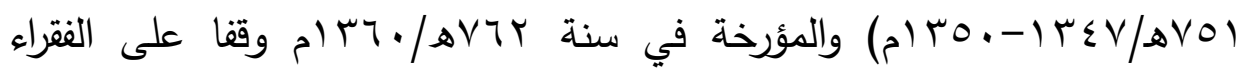

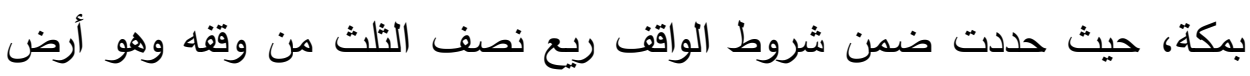
بحماه على الفقراء والمساكين المجاورين بالمسجد الحرام من الذكور والإناث، حسب ما يراه الناظر ويؤدي إليه اجتهاده(·r). 


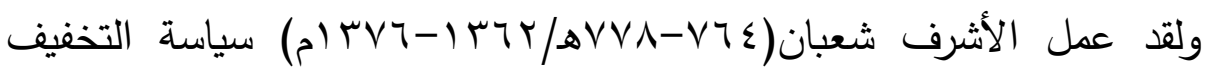
عن سكان الحجاز خلال فترة حكمه، حيث اتقق مع أمير مكة (عجلان)، على الى

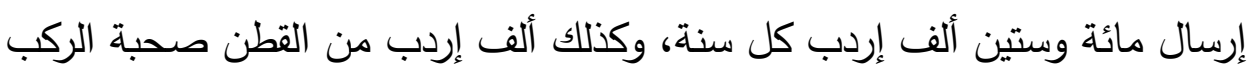

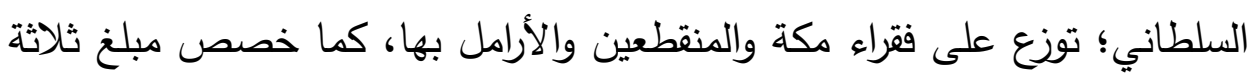
آلاف درهم؛ لشراء أكفان للموتى بالحرم، كما حدد خمسة آلاف درهم كنلك سنويا

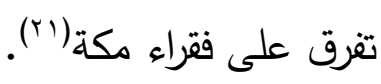

ولقد حرص الواقف أحمد بن محم النحاس(rr) على تحديد ألف درهم نقرة تصرف

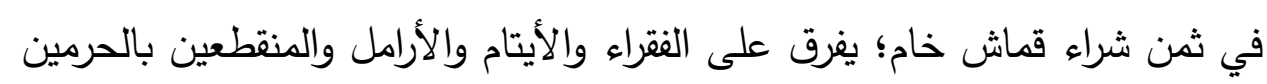

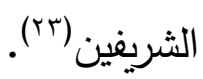

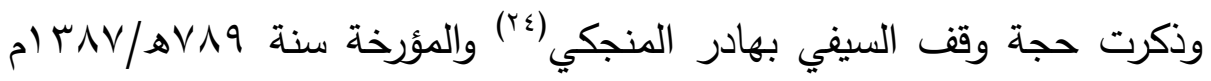
أنه أوقف أرضا ودورا بالقاهرة على ذريته من بعده، ثم يصرف ريع الوقف كله بعدهم على فقراء الحرمين الثريفين (ro).

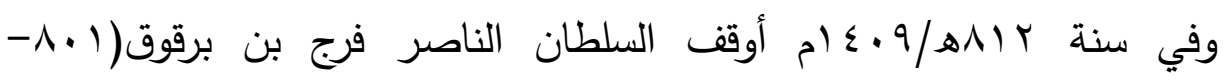

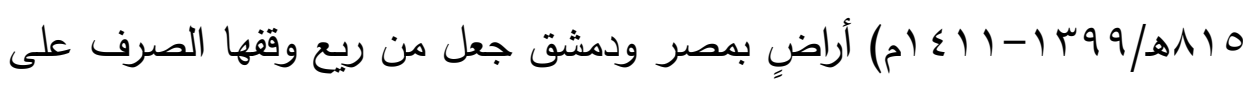
الفقراء والأيتام والأرامل والمجاورين المقيمين بالحرمين من المسلمين، وكنلك في إطعام الجائعين وكسوة العرايا ويفرق ذلك فضة أو نقودا(؟r).

ومن الجدير بالذكر أن السلطان الأشرف برسباي(ب)

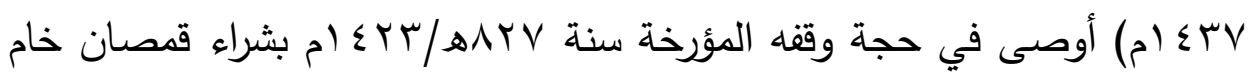


تحمل كل سنة إلى الفقراء والمجاورين بالحرم المكي والمدني، وتقسم بينهم وفق ما يراه الناظر ويؤدي إليه اجتهاده، وذلك من ريع أراضي بالجيزة من مصر(rV) فضلا عن ذلك فقد أوقف الزيني خشقدم زمام(^^) الأدر الثريفة(ه) والمؤرخة سنة VR هـ/R ام ام لتذكر أنه وقف وقفا عبارة عن: رباط، ومجموعة مخازن، يصرف من ريعها على فقراء ومساكين وأرامل وغرباء مكة المكرمة(·r). وقد ذكرت حجة وقف الجمالي أبو المحاسن يوسفوالمؤرخة سنة 9 ^هـ/0ـ ؛ ام أن من ضمن أوجه صرف وقفها صرف ثمن مائتي قميص خام ترسل كل سنة، وتوزع على الفقراء المقيمين بمكة، أو ما يعادل قيمتها حسب ما يراه الناظر ('r)،

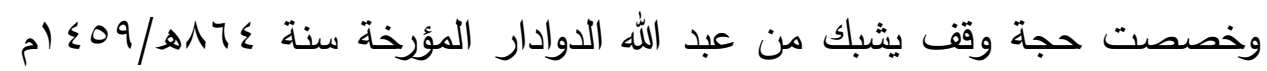
الصرف على شراء خمسين قميصا مخيطا من الكتان كل سنة ترسل بصحبة المحمل إلى مكة والمدينة، وتوزع على الفقراء والمساكين، كما خصصت في مكان آخر صرف أربعة آلاف درهم أو ما يقوم مقامهما من النقود يتصدق بها على فقراء ومساكين المدينتين المقدستين بالسوية حسب ما يراه الناظر (rم).

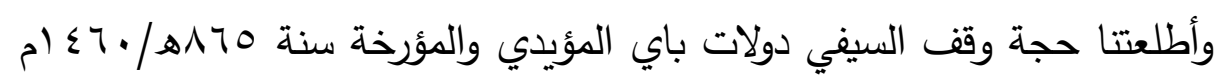
بوقف على الفقراء، حيث ذكر الواقف أنه إذا تعذر الصرف في جميع الجهات المذكورة بالحجة صُرف كامل الريع المذكور بالحجة للفقراء والمساكين القاطنين بالحرمين، حيث يقوم الناظر بشراء كسوة لهم أو غير ذلك حسب ما يراه ويؤدي إليه

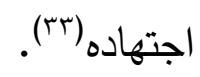


ونصت حجة وقف تمرباي بن عبد الله المحمدي(๕) والمؤرخة سنة

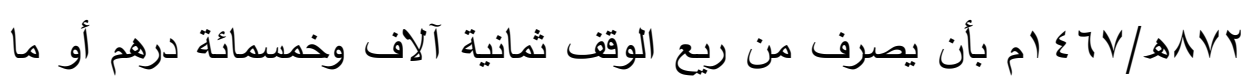
يقوم مقامهما من النقود كل عام في شراء ثمن قمصان خام، إلى جانب طُحح مخيطة، ويصرف منه تكلفة من يحملها إلى الحرمين، وكذا من يتولى تغريقها بالسوية فيما بين الفقراء والمجاورين بالحرمين، وذكرت الحجة في مكان آخر أن المبلغ سبعة آلاف وخمسمائة درهم (ror).

وفي نفس السنة أوقف السيفي طوغان بن عبدالله السيفي ادوم بغا قطعة أرض ناحية القليوبية محدودة بحدود أربعة، وبها قاعات وأروقة وخزائن ودهاليز ومطابخ وحمامات يؤول ريع السبع منها شهريا على فقراء الحرمين الثريفين(بَ).

وتأتي حجة وقف تحمد بن الثهاب أحمد العجمي، والمؤرخة سنة

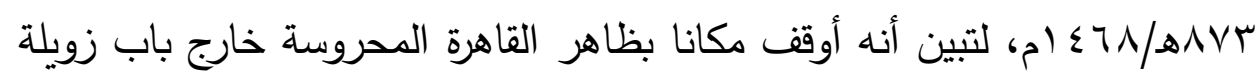
بحارة القشاشين محدود بحدود أربعة وبه قاعات وأروقة وخزائن ومطابخ يؤول ريعها

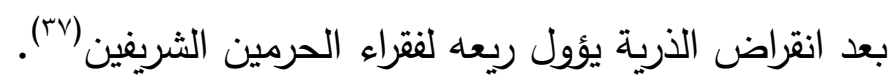

وتمد البحث حجة وقف الأمير صارم الدين إبراهيم(^) والمؤرخة سنة

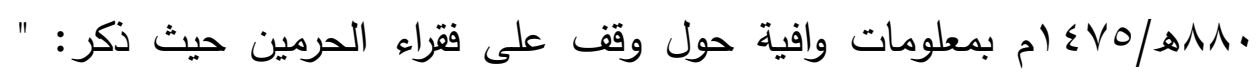
وجعلت من ريع ذلك وقفا على فقراء الحرمين، حرم مكة والمدينة بالسوية في العطاء، فإن تعذر الصرف لفقراء أحدهما صرف لفقراء الآخر ، فإن تعذر الصرف لهما معا صُرف لفقراء المساكين والأرامل والمحتاجين من المسلمين أينما كانوا حسب ما يراه الناظر (ra) . 
وتطلع البحث حجة وقف السيفي جاني بك بن عبد الله الظاهري(•(ఓ)والمؤرخة سنة

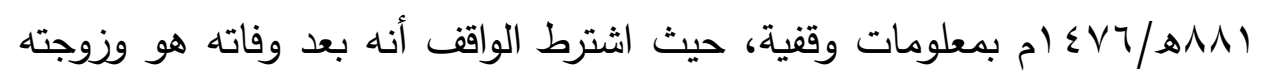
وانقراض ذريته يؤول نصيبهما في العين الموقوفة إلى فقراء الحرمين، فإن تعذر الصرف لأحدهما صرف للأخر ، والنصف الثاني من ريع العين الموقوفة يصرف ثمن خبز وماء يسبل في ليلة الجمعة من كل أسبوع على الفقراء والمساكين حسب ما يراه الناظر (1).

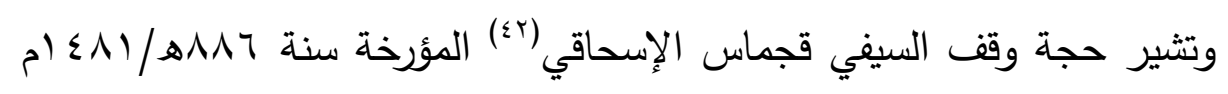
بأنه خصص عشرة آلاف درهم ترسل في صحبة من يوثق به صحبة الركب الثامي الموسمي؛ للصرف على فقراء الحرمين، فإن تعذر الصرف لفقراء أحدهما يصرف للآخر حسب ما يراه الناظر ويؤدي إليه اجتهاده(r؛)، وتطلعنا كذلك حجة وقف القاضي محم الخزرجي الإخميمي(ء) والمؤرخة في سنة بتحديد مبلغ ثلاثمائة درهم كل عام من ريع الوقف الموقوف، تصرف كل سنة على فقراء الحردين والمجاورين (0؛) ولقد ذكرت حجة وقف شمس الدين خحمد بن خحمد بن أحمد الأكيادي( (؟) والمؤرخة سنة 9 .9هـ/r •-0 أنه أوقف أربع وعشرين قيراطا بمنطقة العدوة بالفيوم، وأنه جعل ريع حصة قدرها أربعة قراريط للصرف على فقراء الحرمين ومصالحهاه(\&).

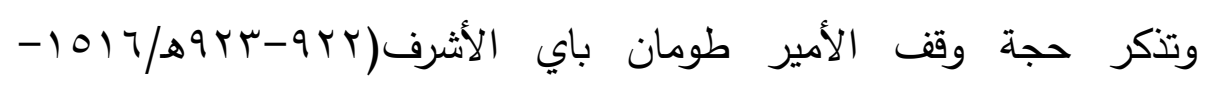

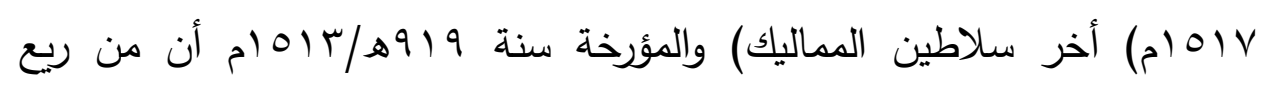
الوقف الموقوف الصرف على الفقراء والمتاجين من أهالي المدينتين المقدستين (ఓ^). 


\section{ثانيا: الأوقاف ودورها في رعابة الفقراء والأيتام والمجاورينبالمدينة المنورة:}

ذكر البحث في كثير من الأوقاف الموقوفة بمكة المكرمة، أنها كانت تخص كذلك الدينة المنورة، حيث وقفت العديد من حجج الوقف ريعها على الحرمين الثريفين، نتيجة حرص كثير من المسلمين حكام وأمراء وأفراد، على تقديم الأموال لتوزيعها بالحرمين، فكانت ترد إلى المدينة المنورة خاصة في وقت الموسم حصيلة الأوقاف التي أوقفها المسلمون على أهل الحرمين بوجه عام وأهل الدينة بوجه خاص فتوزع على الفقراء والمجاورين.

لكن وجدت بعض الأوقاف الخاصة بالدينة المنورة، ومنها: ما ذكرتها حجة وقف

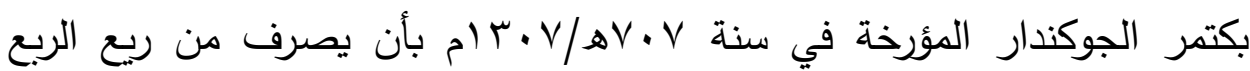
الثاني من الوقف الموقوف بالصرف على الفقراء والأرامل والمجاورين والمنقطعين والعاجزين بدينة طيبة، وذلك حسب ما يراه الناظر (9).

وتوضح حجة وقف السلطان الناصر حسن بن تحمد بن قلاوون والمؤرخة في سنة

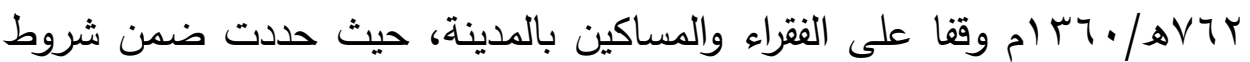
الواقف ريع نصف الثلث من وقفه وهو أرض بحماه على الفقراء والمساكين بالمدينة الشريفة الذكور والإناث السنيين غير الزيديين والروافض، حسب ما يراه الناظر

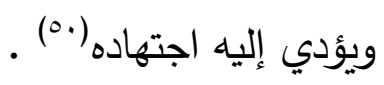

كما ذكرت حجة وقف الأمير مثقال(1)، مقدم المماليك(بr) والمؤرخة في سنة  
الحرم النبوي، فإن تعذر الصرف للذدام فللفقراء بالمدينة، فإن تعذر فلمسلمين أينما

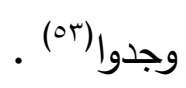

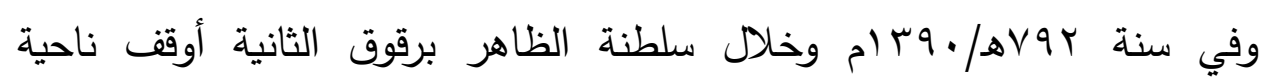

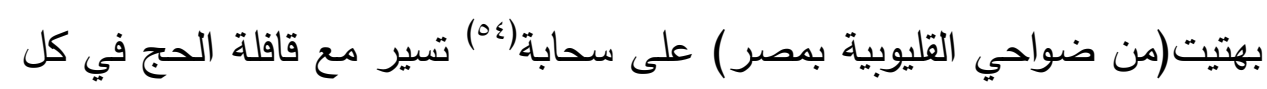

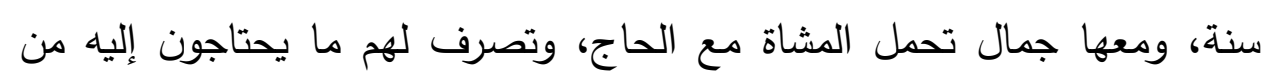
الماء والزاد ذهابا وإيابا(00)، كما أوقف على الحرمين الثمال الثريفين في كل سنة ثلاثة آلاف إردب قمح تقرق فيهما سنويا (ه).

ومن الجدير بالذكر أن السلطان مراد الثاني العثماني أوقف محاصيل القرى الواقعة

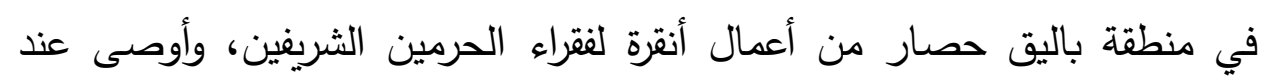
وفاته بتخصيص مبلغ . . . فلورين مناصفة بين فقراء مكة والمدينة المنورة (ov. ولقد ذكرت حجة وقف جوهر اللالا(ه) والمؤرخة سنة عبههـ/·r؟ ام أنه تم

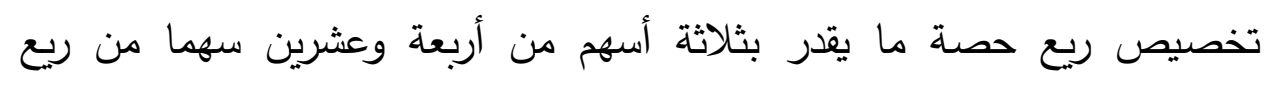

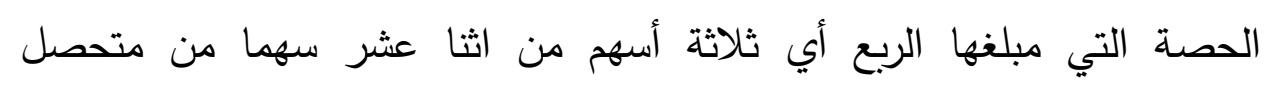

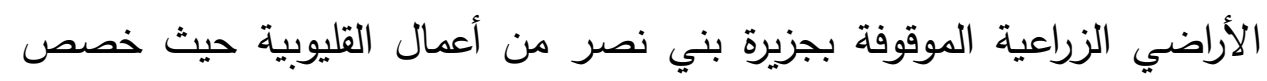

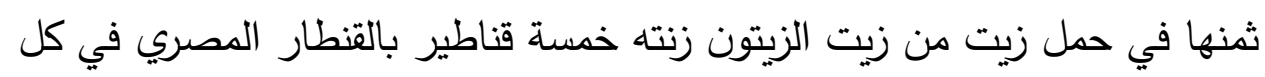
سنة يرسل إلى الدينة تكون وقود للحرم النبوي، فإن تعذر الصرف يفرق على

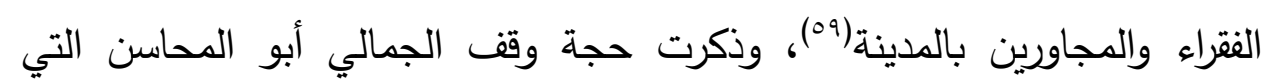

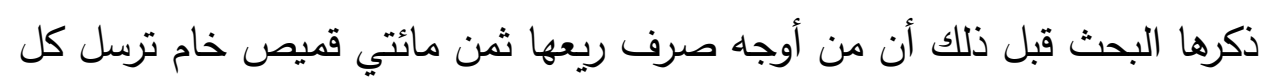
سنة، وتوزع على الفقراء المقيمين بمدينة طيبة (·). 
كما أفادت حجة وقف السيفي بن عبد الله الجكمي والمؤرخة سنة

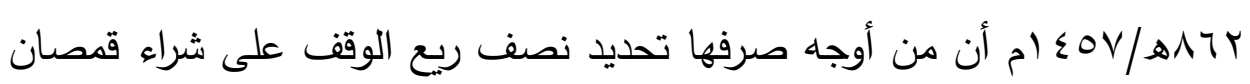
خام مخيطة وتكليف من يحملها في صحبة محمل الحج كل عام، وتقريقها على الفقراء والمستحقين بالحرم النبوي وذلك حسب ما يراه الناظر (آ) . وبينت حجة وقف عمر بن الغرس خليل الحسامي المنصوري والمؤرخة سنة

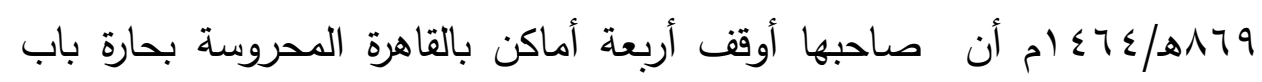
القتوح بها قاعات وخزائن ومطابخ وحمامات محدودة بأربعة حدود على ذريته ثم على مصالح الحرم النبوي، ثم أوقفها على الفقراء القاطنين الحرم النبوي

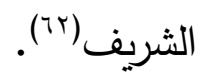

كما أعطت البحث حجة وقف الأمير يشبك من مهدي الدوادار (זٓوالمؤرخة سنة

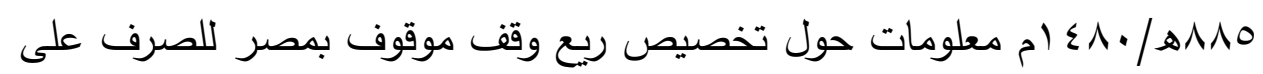
الفقراء والمساكين بالمدينة، حيث يُطَبُُْ كل يوم لحم وخضار وخبز يفرق على فقراء المدينة، فإن تعذر عمل السماط، فيضاف ذلك لعمل دشيشة السلطان الظاهر جقمق، فإن تعذر الصرف فيتم الصرف على الجامع الأزهر الشريف(؟؟).

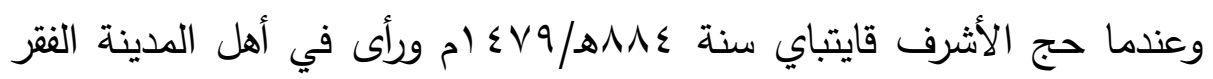
والحاجة؛ أرسل بعد عودته لمصر إلى المدينة ستين ألف دينار يثترى بها أمساكن بها تكون وقفا يحمل ريعها؛ لخدمة الحجرة الشريفة، كما يعمل منها سماط كبير؛ ينتفع به الفقراء والمحتاجين، وقيل إن هذه الأماكن الموقوفة كان يتحصل منها سبعة آلاف وخمسمائة إردب كل سنة، تفرق كلها على أهل المدينة(70). 


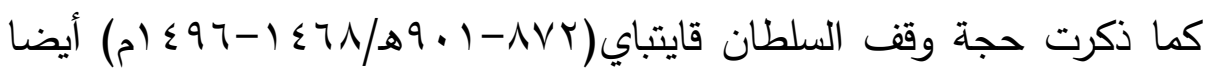
المؤرخة سنة 190/19 § أم أنه بعد انقضاء الذرية الموقوف عليهم، يتم صرف ريع الوقف الموقوف بمصر على عمل دشيشة(Tr) وكذا توزيع أموال على أهل

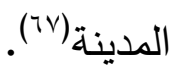

ومن الجدير بالذكر أن الأوقاف التي أوقفها سلاطين المماليك وأمراءهم ظلت لها حرمتها ومرافقها حتى عصر متأخر بعد السلطان الغوري، فظل ريعها يصل لأهل المدينة فيفرق بين المستحقين لها من الفقراء والمجاورين شهريا، بطرق مختلفة سواء أكانت مالية أم عينية(^^ان.

ويشير البحث إلى أن هذه الأوقاف تعرضت للانهيار ، ولعل من أسباب انهيارها بعض من القائمين على شئونها كالقضاة والنظار الذين خرجوا على نظامها، حيث أهمل بعضهم في الاهتمام بها، كما استولى بعضهم على ريعها، مما ساعد على ظهور بعض السلوكيات السيئة كالتحاسد والتتاحر للحصول على عائد هذه الأوقاف، كما عمل بعضهم على إرضاء السلطة للفوز بالأوقاف وعوائدها، مما كان له دوره في إبراز بعض الانحرافات في سلوك بعض فئات المجتمع؛ لانعدام

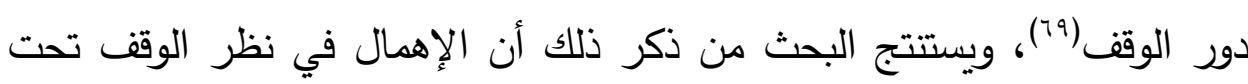
ذكر الواقف حسب مايؤدي إليه اجتهاد الناظر في أغلب حجج الوقف التي أطلع عليها البحث، ما جعل بعض الواقفين يشترط على الناظر أن لا يستبدل شيئًا من الوقف حتى ولو بلغ الخراب، وإن فعل الناظر ذلك يكون معزولا هو أو غيره كما ذكرت بعض حجج الوقف.

ثالثا: أوقاف المرأة ودورها في رعاية الفقراء والأيتام والأرامل: 
اهتمت المرأة في العصر المملوكي عامة وفي بلاد الحجاز خاصة بالرعاية الاجتماعية، وظهر ذلك جليا بين سطور المصادر وحجج الوقف، حيث أوقفت بهرد

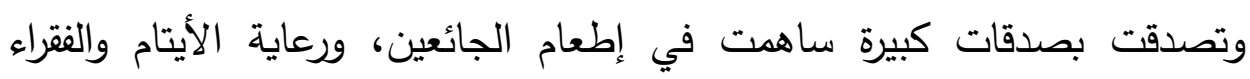
والمعدمين، وخفت عنهم شظف العيش وقسوة الحياة، بل تعدت ذلك كله في إقامة

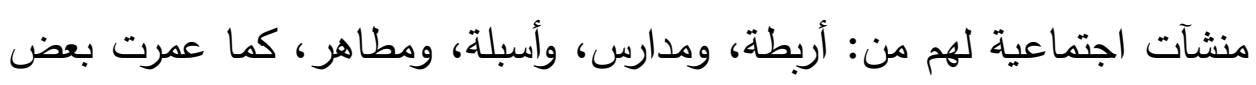

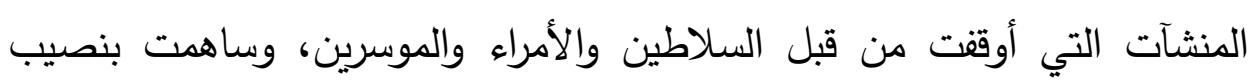
كبير في الرعاية الاجتماعية، وكانت جزءا أصيلا في رعاية المجتمع والاهتمام بشئونه.

ورغم القيود الاجتماعية التي فرضتها التقاليد السائدة على المرأة في عصر

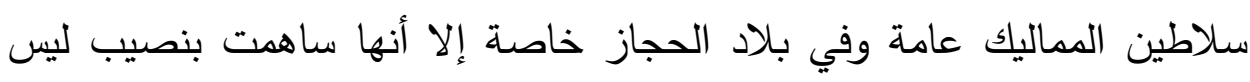

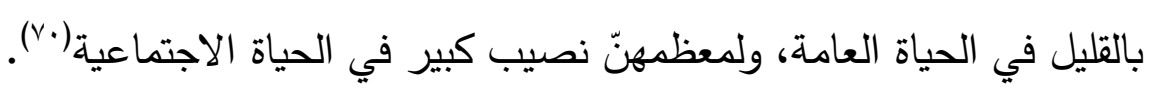
ويؤكد البحث أن رقي أية مجتمع يقاس دائما بمدى تقدير ذلك المجتمع للمرأة ومنحـها حقوقها؛ بوصفها شريكة الرجل إلى جانب كونها الخلية الأولى لبناء

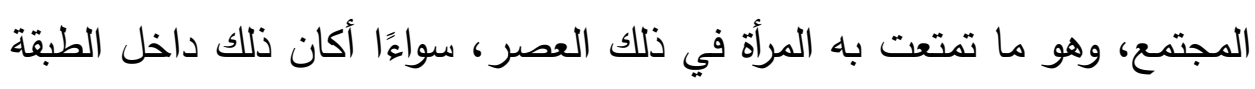
الحاكمة، أو عند سائر طبقات الثبب؛ فالمماليك نظروا إلى نسائهم نظرة إجلال؛

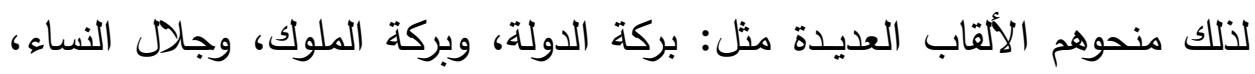

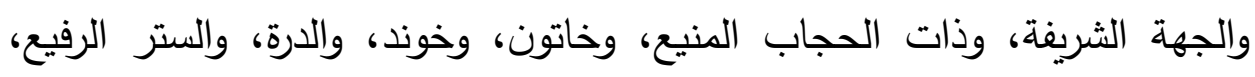

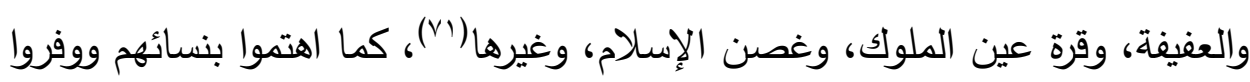

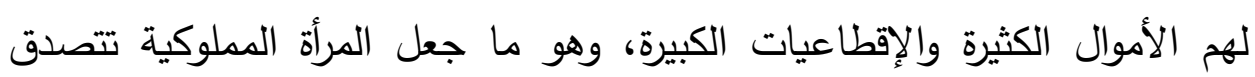


بالصدقات الكبيرة وتوقف المنشآت الاجتماعية في مصر والثام والحجاز؛ طمعا فيما عند الله عز وجل من الثواب الجزيل.

ولم تتوقف الأوقاف والصدقات وإقامة المنثآت وعمارتها عند المرأة المملوكية وحسب، بل تعدته إلى زوجات ملوك الدول الإسلامية وبناتهم، وكذلك النساء

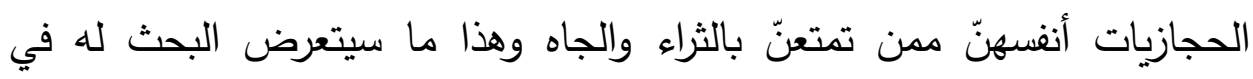

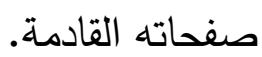

ولقد أوقفت المرأة الأوقاف؛ لعلها تخفف عن الدحتاجين والفقراء قسوة الحياة؛ راجية من الله الثواب والعطاء الجزيل ومن ذللك: ما قامت به المصونة أردكين ابنة السيفي زوجة السلطان الناصر محمد بن قلاوون، من وقف أكثر من ثلاثين مكان بمصر مابين دور وفنادق وحمامات وأراض زراعية وغيرها بمصر بحجة برون وقفها

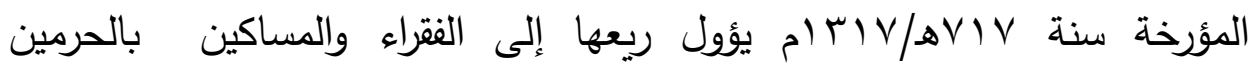
الثريفين بعد انقراض الذرية، يفرقه الناظر حسب ما يؤدي إليه اجتهاده من مساواة

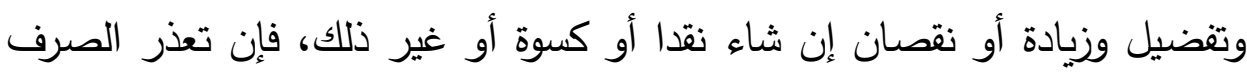

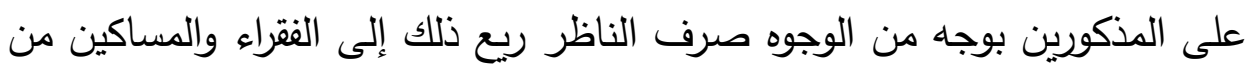

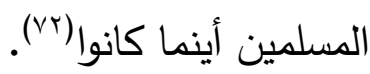

وتأتي حجة وقف خوند(YrF) بركة أم السلطان الأشرف شعبان والمؤرخة سنة

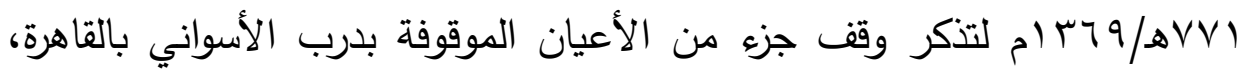

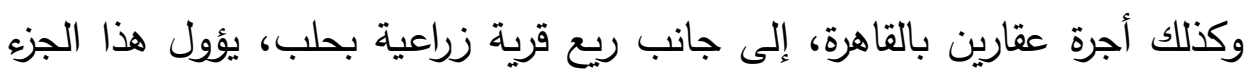

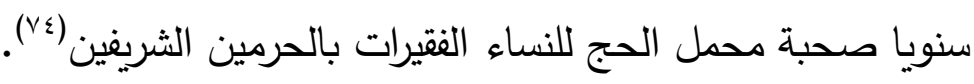


ومن أوقاف المرأة أيضا ما قامت به خوند شيرينزوجة السلطان الظاهر برقوق، من تخصيص ثلث ريع وققها الموقوف بمصر والثام من أراض زراعية وعقارات في مصالح الحرمين الثريفين، من عمارة للكعبة والحجرة الثريفة، وكذا عمارة المسجد النبوي الثريف، كما أوصت في جانب آخر من الوثيقة المؤرخة سنة ץ.^هـ/9 9 ام بالصرف على فقراء الحرمين وعلى الsقيمين بها والواردين إليهما، وللخدام كذلك بينهم بالسوية، ولكل حرم وفقرائه سهمان كاملان وثلثا سهم من ذلك

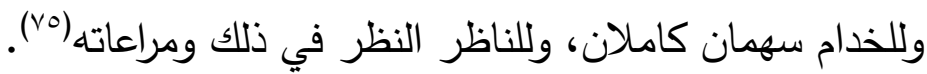

وتطلع البحث حجة وقف المصونة ابنة اسندمر الثامية(V) والمؤرخة

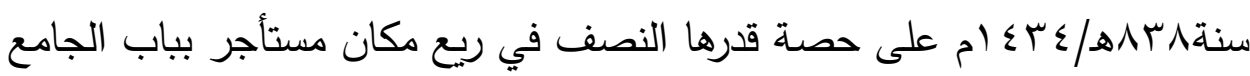
الطولوني بالقاهرة، يؤول ريعها بعد انقضاء الذرية في الصرف على مصالح وفقراء الحرمين الثريفين (rV)

وتغيد حجة وقف الست(V^) بيرم(V9) ابنة السيفي قرقماش بن عبدالله والمؤرخة

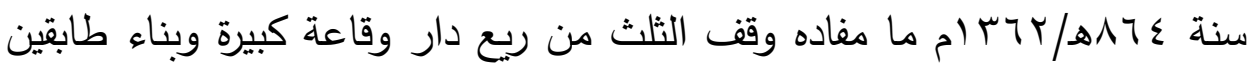
بمنطقة دار الفتوح بالقاهرة، على أهالي الحرمين الثريفين بالسوية حسب ما يؤدي

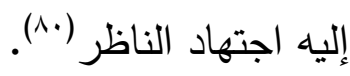

ولقد قامت عائثة ابنة برجك بن عبد الله الأقبغاوي(')، من تخصيص مبلغ أربعمائة درهم سنوية بحجتها الموقوفة سنة 170هـ/. بـ ام؛ تصرف بعض انتضاء الذريةعلى الفقراء والمساكين المجاورين وغيرهم من المحتاجين بالحرم المدني وذلك حسب مايراه الناظر ويؤدي إليه اجتهاده، وكان الوقف أراض زراعية بمنطقة 
الدقهلية، وحصة قدرها قيراط ونصف بالقليوبية، ونفس الحصة بالغربية، يؤول ريعها

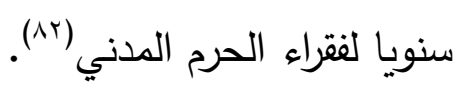

وتأتي حجة وقف المصونة خديجة(ش广) بنة أحمد بن أرغون شاه والمؤرخة

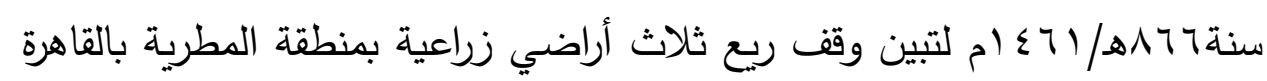

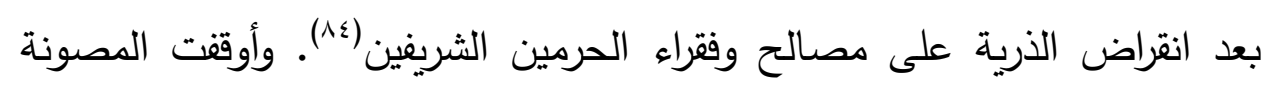

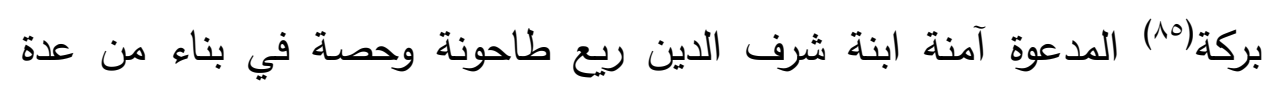

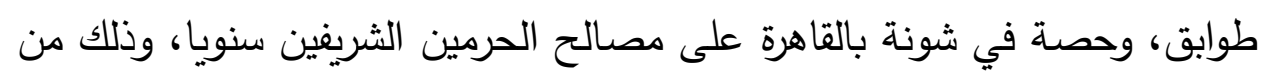

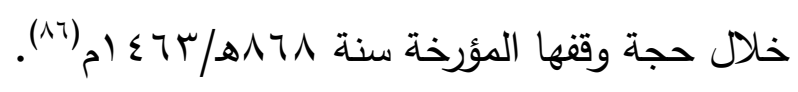

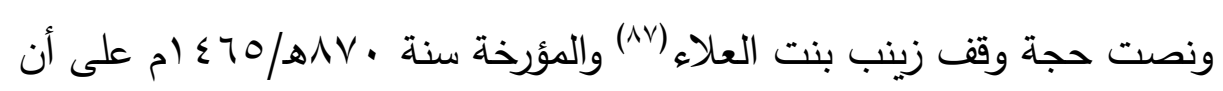
يصرف من ريع الوقف الذي وققته وهو أراض زراعية بمصر عشرة آلاف درهم في كل سنة صحبة الركب الشريف ثمن قصصان خام تفرق على الفقراء والمساكين القاطنين والواردين إلى حرم مكة الدكرمة والمدينة المنورة من أي الجنسيات كانوا تهني

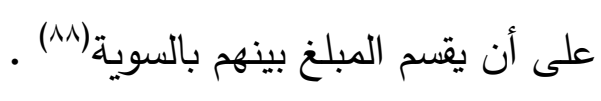

كذلك أوصت الواقفة فاطمة زوجة الزيني شعبان(^) في حجة وقفها المؤرخة

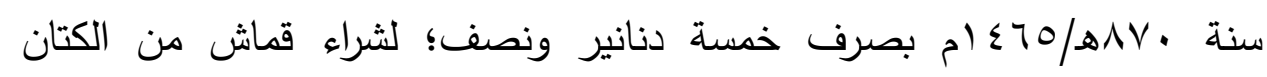
وتفصيله قمصانا توزع على فقراء الحرمين الثريفين، وأن يتم صرفها دفعتين كل

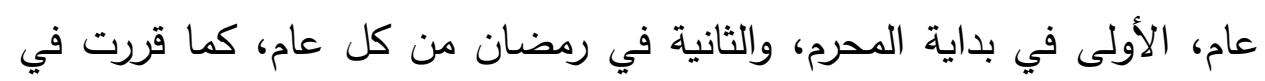

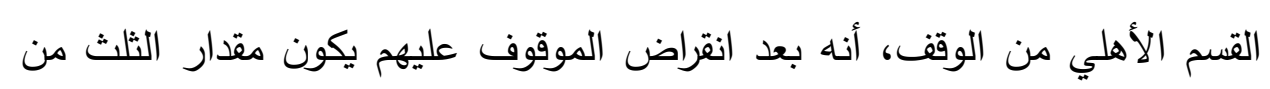

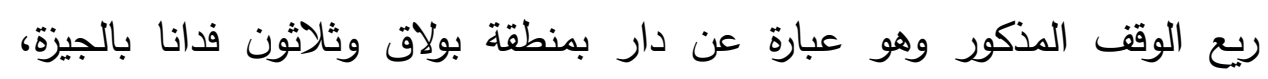


مصروفا على الفقراء والمساكين بالحرمين بالسوية على مايراه الناظر ويؤدي إليه

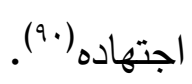

وذكرت حجة وقف فاطمة بنت العيلمي(19سليمان أمير آخور

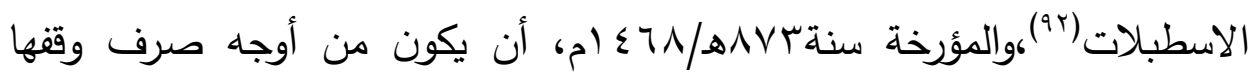
الذي وقفته في حجتها صرف شراء قصان تحمل إلى بلاد الحرمين الشريفين سنويا صحبة محمل الحج، وتوزع على فقراء المدينتين المقدستين، وكذلك جزء من ريع الوقف الموقوف وهو حصة في ثلاثة أبنية مؤجرة بسويقة السباعين بالقاهرة سنويا على مصالح الحرم النبوي الثريف على مايراه الناظر في ذلك ويؤدي إليه اجتهاده(r9)، كما أوصت الواقفة فاطمة ابنة شهاب الدين أحمد والمؤرخة سنة

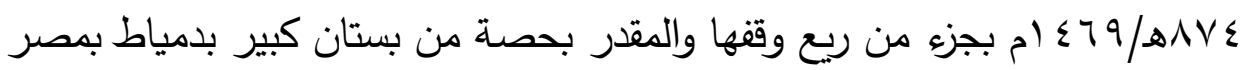
يصرف جزء من ريعه سنويا على فقراء ومصالح الحرم الشريف النبوي، حسب مايؤدي إليه اجتهاد الناظر (؟9). وتقيد البحث حجة وقف المصونة فاطمة والمدعوة ستيتة بنت تاج الدين أبو الإخلاص، والمؤرخة سنة 91/هـ/ (9٪ ام ما مؤداه ريع حصة في بناء ببولاق، وكذلك حصة في بناء بالقاهرة ثلاثة طوابق، يأول ريعها بعد انقضاء الذرية إلى فقراء الحرمين الثريفين (90).

ومن الجدير بالذكر أن ابن فهد ذكر أن " بلقيس بنت نائب الثام ( حاتم بن عبد الله ) والتي توفيت سنة r ·9هـ/9 § (م، أنها أوقفـت دورا لها وجهـازها على سبعـة أيتام بمكة (ד9). 


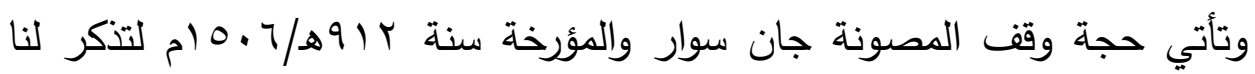
وقف ريع عقار بالقاهرة تصرف أجرته كاملة سنويا على فقراء المجاورين بالحرم النبوي الثريف(`^). وأطلعت البحث حجة وقف ورد قان ابنة عبد الله عتيقة السيفي يشبك الدوادار والمؤرخة سنة . ب9هـ/ع اه ام، بصرف جزء من ريع الأعيان الموقوفة وهي عبارة عن أراض زراعية بمنطقة الدقهلية بمصر بعد انقضاء الذرية

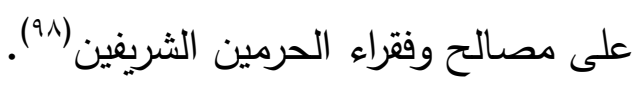

وحرصت الواقفة المصونة جان سوار ابنة عبدالله(99)، في حجة وقفها على أن يكون من أوجه صرفها صرف ألف وخمسمائة درهم أو ما يقوم مقامهما من النقود على الفقراء والمساكين والمجاورين بالحرم النبوي، وعلى ما يراه الناظر ويؤدي إليه

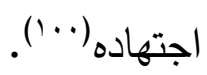

كما أوصت زينب بنت شعبان مربية القاضي صلاح الدين بن أبي السعود بن ظعيرة قبل وفاتها عام اب9ه/010/م بعتق جارية، وأوصت لأقاربها الفقراء ببعض الأموال وقفا عليهم(1 +1)، كما أوصت فاطمة بنت الثريف ثقبة بن رميثة بن أبي نمي لإمائها وجواريها وفقراء مكة ومجاوريها بوقف ريع أراض تمتلكها بمكة عليهم (1.r)

مما سبق يتضح لنا الدور الذي قامت به الأوقاف في الرعاية الاجتماعية في الحجاز، حيث لعبت الأوقاف دورا كبيرا في رعاية الفقراء والمحتاجين والمجاورين والأيتام، ووفرت لهم الغذاء والكساء، وأن هذه الأوقاف تبارى في تقديمها سلاطين المماليك وأمرائهم ونسائهم، وكذلك ملوك وأثرياء الدول الإسلامية المعاصرة لهم، فضلا عن أشراف الحجاز وتجارها ونساءها؛ طلبا للمثوبة من الله(سبحانه وتعالى). 
الوقف لغة: مصدر يطلق على اسم المفعول، فيقال هذا بيت وقف أي موقوف ويجمع على الثى

أوقاف وهو الثائع في الاستعمال، والوقف في اللغة معناه الحبس والدنع، ووقف الأرض لعلى لعلى الدساكين:

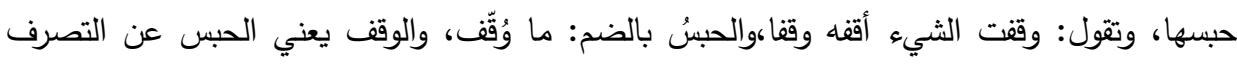

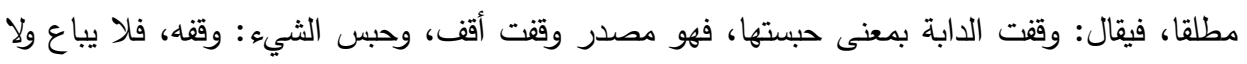
يورث وإنما تملك غلته ومنفتته، والواقف: الحابس لعينه، إما على ملكه، وإما على ملك الله تعالى، والوقف: حبس العين على ملك الواقف أو على ملك الله تعالى، ويطلق الوقف ويراد به الموقوف، فقد

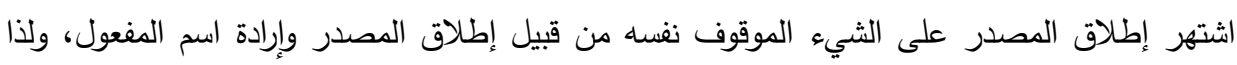

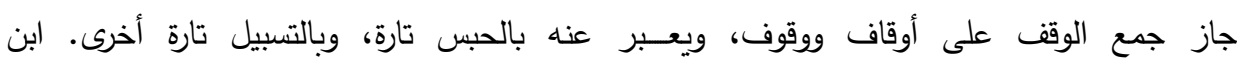

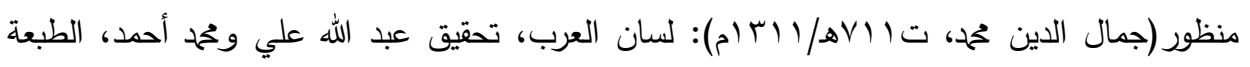

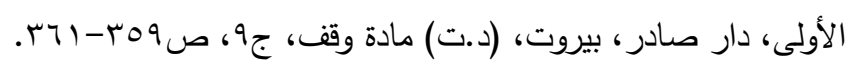

واصطلاحا: يعني التصرف في ريع العين وما تدره من مال، مع بقاء العين في ذاتها وجعل منفعتها

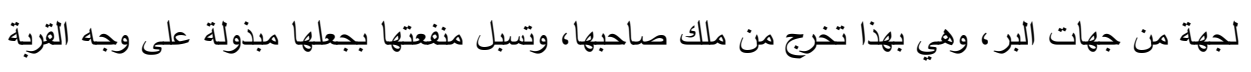

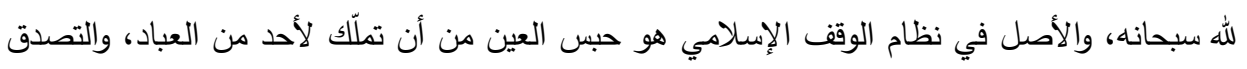

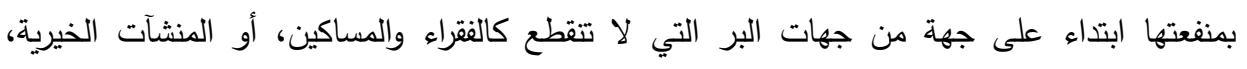

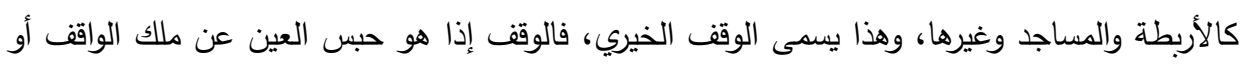

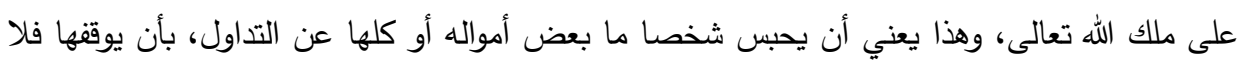

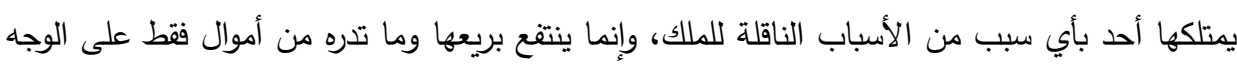

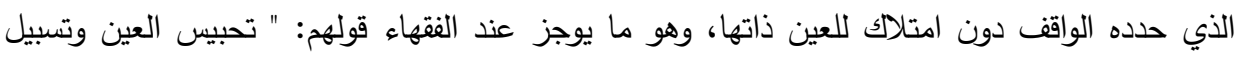

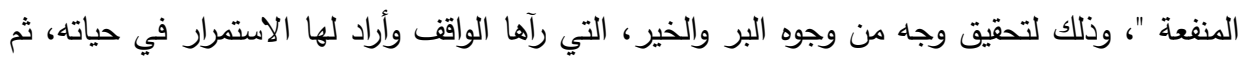

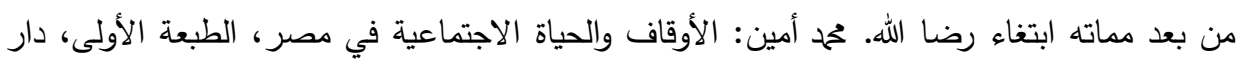

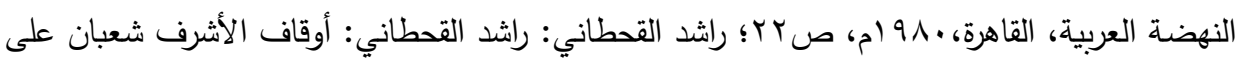

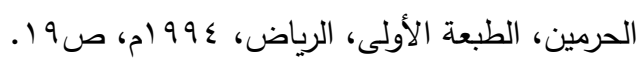

lapidus; Maslim cities in the later middle ages"Harvard 1967"p.74.

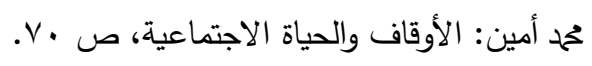

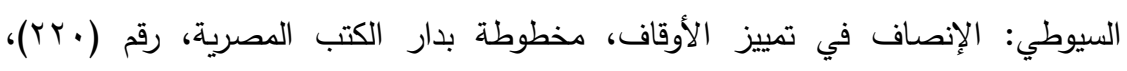

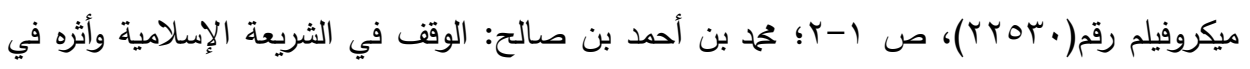

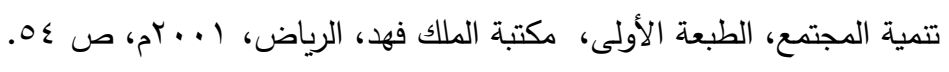


وهن الوظائف التابعة لناظر الوقف: مباشر أوقاف الحرمين، وهو الموظف المكلف بإدارة العمل

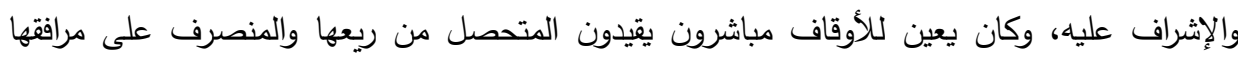

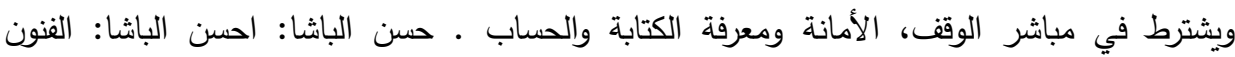

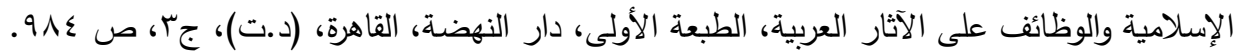

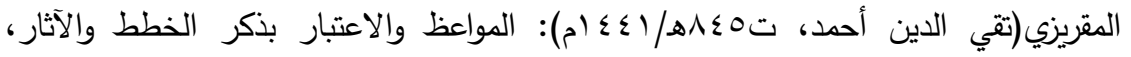

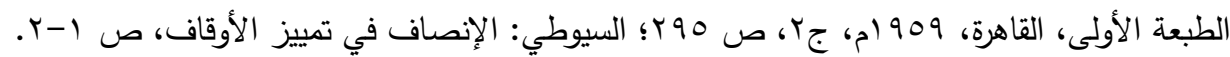

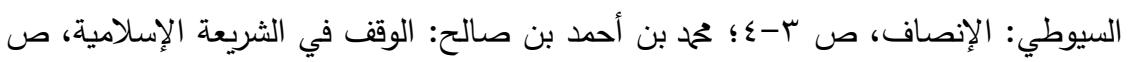

السيوطي: الإنصاف، ص ؛؛ حمح بن أحمد بن صالح: الوقف في الثريعة الإسلامية، ص

هو ديوان الأوقاف، ولفظة ديوان عرفت اولًا في الدولة الإسلامية بمعنى السجل، وأول من دون

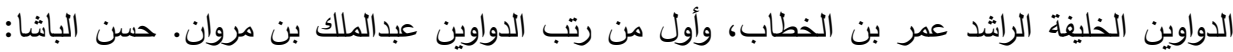

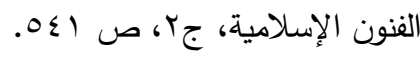

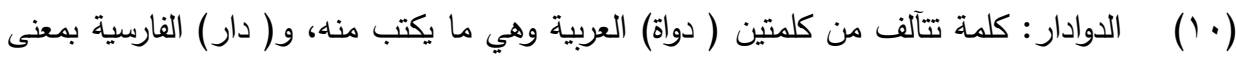

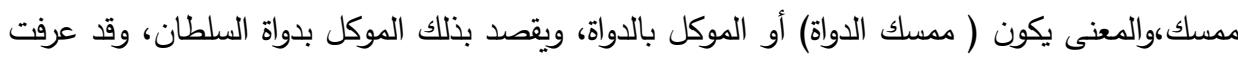

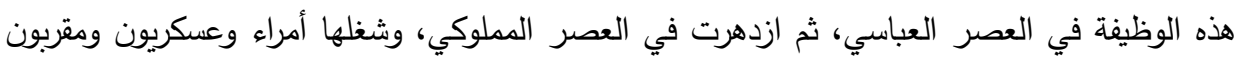

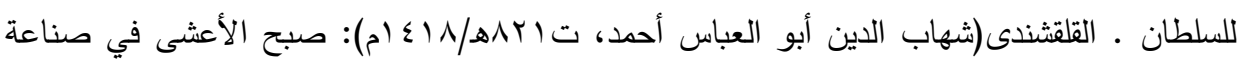

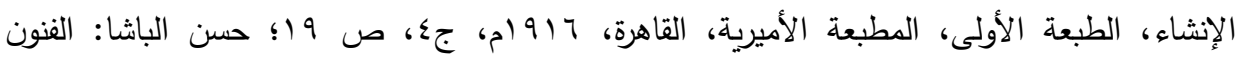

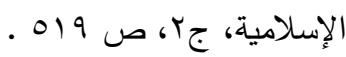
ناظر الأحباس: هو ناظر الوقف، وهو اسم وظيفة مكون من لفظة ( ناظر)، والناظر في

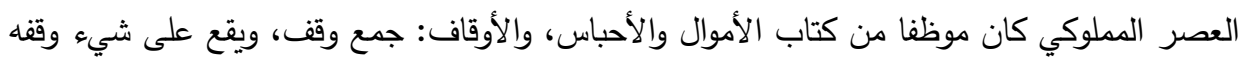

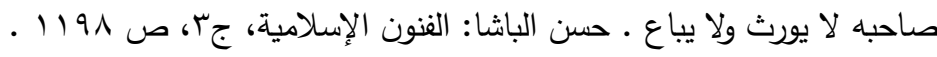
الدقريزي: السلوك لمعرفة دول الملوك، تحقيق محمد عطا، الطبعة الأولى، دار الكتب العلمية،

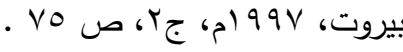

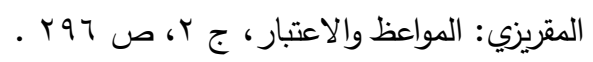
حياة الدجي: السلطان الناصر تحمح بن قلاوون والوقف في عهده ، الطبعة الأولى، مكتبة

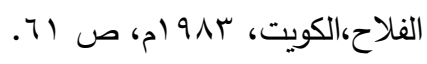

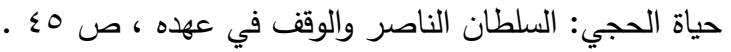

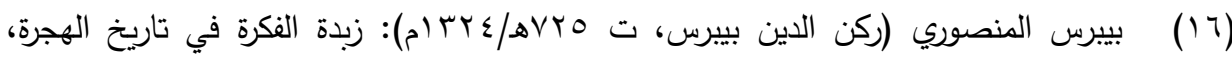

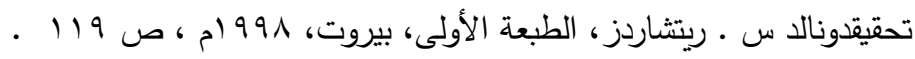




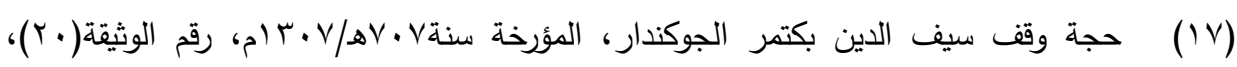

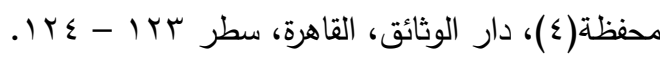

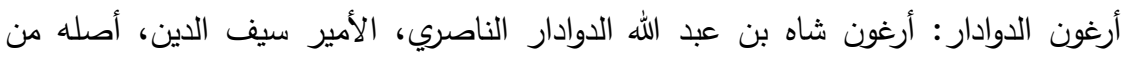

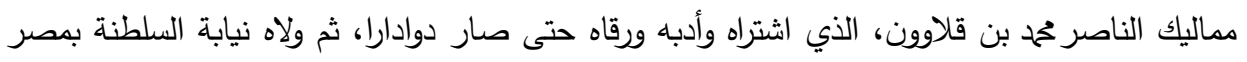

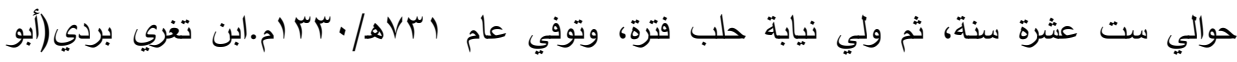

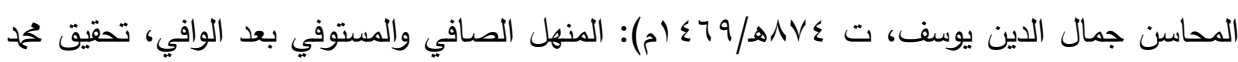

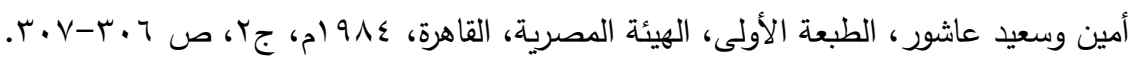

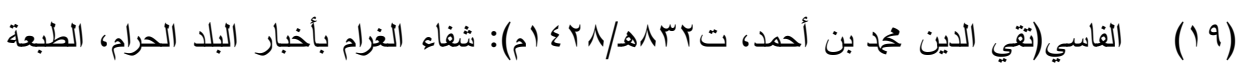

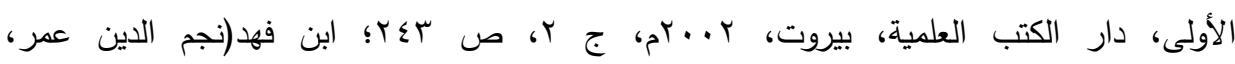

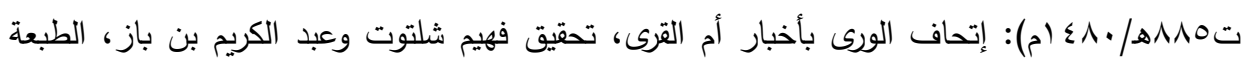

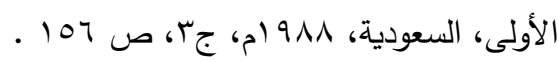

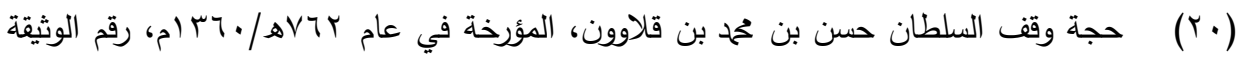

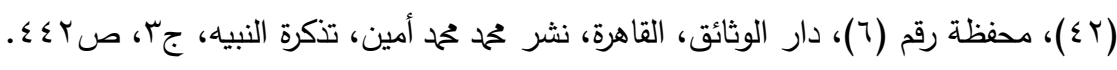

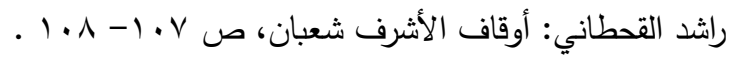

$$
\begin{aligned}
& \text { لم توجد له ترجمة في الكصادر التي اطلعت عليها. }
\end{aligned}
$$

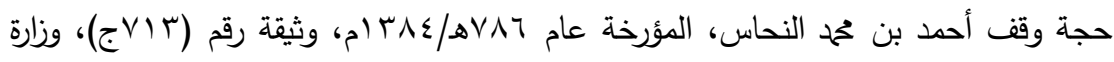

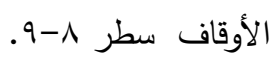

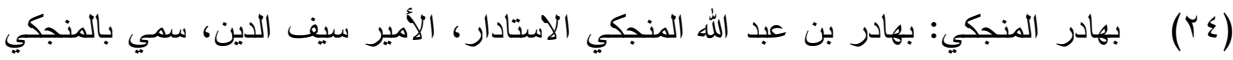

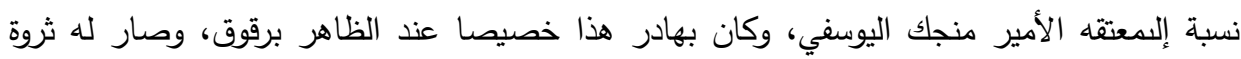

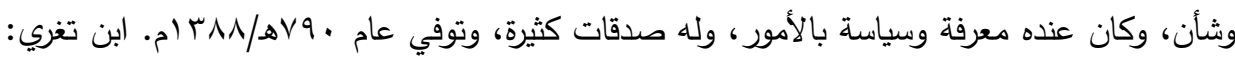

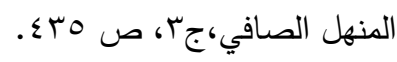

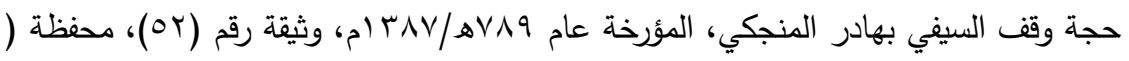

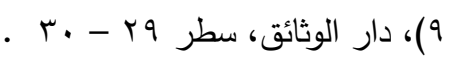

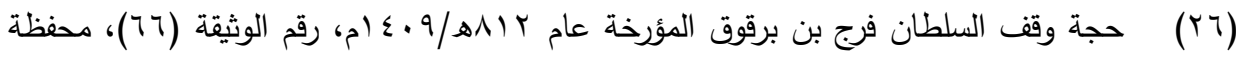

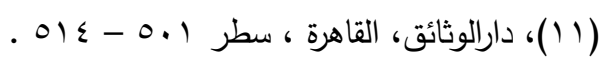

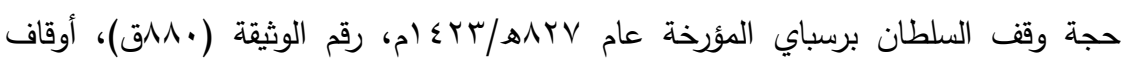

$$
\text { IVV - IVT القاهرة، سطر (Y) }
$$

(Y^)

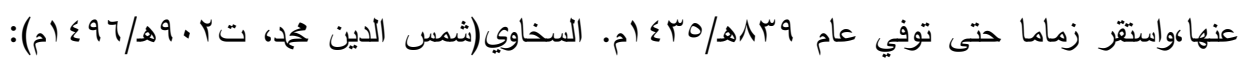

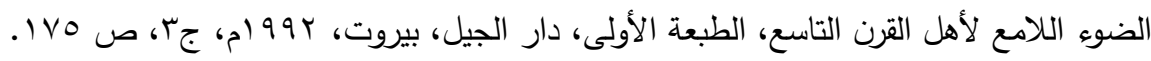




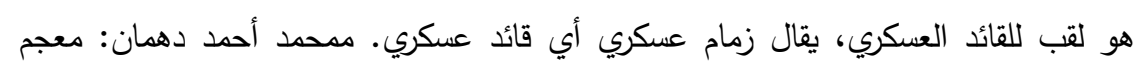

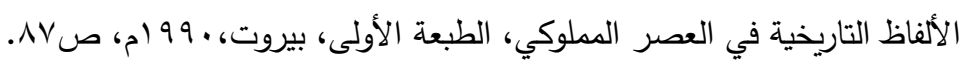

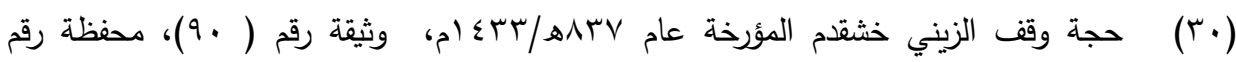

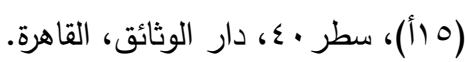

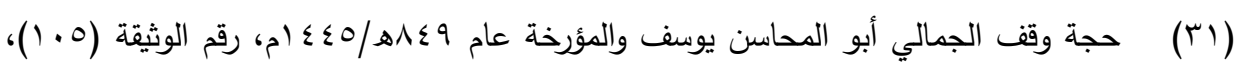

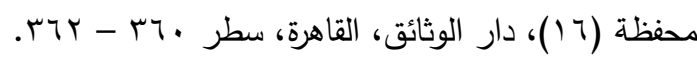

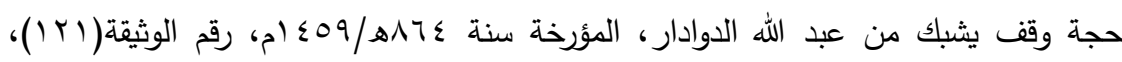

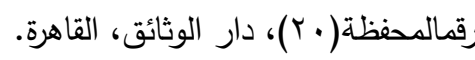

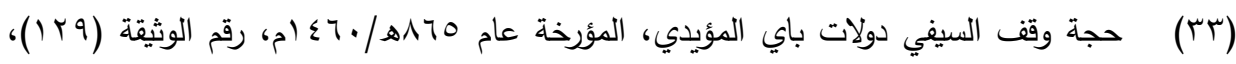

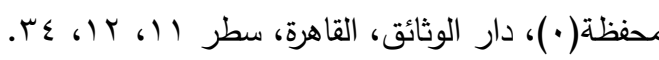

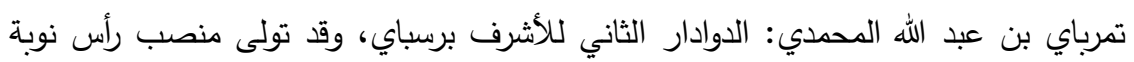

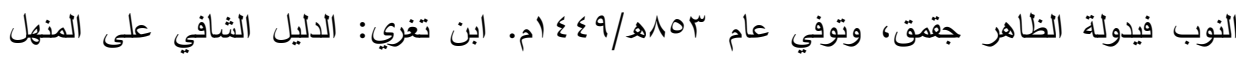

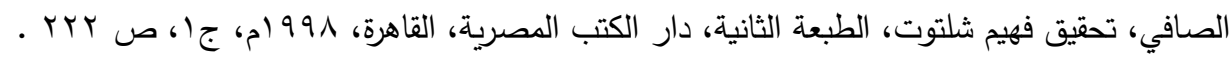

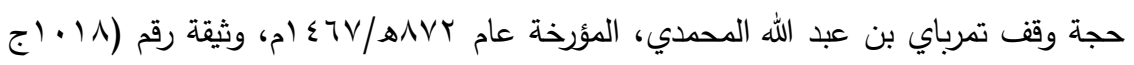

$$
\text { أوقاف)، سطر } 17 \text { : } 19 \text { ( } 19 \text {. }
$$

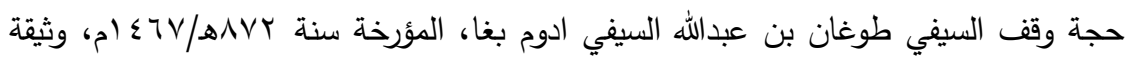

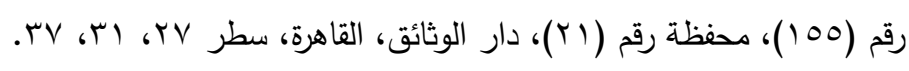

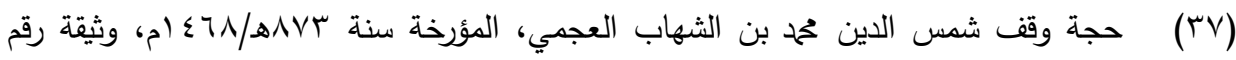

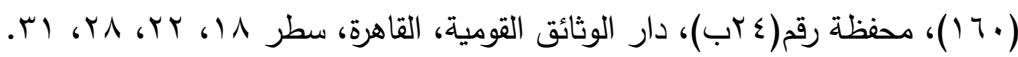

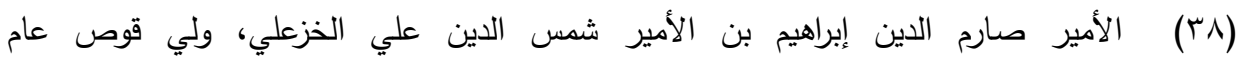

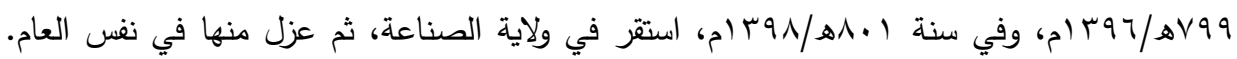

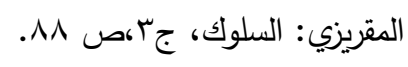

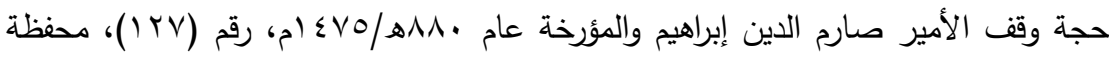

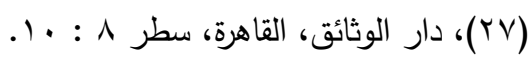

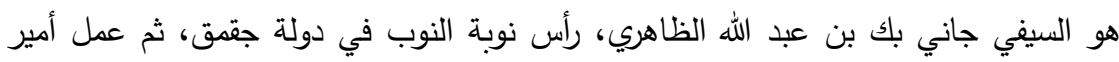

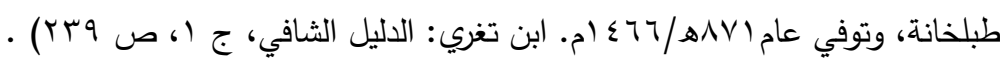

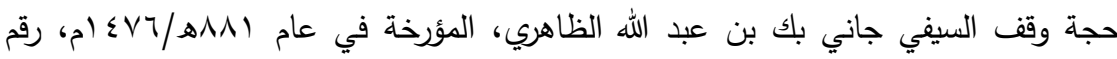

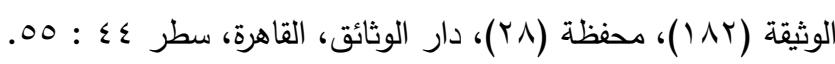

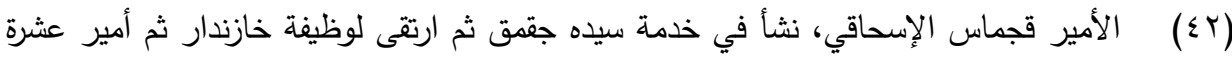

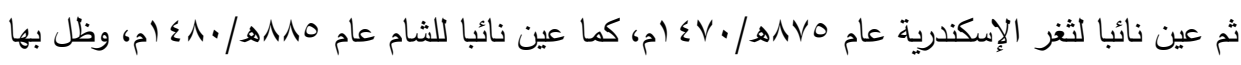

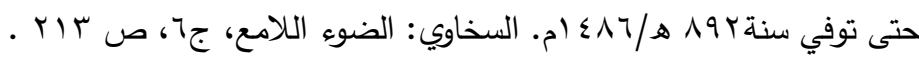




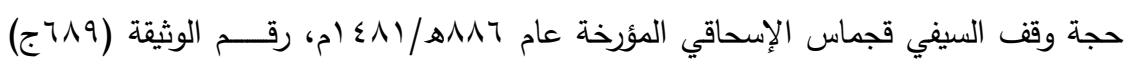

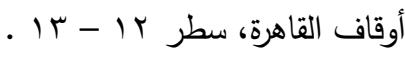

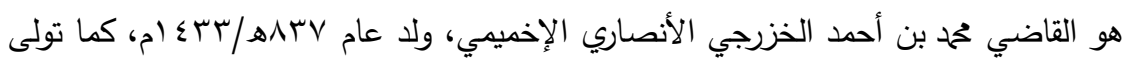

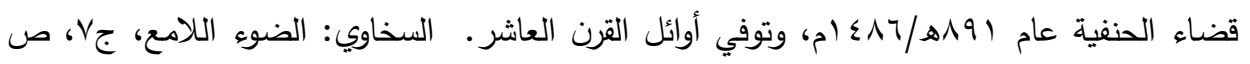

(or - o)

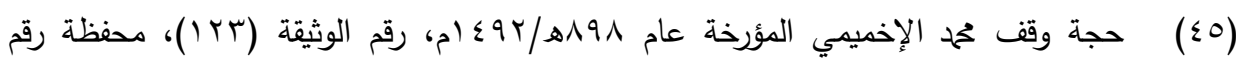
إ)

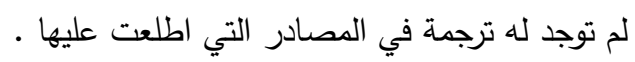

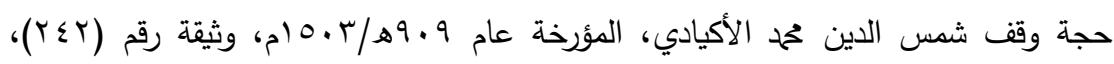

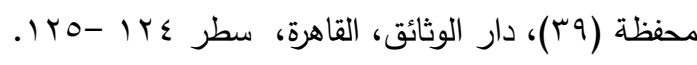

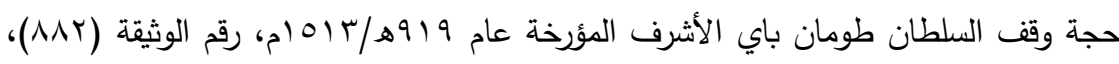

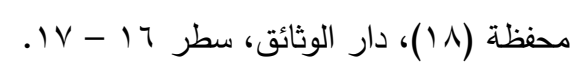

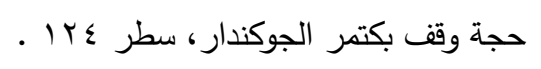

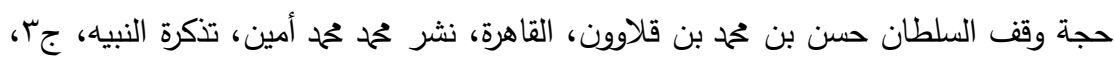

$$
\text { صن }
$$

هو مثقال بن عبد الله الأنوكي الطواشي، مقدم المماليك السلطانية، أصله من خدام آنوك بن

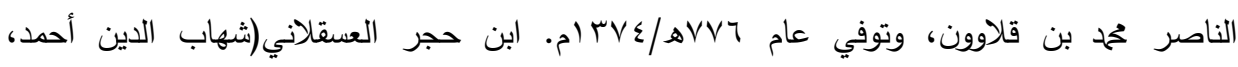

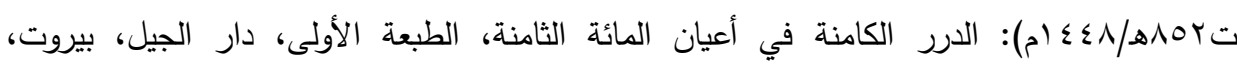

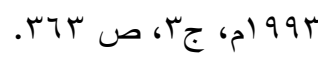

مقدم المماليك: هي الوظيفة الخامسة عشرة من بين الوظائف التي يشغلها عسكريون بحضرة

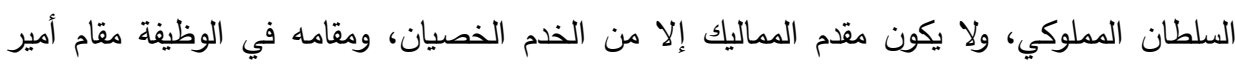

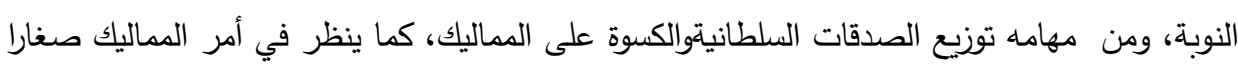

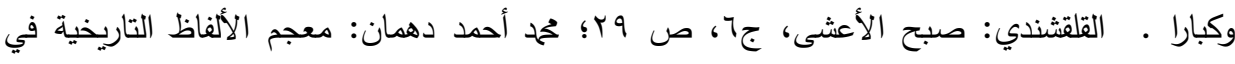

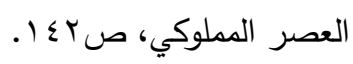

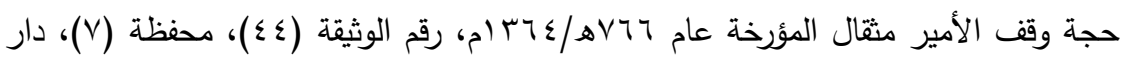

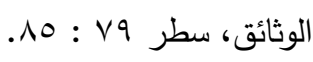

السحابة: يراد بها هنا طائفة ممن يرافقون الحاج للمحافظة عليه وحمايته. حسن أحمد: المدينة

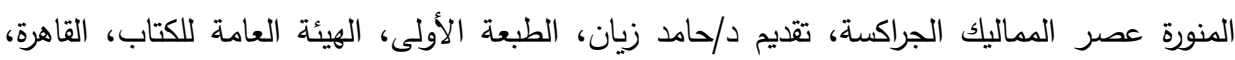

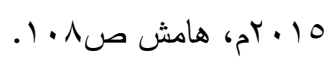

ابن تغري: النجوم الزاهرة في أخبار مصر والقاهرة، تحقيق محمد حسين، الطبعة الأولى، دار

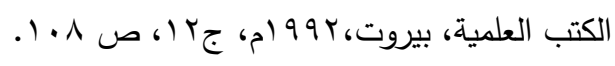




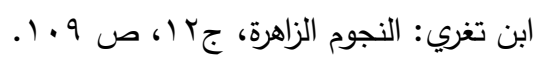

حسن أحمد: المدينة المنورة عصر سلاطين المماليك الجراكسة، ص 9 هـ 1.

اللالا: لفظة فارسية تعني مربي الأطفال، كما تطلق على مربي أولاد الملوك والسلاطين

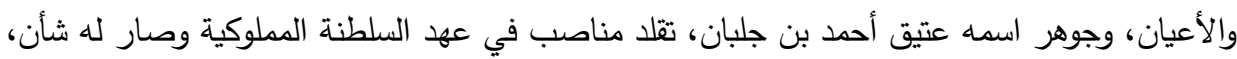

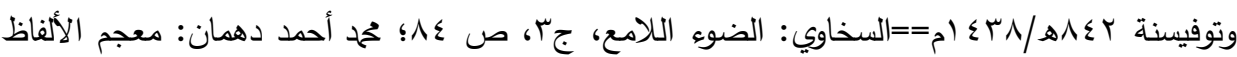

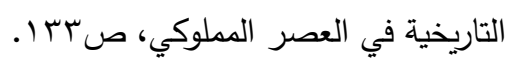

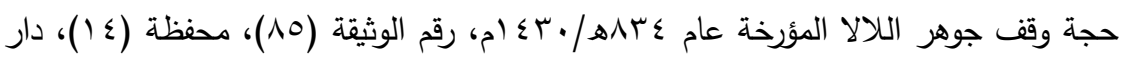

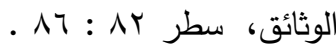

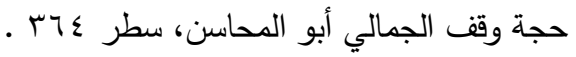

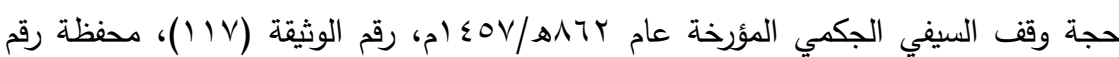

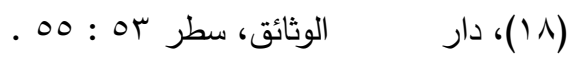

حجة وقف عمر بن الغرس خليل الحسامي المنصوري، المؤرخة سنة 179هـ/؟ج؟ ام، رقم

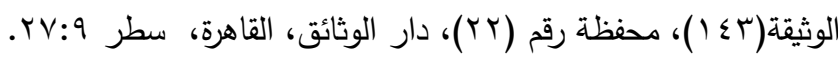

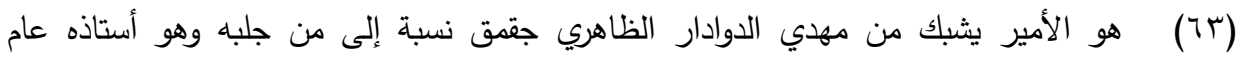

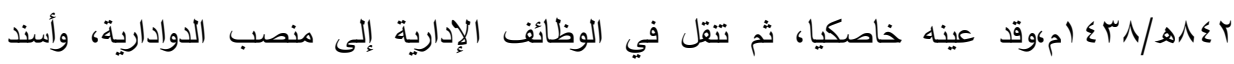

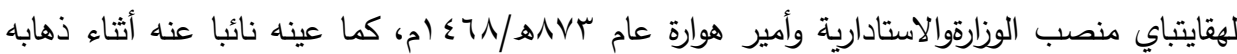

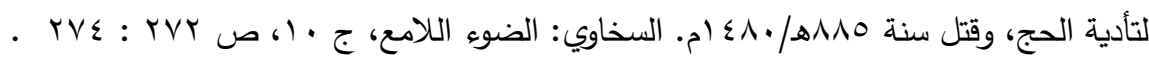

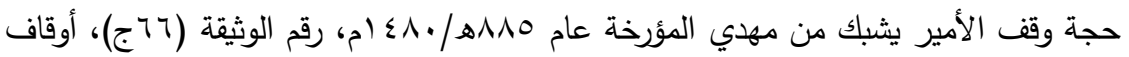

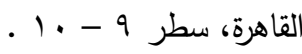

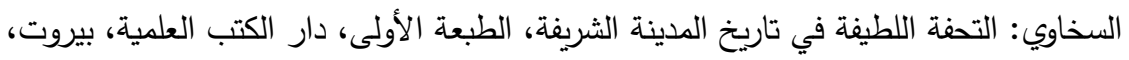

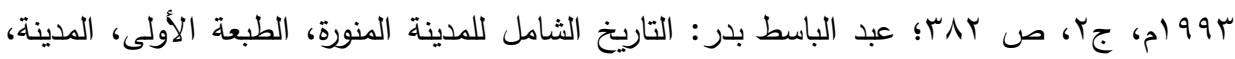

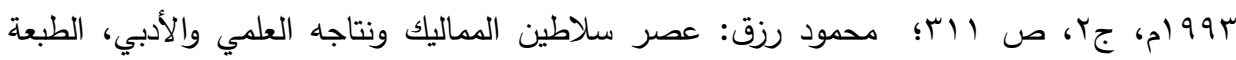

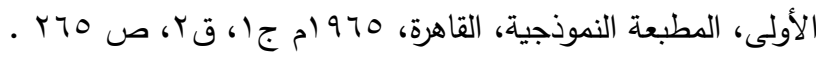

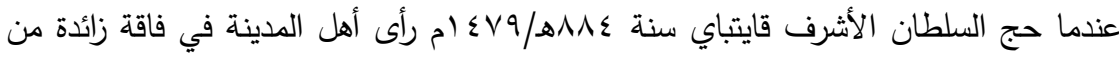

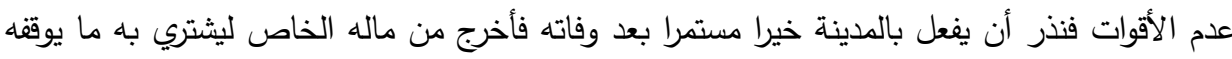

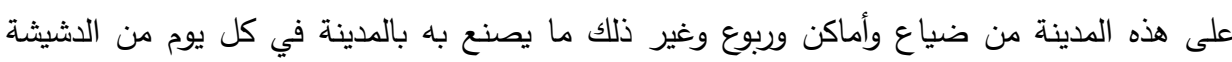

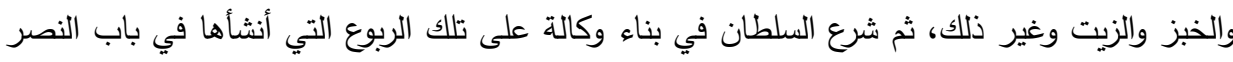

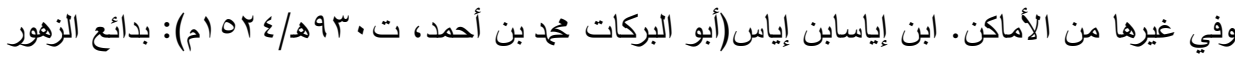

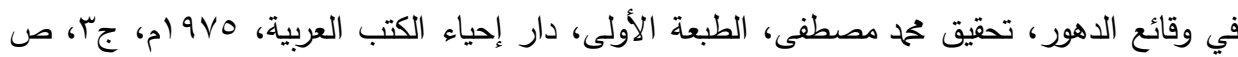

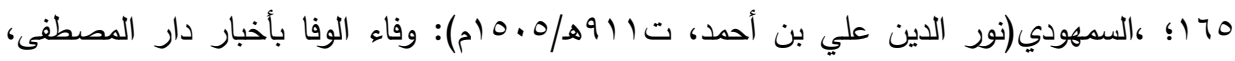

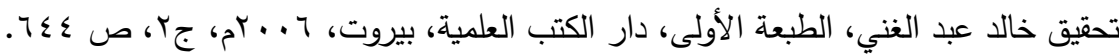




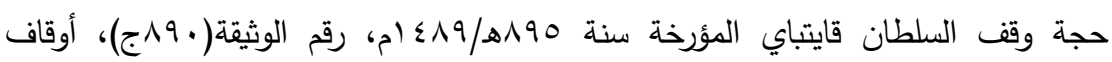

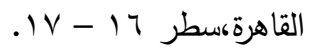

علي بن حسين السليمان: علاقة مصر بالحجاز زمن سلاطين المماليك، رسالة ماجستير

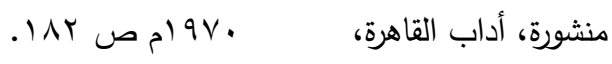

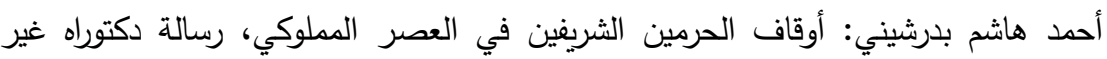

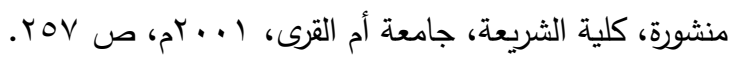

احمد عبدالرازق: المرأة في مصر المملوكية، الطبعة الأولى، الهيئة العامة لقصور الثقافة،

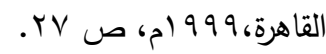

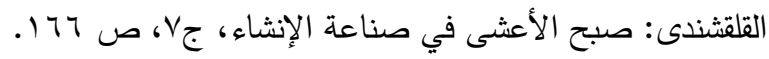

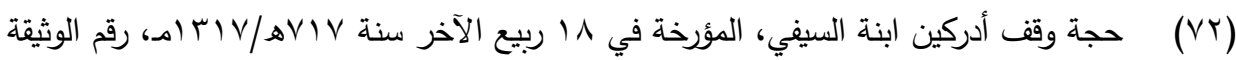

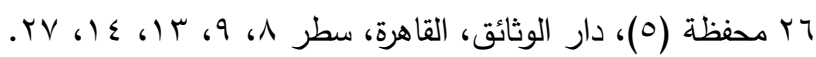
(VT)

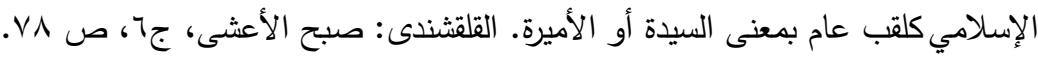
(V乏)

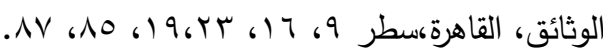

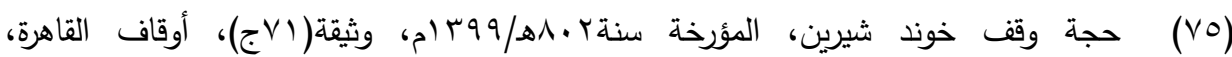

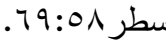

لم يوجد لها ترجمة في المصادر التي أمكن للبحث الاطلاع عليها.

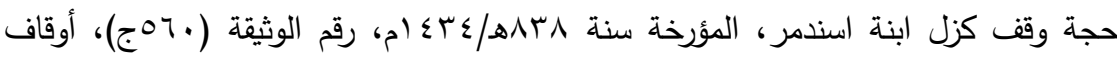

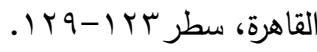
الست لقب عام يطلق على المرأة مثل السيدة. حسن الباشا: الألقاب الإسلامية في التاريخ

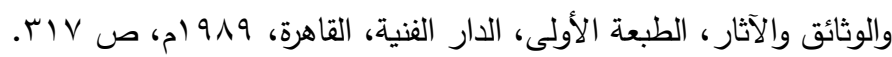

$$
\text { لم يوجد لها ترجمة في المصادر التي أمكن للبحث الاطلاع عليها. }
$$

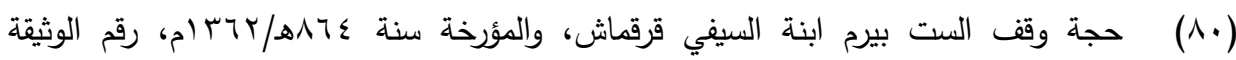

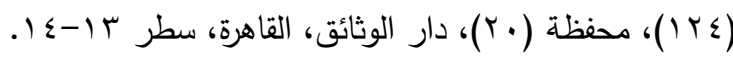

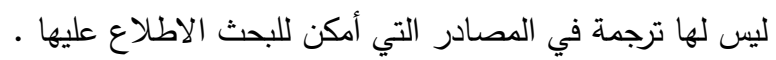

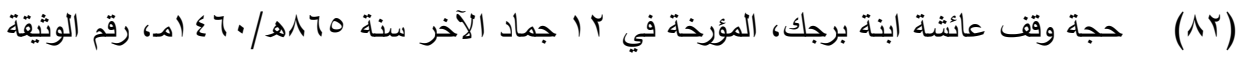

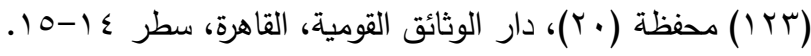

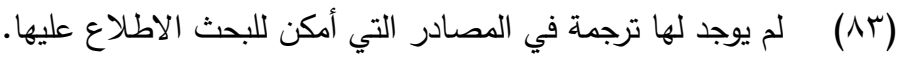

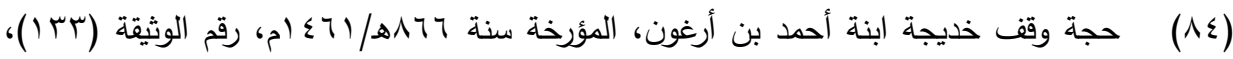

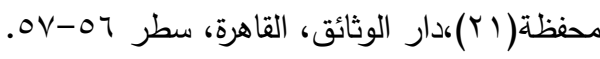


لم يوجد لها ترجمة في المصادر التي أمكن للبحث الاطلاع عليها.

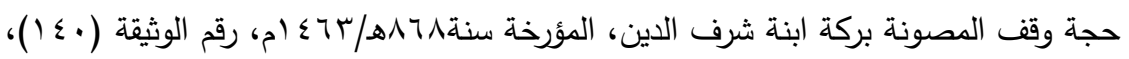

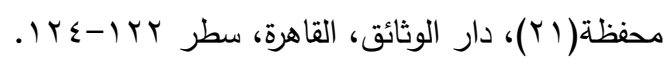

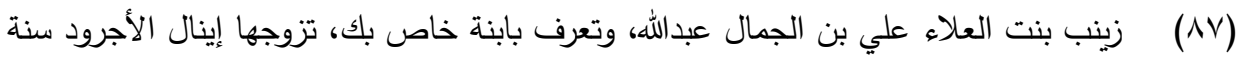

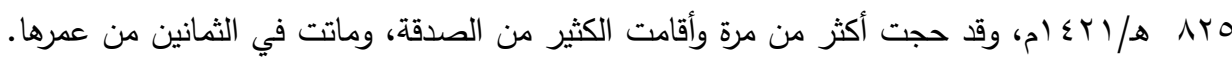

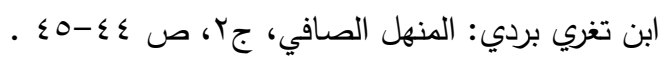

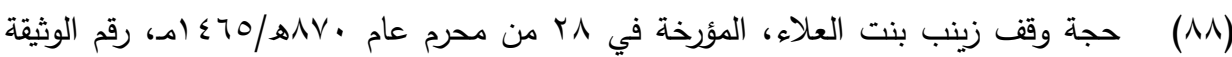

$$
\text { (190) }
$$

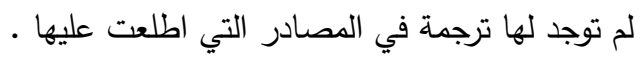

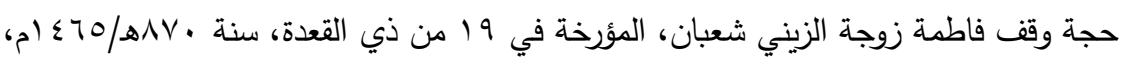

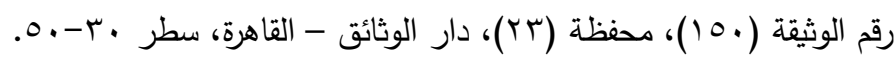

$$
\begin{aligned}
& \text { لم يوجد لها ترجمة في المصادر التي أمكن للبحث الاطلاع عليها. }
\end{aligned}
$$

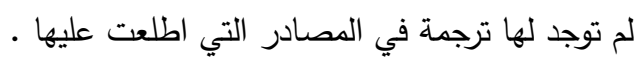

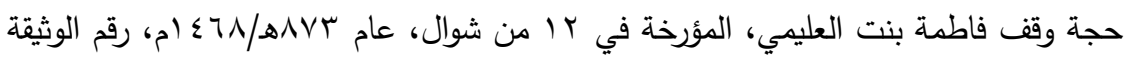

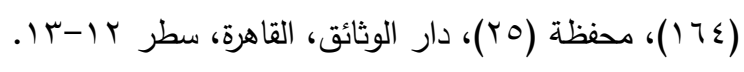

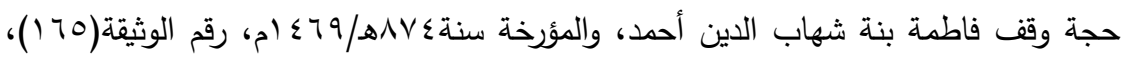

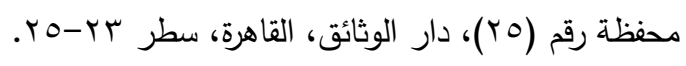

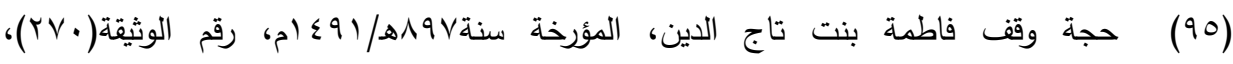

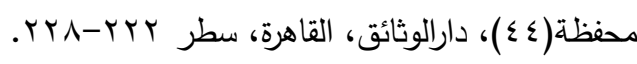

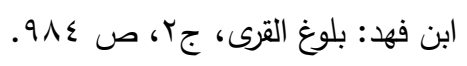

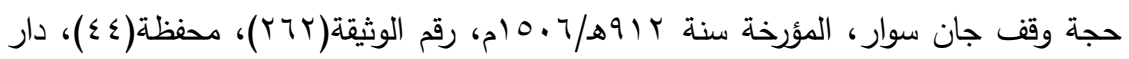

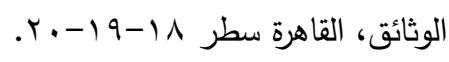

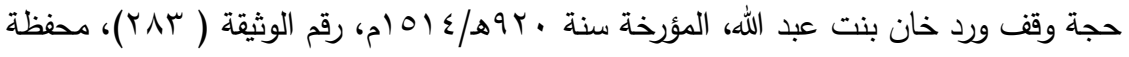

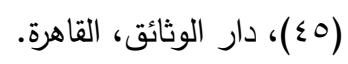

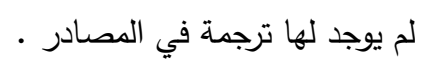

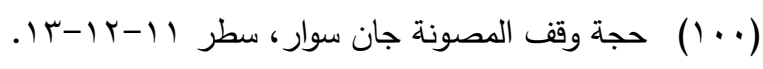

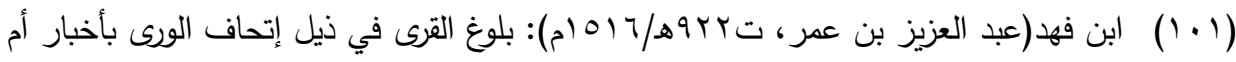

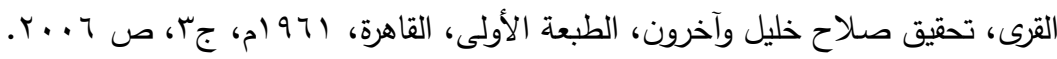

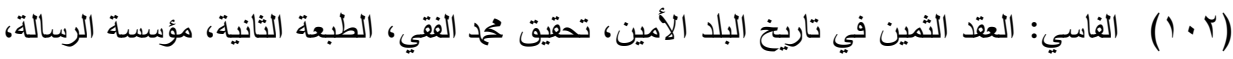

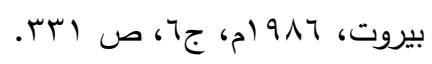




\title{
الخريطة المورفولوجيةلمنطقة حلايب كاداة أساسية للتنمية

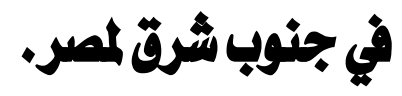

\author{
د.ناصر عبد الستار عبد الهادي نوح \\ مدرس الجغرافية الطبيعية \\ معهد البحوث والدراسات الاستراتيجية لدول حوض الجيعة النيل \\ جامعة الفيوم
}

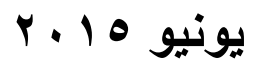


مقدمة.

تقع منطقة حلايب (1)بين دائرتي عرض بَّ سَّْ شمالاً ، وخطي طول

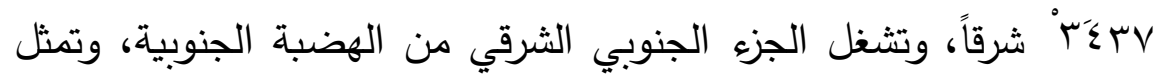
أعلى جهاتها ارتفاعاً في سلسلة جبال البحر الأحمر، و تشغل رقعة جغرافية

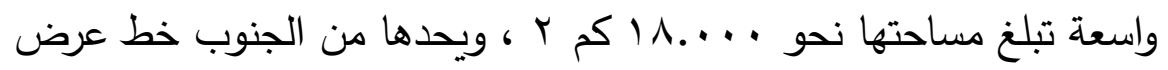
r Yُ (الحدود المصرية السودانية) ، ومن الثمال وادي حوضين ومن الجهة الشرقية ساحل البحر الأحمر ، أما الجهة الغربية فتتمثل في خط تقسيم المياه بالصحراء الشرقية والذي يفصل بين شبكات التصريف المائي التي تتجه صوب منطقة الدراسة وشبكات التصريف المائي المتجهة صوب نهر النيل، وهذا الخط أكثر اقتراباً من البحر الأحمر ولهذا فإن الأودية المتجهة صوب البحر الأحمر أقل طولاً وأكثر انحداراً وسرعة في تدفق المياه ، ويتكون خط تقسيم المياه في منطقة المثلث من مجموعة كتل جبلية أهمها جبل علبة وجبل ايس وجبل سواريب وجبل اتويب وجبل الناقة وجبل شياتيت وجبل أم حطة وجبل عقاب النجوم وجبل صول حامد، وتفصل بينها أودية سريعة الجريان أهمها أودية سفيرة وشاب وشبيب وميسبة وكراف والدريرة ودعيب وسرمتاي وشلال وأي -كوان وحدربة. وتنقسم المنطقة على أساس اختلاف المظهر الجيومورفولوجي العام ودئي والارتفاع النسبي واختلاف التكوينات الجيولوجية إلى ثلاثة أقسام رئيسية؛

(1) تثكل منطقة الدراسة ما يشبه بمثلث متساوي الساقين ، تتمشى قاعتته بطول .. كم مع خط

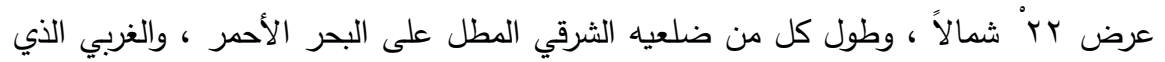

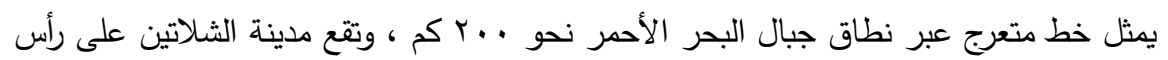

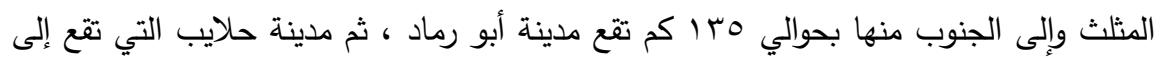
الجنوب من أبو رماد بحوالي Vo كم والتي تمثل قاعدة المثلث في الجنوب عند خط الحدود المصرية السودانية. 
الأول منها يتمثل في خط الساحل حيث التكوينات المرجانية بصورة متصلة فيما عدا مصبات الأودية الكبرى ، حيث تظهر كثير من الخلجان

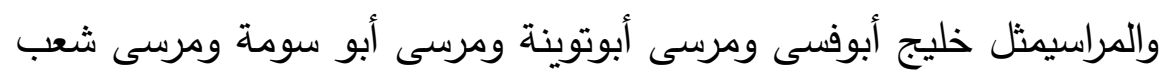
ومرسى حلايب ، أما القسم الثاني فيتمثل في السهل الساحلي والذي تغطيه

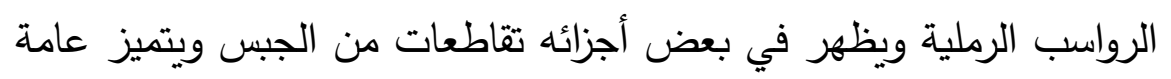
بتضاريس غير منتظمة متمثلةفي مصاطب الثعاب المرجانية المتتابعة والتي تمتد طولياً على اليابس بموازاة خط الثاطىء وتحاط من من الخارج بحزام من السبخات يسير بمحاذاة الساحل كله، و يقطعها عدد من الأودية

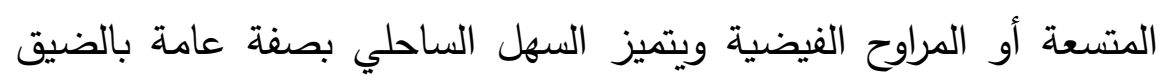

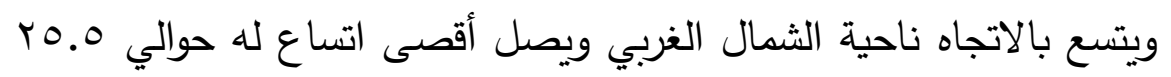

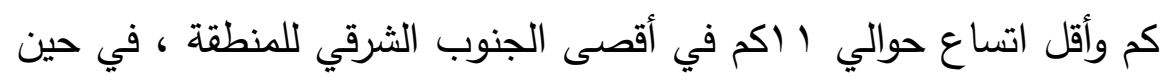

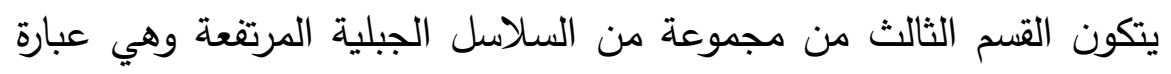
عن سلاسل جبلية وعرة شديدة التعقيد بها كثير من الثقوق الطولية

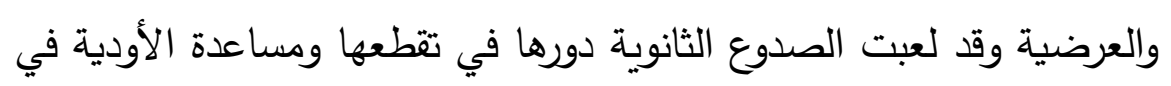

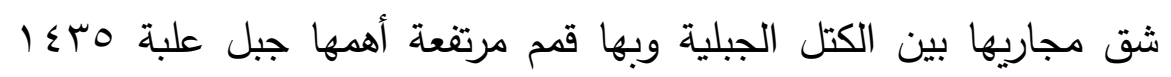

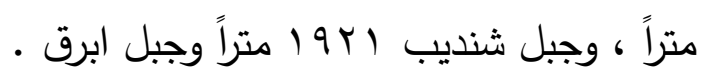

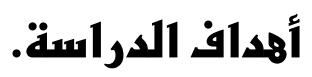

1-التعرف على الأثكال الأرضية بالمنطقة بثكل تفصيليومحاولة تقسيمها

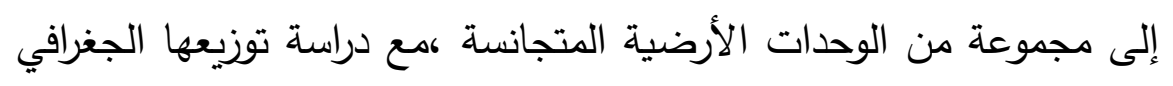

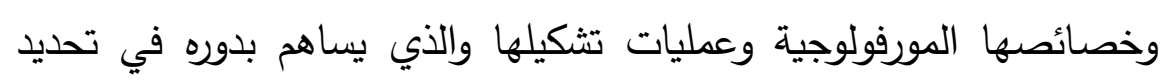

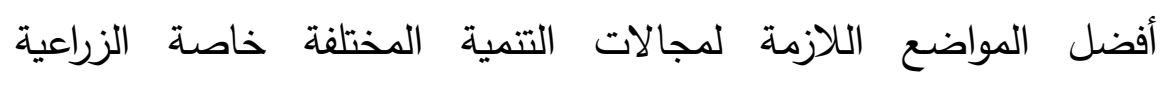
والصناعية والعمرانية والسياحية في تلك المواضع. 
ץ-محاولة الربط بين السمات المورفولوجية لدنطقة الدراسة وبعض مجالات التتمية خاصة الزراعية والعمرانية والسياحية وتتمية الثروة السمكية.

r-تحديد أهمالثروات الطبيعية التييمكن أن توفرهاالأشكال الجيومورولوجية بالمنطقة ، وإبراز أفضل السبل للاستفادة من تلك الثروات.

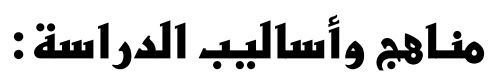
اعتمد الباحث في دراسته على المنهج الإقليمي لدراسة ظاهرات عديدة في

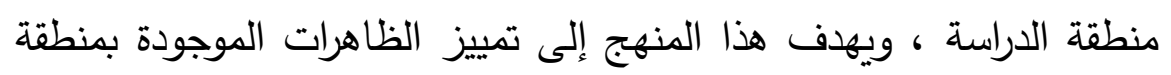

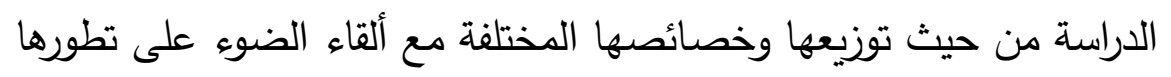

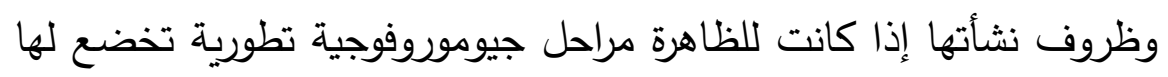
أو يمكن تمييزها .

كما أستخدم الباحث عدة أساليب من أهمها.

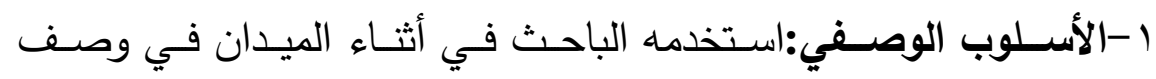

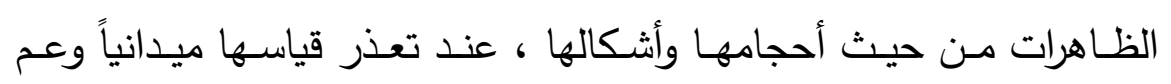
وضوحها على الخرائط والصور الجوية والفضائية.

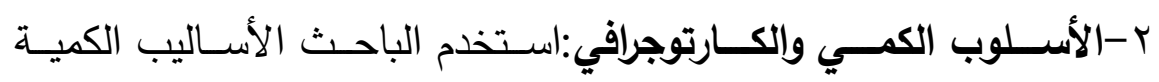

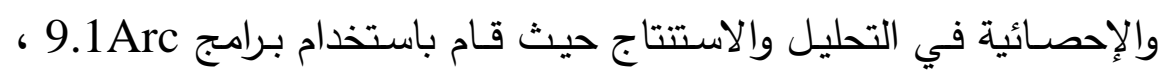

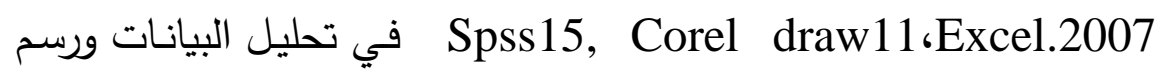
الأشكال سواء على شكل منحنيات أو أعمدة بالإضافة إلى تطبيق المعادلات

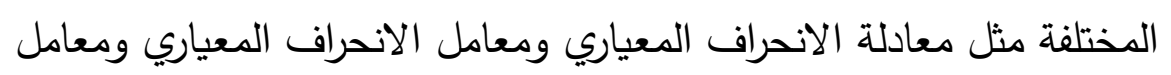
الاختلاف ومعامل الارتباط.

\section{طرق وأساليب البهث ووسائله.} اعتمدت الدراسة على طرق وأساليب البحث التالية:- 
1-فحص وتحليل الخرائط الطبوغرافية //...... (والتي تضمنت عشر لوحات وهي حلايب، وجبل علبة، وجبل سروك، وجبل ايس،وجبل أم الطيور

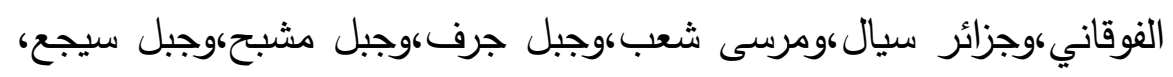

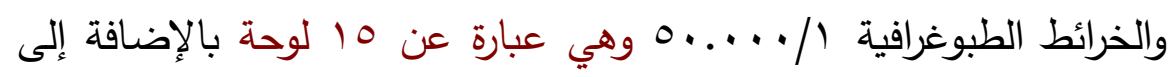

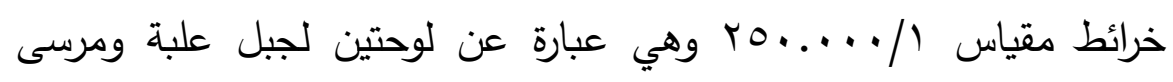

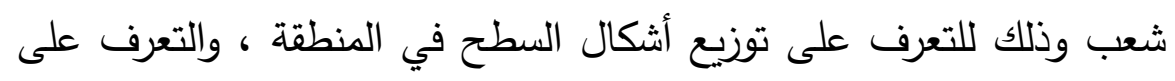
العلاقات المكانية بينها. r-رسم الخريطة الجيولوجية لمنطقة الدراسة بالإضافة إلي الحصول علي لئلي

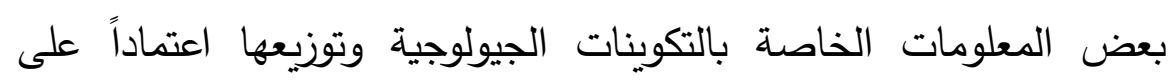

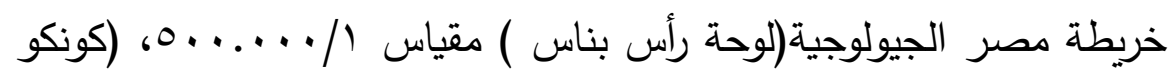

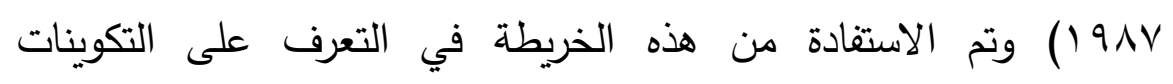
الجيولوجية السطحية والبنية الجيولوجية والأشكال الخطية.

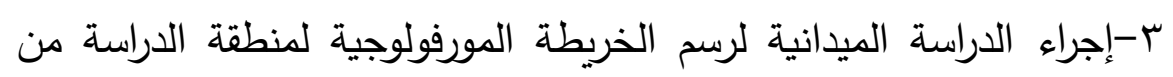

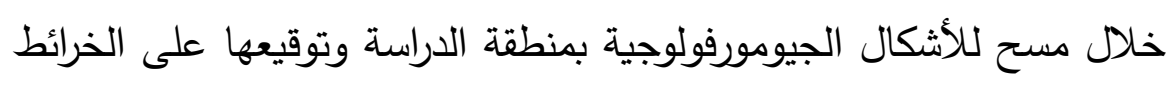

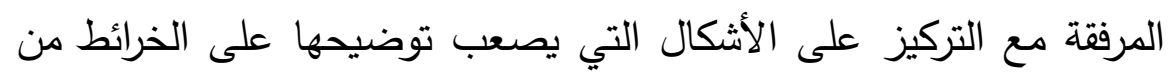

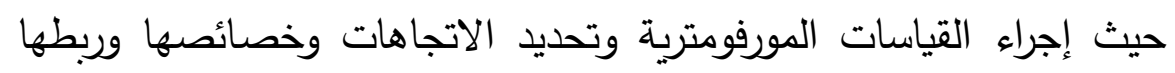
بالأشكال الجيومورفولوجية المجاورة. ع -التقاط الصورالفوتوغرافية اللازمة للتدليل على كافة الظاهرات المورفولوجية التي تضمنتها منطقة الدراسة. تساؤلات الدراسة: 1- ما هي الظاهرات الجيومورفولوجية التي تميز منطقة الدراسة ؟ وما هي خصائص كل ظاهرة وسماتها المورفولوجية ؟ 
ץ- ما هي الظاهرات والعمليات الجيومورفولوجية المؤثرة على تتمية النشاط

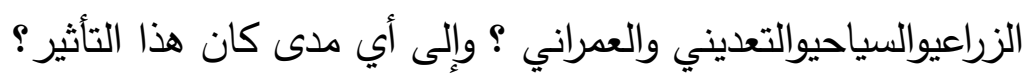

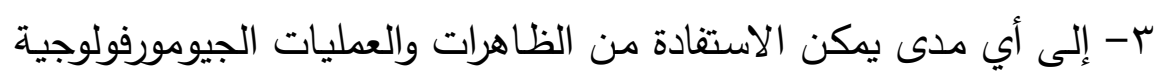

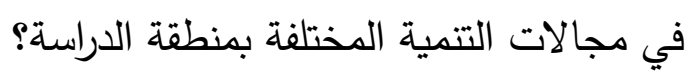

أو لاً:-الملامح الطبيعية العامة لمنطقة الدراسة.

1-الخصائص التضاريسية.

تتميز الخصائص التضاريسية بمنطقة الدراسة بالتتوع في الارتفاع

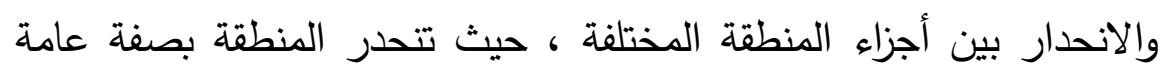

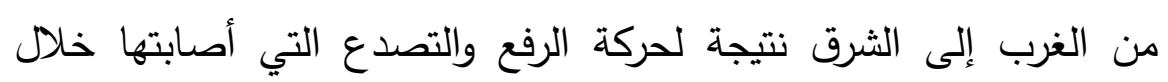
العصور الجيولوجية السابقة ،وبالتالي تتخفض زلئل زوايا الانحدار كلما اتجهنا

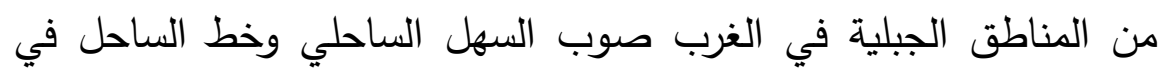

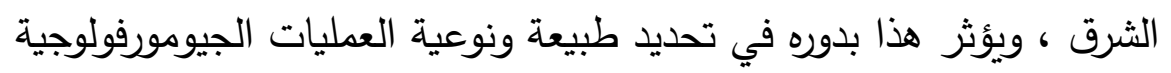
كالنحت والإرساب ومن ثم الظاهرات الجيومورفولوجية المختلفة الناتجة عن تلك العمليتين ، ومن خلال الدراسات الميدانية، وتحليل الخرائط الطبوغرافية

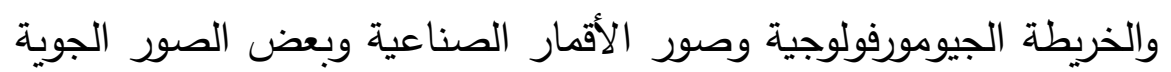

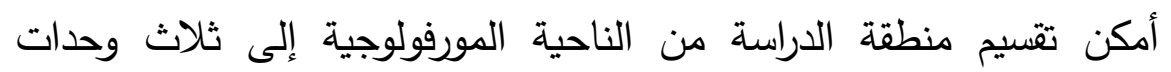
تضاريسية وهي:-

أ-وحدة السهل الساحلي: وهي عبارة عن شريط يمتد على طول الساحل

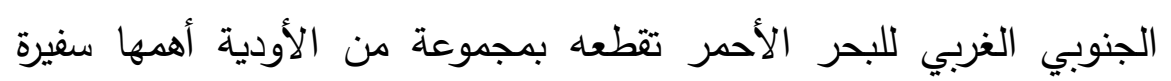

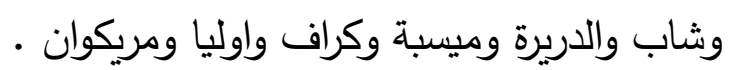

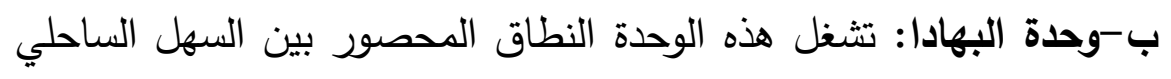

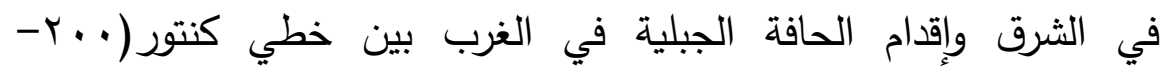


. . عم),ويمكن اعتبارها منطقة الإرساب الرئيسية أو مستوى الأساس المحلي لأودية منحدرات الجبال والتلال.

جـ - وحدة الجبل: تتميز هذه الوحدة بثدة انحدارها مقارنة بالوحتين

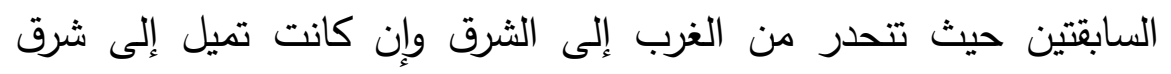

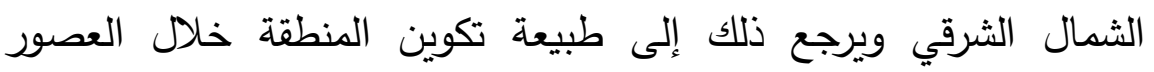
الجيولوجية القديمة حيث إصابتها حركات الرفع والتصدع والتي أدت بدورها

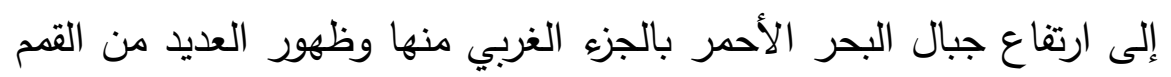

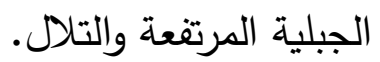




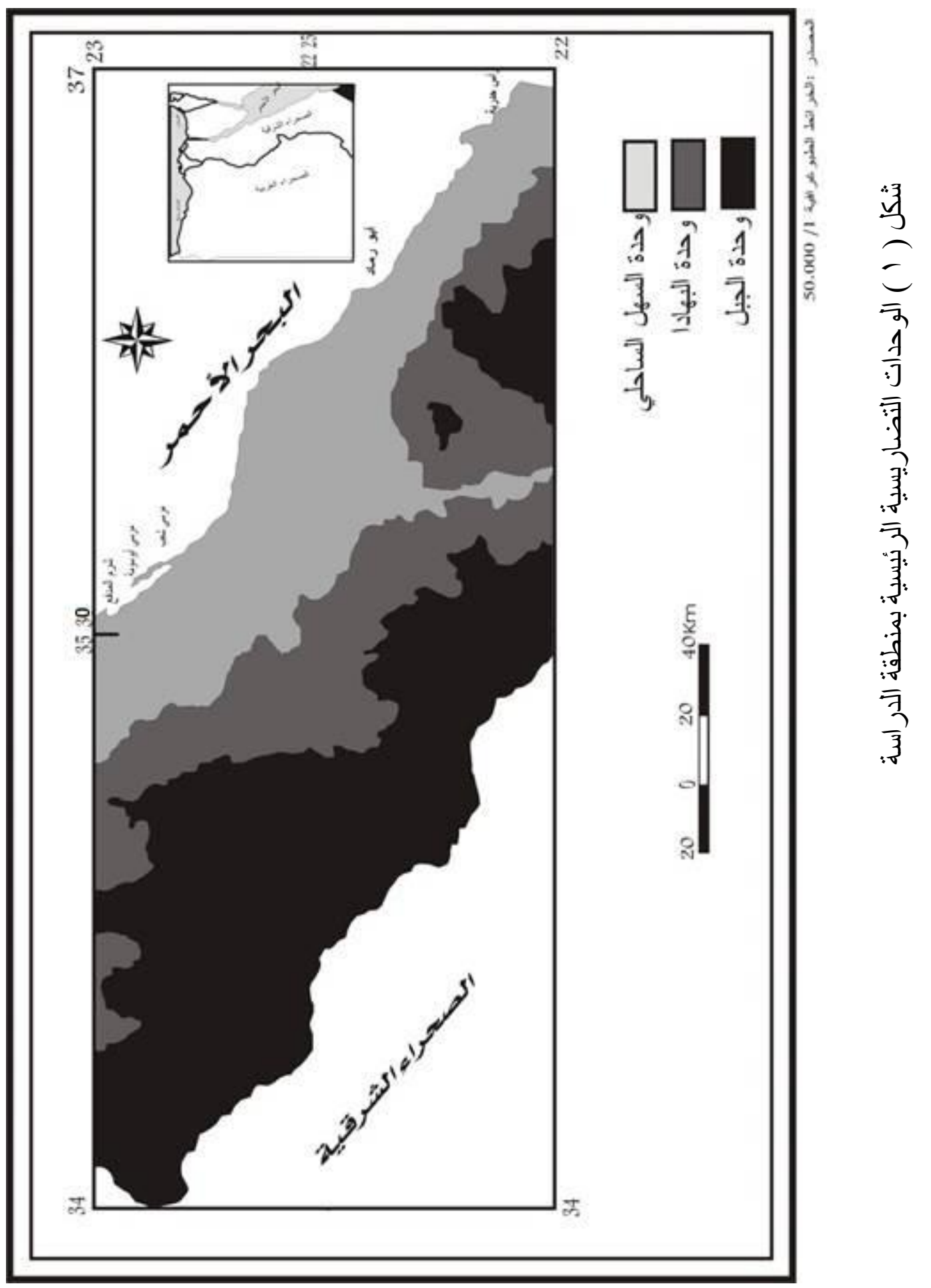




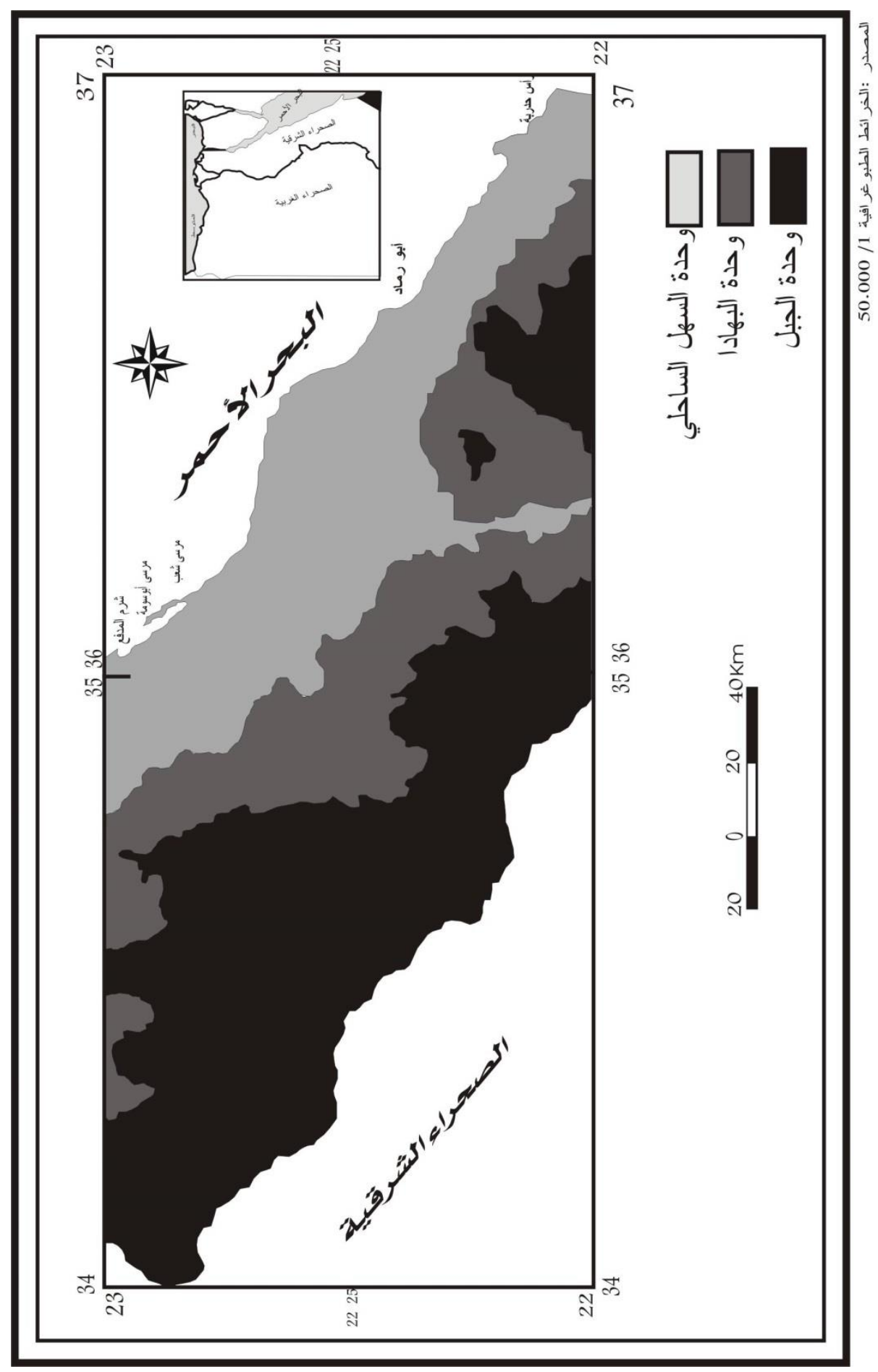




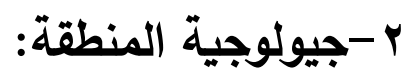

تتميز منطقة الدراسة جيولوجياً بالتتوع الثديد في محتواها الصخري

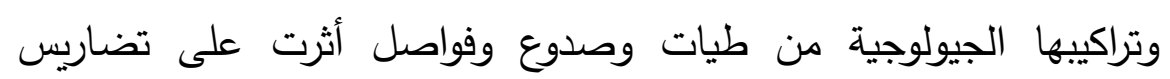

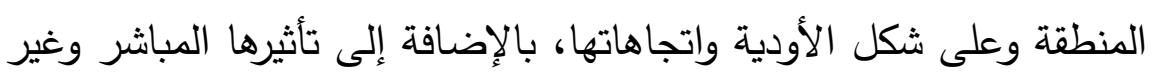
المباشر على ساحل البحر الأحمر من حيث الاتساع والانحدار والاتجاه

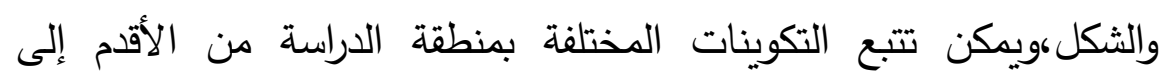

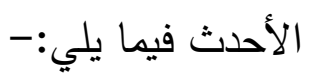

أ-صخور القاعدة: هي أقدم الصخور الدكثوفة وأكثرها ارتفاعاً وتضرساً

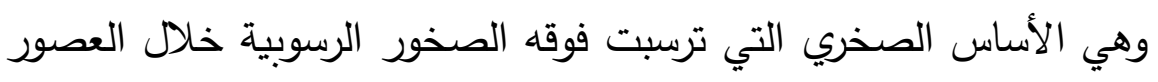

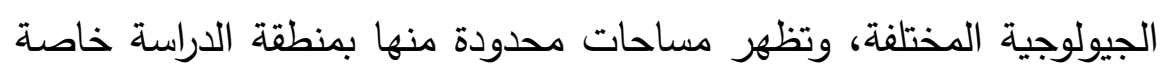
الصخور البركانية والتي تظهر في غرب وجنوب غرب جبل ونل علبة ، أما

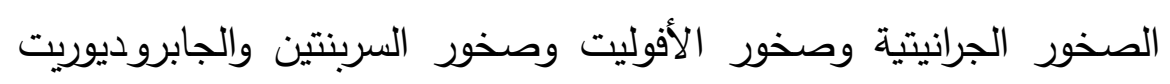
فتظهر في مناطق جبل ايس ، وجبل سواريب. ب-الصخور الرسوبية:تغطي مساحة كبيرة من منطقة الدراسة ، ومن خلال

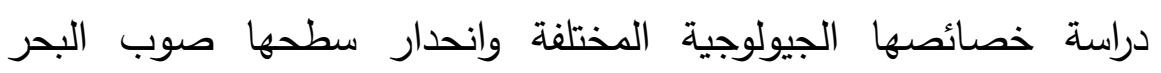

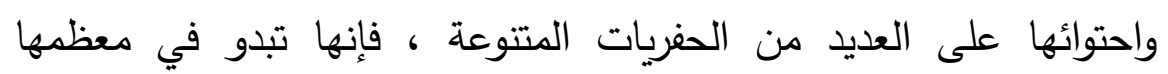

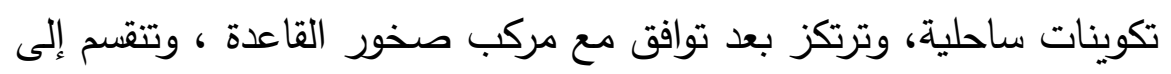

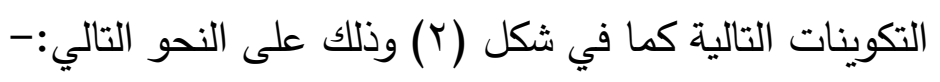

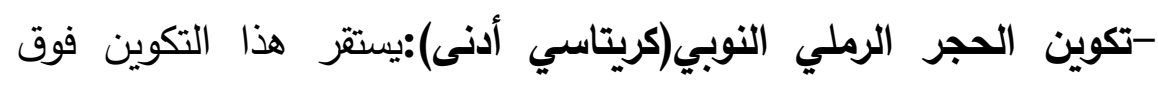

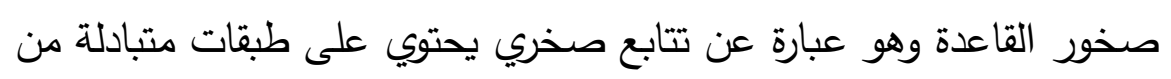

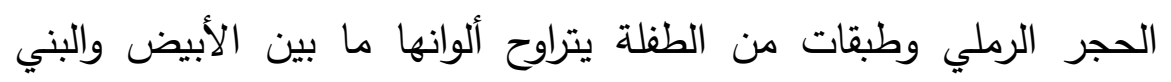

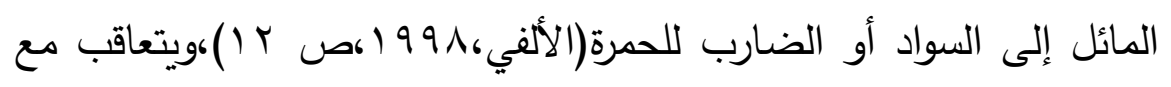


هذه الطبقات طبقات من الصلصال يسودها اللون الرمادي مختلطة ببعض

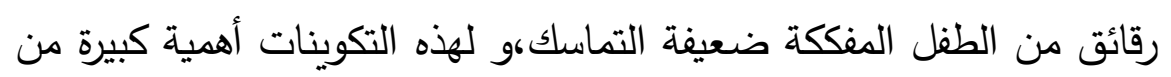

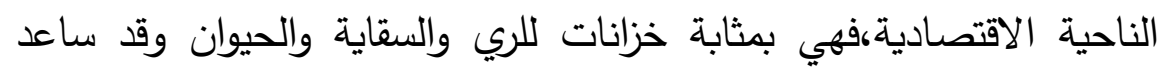

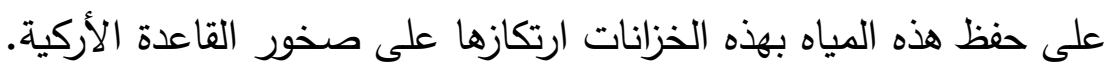

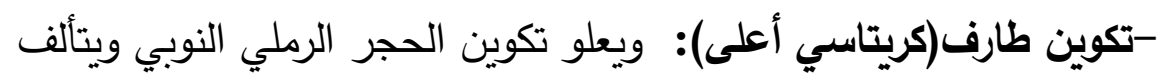

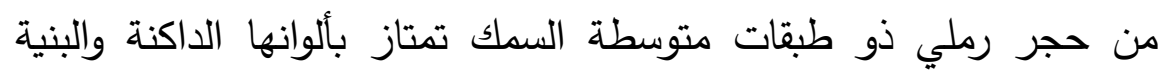

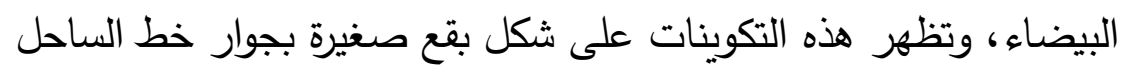

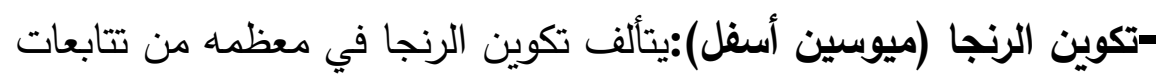
من الكونجلوميرات والأحجار الرملية الخشنة التي تتميز بألوانها الحمراء

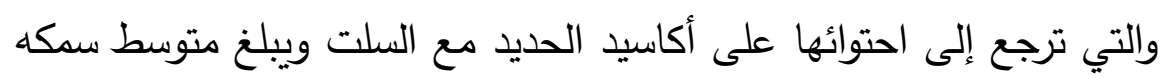

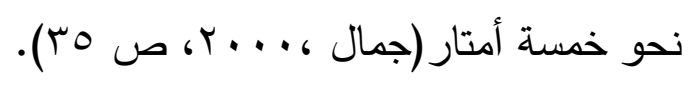
شكل(ץ) يوضح التتابع الطباقي للصخور الرسوبية بمنطقة الدراسة.

\begin{tabular}{|c|c|c|c|c|c|}
\hline السمك(بالمتر) & وحدة الصخر & الوصف الليثولوجي & & العصور & الجيولوجية \\
\hline$r \cdot-1$. & & شرملية ورواسب الأوديةً حصوية & & والبلايستوسين & 可高 \\
\hline $17 .-1 \%$. & & تكوين شجرة & أعلى & \multirow[t]{2}{*}{ البلايوسين } & \multirow{5}{*}{ 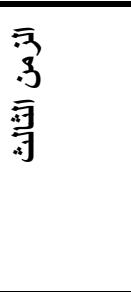 } \\
\hline TrE & & تكوين جابر & أسفل & & \\
\hline $0 .-r_{0}$ & & تكوين أبود باب & أوسط & \multirow[t]{3}{*}{ الميوسين } & \\
\hline A. & & تكوين جبل الرصاص & أوسط & & \\
\hline 。 & & تكوين الرنجا & أسفل & & \\
\hline$v \cdot-q$ & & تكوين طارف & الأعلى & \multirow[t]{2}{*}{ الكريتاسى } & \multirow{2}{*}{$\overline{3} \overline{3}$} \\
\hline $10 \cdot-1 \ldots$ & & الحجر الرملي النوبي & أسفل & & \\
\hline
\end{tabular}

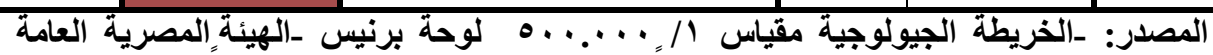

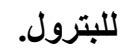

-تكوين جبل الرصاص(ميوسين أوسط): تتألف صخوره من الحجر الرملي

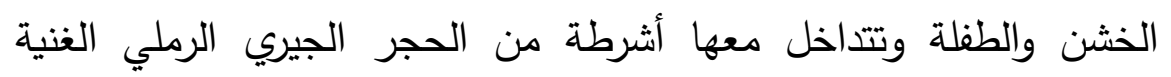

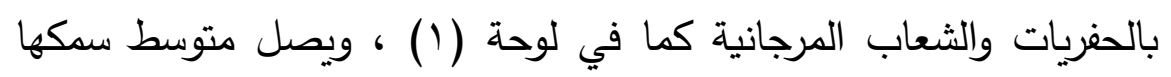


نحو • 1 متراً، وتكمن الأهمية الاقتصادية لهذا التكوين في احتوائه على خام

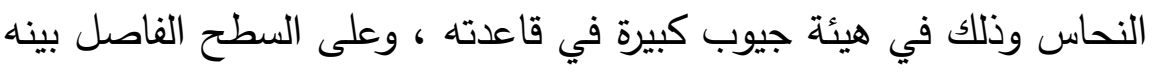
وبين تكوين الرنجا ، بالإضافة إلى احتوائه على الرمال السوداء بين حبيبات

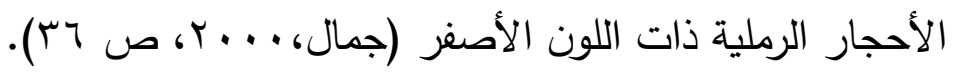
-تكوين أبودباب(ميوسين أوسط):يتوزع هذا التكوين على الثريط الاصني الساحلي

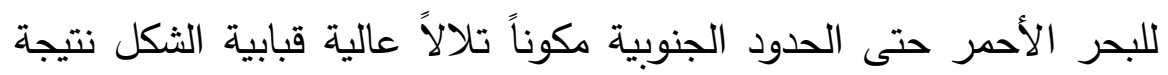

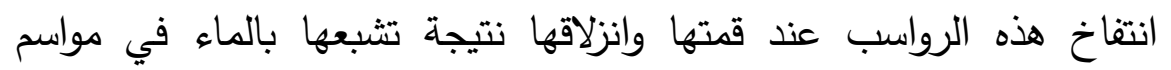
الأمطار الثديدة، ويتألف من الجبس الأبيض الصلب عليه قثرة بنية اللون المتدرج ما بين الفاتح الضارب للصفرة إلى الداكن وتبدو هذه الرواسب الدابن

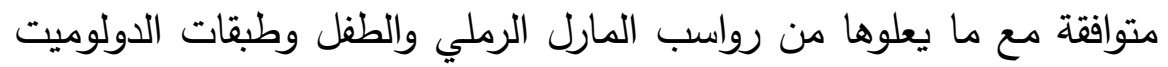

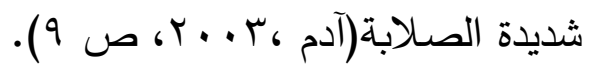

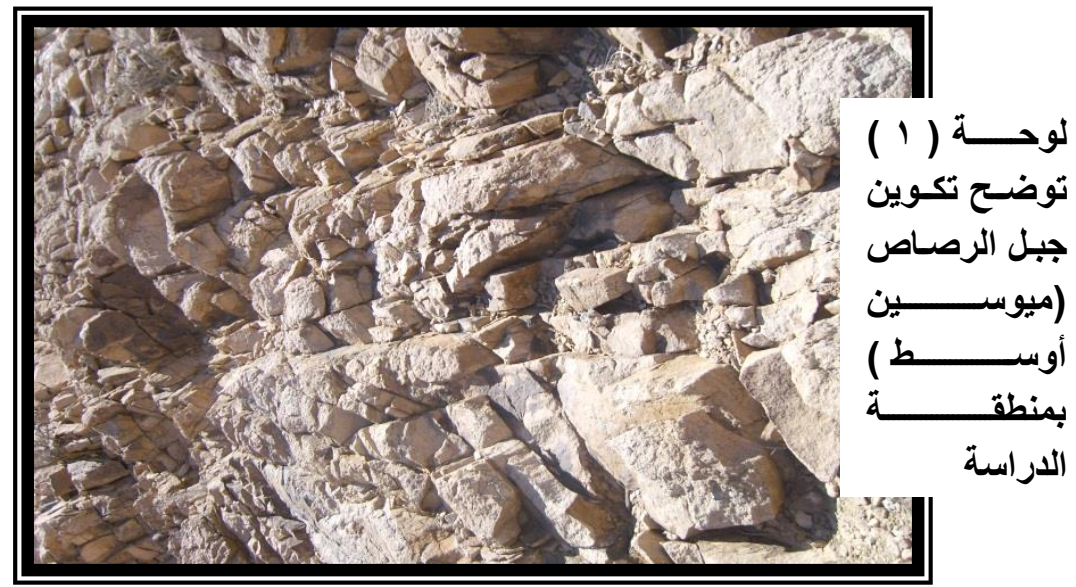

-تكوين جابر(بليوسين أوسط): يتكون من الحجر الجيري البطروخي والذي

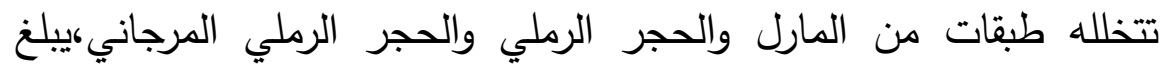

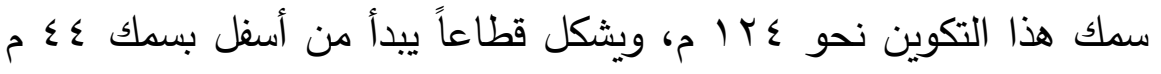
متكوناً من الحجر الرملي يعلوها طبقة من الحجر الرملي الدولوميتي وطبقة من المارل والحجر الرملي المرجاني بسك ــ م م(Said,R,1990,p.356). 
-تكوين شجرة(بليوسين أعلى): يتألف من طبقات من الأحجار الجيرية والكونجلوميرات والتي ترسبت في ظروف بيئية نشطة ، ويتراوح سككه ما بين

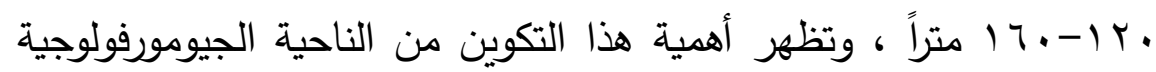

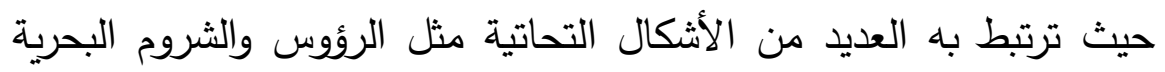

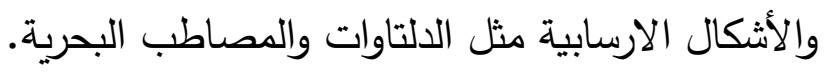
-رواسب بحرية ساحلية (بلايوستوسين):تتمثل في الثعاب لمرجانية

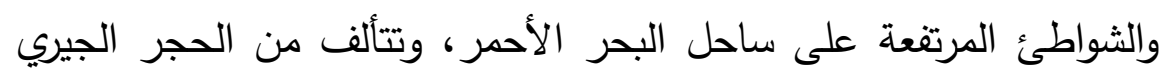

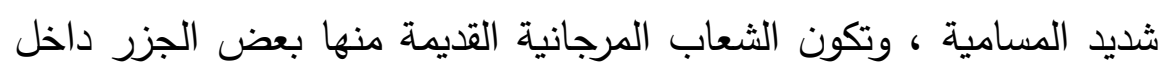

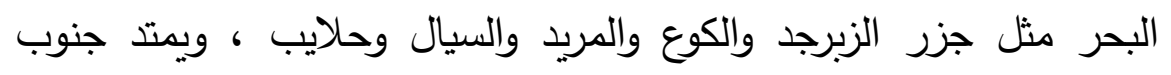

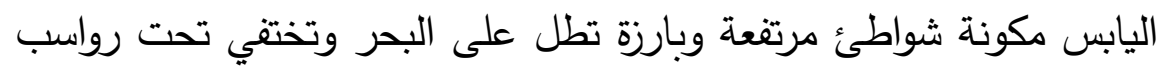

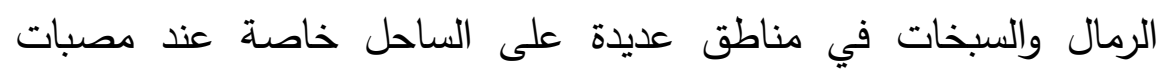
الأودية الرئيسية .

رواسب فيضية(بلايوستوسين): وتتألف هذه الرواسب من الزلط و الحصى الزئية

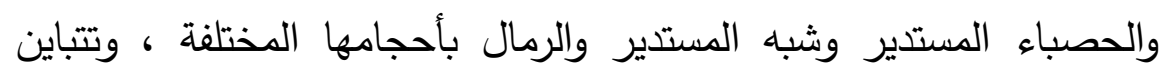
الحبيبات بها حسب نوعية صخور المصدر ، وتركيبها عادة من الكوارتز والفلسبار والرمال السوداء،وهذه الرواسب توجد على هيئة طبقات معقدة

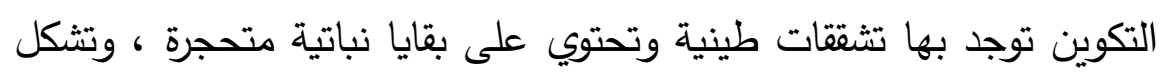

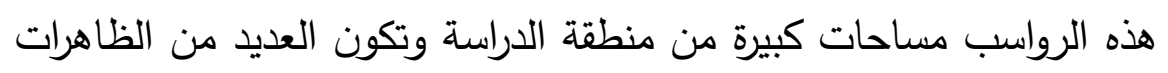

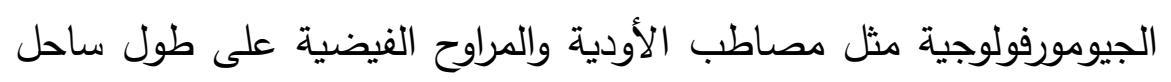

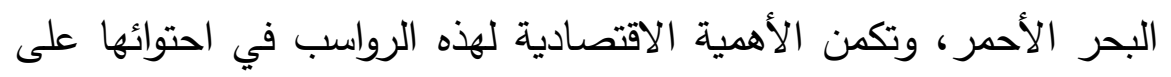

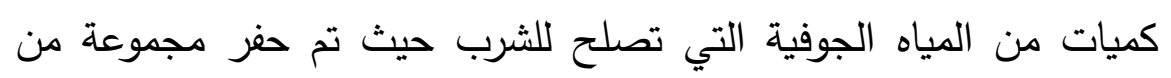
الآبار أهمها حلايب وأم ستيت وماضي ورحبة الهي تصليح. 
رواسب المنحدرات والأودية(هولوسين):تتألف هذه الرواسب من حبيات من

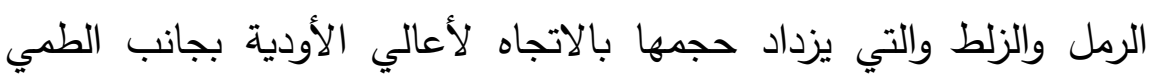
والسلت، وتتمثل الأهمية الاقتصادية لهذه الرواسب في احتوائها على أغلب التباه

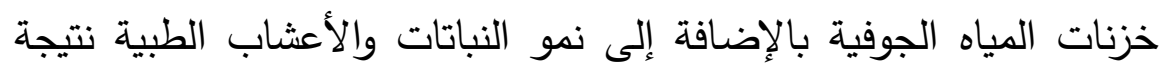

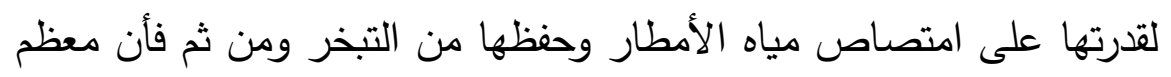
الآبار ذات القدرة الإنتاجية العالية تتبع من هذه الرانيا الرواسب مثل آبار منيحة

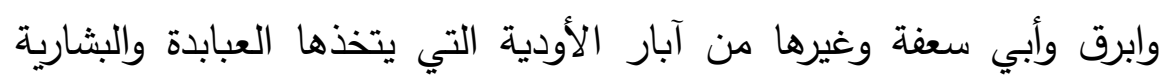
كمطات تموين إثناء ترحالهم بين ساحل البحر الأحمر ومدن وادي التئ النيل.

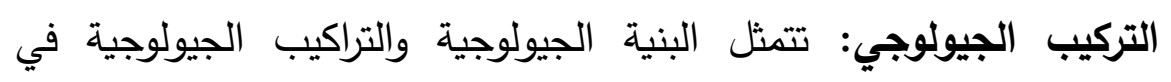

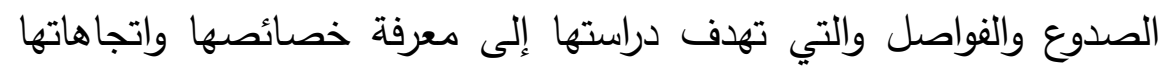

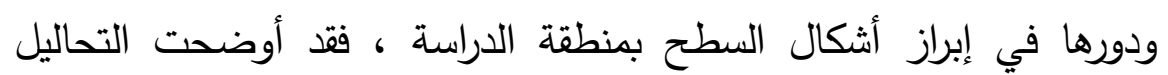

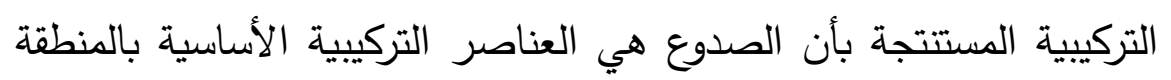

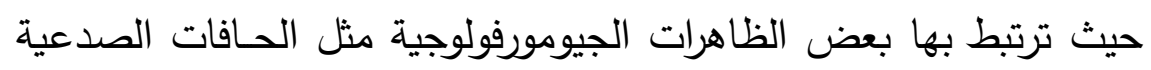
Faults scarps الأخدود كما أنها تتحكم في خطوط التصريف(مجاري الأودية) لأنها منطقة

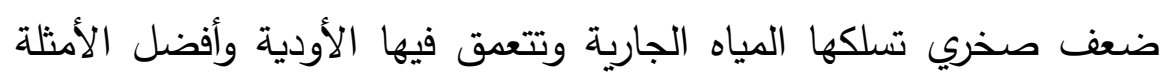
على ذلك أودية 


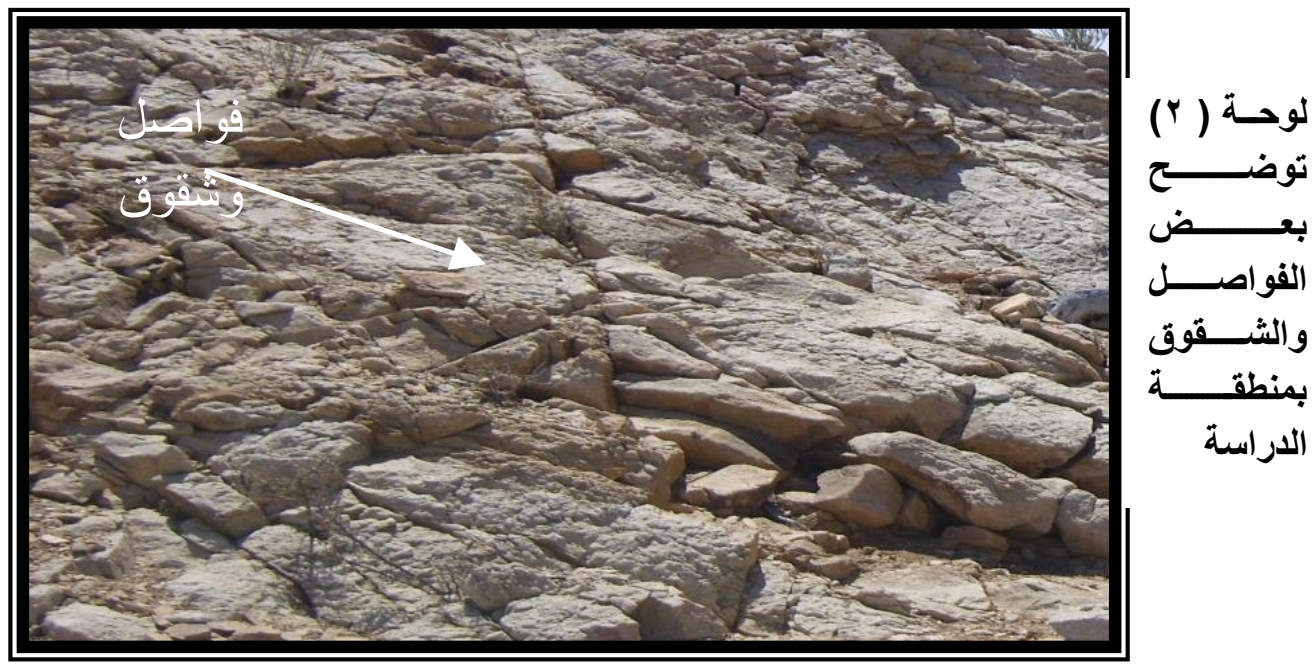

(دعيب وابب و سرمتاي ) كنلك تأثر خط الساحل بالصدوع والطيات؛ حيث

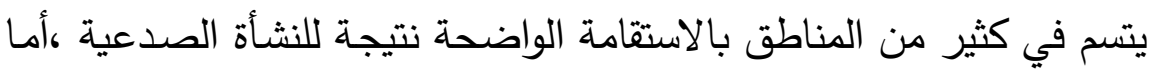
الفواصل والثقوق فقد ساهمت بشكل كبير في تكوين العديد من الظاهرات

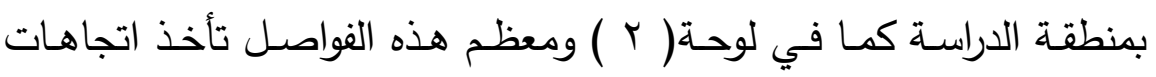

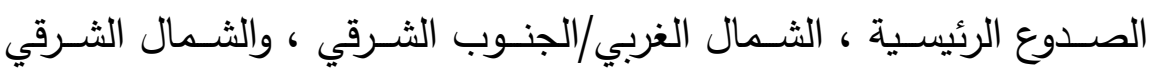

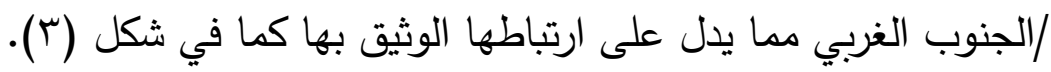




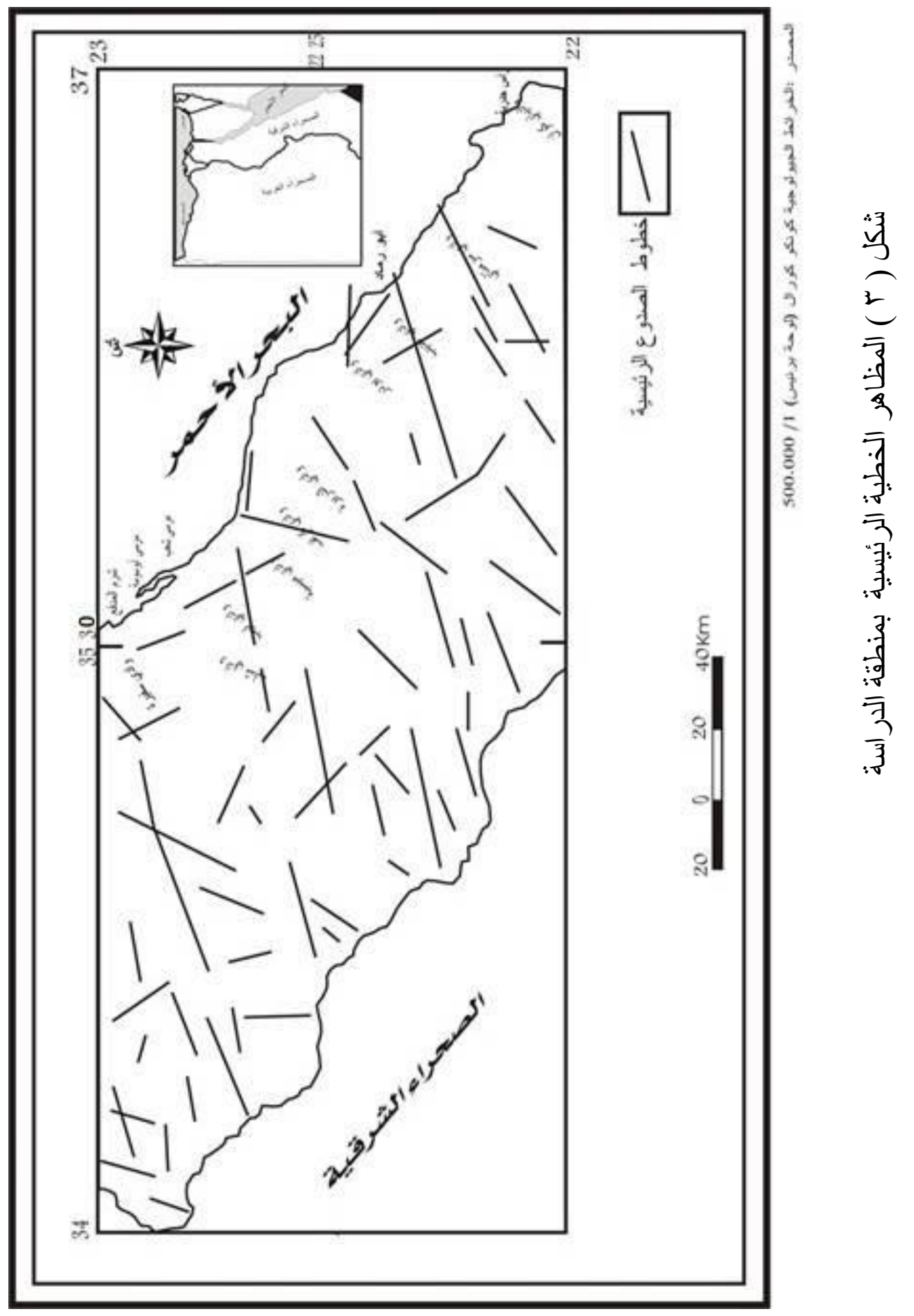




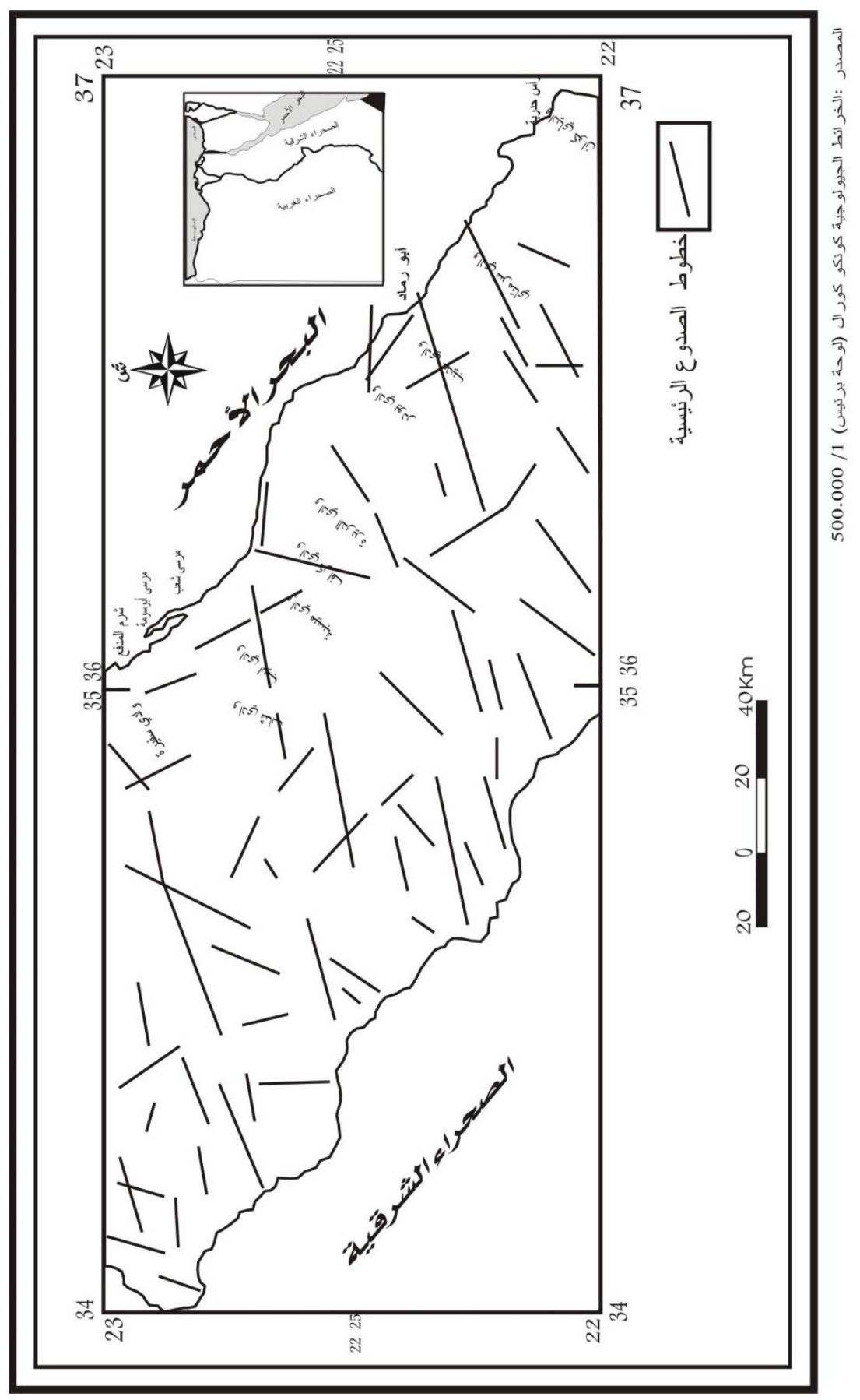


التطور الجيولوجي:-يدو التطور الجيولوجي لهنطقة الدراسة في إطار

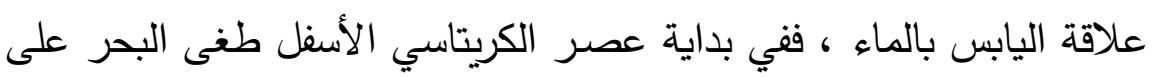

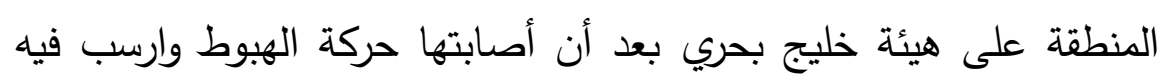

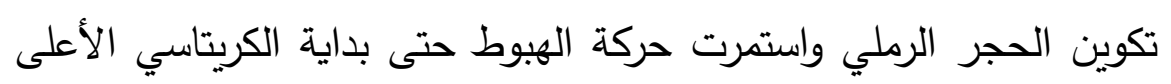

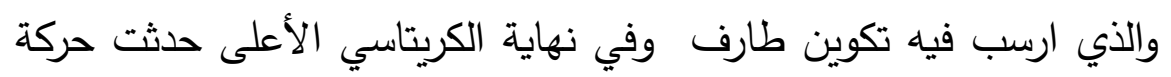

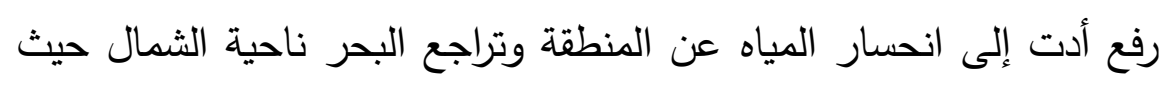

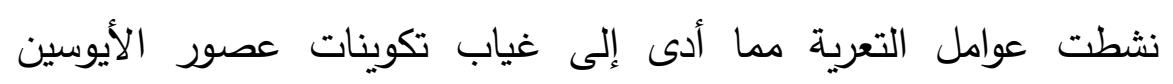

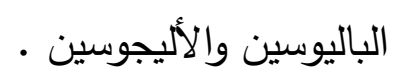
-وفي عصري الإيوسين والاوليجوسين حدثت حركة رفع قوية للجزء الشرقي من الأراضي المصرية كانت حركة عنيفة صاحبها طيات وصدوع ونتج عنها

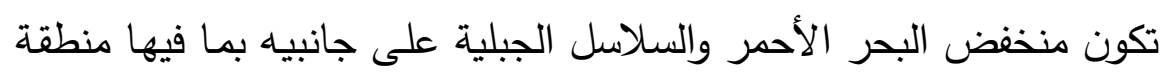

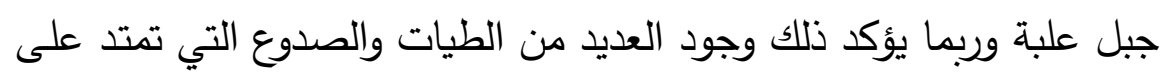

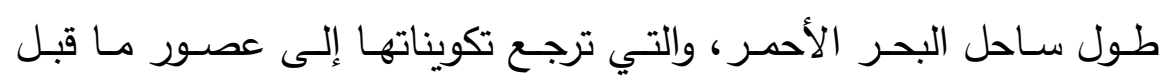

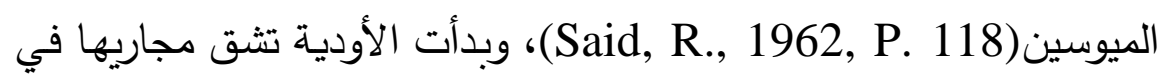
مناطق الضعف الجيولوجي وخاصسة على طول مضرب الطبقات والثثقوق العمودية على اتجاه ميل الطبقات نحو غور البحر الأحمر الوليد وحولته إلى الى الطي

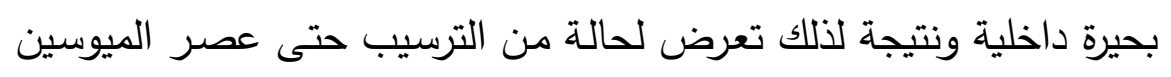

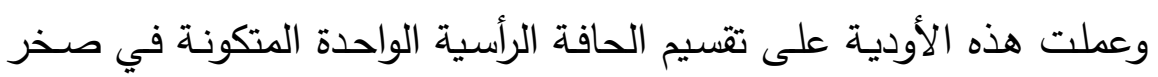

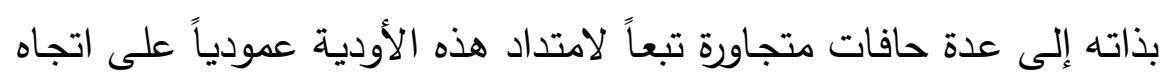
واجهات الحافات الرأسية.

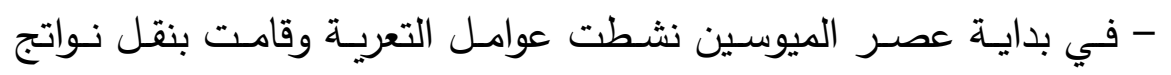
عمليات النحت التي تعرضت لها جبال البحر الأحمر بعد ارتفاعها وألقت 
بهـذه المـواد التـي كـان أغلبهـا رواسـب رمليـة وكنجلوميراتيـة في البحـر

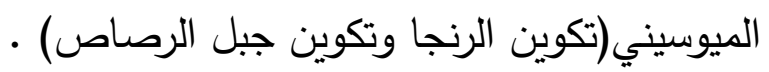

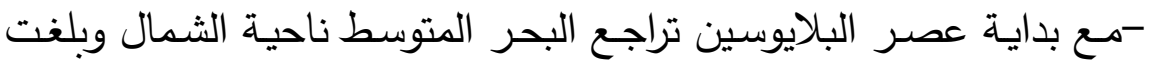

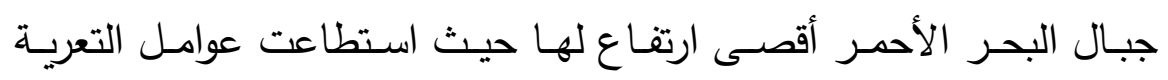

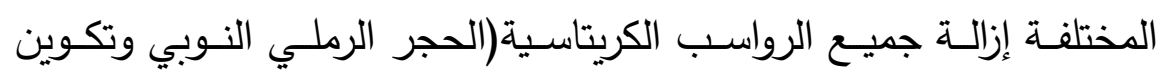
طارف) من فوق القمم الجبلية النارية.

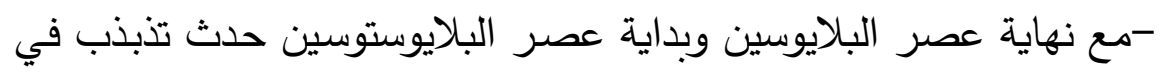

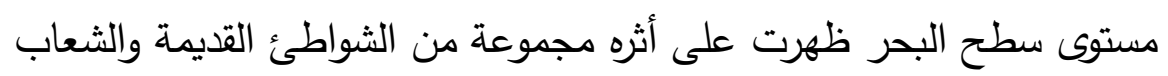

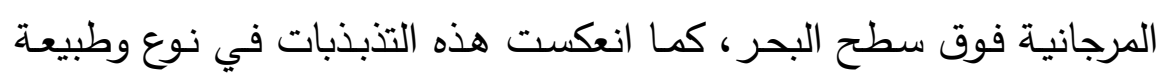
رواسب البليوستوسين ومن ثم تعدد أشكال السطح المرتبطة بها. -خلال عصر الهولوسين سادت ظروف الجفاف واستقرت معظم الأشكال

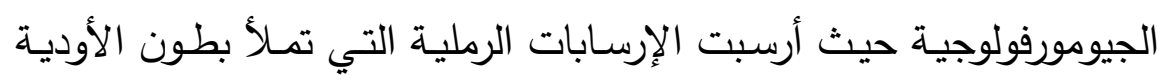

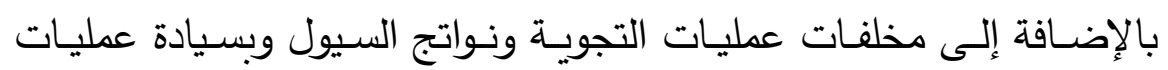
التعرية أخذت المنطقة شكلها الحالي. r-الأحوال المناخية الراهنة ودورها في تثكيل المنطقة.

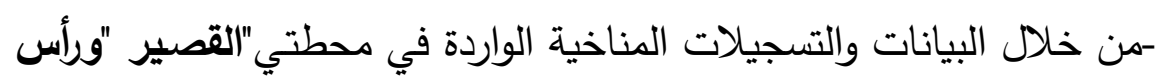

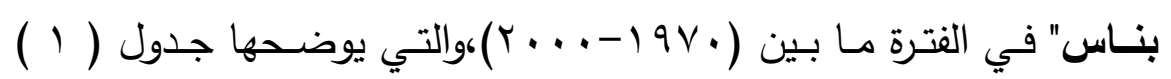

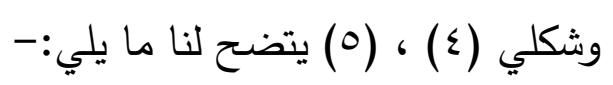

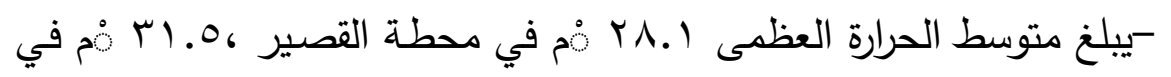

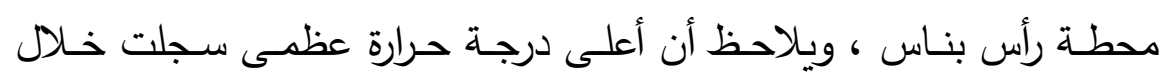

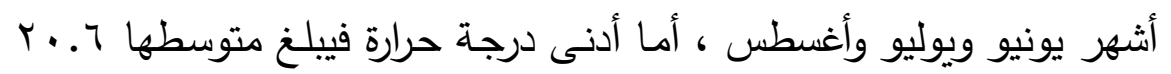

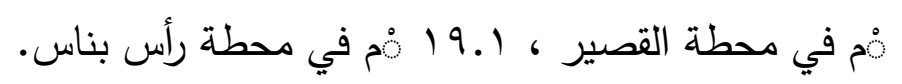

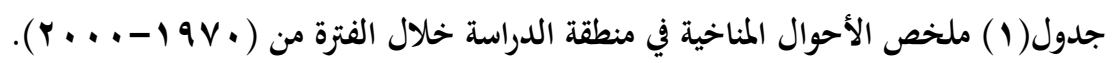

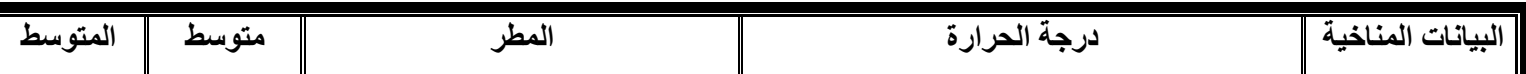




\begin{tabular}{|c|c|c|c|c|c|c|c|c|c|}
\hline \multirow{2}{*}{ التبومي التبخر } & \multirow[t]{2}{*}{ الرطبية } & \multicolumn{2}{|c|}{ أكبر كمية مطر سقطت } & \multirow[t]{2}{*}{ سنويط } & \multirow[t]{2}{*}{ الحراري } & \multirow{2}{*}{ الدرجة الدرارة } & \multirow{2}{*}{ العتوجة العرارة } & \multirow[t]{2}{*}{ ستوسط } & \multirow[t]{2}{*}{ المحطة } \\
\hline & & بالملايمترة & التاريخ & & & & & & \\
\hline $1 \% .9$ & $\varepsilon 9$ &.$\wedge$ & $7 \mathrm{~V} / \mathrm{Y} / \mathrm{T}$ &.$V$ & $v . r$ & $r . .7$ & r^.1 & $r \varepsilon . \varepsilon$ & القصير \\
\hline 17.8 & $\varepsilon r .1$ & $7 \leq$ & $74 / 1 / Y \leq$ & 1.7 & IY. & 19.1 & M.0 & Yo.^ & رأس بناس \\
\hline
\end{tabular}

ملخص عن بيانات هيئة الأرصاد الجوية

-تكمن أهمية عنصـر الحرارة فيمـا يعرف بالمدى الحراري حيث بلـن المدى الحراري السـنوي r.Vْْْم في محطة القصسير ، و ع.ب أم في محطة رأس بناس وقد سجل شهري يناير وفبراير أعلى مدى حراري بمتوسط 7.1 درجة مئوية في محطة القصير ، أما محطة رأس بناس فقد سجل شهر يونيو أكبر مدى حراري بالمحطة وبلـغ ب. أ درجة مئويـة مدا يدل على مدى حـراري كبيـر يـعكس بصـورة مباشـرة على عمليـات التفكك الميكانيكي والانشطار الصـخري نتيجة لحدوث عمليـات التجويـة وخاصـة التجويـة الفيزيائيـة، والتي

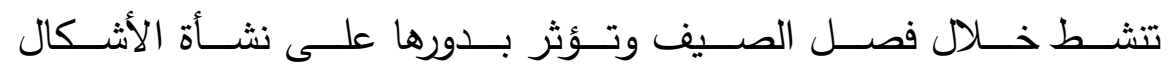
الجيومورفولوجية بمنطقة الدراسة. 


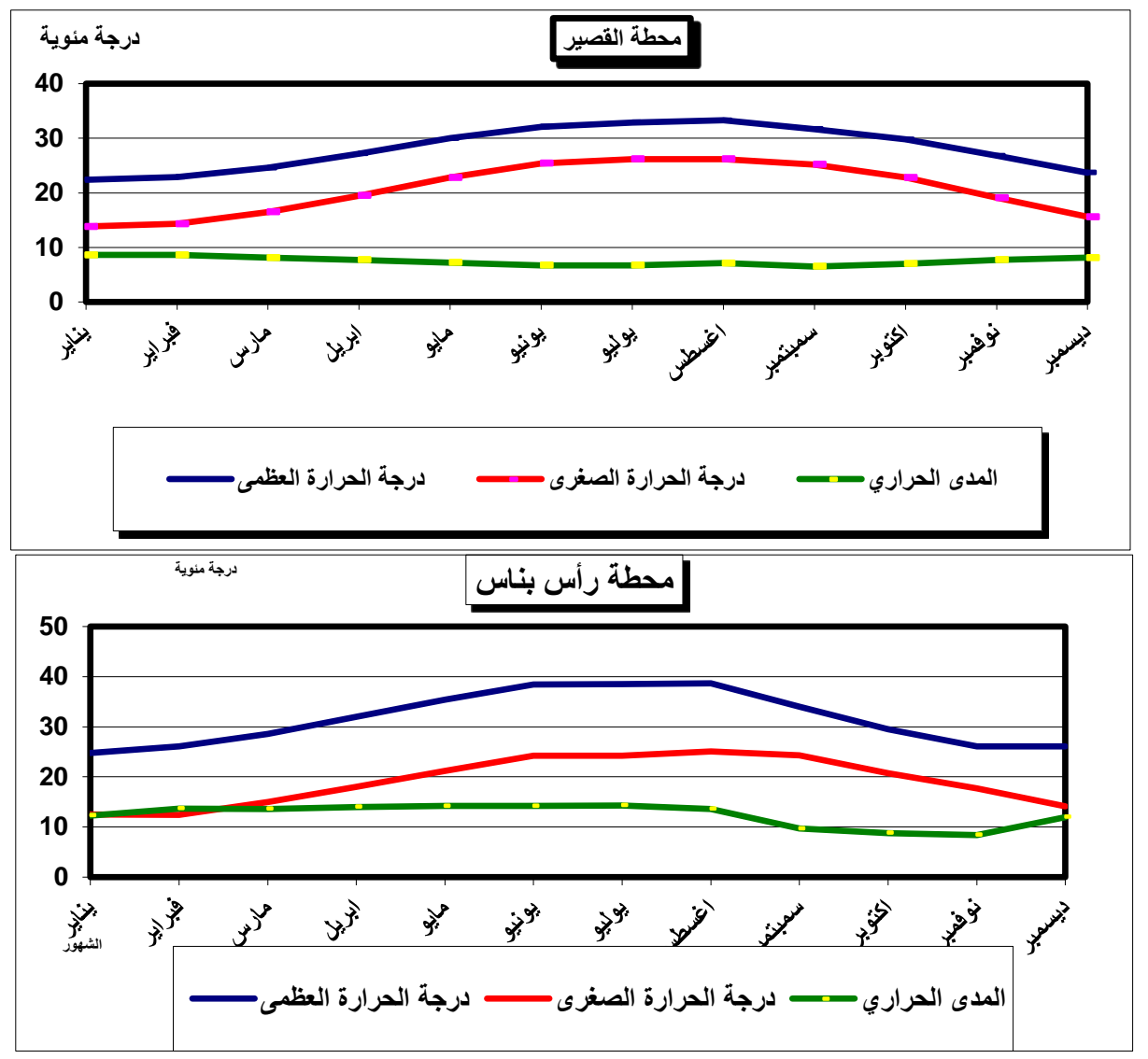

شكل ( ع ) المتوسط الشهري للحرارة العظمى والصغرى والمدى الحرارى بمحطتي منطقة الدراسة -يلـغ متوسط المطر السنوي( (. (1 مح) وهو متوسط منخفض للغاية وشير ذلك إلى مـا تعانيه منطقة الدراسـة من جفاف شديد باستثناء منطقتي جبل علبة وشنديب والتي لا تخلو من ظاهرة السحب إلا فيما ندر وهي تعد بلا جدال أغزر جهات الصحراء الثرقية أمطاراً (أبو العز، ، 9 (، ص سهـ). سيسط المطر خـلال الفترة من شـهر أكتوبر حتى شهر ديسـبر و يعتبر شهر نـوفمبر أكثر شههر السـنة في متوسط كميـة المطر المتسـاقطة، فقد سجلت محطتي القصير ورأس بناس ه. م مم ، ا.با مم على الترتيب. 


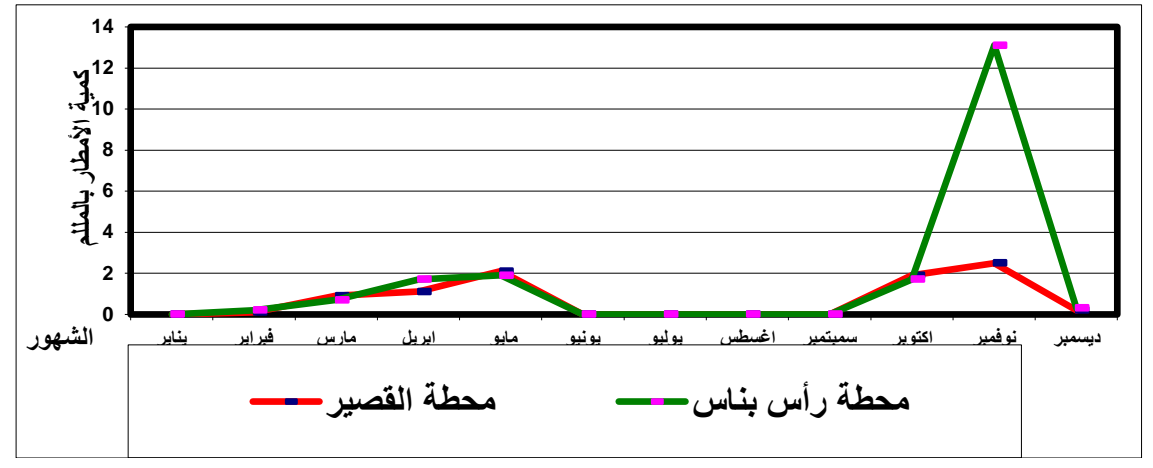

شكل ( • ) يوضح كمية الأمطار الساقطة بمنطقة الدراسة.

-تتميز الأمطار الساقطة بعدم انتظامها وتغايرها زمانياً ومكانياً حيث تختلف بوهيل في سقوطها بصورة كبيرة في توزيعها اليومي أو الفصلي والسنوي مما يزيد من فرص حدوث السيول نتيجة لتفوق قدرة المفتتات على التسرب والتبخر وتسـاهم هذه السيول بشكل واضـح في تعديل ملامسح السطح عن طريـق عمليتي النحت والإرسـاب ، كمـا تسـاهم الأمطار السـاقطة على التجمعـات الرملية في نمو بعض الأعشاب الصحراوية لا سيما على الأجزاء السفلية من جوانب الكثبان حيث تزيـد كميـة المياه بسبب تسربها من رمـال الكثبان ، وبالتالي تؤدي هذه الأعشاب إلى زيـادة عرض الكثبان الرملية نتيجة تراكم

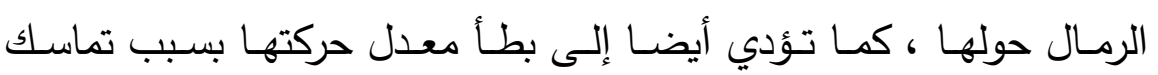

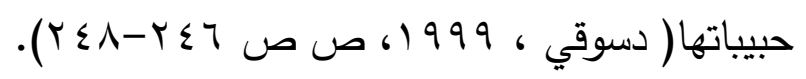
-تعد الريـاح مـن العناصـر المهمـة الأكثر تأثيراً في تشكيل مظـاهر سطح الأرض ونحت التكوينـات الصـخرية الضـعيفة ، كمـا تقـوم الريـاح بتوسـيع المسافات البينية بين الفواصل والثقوق وبالتالي تمهد البيئة المناسبة لتقوم الميـاه الجاريـة بـدورها كعامـل تعريـة ومـن دراسـة المعدلات الثـهرية لتوزيـع النسب المئوية لاتجاهات الرياح في محطتي منطقة الدراسة يلاحظ أن الرياح السائدة طول العام هي الرياح الثمالية والثمالية الغربية،كما أن سرعة الرياح تزيد خـلال شهري نوفمبر وديسمبر بمحطة القصير ، في حين يعد شهر 
يونيو هو أكثر الثهور سرعة للرياح في محطة رأس بناس، حيث وصلت سرعة الرياح إلى ، 0.0 كم/ساعة كما في شكل (T).

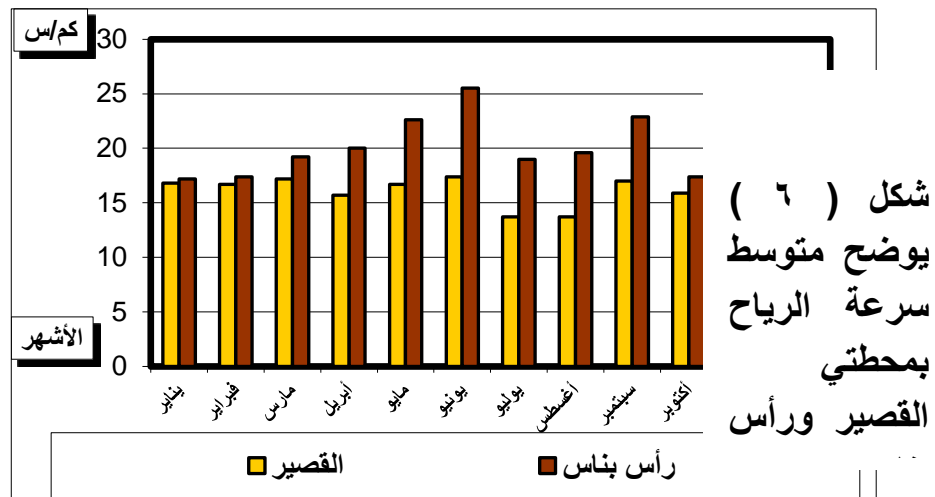

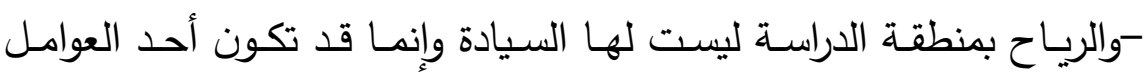

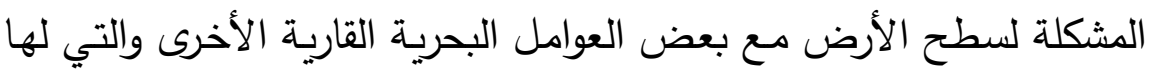

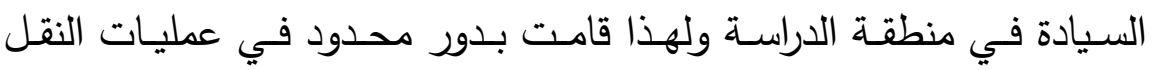
والترسيب وكذلك تكوين النبكات والفرشات الرملية .

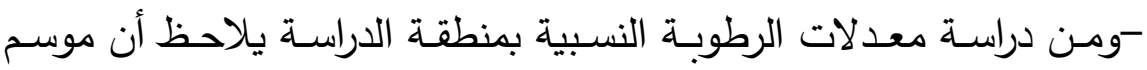
ارتفاع الرطوبة النسبية يتفق مع سقوط المطر بمحطتي منطقة الدراسة حيث ة

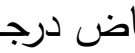
ترن بانخف يقت

الحرارة،فالعملياتالجيومورفولوجيةالمتعلقةبالرطوبةكالتجويةالكيميائيتتنشطفيفـ

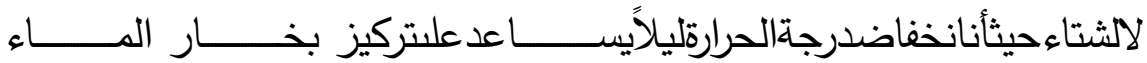
،وتثبعالهواءببخارالماءوالذييتفاعلبدورهمعكوناتالصخروثانيأكسيدالكربونمكوناً ناصرجديدةكمايحدثلصخورالجيرية،والتي تعتبر من أكثر أنواع الصخور قابلية

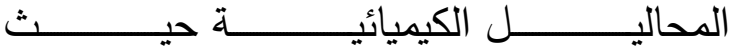

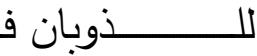
تحتويعلنكربوناتالكالسيوموالتيتحولنتيجةل لهذهالعمليةإلبيكربوناتالكالسيومالهشةتوت

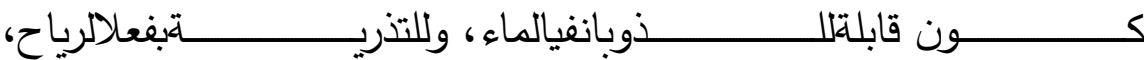
فتنتـأنتيجةلذلكالعديدمنالملامحالجيومورفولوجية بمنطقـة الدراسـة،ولا شكك أن 
شيوع الصـور الجيريـة أيضـاً في منطقة الدراسـة وانكثـافها أمسام عمليات التجوية المختلفة يجعل منها فريسة سهلة لعمليات التكربن والإذابة و غيرها من عمليات التجوية الكيميائية.

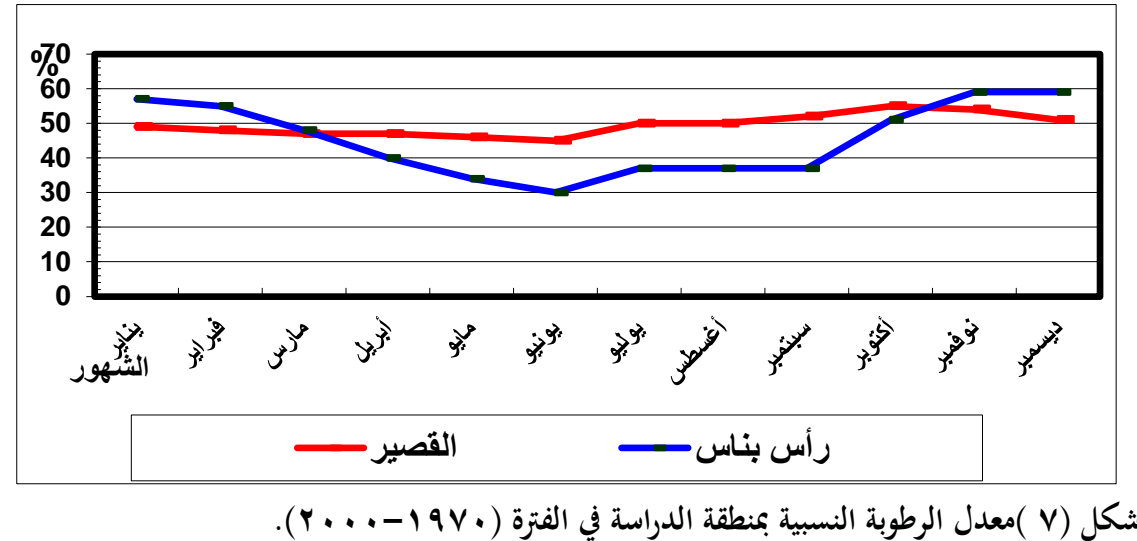

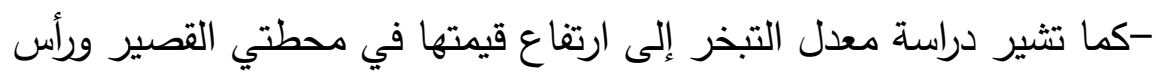
بناس خلال شهور يونيو ويوليو وأغسطس شكل( V ) هويرجع ذلك إلى جفاف إنى الهواء وارتفاع درجة حرارته وانكثاف السطح وخلوه من النبات الطبيعي. وجدأنهناكعلاقة عكسيةبينمعد لالتبخروالرطوبةالنسبيةفانخفاضقيمةالرطوبةالنسب يتةفيالهواءتؤدياللارتغاعمعدلاتالتبخروبالتالي زيادة معدل الجفاف ،مما يعمل على تدهور التربة وتعرضها لعمليات التعرية لاسيما التعرية الهوائية والتي يزيد نشاطها عندما يحل الجفاف وبالتالي تكوين العديد من الظاهرات

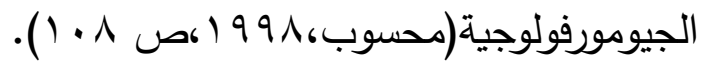
ثانياً : أثنكال السطح الرئيسية بمنطقة الدراسة.

\section{ألأشكال البنيوية.}

أ)-الكويستا:-يتألف الشكل العام لهذه الظاهرة من انحدارين أحدهما شديد

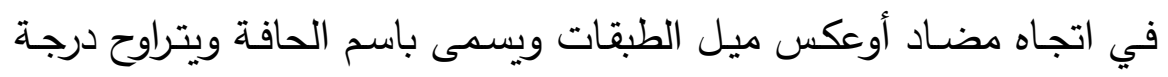




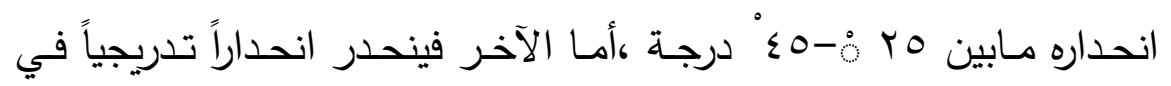
اتجاه ميل الطبقات ويتميز بطوله عن الجانب الأول والذي يظاهره ويطلق عليه انحدار ظهر الكويستا (Abu-EL-Einin,H,1966,PP:197:180). وتتوزع الكويستات في الأجزاء الثرقية لمنطقة الدراسة في نطاق البهادا

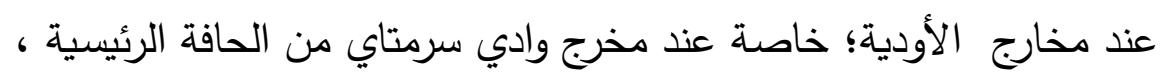

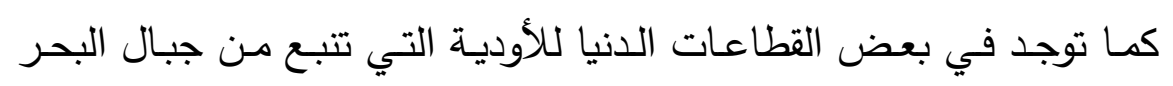

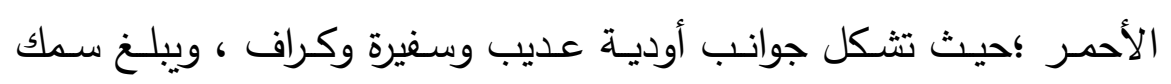

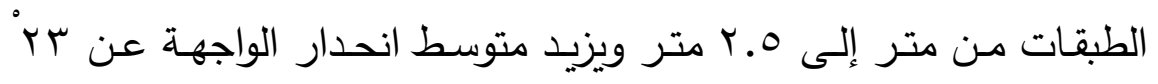

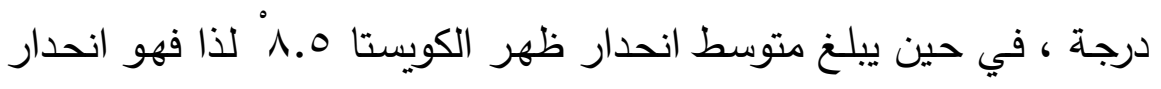
متوسط طبقاً لتصنيف يانج لدرجات الانحدار (Young,1972, p.173). ويمكن القول بأن الكويستات في منطقة الدراسة نثأت وتطورت التحار نتيجة

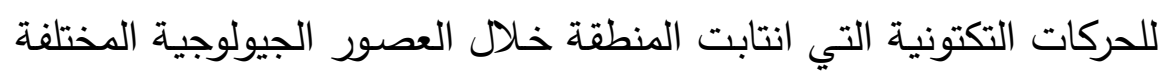

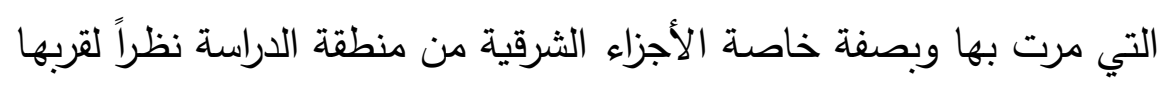

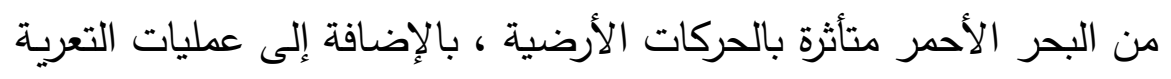

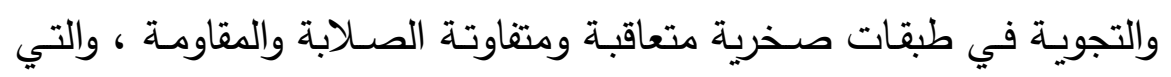

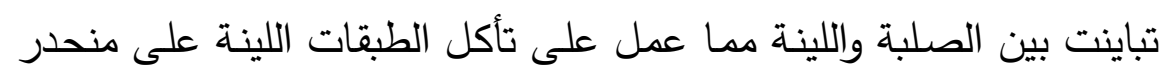
الميل الرواسب ، أما الطبقات الصلبة شكلت واجهات لبعض البل الكويستات.

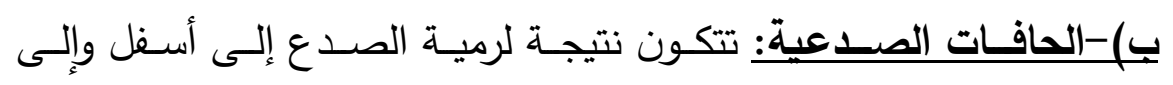

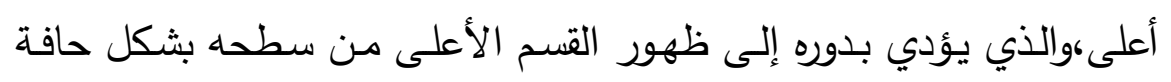
يختلف ارتفاعها حسب شدة رمية الصدع ويتوقف شدة انحدارها على مقدار

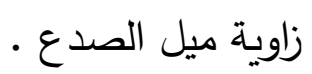

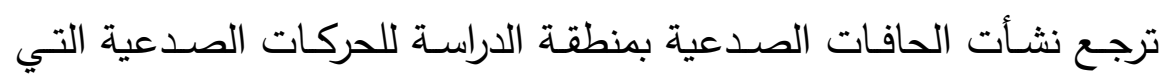

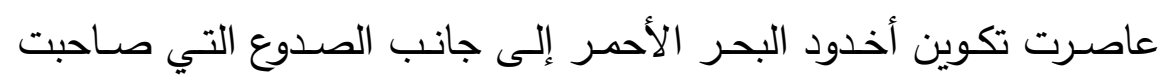


تداخل صخور الجرانيت الحديث بالمنطقة ، وتتميز هذه الحافات بالاستقامة، وتبدو شديدة الانحدار شبه راسية شديدة التقطع بفعل المجاري المائية كما يتضح من لوحة( r ) ،وتتمثل هذه الظاهرة بوضوح في الحافة الرئيسية شرق رل منطقـة الدراسـة والتي تمتـد بصفة عامـة مـن الجنـوب الثـرقي إلى الثـمال الغربي حيث تمثل نطاق مخارج الأودية و قمم المراوح الفيضية .

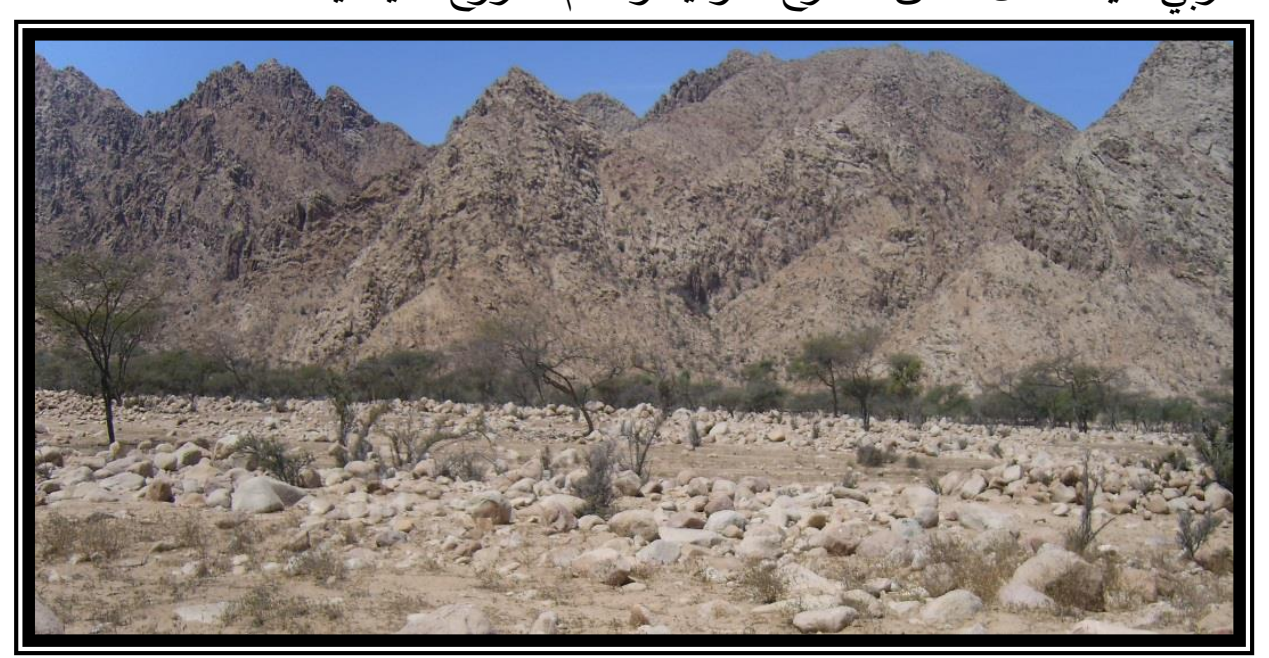

لوحة( r ) الامتداد الخطى للحافة الصدعية ويلاحظ تقطعها إلى واجهات مثلثيه بفعل التعرية المائية

وتظهر كذلك حافات صدعيه في المناطق العليا لأودية سرمتاي وأوليا وشلال عاصرت تداخل كتلة جرانيت جبل علبة مشكلة فيما بينها مستوى

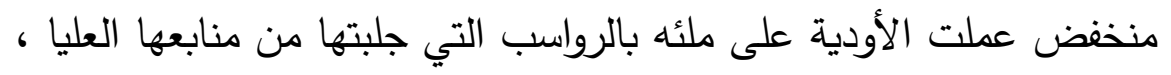
كما تظهر على جوانب الأودية على هيئة حروف كما في أودية كراف والدريرة وباشويا يودر وعديب و اوتمتاب وميركوان •

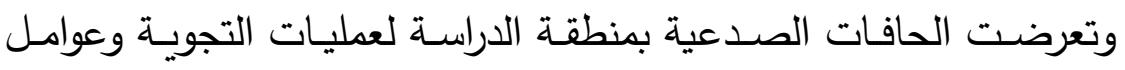

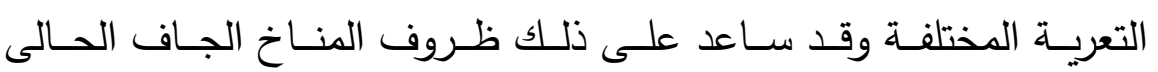
بالإضـافة إلى أضـعافها بالفواصل والثقوق الموجودة بها إلى جانب نشاط التعريـة المائية فتآكلت بعض أجزاءها وتراجعت هذه الحواف ومهع استمرار 
ونثاط هذه العمليات تراكمت الرواسب عند قاعدتها مكونة بعض الظاهرات أهمها مخاريط الهاشيم والمراوح الفيضية.

\section{r ـأشكال التحث.}

أ)- الأودية الجافة:تصب في هذه المنطقة مجموعة من الأودية تتحدر في

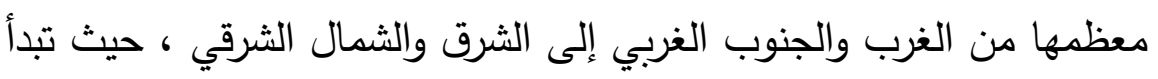

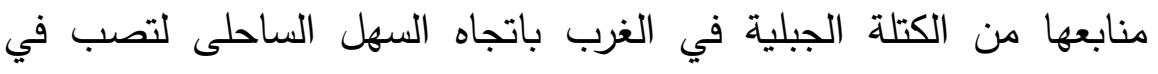

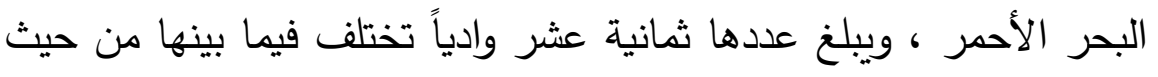
الخصائص المورفومترية و المورفولوجية بسبب التباين في الانحدار والخصائص الليثولوجية للصخور ،ولكنها تتفق فيما بينها من حيث صفة بلة

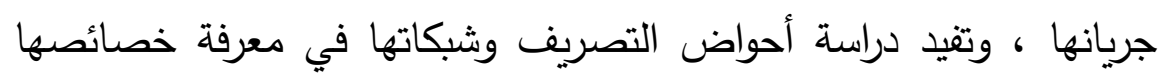
المساحية والثكلية التضاريسية ، كما يمكن من خلالها تحديد أماكن الأخطار الجيومورفولوجية وأنسب الطرق في تتمية منطقة الدراسة.

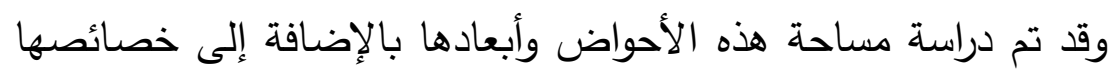

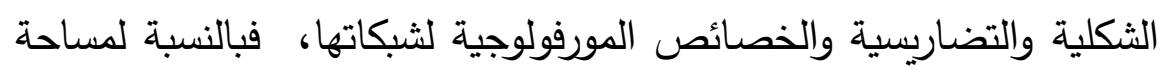

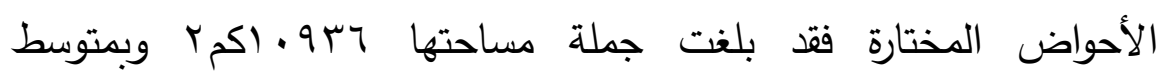

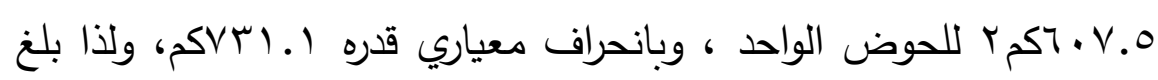

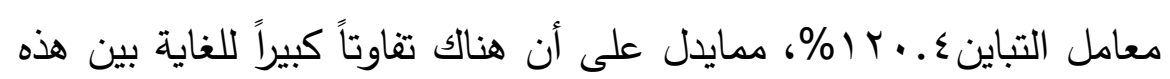

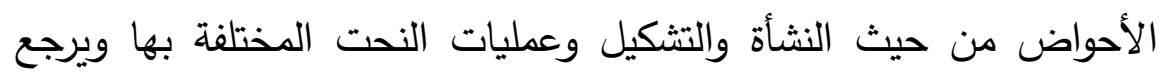
ذلك إلى مجموعة من العوامل أهمها قلة الانحدارات في الأحواض الكبيرة

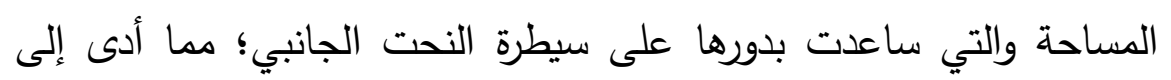

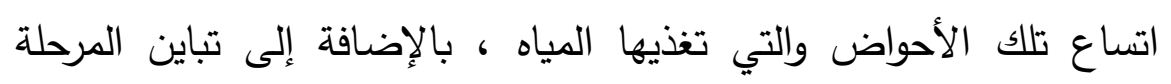

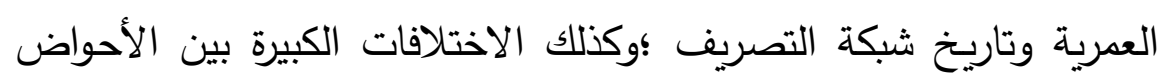

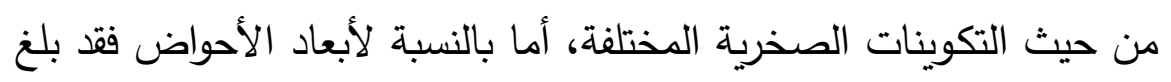


متوسط طولها نحو 00.ب عكم،وبلغ متوسط اتساعها نحو 9.ب اكم ،في حين

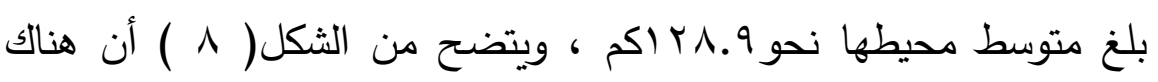

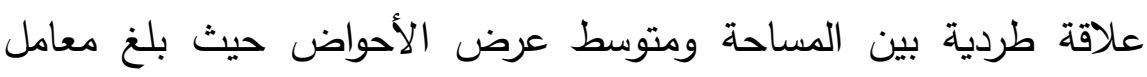

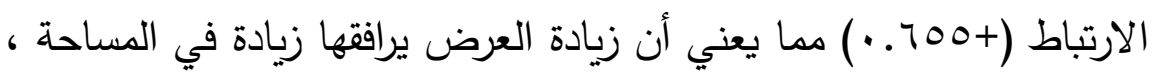

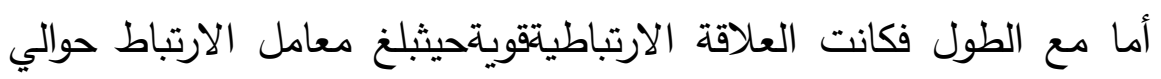

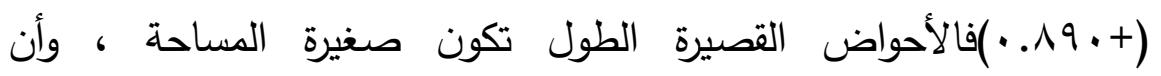
الأحواض كبيرة المساحة تكون كبيرة الطول وهذاله علاقة قوية بعمليات

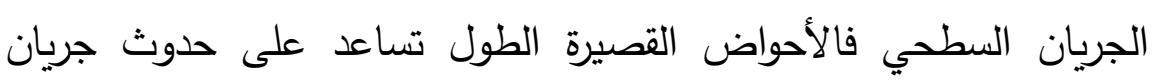

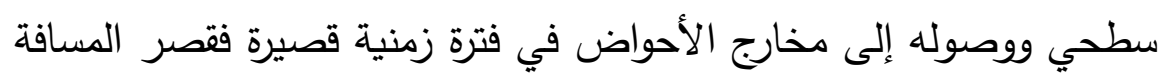

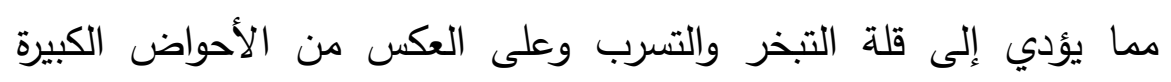

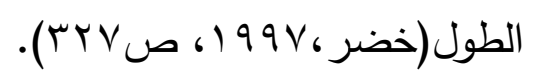

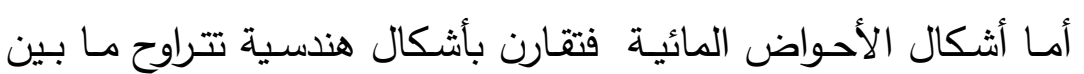
الثكل المستدير والمستطيل والمثلث ، ويمكن الاستفادة من دراستها في لإني

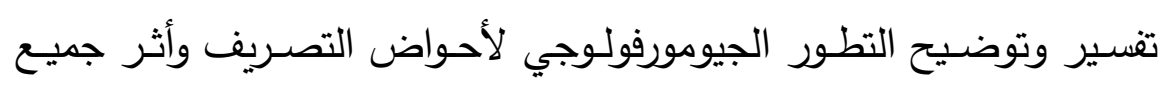

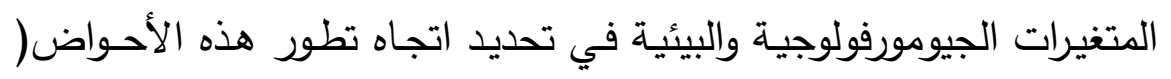

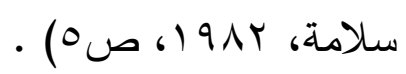

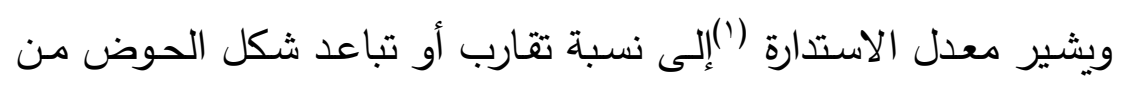

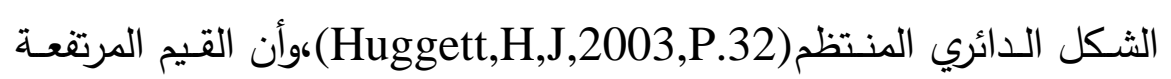

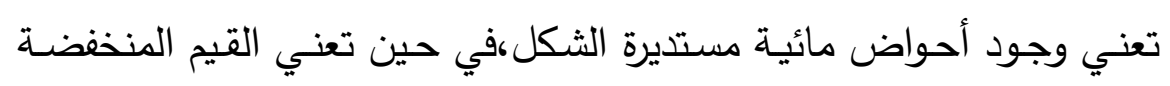
عدم الانتظام وميل الحوض إلى تعرج خطوط تقسيم الدياه الدحيطة بـه

$$
\begin{aligned}
& \text { C=4JA/P2 - (1) } \\
& \text { حيث C:معامل الاستارة المكل التاي:- }
\end{aligned}
$$

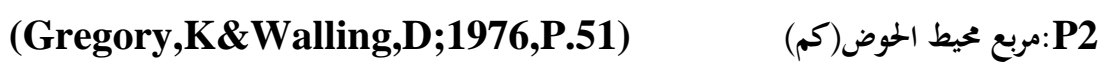


والمحدة لله مما يؤثر على طول المجاري المائية وقد بلغ المتوسط العام

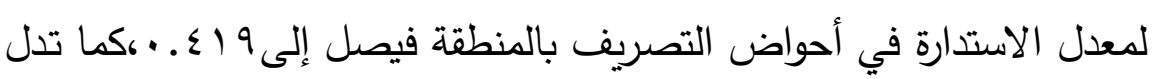

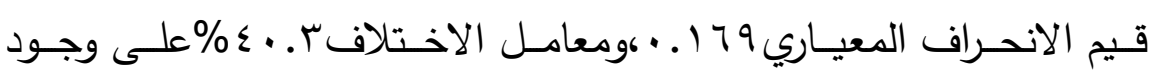

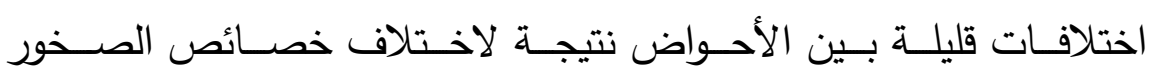

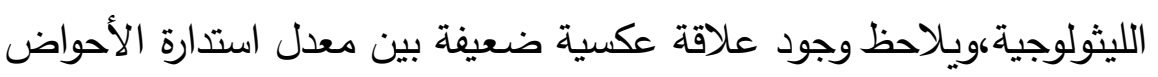
ومساحتها بلغت قيمتها (- • بس. •).

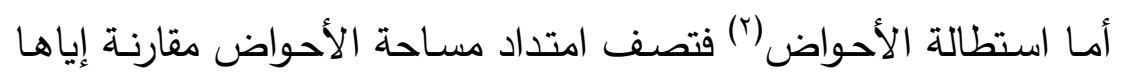

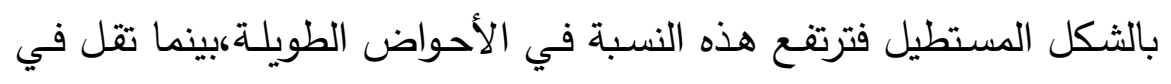

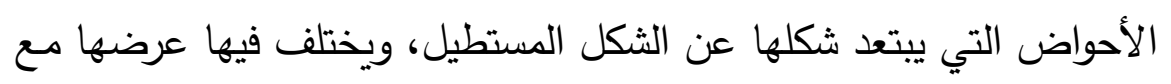

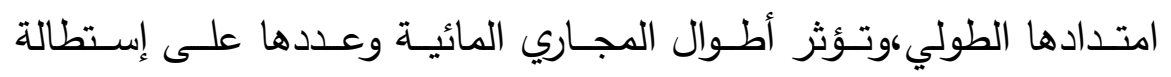

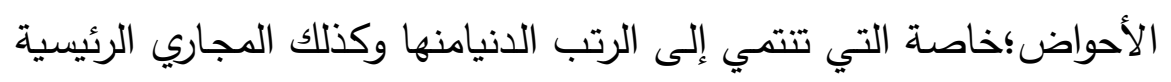

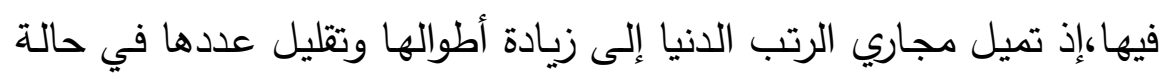

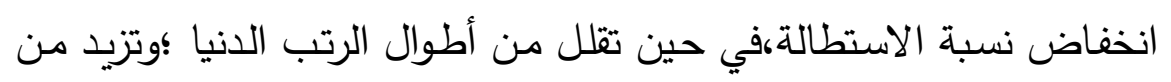

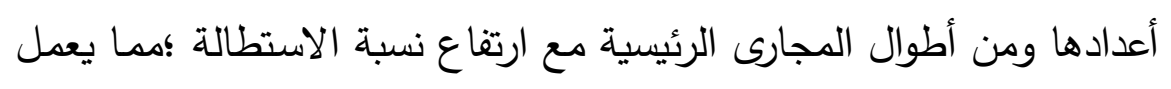

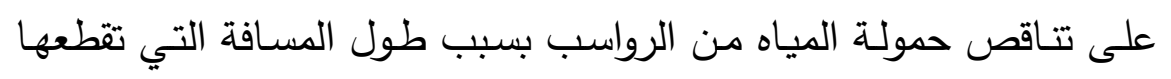

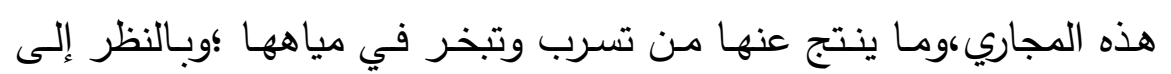

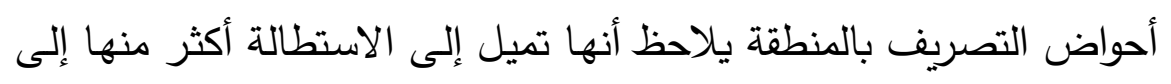

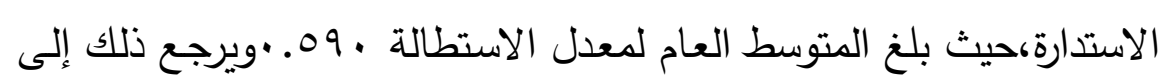

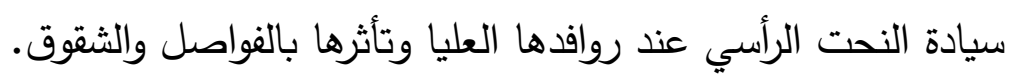

$E=\mathbf{D} / \mathbf{L}_{\mathbf{m}}$

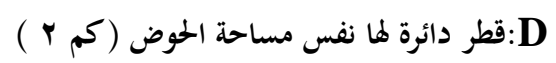

(r) وتتخذ معادلة معامل الاستطالة الشكل الثالي:حيث أن E : Eعامل الاستطالة 


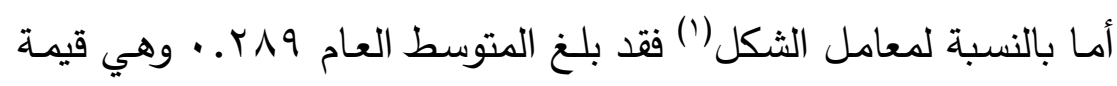
مرتفعة تشير إلى كبر مساحة الحوض على حساب طوله وبالتالي اقتراب

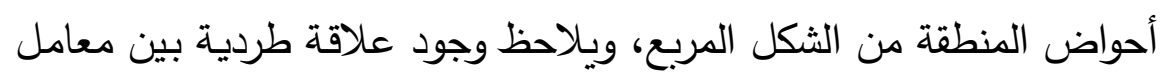

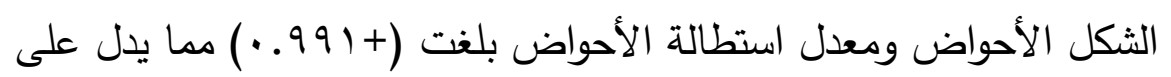
أن كلما زادت قيم معامل شكل الأحواض زادت معدل استطالتها والعكس.

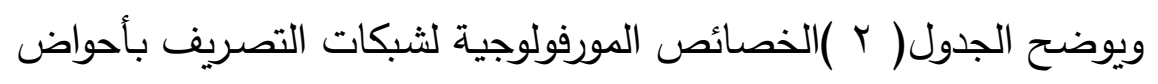
التصـريف النهري بمنطقـة الدراسـة ويظهر مـن دراستها أن المتوسط العـام

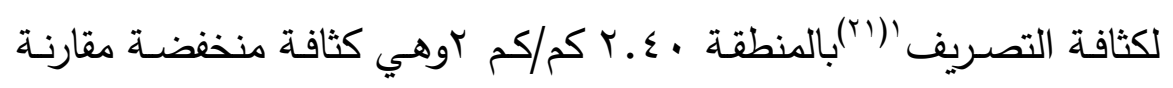
بمتوسط كثافة التصريف في مناطق أخرى تم دراستها مثل متوسط كثافة

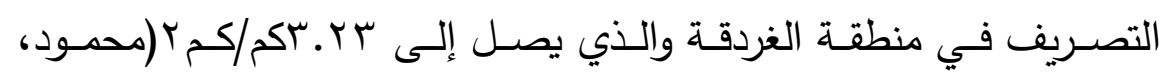
بو 9 (،ص ع V)ومتوسط كثافـة التصـريف في حوض وادى العريش والذي يصل إلى 0كم/ كم ب (صالح، 919 (،ص (1 (1) )،وحوض وادى الرشراش والذي

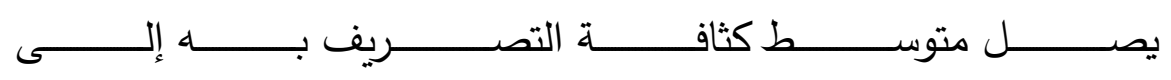

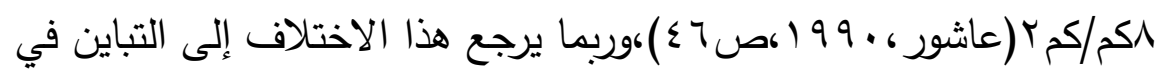

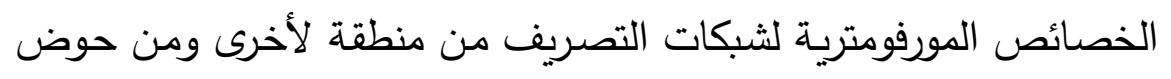
لآخر ،وذلك تبعاً للتباين في خصائص السطح والمرحلة العمريـة والخصائص الهيدرولوجية.

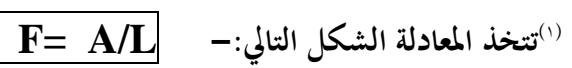

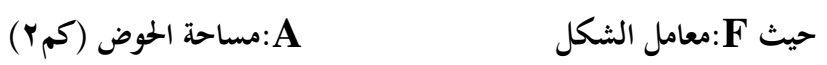

(Ritter \&et-al , 1995, P .54 مربع طول الحوض) L2 Da= EL/A ت التخذ المعادلة الشكل التالي:EL

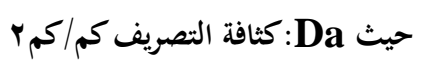
(Goudie.A,et-al,1981,p.53 ( مساحة الحوض (كم ץ ) )
} 
جدول ( r ) خصائص أحوض التصريف وشبكان البخاري بنطقة الدراسة بنطقة الندراسة.

\begin{tabular}{|c|c|c|c|c|c|c|c|c|c|c|c|}
\hline كثلقة & بقاء & أسولري & أعجاد & الشكل & مستطل & معلدارة & لحميط & لعرض & لحهل & الحرض & \\
\hline $9 . .4$ & 0.19 & יו"י & 849 & . & .081 & 0.794 & 184 & 18.0 & 01 & $04 \mathrm{v}$ & \\
\hline P. . v & $\cdot .6 \mathrm{~A}$ & ripo & 1910 & .rav & .9.8 &., 689 & 104 & in & 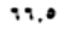 & 1R2A & \\
\hline 1.48 & .01 & ralp & $r a$. & . P & צים & मश & rir & $r \varphi$ & a & $P .1 \%$ & \\
\hline 1.64 & . 2v & $7: 87$ & $7+8$ & .rvv & - .949 &., 817 & $7+8$ & $r$ & १ & 196 & \\
\hline -AS & $1 . r \%$ & 1498 & $\sim 10$ & טוr. & .,Pr & $\cdot, r+i$ & $r . r$ & iv & Av.० & 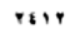 & \\
\hline i.ry & . Tr & PAAV & ris & rי & .rA. &. ,A. & rol & 10 & $\wedge 9$ & AQA & الثزيرة \\
\hline P.१ & .rA & 094 & rvi & $\cdot$ Ivv & . ive & . . & 1.9 & १.० & ro & $r v$ & \\
\hline $8 . . A$ &. .78 & VAA & rro & • & . .१人ץ & ( & ir & A & $r$ & lar & \\
\hline P. A &. .88 & ip & 001 & $\cdot, 104$ &. .614 & .rv. & יז & १.० & $\$ .0$ & TVT & \\
\hline P.8Y & .6 & rap & PA? & $\Rightarrow \pi$ & . .00\% & .,004 & $\because .0$ & ४. & 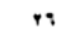 & 194 & \\
\hline P.V\& &.$r v$ & \&AY & iva & $.0 \& 7$ & . ARP & .ov. & o & A.० & iA & צי & اوتتثب \\
\hline P.OV &.$r a$ & 798 & rip & ४ &. $.0 \wedge$ P & - rq & $\mathrm{vr}$ & เ.० & 78 & 10\% & ميركىن \\
\hline r.r. & $\therefore r$. & $v p$ & 98 & $\ldots 18$ &., $8 \times 4$ & .r & $\cdots$ & $1 \cdots 0$ & 79.0 & $\mapsto A$ & سرمتاي \\
\hline P.०v & .rA & 119 & 198 & .rva & .948 & 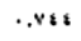 & ra & P.० & 10 & $\wedge \theta$ & \\
\hline P.Pq &. .84 & \& & $m 99$ & $\because 4$. &. .847 & Trtrat & A\&,O & A.० & $r$ & IAT & شلد \\
\hline P.19 &. .80 & 799 & $r .8$ & . & ד: & $\cdot$ rvis & १४.० & a. & Ps & iro & إقهوق \\
\hline P. &. rA & r.P & $\cdots$ & .rv &. $.0 \wedge \wedge$ & . OPY & or.e & 0.9 & $P .0$ & $\cdots$ & أي كلىن \\
\hline$\therefore \mathrm{vv}$ & I.PA & o: & $\because$ & .708 &., 417 & זיט. & $0 \wedge, \theta$ & \$.0 & iv. & 194 & \\
\hline 7,8 &., 0 & T118 & कवा & -, &., 84 &., 818 & Th, & 17.9 & 87 & वा? & رسط \\
\hline
\end{tabular}

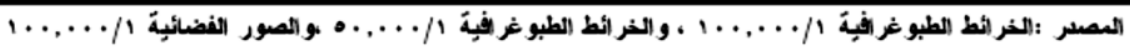
ومسن الملاحظ أن هنـاك اختلاف بـين أحسواض التصـريف في المنـاطق المقارنة وأحواض التصريف بمنطقة الدراسة ؛من حيث كثافة التصريف حيث يـتحكم فيهـا مجموعـة مـن العوامـل منهــا الظـروف المناخيـة وخصــائص المسـاحيةلأحواض وكذلك نـوع الصـخر والتربـة ؛والتي تحدد مـدى مقاومـة سطح الحوض لعمليات النحت. أمسا بالنسبة لمعدل بقاء المجاري( ()فقد بلـخ المتوسط العام لمعدل بقاء المجاري بأحواض التصريف بالمنطقة ، هـ . وهي قيمـة كبيـرة إذا مـا قورنـت بمنـاطق أخـى تم دراسـتها ،فقد بــن معدل بقـاء المجــــاري بالمنطقــــة الممت بــدة بـــين القصــــير ومرســــى أم غـــيج

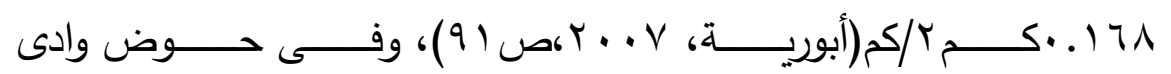

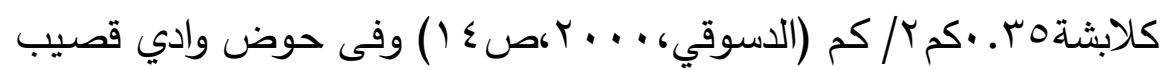

$$
\begin{aligned}
& \text { M= 1/D - (1) تتخذ المعادلة الشكل التالي:- (1) }
\end{aligned}
$$

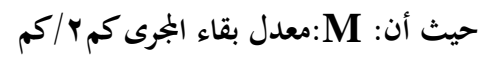

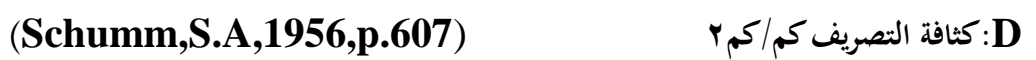




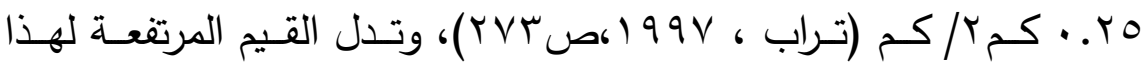
المقياس على اتساع المسـاحة الحوضية على حساب مجاري الشبكة بهذا الحـوض وبالتـالي تقـل قيمـة كثافتهـا التصـريفية وهذا مـا توضـحه العلاقـة

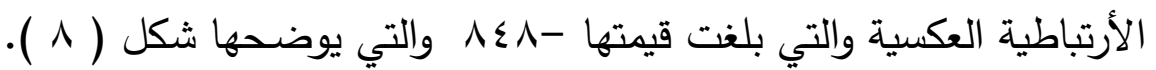
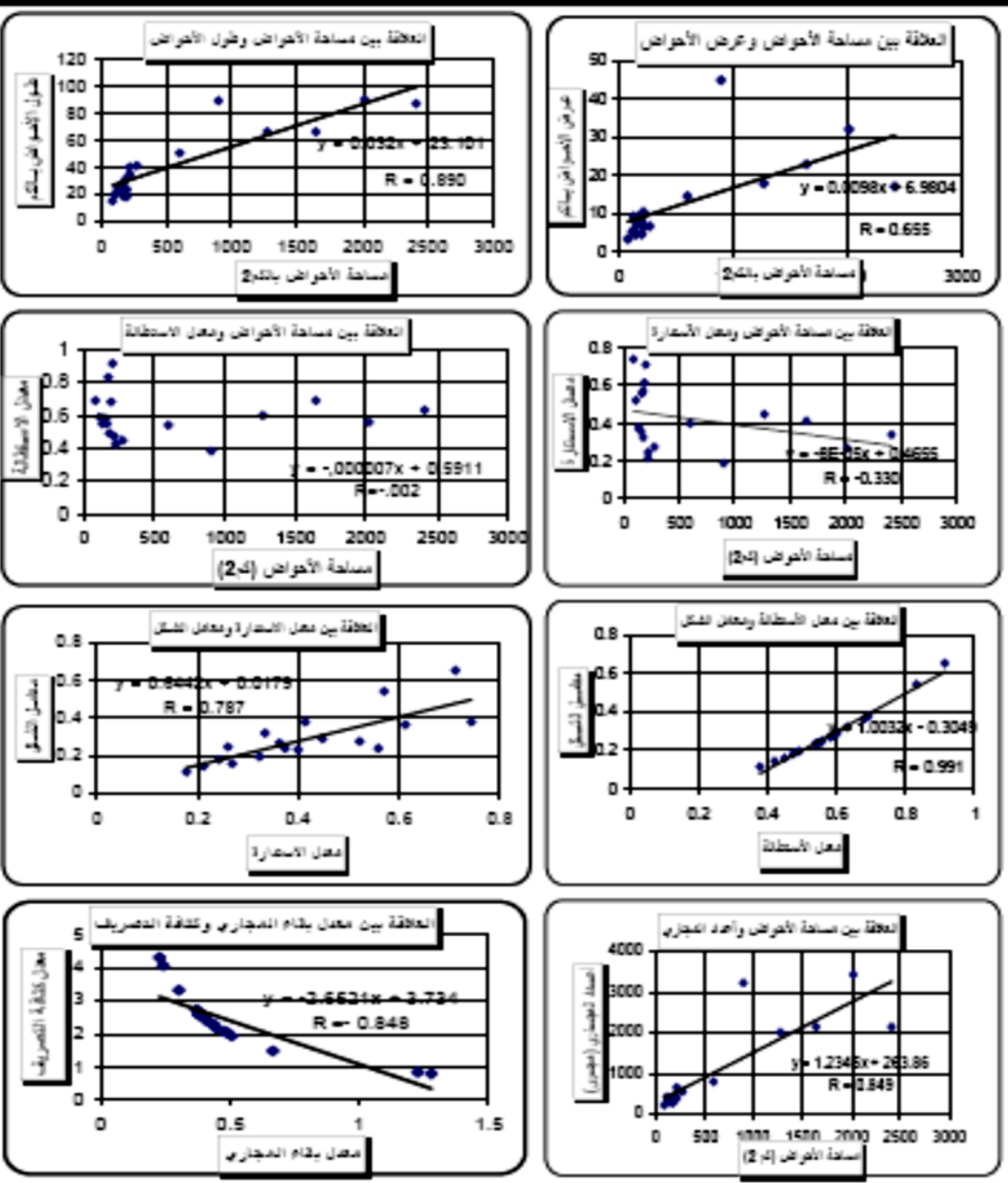

شكل( A ) العلاقة الارتباطية بين الخحائص المورفومترية لأحواضالتصريف بمنطقة الدراسة 
وتعكس المجـاري والأوديـة بشــبكة التصــريف بمنطقــة الدراســة أنماطـاً

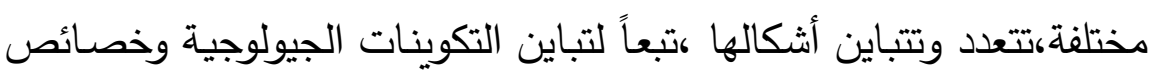
الصخر ،وسمات الانحدار،والحركات الأرضية التي تعرضت لها المنطقة ، وطبيعة الجريان والحمولة ، ويمكن تمييز أربعة أنماط أساسية ، النمط الأول

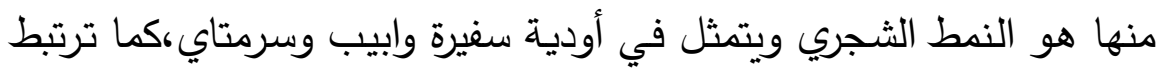
معظم المراوح الفيضية الكبيرة المساحة مثل مراوح أودية سفيرة وشاب وكراف

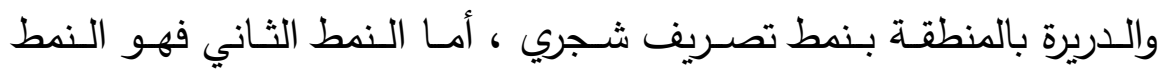

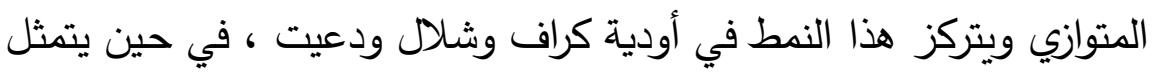

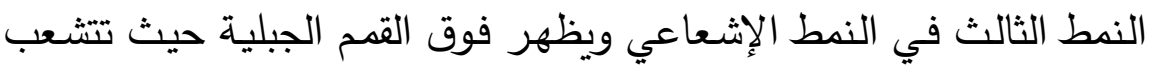

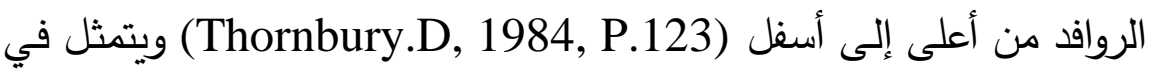
منطقة جبل مشبح وجبل علبة.أما النمط الرابع فهو النمط الحلقي ويظهر هذا النمط بوضوح في أودية سرمتاي وأوليا وشلال.

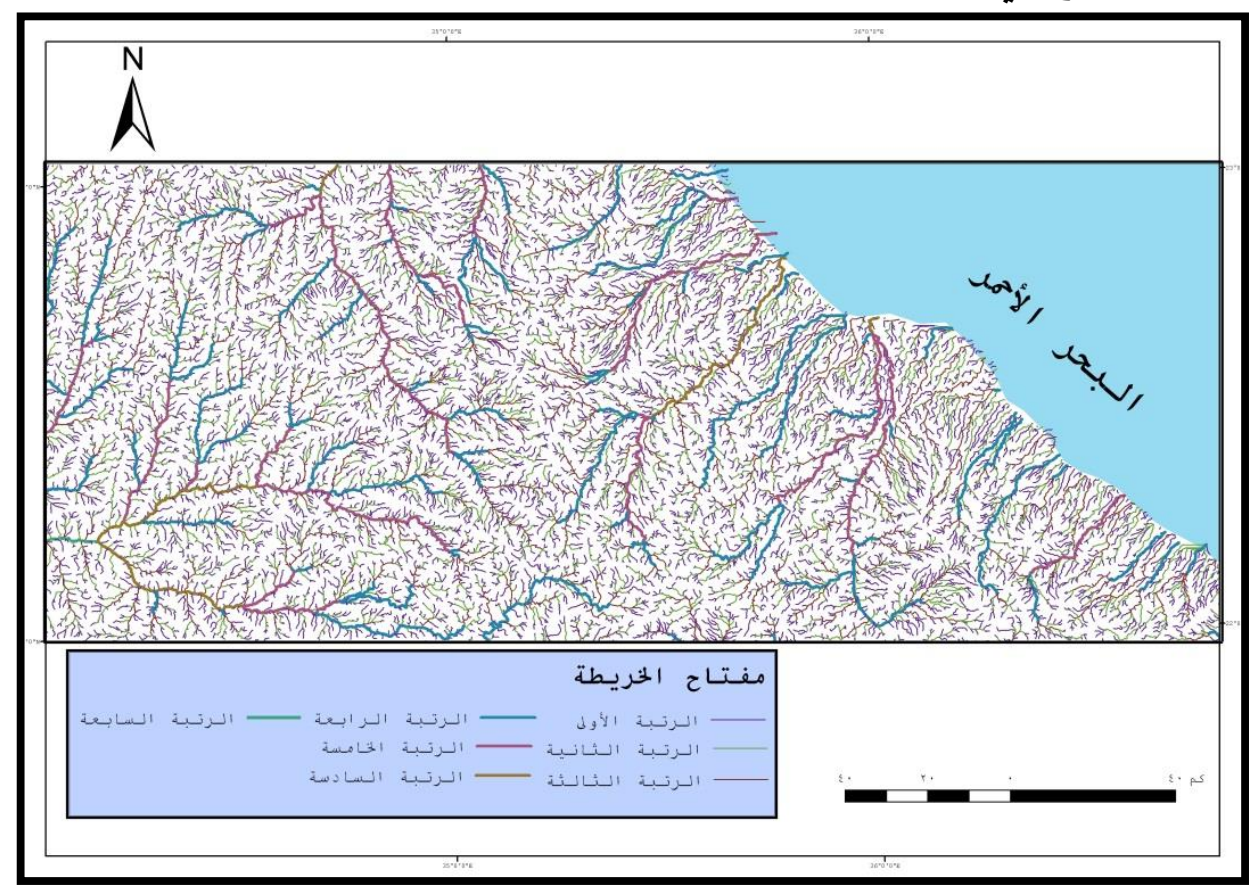

شكل( r ) يوضح الأودية الجافة بمنطقة الدراسة. 
ب)-التلال المنعزبلة:-تنتشر التلال المنعزلة بمنطقة الدراسة ، وتختلف

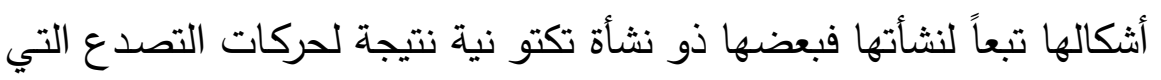

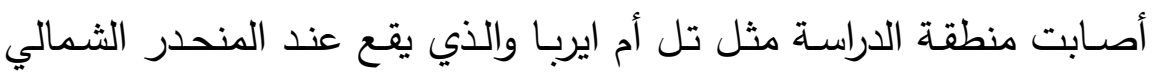

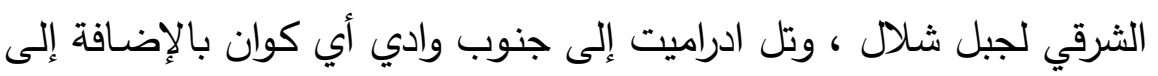

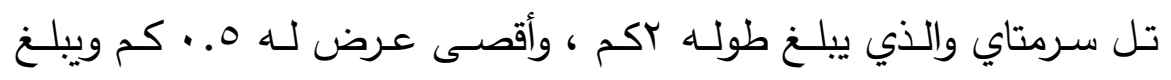

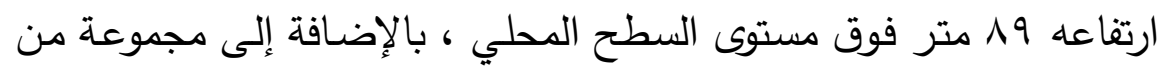
التلال المنعزلة بمنطقة جبل علبة؛ ومعظم هذه التلال تتميز باستواء قمتها

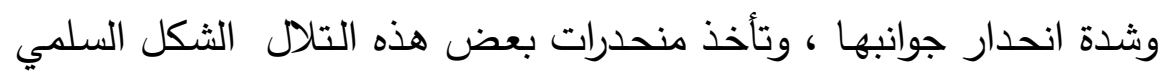

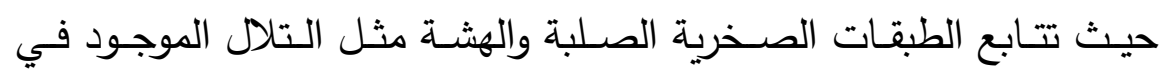
النطاق الأوسط لوادي سرمتاي. وهناك مجموعة من التلال المنعزلة التي نشأت بفعل نحت المياه الجارية الإية وهذا النوع من التلال يوجد في أجزاء عديدة من منطقة الدراسة وقد تكون التهات هذه التلال فردية كما هوالحال عند مصب وادي كراف أو أو قد تكون في شكل مجوعات كما هو في التلال الموجودة بمنطقة جبل علبة لوحة (؟).

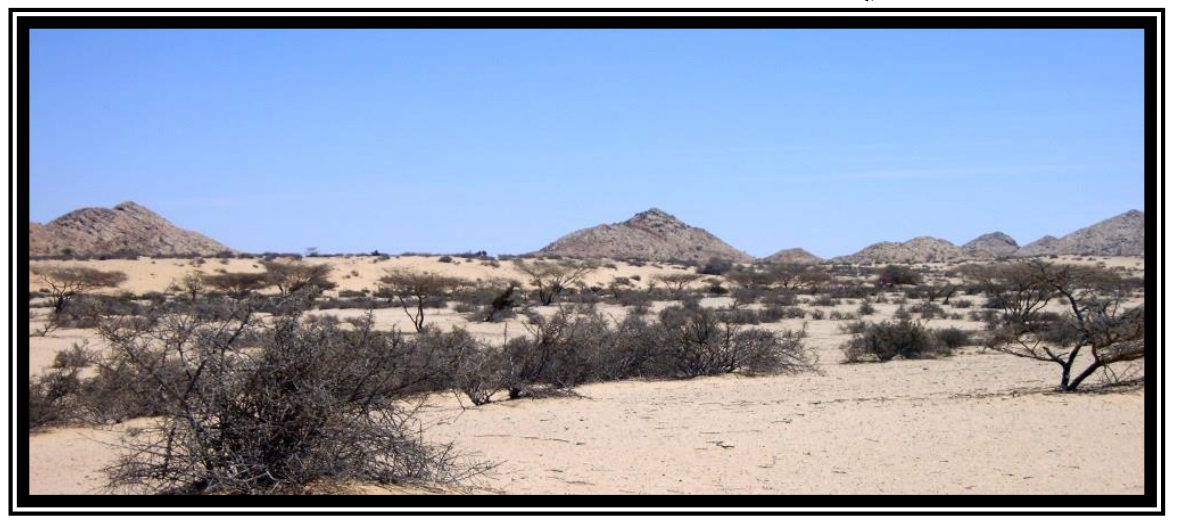

لوحة(ع )تلال منعزلة في منطقة جبل علبة ويلاحظ نمو الأعشاب الطبيعية والتي تستخدمكمراعي 
وتتـألف هـذه الـتلال مـن الحجـر الرملـي النـوبي وتـدخلات مـن الطهي

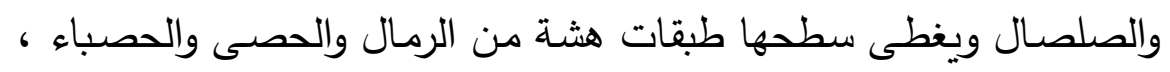

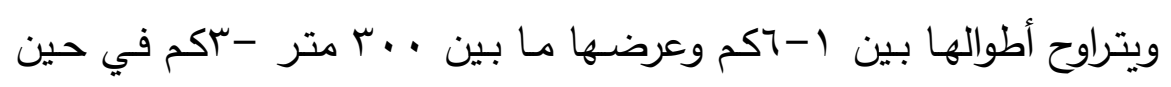

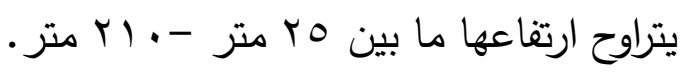

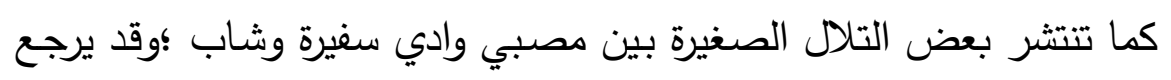

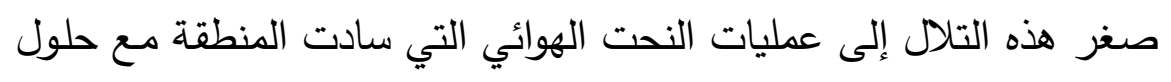

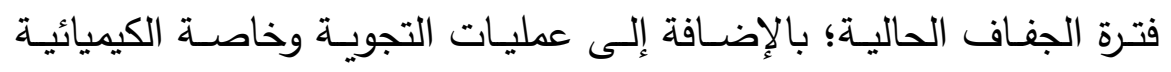
وسقوط الأمطار والتي لعبت دوراً هاماً في زيادة تآكلها وتقلص أحجامها. ج)-الياردنج: تمثل شكلاً من الأشكال الجيومورفولوجية للصحاري والتي فيادي تكونت في صخور لينة قد صقلتها الرياح،وأول من وصفها وأطلق عليها هذا لإنا

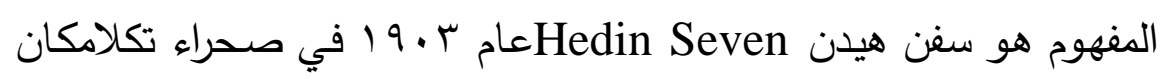

في وسط آسيا (Warren, A\& Livingstone, I ,1996,P.33 ). وتتوزع هذه الظاهرة بمنطقة الدراسة في شكل كتل صخرية متتاثرة كالجزر

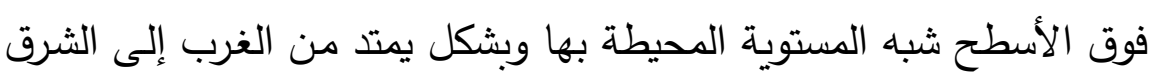
وبمحاور جنوبية غربية -شمالية شرقية.

ويتضح من الجدول ( r ) أن الياردنج بمنطقة الدراسة تتفاوت في أطوالها

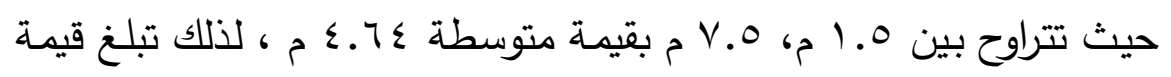

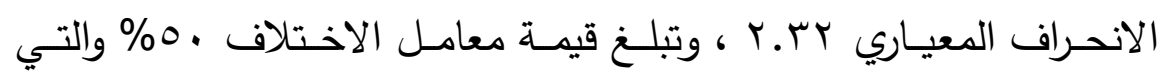

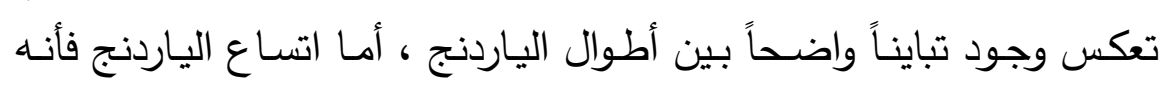

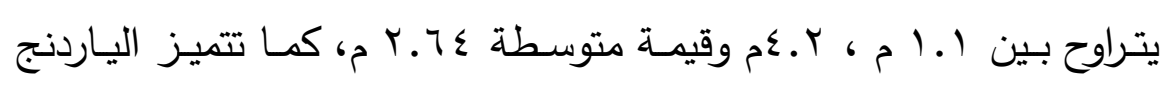

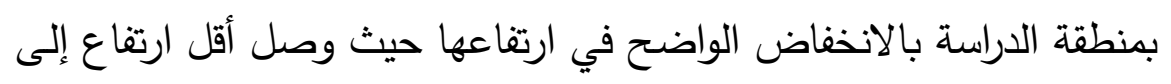

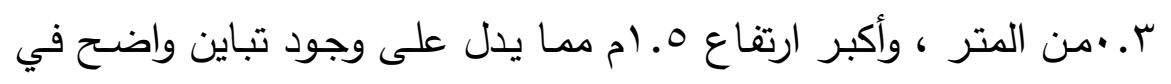


ارتفاعاتها، وهذا مـا يوضحه معامل الاختلاف البالغ \&.به\%، وهذا يدل على شدة انحدار ظاهرة الياردنج بالمنطقة واقترابها من مرحلة الثيخوخة.

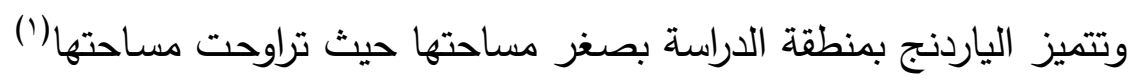

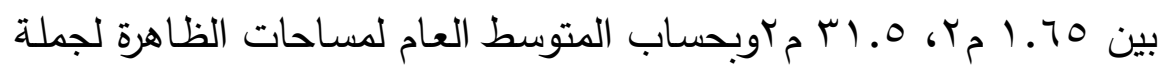

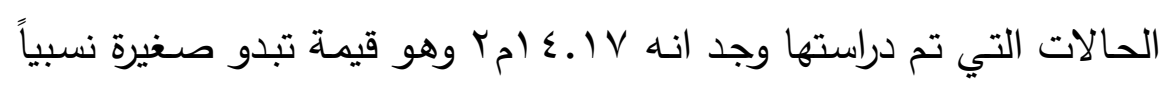

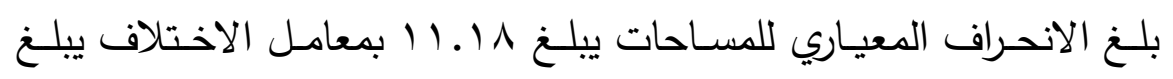
ج \% و و والذي يعكس التفاوت الواضح في مساحات الياردنج بالمنطقة.

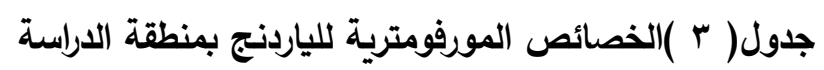

\begin{tabular}{|c|c|c|c|c|c|c|c|c|}
\hline اندجــارة & اندرجـارة & درجـــة & بالمتر ץ & معكلـــل & الالمتر & العترضــ & إلمترل & \\
\hline الظهر & الذيل & الواجهة & & & & & & \\
\hline$\dot{\circ}$ & 11 & rT & $10 . r$ & I & 1.0 & r.o & 8.15 & \\
\hline Orr & rT & $0 \leqslant$ & r..0 & .04 & $\therefore \wedge$ & $\varepsilon_{.} Y$ & $v_{.} .0$ & \\
\hline 814 & ri & 4 & $v_{0} v$ & rT. & 1.1 & r. & $r_{0}$ & \\
\hline$\dot{0}$ & 19 & \&1 & 1.70 & $\cdot v^{V \mu}$ & .7 & 1.1 & 1.0 & \\
\hline$\therefore$ & r & YN & $1 \varepsilon . V Y$ & $\therefore .79$ & $\cdot .^{r}$ & $r . r$ & ๕. & \\
\hline 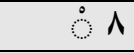 & YY. & Y. \& & 15 & $.7 \xi$ & $\cdot . \wedge 4$ & $Y . T \&$ & $\varepsilon.\rceil \varepsilon$ & المتوسد \\
\hline $0 . V$ & $v .9$ & 18.9 & 11.11 &. .14 & . & 1.10 & T.YT & Lo \\
\hline$\% \vee । . r$ & $\%^{r 0}{ }^{r}$ & $\% \& \varphi^{\prime}$ & $\% \vee \wedge . q$ & $\%^{r} \cdot r^{r}$ & $\% \circ r . \xi$ & $\% \leqslant r .0$ & $\%^{\circ}$ & الاختلاف \\
\hline
\end{tabular}

المصدر:الاراسة الميدانية والخرائط الطبوغرافية //....

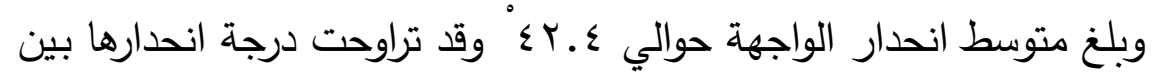

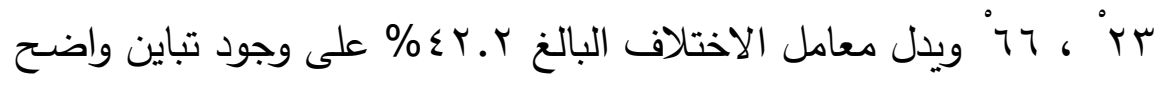

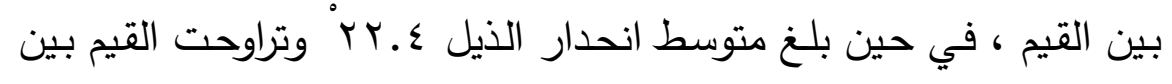

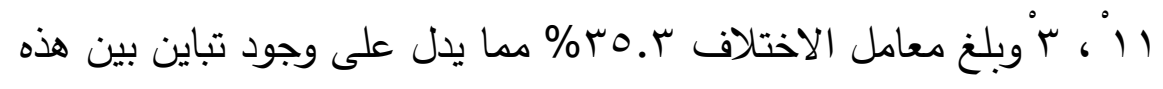

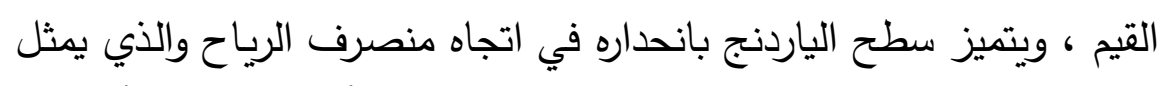

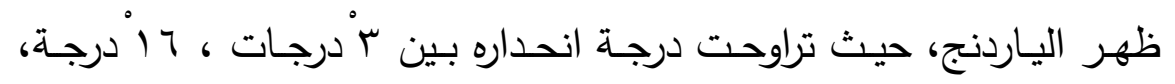

(1) مساحة الياردنج =طول الياردنج × متوسط العرض (التزكماني،9919، ص 119) 
وقيمة متوسطةم درجات وهي قيمة متوسطة تعكس اعتدال الانحدار بشكل

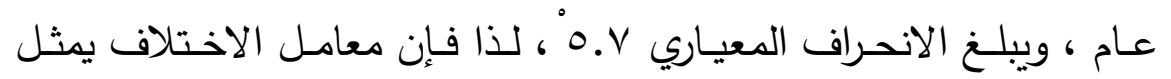
r. اVوهو اختلاف كبير يدل على تباين عمليات البري لأسطح الياردنج

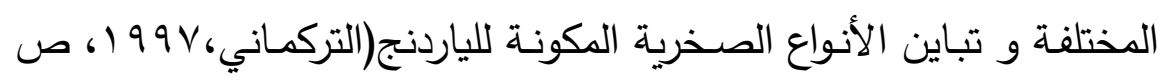
$\cdot(1 \leq 9$

أما بالنسبة لمعامل شكل الياردنج (العرض / الطول) فيزيد معدله بمنطقة الدراسـة حيث يزيــ طول الياردنج فيقل بذلك العرض مقارنـة بالطول (اكبر مـن ( : ع)(') وبالتالي يزيــ معامـل الشكل ويـدل هذا على تـأثير الهيئة الانسيابية السائدة والتي تقلل بدورها من اتساع الثكل بسبب عملية النحت.

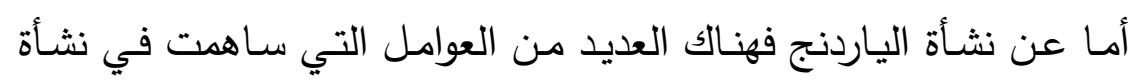
اليـاردنج بمنطقـة الدراسـة متمثلــة فـي العامـل الصــخري و عامـل البنيــة الجيولوجية حيث ترتبط ظاهرة الياردنج باتجاهات بنائية متقاطعة توجد في

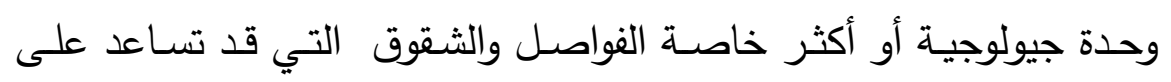
التجويـة الميكانيكيـة كمـا تعرضـت للحركات التكتونيـة التي انتابت المنطقـة خـلال العصـور الجيولوجيـة المختلفــة والتـي مـرت بهـا بدايـة مـن العصـر الكريتاسي إلى العصر الحديث(الهولوسين)، أما العامل المناخي متمثلاً في في لفي عنصر الرياح فكان لله أثر كبير في نشأة الياردنج بالمنطقة ، فالرياحتساهم

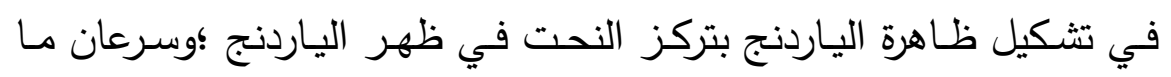

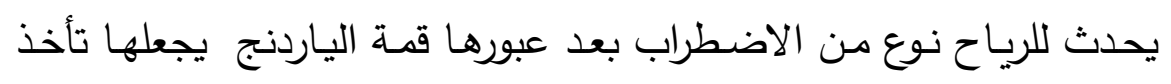

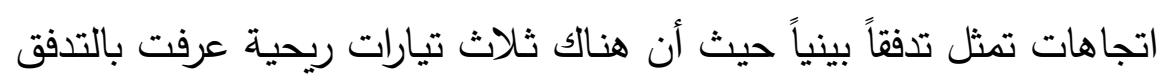

(1) إذا كان معامل شكل الياردنج (العرض /الطول) اكبر مـ 1 : ؛ فبإن هذا يدل على تأثير الهيئة

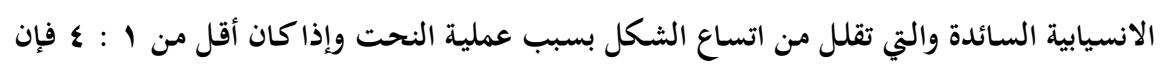

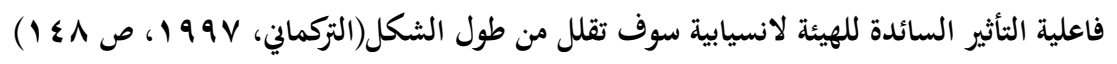


البيني Interfacial flow وهي المسئولة عن نشأة وتثكيل الياردنج أولها تيار التدفق الإيجابي وهو المسئول عن نحت مقدمة الياردنج وثانيها تيار التدفق السلبي وهو الدسئول عن النحت السفلي لجوانب الياردنج وثالثها

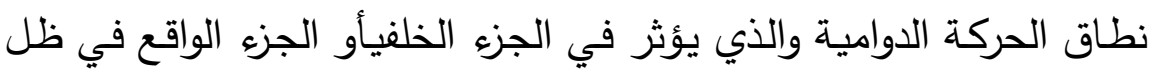
الرياح والذي يمكن تسميته بذيل الياردنج(Breed\&et-al ,1989, p.302)،

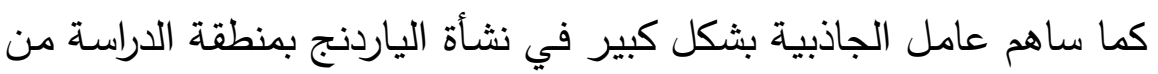

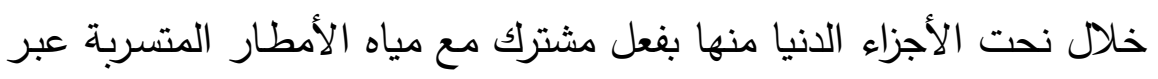

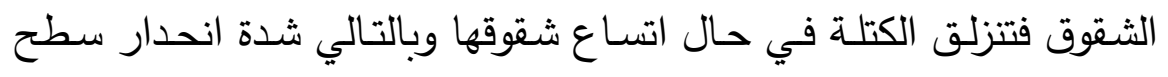

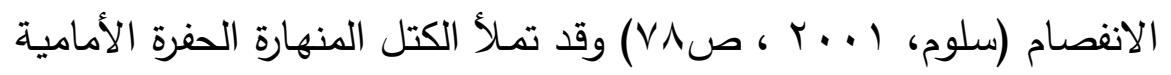

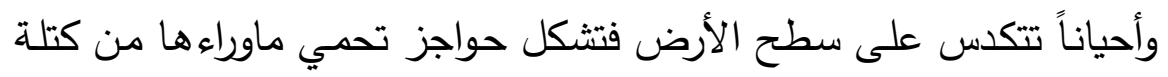
الياردنج من تأثير عامل الرياح.

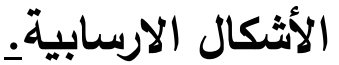

أ)-الدالات الفيضية :- من أهم الظاهرات الإرسابية بمنطقة الدراسة وتتشأ نتيجة لحدوث تغيرات في طبيعـة الجريـان السطحي ، حيث تتبثق الميـاه الجارية والمتجمعة من مناطق تصريف تتميز بوضوح انحدارها من مخرج

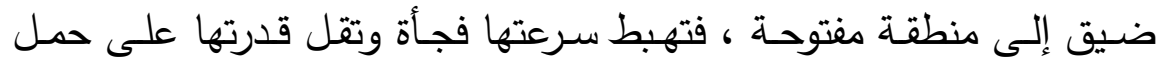

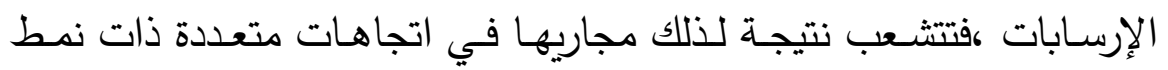
توزيعي إثعاعي ، ثم تتساب المياه في مجاري ضحلة في منطقة رأس الدلتا وتكون هنا مضفرة ، وتمتد الدالات الفيضية بمنطقة الدراسة على هيئة نطاق

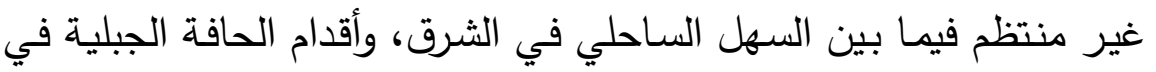

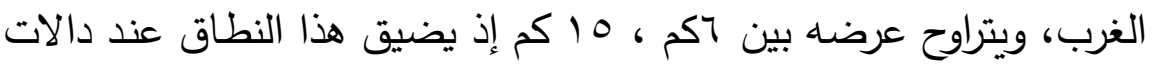

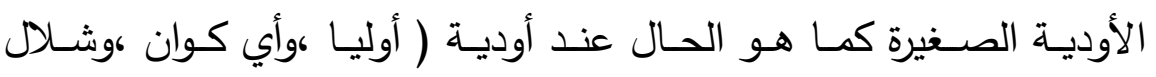

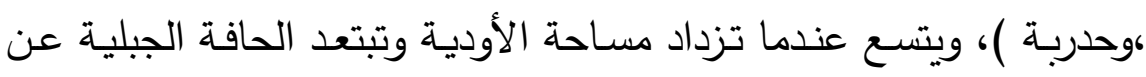


السهل الساحلي وتتقدم الدالات ناحية الثرق على حساب السهل الساحلي كم هو الحال عند دالات أودية (سفيرة ،وشاب ،وايبب ،وميسبة ،وكراف).

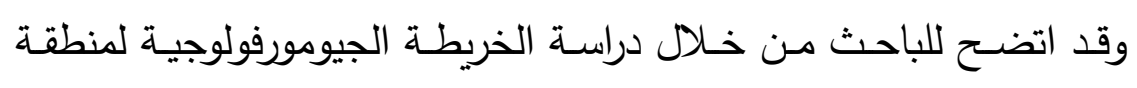

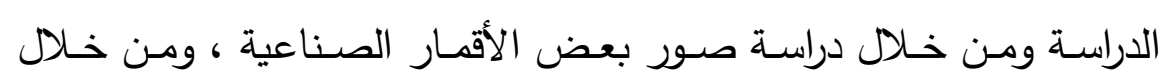

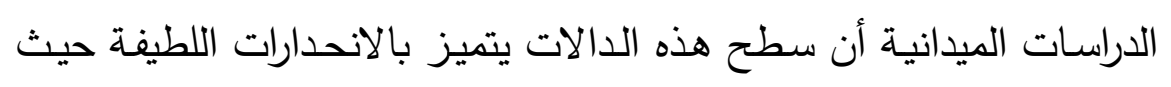

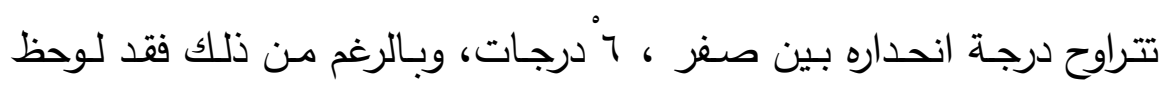

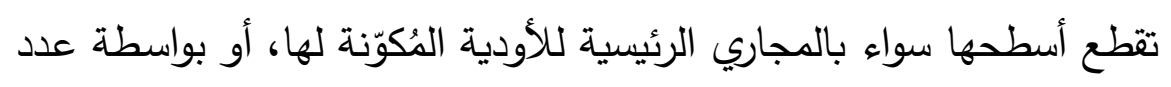

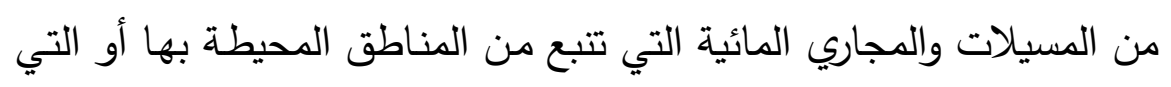

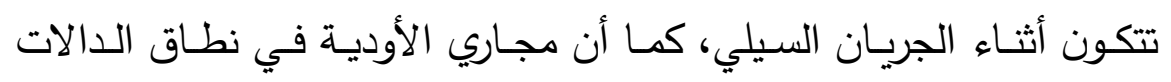
الفيضية تعمق وتُعدل مجاريها بين الحين والآخر .

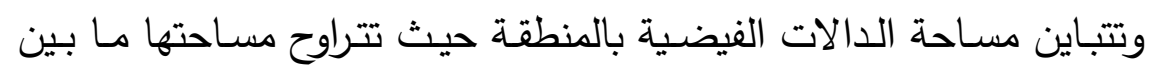

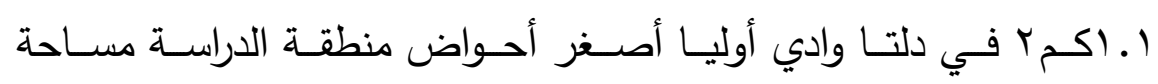

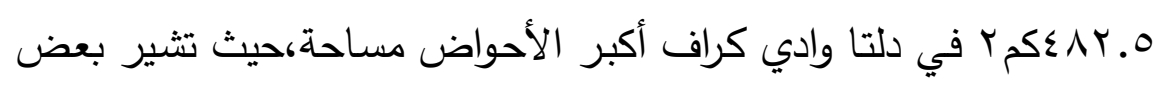
الدراسات(Bull, W, 1977, P.246) \& (Denny,C.S, 1965, P.15) إلى أن مساحة الدالات الفيضية تتناسب طرديًا غالبًا مـع مساحة المنطقة المصدرة لرواسبها (أحواض التصريف بمنطقة الدراسة).

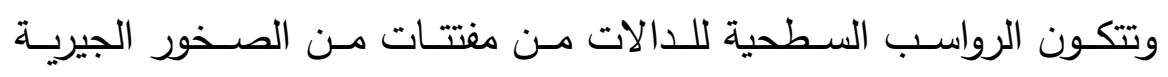

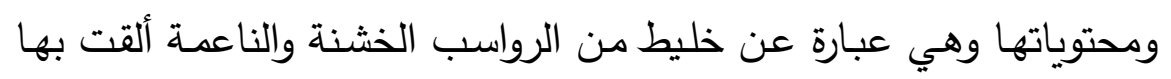

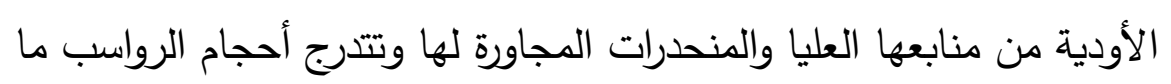

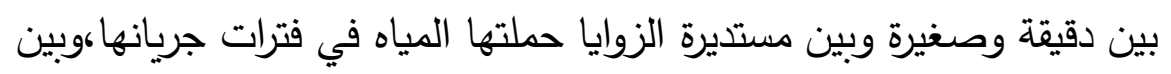

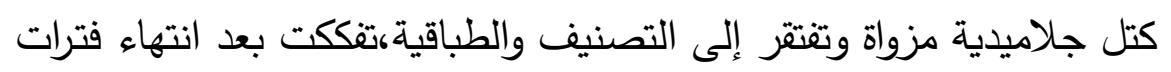

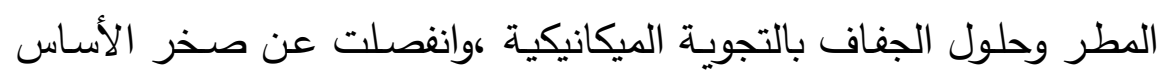
في الحافة،وسقطت لتتراكم على الناعمة وتخفيها أسفلها. 


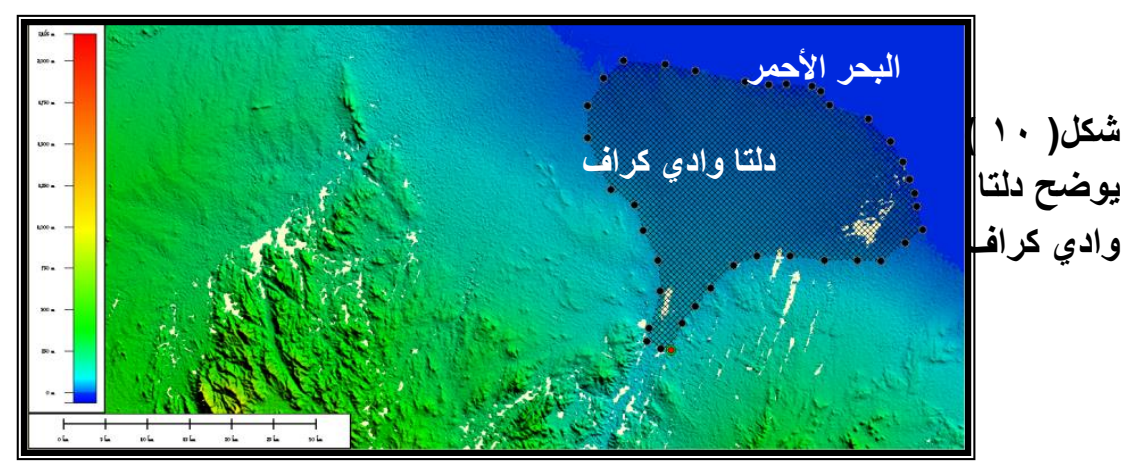

ب)-المصاطب:-من الظاهرات الجيومورفولوجية الخاصة بالتعرية النهرية

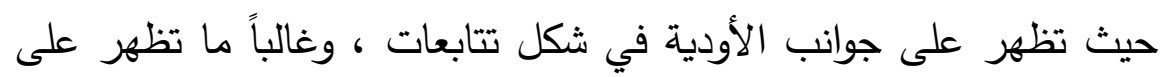

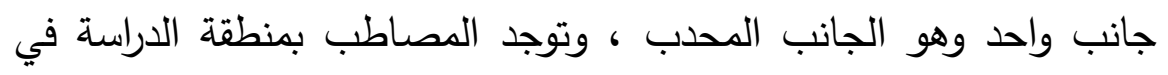

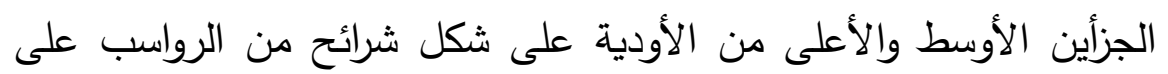

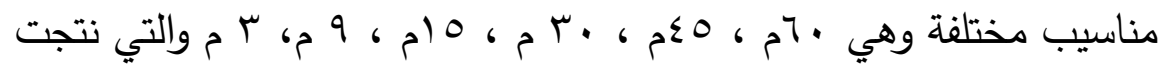

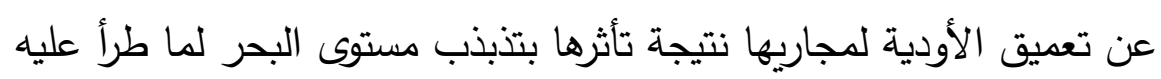

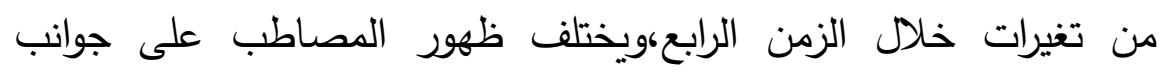
الأودية حيث تعتبر مصطبة 10 ، مصطبة ومن أكثر المصاطب التربن انتشاراً

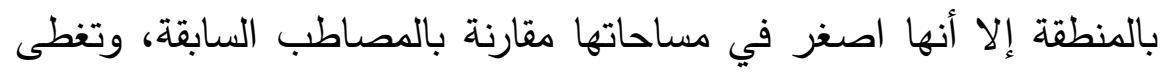
سطوح هذه المصاطب بطبقة مفككة في حجم الحصى والحصباء وتتميز بأنها مشطوفة أو حادة الزوايا وذلك نتيجة لتعرضها لعمليات التجوية

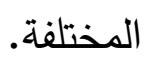

ج)-النباك الرملية:هي شكل من أثكال التراكمات الرملية التي كونتها الرياح

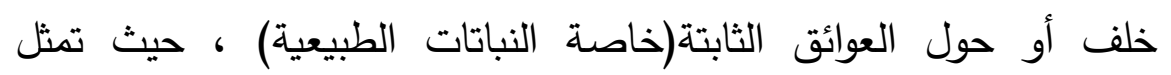

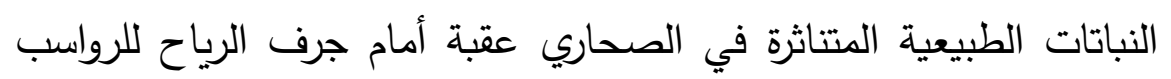

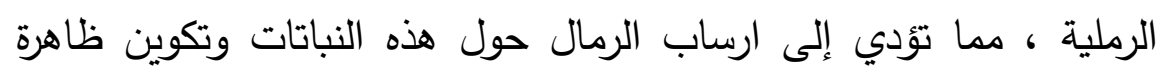

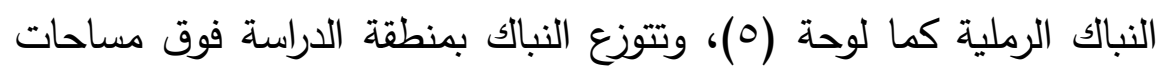

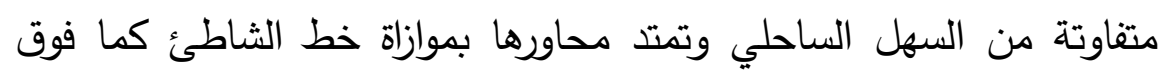


المراوح الفيضية (مراوح أودية سفيرة، شاب، وكراف وابيب وميسبة )، وفي

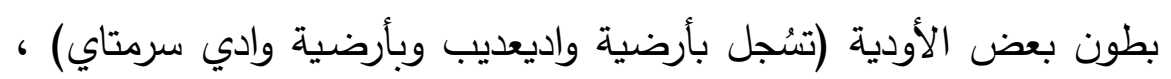

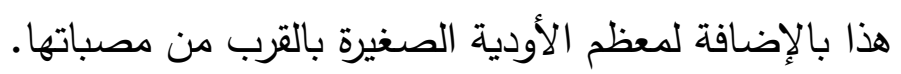

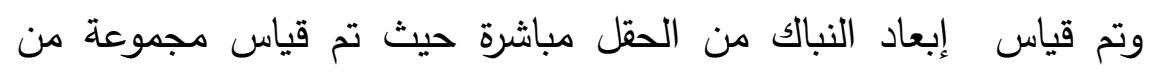

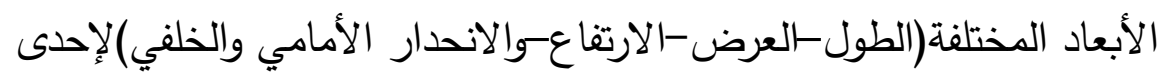

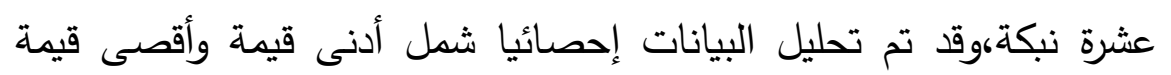

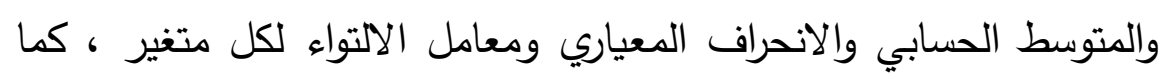

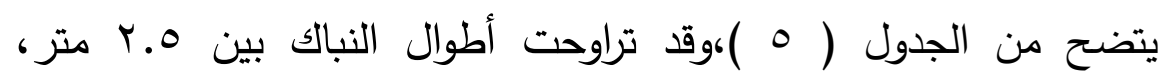

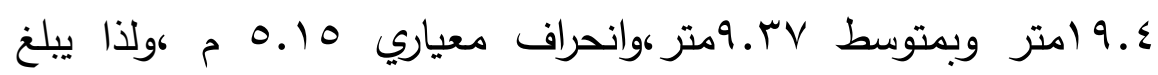
معامل الاختلاف نحو 00\%وهي نسبة تعكس التباين الواضح بين أطوال النباك، ويرجع ذلك الك

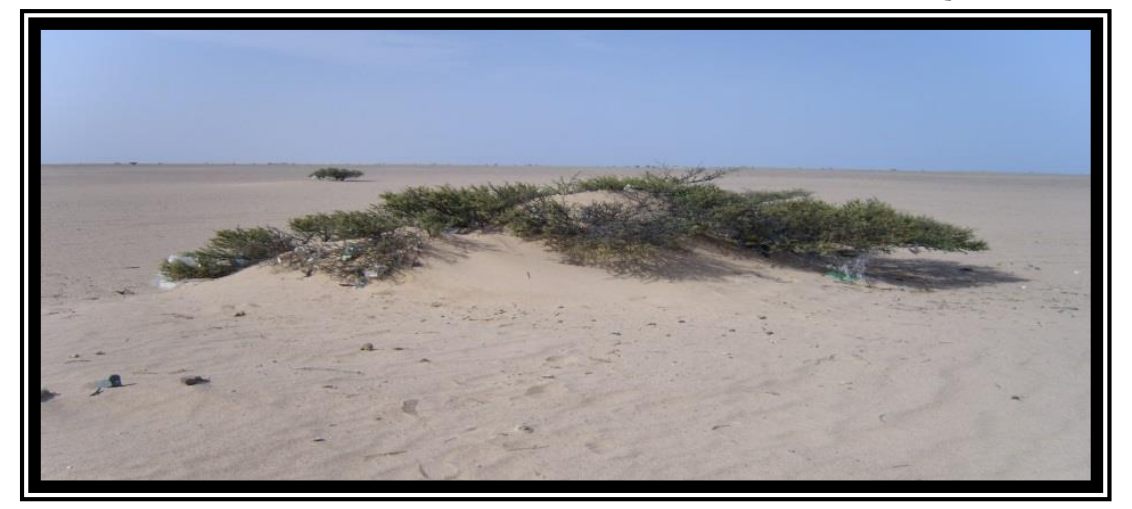

لوحة ( • ) أحدى النباك عند مصب وادي سفيرة. إلى زيادة أطوال النباك بالقرب من خط الساحل مقارنة بالنبالك الموجودة في

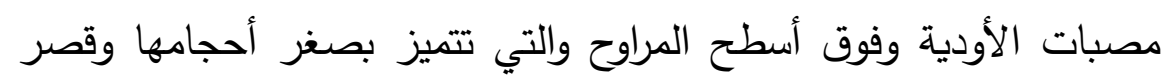

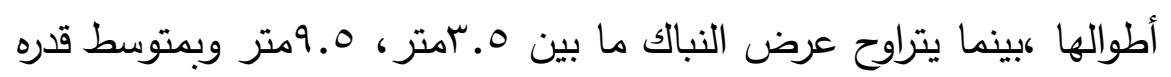

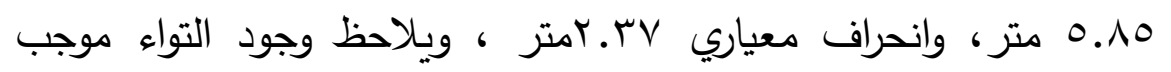

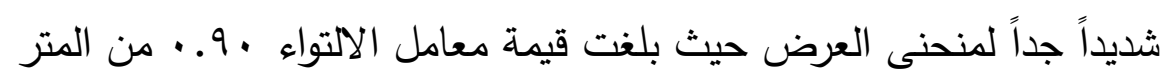




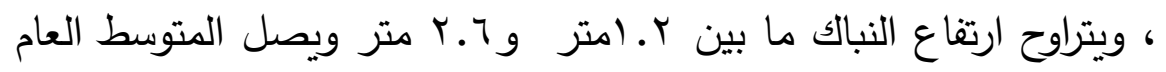

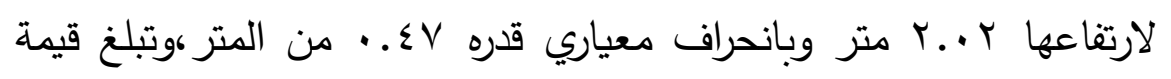

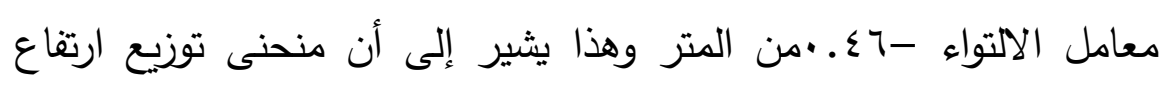

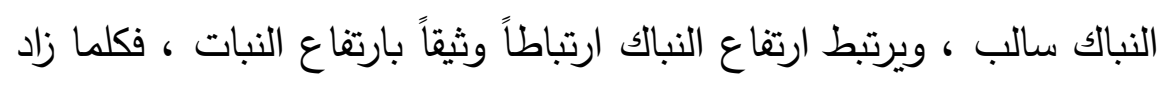

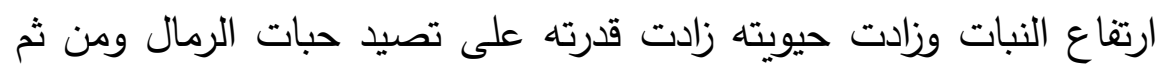

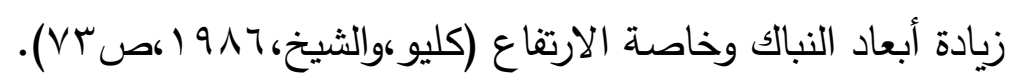

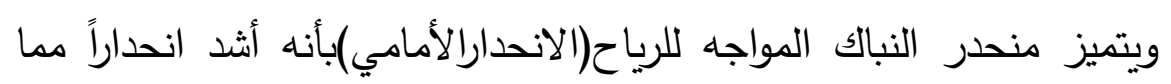

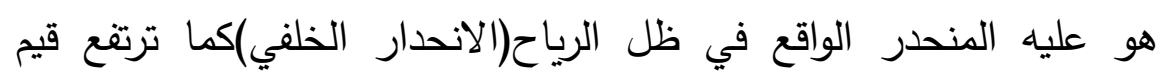

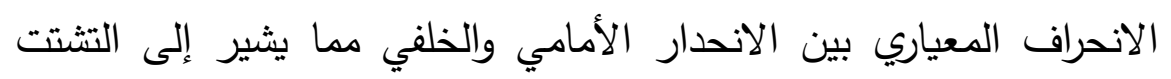

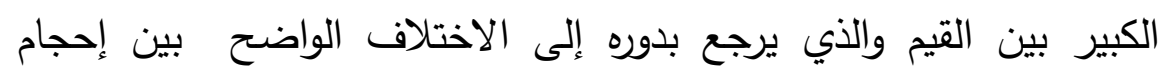

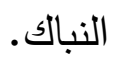

جدول ( ع ) نتائج التحليل الإحصائي لأبعاد النباك بمنطقة الدراسة.

\begin{tabular}{|c|c|c|c|c|c|}
\hline الأمامدار & الخلفي & 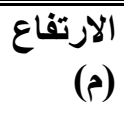 & العرض(م) & $\begin{array}{l}\text { الطول } \\
\text { (م) }\end{array}$ & التحليل لإحصائص \\
\hline ri & 15 & $1 . r$ & r. & r.o & أدنى قيمة \\
\hline$\$ 1$ & YA & Y.T & 9.0 & 19.8 & أقصى قيمة \\
\hline$r 9 . \leqslant 0$ & 11.07 & $r_{.} \cdot Y$ & $0 . \wedge 0$ & $9 . \mathrm{VV}$ & المتوسط \\
\hline $7.7 \mathrm{~V}$ & \&.Y. & $\cdot . \leqslant V$ & Y.rV & 0.10 & أ. معياري \\
\hline$\%$ \%Y.V & $\%$ \% & $\%$ \% & 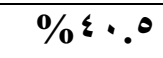 & $\% 00$ & م. الاختّلاف \\
\hline$\because \leqslant Y$ & 1.14 & $\because \leqslant Y_{-}$ & $\because 9$ & .07 & م. الالتواء \\
\hline
\end{tabular}

تم التحليل الإحصائي باستخدام برنامج15 SPSS اعتماداً على نتائج الدراسة العيدانية.

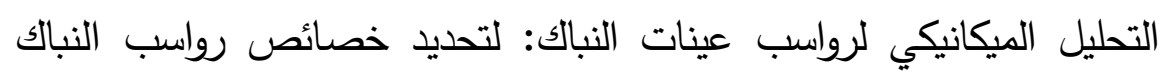
بمنطقة الدراسة تم جمع أربع عينات من رواسبها موزعة توزيعا عشوائيا 
بالمنطقة.و أسفرت نتائج التحليل كما في جدول(0) وشكل (1) عن

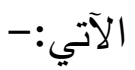

- ارتفاع نسبة الرمال الناعمة والناعمة جدا والطمي والصلصال في جميع العينات، حيث تمثل (.97\%من جملة رواسبها ويدل ذلك على أن هذه الرواسب مشتقة من رواسب الرمال ورواسب بطون الأودية. جدول( ه ) نتائج التحليل الميكانيكي لرواسب النباك بمنطقة الدراسة.

\begin{tabular}{|c|c|c|c|c|c|c|c|c|c|}
\hline 豙 & 年 & 萐 & 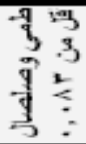 & 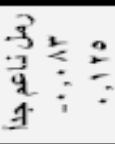 & 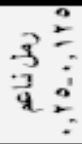 & 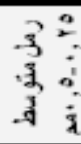 & $\frac{3}{3}$ & $\frac{3}{3} \frac{1}{1}$ & \\
\hline & -'י & & $r$ & $\mu^{\prime \prime, r}$ & ix & rr & 19 & , & \\
\hline , , & $\because, \infty$ & 1 & $r, 0$ & rध & $r r$ & iv & 1,0 & -- & \\
\hline$\overline{\theta, v}$ & & $\cdots$ & 9 & $r$ & $\Leftrightarrow$ & ri & $\lambda$ & -- & \\
\hline$r_{-}$ & $\because, \wedge$ & $\cdots$ & $\Lambda, \uparrow$ & $T^{\prime}$ & ro & 17 & $\overline{\gamma, \lambda}$ & $r, 7$ & \\
\hline
\end{tabular}

r- كذلك ترتفع نسبة الرمال الخشنة جدا والخشنة والمتوسطة في جميع العينات لتصل إلى 9 . • \% من جملة العينات، ويرجع تباين أحجام الرمال

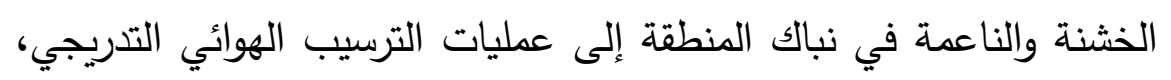

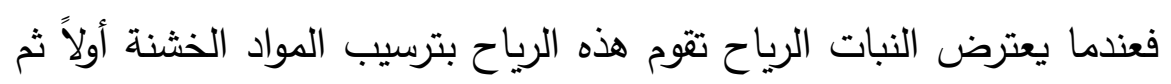

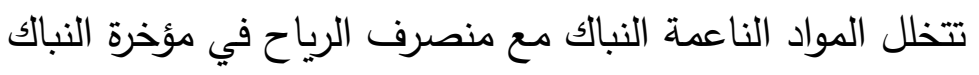

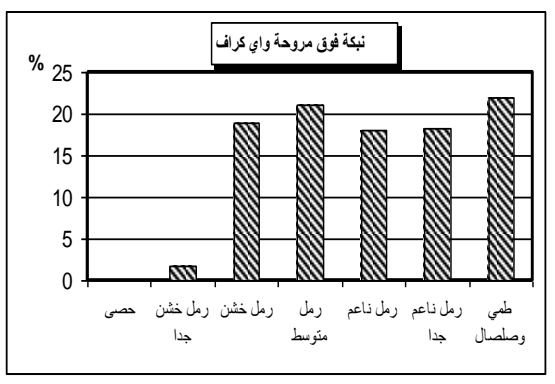




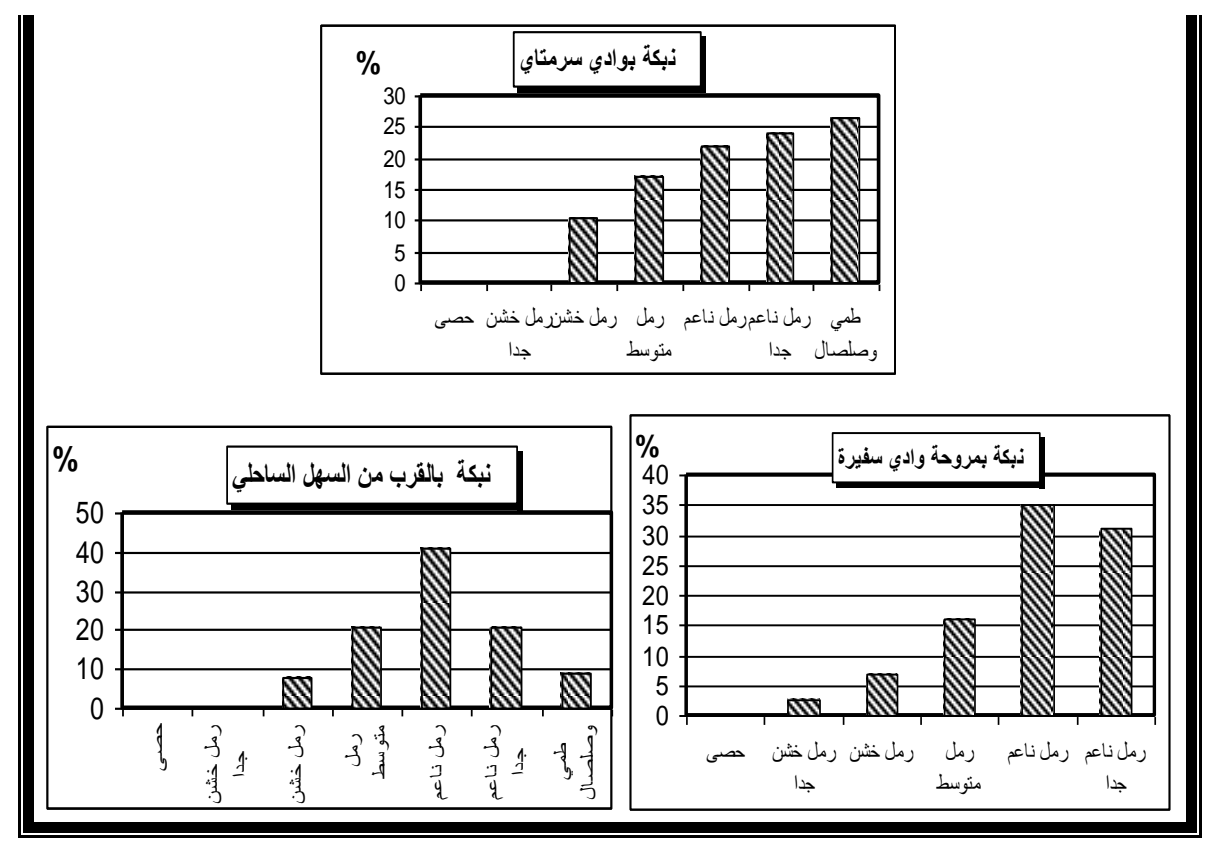

شكل(1 1 ) ) توزيع أحجام رواسب النباك بمنطقة الدراسة

أما عن الالتواء فبلغ متوسطه ا .. أي التواء موجب، وقد اختلف من عينة

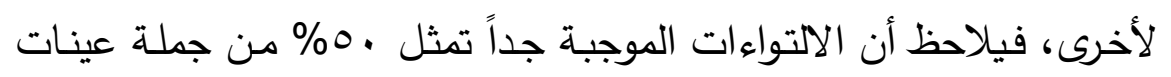
الدراسـة، وأن الالتواءات السالبة جدا تمثل ــــن جملة العينات. وقد تم حساب التفلطح، ووجد أن منحنيات الرواسب بالمنطقة تتسم بأنها ذات تفلطح شديد التدبب. وتمثل المنحنيات ذات التقلطح الشديد التدبب ه٪\%من جملة منحنيـات العينات، وتمثل المنحنيات المفلطحة هب \% مـن جملـة منحنيـات العينات،وهذا يدل على أن رواسب النباك من أصل قاري مع وجود العديد

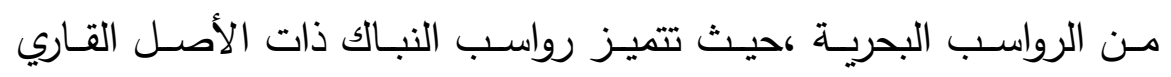
بالالتواء السالب في حين تتميز رواسب الكثبان الساحلية بالالتواء الموجب. جدول ( 7 ) خصائص توزيع أحجام رواسب النباك 


\begin{tabular}{|c|c|c|c|c|c|c|c|c|c|c|c|}
\hline \multicolumn{12}{|c|}{ التعبيرات الوصفية لفئات التواء منحنى توزيع أحجام النباك. } \\
\hline \multicolumn{2}{|c|}{ المجموع } & \multicolumn{2}{|c|}{ التواء موجب جداً } & \multicolumn{2}{|c|}{ التواء موجب } & \multicolumn{2}{|c|}{ التواء متماثل } & \multicolumn{2}{|c|}{ التواء سالب } & \multicolumn{2}{|c|}{ التواء سالب جداً } \\
\hline$\%$ & عدد & $\%$ & عدد & $\%$ & عدد & $\%$ & عدد & $\%$ & العدد & $\%$ & عدد اد \\
\hline$\cdots$ & $\varepsilon$ & $\circ$. & $r$ & - & - & - & - & - & - & $\circ$. & r \\
\hline \multicolumn{12}{|c|}{ التعبيرات الوصفية لفئات تفلطح رواسب النباك. } \\
\hline \multicolumn{2}{|c|}{ المجموع } & \multicolumn{2}{|c|}{ تفلطح شديد التدبب } & \multicolumn{2}{|c|}{ تفلطح مدبب } & \multicolumn{2}{|c|}{ تفلطح متوسط } & \multicolumn{2}{|r|}{ 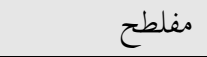 } & \multicolumn{2}{|c|}{ تفلطح شديد } \\
\hline$\%$ & العدد & $\%$ & العدد & $\%$ & العدد & $\%$ & العدد & $\%$ & العدد & $\%$ & العدد \\
\hline- & - & - & ro & 1 & Vo & - & - & - & ro & 1 & $v_{0}$ \\
\hline
\end{tabular}

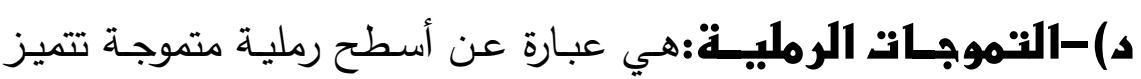
بشذوات سطحية نتيجة عملية ترسيب سريعة فوق سطح مستوي نسبياً عن طرق الزحف Creep والقفز Saltation،وتتكون من رمال مفككة متجانسة الحجم نسبياً تأخذ هيئة مموجة على أسطح الصحراء،وتأخذ اتجاهات متأثرة

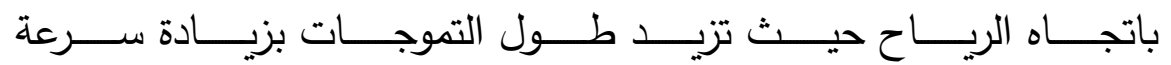

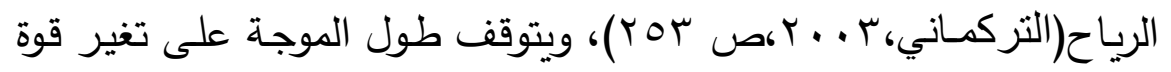
الرياح ،بينما يؤثر التغير في اتجاه وسرعة الرياح على انتظام أشكالها كما يتضح من الشكل (Y)

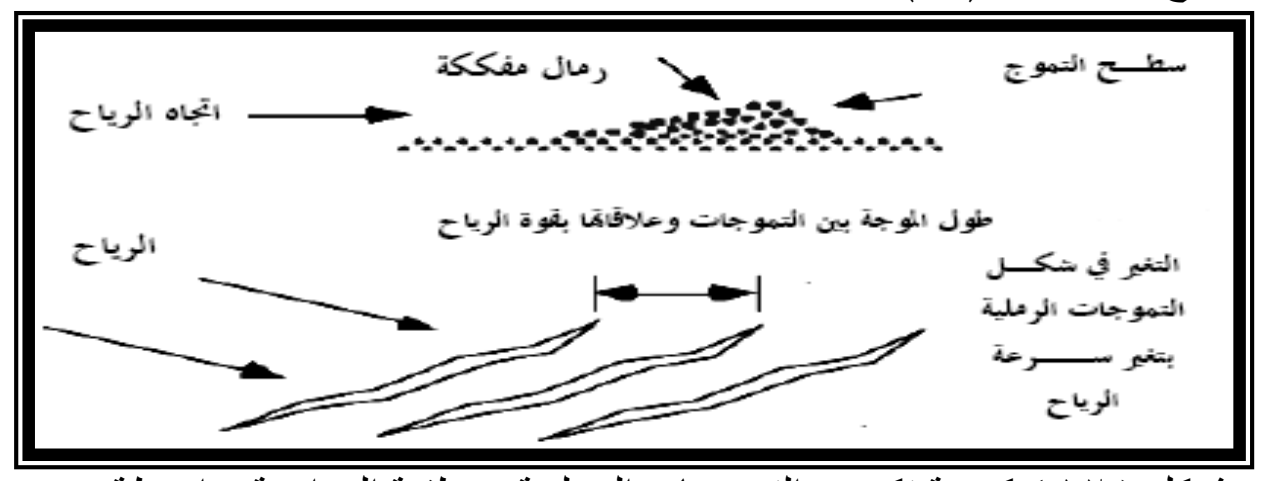

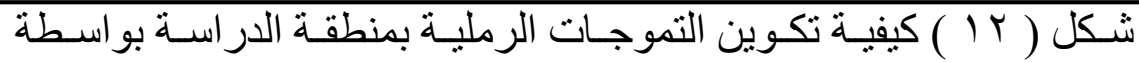
الرياح. 
وتتميز كل موجة بوجود جانبين ينحدران في اتجاهين متضادين ويلتقيان في

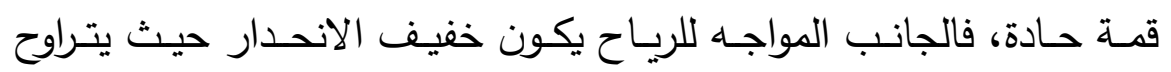

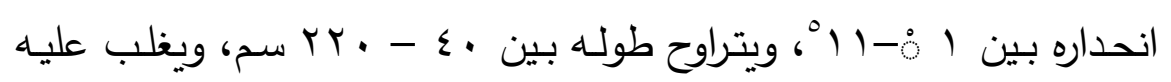

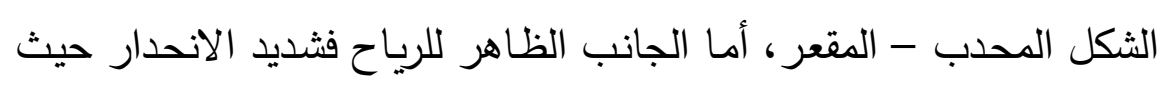

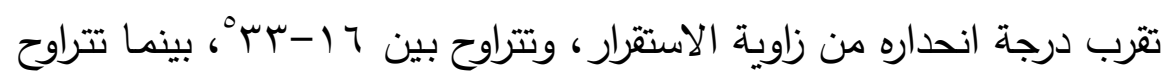

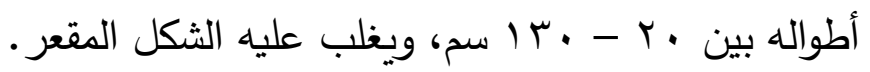

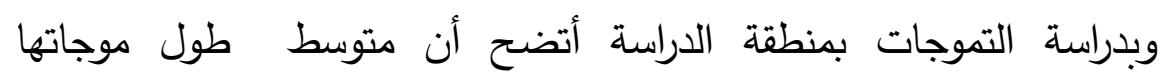

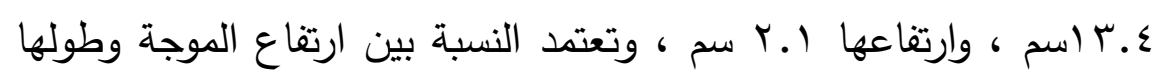

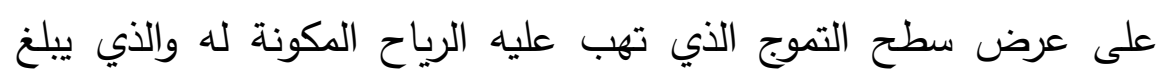

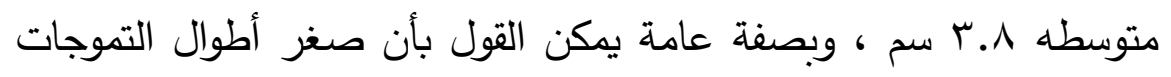
الرملية بمنطقة الدراسة يدلعلى ضعف وسبط سرعة الرياح نظراً لأن أطوال

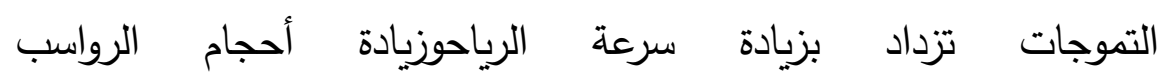
.(Cooke,R.,\&Warren,A.,1973,p.268)

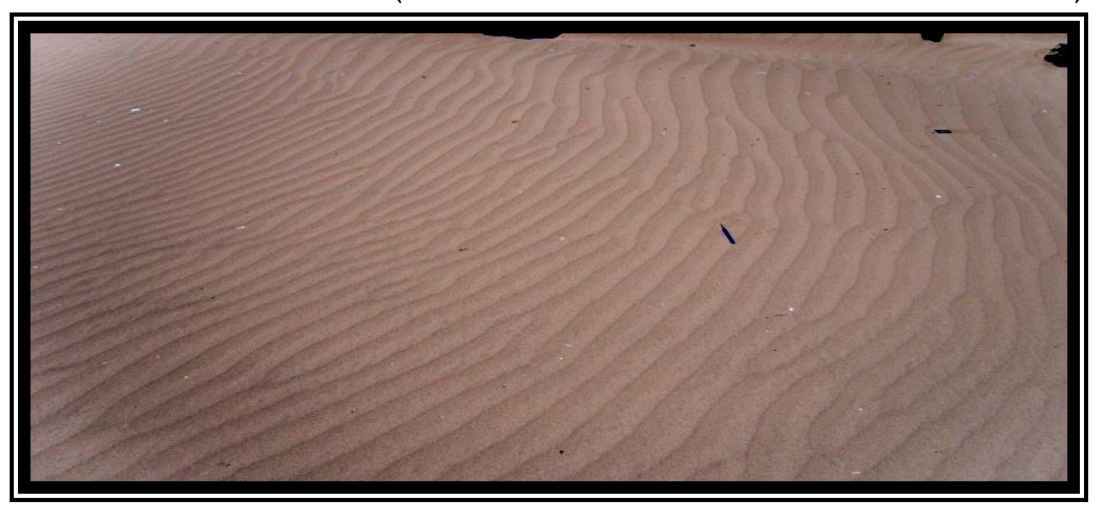

لوحة ( V ) توضح التموجات الرملية بمنطقة جبل علبة

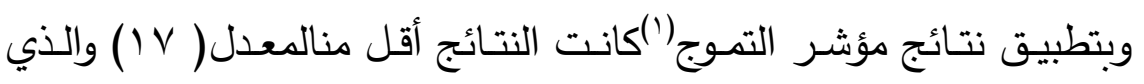

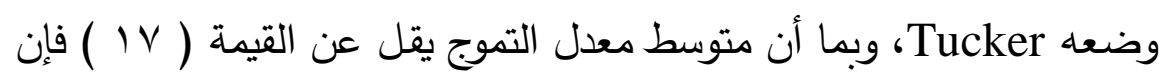


ذلك يفسر بأن أصل الرمال ليست الريـاح وحدها بل تدخلت فيها عوامل

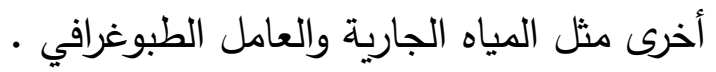
ومسن خـلال التحليل الميكانيكي لثناث عينـات لرواسب التموجـات الرملية

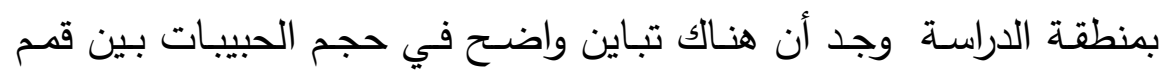

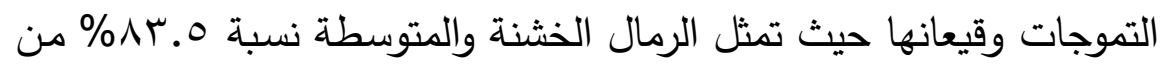

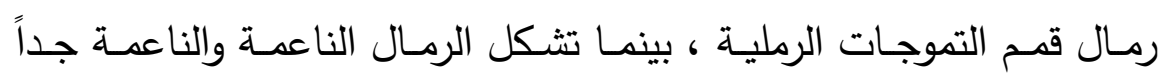

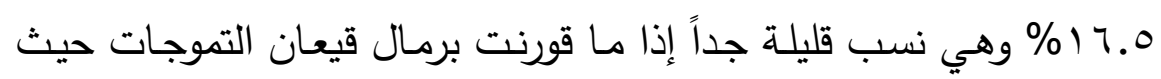

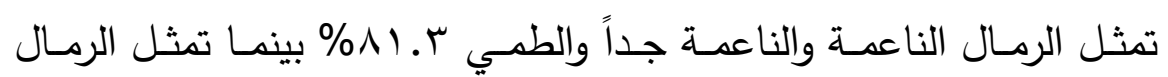

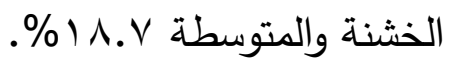
ثالثاً:-الظاهر ات الساحلية: تساهم التعرية الساحلية بدور كبير في تثكيل مظاهر السطح بمنطقة الدراسة

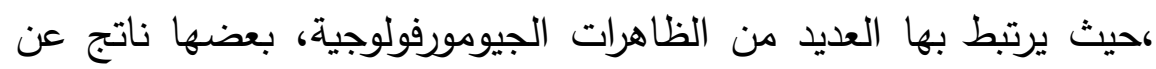

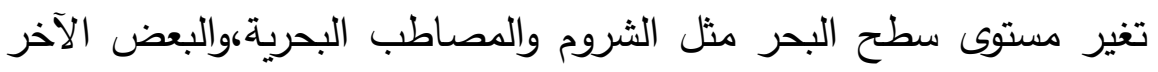

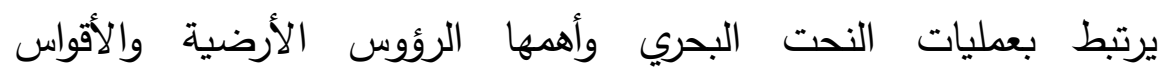

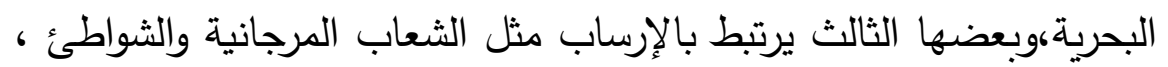
والسبخات وفيما يلي دراسة تفصيلية لكل منها على النحو التالي:ا ـالظاهر ات الناتجة عن تغير مستوى البحر.

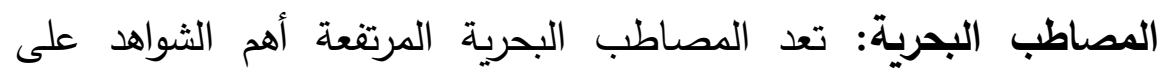

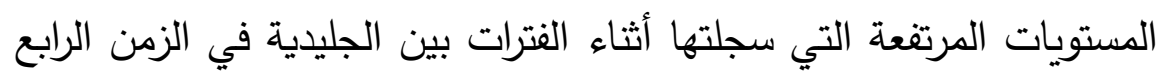

مؤشر التموج.Thipple. Index

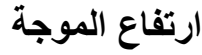

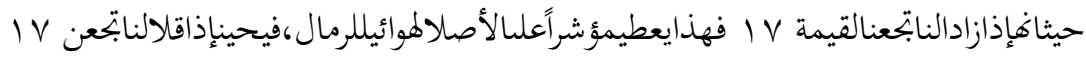

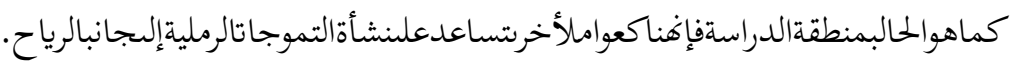


، ويعود عمرها إلى عصر البلايوستوسين. وتشاهد بقايا أسطح هذه المصاطب المرتفعة على مناسيب مرتفعة عن مستوى سطح البحر الحالي

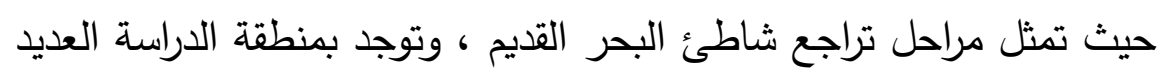

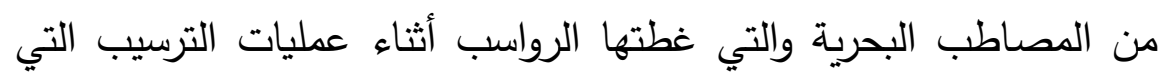

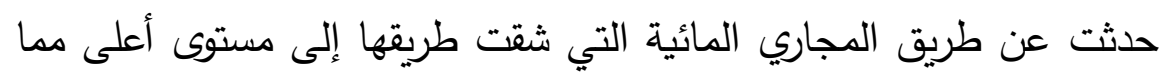

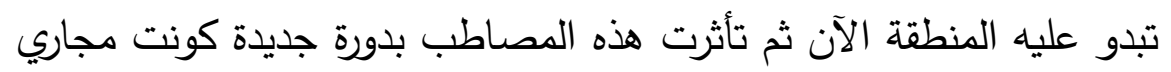

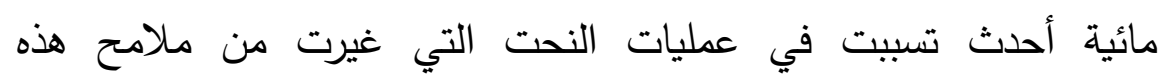

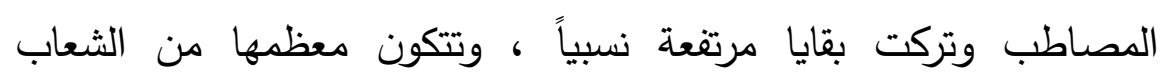
المرجانية والحجر الجيري والحجر الرملي المرجاني.

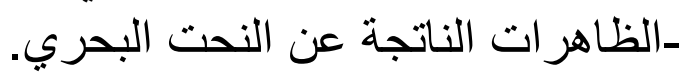

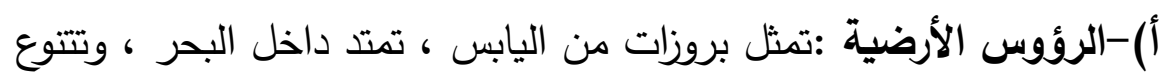

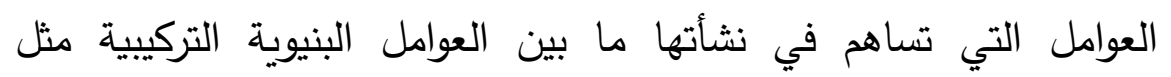

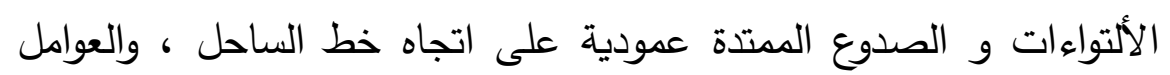

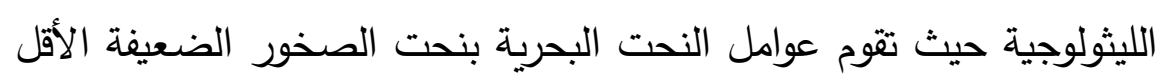

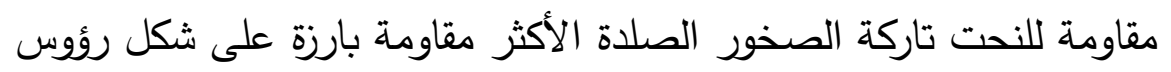
ناتئة متعمقة في البحر ،وتتميز الرؤوس الأرضية بمنطقة الدراسة بأنها ظاهرة

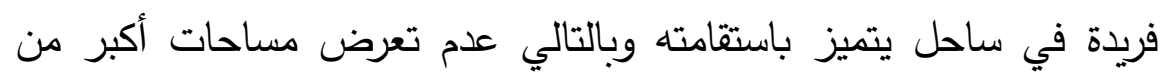
مكاشف الصخور أمام عوامل التعرية البحرية،ويبلغ عدد الرؤوس الأرضية

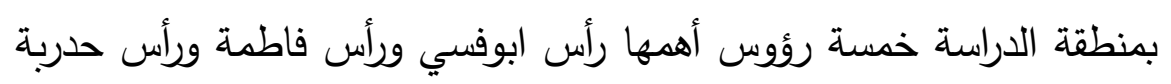

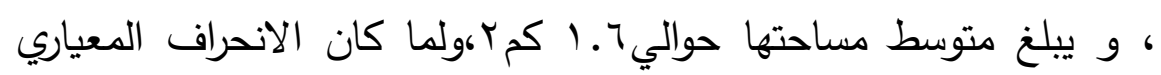

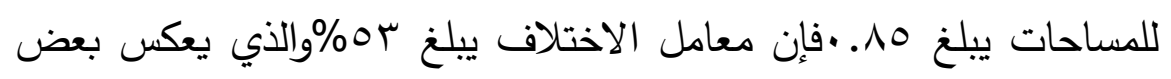
التفاوت في مساحات الرؤوس الأرضية بالمنطقة. ب)- الأقواس البحرية:تتكون في المناطق الساحلية التي يمتد فيها اليابس الترفي على هيئة لسـان صخري في عرض البحر ، مما يؤدي إلى ارتطام مياه 
الأمواج به من كلا جانبيه. فتتكون كهوف بحرية عند كلا هذين الجانبين ومع استمرار النحت يتقابل الكهفان. ويتكون في هذه الحالة نفقُ محفور في

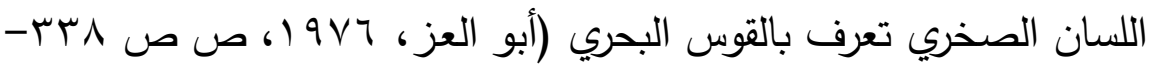

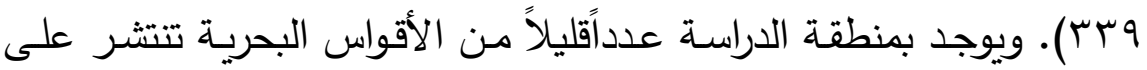

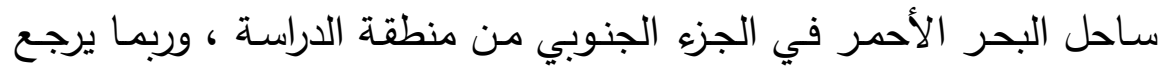

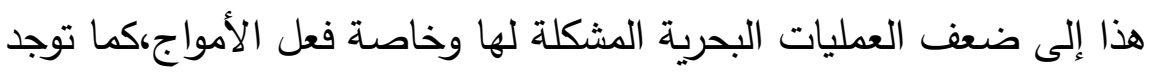

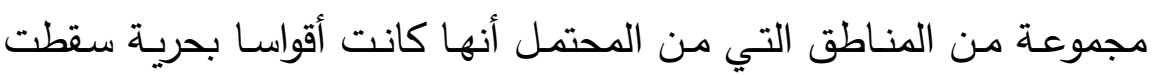

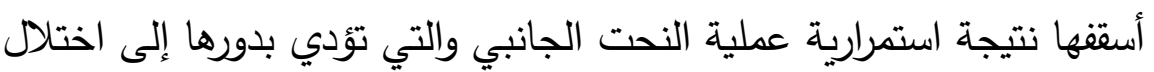

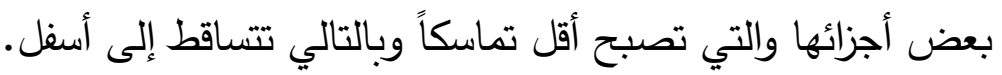
r- الظاهر ات الناتجة عن الإرساب البحري.

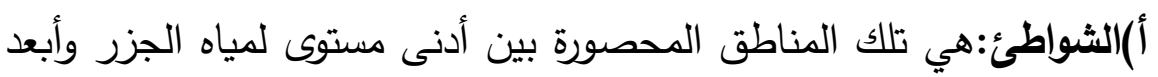

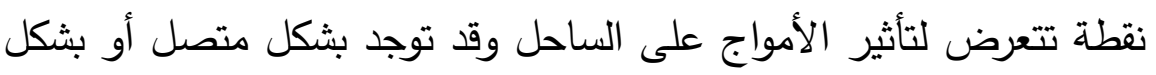

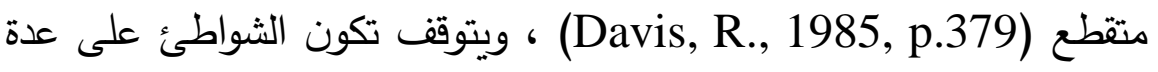
عوامل منها مدى اقتراب الجروف البحرية من الساحل ، ودرجة انحدار الرفرف القارى والمنطقة الساحلية ، والمنسوب الذي تصل إليه أمواج الدد ،

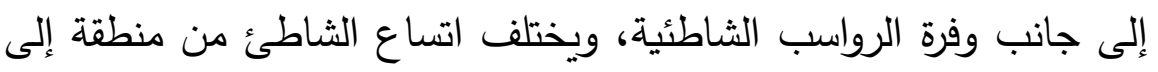

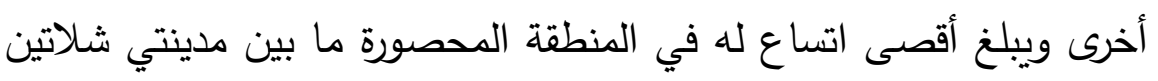

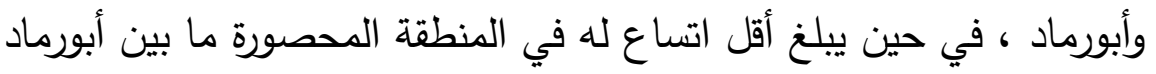

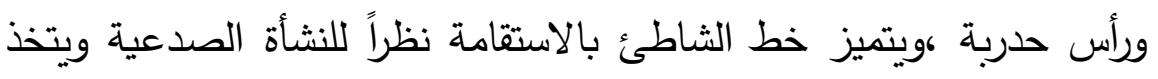

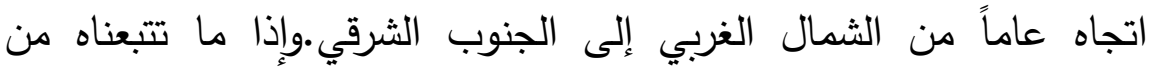

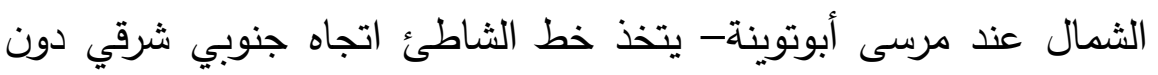

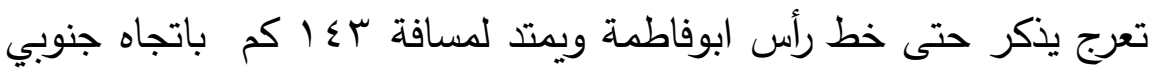

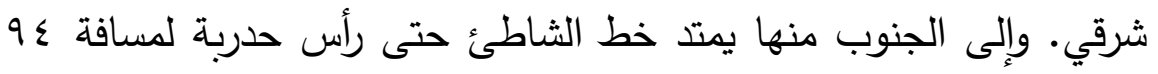

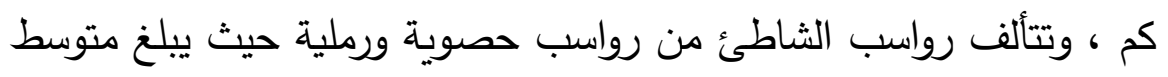




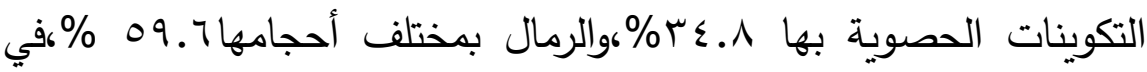
حين لا تتعدى نسبة الطين والصلصال 0.7 \%ويرجع التباين في هذه الرواسب إلى المصدر الذي اشتقت منه.

ب)-السبخات :هي عبارة عن مسطحات أرضية أو مناطق حوضية تغرها

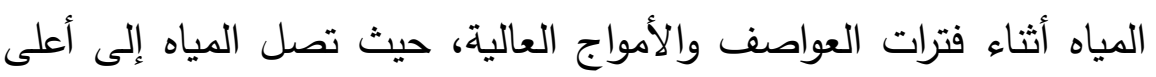
من سطح الحاجز فتكون سببا مباشرا في نشأتها وتغطيها طبقة من الطين

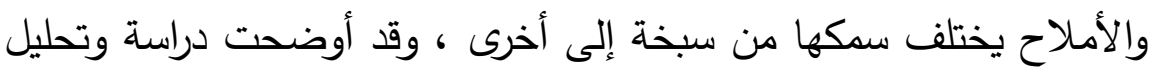
الخرائط والمرئيات الفضائية أن السبخات بمنطقة الدراسة تثغل مساحة تقدر التراح

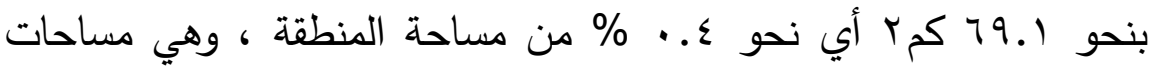
صغيرة حيث تتقلص مساحات بعض السبخات ويندثر البعض الآخر نتيجة

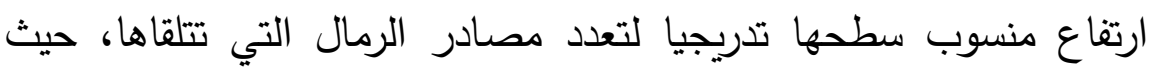

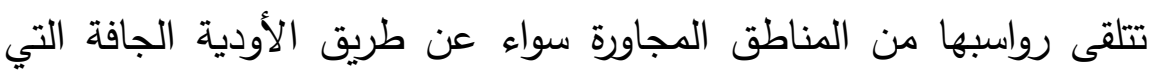

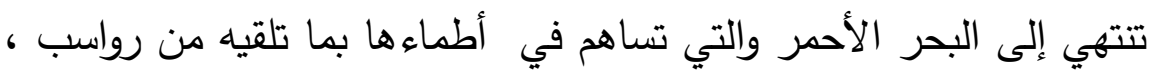

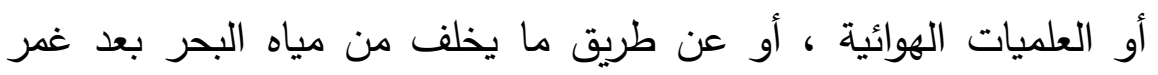

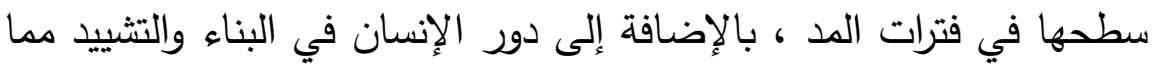
أدى إلى إزالة العديد من السبخات خاصة السبخات الساحلية منها.

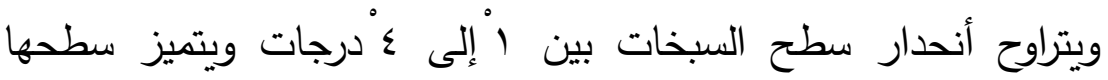

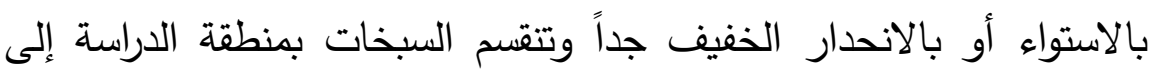
سبخات ساحلية وسبخات داخلية وفيما يلي دراسة لكل منها:-السبخات السـاحلية :عبارة عن مسطحات شبه مستوية، مغطاة بقشرة

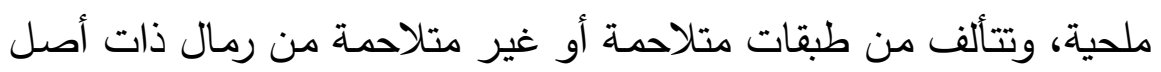

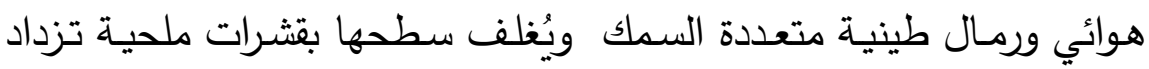

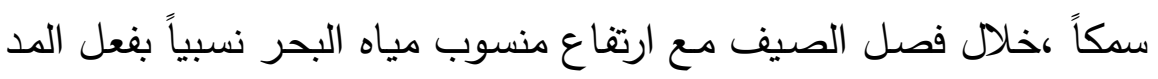


العالي وصعود جزء من المياه إلى السطح عن طريق الخاصسة الثعرية ،كما تنمو النباتات في بعضها خاصة النباتات الملحية وتمتد السبخات على طول خط السـاحل في النطاق الممتد من شرم المدفع حتى مرسى حفرات الملح كويرجع ذلك إلى ابتعاد الحافة الجبلية واتساع نطاق السهل الساحلي ،مما لايدع مجالاً أمام عوامل التعرية السائدة على سطح المنطقة حالياً في طمس معالم هذه السبخات أو إزالـة بعض الأجزاء منها ،فمعظم الأوديـة المنتهية للسـاحل ليس لها القدرة على أطماء السبخات المنتشرة على طول السـاحل وإزالتها ، كمـا يقتصـر دور الريـاح على نقل المـواد أو المفتتات المتوسطة والناعمـة و إرسـابها في ظل النباتـات المنتشـرة حول هـوامش السـبخات ، بالإضـافة إلى أن التدخل البشرى لم يمتد إلى السبخات القريبة من مراكز العمران والمتمثلة في منطقتي حلايب وابورماد.

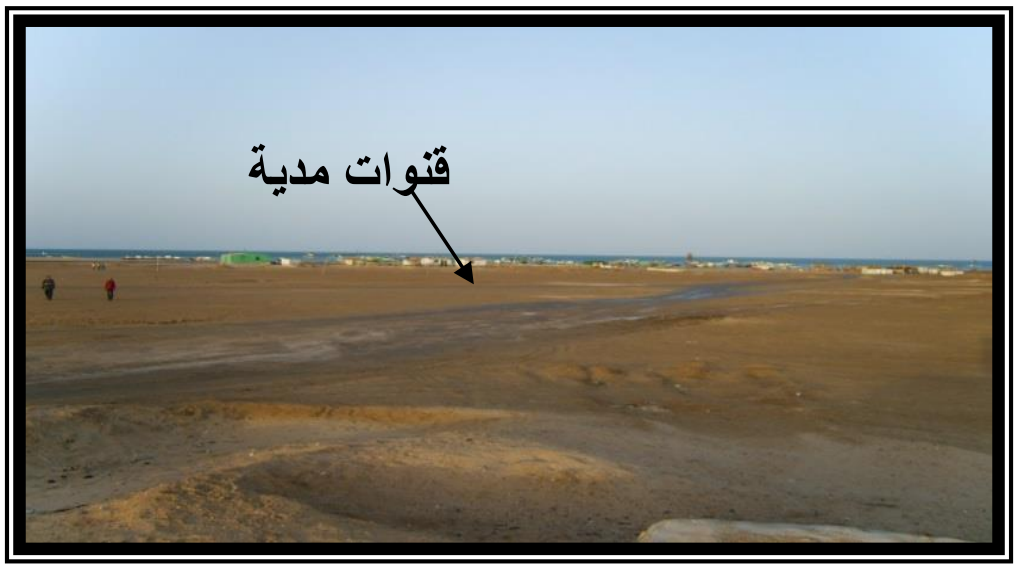

لوحســــــ 1 ( ) إحدى السبخات

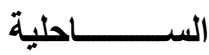
بــالقرب مسـن مدينــة شـلاتين ويلاحظظ إقامـة بعض المنشـآت العمرانيـة فوق سطحها

وقد بلـغ عدد السبخات السـاحلية بمنطقة الدراسـة سا سبخة،تشـل مسـاحة

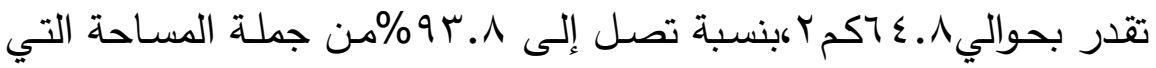

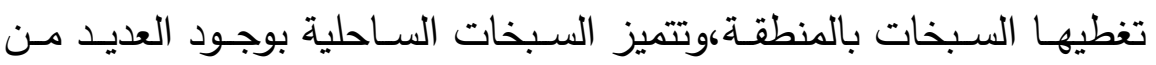
الظـاهرات الجيومورفولوجيـة فـوق أسطحها أهمهـا القنـوات المديـة والخوانتق الصغيرة والمضلعات والتتهدات الملحية والقباب أو الأقماع الملحية. 
-السبخات الاخليـة:تقع بعيداً عن السـاحل فيما وراء تأثير المد البحري وتتثابه في الخصائص مع السبخات الساحلية حيث أنها ليست سوى بقايا

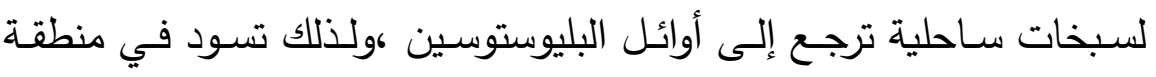

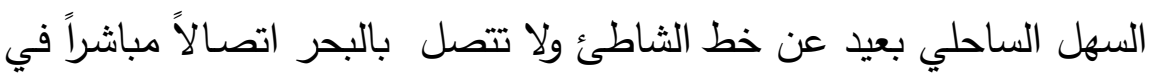

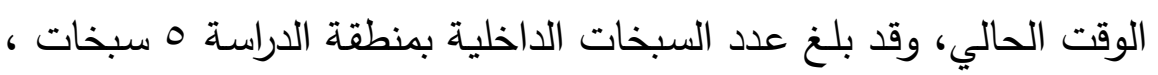

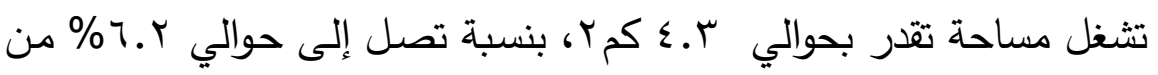

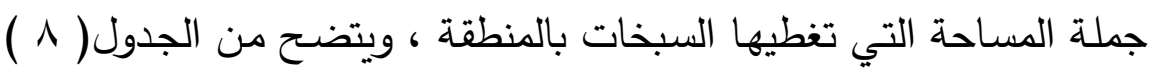
للخصائص الميكانيكية لرواسب العينات التي جمعت من بعض التبات السبخات

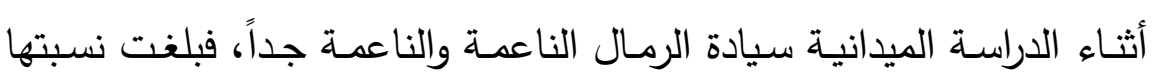

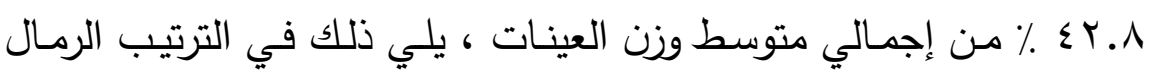

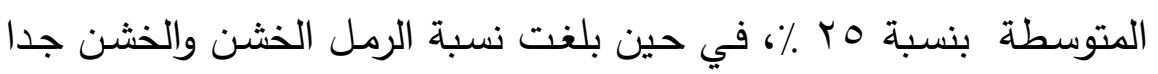

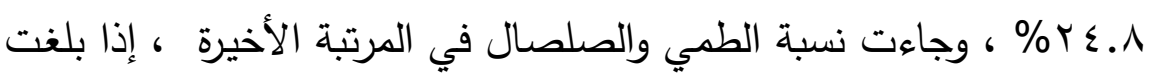
نسبتها ؟. ٪\% من إجمالي متوسط وزن العينات.

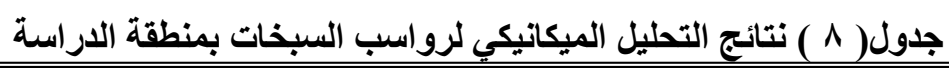

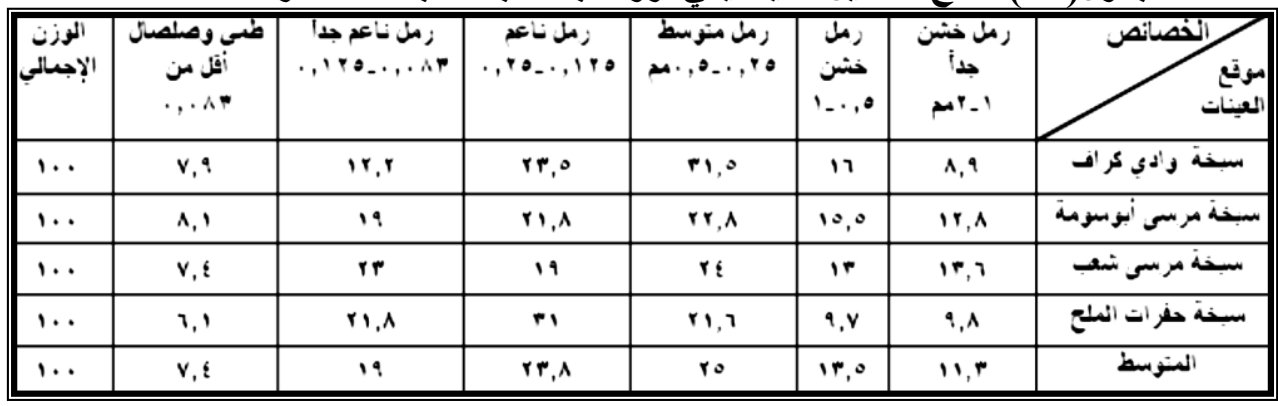

وللتعرف على الخصائص الطبيعية للبنية الداخلية لرواسب السبخات فقد

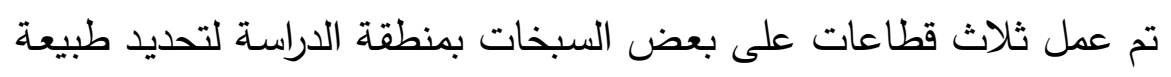

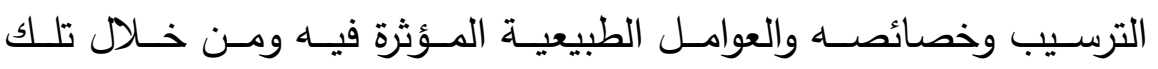
القطاعات يتضح أن هناك بعض السبخات التي تغطى بقشرة ملحية رقيقة 
كما في سبخة حفرات الملح في حين تغطى سبخة مرسى شعب بقشرة ملحية يميل لونها إلى البني الفـاتح والتي ربمـا يرجع وجودهـا إلى تبخر الميـاه الجوفية الموجودة على سطحها.

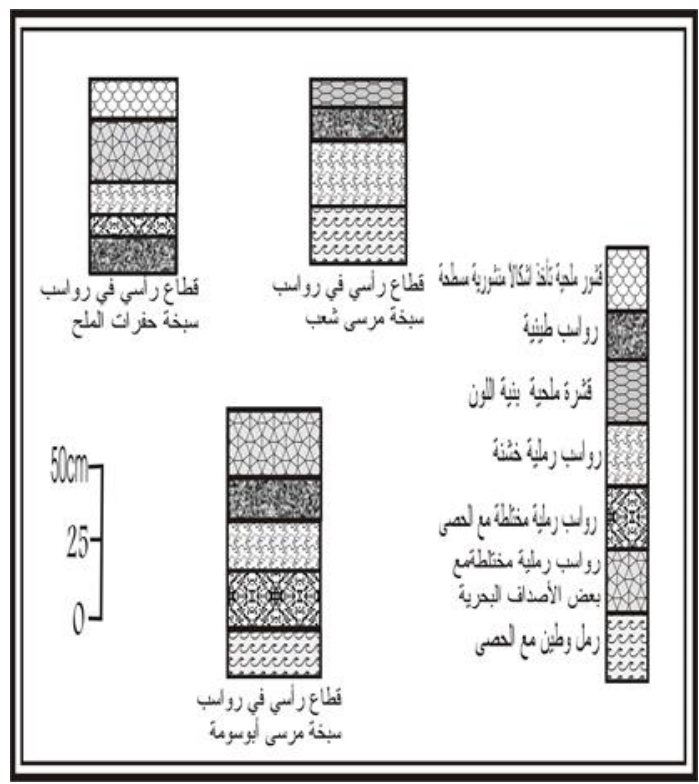

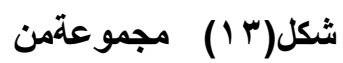
القطاعات الرأسية في رواسب بعض سبخات منطقة الدراسة

كما يتضح من خلال دراسة هذه القطاعات أن تتوع مصادر رواسب هذه

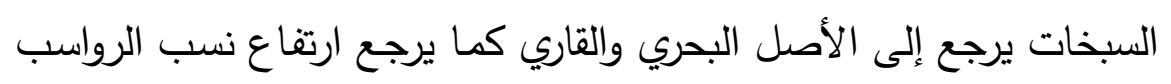
الطينية إلى تفوق البحر وطغيانه على تلك المناطق لفترة طويلة. رابعاً:دور الخريطة المورفولوجية لمنطقة حلايب في التتمية:

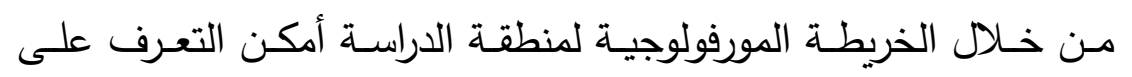
العديد من المقومات الطبيعية ،والتي يمكن أن تجعل منطقة حلايب محوراً

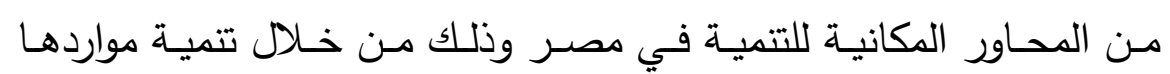

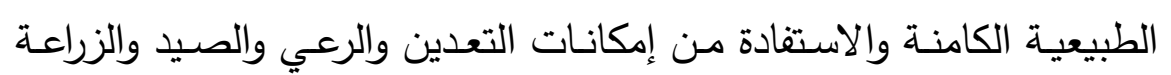

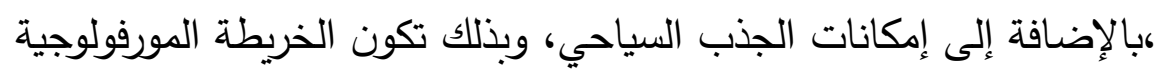


وسيلة لايمكن إنكار حاجة المخطط لها ـ وفيما يلي بعض مجالات التتمية التي تساهم فيها الخريطة المورفولوجية لنطنقة الدراسة. -تنميـة الثروة المعدنيـة:تعد منطقة حلايب من المنـاطق الغنيـة بـالثروة

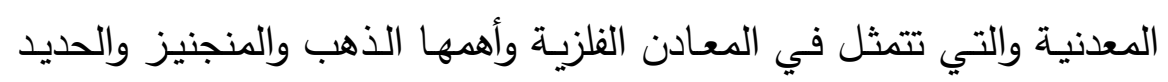

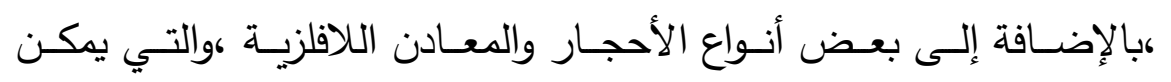

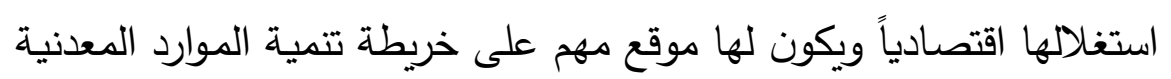
بمنطقة الدراسة ،والذي ينعكس بدوره على الإسهام في تتمية البنية التحتية

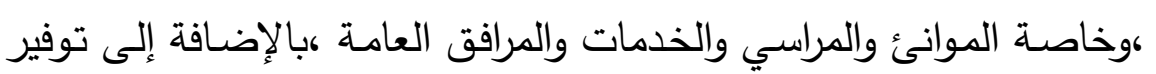

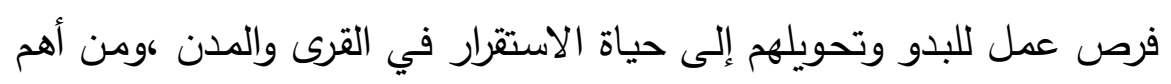

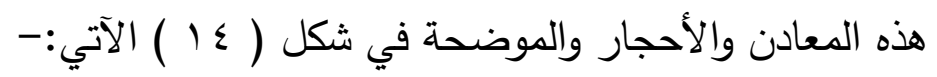

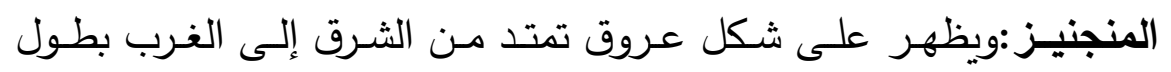

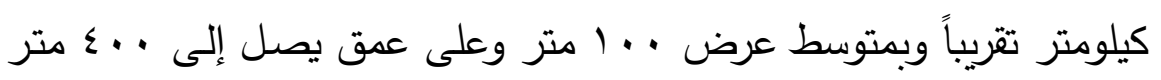

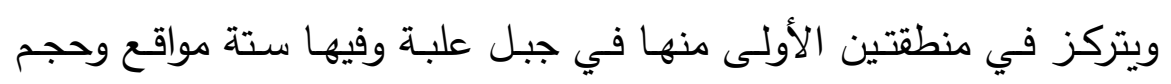

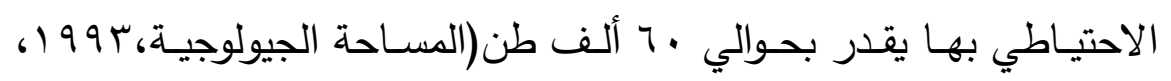

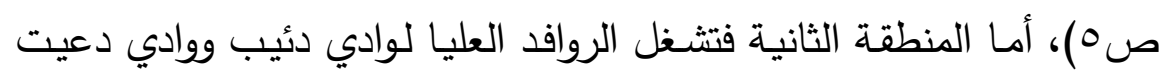

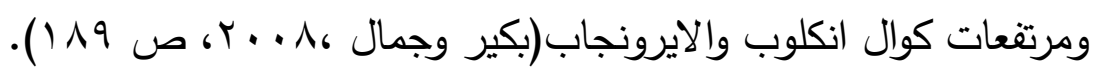

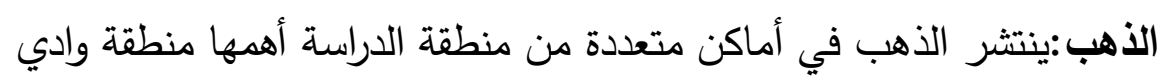

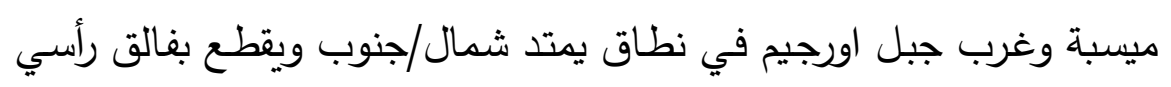
شمال غرب/جنوب شرق ، وبالرغم من قدم استغلال هذه المناجم منذ العهد

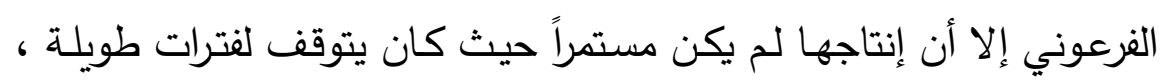

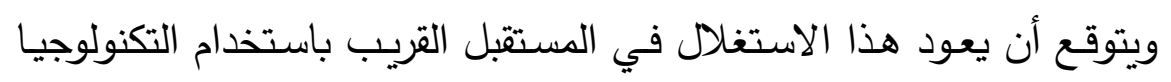
الحديثة لتقلل من تكاليف الاستغلال. 
الكروم:يقتصر توزيعه على موقع واحد فقط يتمثل في أم الطيور الفوقاني حيث يظهر فيها على هيئة عدسات صغيرة تتخلل تكوينات السربنتين والتلك. الحديد: تتركز خامـات الحديد في موقعين كما هو موضـح بشكل ( \& () الموقع الأول في وادي يودر وفي أقصى الجنوب الثرقي لمنطقة الدراسة

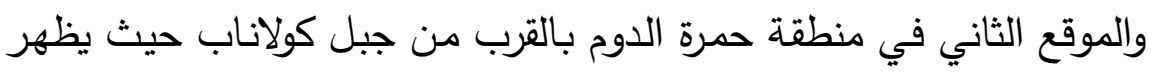
في هيئة عدسات ملتصقة بصخور الجابرو.

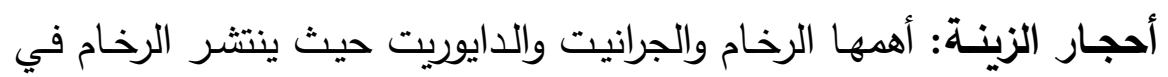

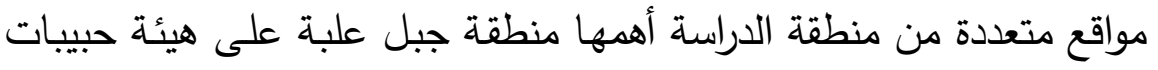

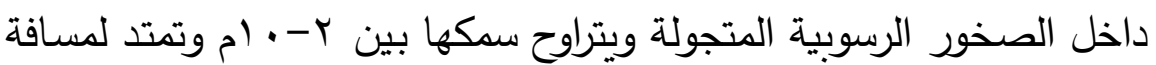

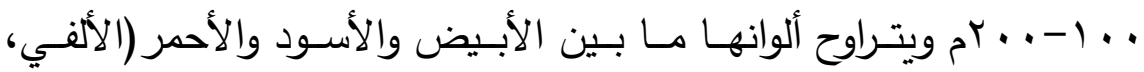

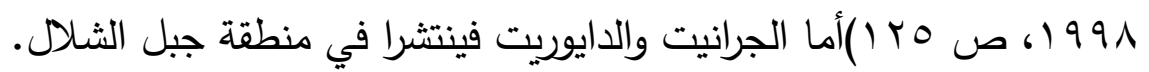




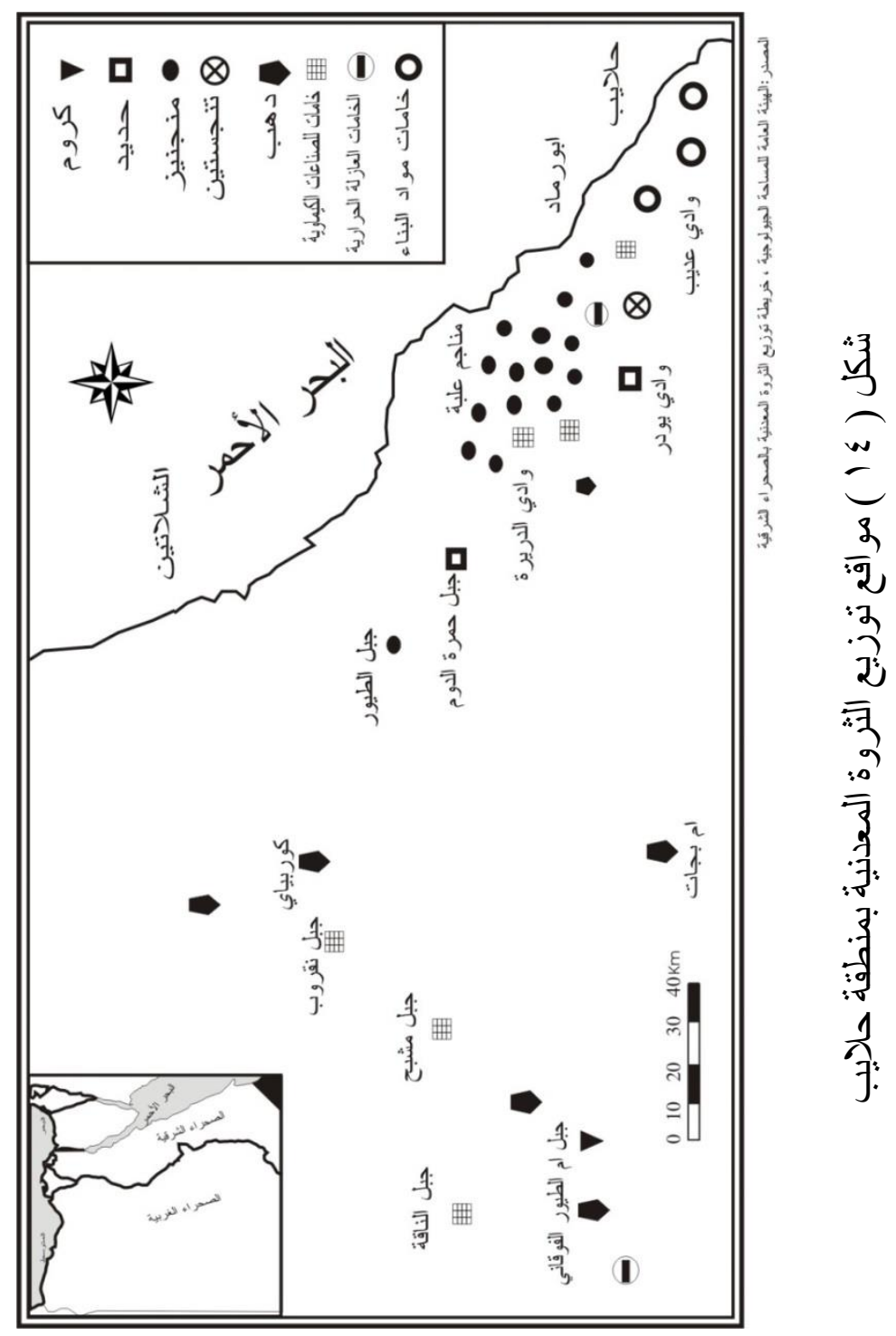

خامـات الصـاعات الكيماويـة :تضم الباريت والنيفين ساينت حيث تتواجد

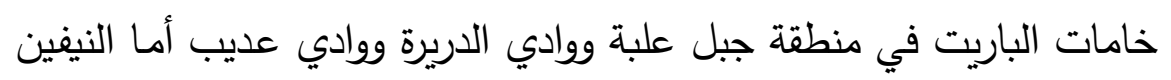
ساينت فيوزع في منطقة جبل نقروب وجبل مشبح ومنطقة جبل الناقة.

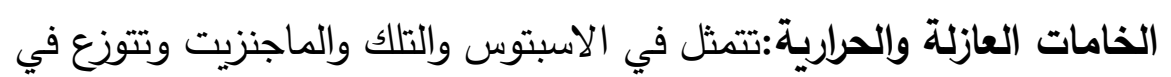
أماكن متعددة من منطقة الدراسة أهما منطقة جبل علبة ووادي عديب. 
مـواد البنـاء: تتوافر خامات البناء من حصى ورمل وزلط وأنواع الصخور

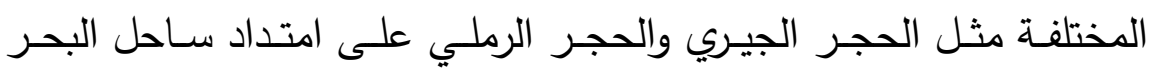
الأحمر وعلى جوانب الأودية وعند أقدام المنحدرات الجبلية لـنطقة الدراسة.

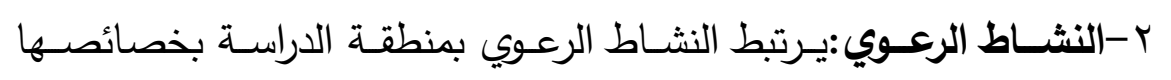

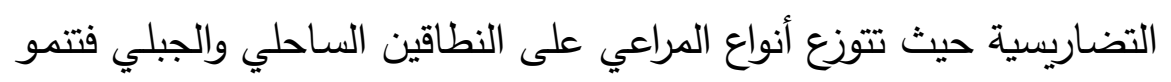

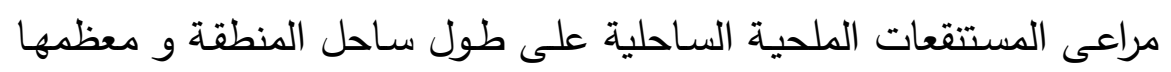

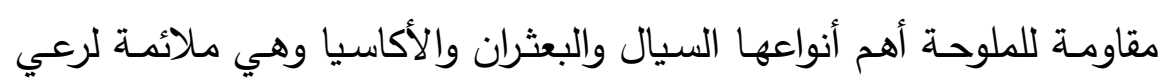

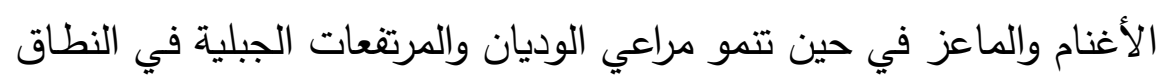

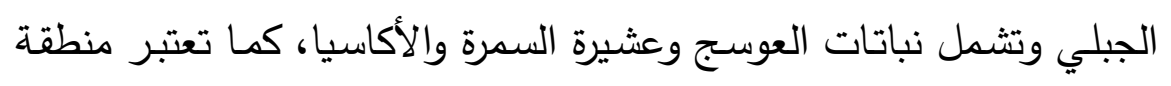

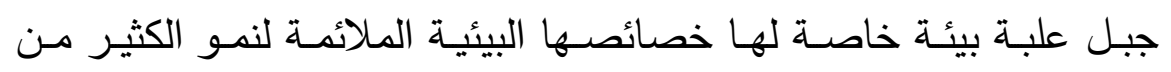
الأشجار والنباتات التي لا تتمو إلا في هذه المنطقة من مصر والتي تتميز بأهميتها الطبية والدوائية. ب-الصيد:تتميز منطقة حلايب عن كثير من مناطق البحر الأحمر الأخرى بميزة تعدد أنواع الأسماك التي يمكن استغلالها اقتصادياً

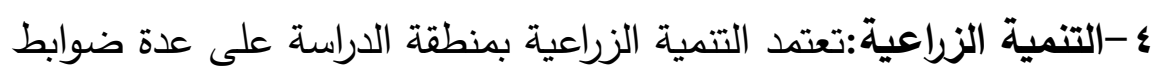

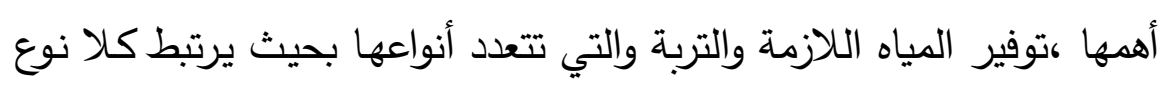

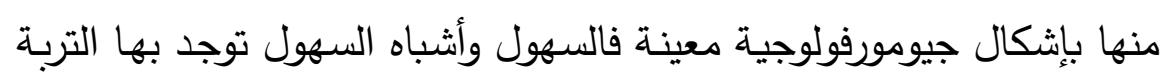

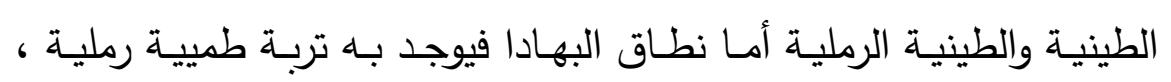

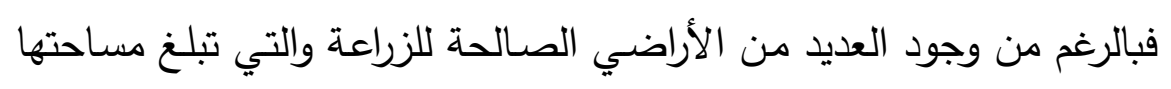

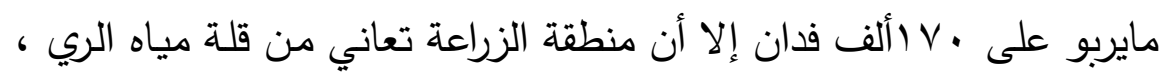

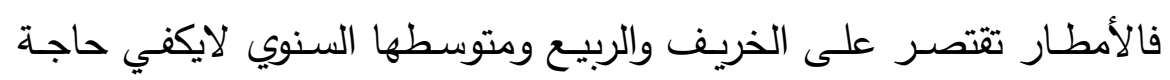

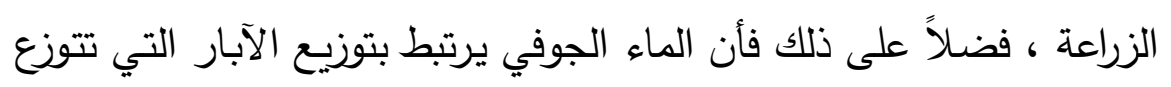

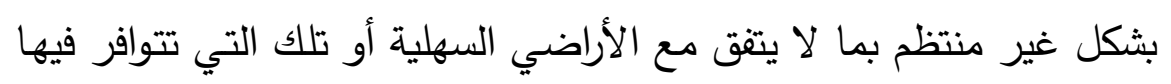


تربـة غير صـالحة للزراعة ، كما أن الماء الجوفي الناتج عن حفر الآبار بالقرب من الساحل لايمكن استغلاله بشكل مباشر حيث تزيد نسبة الملوحة به عن •70 جزء في المليون ،ويمن التغلب على هذه المشكلة من خلال

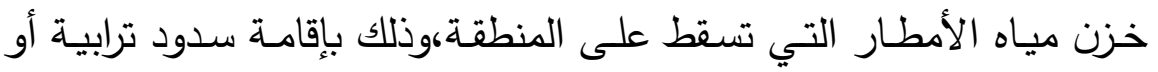

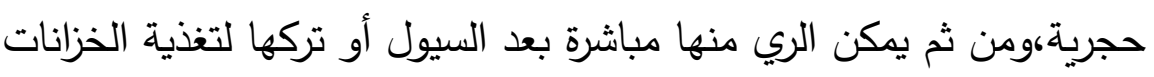

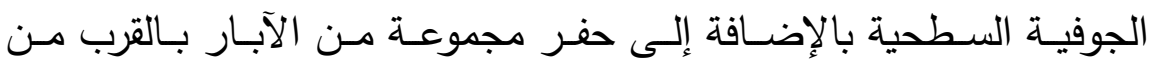

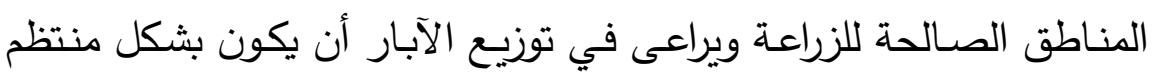
بحيث يضمن الاستمرارية لفترات طويلة،بالإضـافة إلى معالجة المياه الناتجة عن حفر الآبار في الأجزاء القرببة من الساحل ،بحيث لا تزيد نسبة الملوحة بها عن •70 جزء في المليون. ه-التنميسة السياحة:أوضحت الخريطة المورفولوجية لهنطقة حلايب أنها تتميز بشخصية جيومورفولوجية فريدة ،حيث أن السهل السـاحلي وسـاحل

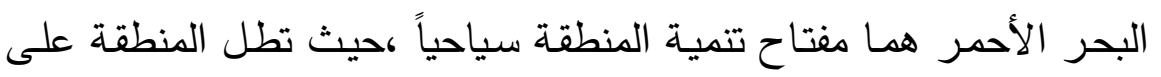

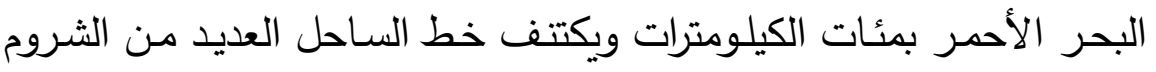

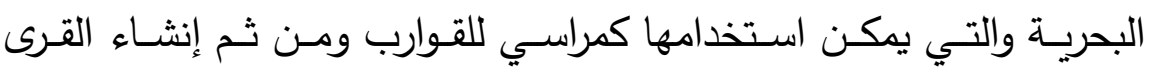

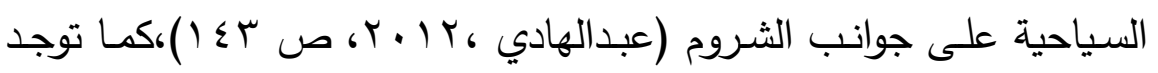

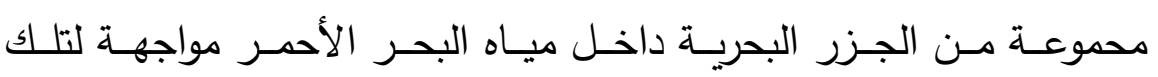

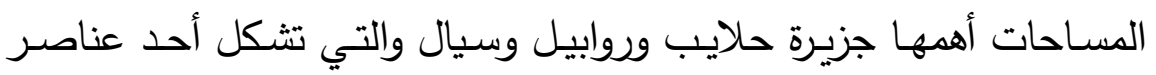

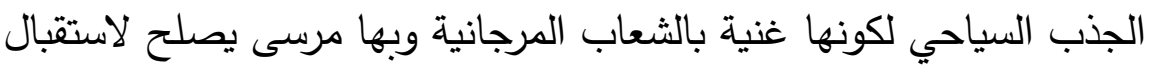

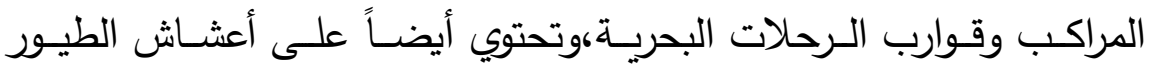

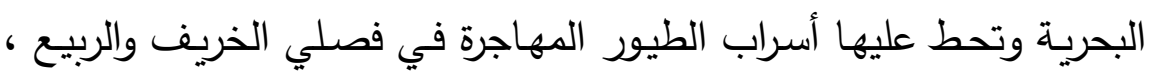
وهناك أيضاً منطقة جبل علبة والتي يمكن أن تتحول لمنطقة جذب واستغلال لمميزاتها الطبيعيـة ،حيث تتميز المنطقة بوجود الحافـات الجبليـة وظهور 
مكاشفها الصخرية عارية من الرواسب الأمر الذي يمكن أن يكون عنصر

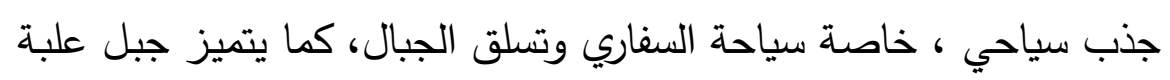

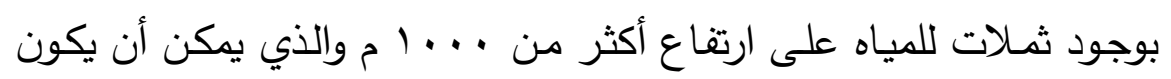

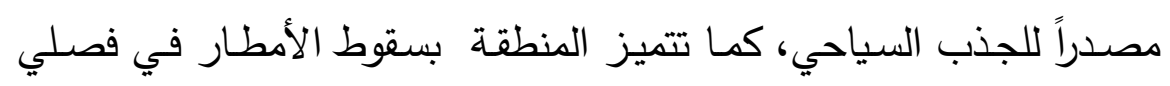

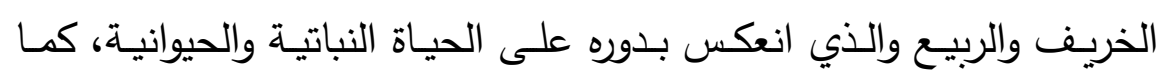

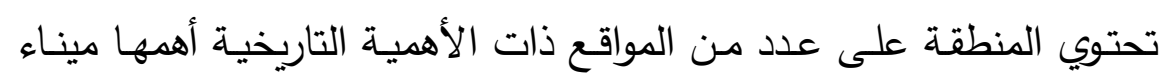

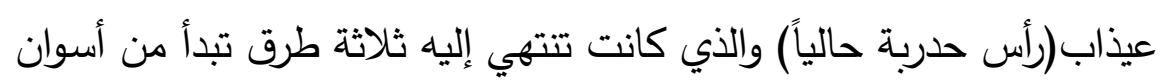

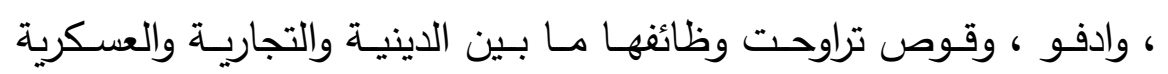

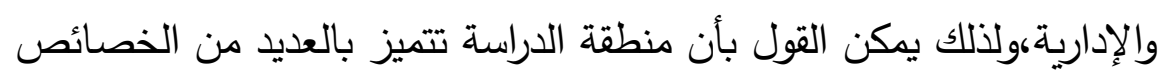
التي تظهر بوضوح ددى صلاحيتها للسياحة وتنميتها سياحياً.

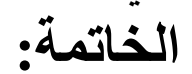

بدراسة الخريطة المورفولوجية لمنطقة حلايب أمكن الخروج ببعض النتائج وكنلك التوصيات التي قد تسهم في تتميتها ،و ذلك على النحو التالي:-

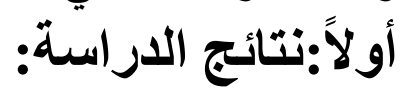

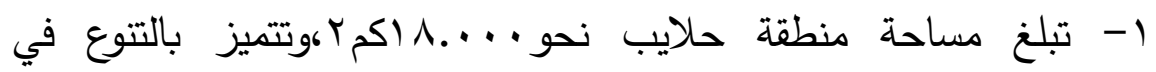

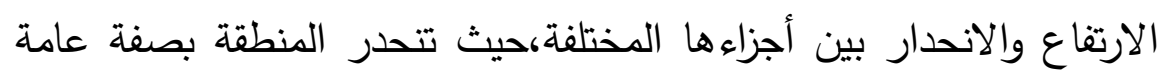

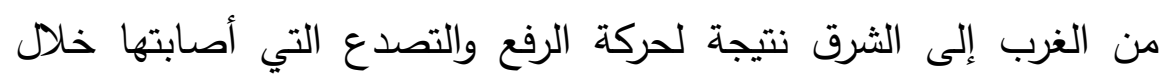

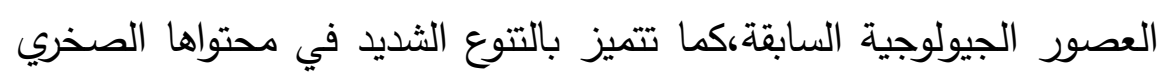

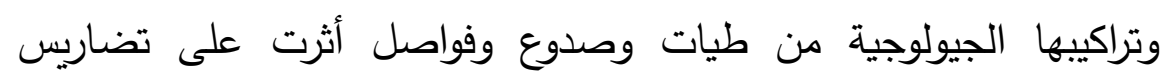

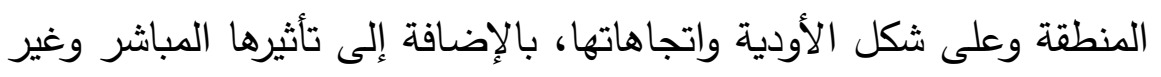

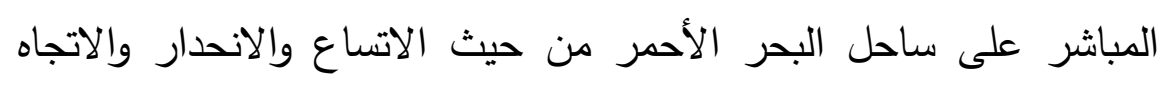
والثكل.

r- تتوعت وتعددت الأشكال الجيومورفولوجيـة الموجودة بمنطقـة الدراســة

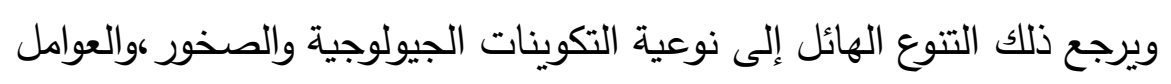


التكتونية المتمثلة في الصدوع والثقوق ، وكذلك العامل المناخي ، وتتقسم

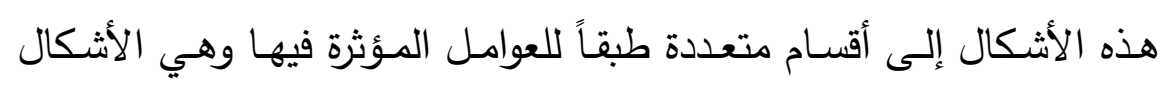

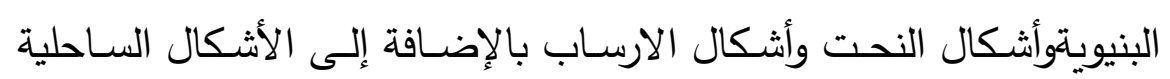

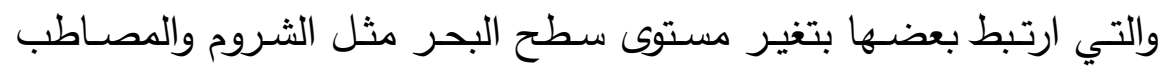

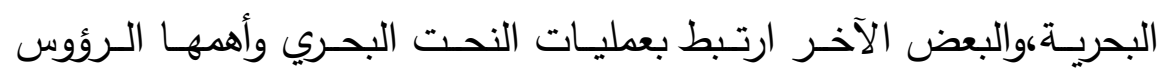

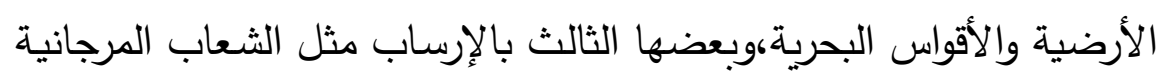

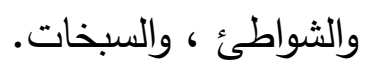
r-تمتلك منطقة الدراسة العديد من المقومات الطبيعية التى تجعلها بيئة

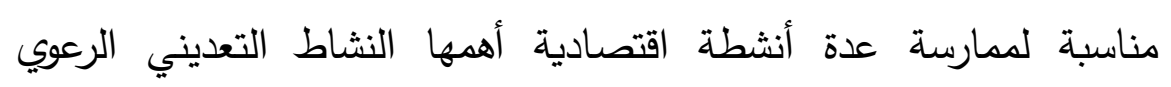

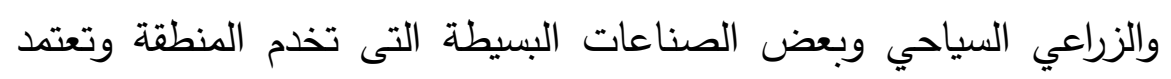
على معطياتها. ثُانياً:التوصيات: بعد الدراسة التفصيلية للمنطقة ،وتقييم إمكاناتها من خـلال وجهة النظر

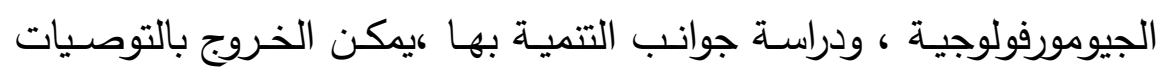
التالية التي قد تقيد المخططين ومتخذي القرار وذلك على النحو التالي:-

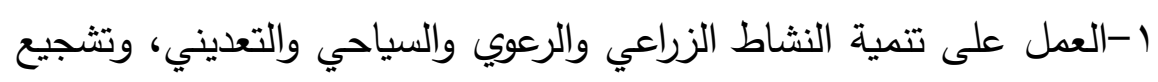

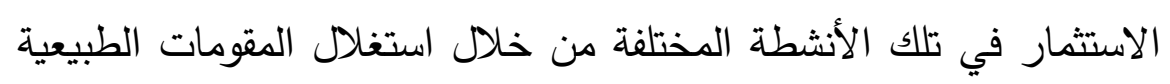
المتوفرة بمنطقة الدراسة. 1-الاستغلال الأمثل للثروات المعدنية من خلال استعمال التقنية الأكثر كفاءة

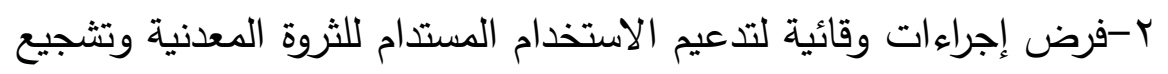

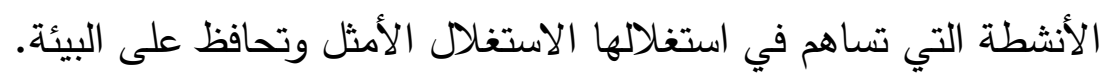

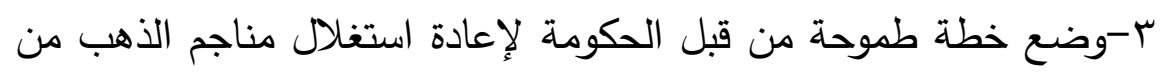
جديد من خلال استخدام وسائل تكنولوجية حديثة تقلل من تكاليف الاستغلال 
لاسيما وان ارتفاع أسعار الذهب عالمياً يجعل من استغلال هذه المناجم

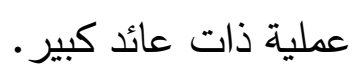

ع-تثجيع الاستثمار السياحي عن طريق بناء قرى سياحية وإقامة الرياضات البحرية بمنطقة الدراسة ،لاسيما أنها تعد مناطق بكر للاستثمار .

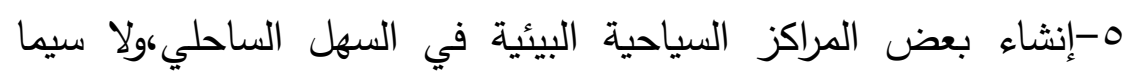

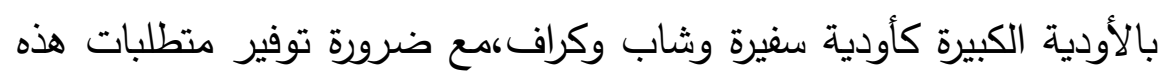

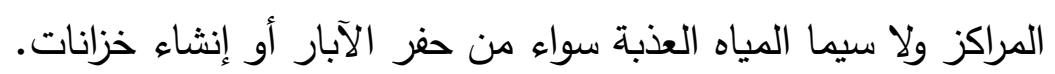

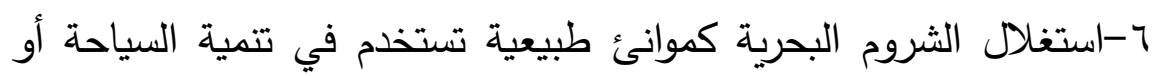
استخدامها في تتشيط الصيد في البحر الأحمر .

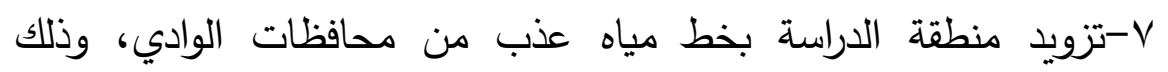
لتقليلالإعتماد على المياه المحلية ذات الملوحة العالية.

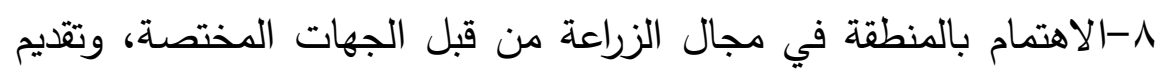

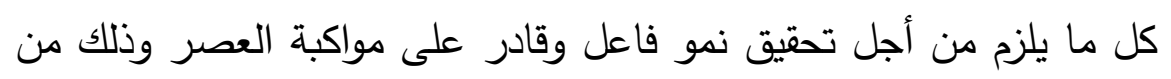

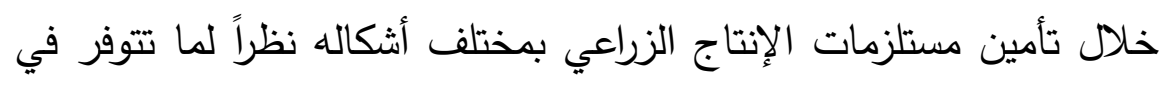
المنطقة من مقومات الزراعة الطبيعية والبشرية.

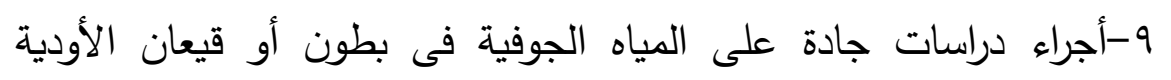

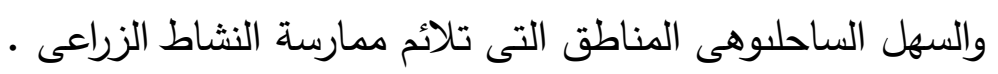

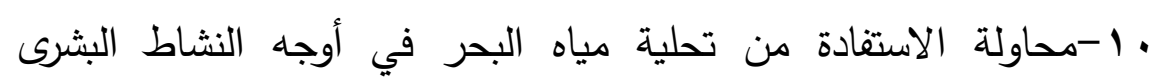

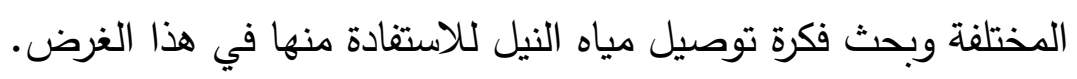
11-1اكثار نباتات المراعي وتسوير بعض المساحات ومنع الرعي فيها لفترة كافية تسمح بنمو الغطاء النباتي وازدياد كثافة النباتات النافعة. 
r ا - تحسين المراعي بمنطقة الدراسة من خلال نقل تقاوي نباتات المراعي

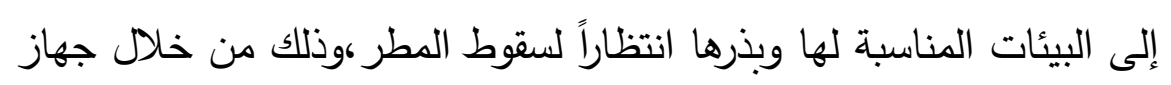

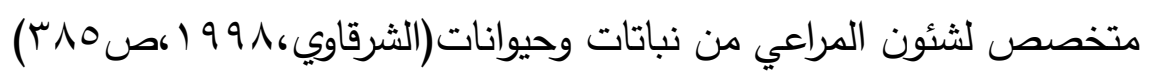

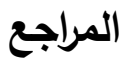

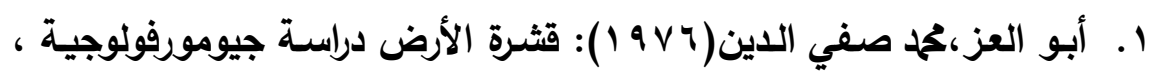

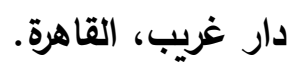

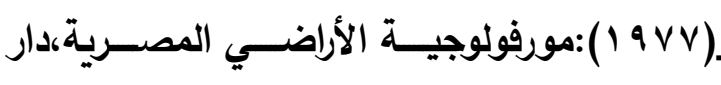

النهضة العربية ،القاهرة

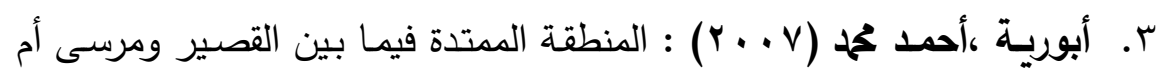

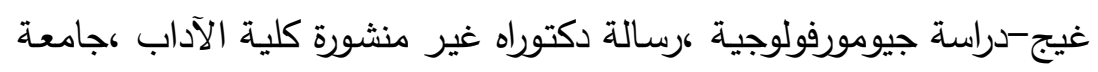
الإنكندرية.

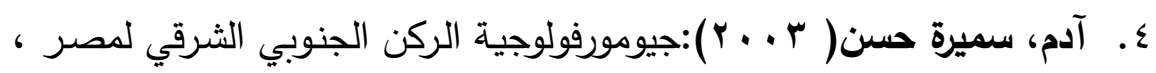

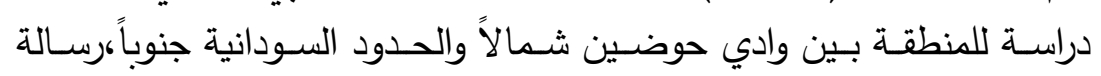

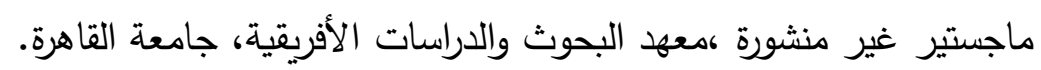

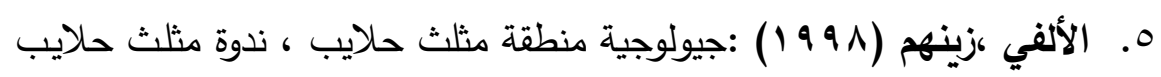

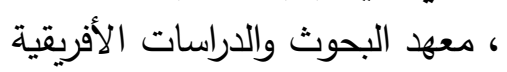

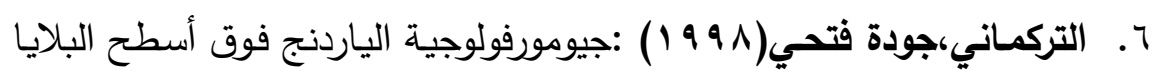
بمنخفض الخارجة ، مجلة الإنسانيات العدد الثاني، الإسكندرية.

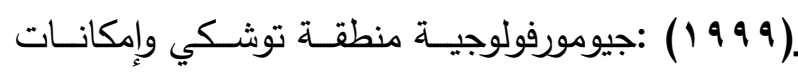

التتمية ، سلسلة بحوث جغرافية، العدد الرابع ، الجمعية الجغرافية المصرية.

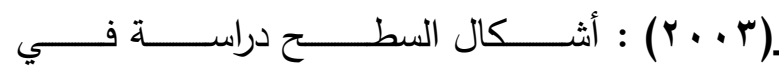
أصولالجيومورفولوجيا ،دار الثقافة العربية-القاهرة.

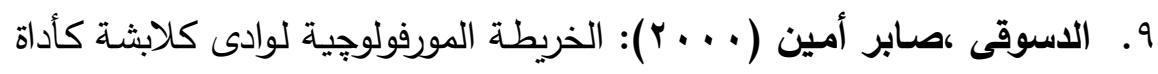

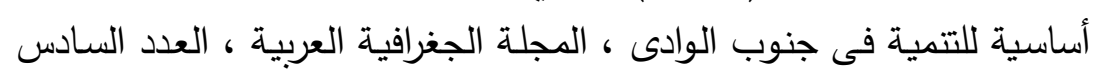
والثلاثون ، الجزء الثاني ، القاهرة . 
• 1 ـ الشيخ ، أحمد محما(9 9 ( 9 ) ) :جيومورفولوجية الهوامش الثرقية لهضبة طيبة فيما بين وادي البعيرية جنوباً والكولا شمالاً ، رسالة دكتوراه غير الحير منشورة كلية

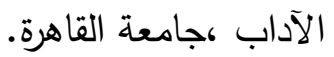

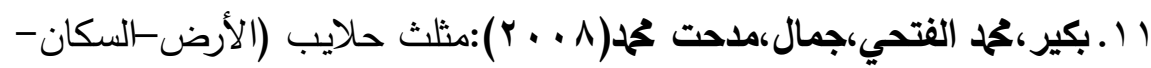
التتمية)،دار المعرفة الجامعية ، الإسكندرية.

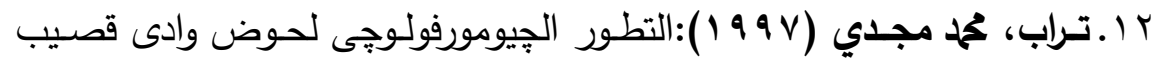

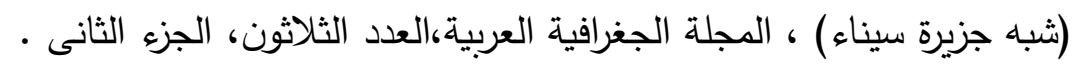

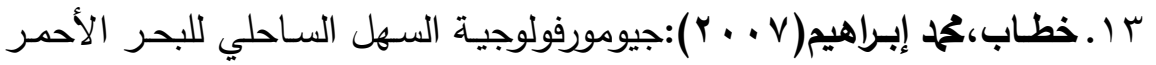
بين القصير ومرسى علم وأثرها على السياحة "دراسة تطبيقية"رسالة ماجستير غير منشورة كلية الآداب ،جامعة القاهرة.

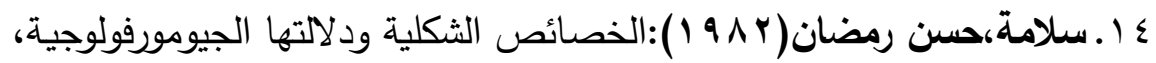

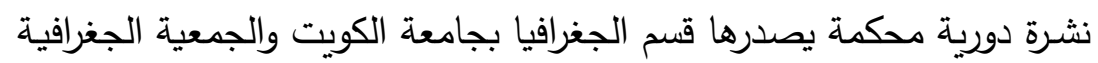
الكويتية ،العدد (ب ع) ،الكويت.

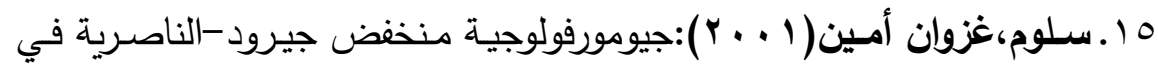
الجمهوريـة العربية السورية،رسالة ماجستير غير منشورة، كلية الآداب،جامعة القاهرة

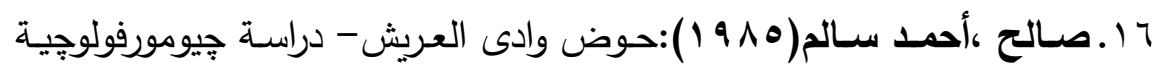
كرسالة دكتوراه غير منشورة ، قسم الجغرافيا- كلية الآداب - جامعة القاهرة.

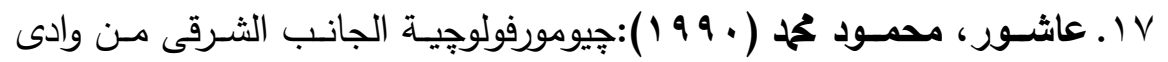

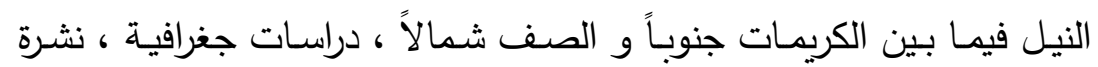

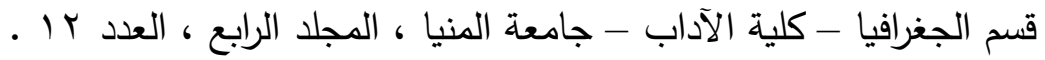

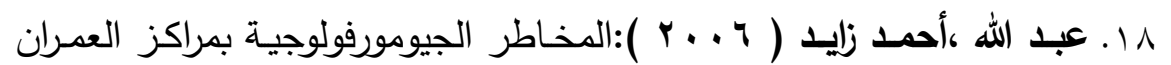

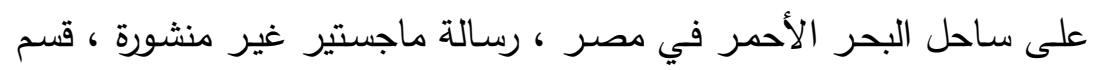
الجغرافيا ، كلية الآداب ،جامعة القاهرة. 9 1. عبد المادي ،ناصر عبد الستار ( Y 1 • ) ): جيومورفولوجية منطقة حلايب وامكانات

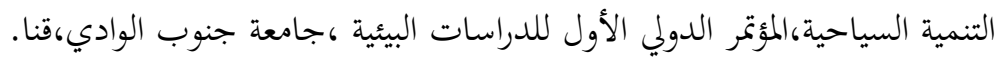




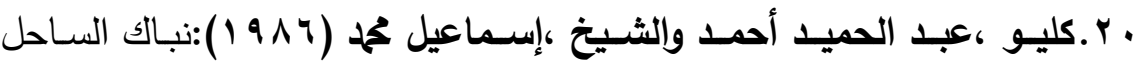

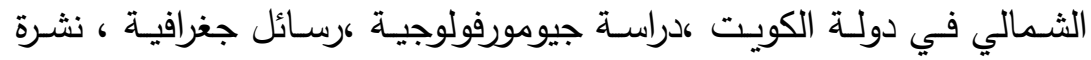

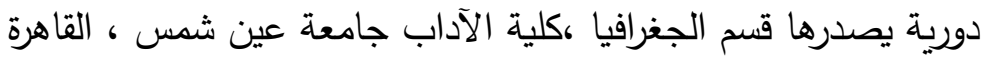

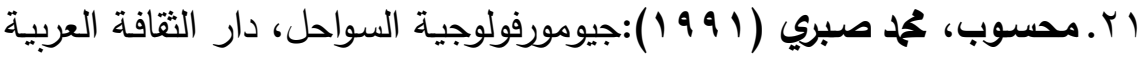

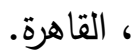

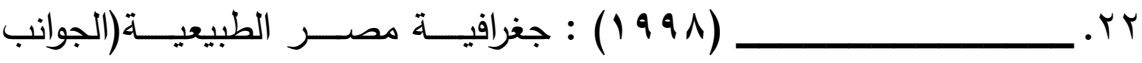

الجيومورفولوجية)، دار الفكر العربي، القاهرة

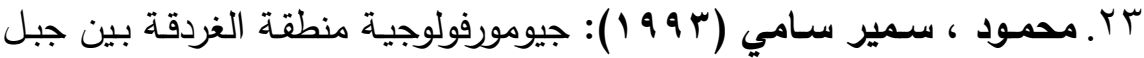

نقادة جنوباً وجبل أبو شعر القبلي شمالاً سرسالة دكتوراه غير منشورة ،كلية

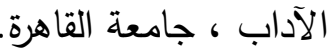

24. Abu-EL-Einin, H,A, (1966) : Questa features in the Moghara District Northern Sinai , Bull . Soc., Geogr. d'Egypte, Vol.39, PP: 177:180)

25. - Bird, E., ( 1984):Coasts - An Introduction to Coastal Geomorphology ,3rd. Ed ., Basil Blackwell, New York.

26. Breed,S\&et-al.,(1989):Wind Erosion Forms, in Thomas ,D.S.G,(ed),Arid zone Geomorphology,Belhaven Press, London.

27. Bull, W,B., (1977): The alluvial fan environment, progress in physical geography, Vol. 1, No. 2, Edward Arnold, London

28. Cook,R. and Warren, A.,(1973): Geomography in Deserts,Univ. of California Press, Berkeley and Los Angles

29. Davis,J., (1985): Coastal Sedimentary Environments, Springer-Verlag, Berlin

30. Denny, C,S.,(1965): Alluvial fans in the Delta Valley region, California and Nevada, G.S. professional paper 466, part 2

31. Huggett,H,J,(2003):Fundamentals of geomorphology. London : Routledge

32. Goudie , A \& Et-al ., (1981):Geomorpholgical Techniques .George Allen, Union, London

33. Gregory , K .J \&Walling,D. E .,(1976):Drainage form and process geomorphology approach ,Edward, Arnold ,London

34. Pitty,A,F,(1982): The nature of geomorphology,New York 
35. Ritter,D.F\&et-al.,(1995) : Process Geomorphology Third Edition, Wm . C .Brown Publishers, London

36. Said,R.,(1990) : The Geology of Egypt , A ,A . Balkema, Rotterdam, nether lands.

37. Schumm,S.A., (1956) : Evolution of The Drainage systems and Badlands at Perth Amboy New York, Geol .Soc Slope in .Am. Bull .Vol. 67.

38. Thornbury,D.W.,(1984) : Principle of Geomorphology ,Second Edition ,John Wiley \& Sons , New York

39. Tucker,E,M.,(2003) : Sedimentary rocks in the field, Third Edition Black well science, London .

40. Warren,A\&Livingstone,I.,(1996): Aeolian Geomorphology: an introduction, Longman, Harlow,

41. Young, A., (1972): Slopes, Oliver and Boyd, Edinburgh.

الخريطة المورفولوجية لمنطقة حلايب كأداة أساسية للتنمية في جنوب شرق لمصر.

تمتلك منطقة حلايب العديد من المقومات الطبيعية التى تجعلها بيئة مناسبة لممارسة عدة أنشطة اقتصادية أهمها النشاط التعديني الرعوي و الزر اعي السياحي وبعض الصناعات البسيطة التى تخدم المنطقة وتعتمد على معطياتها.

ومن خلال الخريطة المورفولوجية لمنطقة الدراسة أمكن التعرف على العديد من المقومات الطبيعية ،و التي يمكن أن تجعل منطقة حلايب محوراً من المحاور المكانية للتنمية في مصر وذلك من خلال تتمية مواردها الطبيعية الكامنة و الاستفادة من إمكانات التعدين و الرعي و الصيد و الزر اعة ،بالإضافة إلى إمكانات الجذب السياحي، وبذلك تكون الخريطة المورفولوجية وسيلة لايمكن إنكار حاجة المخطط لها. وقد هدفت الدراسة إلى التعرف على الأشكال الأرضية بالمنطقة بشكل تفصيلي ومحاولة تقسيمها إلى مجموعة من الوحدات الأرضية المتجانسة 
كمع دراسة توزيعها الجغرافي وخصائصها المورفولوجية وعمليات تشكيلها و الذي يساهم بدوره في تحديد أفضل المواضع اللازمة لمجالات التنمية المختلفة خاصة الزر اعية و الصناعية و العمر انية و السياحية في تلك المو اضع. وقد خلصت الدراسة بمجموعة من التوصيات أهمها العمل على تنمية النشاط الزر اعي و الرعوي و السياحي و التعديني ، وتشجيع الاستثمار في تلك الأنشطة المختلفة من خلال استغلال المقومات الطبيعية المتوفرة بمنطقة الدر اسة.

\section{The Morphological Map of Halayeb Region as an}

\section{Essential Tool for the Development of Southeastern}

\section{Egypt}

Halayeb Region has many natural factors that make it a suitable environment for practicing several economic activities. Primary among these activities are are mining, pastoral and agricultural tourism and some simple industries that serve the region and depend on its data. Through the morphological map of the study area, the research has identified many natural factors that can make Halayeb Region one of the spatial dimensions of development in Egypt. This can be achieved through developing its potential natural resources and benefiting from the mining, pastoral, hunting, and agricultural 
potentials in addition to the tourist attraction's possibilities. Thus, the morphological map will be a means that cannot be denied by the planner. The study aimed at identifying the terrestrial forms in the region in details. It also tried to divide them into a group of homogeneous terrestrial units. Moreover, it studied their geographical distribution, morphological characteristics and formation processes which in turn contribute to determining the best places necessary for different fields of development, especially agricultural, industrial, urban and tourist ones in such places. The study concluded with a number of recommendations. Primary among these is the need to develop the agricultural, pastoral, tourist and mining activities and to encourage investment in these various activities by making use of the available natural resources in the study area. 


$$
\text { سكوت النبي- صلى الله عليه وسلم- عند }
$$

الباحث: خالد رمضان عبد الفتاح

$$
\text { يونيو 10 ب ب }
$$




\section{المقدمة}

بسم الله والحمد الله والصلاة والسلام على رسول الله، وبعد:

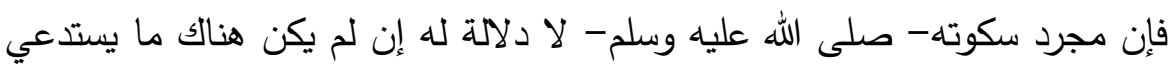

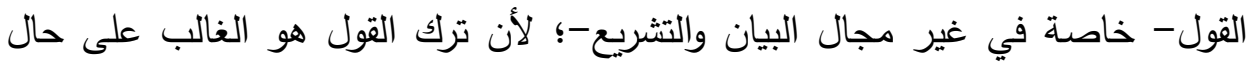

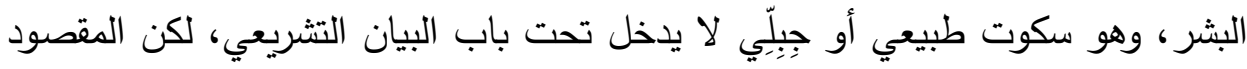
هنا هو السكوت الدال على بيان حكم شرعي، أي السكوت عند الحاجة إلى البيان. فإذا حدث ما يستدعي القول لبيان الحكم الشرعي، ثم سكت النبي- صلى الله اله عليه وسلم-، فإن سكوته قد يدل على حكم. فإن كان الذي يستدعي القول فعلاً حدث أمام النبي- صلى الله عليه وسلم-، أو قولاً قيل أمامه، أو علم به أو نُقل إليه فسكت عن الإنكار عليه، فذلك النوع من السكوت

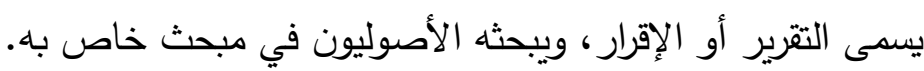
وإن كان الذي يستدعي القول والبيان حادثة وقعت تستدعي بيان حكمها، أو سؤالاً

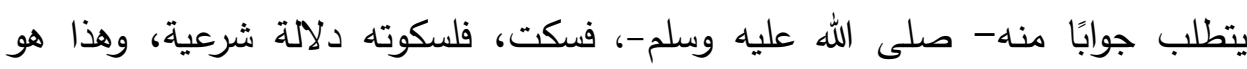
موضوع هذا البحث. 
وسيكون هذا البحث من الناحية الأصولية مدعمًا بالأمثلة الفقهية. وقد جاء هذا البحث في مقدمة وثلاثة مطالب وخاتمة. المقدمة: تثتمل على موضوع البحث وأهميته. المطلب الأول: تعريف السكوت لغة واصطئل المطاحًا. المطلب الثاني: سكوته - صلى الله عليه وسلم -عما لم يتبيَّن حكمه. المطلب الثالث: سكوته- صلى الله عليه وسلم -عَمّا تبين حكمه من قبل. الخاتمة: وتثتمل على نتائج البحث.

المطلب الأول: تعريف السكوت لغة واصطلاحًا

أولاً: تعريف السكوت لغة: السكوت مصدرُ مِنْ "سَكَت"، "يَسكُت"، "سُكوتًا"، فهو "ساكت"، ورجل سِكِيتٌ، وسَاكُوتُّ: كثير السّكوت، والصمت أبلغ من السَّكُوت،

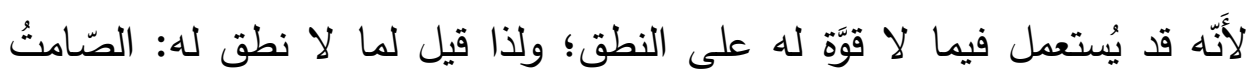

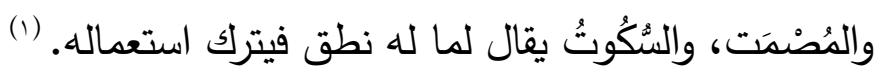
وجاء في تاج العروس: السُّكُوتُ ترك الكلام مع القدرة عليه. وبالقيد الأَّير

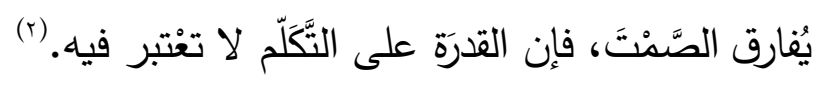

(1) انظر : مادة (سكت) في الصحاح(تاج اللغة وصحاح العربية): لأبي نصر إسماعيل بن

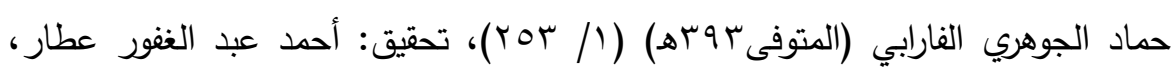

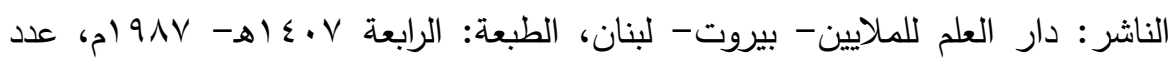

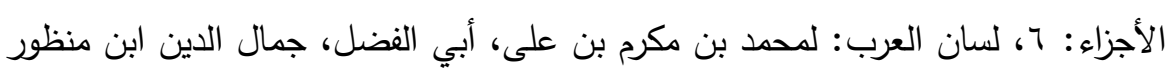

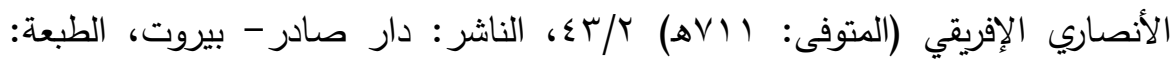

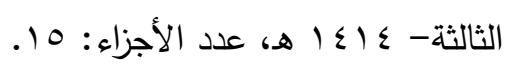

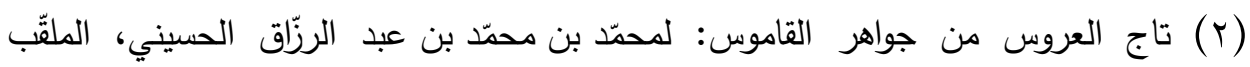

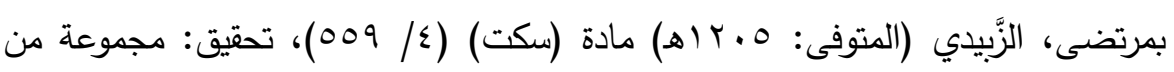


ثانيًا: السكوت في الاصطلاح: استُعمِل السكوت عند الأصوليين والفقهاء بنفس المعنى اللغوي، ولم يخصُوه بمعنى آخر.

قال الجرجاني في التعريفات: "السكوت هو ترك التكلم مع القدرة عليه".(1)

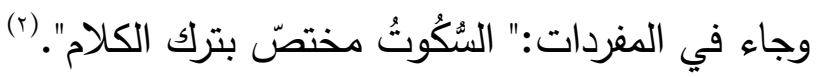

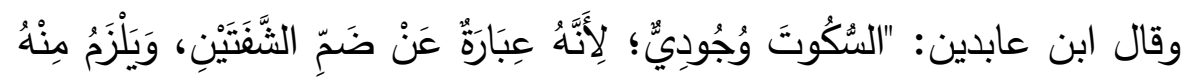

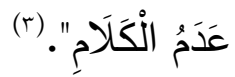

ويفهم من ذلك أن السكوت أحد صور الترك؛ لأنه في حقيقته كفتُ عن القول،

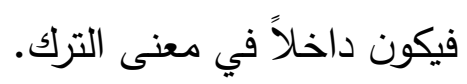

فكما يكون بيان الأحكام من النبي - صلى الله عليه وسلم-، بترك الفعل يكون بترك القول - أي السكوت - كذلك، وهذا ما قرره علماء الأصول: فقد ذكر الثاشي الحنفي أن:" السكوت في موضع البكان الحاجة إلى البيان بمنزلة

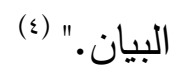

المحقين، الناشر: دار الهداية- القاهرة، عدد الأجزاء:·ــ.

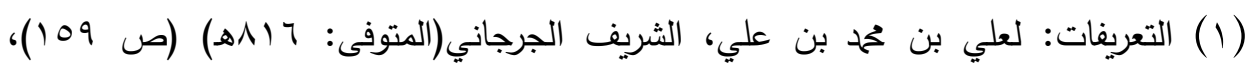

ضبطه وصححه جماعة من العلماء بإشراف الناشر، الناشر : دار الكتب العلمية- بيروت-

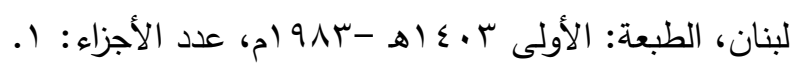

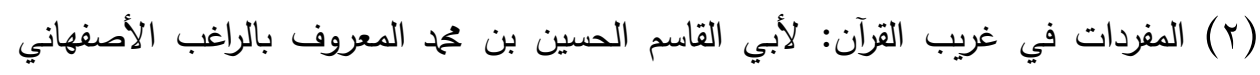

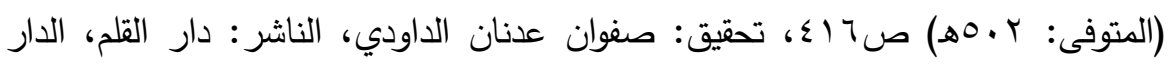

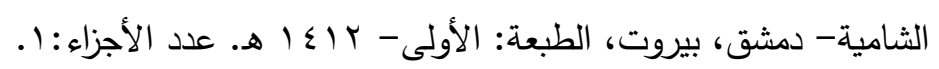

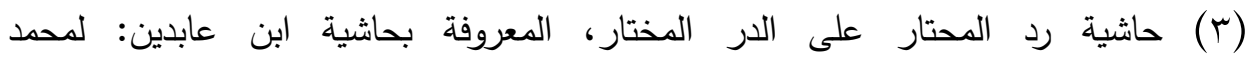

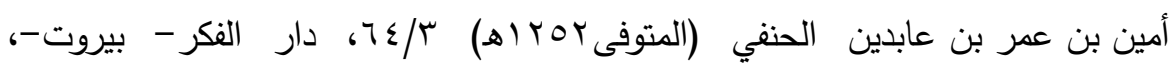

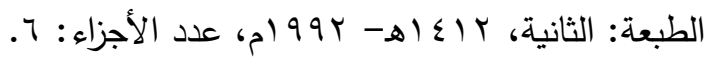

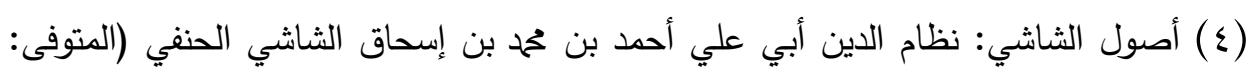

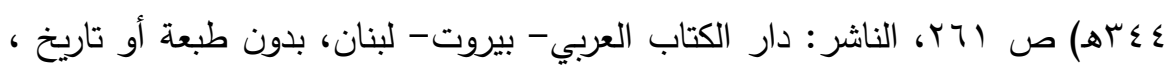

عدد الأجزاء: 1. 
وقال البزدوي:" السكوت في موضع الحاجة إلى البيان بيان".(1) وقال ابن حزم:" وليس قول أحد ولا سكوته حجة إلا رسول الله- صلى الله

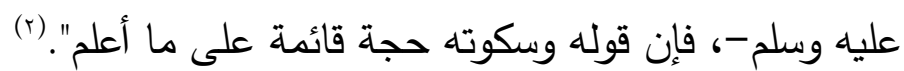
ويمكن تقسيم سكوته- صلى الله عليه وسلم- عند الحاجة إلى البيان قسمين: الأول: السكوت عما لم يتبيَّن حكمه من قبل. والثاني: السكوت عَمّا تبين حكمه من قبل. وفي كل قسم مطلب. المطلب الثاني: سكوته- صلى الله عليه وسلم-عما لم يتبيَّن حكمه من

سكوته- صلى الله عليه وسلم- بعد السؤال عن حكم أو واقعة من الوقائع يعتبر من البيان، فيدلَّ سكوته حينئذ على أنه لا حكم للشرع في هذه الواقعة، ويكون سكوته- صلى الله عليه وسلم-انتظارًا للبيان من الوحي.

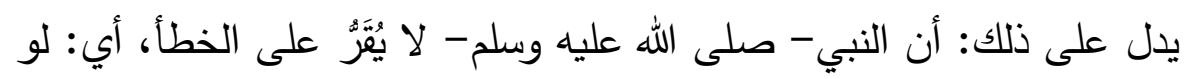
كان سكوته عن بيان الحكم في تلك الحالة خطأ لبيَّن له اللَّه- تعالى - ذلك، فيكون سكوته بيانًا في أن هذه الواقعة لا حكم لها.

(1) كثف الأسرار شرح أصول البزدوي: لعبد العزيز بن أحمد بن ححد، علاء الدين البخاري

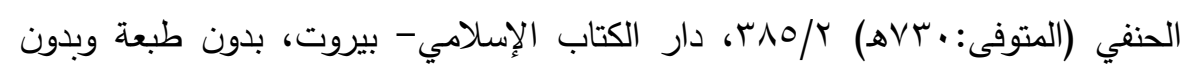

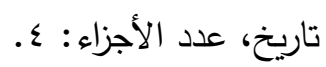

(r) الإحكام في أصول الأحكام: لأبي حمح علي بن أحمد بن سعيد بن حزم الأندلسي القرطبي

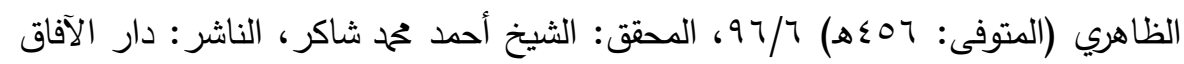

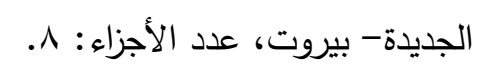

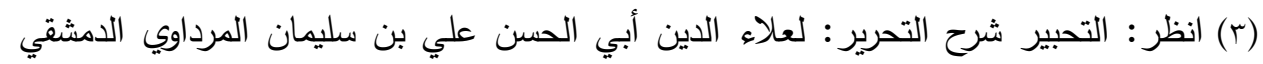

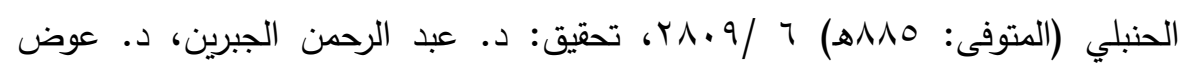

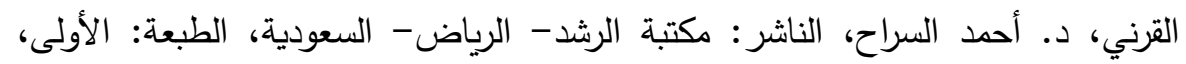


وفي ذلك يقول الثريف التلمساني:" ومما يلحق بالترك في الدلالة على عدم

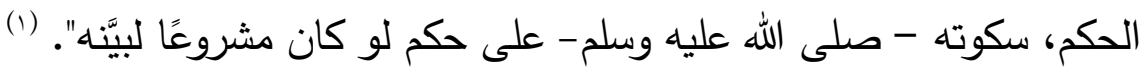

ويقول تاج الدين السبكي:" السكوت عند السؤال يحمل على عدم نزول الحكم؛

لأن السؤال عما لم يقع، أو عما وقع والسائل ينتظر حكمه، فيفهم من السكوت عدم على على لرول

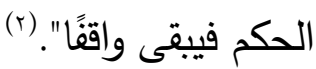

فإذا سُئل النبي- صلى الله عليه وسلم- عن مسألة ليس فيها حكم فسكت، فإن ذلك السكوت لا دلالة له على حكم، وإنما يؤخذ الحكم بعد نزول الوحي، فإذا لم يأت بيانٌ بعد ذلك بقي حكم تلك الحادثة على الأصل. أما إن كان فيها حكم، فقد كان- صلى الله عليه وسلم- يبيّنُه؛ لأنه مأمور

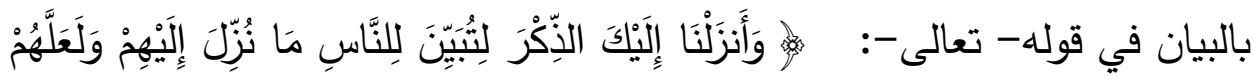

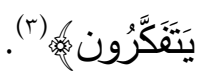

ومما ورد في السنة من هذا النوع من سكوته- صلى الله عليه وسلح-:

- ما رواه جابر بن عبد الله- رضي الله عنهما-، قال:" جاءت امرأة سعد بن الربيع- رضي الله عنه- بابنتي سعد إلى النبي- صلى الله عليه وسلم-

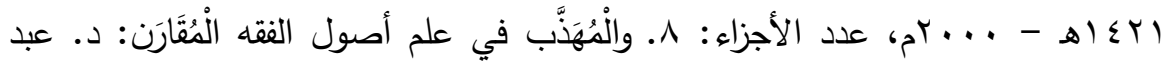

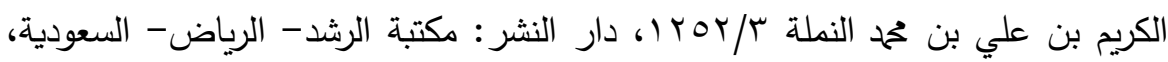
الطبعة الأولى: . بأن اهـ - 999 ام، عدد الأجزاء: 0.

(1) مفتاح الوصول إلى بناء الفروع على الأصول: للشريف أبي عبد الله محمد بن أحمد الحسيني

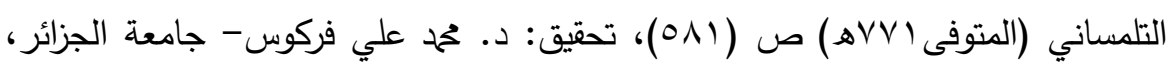

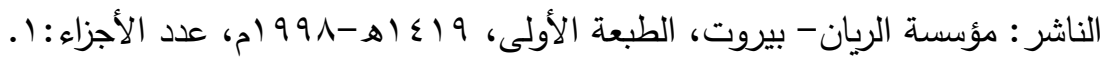

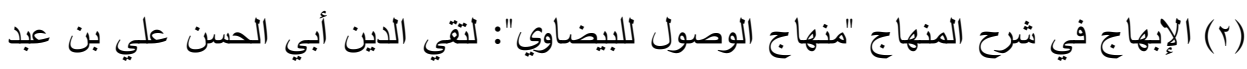

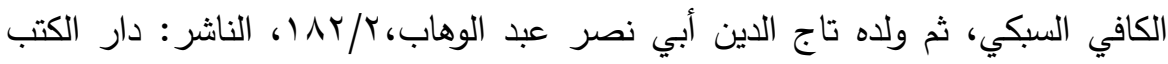

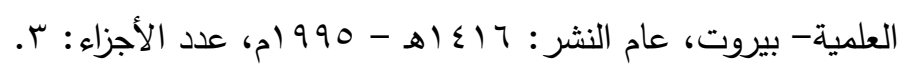


فقالت: يا رسول الله، هاتان ابنتا سعد قُتل معك يوم أحد، وإن عمهما أخذ جميع ما ترك أبوهما، وإن المرأة لا تُكح إلا على مالها، فسكت رسول الله- صلى الله عليه

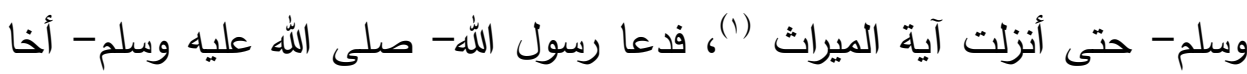

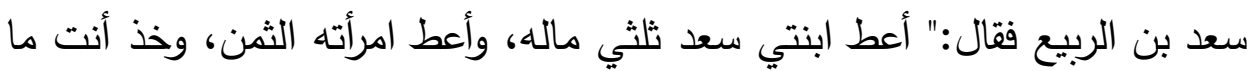
بقي". (r) فدل ذلك على أنه قبل نزول آية الميراث لم يكن في المسألة حكم، وإلا لما جاز تأخيره عن وقت الحاجة إليه.(r) - ومنه كذلك: ما روى عمرو بن شعيب عن أبيه عن جدّه:" أن مِرْنًََ بن أَبِي

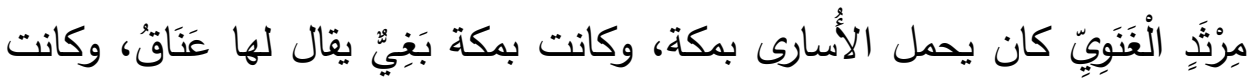
صديقته. قال: فجئُ النبي- صلئ الله عليه وسلم-، فقلت: يا رسول الله، أنكِح

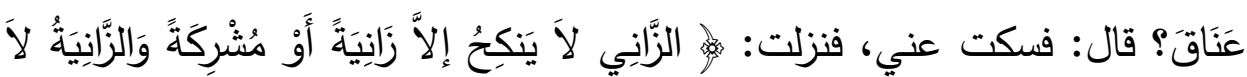

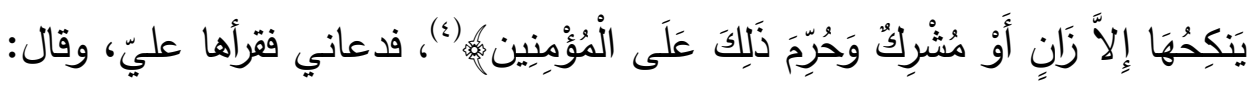
"الا تتكحها". (0)

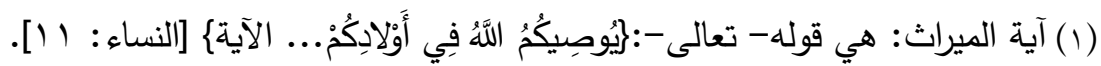

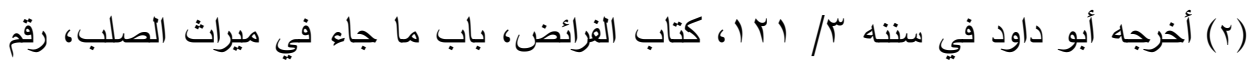

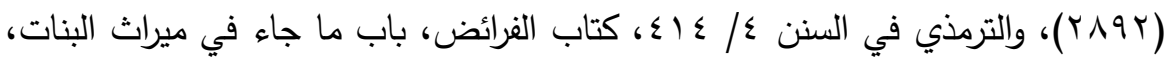

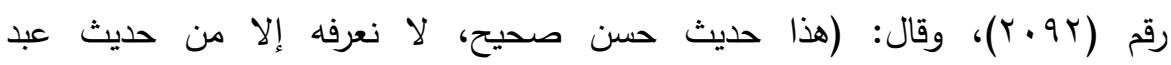

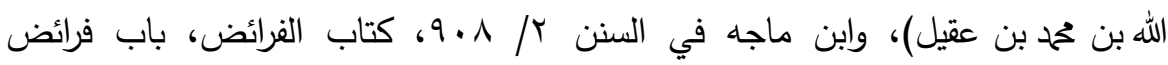

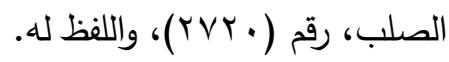

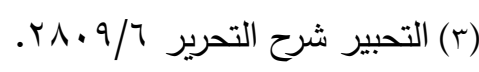

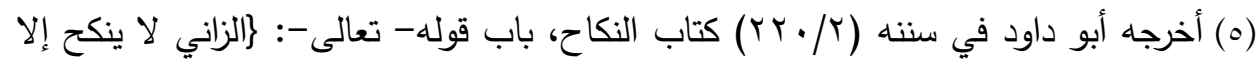

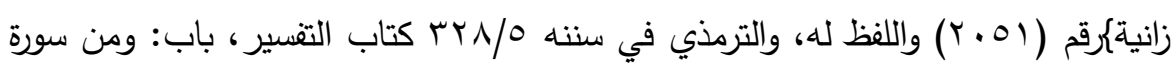
النور، رقم (TIVV) وقال: "حديث حسن غريب، لا نعرفه إلا من هذا الوجه". 
وقد ذكر الثاطبي عشرة مواضع لكراهية السؤال، منها: (1) أن يكون سكوته- صلى الله عليه وسلح- عن الجواب على سبيل الإنكار للسؤال نفسه؛ لأنه مما لا ينبغي أن يُسأل، أو لما يترتب على الإجابة من مشقة

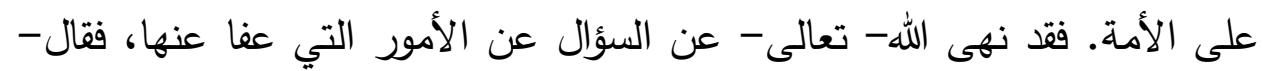

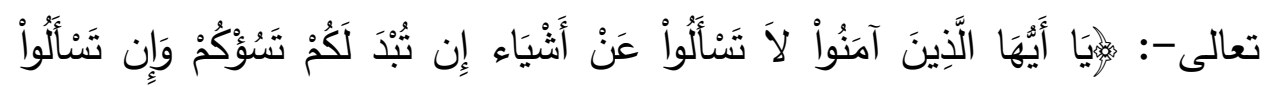

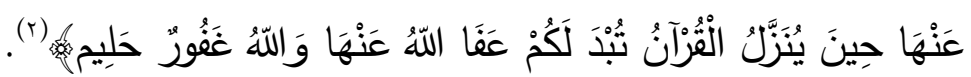
وقد نهى النبي- صلى الله عليه وسلم- عن كثرة السؤال، فقد روى المغيرة بن شعبة- رضي الله عنه- أن النبي- صلى الله عليه وسلم- قال:" إن الله حرم عليكم: عقوق الأمهات، ووأد البنات، ومَنَعَ وهات، وكره لكم قيل وقال، وكثرة

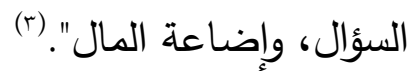
وروى أَبو هُرَيْرَةَ- رضي الله عنهـ- قَالَ: خَطَبَنَا رَسُولُ اللهِه- صلى الله عليه

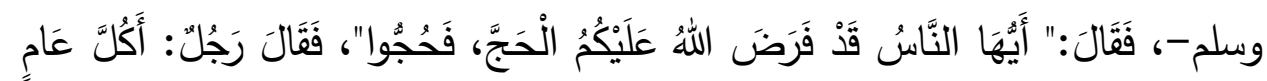

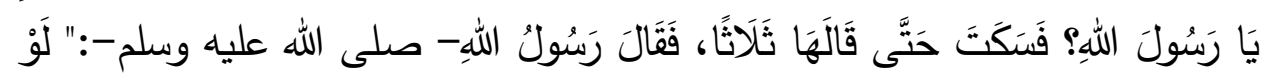

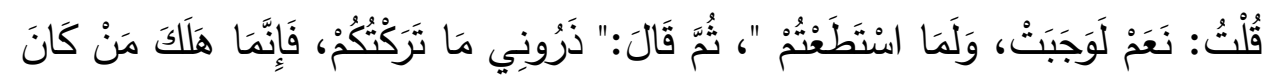

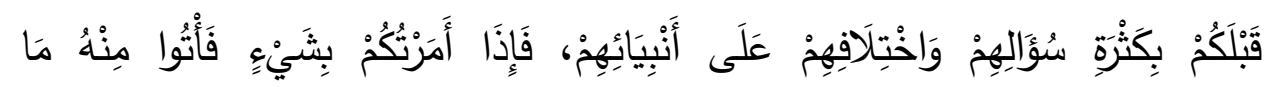

(1) راجع: الموافقات في أصول الثريعة: لإبراهيم بن موسى بن محمد اللخمي الغرناطي الثهير

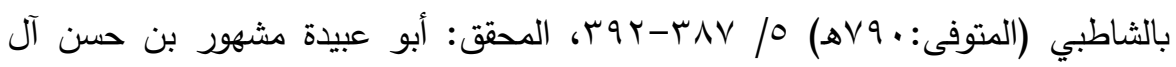

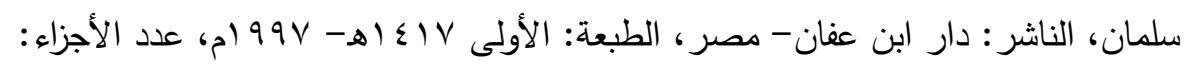
.$V$ (r) سورة المائدة:1 (1.

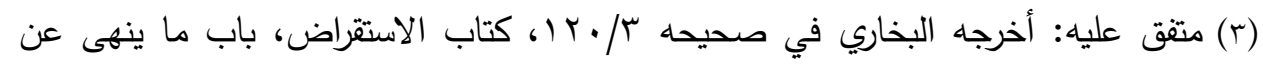

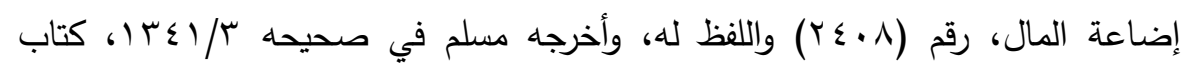

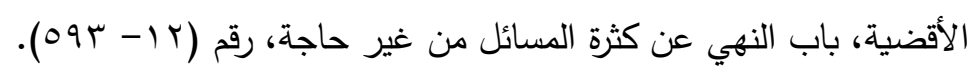




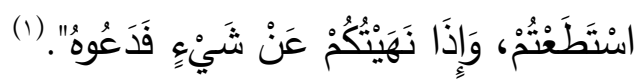

المطلب الثالث: سكوته- صلى الله عليه وسلم-عَّا تبين حكمه من قبل.

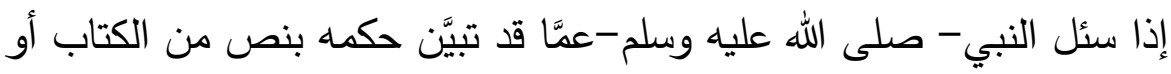
السنّة قبل ذلك فسكت، فإن هذا السكوت قد يكون إحالةً منه- صلى الله عليه وسلم- على البيان السابق. قال السمعاني:" وأما الثيء إذا كان له أصل في الوجوب أو السقوط، فإن السكوت قد يقع عنه في بعض الأحوال استغناء بما تقدم من البيان فيه، وليس تكرار البيان واجبًا في كل حال". (r) فهل إذا سئل النبي- صلى الله عليه وسلم- عن حكم واقعة، أو حدثت الواقعة بحضرته، فبيّن بعض أحكامها، وسكت عن البعض الآخر ، فهل يدل سكوته عنه على انتفائه؟

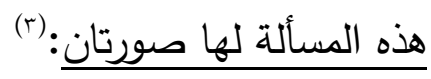

الصورة الأولى: أن يكون المسكوت عنه قد تبيّن حكمه قبل ذلك بدليل

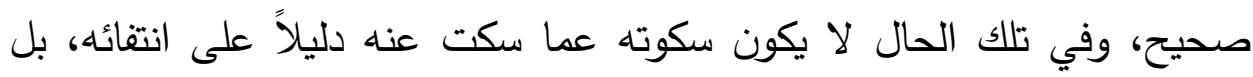

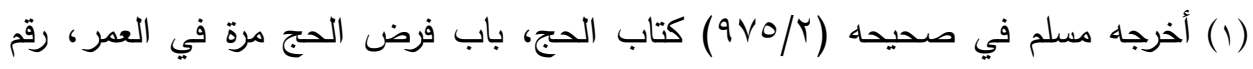
(ITV/LIT)

(r) قواطع الأدلة في الأصول: لهنصور بن محمد بن عبد الجبار ابن أحمد المروزى السمعاني

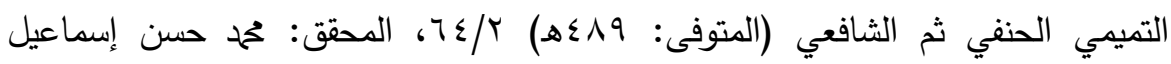

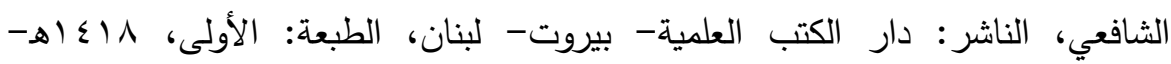

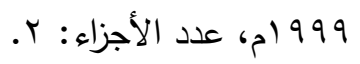

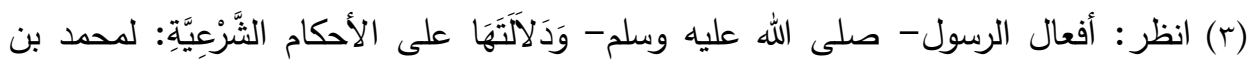

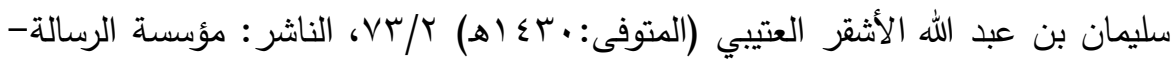

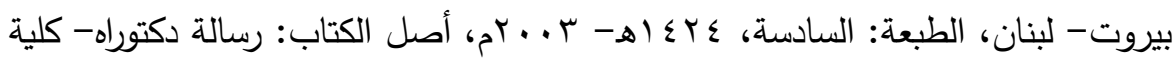

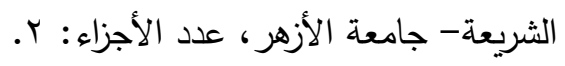


يكون إحالة منه - صلى الله عليه وسلم- على البيان السابق. فإذا ورد دليل ببيان حكم في مسألة، وسكت- صلى الله عليه وسلم- عن بيان بعض أحكامها مع اقتضاء المقام بيانها، فإنه يدل على عدم إرادة الثارع لله؛ لأنه لو أراده لما سكت عنه في موضع يحتاج فيه المكلف إلى بيان حكمه. وفي ذلك يقول شهاب الدين الزَّْجَانِيُّ: "إِذا سُئِلَ رَسُول اللهـ- صلى الله عليه

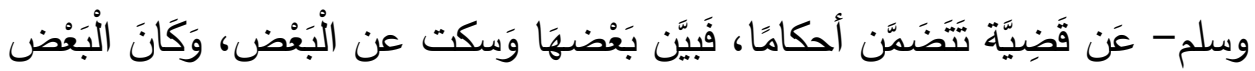

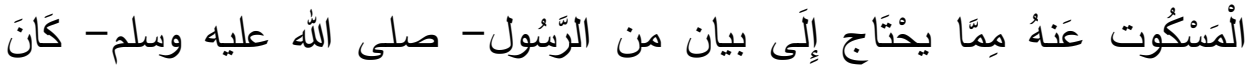

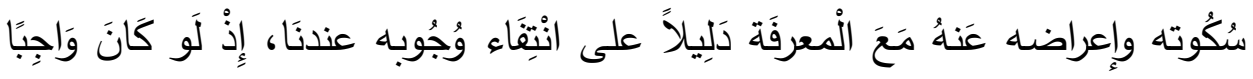

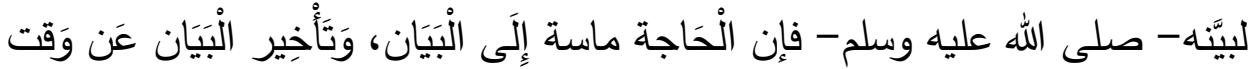

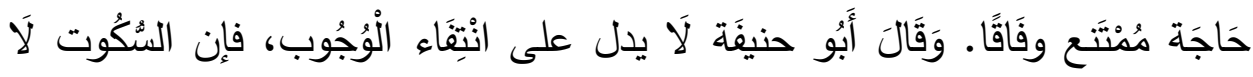

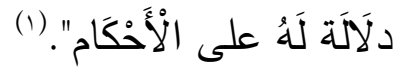
الصورة الثانية: أن يكون المسكوت عنه مما يُظَنّ ثبوته، أو يُتردّد فيه، لتعارض الأدلة، فينبخي أن يكون السكوت عنه دليل انتفائه.

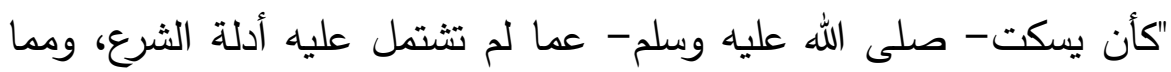
ذكر له في القرآن، والمستفتي ليس خبيرًا بأدلة الشرع بصيرًا بالأحكام. فسكوتهصلى الله عليه وسلم- في مثل ذلك حجة، وإلا لزم تأخير البيان عن وقت الحاجة،

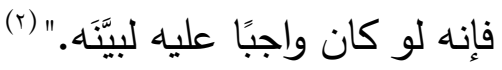

(1) تخريج الفروع على الأصول: لـحمود بن أحمد بن محمود، شهاب الدين الزَّنْجاني الثافعي

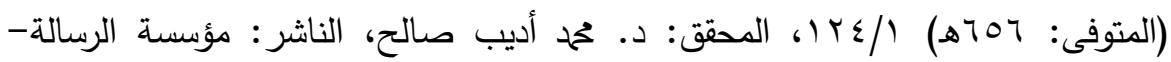

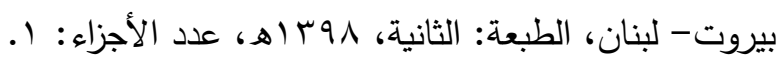

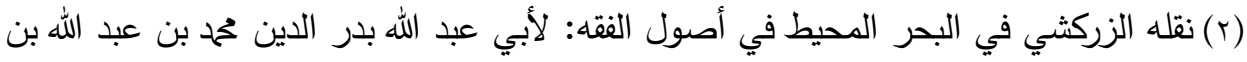

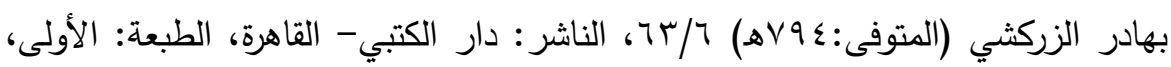

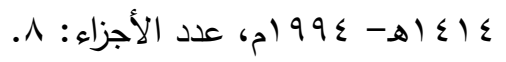


وقد ذكر الأصوليون أمثلة لهذه المسألة، أورد منها مثالين:(1) المثال الأول: ما ورد في حديث يعلى بن أمية:" أَنَّه قَالَ لِعُدَرَ - رضي اللهِ

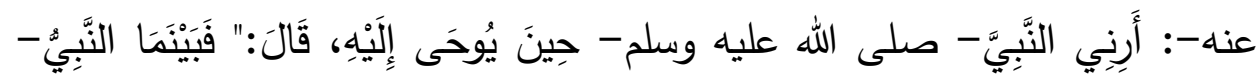

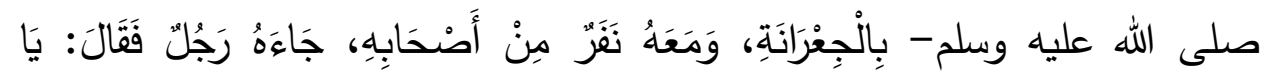

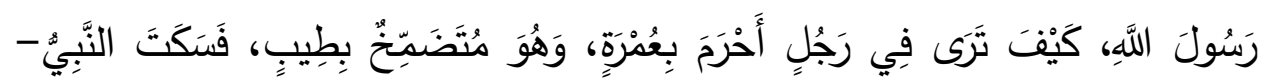

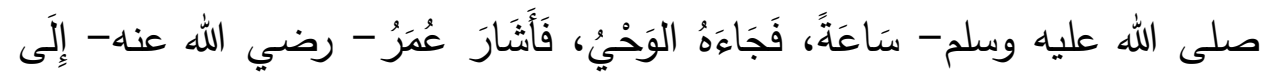

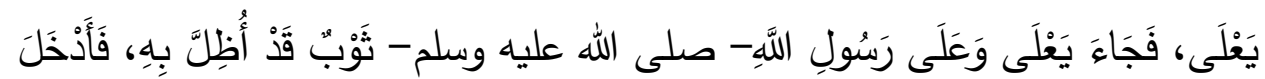

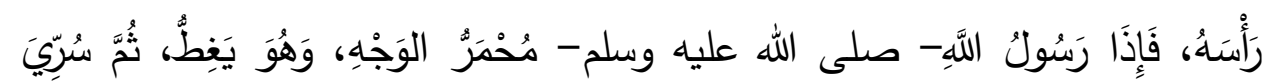

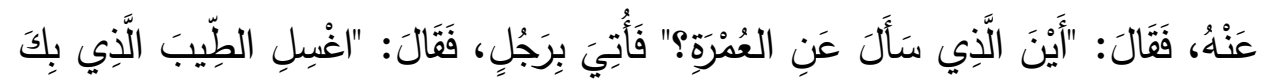

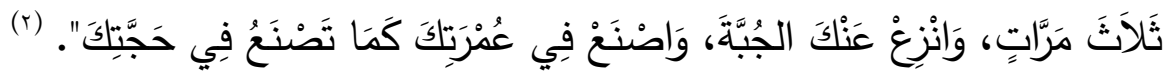

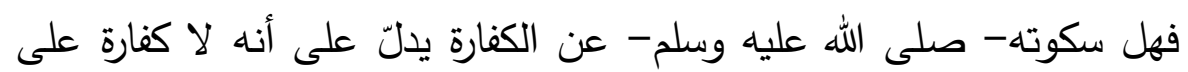
الجاهل؟ أم أنه إنما سكت عن ذلك إحالةً على ما ورد من نصوص أخرى في وجوب الفدية على خرق محظورات الإحراج؟ ذهب الحنفية (r) والمالكية (๕) إلى وجوب الإحرام الكفارة بناءً على أن السكوتَ هنا

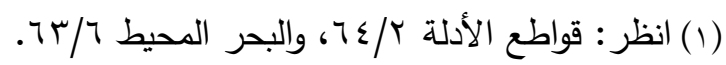

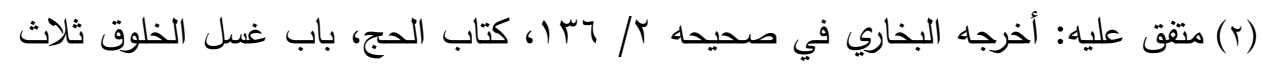

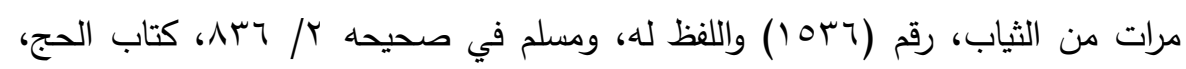

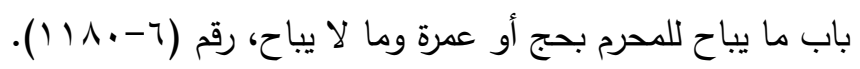

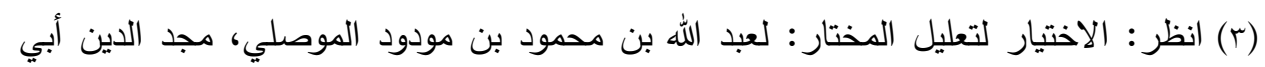

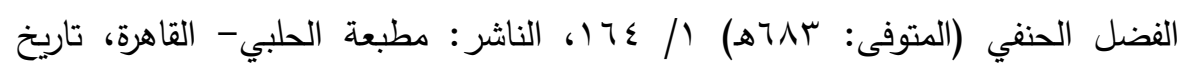

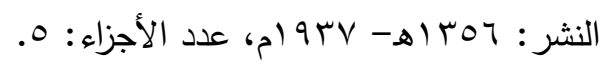

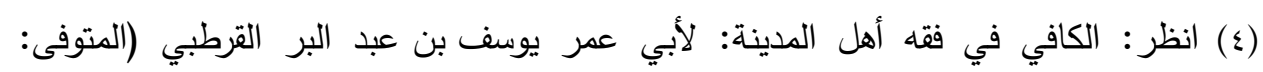

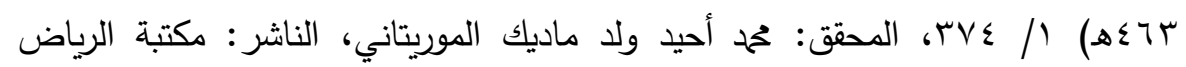

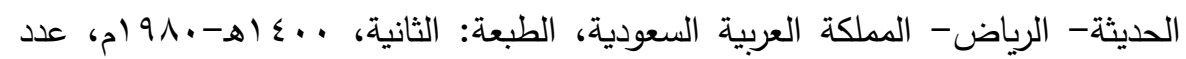


إحالةٌ على ما ورد من نصوص في حُكْم خرق محظورات الإحرام. كقوله- تعالى -:

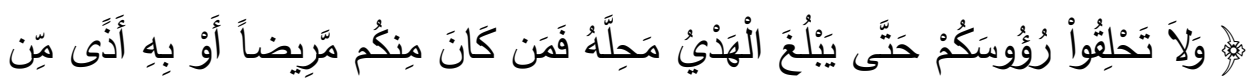

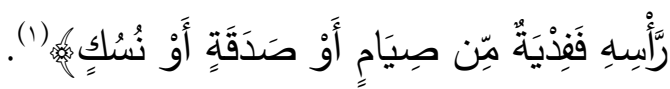
وذهب الثافعية (r) والحنابلة (r) إلى أن السكوت هنا دليل ألى على على عدم وجوب

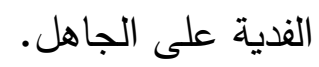

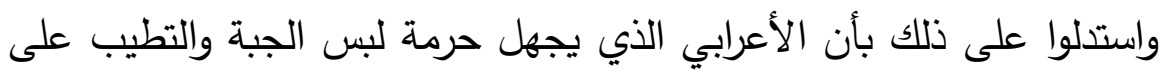

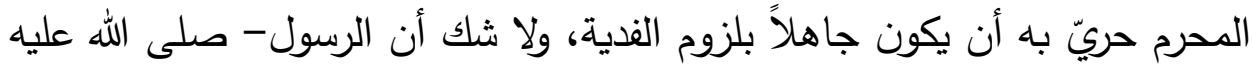

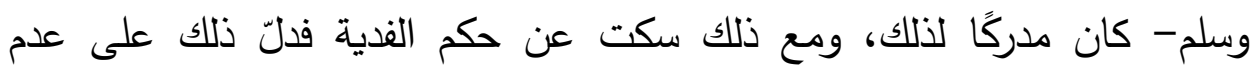
وجوبها. فقد أمر النبي - صلى الله عليه وسلم- السائل بغسل الطِّيب ونزع الجبَّة، لكنه

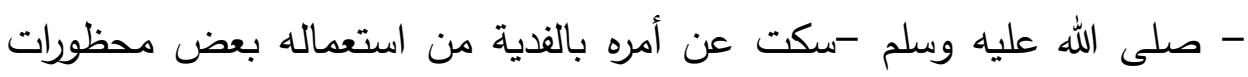

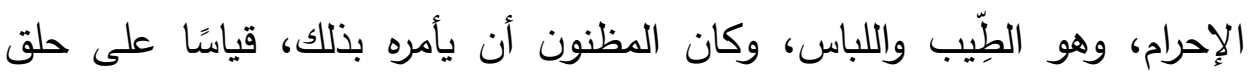

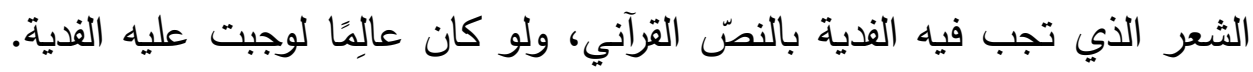

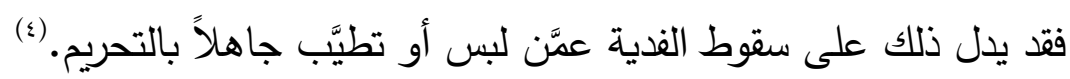

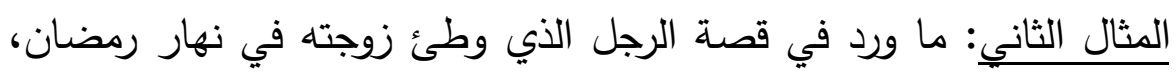

(1) - مورة البقرة: 197.

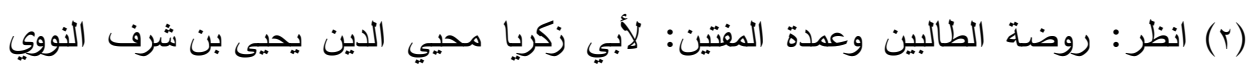

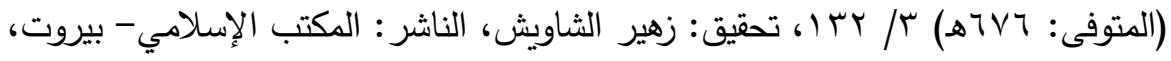

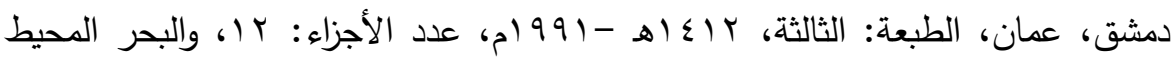

$$
\text { .rVI / }
$$

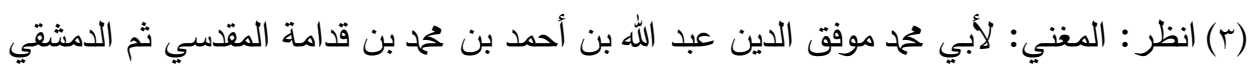

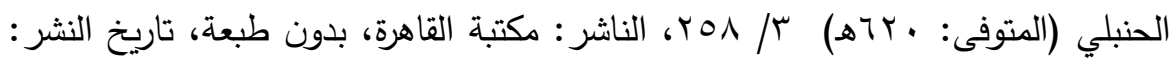

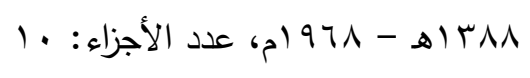

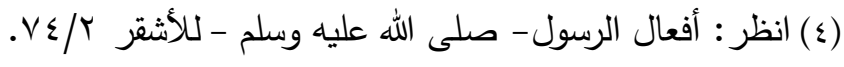


فأمره النبي - صلى الله عليه وسلم- بالكفارة، وسكت عن بيان حكم زوجته. فقد ورد من حديث أبي هريرة- رضي الله عنه الله- أنه قال: "بَيَنَمَا نَحْنُ لَّن

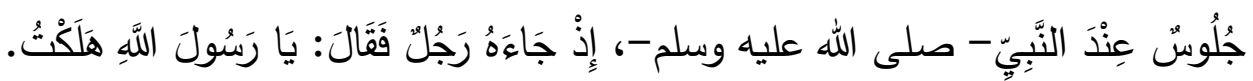

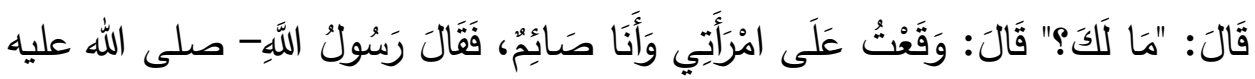

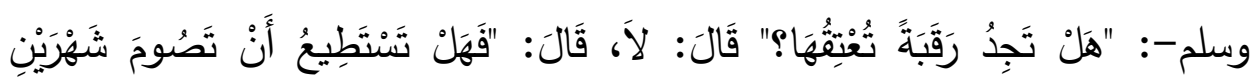

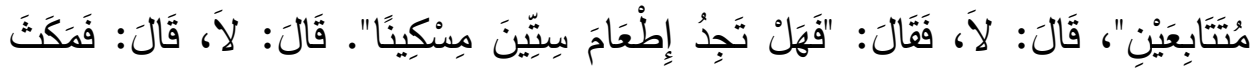

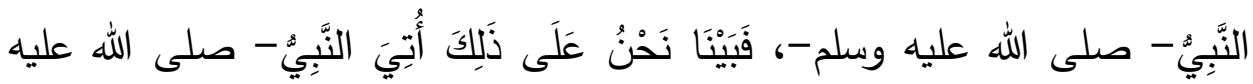

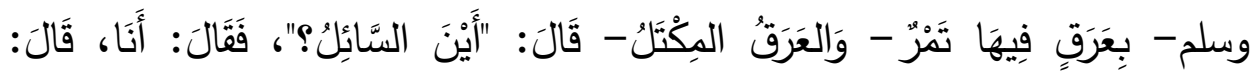

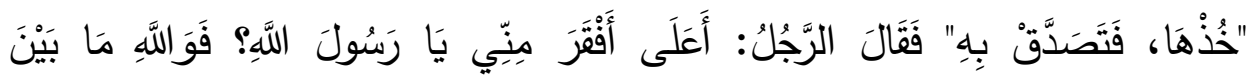

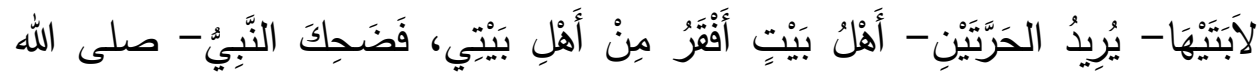

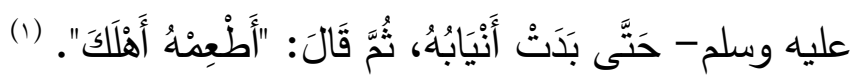

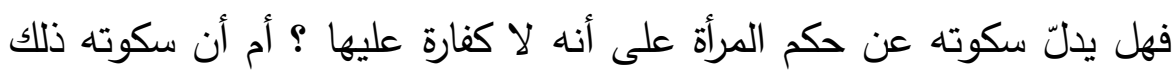

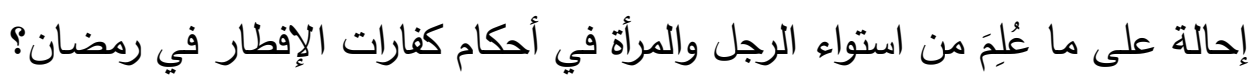
استدل بذلك بعض الفقهاء على أن المرأة لا يجب عليها لذئل الذب كفارة.

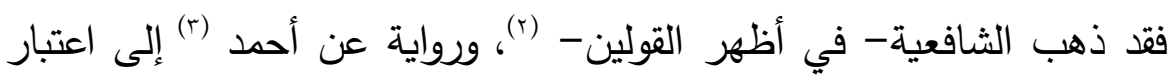
السكوت دليلاً على عدم وجوب الكفارة على المرأة. وذهب الجمهور() إلى خلاف ذلك بناءً على كون السائل عالًِِا بأحكام

(1) متفق عليه: أخرجه البخاري في صحيحه r/ بr، كتاب الصوم، باب إذا جامع في رمضان

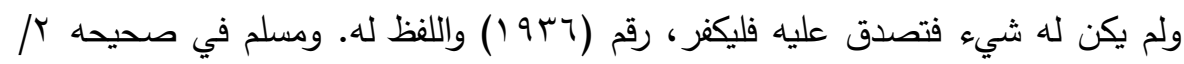

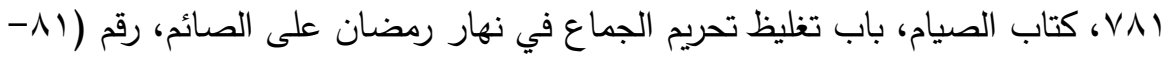

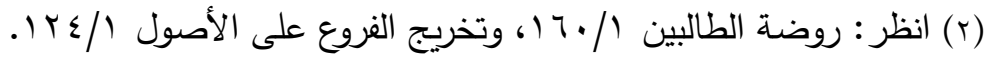

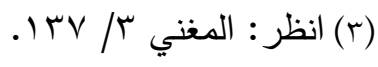

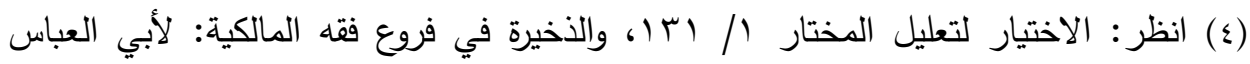


الدين، واستواء الرجال والنساء في أحكام الدفطرات. وأما المرأة فيجب عليها إذا

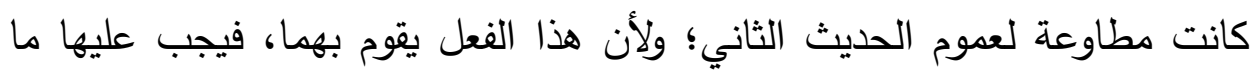
يجب عليه كالغسل والحد، وإن كانت مكرهة لا كفارة عليها كما في النسيان

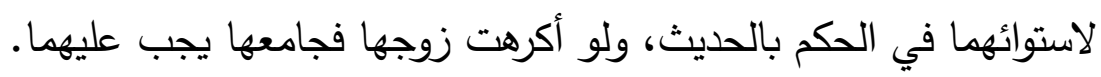

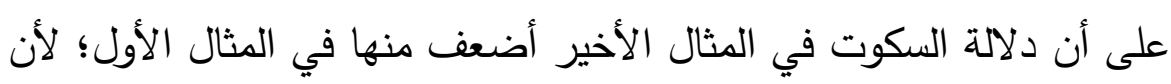

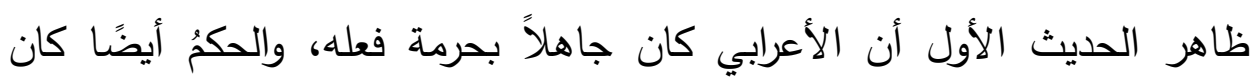

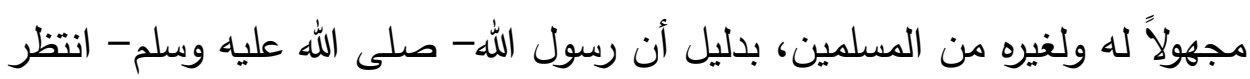

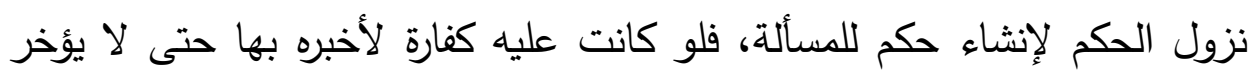

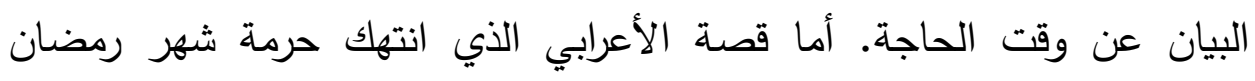

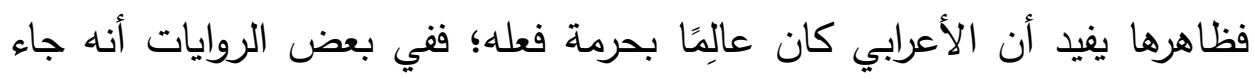

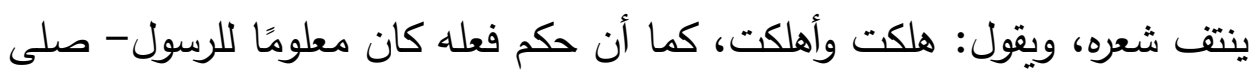

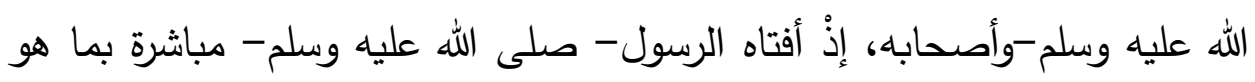

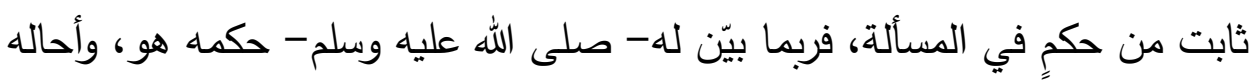

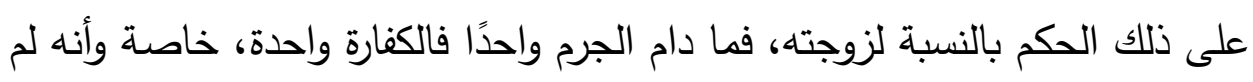

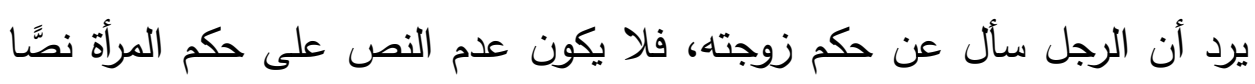

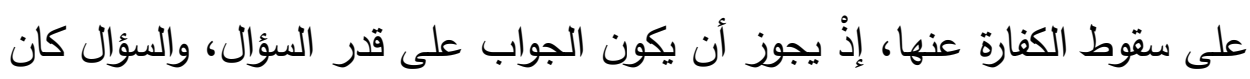

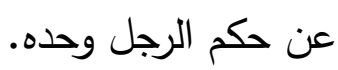

ويُستخلص من هذين المثالين التفريق بين كون المسكوت عنه قد تبيّن حكمه

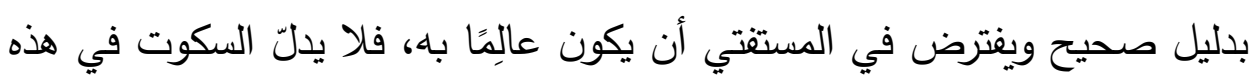

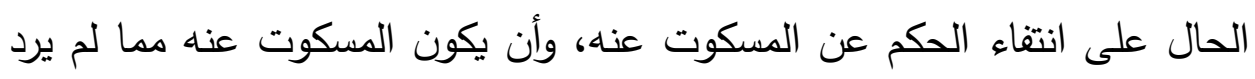

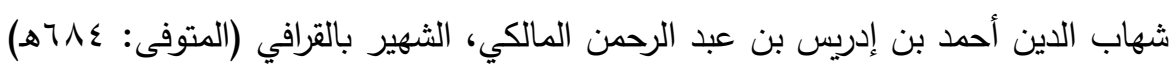
1

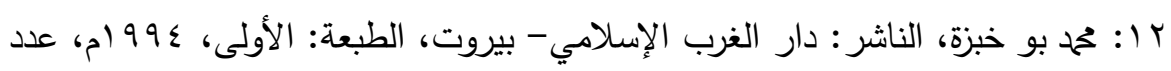

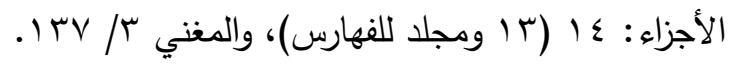


فيه حكم من قَبْلُ، أو مما يتردد حكمه، أو يلتبس على المستفتي فيمكن أن يكون

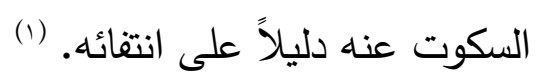

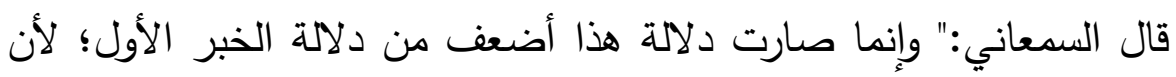
السائل في هذا الخبر قد أنبأ عن علمه بأنه ارتكب معصية، ألا ترى أنه قال:

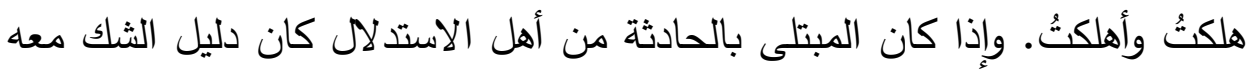
أوهى وأضعف.

ثم قال: "ومجرّد السكوت لا يدل عندنا على سقوط ما عدا الدذكور، كما يدل عند من يذهب إلى أن الأصل في الأشياء الإباحة، وإنما هو بحسب علإل الحال، وقيام

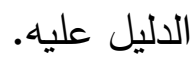

ومراتب الاستدلال بالسكوت تختلف، فأقوى ما تكون دلالة السكوت على

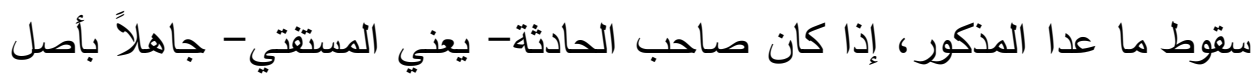

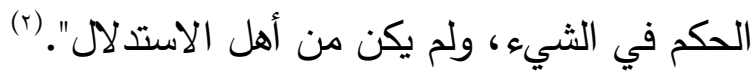

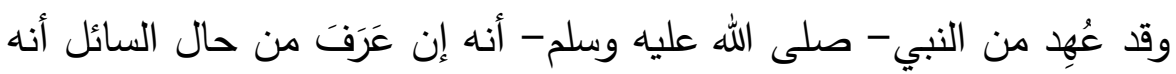

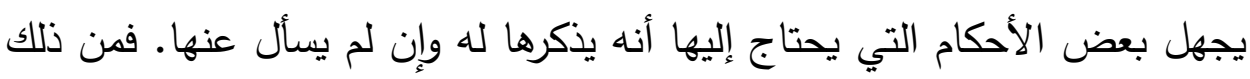

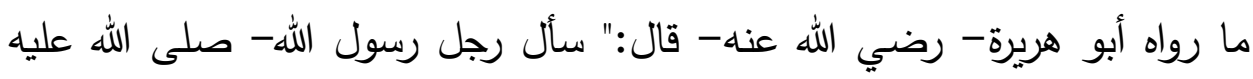
وسلم- فقال: يا رسول الله، إنا نركب البحر ونحمل معنا القليل من الماء، فإن توضأنا به عطشنا، أفنتوضأ بماء البحر؟ فقال رسول الله- صلى الله عليه وسلم-:

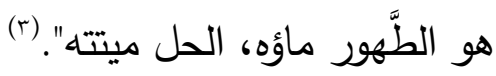
فأفادهم حكمًا لم يسألوا عنه، وهو حكم الميتة؛ لأن جهلهم جواز الطهارة

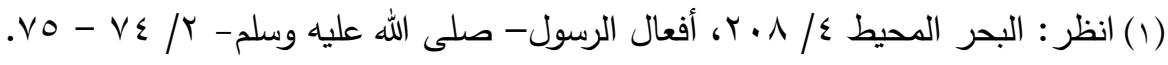

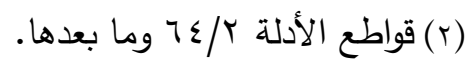

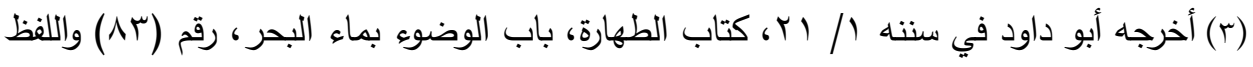

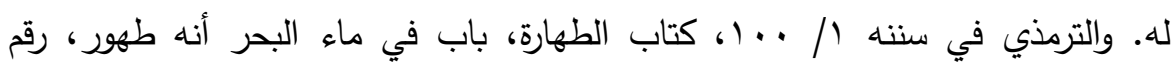

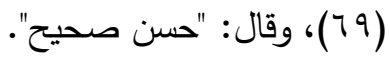


بمائه يدل بالأوَّلى على جهلهم إباحة ميتته، وهم يحتاجون إلى معرفة ذلك. فإن كان السائل ممن له حظ من العلم، وكان له بصر بالأدلة والأحكام، لإلها

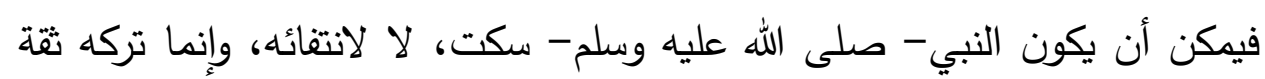

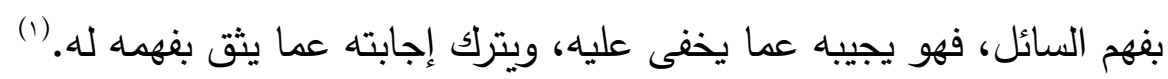
(1) أفعال الرَّسول-صلى الله عليه وسلم- للأشقر Vo/r. 


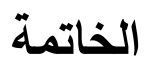

الحمد لله حمدًا يوافي نعمه ويكافئ مزيده، والصلاة والسلام على رسول الله، وآله وصحبه ومن والاه، وبعد:

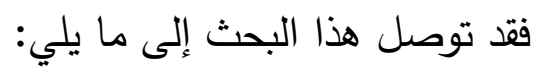

السكوت في موضع الحاجة إلى البيان بنزلة البيان، وسكوت النبي- صلى الله

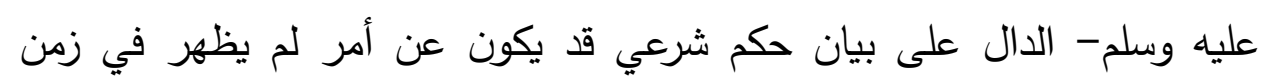

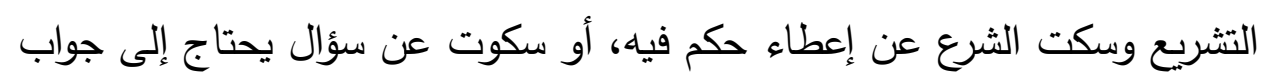

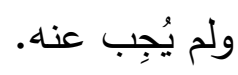

فيكون سكوته- صلى الله عليه وسلم- بعد السؤال عن حكم أو واقعة لم يتبين

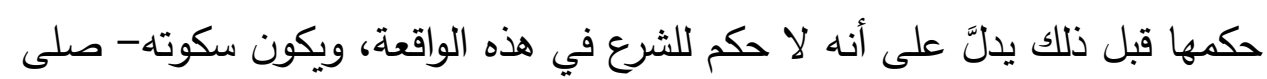

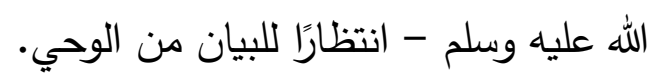

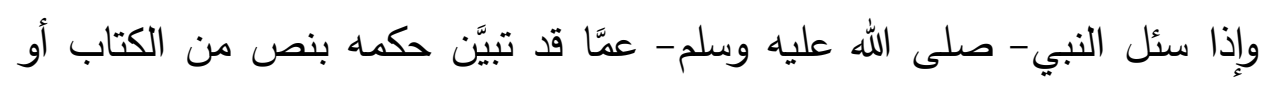
السنّة قبل ذلك فسكت، فإن هذا السكوت قد يكون إحالةً منه- صلى الله عليه

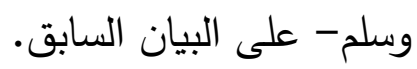

فإذا سُئل النبي - صلى الله عليه وسلم- عن مسألة ليس فيها حكم فسكت،

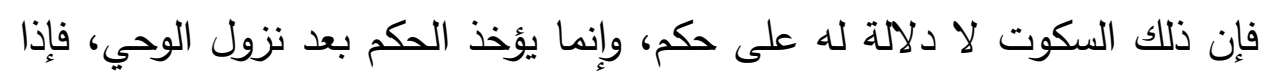

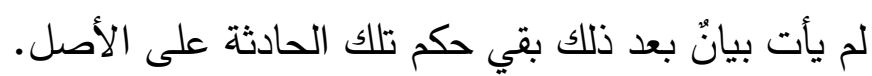
أما إن كان فيها حكم، فقد كان - صلى الله عليه وسلم- يبيِّنُّ؛ لأنه مأمور

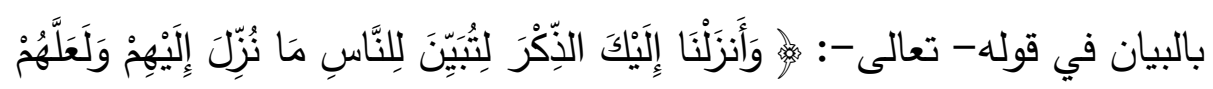

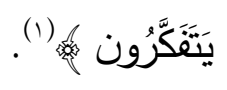

والله أعلى وأعلم.

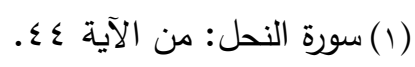




\section{فهرس المصادر والمراجع}

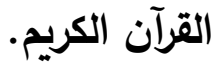

• الإبهاج في شرح المنهاج "منهاج الوصول للبيضاوي": لتقي الدين أبي الحسن

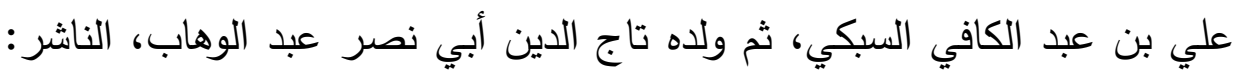

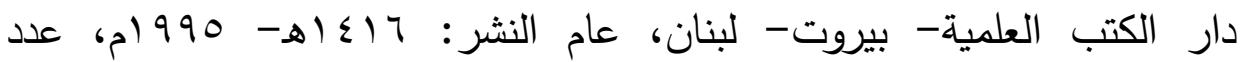

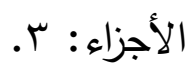

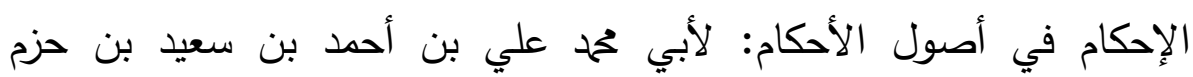

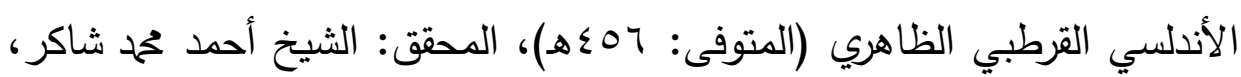

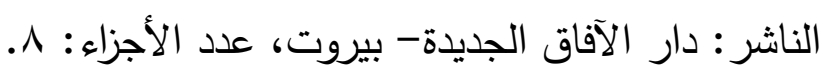

الاختيار لتعليل المختار : لعبد الله بن محمود بن مودود الموصلي، مجد الدين الدالين

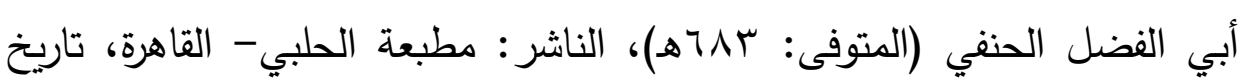
النشر:

أصول الثاشي: نظام الدين أبي علي أحمد بن محمد بن إسحاق الثاء الثاشي الحنفي

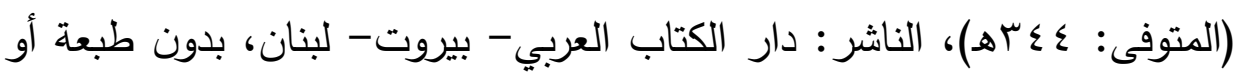
تاريخ ، عدد الأجزاء: المه)، الناشر:

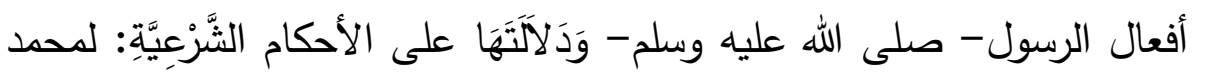

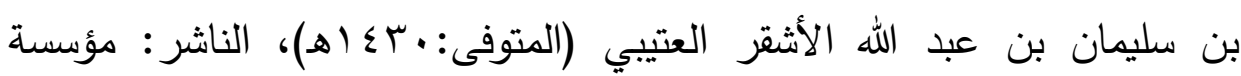

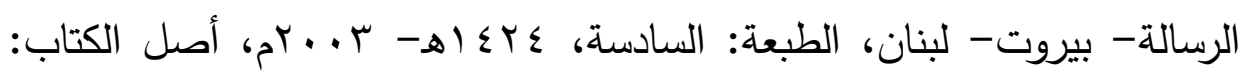

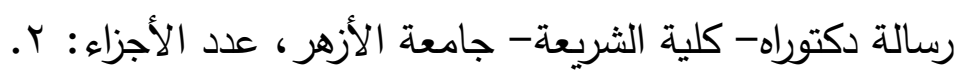

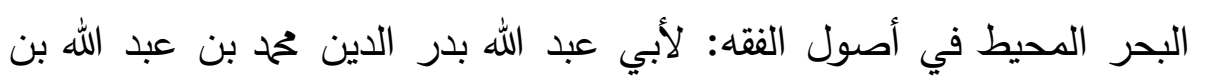

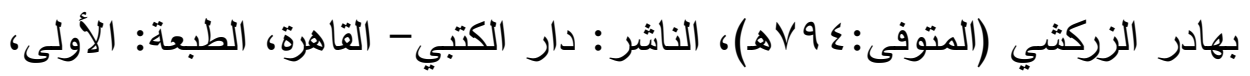

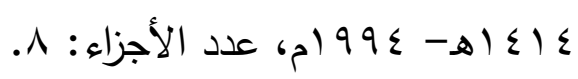

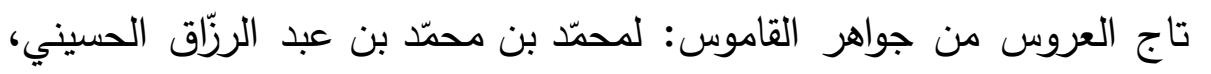

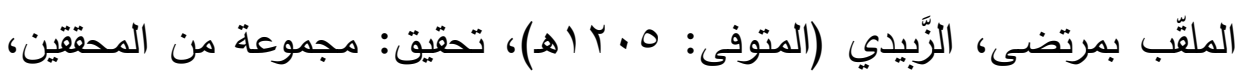


الناشر : دار الهداية- القاهرة، بدون طبعة أو تاريخ، عدد الأجزاء: • ع. التحبير شرح التحرير : لعلاء الدين أبي الحسن علي بن سليمان المرداوي

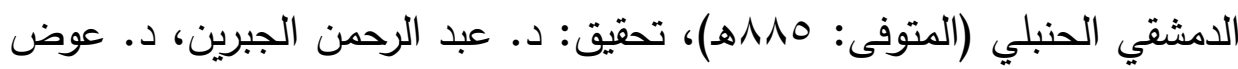
القرني، د. أحمد السراح، الناشر: مكتبة الرشد- الرياض- السعودية، الطبعة:

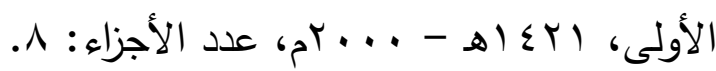

• تخريج الفروع على الأصول: لمحمود بن أحمد بن محمود، شهاب الدين الزَّنجاني الثافعي (المتوفى: 704هـ)، المحقق: د. محمد أديب صالح، الناشر: مؤسسة الرسالة- بيروت- لبنان، الطبعة: الثانية، ^وب اهـ، عدد الأجزاء: 1 . التعريفات: لعلي بن تحمد بن علي، الثريف الجرجاني (المتوفى: 7 (1/هـ) ضبطه وصححه جماعة من العلماء بإشراف الناشر، الناشر: دار الكتب العلمية-

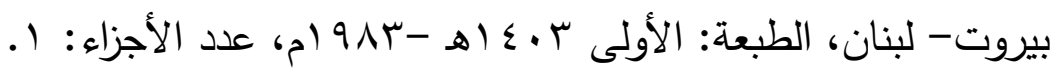
الجامع المسند الصحيح المختصر من أمور رسول الله- صلى الله عليه وسلم-

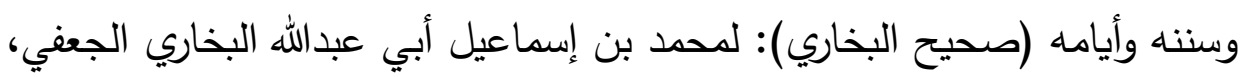
تحقيق: ححم زهير بن ناصر الناصر، الناشر: دار طوق النجاة (مصورة عن

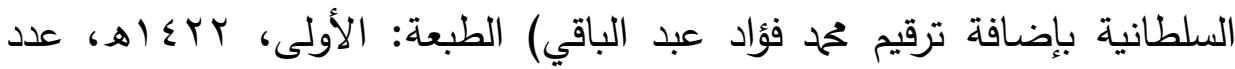
الأجزاء: 9 (مع الكتاب: شرح وتعليق د. مصطفى ديب البغا، أستاذ الحديث وعلومه في كلية الثريعة - جامعة دمشق). هاشية رد المحتار على الدر المختار، المعروفة بحاشية ابن عابدين: لمحمد

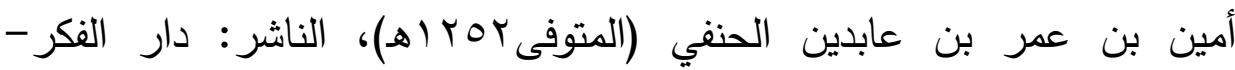

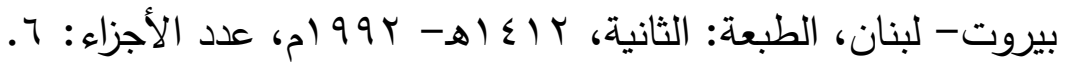
الذخيرة في فروع فقه المالكية: لأبي العباس شهاب الدين أحمد بن إدريس بن

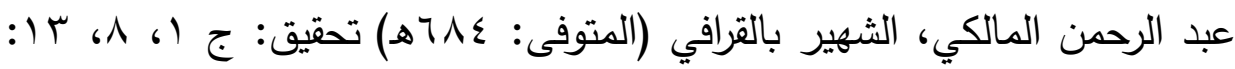

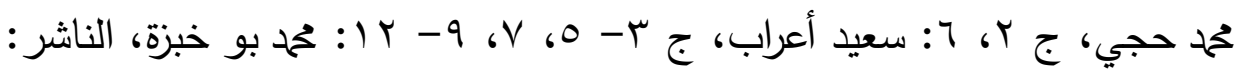

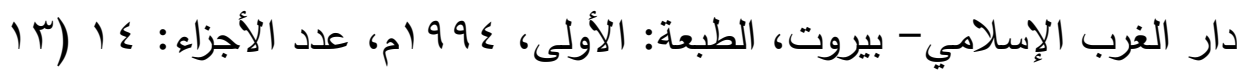




\section{ومجلد للفهارس).}

روضة الطالبين وعمدة المفتين: لأبي زكريا محيي الدين يحيى بن شرف النووي (المتوفى: TV7 7هـ تحقيق: زهير الثاويش، الناشر: المكتب الإسلامي- بيروت،

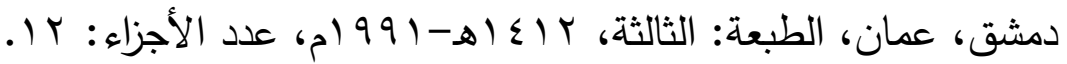
• سنن أبي داود: لأبي داود سليمان بن الأشعث بن إسحاق بن بشير بن شداد

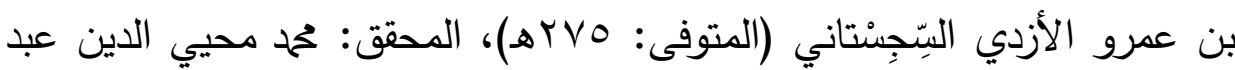
الحميد، الناشر: المكتبة العصرية، صيدا- بيروت، بدون تاريخ أو طبعة، عدد

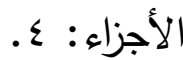
• سنن الترمذي (الجامع الصحيح): لمحمد بن عيسى بن سَوْرة بن موسى بن الضحاك، الترمذي، أبي عيسى (المتوفى: (، Y)، وخحمد فؤاد عبد الباقي (ج r)، وإبراهيم عطوة عوض (جء، 0) الناشر: مكتبة ومطبعة مصطفى البابي الحلبي- مصر، الطبعة: الثانية، 90 باهـ 9V0 ام، عدد الأجزاء: 0 أجزاء. الصحاح(تاج اللغة وصحاح العربية): لأبي نصر إسماعيل بن حماد الجوهري

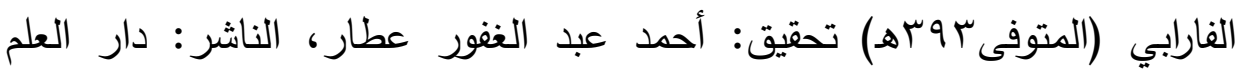

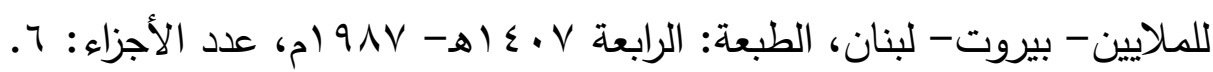
قواطع الأدلة في الأصول: لمنصور بن ححمد بن عبد الجبار ابن أحمد المروزى

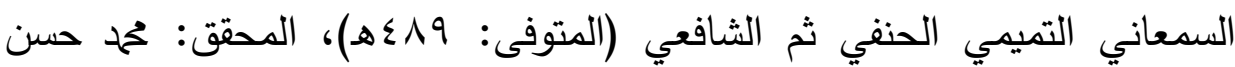
إسماعيل الثافعي، الناشر: دار الكتب العلمية- بيروت- لبنان، الطبعة: الأولى،

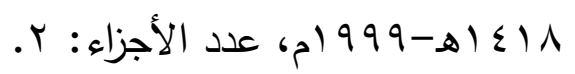
الكافي في فقه أهل المدينة: لأبي عمر يوسف بن عبد البر القرطبي (المتوفى:

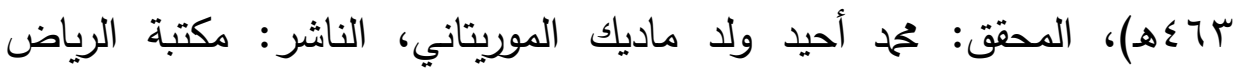

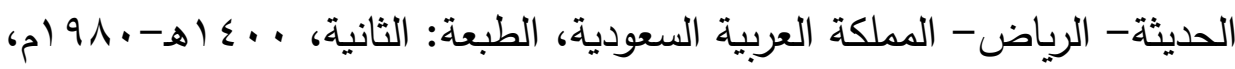

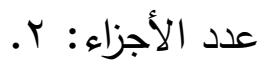


كثف الأسرار شرح أصول البزدوي: لعبد العزيز بن أحمد بن ححم، علاء الدين

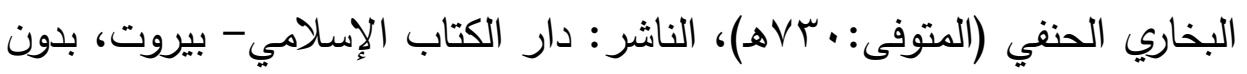

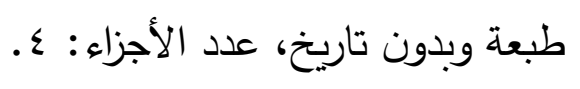

لسان العرب: لمحمد بن مكرم بن على، أبي الفضل، جمال الدين ابن منظور

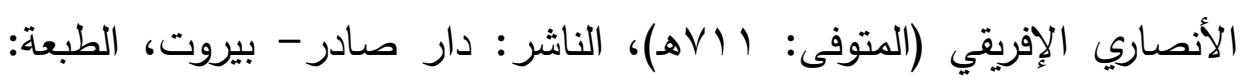

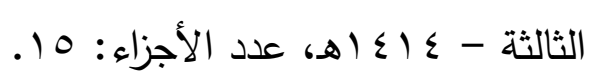
• المسند الصحيح المختصر بنقل العدل عن العدل إلى رسول الله- صلى الله عليه وسلم-(صحيح مسلم): لمسلم بن الحجاج، أبي الحسن القشيري النيسابوري (المتوفى: ابrrهـ) المحقق: محمد فؤاد عبد الباقي، دار إحياء التراث العربيبيروت، عدد الأجزاء: 0. • مفتاح الوصول إلى بناء الفروع على الأصول: للشريف أبي عبد الله محلد بن

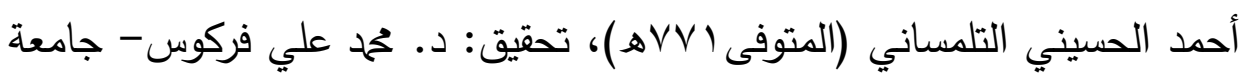

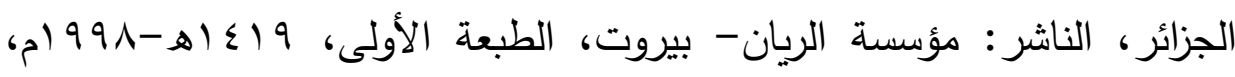

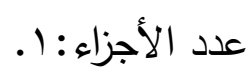

المفردات في غريب القرآن: لأبي القاسم الحسين بن تحمد المعروف بالراغب

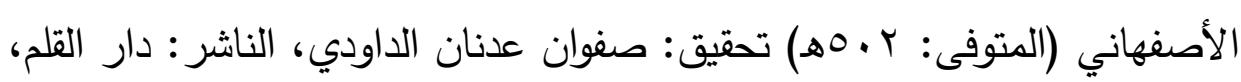

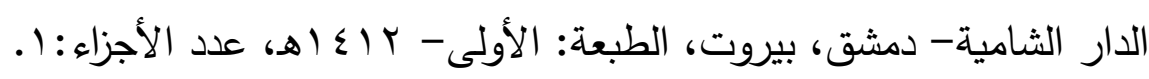

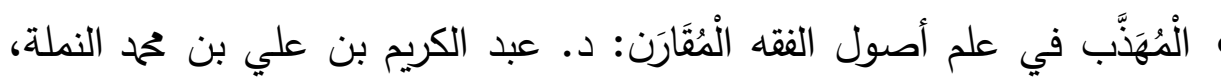

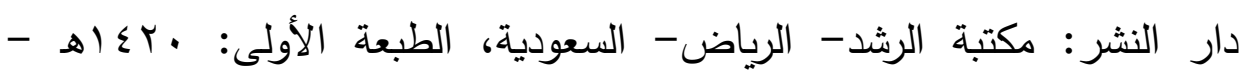

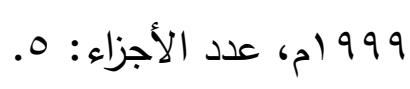
• الموافقات في أصول الثريعة: لإبراهيم بن موسى بن محمد اللخمي الغرناطي

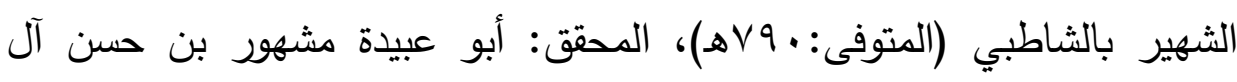

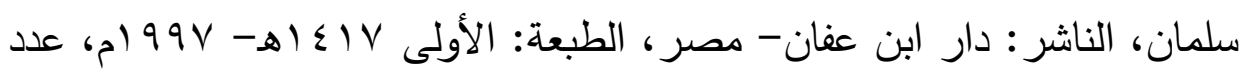

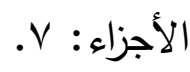




\title{
الماركسية الجديدة ولانهانية التارية عند جاك دريدا
}

\author{
د. شريف مصطفى أهمد \\ مدرس بقسم الفلسفة - كية الآداب

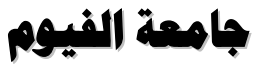

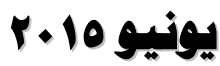




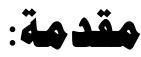

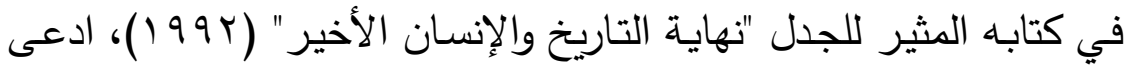
المنظر السياسي الأمريكي فرانسيس فوكوياما (190ץ (- ؟)أن التاريخ قد انتهى؛ لأن الديمقراطية الليبرالية الغربية قد انتصرت على الثيوعية والماركسية، وأعلن أن

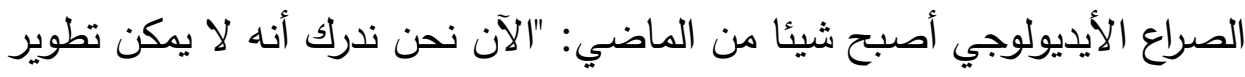

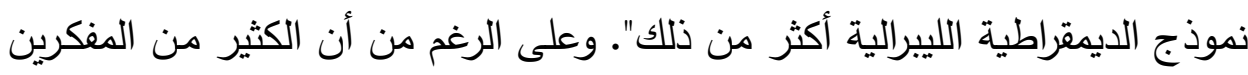
قد دعموا هذا الطرح الجريء الذي طرحه فوكوياما، خاصة خلال الفترة الأولى التي التي التئي

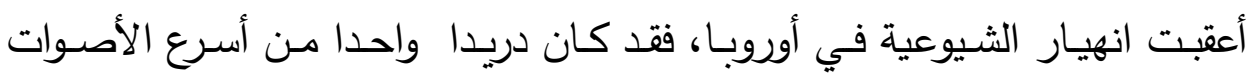

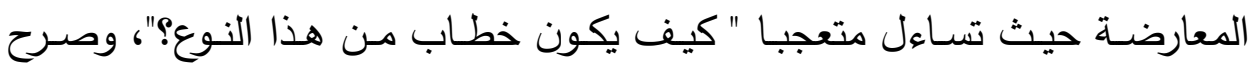

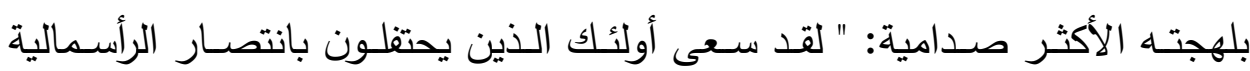

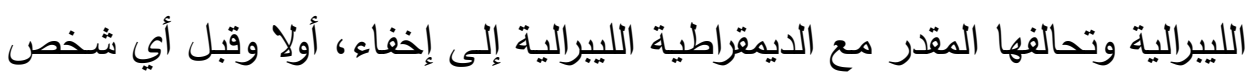

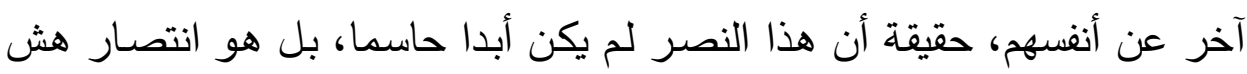

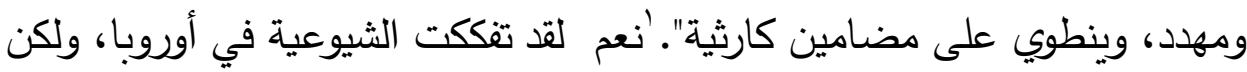

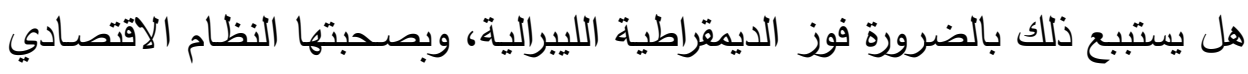

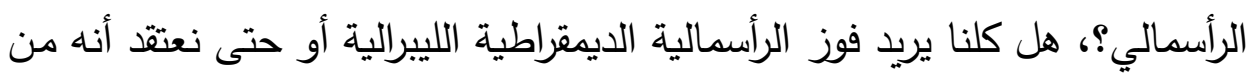

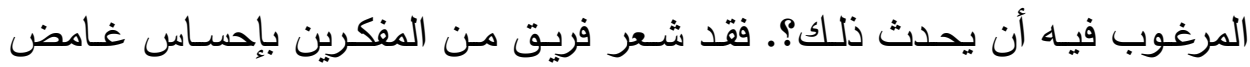

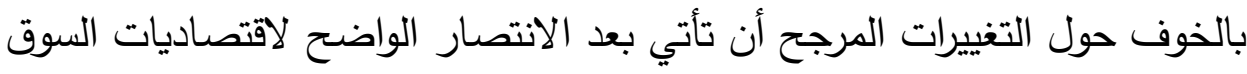

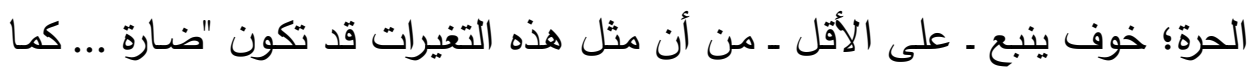

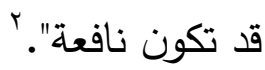

من هنا كانت المهمة التي حددها دريدا لنفسه في مؤلف بعنوان "أشباح

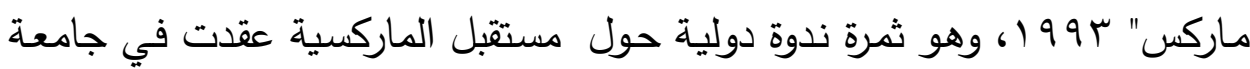
كاليفورنيا عام بو9 1، تجسد ما يكمن وراء هذا الشعور بالتخوف، من أجل إثبات

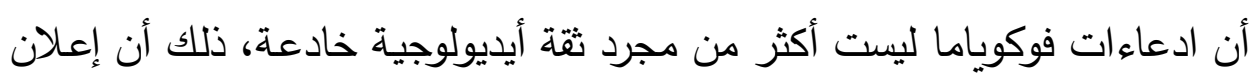

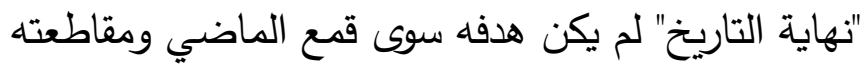


لقد حاول دريدا إحياء سمعة كارل ماركس ربما من أدنى نقطة في التاريخ

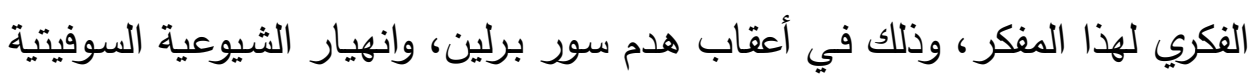

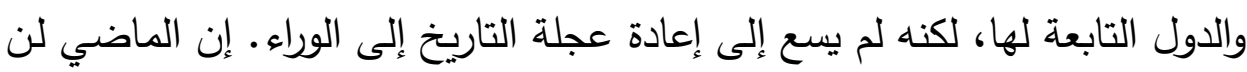

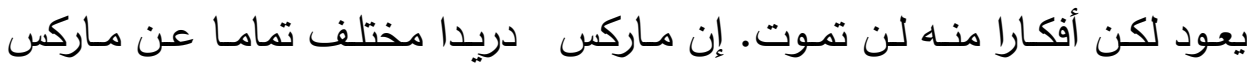
التقليدي، كما يقول "هو ماركس تعددي". فهناك أكثر من ماركس، بل "إن هناك لكاركي

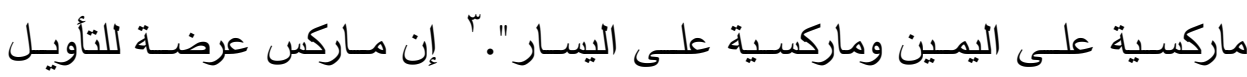
والمراجعة استجابة للظروف الثقافية المتغيرة، لكنه لم يكن ـ ولن يكون ـ مصدرا لحقيقة إنجيلية عن كيفية تغيير العالم للأفضل عبر إعادة تتظيم الحياة الاقتصادية والسياسية وفقا لمباديء قابلة للتطبيق عالميا.

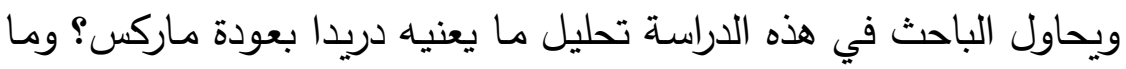
الذي يقصده بالماركسية الجديدة؟ وكيف يمكن التوفيق بين الليبرالية والماركسية؟

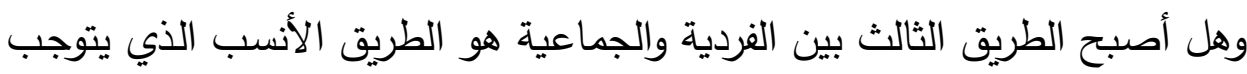

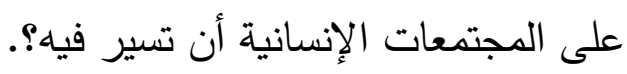
وحيث تسعى هذه الدراسة إلى تقديم تحليل نقدي لهفهوم نهاية التاريخ في

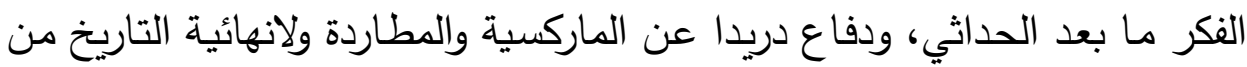

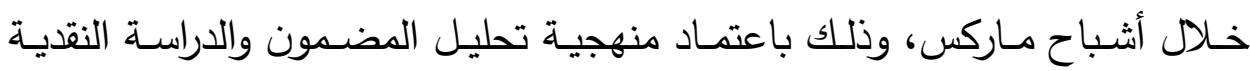

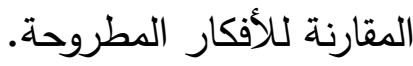
ولتحقيق هذه الأهداف يتعرض الدارس بالبحث والتحليل للعناصر الآتية:

أولا: الفكر النهاني فيسما بعد المداثة الهديق ا - ا- بودريار ونهاية التارينغ

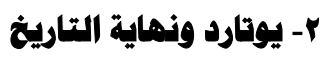

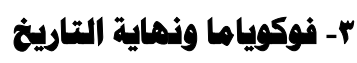

ثانيا: دريدا: شبح هاركس وتأهيل النهاية

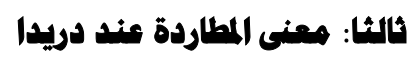
رابعا: ماركسية دريدا وليبرالية نوكوياما خاتهة 


\section{أولا: الفكر النهائي فيسما بعد المداثة}

عندما نستعرض تاريخ الفلسفة ومراحل تطورها سنجد أن هناك عددا كبيرا من المفكرين يعلنون "نهاية" شيء أو آخر ، فقد أعلن بعضهم نهاية التاريخ، وأعلن

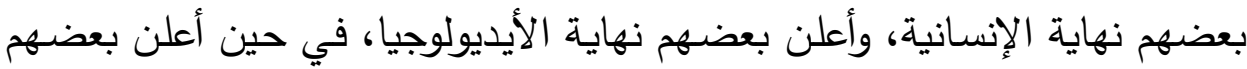
الآخر نهاية الحداثة، وأعلن غيرهم نهاية الفلسفة، وأعلن آخرون نهاية الإنسان، ويعد العالم من بين المرشحين الأكثر شعبية في الآونة الأخيرة لإعلان نهايته. ومن التاني

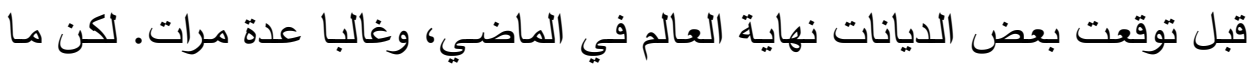
يمنح فكر النهاية تطورا جديدا، أو أعطاه ـ على أقل تقدير ـ دفعة إضافية ورنينًا،

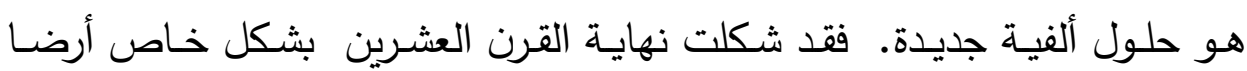

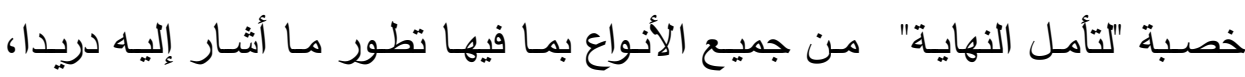

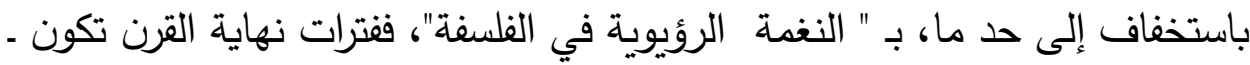
بشكل تتقليدي ـ الأكثر استجابة لمثل هذه التكهنات "الرؤيويـة". والجدير بالاعتبار هو أن العديد من هذه النهايات مترابط: فعندما تتنهي الايديولوجيا، كذلك ينتهي

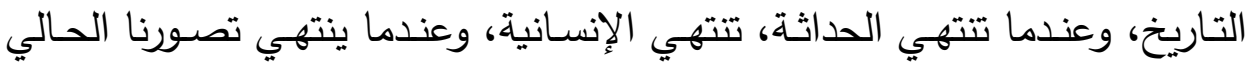
للإنسان، كذلك تتنهي الإنسانية مرة أخرى. وقد تحدث نهاية العالم، كما حذرتنا

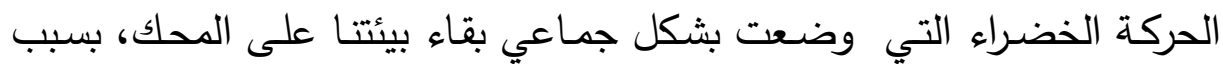
التجاوز المتزامن للأيديولوجيا، والحداثة، والإنسانية والماركسية. ويدعونا بعض بلاهي العلماء والفلاسفة إلى التنكير في نهاية لا مفر منها على ما يبدو لكوننا عندما تتوقف شمسنا عن السطوع خلال بضعة مليارات من السنوات، ويتساءلون ما إذا كان ينبغي أن يصبح هذا الحدث شاغلنا الرئيسي؟. وقد رأي يوتارد في وقت متأخر من حياته أن هذه الكارثة القادمة قد تكون أكبر مشكلة ت تواجهنا: "بينما نحن

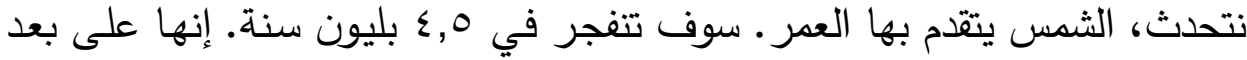
قليل من نقطة منتصف الطريق من حياتها المتوقعة ...ذلك، في رأيي، هو السؤال الخطير الوحيد الذي يواجه البشرية اليوم".؛ 
ويتاسب الفكر النهائي تماما مع الحركة الثقافية المعروفة باسم ما بعد

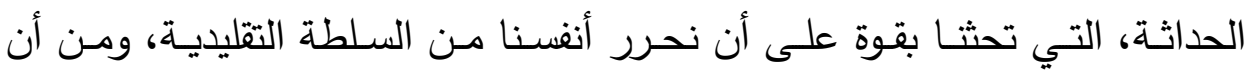

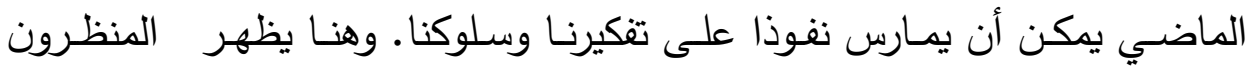

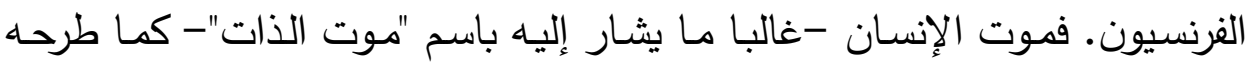

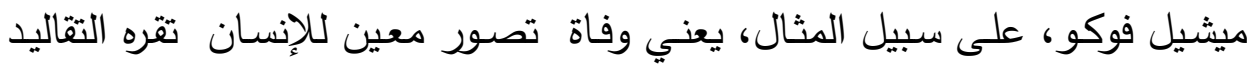
الإنسانية التي نظرت إلى الإنسان باعتباره مقياس كل الأثياء، وباعتباره قادر علي لئي

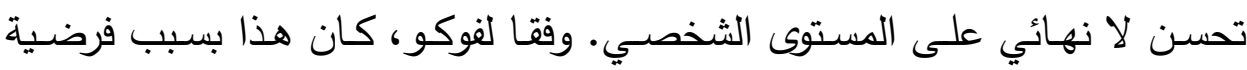

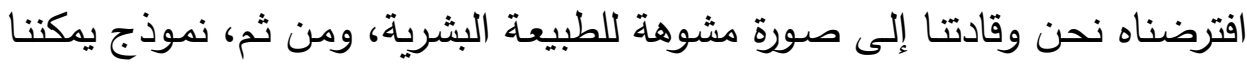

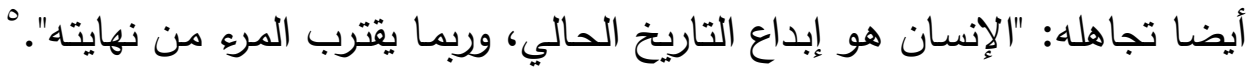

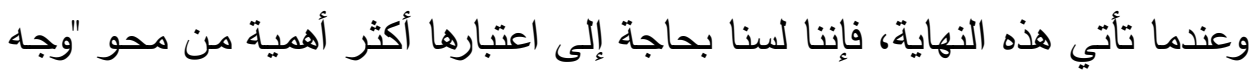
مرسوم في رمال على حافة البحر". وقد ردد كلود ليفي شتروس مشاعر مماثلة في

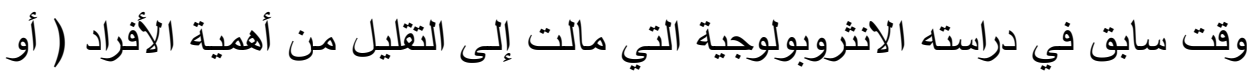

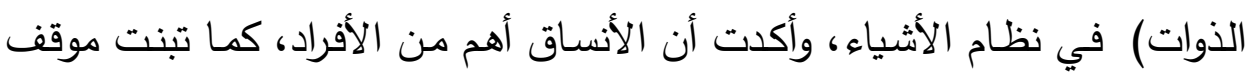
metanarrative التثكك تجاه السردية الماورائية، حيث تثير السردية الماورائية

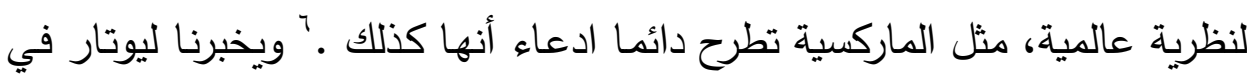

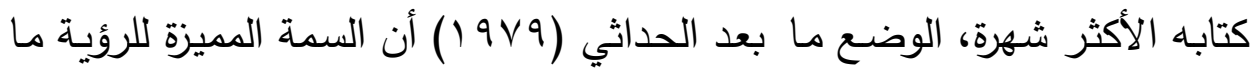

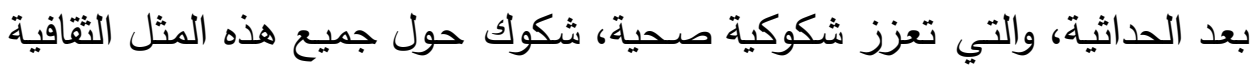
باسم "إنسان" الإنسانية، وأيضا عن المجتمعات الاستغلالية التي ساعدت هذا المثال

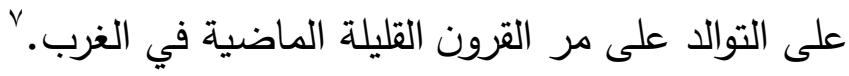
لكن السؤال هو هل يمكننا بسهولة أن نتجاهل التقليد والماضي كما يعتقد

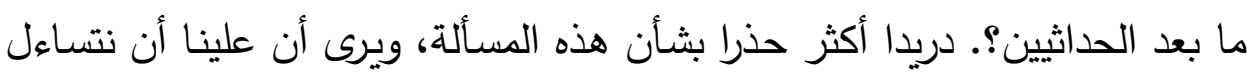
عن دوافع أولئك الذين يضغطون علينا بقوة لرفض ماضينا؟. 


\section{1- بودريار ونهاية التاريخ}

انجذب مفكرو ما بعد الحداثة إلى مفاهيم مثل نهاية التاريخ. ولا يعد هذا مدهثا

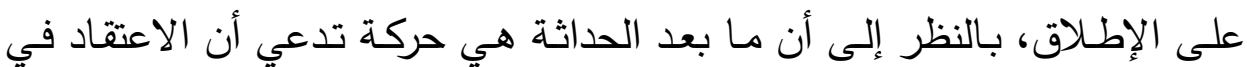
الطرق القديمـة في عمل الأشياء قد كسر دون رجعهـ. ووفقا للعبارة الشهيرة التي

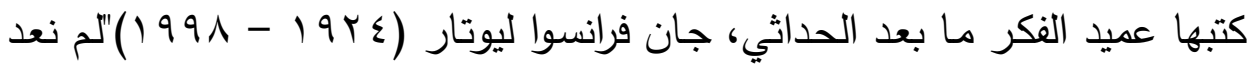
نلجأ إلى الحكايات الكبرى - لا يمكننا الجوء إلى جدل الروح ولا حتى تحرير

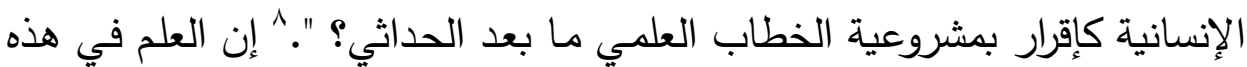

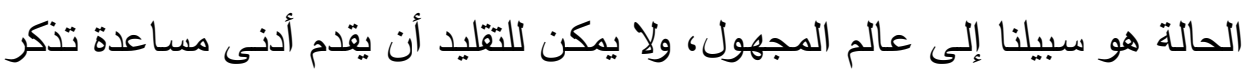

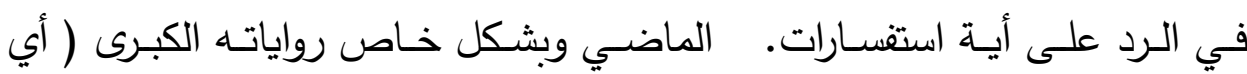

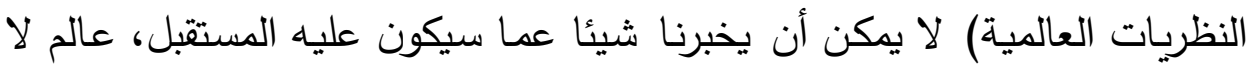

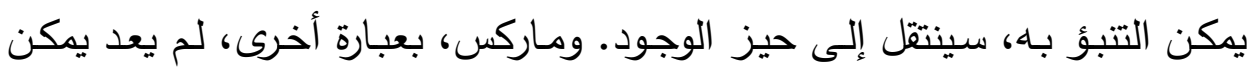
اعتباره نبيا ينشر حكمة لا تقبل الجدل. لقد جربنا روايته الكبرى ووجدناها معيبة بشدة، وليس لدينا في النهاية أي شيء أكثر نأمله منها. صحيح أن هناك أشياء نستطيع أن نتعلمها من الماضـي، التاريخ يتألف من حداثيات ومابعد حداثيات متتاوبة وفقا ليوتارد، ولكن لسنا مضطرين مطلقا إلى اعتبار أنفنا مقيدين برؤاه أو لو لئ تصوراته العالمية للتطور الاجتماعي والتاريخي :وداعا هيغل، وداعا ماركس.

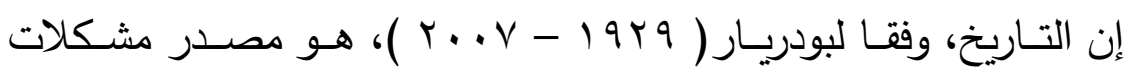
البشرية وليس مجرد موقع وجودها، وفي أفضل مواقفه من التاريخ هو يدعو لإلغاء

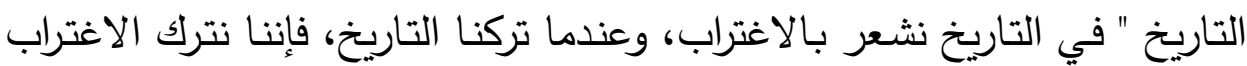

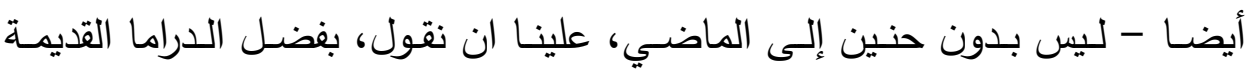

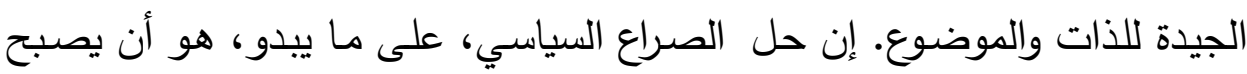

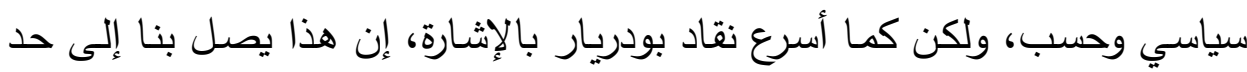

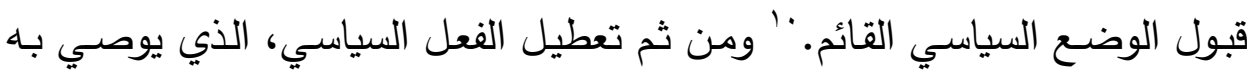
بودريار بقوة كمجال من مجالات الوجود في العديد من أعماله اللاحقة، بل وعلى لئ 
أقل تقدير، كما يلاحظ منتقدوه، يجعل الحياة أسهل بكثير بالنسبة لمن يسيطرون

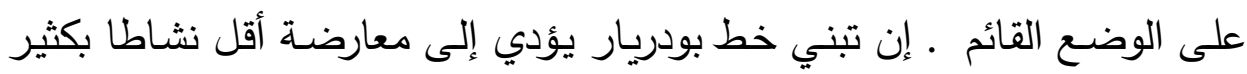

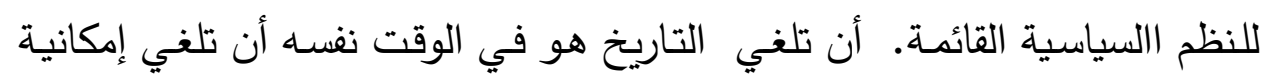

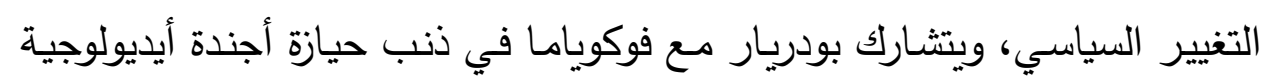
مستترة.

\section{r- ب - بوتارد ونهاية التاريخ}

يقدم يوتارد رؤية قاتمة لنهاية التاريخ ونهاية العالم. ففي مؤلفه "اللاإنساني"

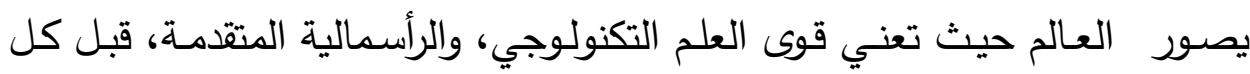

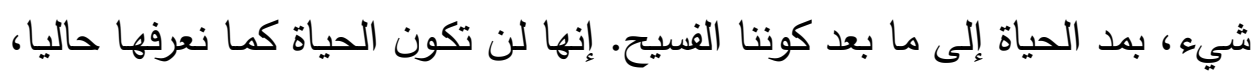

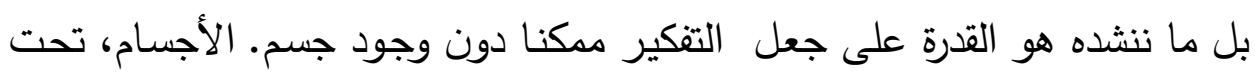

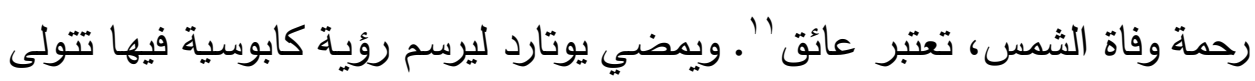

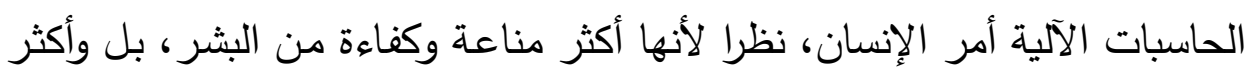

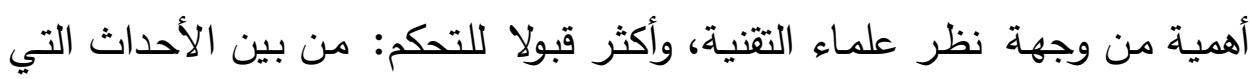

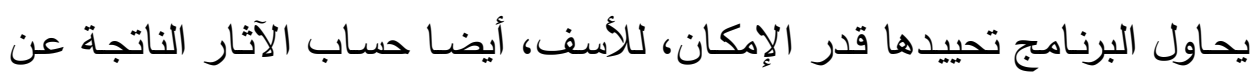

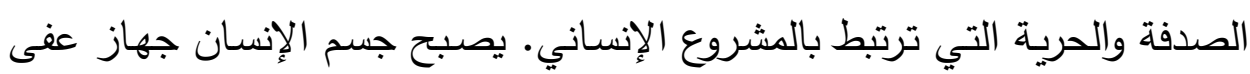

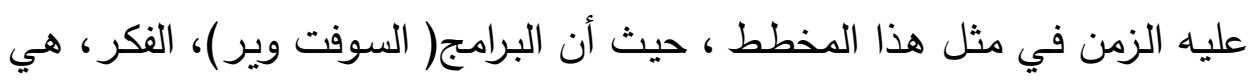

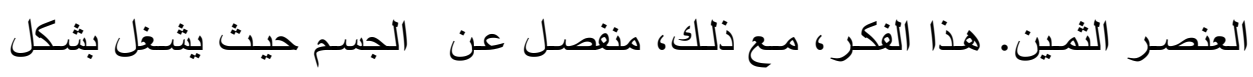

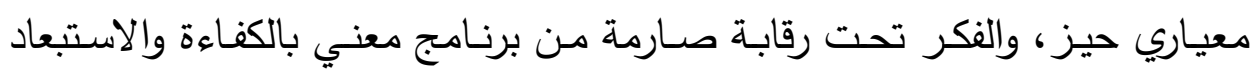

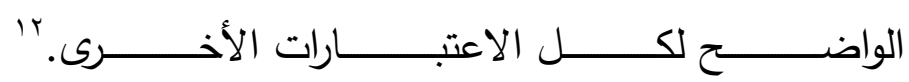

مـا يصوره يوتارد هو الجانب المظلم من دولة بودريار مـا بعد التاريخية الإنية

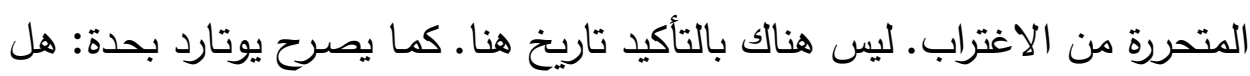

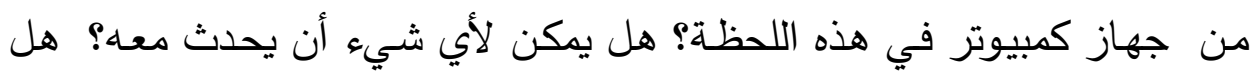

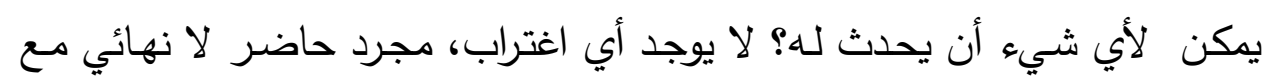

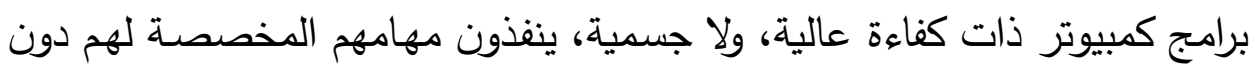


طوارئ وحرية مرتبطة بالمشروع الإنساني. "بنهاية التاريخ ، كما هندستها القوى

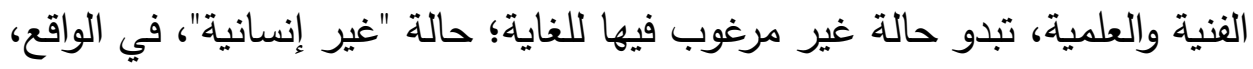
حالة من واجبنا أن نعارضها بكل ما أوتينا من قوة - على الرغم من أنه أقل تفاؤلا

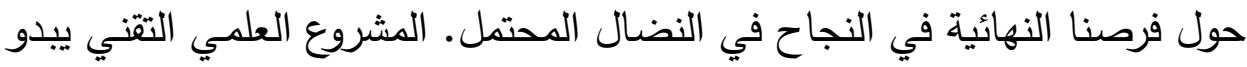

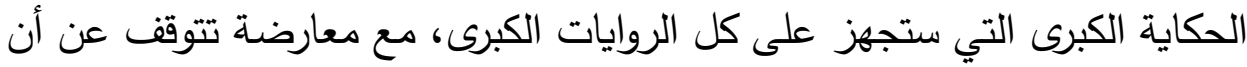
تكون فعالة في غياب الإنساني.

\section{r- بوكمياها ونهاية التارية}

لقد راجت نسخة فوكويامـا الدرامية من نهايـة التاريخ خـلال الفترة التالية

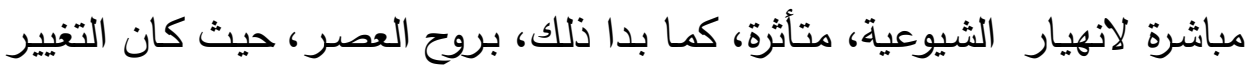

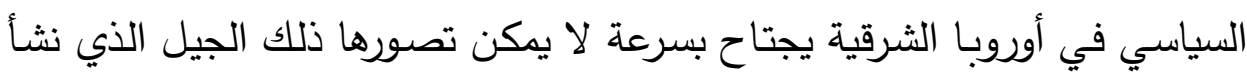

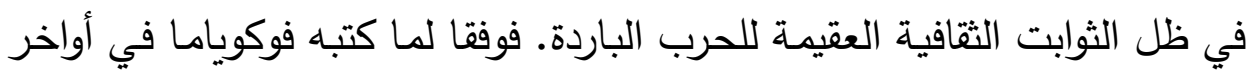

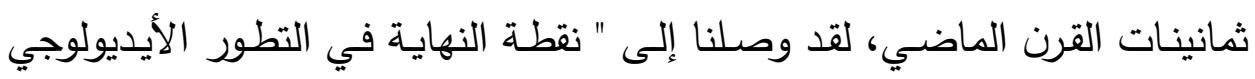

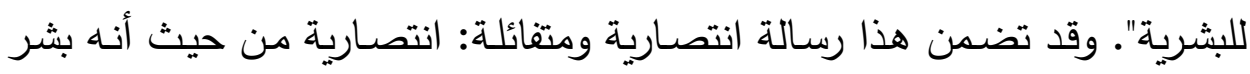
بوفاة الثيوعية؛ ومتفائلة لأنه احتفى بنهاية الحرب الباردة، وسباق التسلح النووي

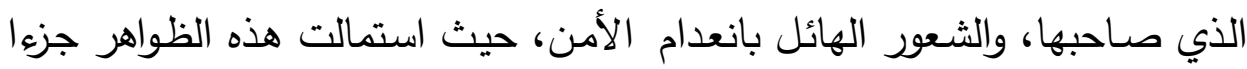

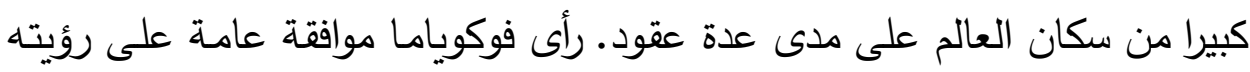

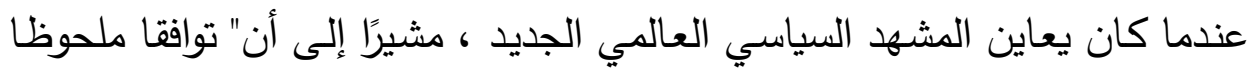

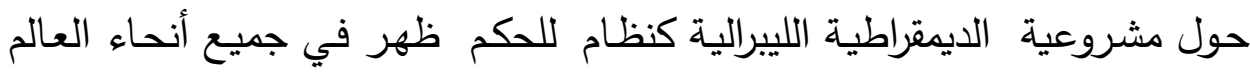
على مدى السنوات القليلة الماضية، كما أنه غزا أيديولوجيات منافسه مثل الملكية الوراثية، والفاشية، والثيوعية مؤخرا. فليس أمام المرو سوى خطوة قصيرة للاعتراف

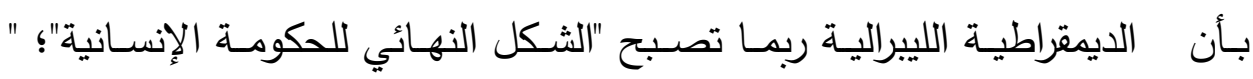

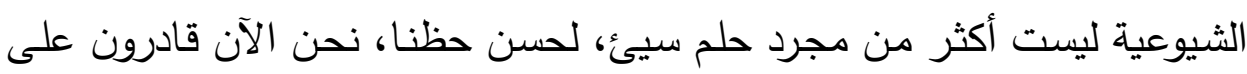
وضعه وراء ظهورنا" أ. 


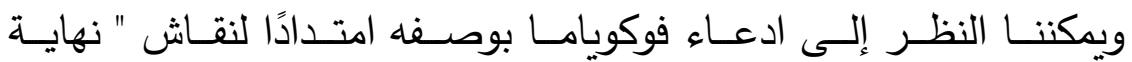

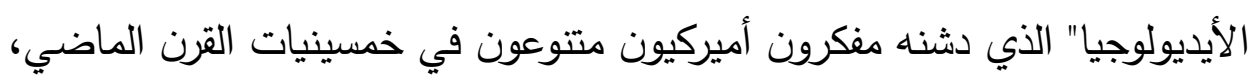

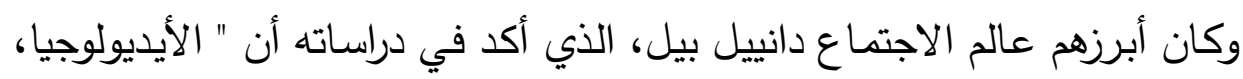

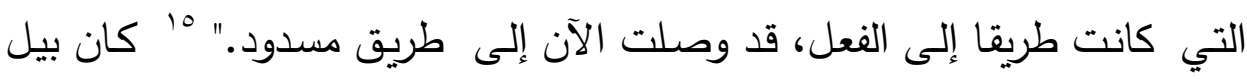

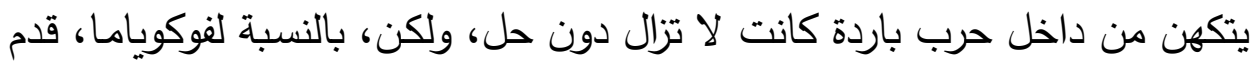

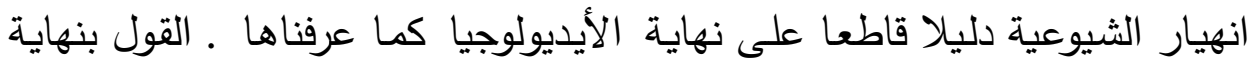

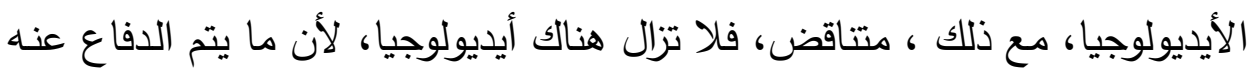

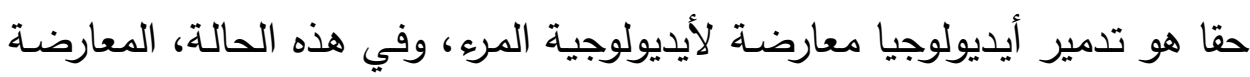

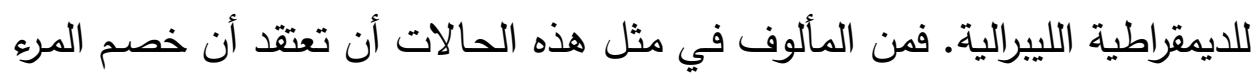

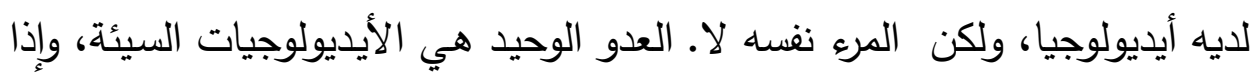

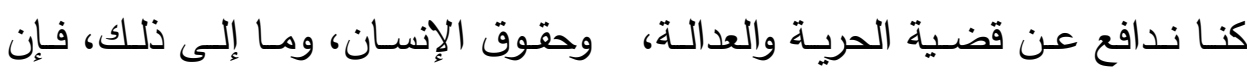
الديمقراطية الليبرالية ليست أيديولوجيا بقدر ما هي حالة مثالية للأمور ، والتي، كما كاليا

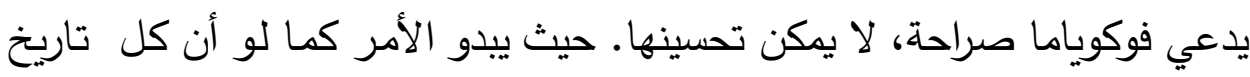
العالم لا بد من النظر إليه باعتباره تقدم نحو هدف أدركناه الآن، وحمدا لله على لإنى

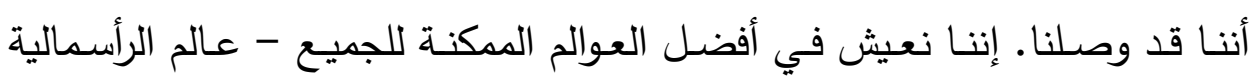

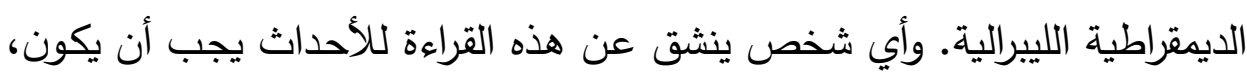

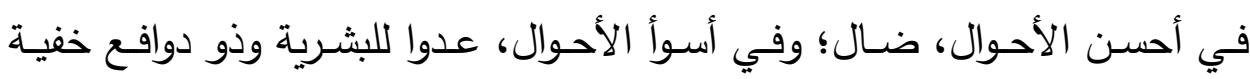

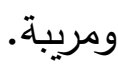

لقد جاهد فوكوياما للإثارة إلى أنه لم يعلن نهاية التاريخ بالمعنى الحرفي،

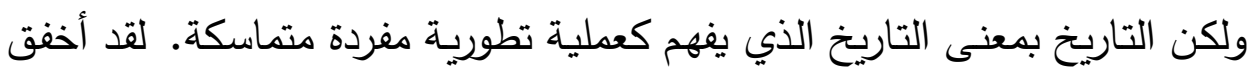

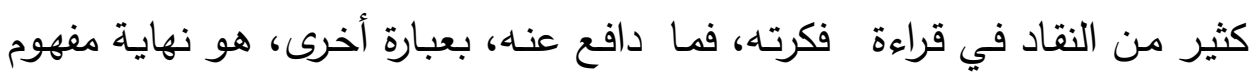

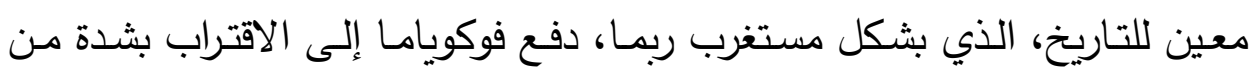

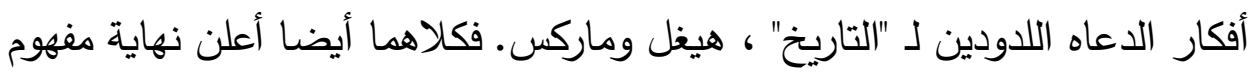


معين للتاريخ، حيث " لن يكون هناك مزيد من التقدم في تطوير مبادئ ومؤسسات أساسية، لأن كل الأسئلة الكبيرة حقا قد تم تسون تسويتها".

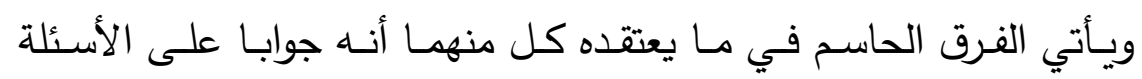

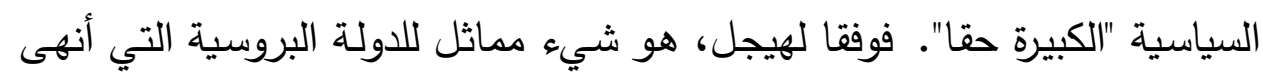

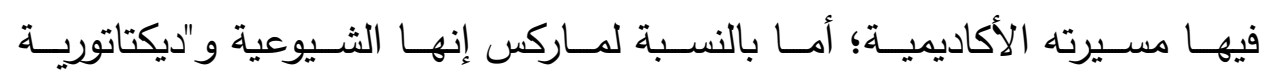

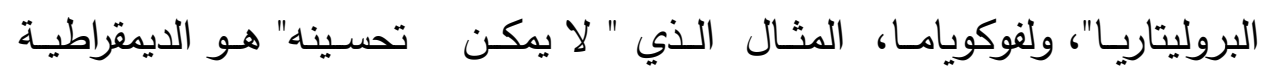

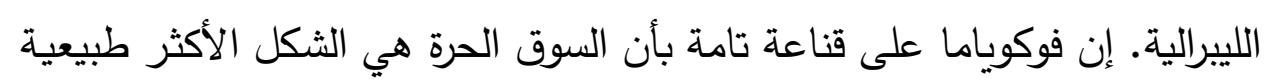

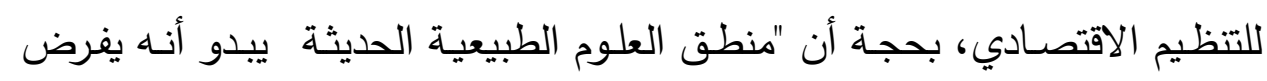

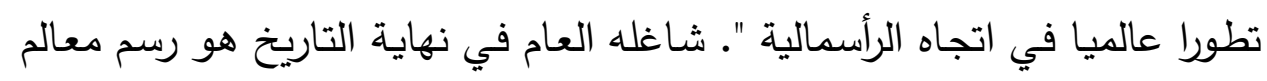

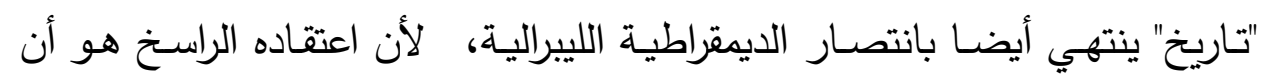

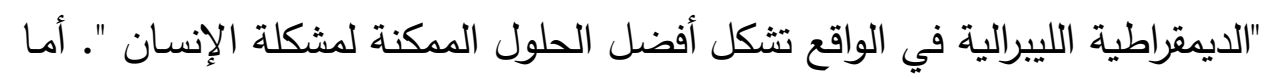

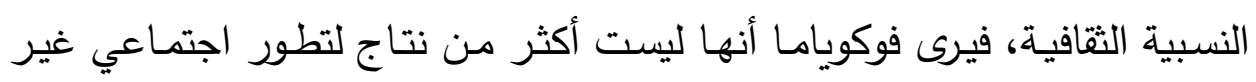

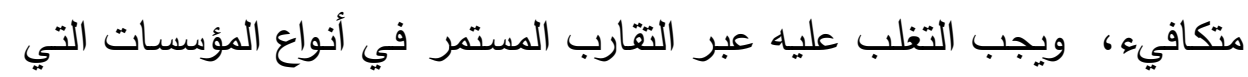

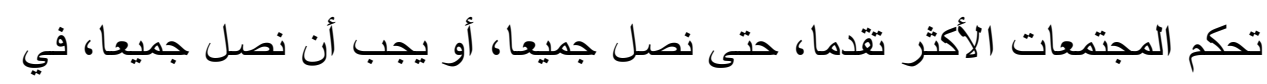
نهاية المِطاف، إلى نفس الوجهة.

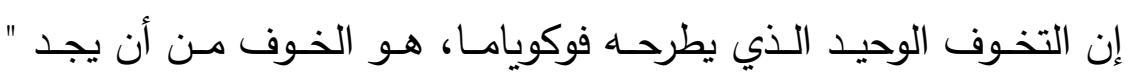

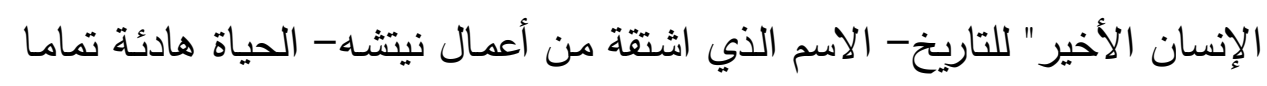

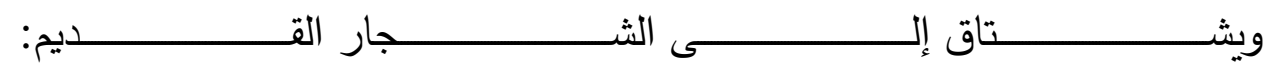

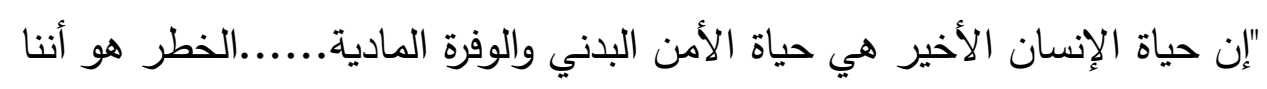

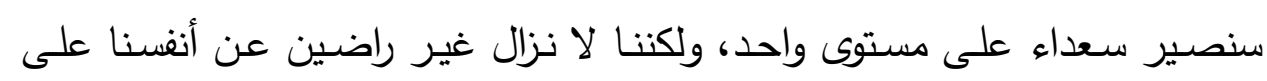

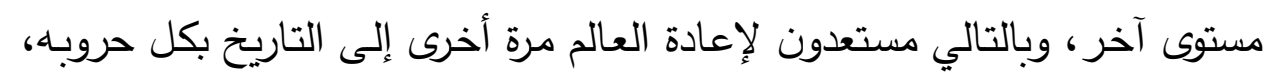

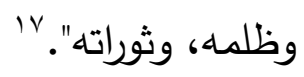


لكن على الـرغم مـن هذه الثكوك المزعجـة ، هو متفائـل حـول آفـاق

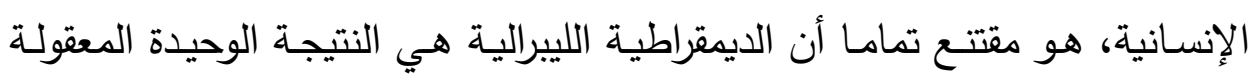
التي لابد أن نسعى إليها.

\section{ثانيا: دريدا: شبه ماركس وتأجيل النهاية}

يصر دريدا أننا لا يمكننا طرد أثباح التاريخ، لأنها ستستمر في مطاردتا

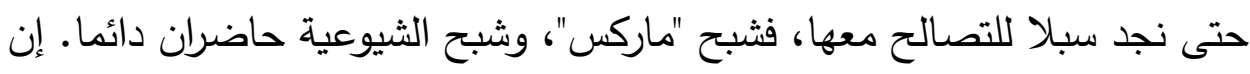

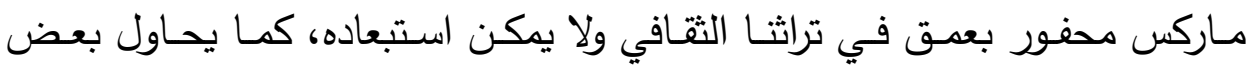

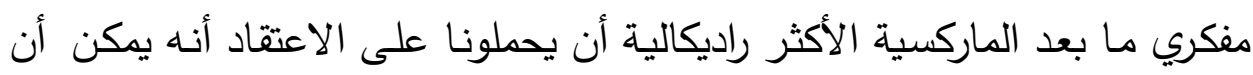

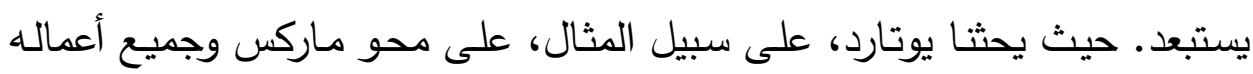

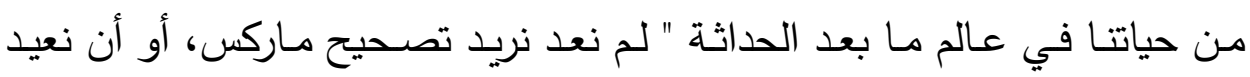

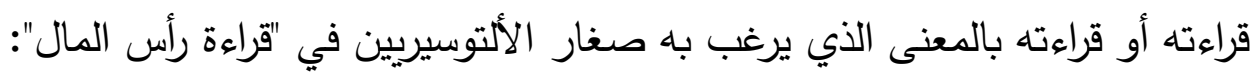

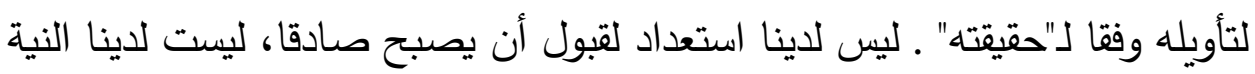

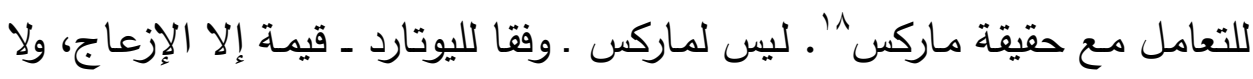
يستحق عناء التأمل أكثر من ذلك. أما بالنسبة لدريدا فلا يزال ماركس مفكرا ذا لإنا

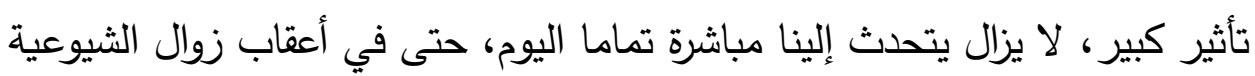

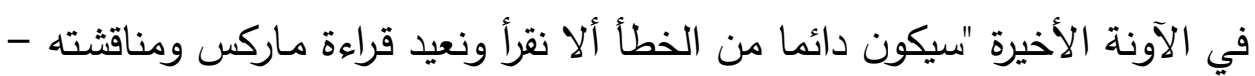

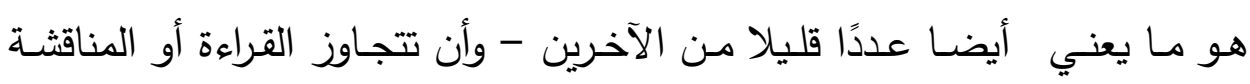
الدرسية. سيكون خطأ أكثر وأكثر نقص الدسئولية النظرية والفلسفية، والدياسية.

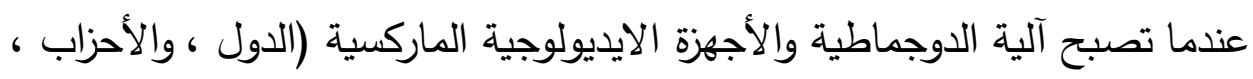

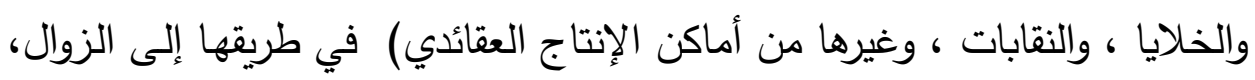

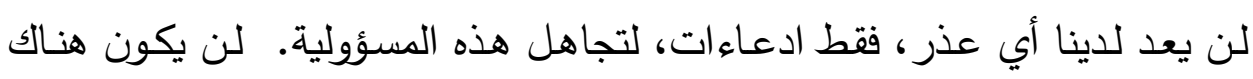

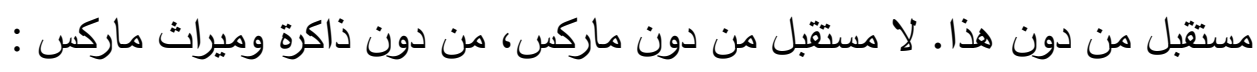
لأي قضية معينة لماركس، لعبقريته، لواحدة على الأقل من أفكاره. 19 


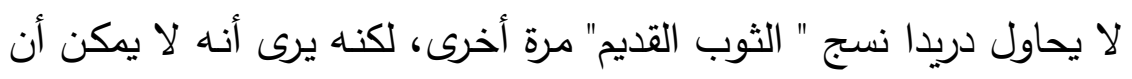

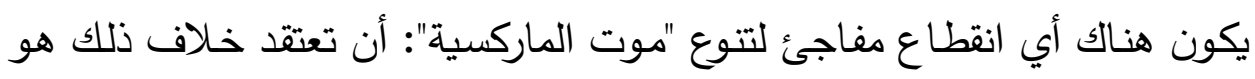

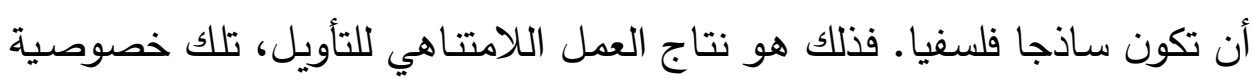

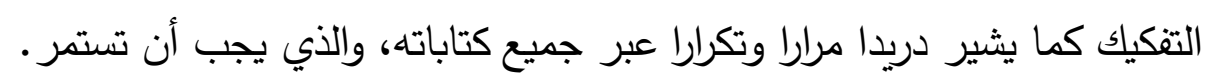

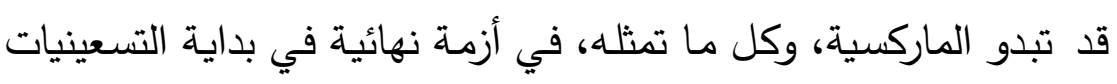

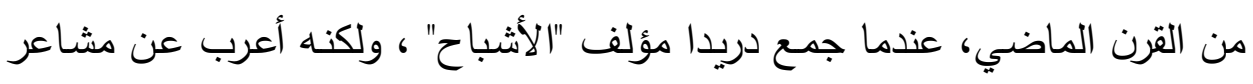

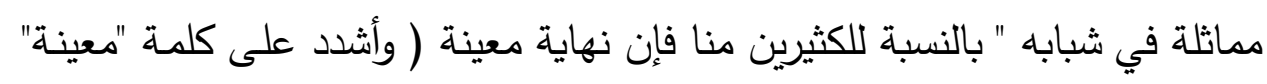

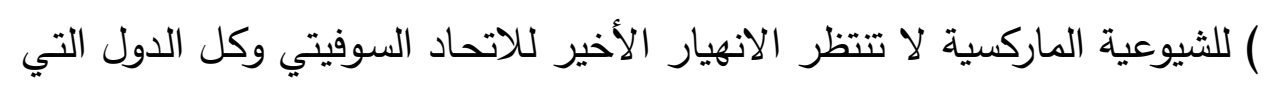

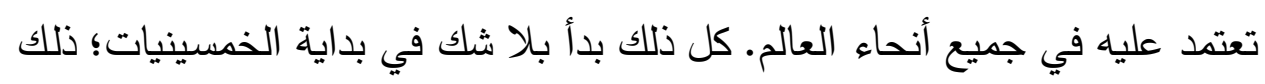

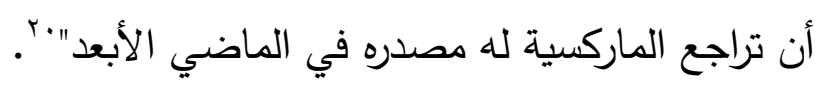

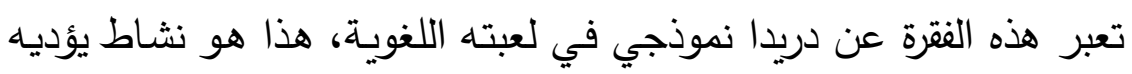

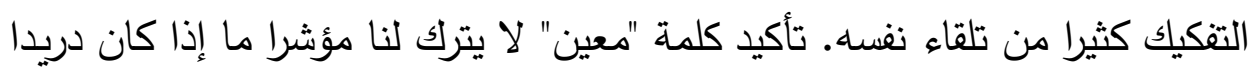

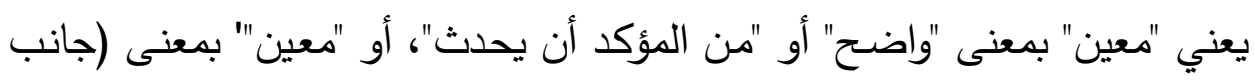

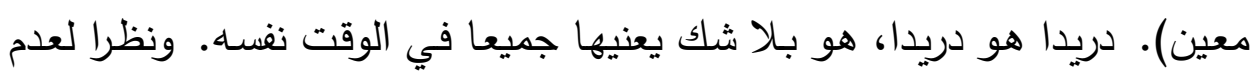

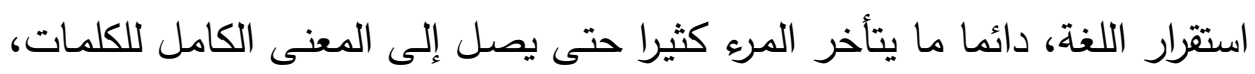

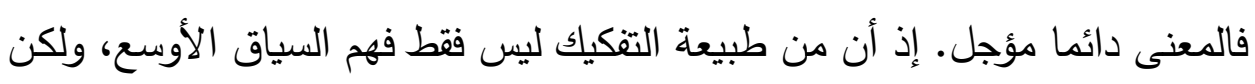

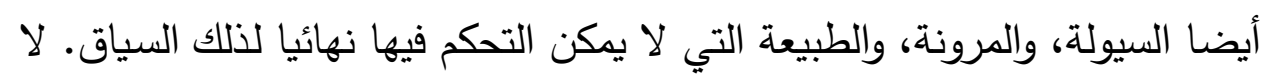

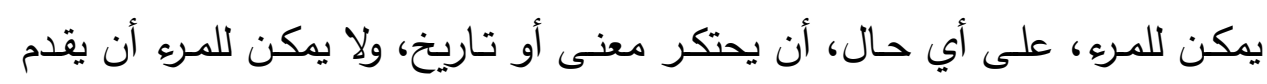

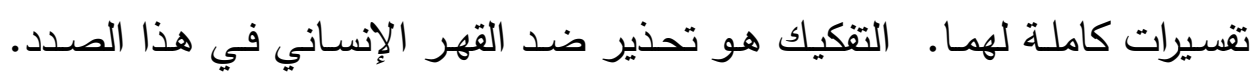

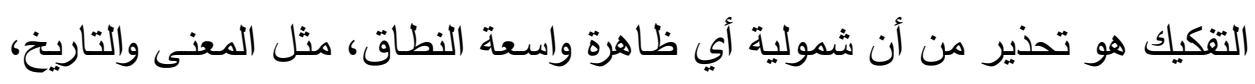

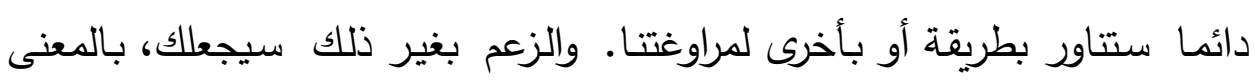

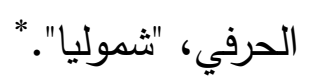

إن دريدا سعيد تماما باللعب على المدلول السياسي الثمولي الذي يحمله

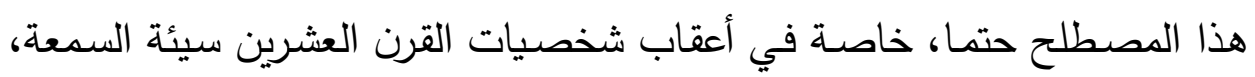




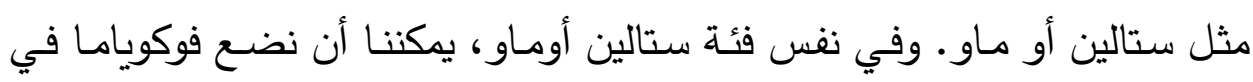
قفص الاتهام نفسه، بمعنى الاتهام بمحاولة استبعاد التفسيرات الأخرى للظواهر التاريخية ما عدا تفسيره. إن دريدا يسعى للحفاظ على المناقثة الدفتوحة، وانطلاقا

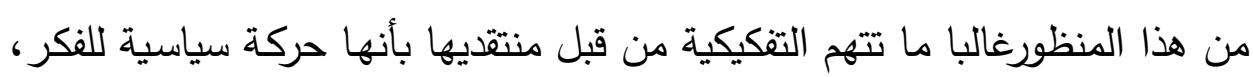
وهي بالفعل ذات جانب سياسي واضح تماما.

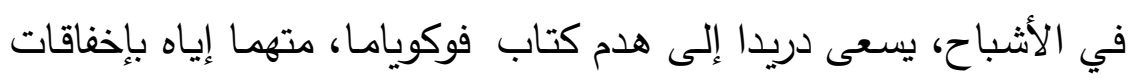

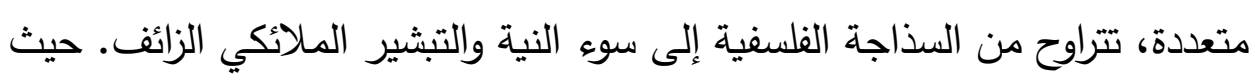

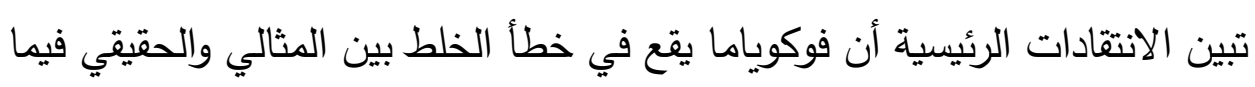

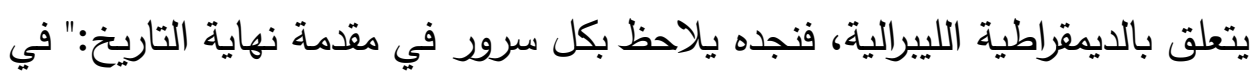

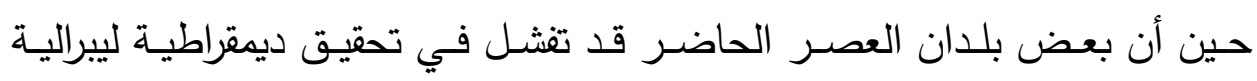

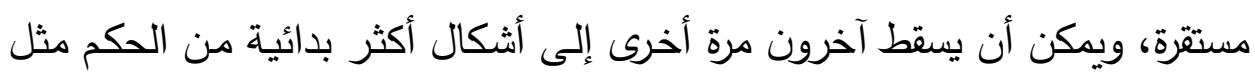

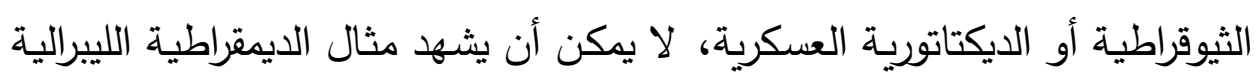

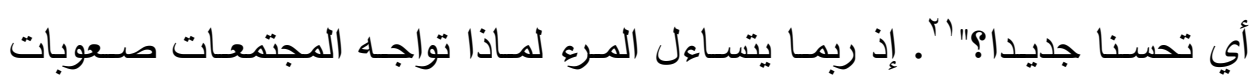

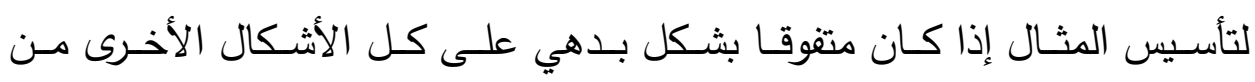

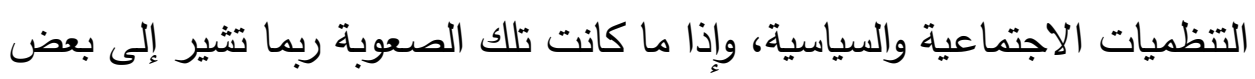

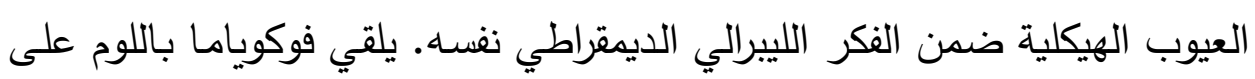

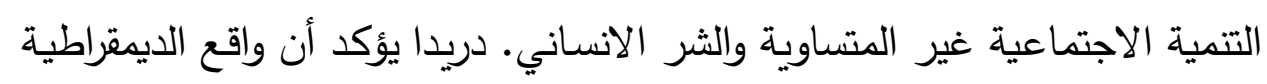

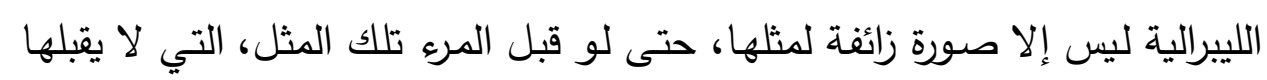
دريدا بوضوح: "سيكون من السهل تماما إظهار أنه بالقياس إلى فثل إقامة ديمقراطية لييرالية،

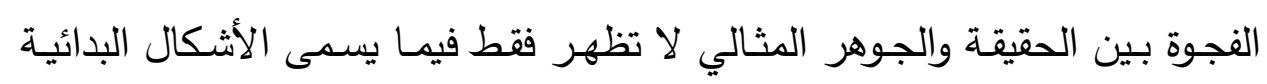

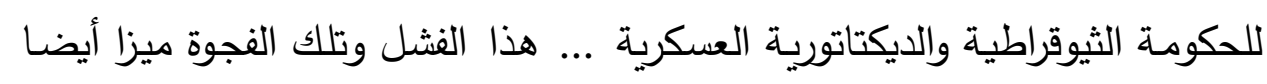

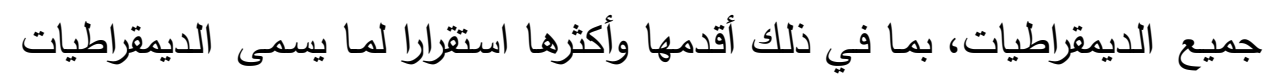
الغربية". r 
يتهم دريدا فوكوياما بالقراءة الخاطئة للوضـع السياسي العالمي المعاصر،

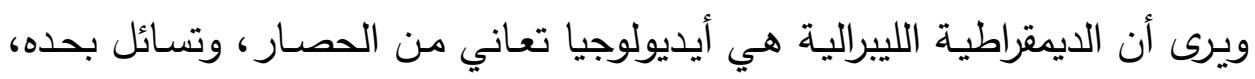

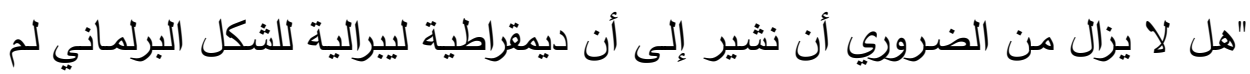
تعد موجودة إلا في عدد قليل للغاية من الدول ومعزولة تمامـا؟ إنها لم تصل من قبل إلى مثل هذه الحالة من الاختلال الوظيفي فيما نسميه الديمقراطيات الغربية. لقد اعتمدت كثيرا على التتمية الاجتماعية غير المتكافئة، هي تتتج قائمسة متتامية بثدة من البطالة الجماعية ومحنة المشردين، من خـلال مكائد صناعة الأسلحة والتلاعب في الأمم المتحدة، وغيرها من المؤسسات الدولية، من قبل القوى العظمى

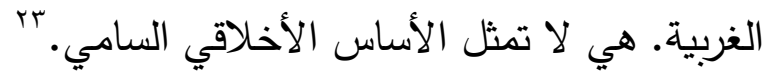
"يجب أن نبكى عليها، في وقت عندما يحوز البعض جرأة التبشير الجديد" باسم مثال الديمقراطية الليبرالية التي أدركت أخيرا نفسها على أنها مثال التاريخ البشري: لن يؤثر العنف وعدم المساواة والإقصاء والجوع، وبالتالي القهر الاقتصادي

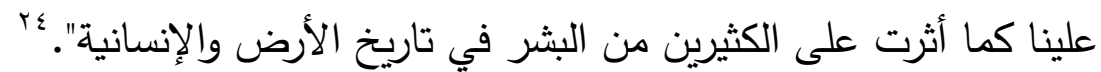
وفقا لمعايير دريدا ، هذا هو خطاب سياسي صريح بشكل غير معتاد، يتبعه بدعوة لبناء "نموذج عالمي جديد" يواصل الكفاح ضد الظلم الذي دفع ماركس إلى تأليف أعماله الرئيسية. ما يسعى دريدا له هو " رباط من الألفة والمعاناة والأمل " يعود بنا مرة أخرى إلى ماركس واهتماماته، حتى لو كان يفعل ذلك بطريقة محسوبة تثير غضب لـ لهب معظم الماركسيين في الوقت الحاضر بالإصرار على روح بدلا من خطاب النقد

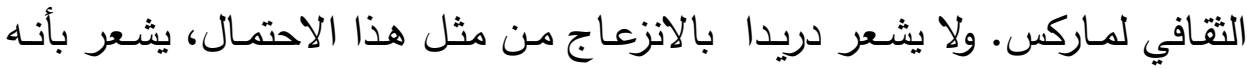

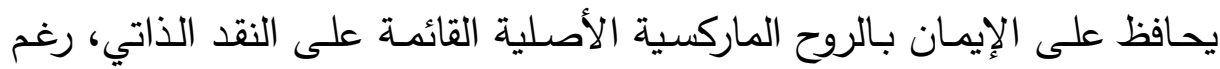
استمراره في اللعب على معنى مزدوج لكلمة "روح"، ويشعر أيضـا أنه لا يمكننا أن

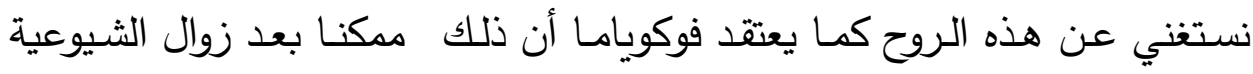
الأوروبية. وفي قراءة دريدا للتاريخ، لن يذهب ماركس بهدوء " سواء رغبوا في ذلك 
وأدركوه أو لا، جميع الرجال والنساء في جميع أنحاء الأرض، هم اليوم إلى حد

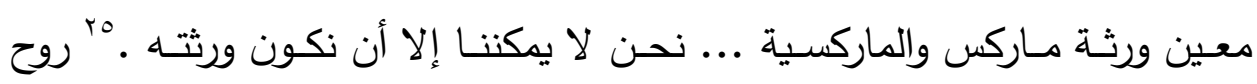
وشبح ماركس تبقى، مهما أعلن فوكوياما وأتباعه الخسوف لأنية السياسي للشيوعية.

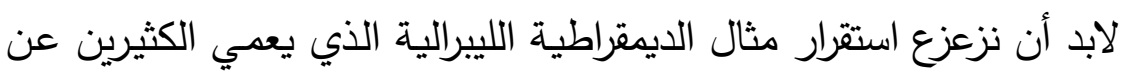

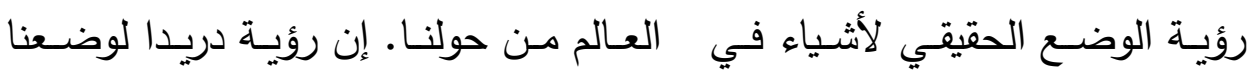

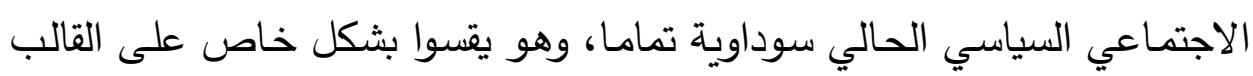

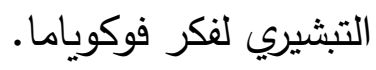

\section{ثالثا: معنى المطاردة عند دريدا:}

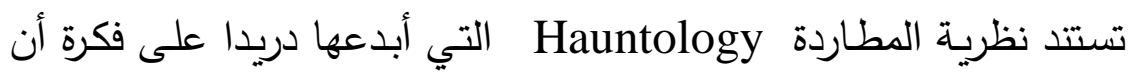
هناك أثباحا تطارد الحاضر وتمنع نهاية التاريخ، هي تبقي على المستقبل مفتوحًا؛

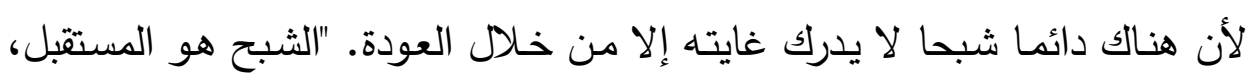

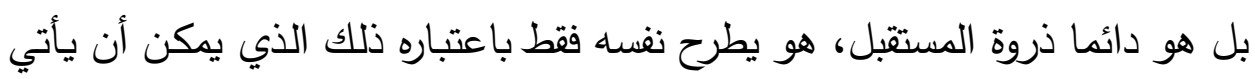

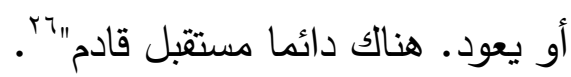

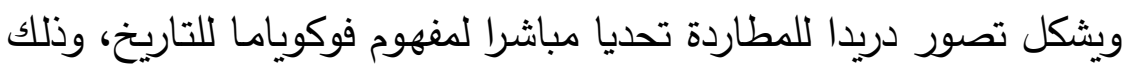

عبر رفضه لربط الماضي بالحاضر والمستقبل. هناك شيء من الماضي حاضر دائما، وهذا الثيء أيضا ينتظر عودته في مستقبل قادم. يستدعي دريدا استعارة

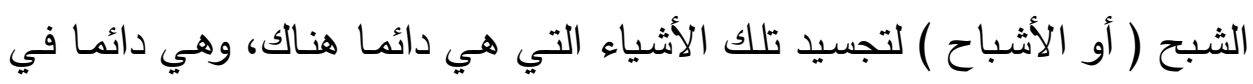

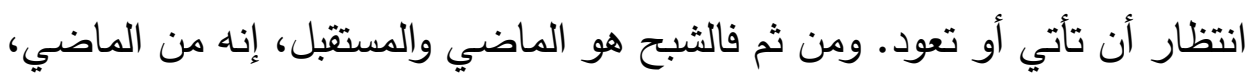
ولكنه في انتظار العودة. إن استعارة شبح يطارد الحاضر تؤسس فكرة وجود شيء شجي يراقب ويحيط

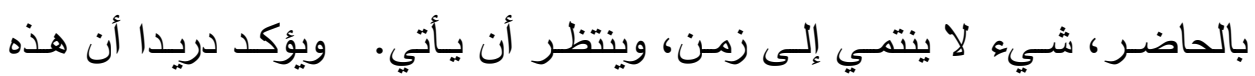

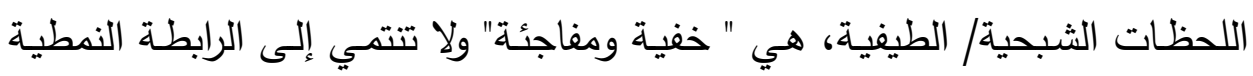

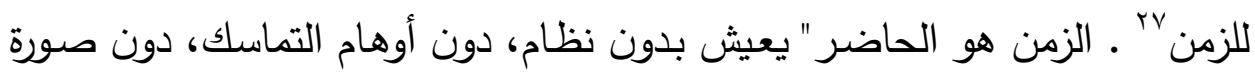

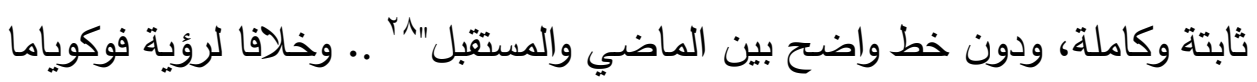


للزمن باعتباره شيء يتابع دورة مثل نهر ، يتحدث دريدا عن نوع جديد من الزمن،

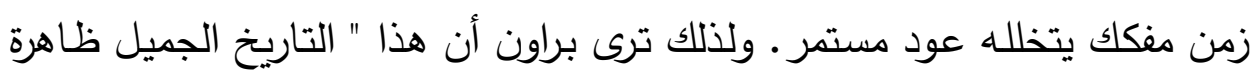

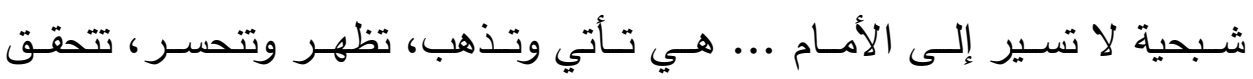

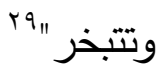

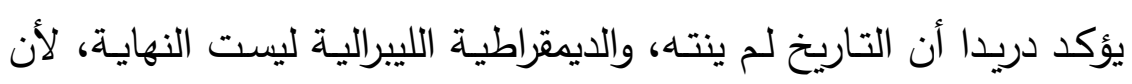

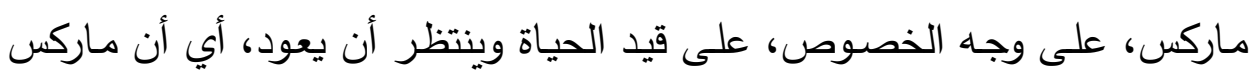

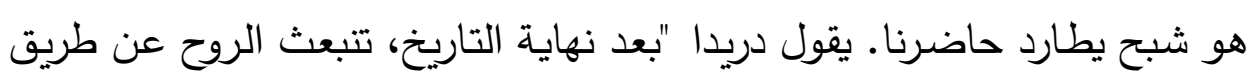

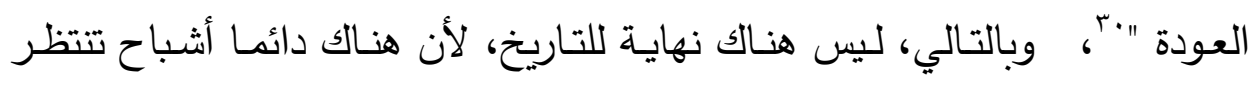

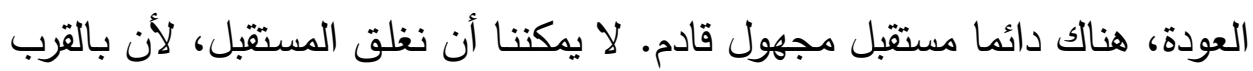

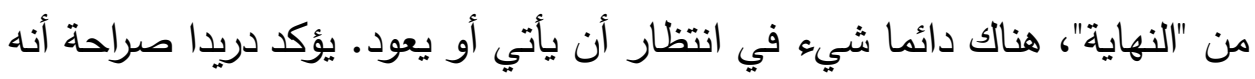

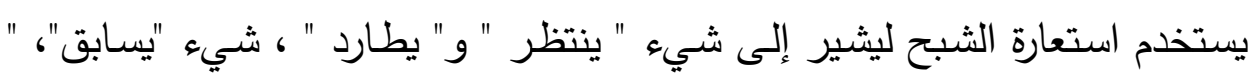

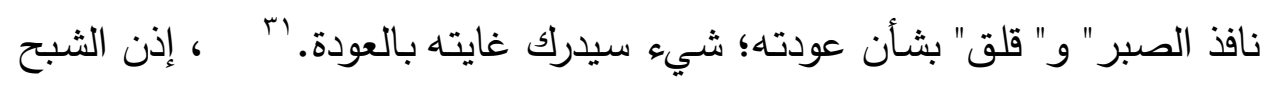
هو المستقبل، وبالتالي ليست هناك نهاية للتاريخ.

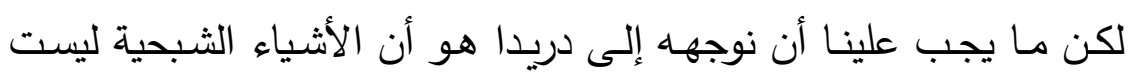

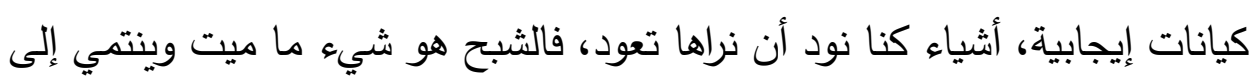

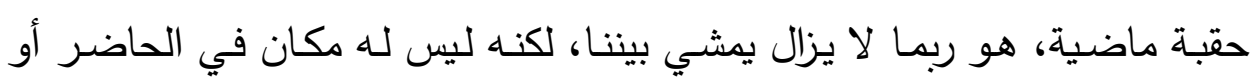

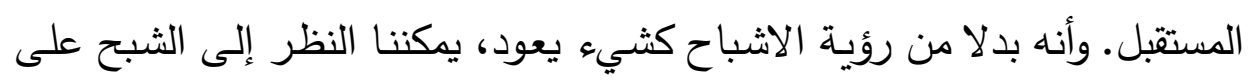

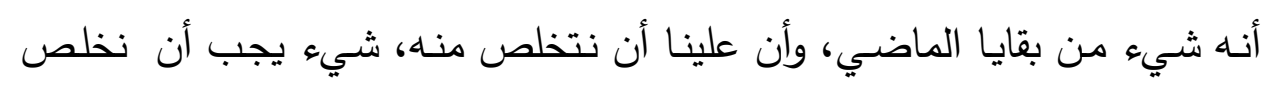

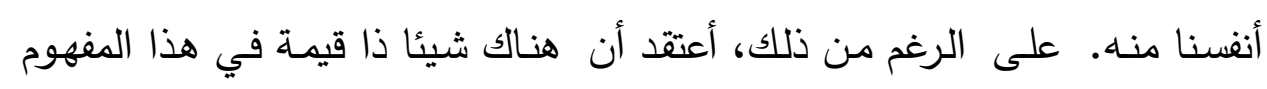

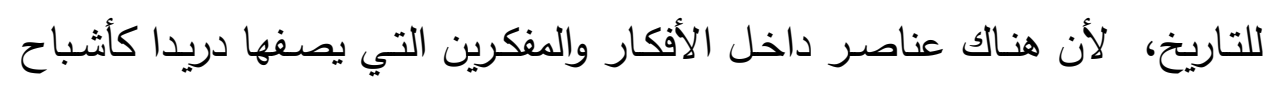

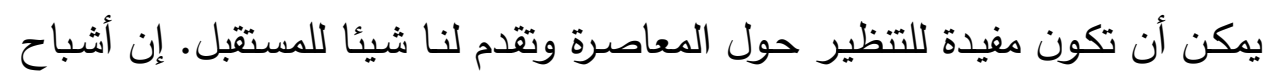

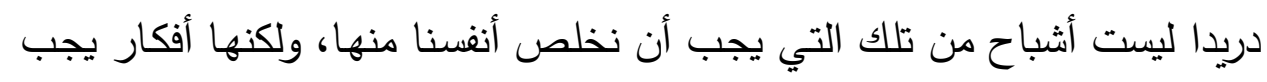

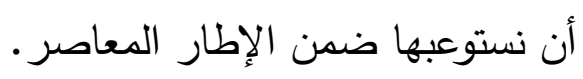




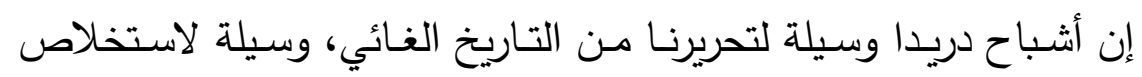

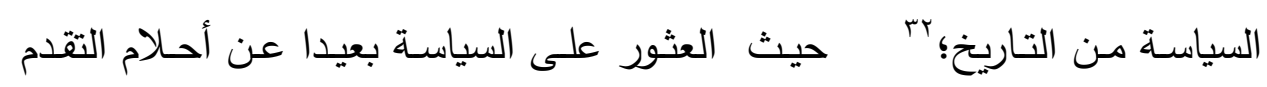

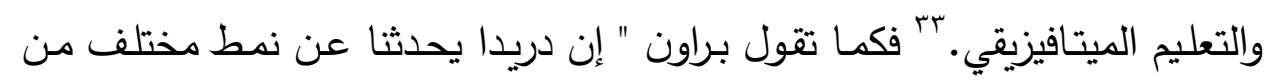

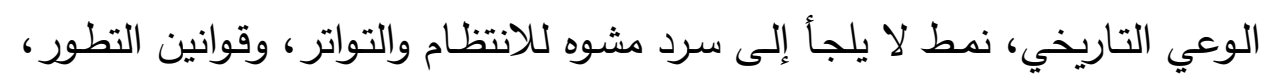

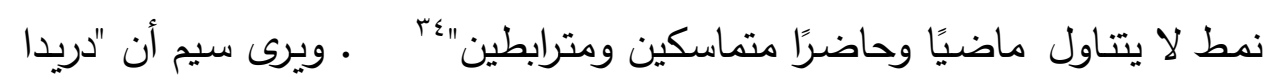

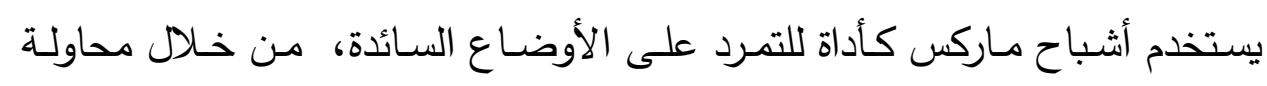

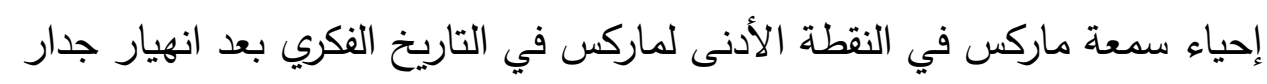

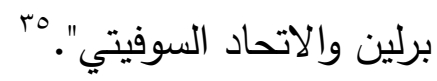

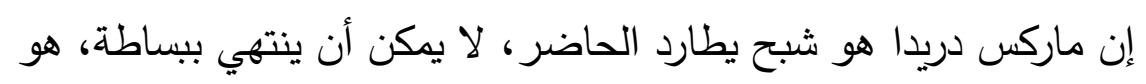

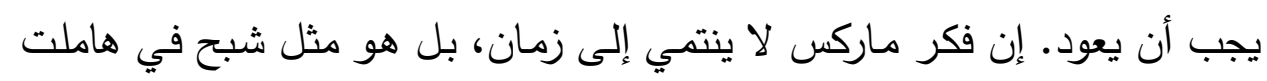

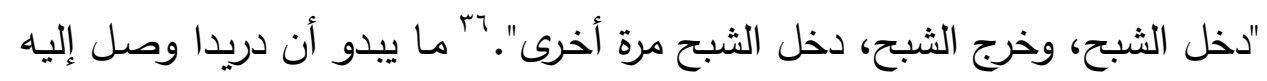

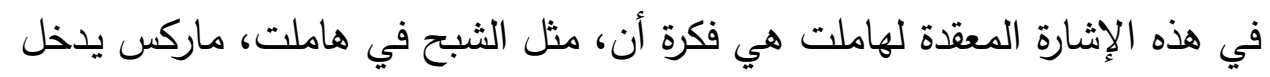

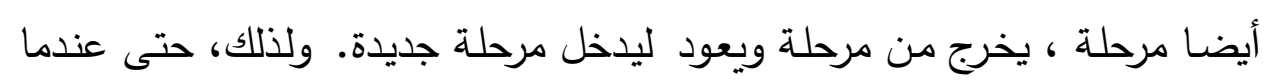

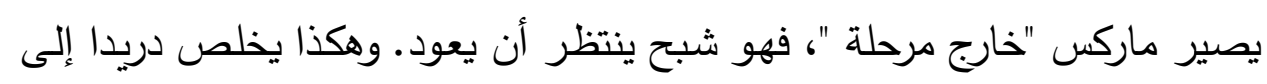

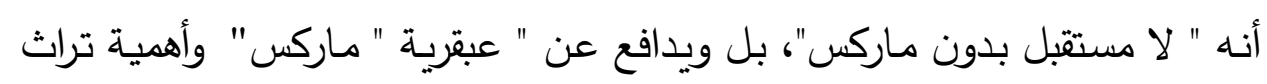

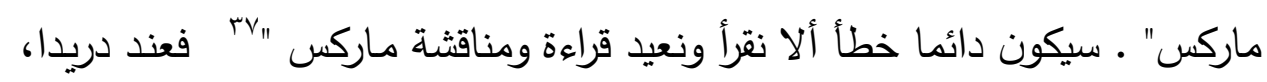
ماركس دائما هناك، ينتظر في الهوامش، ينتظر دائما أن يأتي ويعود.

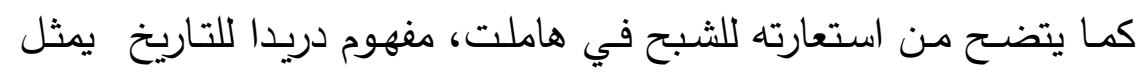

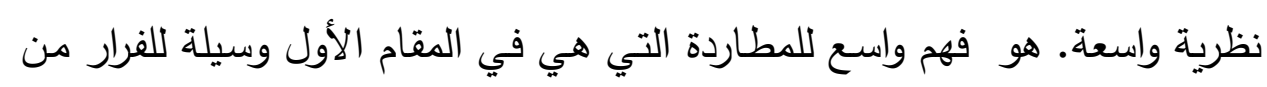

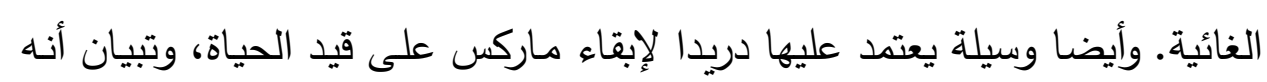

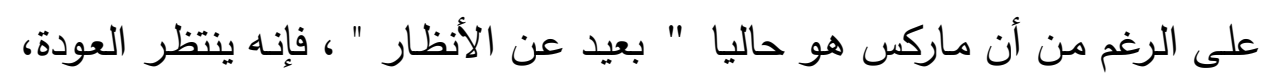

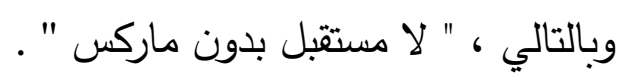

في أشباح ماركس، يسعى دريدا لصياغة ادعاء بأن الماركسية ليست شيئا

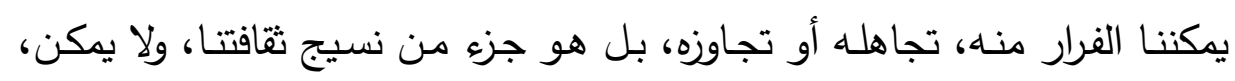


بالتالي، أن ينتهي. رغم ذلاك، فإن الادعاء بأن ماركس يطارد الحاضر ليس ادعاء

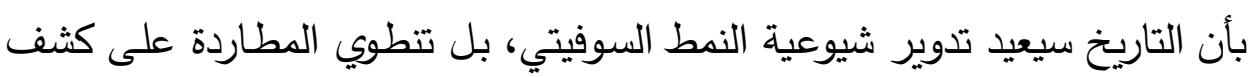

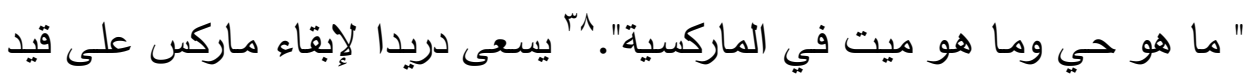

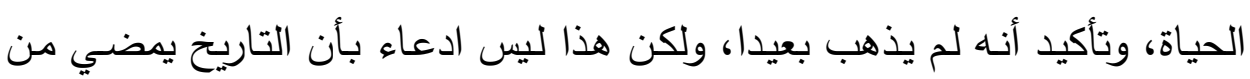

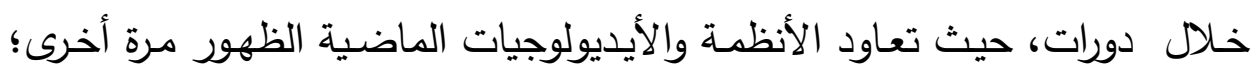

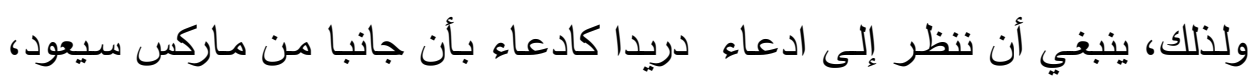
ولكن ليس ادعاء بأن الثيوعية سوف تعود. ويرى دريدا أن الطريقة الوحيدة لإبقاء ماركس على قئل قيد الحياة هي تدريسه

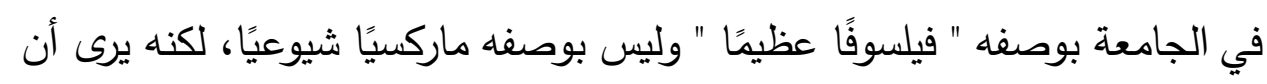

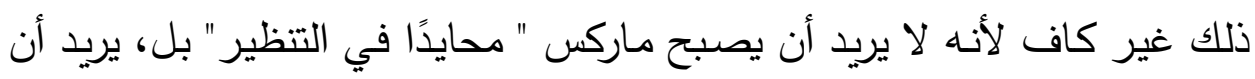

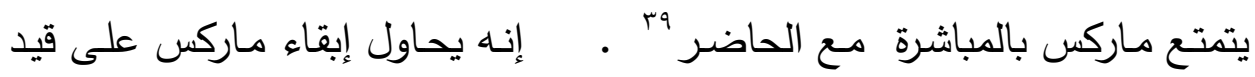
الحياة، ويدعي أن شبح ماركس يطاردنا.

لا يستخدم دريدا ماركس أدة لنقد المناهضين المبار المعاصرين للماركسية، وإذا

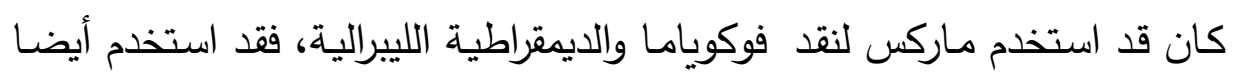

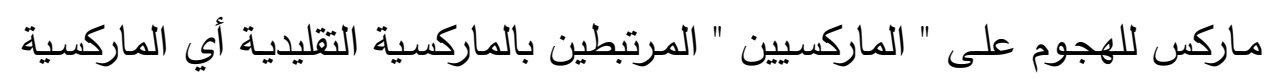

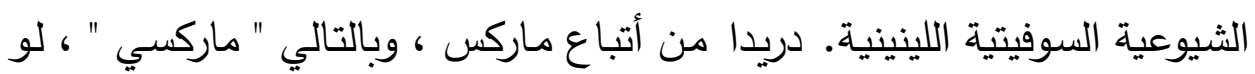

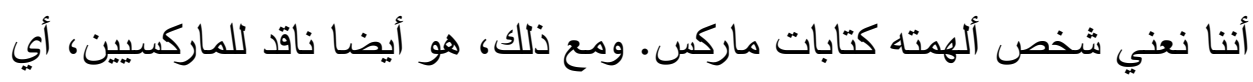

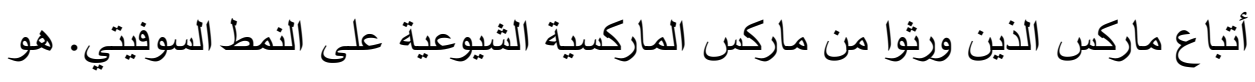

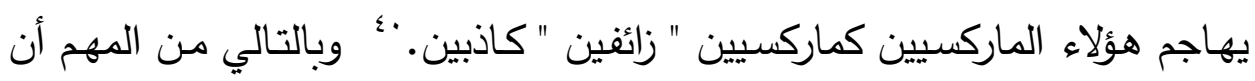

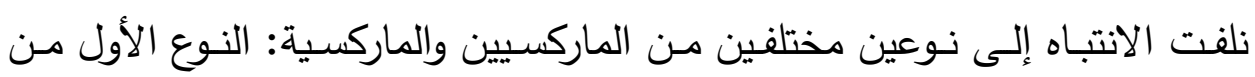

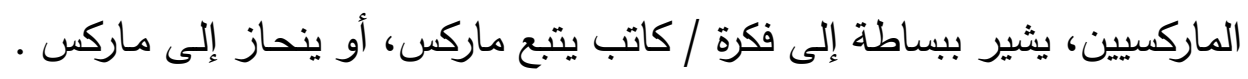

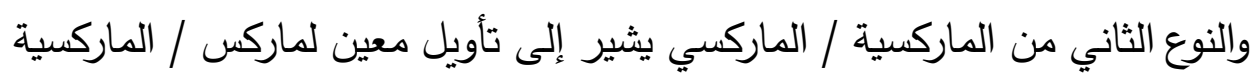

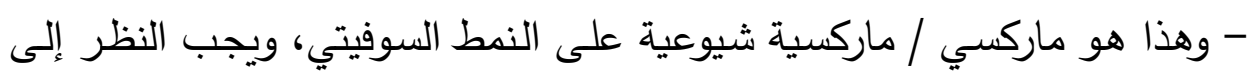

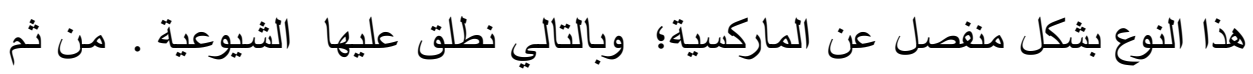


فإننا نتقق مع براون التي رأت أن قراءة دريدا لماركس ... هي قراءة لماركس ضد

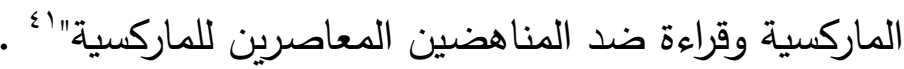
لكن السؤال الذي يجب علينا أن نطرحه هنا هو لماذا نبقي ماركس على ؟ لحي قي

يطرح دريدا تبريرا ممكنا لابقاء ماركس على قيد الحياة على أساس عدم تجانس

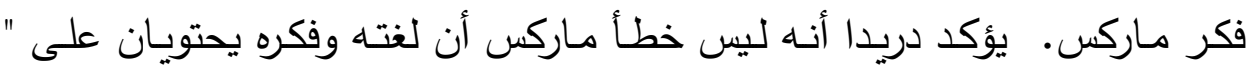

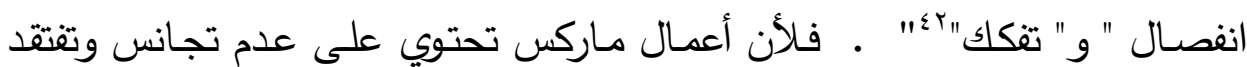
للتماسك، فإن أعمالـه مثل الثبح. يتخذ ماركس أشكالا عديدة، ويقدم العديد من

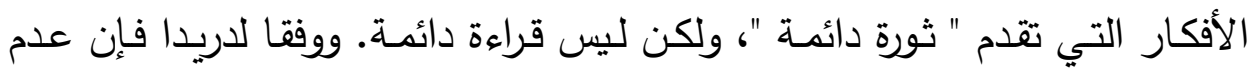
تجانس ماركس وعدم قابليته للاختزال "، و عدم قابلية ترجمته الداخلية" توفر تبريرا

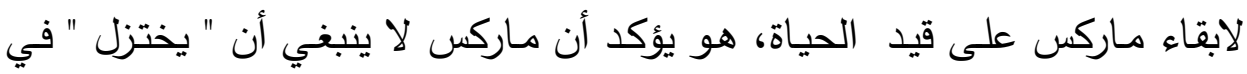

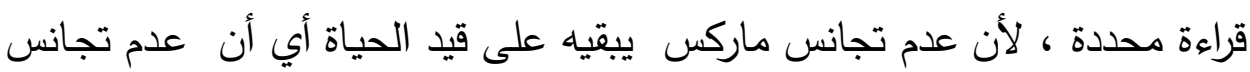

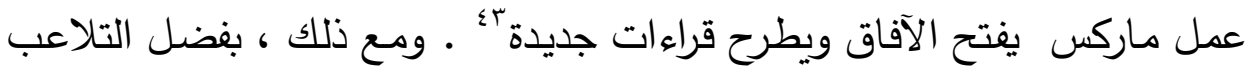

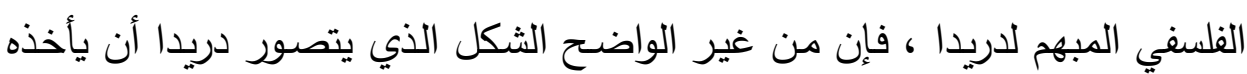
شبح ماركس، وبالتالي فإنه من غير الواضح القيمة الموجودة في ماركس . يقدم دريدا لنا ببساطة ماركس الذي هو "جمع "، ماركس المفتوح لعمليات

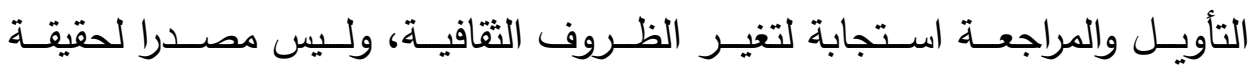
إنجيلية؛ ."مع ذلك، فإن تعددية ماركس في حد ذاتها لا تعني أنه شبح ، لأن عدم

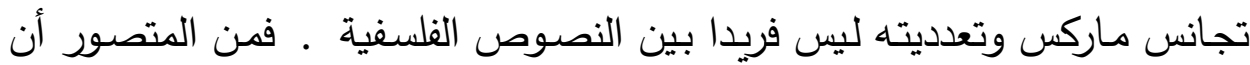
نزعم أن كل النصوص الفلسفية تحتوي على عدد وافر من القراءات وأنها غير

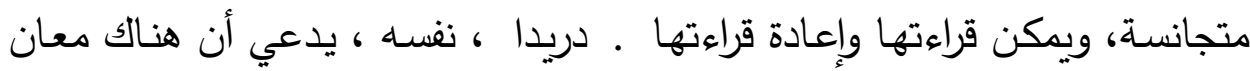
متعددة في جميع النصوص، وتؤكد نظريته في التفكيك حقيقة "عدم التعيين النهائي

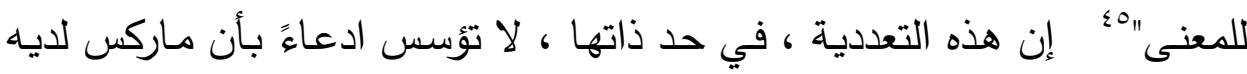
شيء يقدمه للمعاصرة، أو هو شبح يطارد الحاضر . لكي يصبح ماركس شبح نحن 
بحاجة لتبرير أهمية ماركس في الحاضر ، واستكثاف ما يقدمه شبحه للمعاصرة .

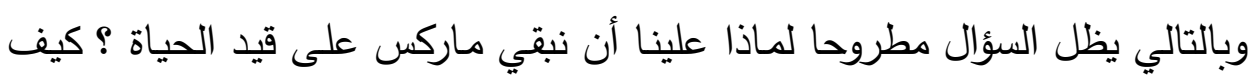
ولماذا يصبح ماركس شبح للمعاصرة؟

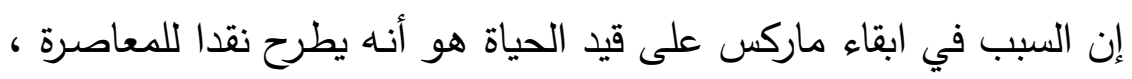

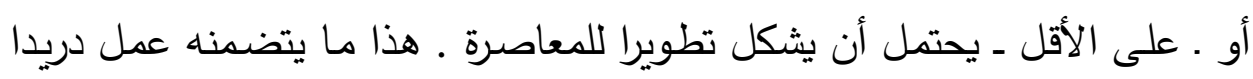

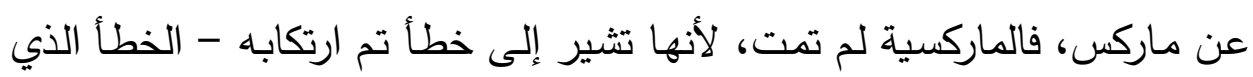

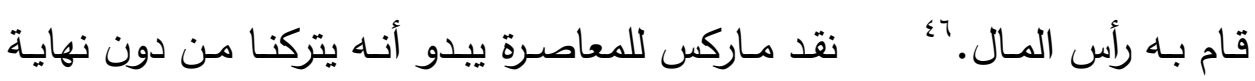

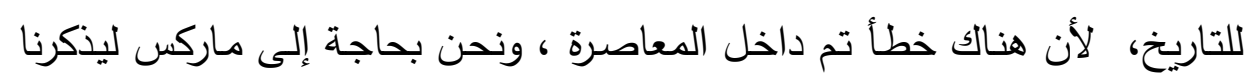

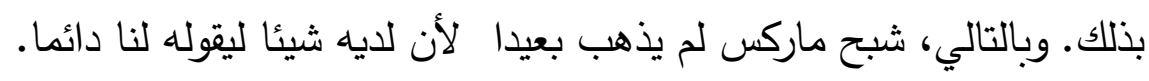

\section{رابعا: هاركسية دريدا وليبرالية فوكمياها}

تنطوي رؤيسة دريدا عن عودة مـاركس على تصسور لماركسية جديدة.

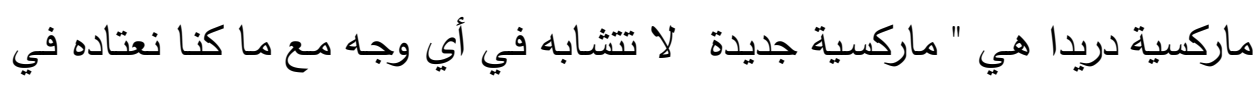

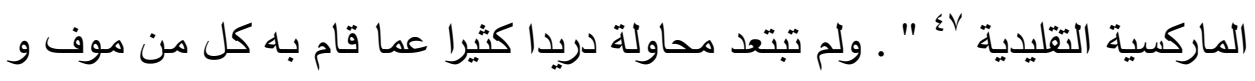

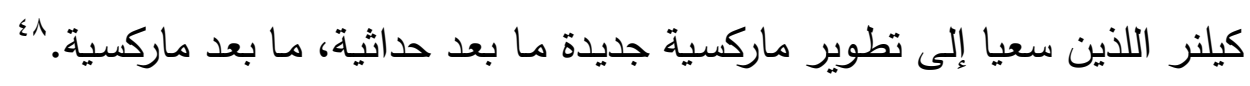

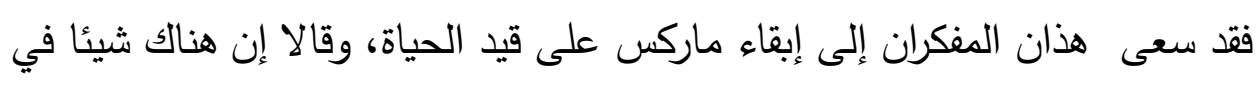

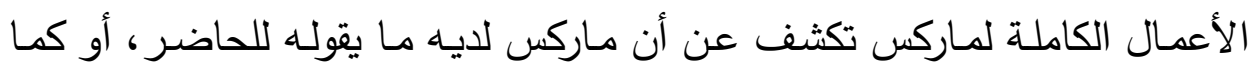

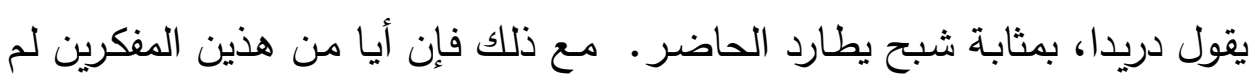

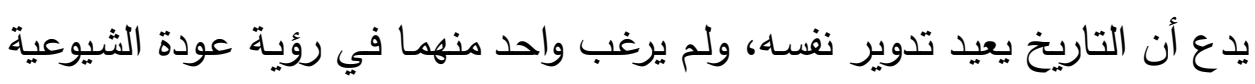

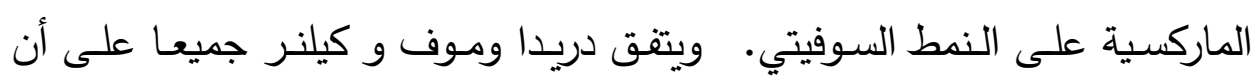

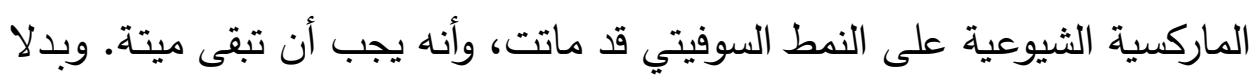

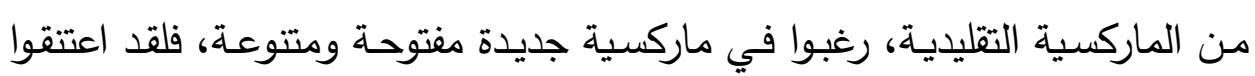

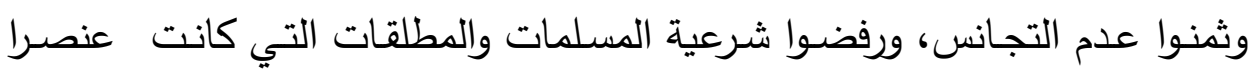

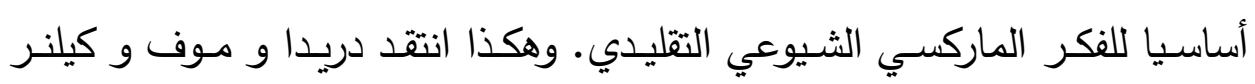

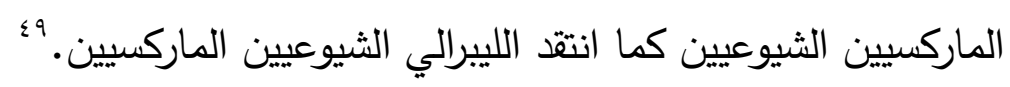


ويعد كيلنر بصفة خاصـة معـاد للثيوعية، ويؤكد أن الربط التاريخي

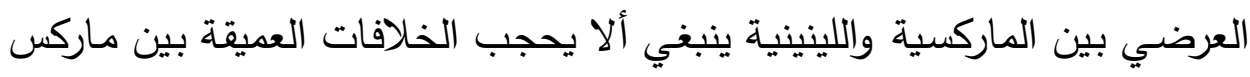

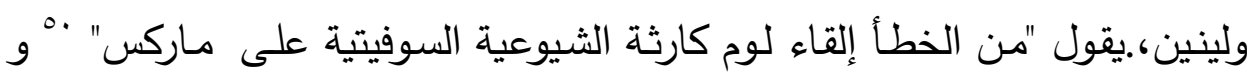

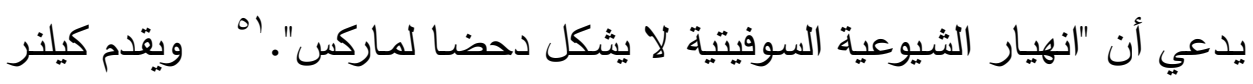

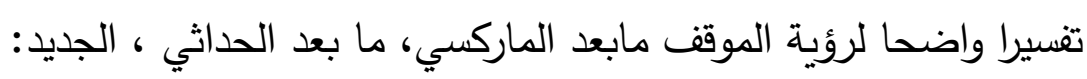

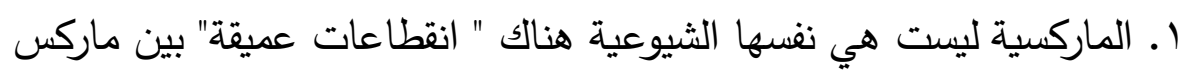

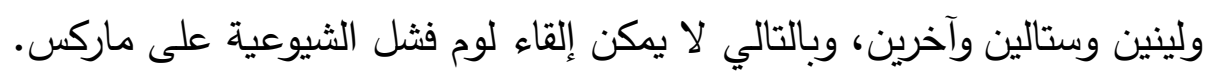

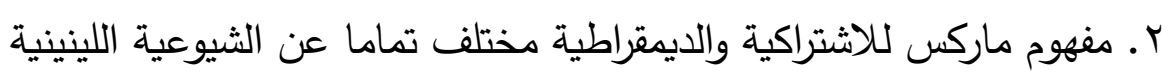

الستالينية السوفيتية. ؟. هزيمة الستالينية تتفق مع مبادئ ماركس.

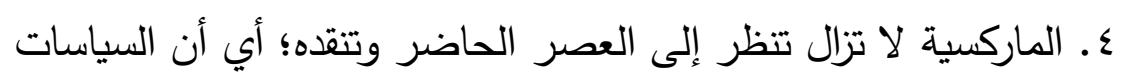

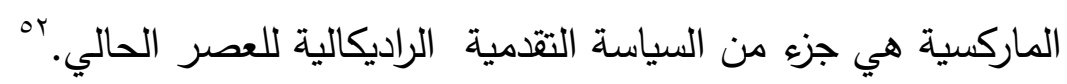

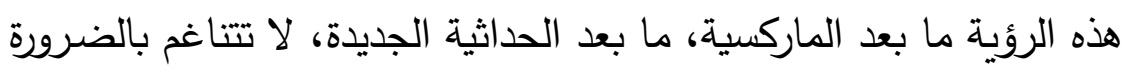

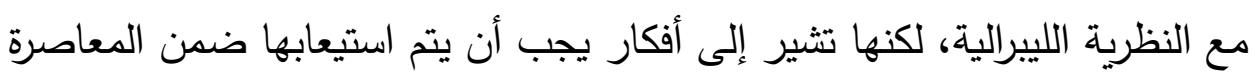

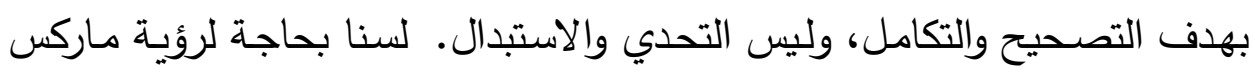

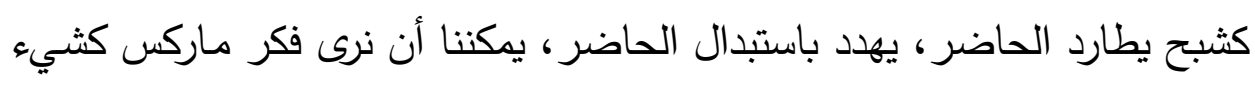

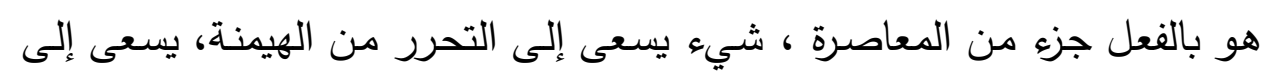

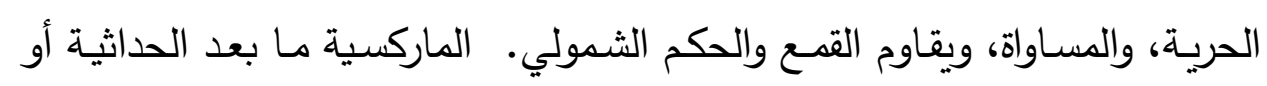

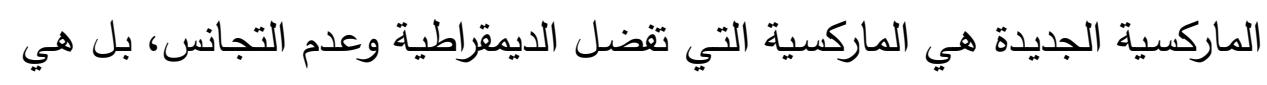

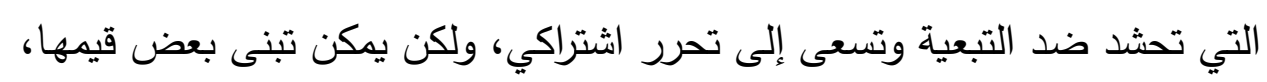
بوعي أو بدون وعي، من قبل لييراليين أمثال فوكوياما.

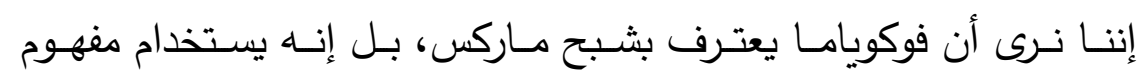

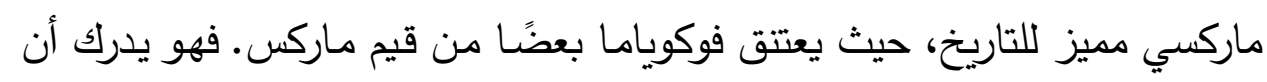

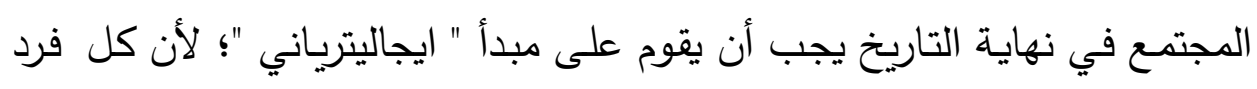


يرغب في الاعتراف بالكرامة والاستحقاق وهذا لا يمكن تحقيقه في ظل نظام السيد/

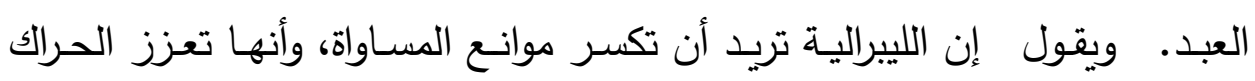

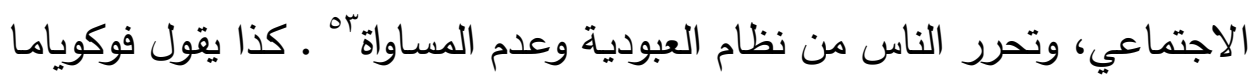

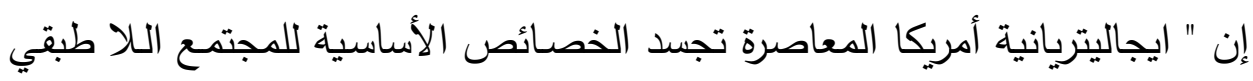

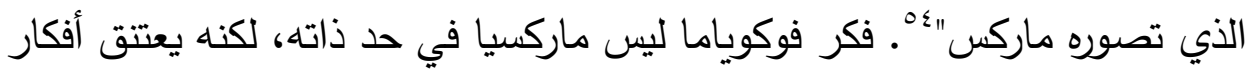

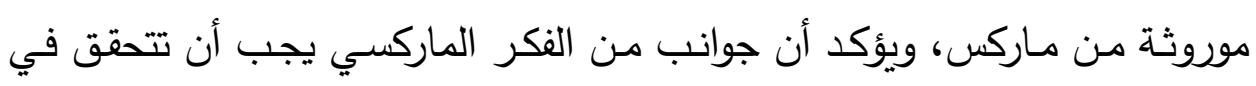

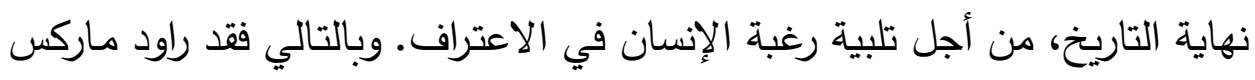

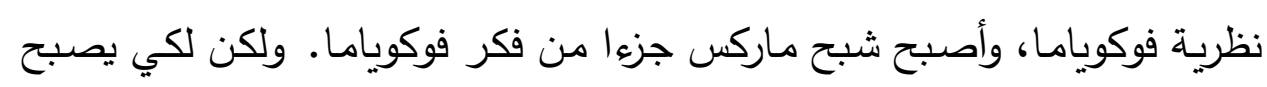

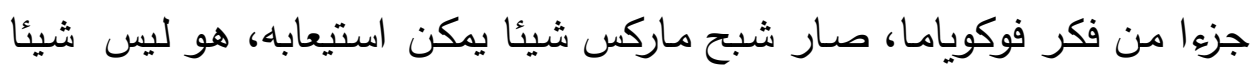

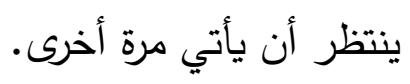

يعترف فوكوياما بأهمية الايجاليتريانية ولكن لايه فهم مختلف تمامـا لـا

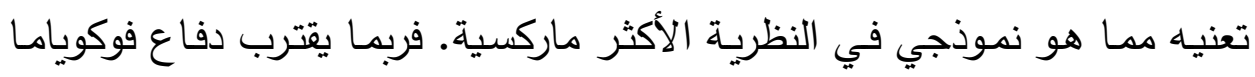

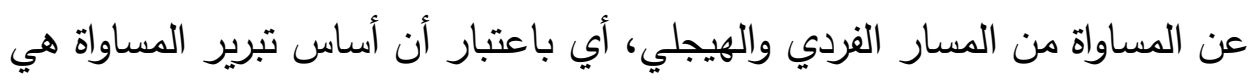

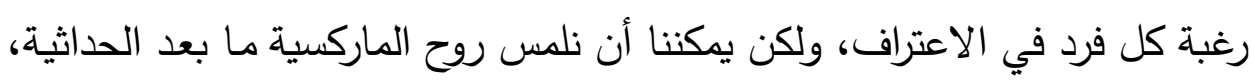

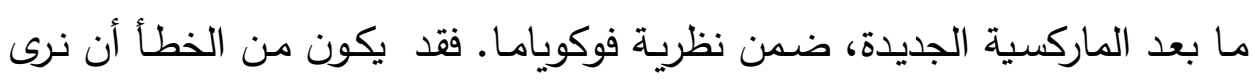

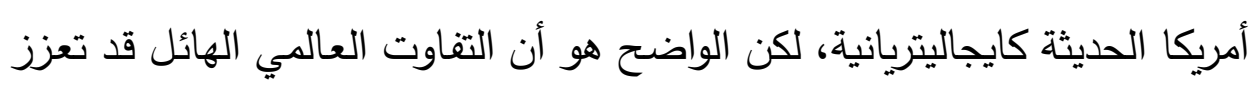

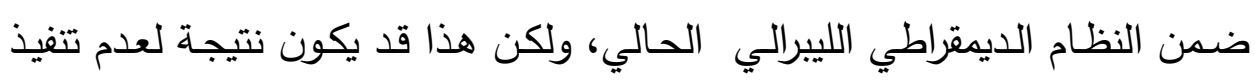

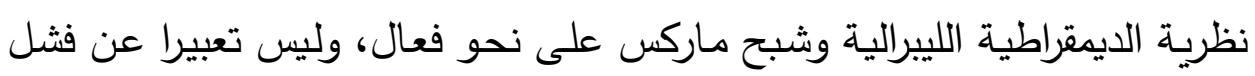

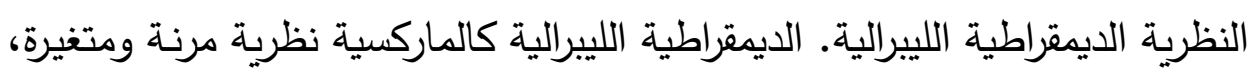

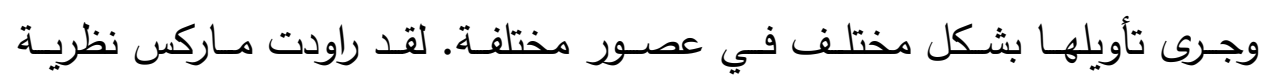
الديمقراطية الليبرالية، ولكن أصبح شبح ماركس جزء ألئل من الفكر الديمقراطي اللييرالي ، وبالتالي لم يعد ينتظر العودة، ولكن يجب أن يتحقق بثكل أكثر فعالية.

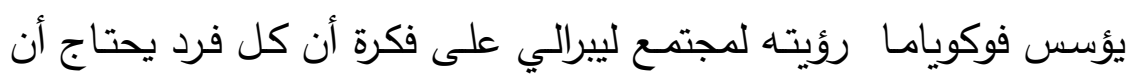

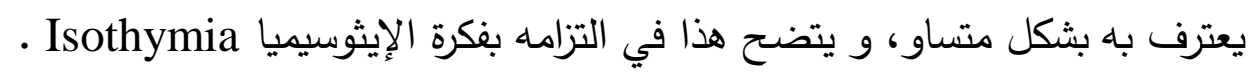


إذ يجب أن يعترف النظام الاجتماعي السياسي في نهاية التاريخ بالرغبة الإنسانية

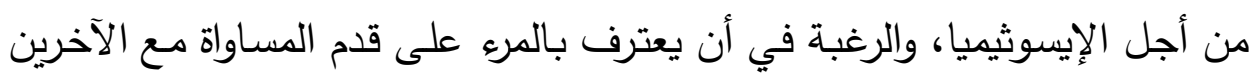

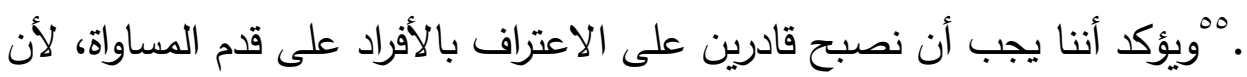

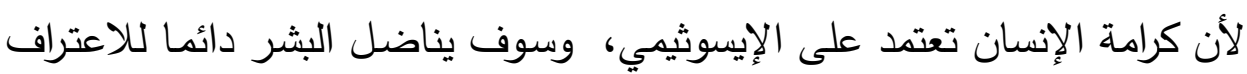

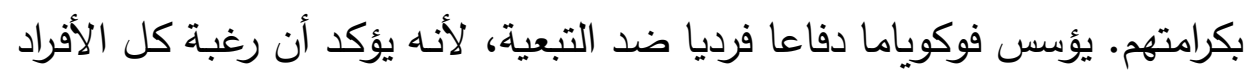

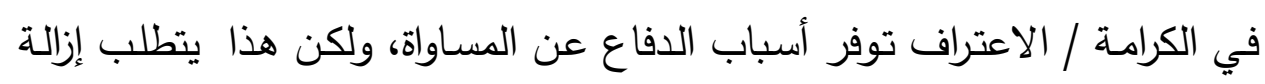

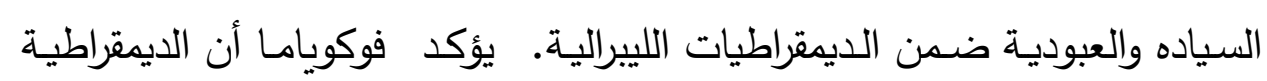

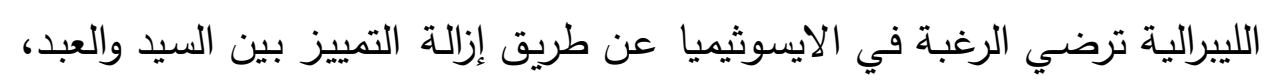

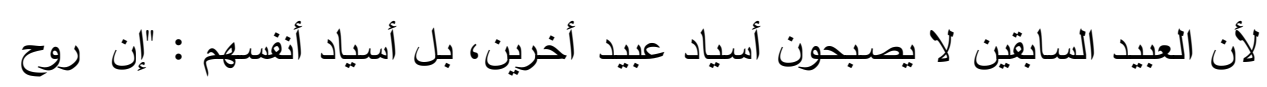

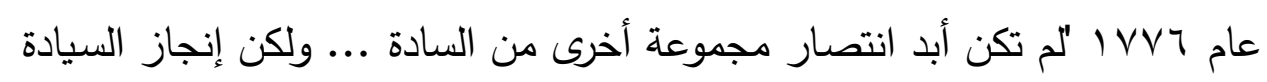
الذاتية".

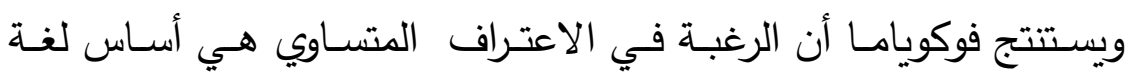

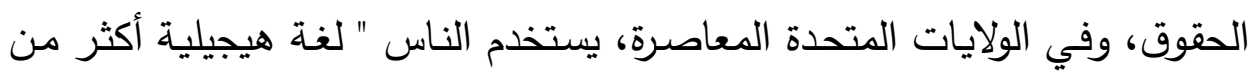

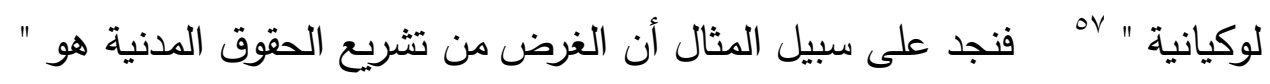

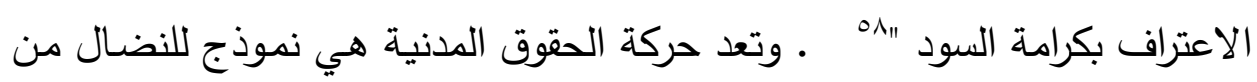

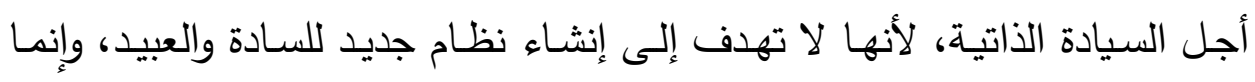

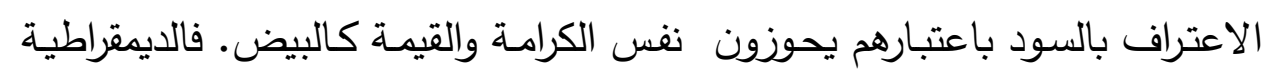

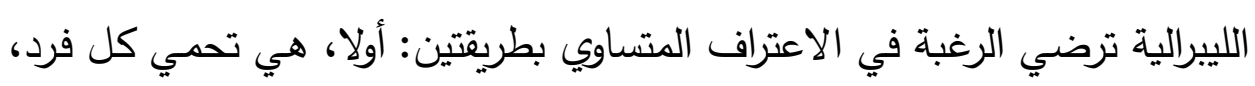

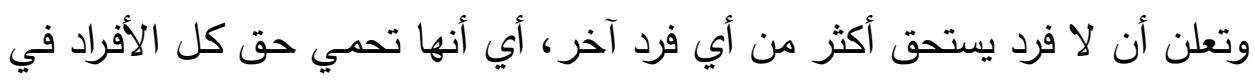

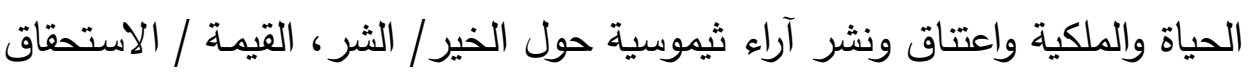
في أي موضوع مثل الدين والسياسة وغيرها، وحق المشاركة في الحياة السياسية. وثانيا، من خلال تأسيس الحق في المشاركة في السياسة والدكومة.

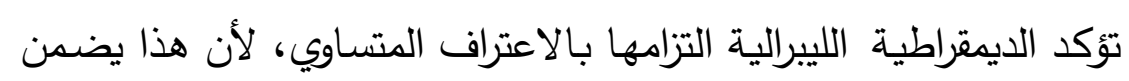

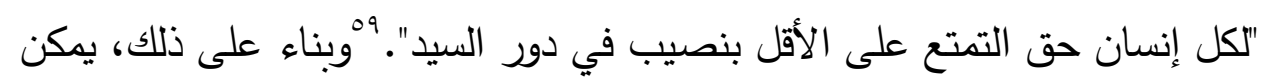


للييرالي أن يطرح الحجة القائلة بأن الديمقراطية الليبرالية هي نهاية التاريخ، لأنها

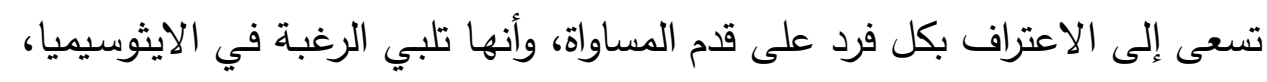

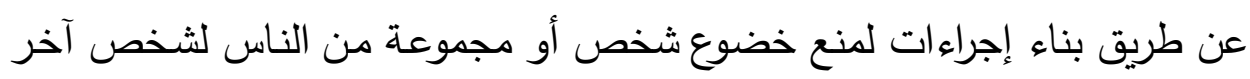
أو مجموعة من الناس.

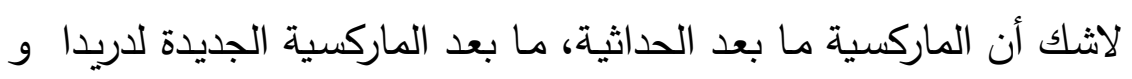

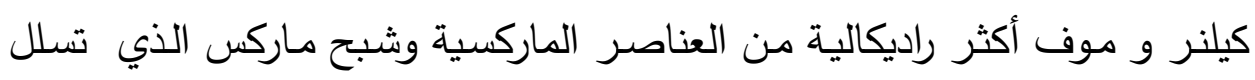

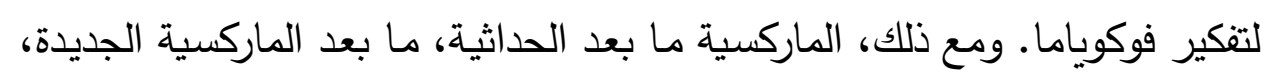

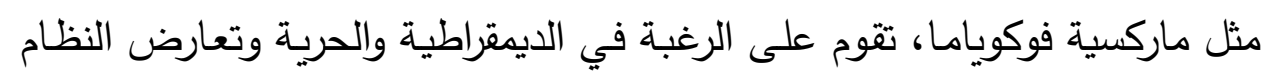

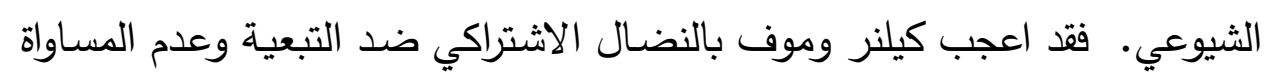

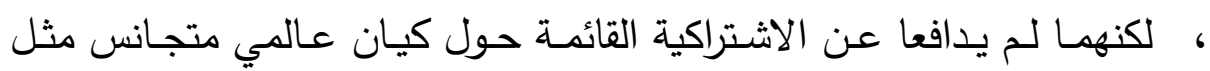

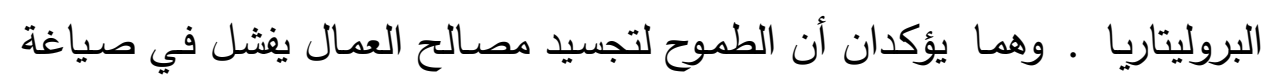

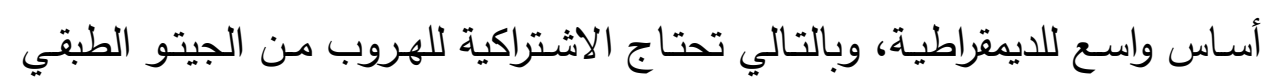

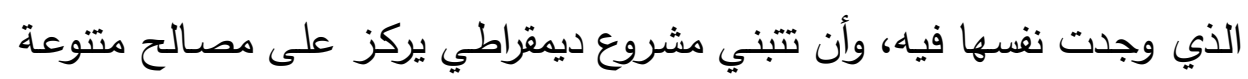

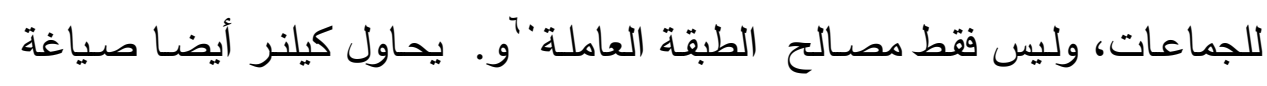

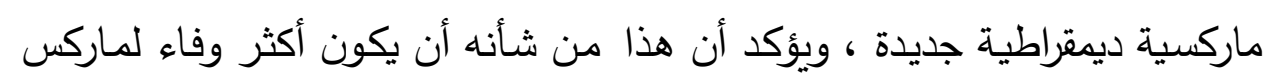

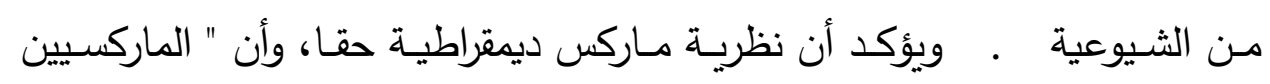

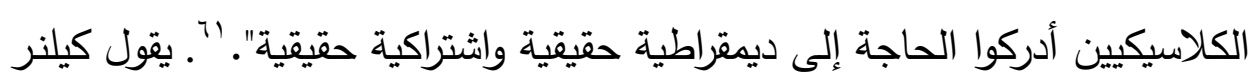

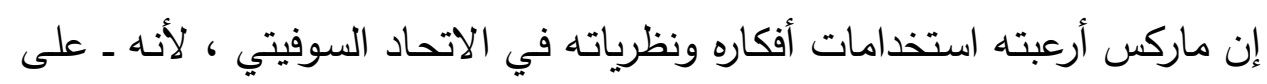

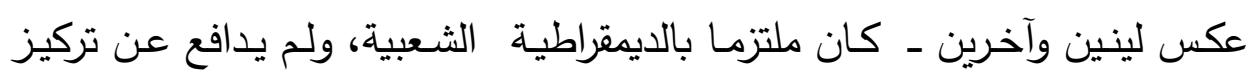
السلطة في حزب. الين واختين

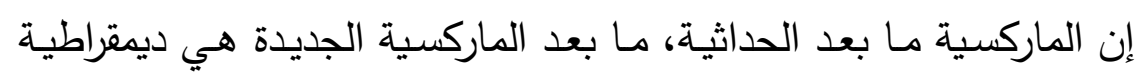

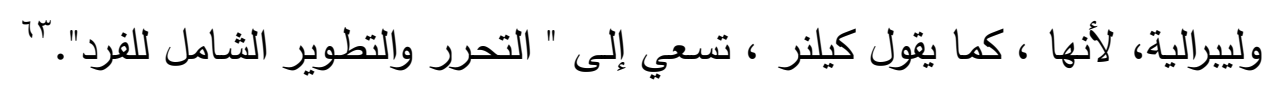

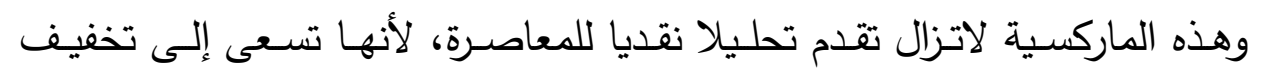

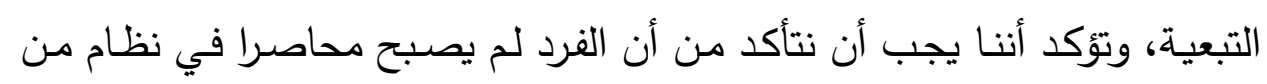


السـياده والعبوديـة. يـدعي كيلنـر أن "الرؤيـة الماركسـية الجديـدة للديمقراطيـة

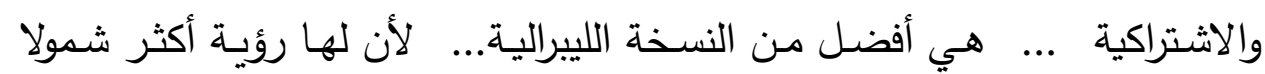
للديمقراطية تتضمن جميع نواحي الحياة الاجتماعية؛'. 'ومع ذلك ، هذه الماركسية الجديدة ورغبتها في إبقاء ماركس على قيد الحياة لا تعني بالضرورة أننا يجب أن نقوم بثورة لتأكيد أن الماركسية هي شبح يطارد التاريخ، بل إنها تشير إلى أننا لا لاءلاهل

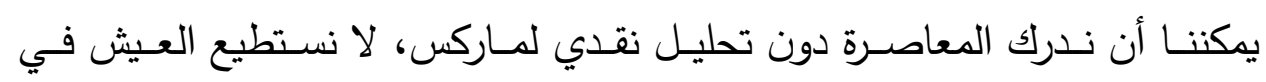
الحاضر دون وعي لمتى تعرض عدم المساواة والتبعية فرص الفرد للتطوير الكامل والاعتراف به للخطر • ويحذرنا ماركس أيضا من الظلم الذي يمكن للتبعية أن تسببه

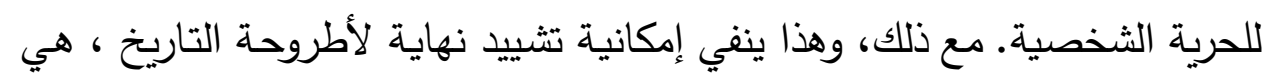
تعني أن النظـام الاجتمـاعي / السياسـي يجب أن يرتكز على شكل مـن الرؤيـة الايجاليتريانية التي تضمن أن كل فرد معترف به وذو قيمة بوصفه فردًا ونظيرًا.

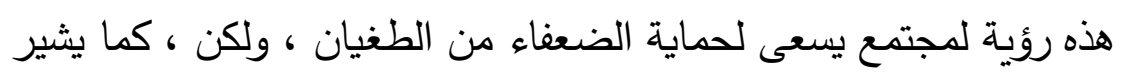

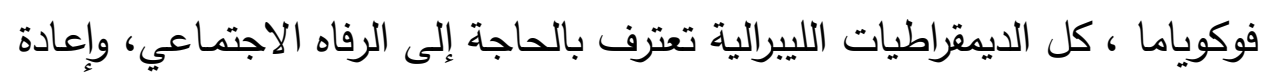
توزيع من الأغنياء إلى الفقراء.

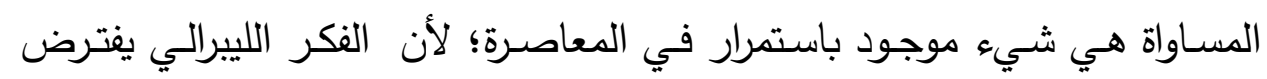

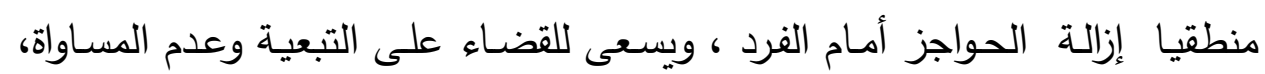
ويعمل من أجل تعزيز ازدهار الفرد.

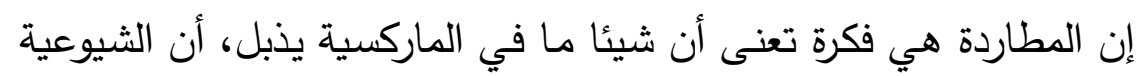

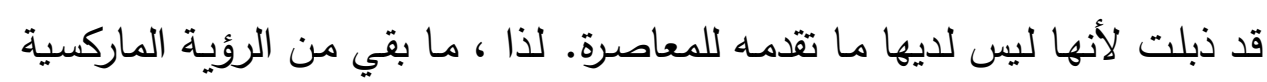

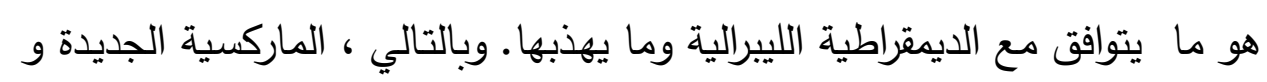

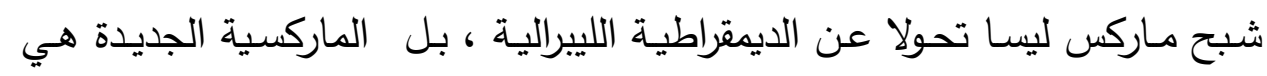
ادعاء أن هنالك أفكارًا من أعمال ماركس لاتزال تحتاج إلى أن تدرك.فإذا كان هناك

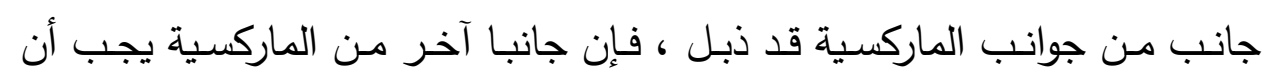
يتحقق و يتحرر. 


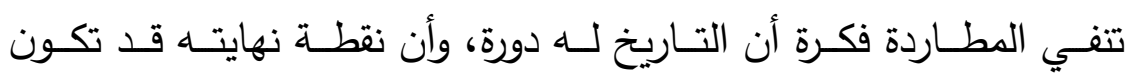
الديمقراطية الليبرالية، وتوضح أن هناك أشباحا تطالب الديمقراطية الليبرالية بإعادة

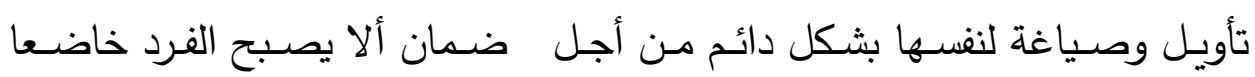

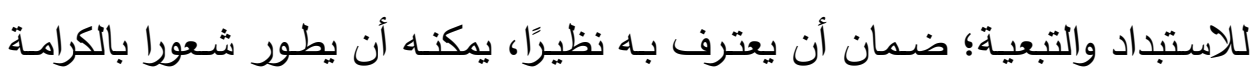

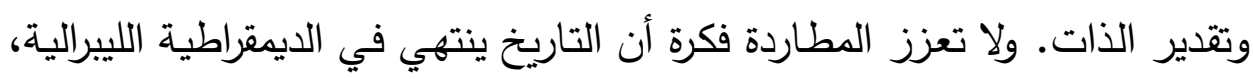

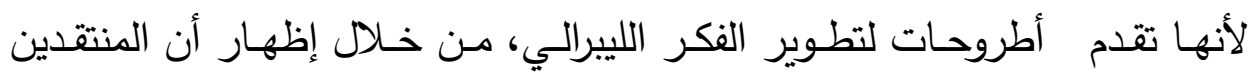

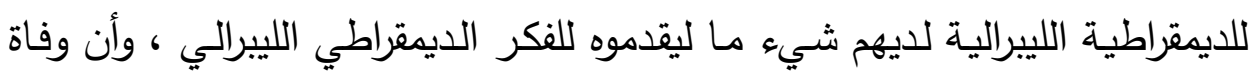

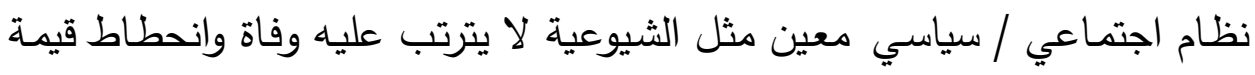

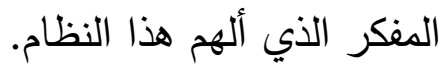




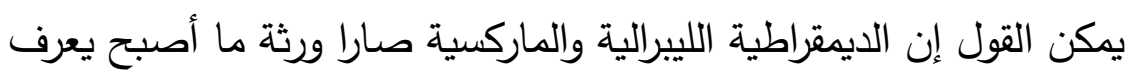
باسم مشروع التتوير ، تلك الحركة الثقافية الغربية التي سعت منذ بداية القرن الثامن

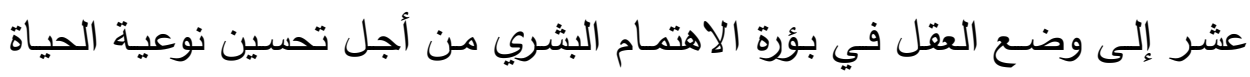

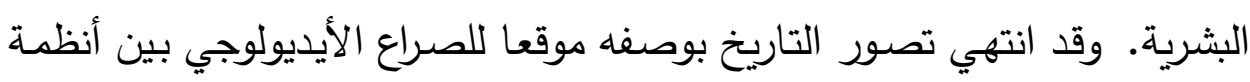

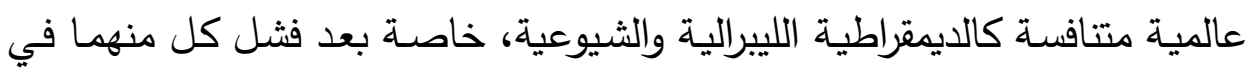

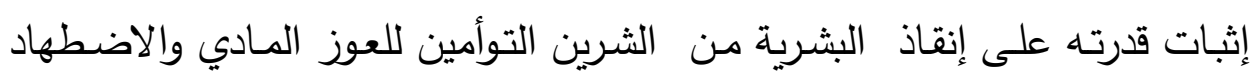

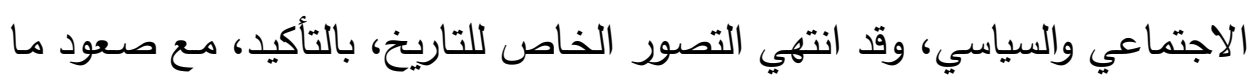

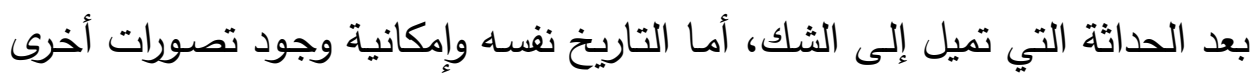

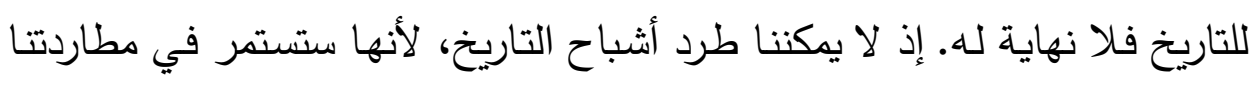
إلى الأبد. - - إن

ويبين شبح ماركس لنا أنه على الرغم من قوة رأس المال، يجب أن ينظر

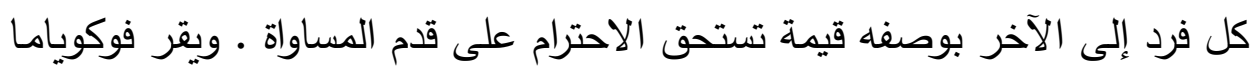

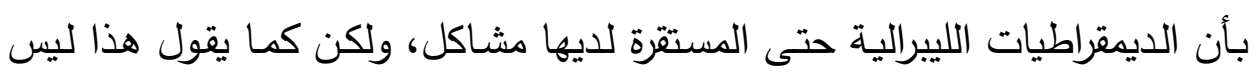

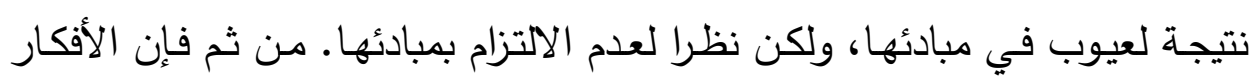

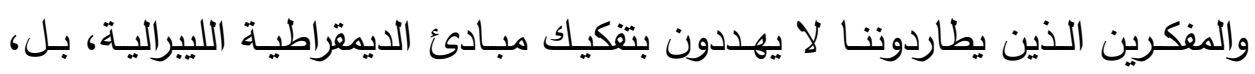
يلقون الضـوه على جوانب القصـور في تطبيـق مبـادئ الديمقراطيـة اللييراليـة

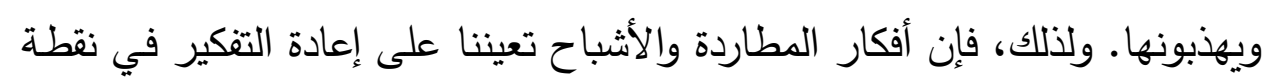

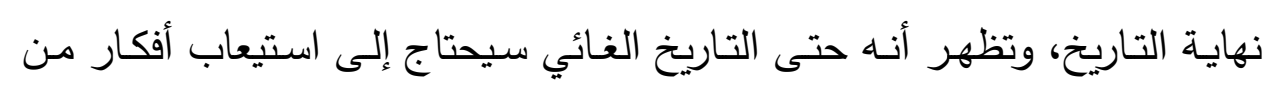
الماضي.

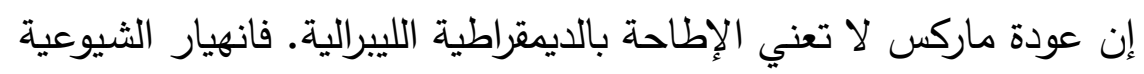

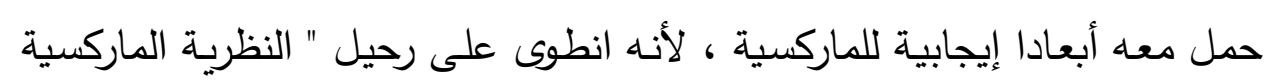

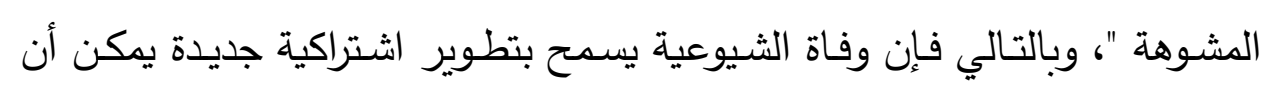


تعزز الحرية والديمقراطية والسعادة البشرية. ولا تهدد هذه الرؤية لكستقبل الماركسية

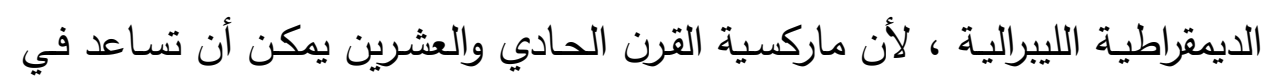

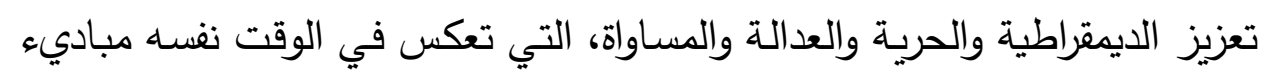

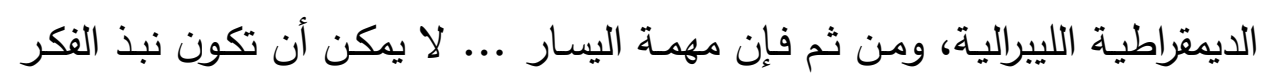

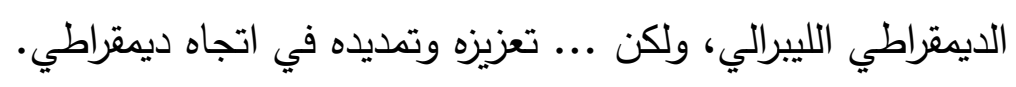

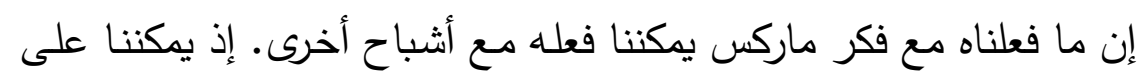

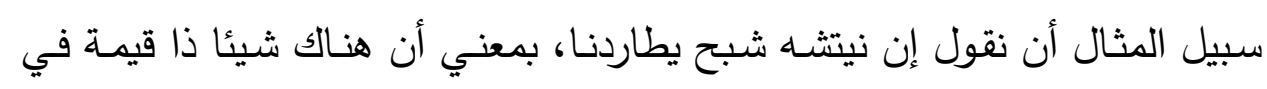

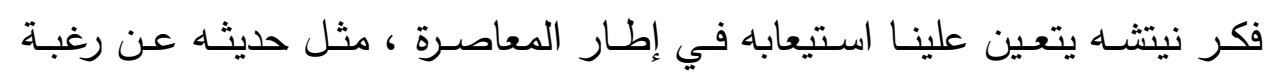

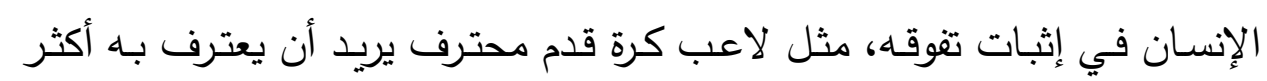

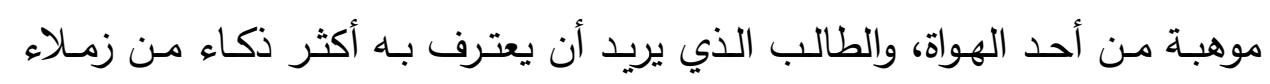

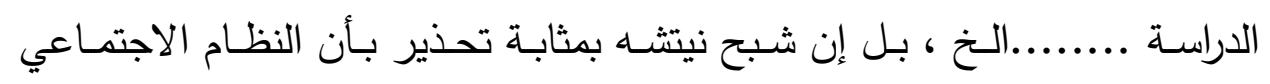

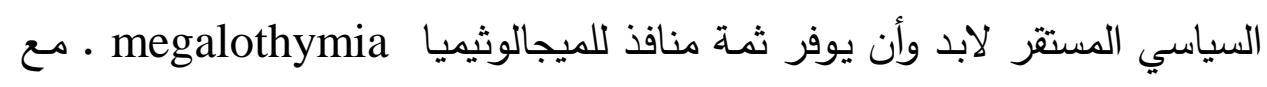

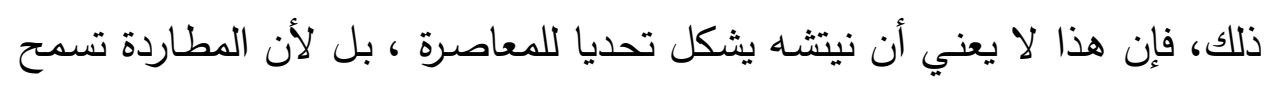

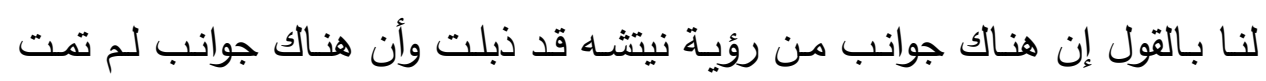

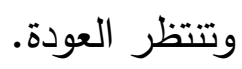




\section{العوامشش}

$\left.{ }^{1}\right)$ Bernd Magnus and Stephen Cullen berg, Editors,(1994), Introduction to Derrida, Specters", New York and London: Routledge Classics, pp. vii, viii.

$\left.{ }^{2}\right)$ Ibid.

3) Jacques Derrida, (1988),"Ear of the Other. Otobiography, Transference, Translation", trans. Peggy Kamuf, ed. Christie McDonald, Lincoln, NA and London: University of Nebraska Press, p. 32.

$\left.{ }^{4}\right)$ Jean-Francois Lyotard,(1991), "The Inhuman: Reflections on Time", trans. Geoffrey Bennington and Rachel Bowlby, Oxford: Basil Blackwell, pp. 8-9.

$\left.{ }^{5}\right)$ Michel Foucault, (1970), "The Order of Things: An Archaeology of the Human Sciences", trans. Alan Sheridan-Smith, New York: Random House, p.387. $\left.{ }^{6}\right)$ Jean-Francois Lyotard, (1984), "The Postmodern Condition: A Report on Knowledge", trans. Geoffrey Bennington and Brian Massumi, Manchester: Manchester University Press, p. xxiv

7) Stuart Sim, (1999),"Derrida and the End of History",

Cambridge; New York: Icon Books; Totem Books, p.16

8) Lyotard, The Postmodern Condition, p. 60.

9) Sim, Derrida and the End of History, p.24

${ }^{10}$ Ibid, pp.24-25

${ }^{11}$ ) Ibid, p.26

${ }^{12}$ ) Ibid.

$\left.{ }^{13}\right)$ Lyotard, "The Inhuman", p. 69.

14) Francis Fukuyama, "The End of History?", The National Interest, 16 (1989), pp. 3-18.

$\left.{ }^{15}\right)$ Daniel Bell,(1962), "The End of Ideology: On the Exhaustion of Political Ideas in the Fifties", New York:

Free Press, p. 393.

16) Francis Fukuyama,(1992), The End of History, London: Hamish Hamilton, p. xii. 
${ }_{18}^{17}$ ) Ibid., p. 312 .

$\left.{ }^{18}\right)$ Jean-Francois Lyotard,(1993), "Libidinal Economy", trans. Iain Hamilton Grant, London: Athlone Press, p.96.

19) Jacques Derrida, (1994),"Specters of Marx", New

York and London: Routledge Classics, p.13.

20) Sim, "Derrida and the End of History", p.49

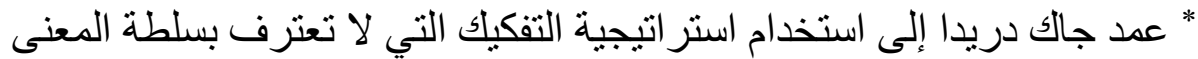

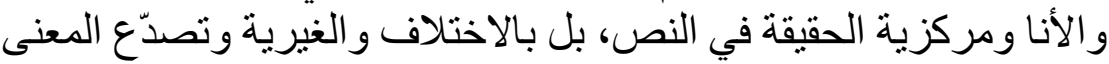

$\left.{ }^{21}\right)$ Fukuyama, The End of History, p. xi.

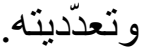

22) Derrida, Specters of Marx, p.p. 78-9.

23) Ibid., p. 85.

${ }^{24}$ ) Ibid.

${ }^{25}$ ) Ibid., p. 91.

26 ) Ibid, p. 48.

27) Ibid, pp.xvi-xx.

${ }^{28}$ ) Wendy Brown, (2001),"Politics Out of History",Princeton:

Princeton University Press, p. 146.

${ }^{29}$ ) Ibid., p.151.

${ }^{30}$ ) Derrida, Specters of Marx, p. 10

${ }^{31}$ ) Ibid., pp. 1-3.

$\left.{ }^{32}\right)$ Brown, Politics Out of History, p. 146.

33 Ibid., p.143.

${ }^{34}$ ) Ibid.

35) Sim, Derrida and the End of History, p. $4 .$.

${ }^{36}$ )Derrida, Specters of Marx, pp.xvi-xx

37) Ibid., p. 14

${ }^{38}$ ) Bernd Magnus and Stephen Cullenberg, 'Editor's

Introduction', in Whither Marxism? ?: Global Crises in

International Perspective,New York and London: Routledge,

1995, p.ix.

${ }^{39}$ ) Derrida, Specters of Marx, 37-39.

40 ) Ibid., p. 62.

$\left.{ }^{41}\right)$ Brown, , Politics Out of History, p. 144. 
$\left.{ }^{42}\right)$ Derrida, Specters of Marx, pp. 39-42.

${ }^{43}$ ) Ibid., pp. 39-42

44) Sim, Derrida and the End of History, p. 5.

${ }^{45}$ ) Jonathan Culler,(1983), "On Deconstruction", London:

Routledge and Kegan Paul, p.133

$\left.{ }^{46}\right)$ Jean-Francois Lyotard,(1988),"The Differend", Manchester:

Manchester University Press, p. 171.

$\left.{ }^{47}\right)$ Derrida, "Specters of Marx", p. 62.

${ }^{48}$ ) Ernesto Laclau and Chantal Mouffe, (2001), "Hegemony

and Socialist Strategy: Towards a Radical Democratic Politics

",(second edition), London; New York: Verso, and Douglas

Kellner, "The Obsolescence of Marxism?" in Whither

Marxism?.

${ }^{49}$ ) Kellner, The Obsolescence of Marxism? ,p. 6.

${ }^{50}$ ) Ibid

${ }_{52}^{51}$ Ibid., p. 5

${ }_{53}^{52}$ Ibid., p. 5

${ }^{53}$ ) Fukuyama, The End of History and The Last Man, pp. 290291.

${ }^{54}$ ) see Francis Fukuyama, "The End of History?"

${ }^{55}$ ) Fukuyama, The End of History , pp.181-198.

${ }^{56}$ ) Ibid.,p. 200.

${ }^{57}$ ) Ibid., p. 203

${ }^{58}$ ) Ibid., pp. 203-204

${ }^{59}$ Ibid., pp. 202-203

${ }^{60}$ Laclau and Mouffe, , Hegemony and Socialist Strategy, pp.

47-48

$\left.{ }^{61}\right)$ Kellner, The Obsolescence of Marxism?, p. 14

${ }^{62}$ ) Ibid., pp. 6-7

$\left.{ }^{63}\right)$ Ibid., p. 22

${ }^{64}$ ) Ibid., p. 22

$\left.{ }^{65}\right)$ Fukuyama, The End of History, pp.290-291. 


\section{دور الإعلانات التلفزيونية في نشر الخرافات الطبية}

\section{د. دمحم كمال احمد"}

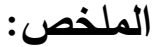

هدفت الدراسة الحالية، إلي التعرف علي دور الإعلانات التلفزيونية في نشر الخرافات الطبية، ومن هنا طرحت الدراسة تساؤلاً يبحث عن إلي أي مدي تلعب الإعلانات التلفزيونية دوراً في نشر الخرافات الطبية. وتتدرج هذه الدراسة ضمن الدراسات الوصفية التحليلية معتمدة في منهجيتها لتحليل وتفسير اشكاليتها علي منهج تحليل المضمون لعدد (10.1) من الإعلانات التلفزيونية التي تروج للخرافات الطبية عبر عدد من

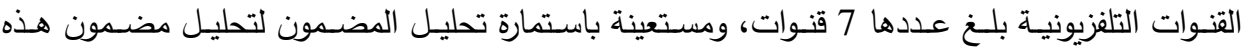
الاعلانات، فضلا عن الاستعانة بمنهج المسح الاجتماعي علي عينة عشوائية قوامها (•99) مفردة مقسمة

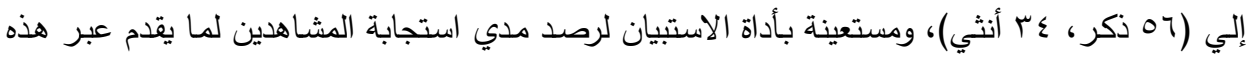
الإعلانـات مـن منتجـات طبيـة. وقد توصـلت الدراسـة إلـي تتـوع الآليات التـي تعتمد عليها الإعلانـات التلفزيونية في نشر الخرافات الطبية، مما أسهم في دعم الخرافة وتقويتها وتتبيتها في ذذهن المتلقي. كما توصلت الدراسة إلي اعتماد الإعلانات علي اللغة العامية في نشر الخرافات الطبية، مما ساعد علي جذب انتباه المشاهدين تجاه ما يعرض. كما أكدت الدراسة أن زيادة الجرعة الإعلانية ساهم في تدعيم وتثبيت الرسالة الإعلانية ذات الطابع الخرافي. كما كثفت الدراسة عن تتوع في الخرافات الطبية التي تروج لها لها لهاتها الإعلانات ما بين خرافات جنسية، خرافات جمالية، وخرافات تتعلق بالثفاء من الأمراض. كما توصلت لإعل الدراسة إلي أن القنوات الخاصة كانت صاحبة اليد العليا في الترويج للخرافات الطبية. كما كثفت الدراسة عن الإقبال المتزايد من قبل الإناث علي المنتجات الخرافية التي تقدم عبر الإعلانات التلفزيونية والمتعلقة

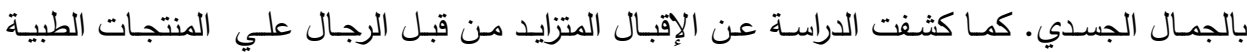
الجنسية. وأخيرا كثفت الدراسة عن حجم الخداع الذي مارسسه القائمين علي تلك الإعلانات في تزييف الإنف الواقع الصحي، ومحاولة تحقيق نوع من الثراء وكسب المال حتى ولو علي صحة الأفراد.

\section{The Role of television advertising in the dissemination of medical superstitions}

\section{Abstract:}

The present study aimed to identify the Role of television advertising on the dissemination of medical superstitions. Hence, the study raises the question of the extent to which television advertisements play a role in the dissemination of medical superstitions. This study is part of the descriptive analytical studies, which are supported in its methodology for analyzing and 
interpreting its problematic on the content analysis methodology of 150 television advertisements promoting medical superstitions through a number of 7 channels, And using using content analysis form to analyze the content of these ads. As well as the use of social survey methodology on a random sample of (90) single, divided into (56 male, 34 female), and using the questionnaire tool to monitor the response of viewers to what is provided through these ads of medical products The study found a variety of mechanisms on which television advertising depends on the dissemination of medical superstitions, which contributed to support the superstitions and strengthen and install in the mind of the recipient. The study also adopted the adoption of advertising on slang in the dissemination of medical, superstitions which helped to attract the attention of viewers to what is presented. The study also confirmed that the increase in ad dose contributed to the consolidation and stabilization of the advertising message of a legendary nature. The study also revealed a diversity of medical superstitions promoted by advertisements between sexual superstitions, aesthetic superstitions, and superstitions related to the healing of diseases. the study found that private channels had the upper hand in promoting medical superstitions. The study also revealed the increasing demand by females for superstitious products, which are presented through television advertisements and related to physical beauty. The study also revealed the increasing demand for sexual medical products by men. Finally, the study revealed the extent of the deception practiced by those responsible for these ads in falsifying health reality, and trying to achieve some kind of wealth and make money even on the health of individuals.

\section{هقدهة الدراسة:}

$$
\begin{aligned}
& \text { مما لاشك فيـه أن التلفزيون علي حد تعبير "بورديو" أصبح فضـاء يميز فيه بين }
\end{aligned}
$$

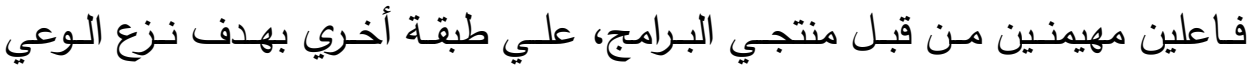

$$
\begin{aligned}
& \text { الإبداعي والنقدي لديهم، ومن ثم تقديم فكرا جاهزا وغذاء ثقافيا سريعا يعرف بالتغذية }
\end{aligned}
$$

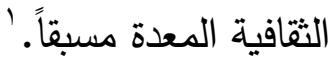$$
\text { حيث يقوم التلفزيون بالترويج لإعلانات هدفها الأساسي لفت الانتباه إلي ما يعرض }
$$$$
\text { والوصول إلي المشاهدين، وخصوصا المشاهدين المنتظرين ولديهم الرغبة في خوض بـ }
$$

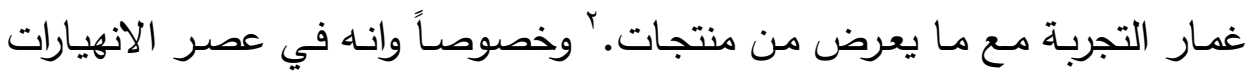$$
\text { الكبرى وفي ظل آليات الهيمنة العالمية تحولت الثقافة الاستهلاكية احد مجالات }
$$$$
\text { تدويل النظام الرأسمالي إلي آلية فاعلة لتشويه البنية التقليدية وتغريب الإنسان وعزله }
$$

$$
\begin{aligned}
& \text { ' - بير بورديو، التلفزيون واليات التلاعب بالعقول، ترجمة وتتديم: درويش الحلوجي، دار كنعان، دمشق، الطبعة الأولي، }
\end{aligned}
$$

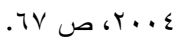

2 - Paual, Chambers" Television Medical Advertising", Journal Of Proc. Roy. Soc.

Med, Vol,62, 1969,P:329. 
عن قضاياه وإدخال الضعف لديه والتتكيك في قناعاته بهدف إخضاعه نهائيا للقوي والنخب المسيطرة، بالإضافة إلي إضعاف روح المقاومة لديه.

ووفقا لما سبق يتضـح لنا إنتا نعيش في مجتمـع إعلامسي يجب التفاوض فيه علي خطط واستراتيجيات الحياة من خلال كتل محيرة من المصادر المتنافسة والمتتاقضـة

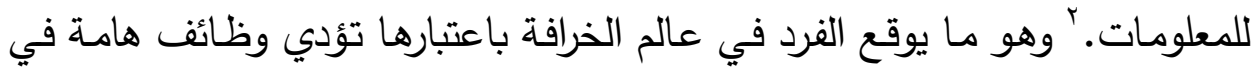
حياة الفرد من خلال إثباع العديد من الحاجات لديه وإرضـاء دوافعه. ويساعد علي

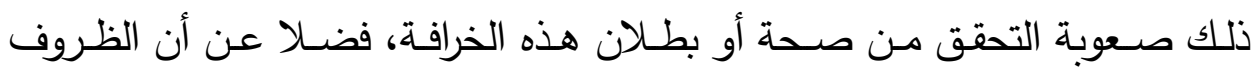

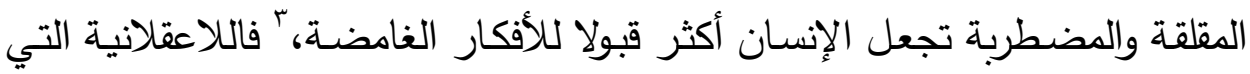
توفرها الخرافة توفر شعورا بالفهم والسيطرة المزيفة. وهو ما يجعل منها عبادة غير عقلانية تعمل علي تبجيل القوي الخيالية مكان العلم، وبالتالي فهي تثكل نمط من أنماط تراجع العلم، باعتبارها تنطوي علي ممارسات ذات قيم مشكوك فيها وتنطوي علي تصنيع أصناف يدعَي إنها تمتلك قوي مذهلة. وهو ما ظهر حديثاً في مجال الطب حيث انتشرت الخرافات الطبية مما جعل الكثير من علماء الاجتماع الطبي يتحدثون عن الطبيعة المتغيرة بين المريض ومقدم الخدمة الطبية في أواخر الحداثة، حيث تراجعت السلطة الطبية نتيجة حالة الانتشار الواسع

'- 'أحمد مجدي حجازي، العولمة بين التفكيك وإعادة التركيب: دراسات في تحديات النظام العالمي

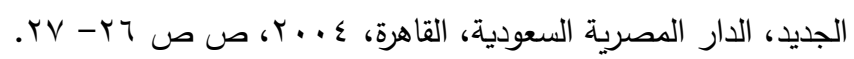

2 - Micheal, Hardey." Doctor In The House: The Internet As A source Of Lay Health Knowledge and The Challenge To Expertise", Sociology Of Health and Illness', Vol,21, No,6,1999,P:831.

3 - George, W,Kisker. "The Disorganized Personality", University Of Cincinnati, Third Edition,1983,P:198.

${ }^{4}$ - David, R, Vinson." Superstitions In Medicine: Bad Luck Or Bad Logic?: Annals Of Emergency Medicine", Madigan Army Medical Center University of Washington Tacoma, WA, Vol,31, Issue,5,1998,P:651.

5 - Dominin, Umohi ."Superstition and Syncretism: Set Backs To Authentic

Christian Practice in Africa", International Journal of Humanities and Social Science Invention, Vol,2, Issue, 7,2013,P:33. 
للمعلومات الطبية التي تقدمها وسائل الأعلام، مما أدي إلي ظهور ما أطلق عليه "جيدنز" المستهلك الانعكاسي.'

هذا المستهلك الذي يتعرض لكم هائل من المنتجات الطبية التي يجد فيها الطاقة

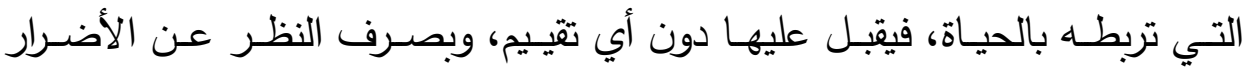
المتوقعة عن استخدامها، ويساعده علي ذلك ما تروج له هذه الإعلانات التلفزيونية

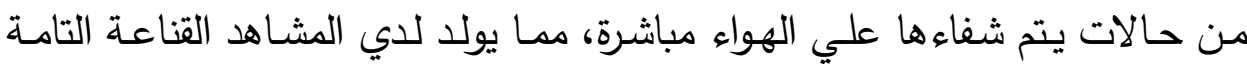
بصداقية ما يعرض فيقع في فخ الخرافة.

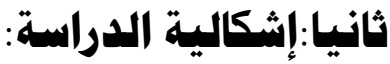

ممـا سبق يتضـح أن إثكالية الدراسـة تتطلق مـن الكثف عن الدور الذي تلعبه الإعلانات التلفزيونية في نشر الخرافات الطبية، فعلي الرغم مما تقوم به الإعلانات التلفزيونية من إتاحتها لكم كبير من الدنتجات الطبية، بالإضـافة إلي السرعة الكبيرة التي يتم بها نقل تلك المنتجات، فضلا عن سهولة تداولها بين كافة أفراد المجتمح، إلا إن خطورتها تتمثل في قدرتها علي خلق واقع طبي افتراضي ملئ بكافة أنماط

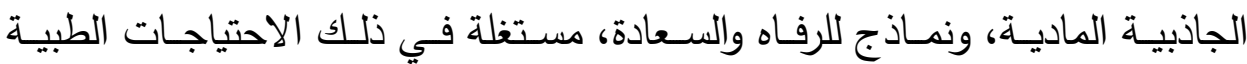

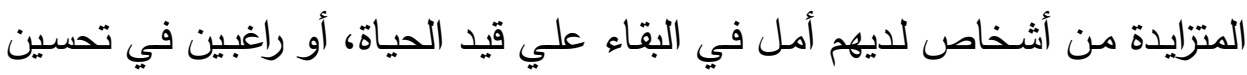
حالتهم الصحية، أو راغبين في الوصول إلي درجة معينة من الكمال، وهو ما يعكس العاه

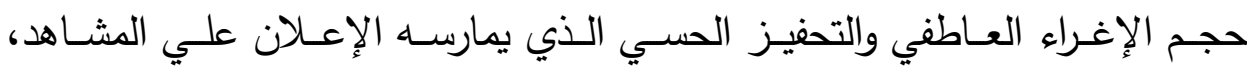
يصاحبه في نفس الوقت حالة من تراجع للفعل العقلاني لاي الدتلقي، الذي يعاني من سيطرة رواسب خرافية لا حدود لها بين مختلف شرائحه الاجتماعية.

${ }^{1}$ - Fils, Henwood, Et al.."Turned On Or Turned Off?: Accessing health information on the Internet", Scandinavian Journal of Information Systems, Vol,14,Issue,2,2002,P:P 82-83. 
ومن هنا كان يجب علينا البحث عن الآليات الفنية التي تعتمد عليها الإعلانات في نشر تلك الخرافات الطبية، ونوعية القضايا الطبية الملحة التي يستغلها القائين علي تلك الإعلانات في نشر الخرافات الطبية، فضـلا عن تحديد هويـة القنوات المروجـة

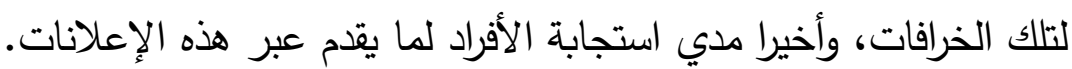
وانطلاقا من القضايا المثارة بإشكالية الدراسة نستعرض بالتحليل والتأصيل النظري" للمفاهيم" الأداة التحليلية لمتغيرات دراستنا الحالية.

\section{ثالثا: هفاهيه الدراسة:}

\section{م هفوم الإعلان}

- "هو أداة رئيسية في عملية التسويق للمنتجات والخدمات والأفكار وله هدفان رئيسان

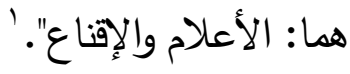
- "هو مظهر من مظاهر الاتصال غير الثخصي لتقديم الأفكار والسلع والخدمات من

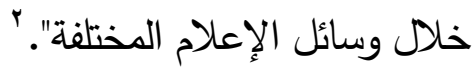

\section{م مفهوم التتلفربون}

- لغويـا كلمـة التلفزيـون تعريـف لكلمـة Television والتـي تتكــون فـي اللغــة الانجليزيـة من مقطعين هما:Tele-Vision ، وكلمـة Tele هي يونانيـة الأصـل وتعني بعيد، أما Vision فهي لاتينية الأصل وتعني مشاهدة وبإضافة الاثنين معا يصبح تعريف التلفزيون هو "مشاهدة البعيد".

1 - Kaptan,S,S. "Advertising: New Concepts,", New Delhi, Sarup and Sons,2002, P:2.

2 - Kotler, Philip. Keller, Kevin. "Marketing Management", New Jersey, Person Prentice- Hall,2009,P:536.

r- جمال محم عبد الحي، مدخل تاريخي لنشأة وتطور التلفاز، مجلة الأكاديمية الأمريكية العربية للعلوم

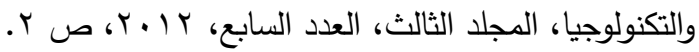


- كما يعرف بأنه "وسيلة نقل الصوت والصورة في وقت واحد بطريقة الدفع الكهربائي، وهي أهم الوسائل السمعية البصرية للاتصال بالجماهير عن طريق بث برامج معينة". م مفهوم الإعلان التلفربيوني

يعرف الإعلان التلفزيوني بأنه "مجموعة من الوسائل الفنية المتتوعة المستخدمة من

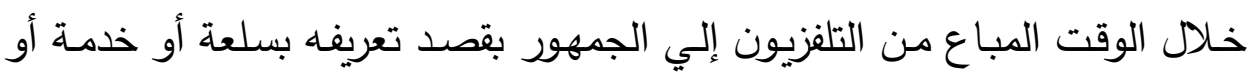
فكر بالثكل والمضمون الذي يؤثر في معلوماته وميوله وقيمه وسلوكه". التعريف الإجرائي: الإعلان التلفزيوني الذي يقصده الباحث هو عمل فني بتقنيات جذابة يقدم عبر شاشات التلفزيون، من اجل تغيير الثقافة الصحية لدي المشاهد. م مفهوم الخرافة مئمة - "هي معتقدات غير عقلانية أو خاطئة تتصل عادة بالسيطرة علي ما يسمي لدي

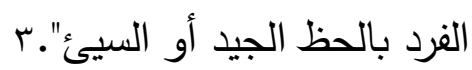
_ "هي فكرة قائمة علي نطاق واسع ولكنها خاطئة". ؛ ـ "هي غرس مختلف المعتقدات والآراء في كافة أشكال التفكير والتي تستمر في التأثير علي سلوكيات وأفعال الأفراد يصاحبها فقد لأساسيات الحقائق".

'- أحمد زكي بدوي، معجم مصطلحات الإعلام، دار الكتاب اللبناني، بيروت، الطبعة الأولي، ؟99 1، ص 10.

r- إيناس محم غزال، الإعلانات التلفزيونية وثقافة الطفل: دراسة سوسيولوجية، دار الجامعة الجديدة

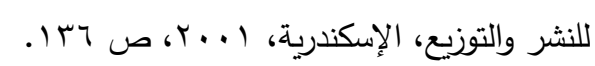

3 - Jane, L, Risen. "Believing What We Do Not Believe: Acquiescence To

Superstitions Beliefs and Other Powerful Intuitions', American Psychological Association Journal, Vol,123,No,1.2016,P:183.

4- Julia,Swannell." The Little Oxford Dictionary Of Current English",,6 Th Ed, Oxford, Oxford University Press,1988,P:562.

5 - Jannifer, Reiling." Superstition in Medicine", American Association, Jama, Vol,295, No,1,2006,P:113. 
- "هي مجموعة من الأفكار والمعتقدات التي تتعارض مع الواقع، أو إنها مجموعة من السلوكيات التي لها معاني مختلفة بالنسبة لمختلف الأفراد والثقافات". م مفهوم الخرافة الطبية مية

"يقصد بها تفسير ومعالجـة المظـاهر الطبيعيـة والمرضـية للحيـاة العضـوية وفق

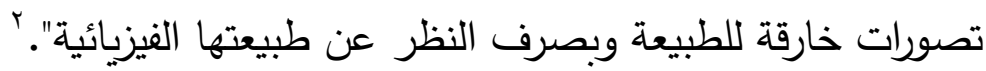
التعريف الإجرائي:

هو الاعتقاد في امتلاكك مجموعة من المنتجات الطبية القدرة علي تغيير الحالـة البيولوجية الآنية للأفراد، والوصول بها إلي مستوي من الكمال الصحي.

\section{رابعا: الدراسات السابقة:}

أن الرجوع إلي الدراسات السابقة يوضح الصعوبات والأخطاء التي مرت بها،لكي

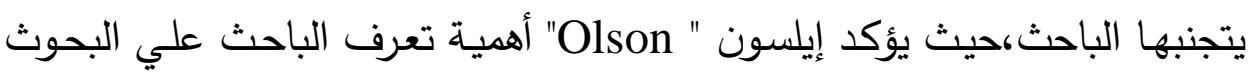
السابقة لدراسته، ويرى أنها حجر الأسـاس الذي ترتكز عليه أيـة دراسـة في بدايـة

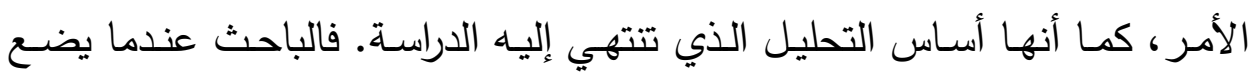

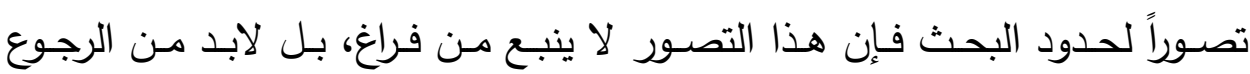
للدراسات السابقة التي تناولت الموضوع بشكل مباشر أو غير مباشر ؛ وذلك لأن مراجعة التراث يلقي المزيد من الضوء علي الأفكار الهامـة والآراء التي كتبت عن الموضوع المراد دراسته وبحثه.كما أنها تعطي صورة واضحة لهذه الآراء المتباينة، وتوضـح النتائج التي توصل إليها الآخرون. ب وهو الأمـر الذي دفع الباحث إلي عرض التراث البحثي لدور الإعلانات التلفزيونية في نشر الخرافات الطبية.

${ }^{1}$ - Silbel, Akova." The Relationship Between Superstitions, Metaphors and

Advertising", Journal Of Academic Marketing Mysticism,Vol,3,No,9,2011,P:138.

2 - Hugo, Magnus." Superstition in Medicine", Translation By: Julius,L. Salinger,

Punk., Wagnalls Company, New York and London,1908,P:4.

${ }^{3}$ - Black, J.Champion,D.;' Methods and Issues in Social Research', John Wiley and Sons, New York,Inc,1976,P.107. 
أولا: الدراسات العربية:

الدراسة الأولي: الإعلانات الدوانية التي تستهدف المستهلك هباشرة في

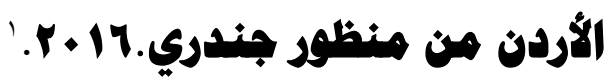

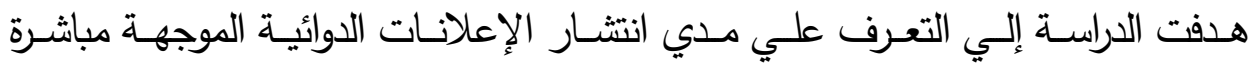
لللمستهلك في الأردن، والفروق اللاحقة وفقا للنوع والجنس فيما يتعلق بهذه الإعلانات. وقد أجريت الدراسـة علي عينتين همـا: المرضـي( المستهلكين للـواء) مـن مراجعي

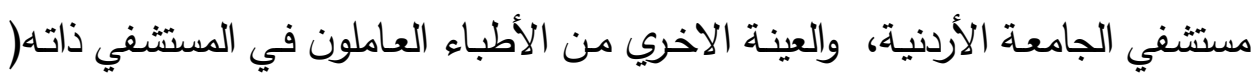
الذين يصفون الدواء). وقد وزع استبيان علي العرضي الذكور والإناث بإجمالي ( (00)

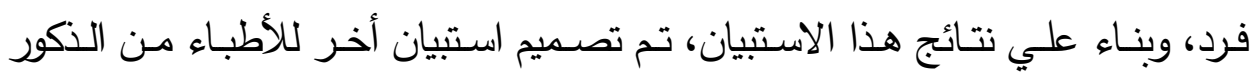

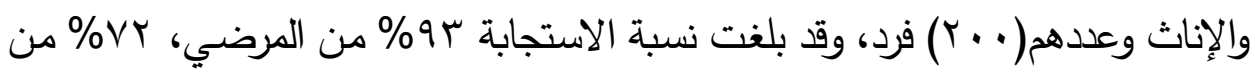

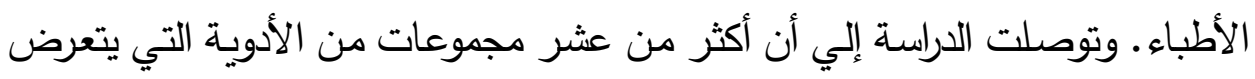

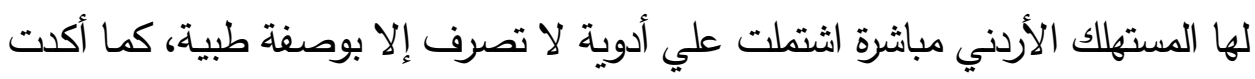

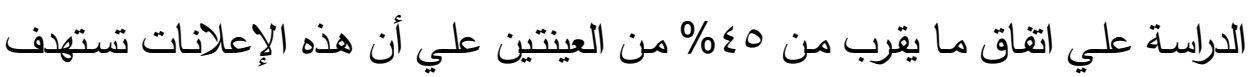

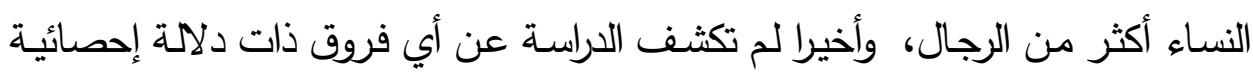

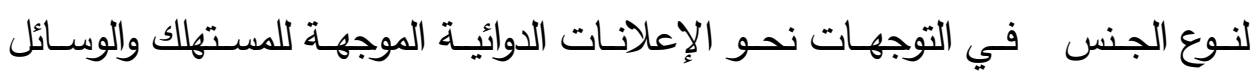
الإعلانية المستعملة.

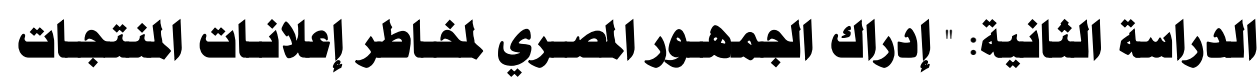

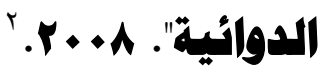

'- هديل عاشور، إبراهيم العبادي، الإعلانات الدوائية التي تستهدف المستهلك مباشرة في الأردن من

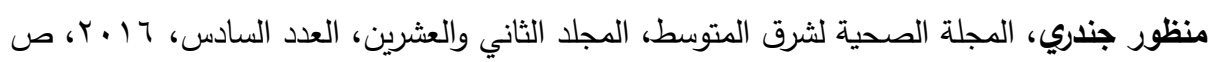

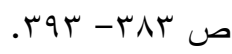

r- نادية عبد النبي القاضي، إدراك الجمهور المصري لإعلانات المنتجات الدوائية، المجلة المصرية

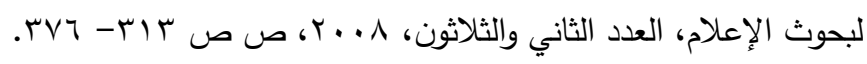


استهوفت الدراسـة رصد معدل تعرض الجمهور المصري لإعلانات المنتجات الدوائية، ومعرفة تأثير التعرض لها في وسائل الإعلام ، والوقوف على مدى إدراك الأفراد لارجة

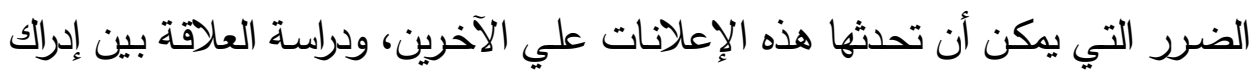
الجمهور لتأثيرات الثخص الثالث وتأييد فرض الرقابة على إعلانات المنتجات الدوائية.

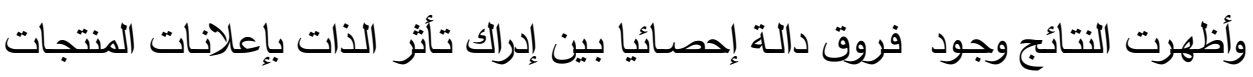

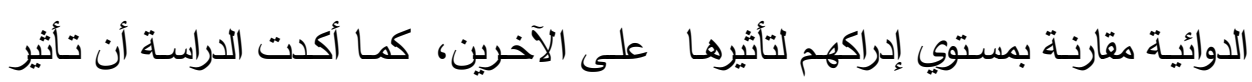

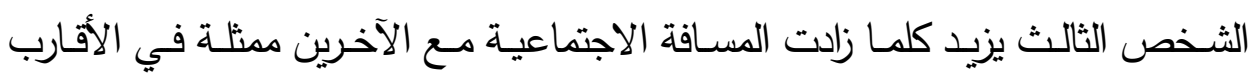
والأصدقاء والجيران.

\section{ثانيا: الدراسات الأجنبية}

\section{"Viewer Perception of Messages in The Television} Advertisement of Herbal Medicine: A survey of Akosombo

\section{Residents".2016.'}

هـفت الدراســة إلـي معرفـة وجهات نظـر المشـاهدين عـن الإعلانـات التلفزيونيـة المروجة للطب العشبي، بالإضافة إلي معرفة مدي اعتقادهم في حقيقة ما يقدم من أدوية عشبية عبر شاشات التلفزيون. وتم جمع البيانات باستخدام أداة استبيان علي

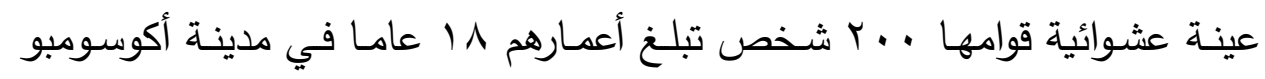
بدولة غانا. وانقسم الاستبيان إلي جزئين: الأول اختص بالبيانات الديموجرافية لعينة الدراسة، والثاني عرج ليعرض مدي اعتقادهم فيما يعرض عبر التلفزيون من أدويـة عشبية. وبعد جمع البيانات تم تحليليها باستخدام برنامج SPSS. وتوصلت الدراسة

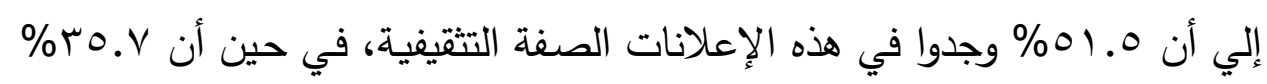
وجدوا أن هذه الإعلانات مبالغ فيها ولا تمت إلي الواقع بأي صلة. كما توصلت

${ }^{1}$ - Patrick, Kwadwo. Boateng Bonna." Viewer Perception of Messages in The Television Advertisement of Herbal Medicine (A survey of Akosombo Residents", The University of Ghana, Llgon, in Partial fillment of The Requirements for The Award of Master of Arts Degree in Communication Studies, 2016,P:P 1-81. 
الدراسة إلي أن ^^^\% من المشاركين في البحث أكدوا علي ضرورة تتظيم مثل هذه الإعلانات للتقليل من المبالغة والادعاءات الطبية التي تقدمها.

الثراسة الثانية:

\section{"Television as A source of Information on Health and}

\section{Illness - Review of Benefits and Problems".2015.'}

هدفت هذه الدراسة إلي تحديد الفوائد والأضرار الناجمـة عن استخدام الوسائل السمعية

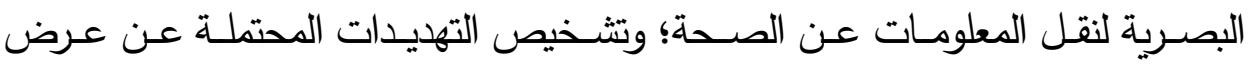
المعلومات الصحية عبر التلفزيون. ومن اجل تحقيق نلك تم مراجعة نقدية ل V؟ ورقة

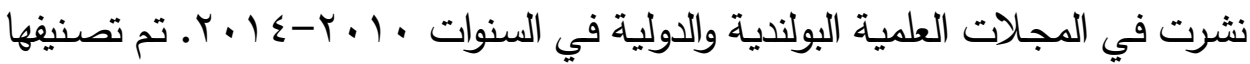
إلى ^ أقسام: (1) المعلومات الصحية في المسلسلات ، (Y) الموضوعات الصحية في البرامج الحوارية ،(ب) المعلومات الصحية في البرامج الإخبارية،؛(ع) موضوعات التغذية

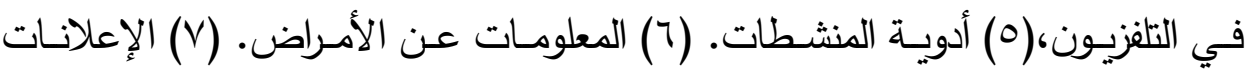
المتعلقة بالصـحة العامـة؛ (^) برامج التتقيف الصـحي. وتوصلت الدراسـة أن التلفزيون مصدر واعد للمعلومات الطبية بشرط توخي الحذر والاعتدال فيما يقدم من معلومات طبية.

الدراسة الثالثة: - تئة

"The Effect of Deceptive Advertising on Consumption of the Advertised Good and its Substitutes: The Case of Overthe-Counter Weight Loss Products" 2013.

هذفت هذه الدراسة إلي التعرف علي تأثير التعرض للإعلانات الخادعة علي استخدام المشاهدين لمنتجات إنقاص الوزن. واعتمدت الدراسة علي منهج المسح الاجتماعي لعينة

1 - Burzyńska J.Et al." Television as a source of information on health and illness review of benefits and problems", International Journal of Health Sciences, Vol,5, Issue, 2, 2015,P:P 174- 184.

2 -John, Cawley. Et al." The Effect of Deceptive Advertising on Consumption of the Advertised Good and its Substitutes: The Case of Over-the-Counter Weight Loss Products" IZA DP No. 724, 2013. P:P 1- 48. 


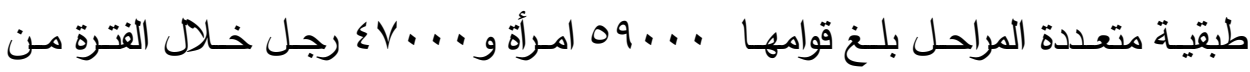

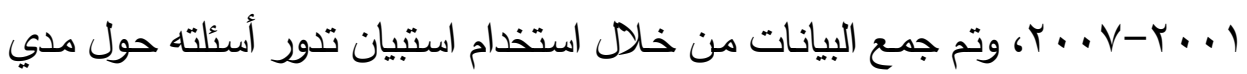

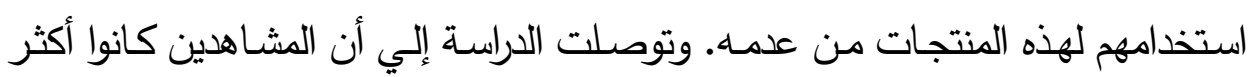
استخداما لتلك المنتجات الخادعة عن إتباع أي نظم غذائية أو رياضية تساعد علي إنقاص الوزن، وهو ما يظهر حجم التأثير الذي مارسته الإعلانات في تغيير نمطحياة الأفراد.

\section{الدراسة الرابعة:}

"Investigating The Relationship between Exposure to Television Programs That Depict Paranormal Phenomena and Beliefs in The Paranormal"2001.'

هدفت الدراسـة إلي اكتشاف العلاقة بين التعرض لوسائل الأعـلام والمعتقدات الخاطئة

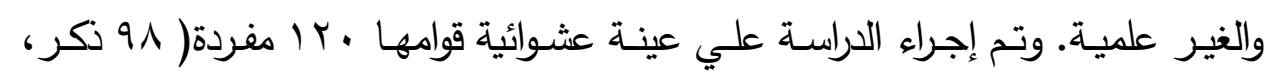
r • أنثي) تم اختيارها من دليل الهاتف، واعتمدت الدراسة في جمع البيانات علي أداة

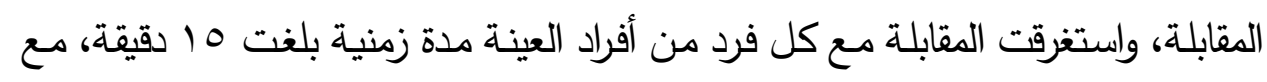

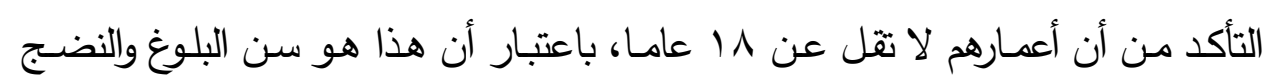

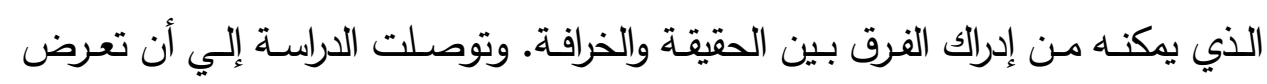

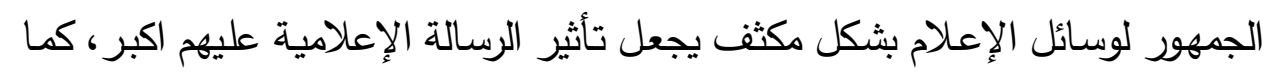
أكدت الدراسـة علي أن الاعتقاد في الخرافات التي تعرض عبر وسائل الأعلام معتمدة لئل في الأساس علي التجربة الثخصية التي يمر بها الفرد.

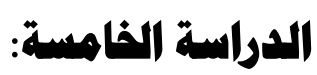

\section{"Understanding the Effects of Direct-to-Consumer} Prescription Drug Advertising". 2001.'

${ }^{1}$ _Glenn,G, Sparks. Will, Miller." Investigating The Relationship between Exposure to Television Programs That Depict Paranormal Phenomena and Beliefs in The Paranormal ", Journal of Communication Monographs, Vol,68, No,1, 2001, P:P 98 113. 
هدفت الدراسة إلي التعرف علي إلي أي مدي يستخدم الأفراد الأدوية التي يروج لها عبر الإعلانـات التلفزيونيـة. وهـل هـذه الإعلانـات تقــدم معلومـات تسـاعد في الثـفاء مـن

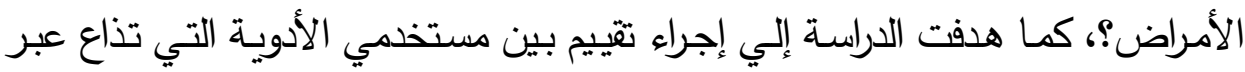
الإعلانات التلفزيونية، وبين المشاهدين لها فقط. ولتحقيق هدف الدراستة تم إجراء مسح

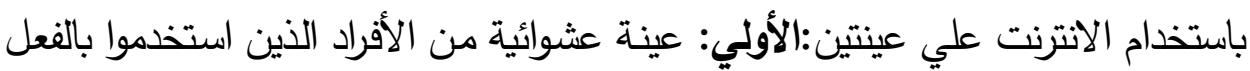
تلك الأدوية المعلن عنها، والثانية: مع عينة من الأفراد المشاهدين للإعلانات فقط دون استخدام، وتم تقسيمهم إلي ثلاث مجموعات عشوائية شاهدت كل منها نوع مختلف من الأدوية. وتوصلت الدراسة إلي أن الأفراد الذين كانوا يعانون من حالة صحية غير جيدة، بالإضافة إلي كبار السن كانوا أكثر الناس استخداما لتلك المنتجات، والتحدث مـع طبيبهم الخاص بشأنها.

\section{الدراسات السابقة"رؤية سوسيولهوجية"}

O مرحت معظم الدراسـات السـابقة حالـة من الانصياع التي انتابت المشـاهدين بثكل كبير لمـا يعرض عبر شاشـات التلفزيون مـن إعلانـات تروج لمنتجـات طبية خادعة، مرتكزة علي التأثير التراكمي للمادة الإعلانية علي المشاهدين، دون الإشـارة للدلالات الاجتماعيـة التي قد تدفع الأفراد للاقتناع بمثل هذه الخرافات الطبية والتي من أههها: الحصول علي حظ من الثفاء،أو الحد من تـدهور الحالـة الصـحية الحاليـة، أو الرغبـة في الانتقـال إلـي حالـة بيولوجيـة كلية أفضل. م لم تكثف لنا الدراسات السابقة عن البنية الفوقية والتحتية للمشاهدين المستقبلين لهذا الإعلانات، والتي عادة ما يكون لها دور في تحديد مدي استجابة الأفراد للاملاءات التي تقرضها عليهم وسائل الأعلام.

\footnotetext{
1 - The Henry J. Kaiser Family Foundation." Understanding the Effects of Direct-to-
} Consumer Prescription Drug Advertising", Menlo Park, California, 2001, P:P 1-12. 
م كثفت الدراسات السابقة عن تغيير عميق في منظومة الرعاية الصحية التقليدية القائمة علي العلاقة المباشرة بين الطبيب والمريض، حيث تراجع دور الطبيب في تقديم الاستشارة للمرضي، وأصبحت الإعلانات هي المنصات التي تتطلق

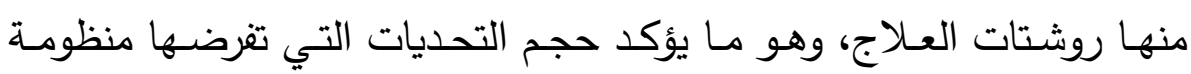
العولمة علي مجال الرعاية الصحية. م أوضـــت الدراسـات السـابقة أن اغلـب الفئـات التـي اسـتهدفتها الإعلانـات التهات

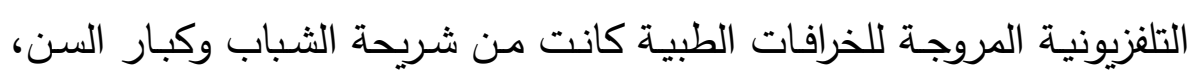
دون أن تكثف لنا عن أسباب استهداف الإعلانات لهذه الفئات. والتي يمكن تفيرها في ضوء أن حجم الطلب من النماذج الأصغر سنا عادة ما يكون في

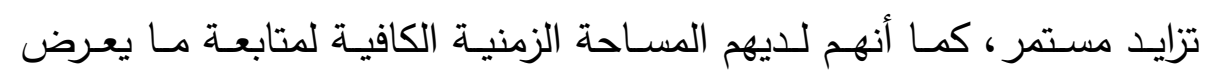
وبالتالي استخدامه، كما أن فترة الشباب هي فترة إجراء التعديلات علي أنماط

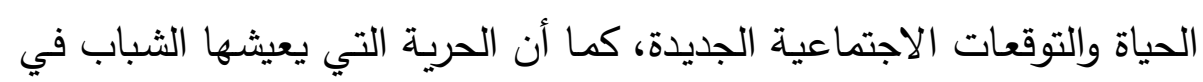

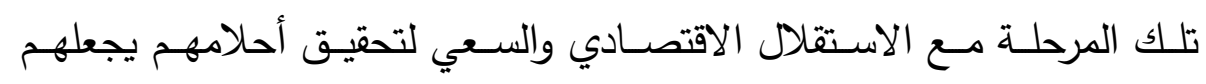
العمـلاء المحتملين للمعلنين.أمـا بالنسبة لكبار السن فنجد أن منظورهم نحو الحياة في السنوات الأخيرة قد تغير من الرغبة في العيش لفترة أطول، إلي

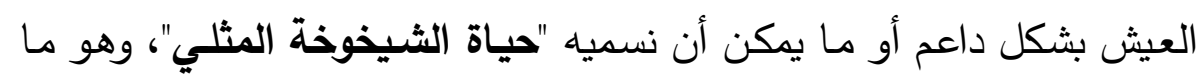

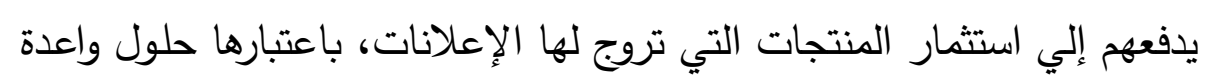
ستحافظ لهم علي فرصهم المستقبلية في الحياة.

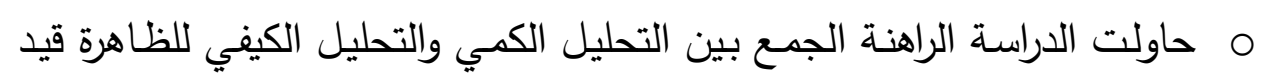

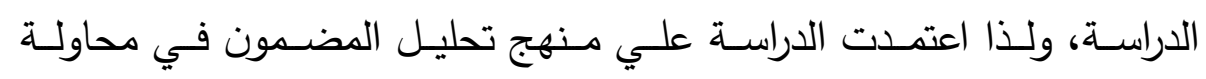
لإخضاع ما يعرض عبر شاشات التلفزيون للمعالجات الإحصائية، من خلال تقييم ووصف مضمونها الشامل ومعناها الرمزي والتعبير عن ذلك بالأرقام وهو ما لم يتوافر في الدراسات السابقة.

خامسسا: الإطار النظري للادراسة: 
يعتمــ تقسيرنا النظـري في معرفـة الـدور الذذي تلعبـه الإعلانـات التلفزيونيـة في نشـر الخرافات الطبية علي منظور رئيسي يتمثل في نظرية الغرس الثقافي. حيث تعرف عملية الغرس "بأنها العملية التي يتت من خلالها التقاعل مع أثكال ثقافية مختلفـة مـع تحقيق الهـف التي ترتكز عليـه الرسـالة الإعلاميـة". 'ونظـراً لان الرسـائل فئل المنتجة تشكل الثقافة، فقد اعتقد جيربنر " Gerbner" مؤسس نظرية الغرس الثقافي أن تأثير نلك يحدث علي المدى الطويل من خلال عملية التعزيز والتغيير. ويعد مفهوم الغرس احد أركان مشروع "جيربنر وزمـلاءه" الذي أطلق عليه "المؤثـرات

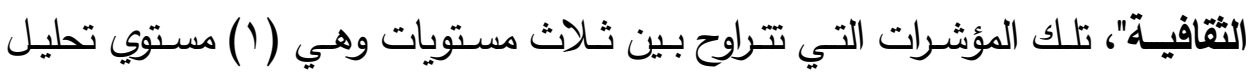
المؤسسة القائمة بعملية الغرس. (Y) مستوي تحليل الرسالة الإعلامية.(ץ) مستوي تحليل تأثير الرسالة علي الجمهور. وتتكون هذه النظربة من عنصرين أساسين هما: 1- محتوي ما يقدم عبر التلفزيون سواء كان حقيقة آم خيال. r- أن التعرض المتكرر للصور المشوهة عبر التلفزيون، يؤدي إلي استيعابها من قبل الجمهر دون تقييم.

فالتعرض المتكرر لما يعرض في التلفزيون يقود المشاهدين إلي غرس ما يعرض من

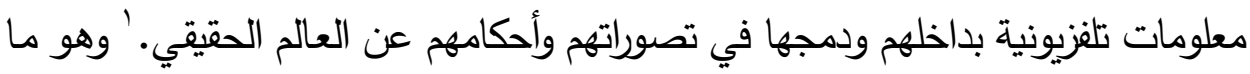

1 - James, Shanahan. Michael, Morgan." Television and Its Viewers: Cultivation

Theory and Research", The Press Syndicate Of The University Of Cambridge, 1999,P:17.

2 - Walim,James,Potter." Critical Analysis Of Cultivation Theory", Journal Of Communication, Vol,64,Issue,6,2014,P:P1015-1036.

3 - Michel, Morgan." Cultivation Analysis and Media Effects" In The Sage Hand

Book Of Media Processes and Effects", Robin,L,Nabi.Mary, Beth.(Edit), Sage Publication,2009,P:7.

4 - Shrum,L,J." A process Model Of Consumer Cultivation: The Role Of Television is A function Of The Type Of Judgment", Journal Of Communcation,Vol,29, No,20.2004, P:179. 
يعد نوع من التعلم العشوائي وغير المتعدد وحالـة من اللاوعي من قبل المشـاهدين. وخصوصاً المشاهدين الذين يشاهدون التلفزيون بكثرة، حيث ذهب "جيربنر" إلي كونهم أكثر تأثرا بالطرق التي يتم من خلالها صياغة العالم. حيث يفسرون ما يعرض عليهم علي انه العالم الحقيقي وليس عالم الأعلام. ؛ فشاهدتهم للتلفزيون لفترات طويلة تجعلهم

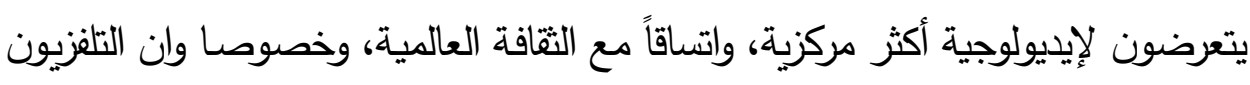
يعهـل علـي توسـيع دائـرة المفــاهيم والمعتقــدات والسـلوكيات لــدي مسـتقبلي الرســالة

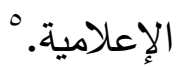

فالتلفزيون إذا كان ييني، ويحفز، ويولد، ويقترح، ويعلم، ويقنع، ويثر، ويعزز ‘، فانـه

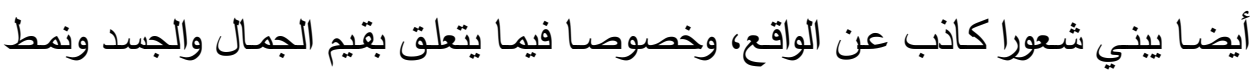
الحياة.

انطلاقا مـن أن التلفزيون لا يعكس مـا يحدث في العـالم الخـارجي، ولكنـه يقدم عـالم

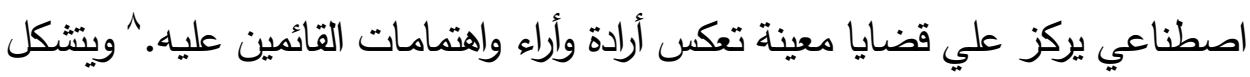
هذا العالم الاصطناعي من خلاع ما يلي:

${ }^{1}$ - Reber,Bryan.Yahmim,Change" Assessing Cultivation Theory and Public Health Model For Crime Reporting, New Paper Research Journal,Vol,21, 2001,P:P99-112. ${ }^{2}$ Omer,Ozeri. "Cultivation Theory and Hegemony: A research From Turkey On Cultivation Role Of Television", The Journal Of Informatol44,Vol,3,2011,P:188.

3 - Running, Head ."Cultivation Theory: Growth Or Phenomenon?: Cultivation

Theory since its Inception ", Sharany alakshmi Sudhakar, Word Press, P:4.

4 - Josefine, Bengtsson." The Power Of The Ideal Man: Exploring The Effects Of

Using Him In Media", Springer, 2012,P:19.

5- Shinichi,Saito "Television and The Cultivation Of G ender- Role Attitude In Japan :Dose Television Contribute To The Maintenance Of The Status Quo? ,Journal Of Communcation, Vol,57,2007,P:521.

6 - George, Gerbner. Et all." Living With Television: The Dynamic Of The Cultivation Process", in "Perspective on Media Effects",Jennings,Bryant. Dolfzillmann,Hillsdale( Edit), Journal Of Advertisting,Vol,16,Issue,3,1987,P:21.

7 - Sarah, Tayer." Instagram: What Makes You Post?", Pepperdine Journal Of Communication Research, Vol,4, Issue,14,2016,P:31.

8- حسن عماد المكاوي، ليلي حسين السيد، الاتصال ونظرياته المعاصرة، الدار المصرية اللبنانية،

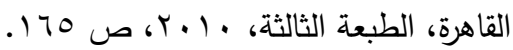


1- أن مؤسســات الاتصـال الجمـاهيري مملوكـة لنخب اجتماعيـة وثقافيـة واقتصـالية ذات

\section{أيدلوجية معينة.}

r- الرسائل الإعلامية التي تبث تميل إلي أن تتقق مع احتياجات الناس ورغباتهم.

ب- أن الجمهور عادة مـا يشاركون في عملية اجتماعيـة يستمعون فيها إلي الرسـائل

ويستخدونها.

ع- أن الجمهور عادة ما ينسجم ويتكيف مع ما يبث ويجعله جزء من ثقافته.'

وهو مـا يجعل خطر التلفزيون ليس في قدرته علي تثكيل وجهة نظر معينة حول

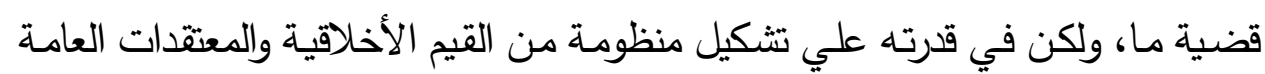

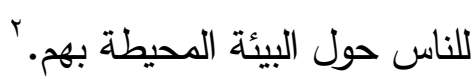
ويرجع ذلك كونه يتميز بالاتي:

أ- أن التلفزيون يخترق حياة الناس بلا إذن. ب- يمكن الوصول والتعامل معه دون أي

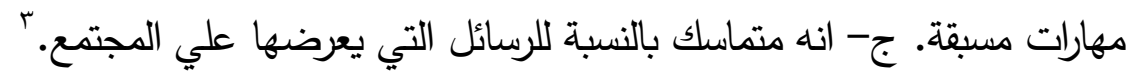
وتتمثل العلاقة بين التلفزيون وعملية الغرس التقافي في الأتي:

1- التلفزيون وسيلة مميزة عن وسائل الأعلام الاخري، نظرا لما يتمتع به من قوة جذب كبيرة تجعله بيئة خصبة للتعلم.

r- رسائل التلفزيون تثكل نظام متجانس مع التيار السائد في ثقافتنا. r- مضمون الرسائل التلفزيونية يقدم مفاتيح الغرس الثقافي.

1 - James, Shanahan. Michael, Morgan." Television and Its Viewers: Cultivation Theory and Research", OpCit,P:P15-18.

2 - Eman, Mosharafa." All You Need To Know About The Cultivation Theory", Global Journal Of Human Social Science: Arts and Humanities-

Psychology,Vol,15,Issue.8,2015,P:23.

3 - Katherine, Miller." Communication Theories: Perspectives Processes and

Contexts", USA: McGraw- Hill INC,2002,P:270. 
ع- تحليل الغرس يركز علي إسهام التلفزيون في صياغة أفكار الجمهور.

0- تزيد المستحدثات التكنولوجية من وصول الرسائل إلي الجمهور.' وفي نهاية عرضـنا عن نظريـة الغرس الثقافي يمكن الإثـارة إلي أهـ القضـايا النظريـة التي ترتكز عليها هذه النظرية وهي:

1- تدرس نظريـة الغرس الثقافي تأثيرات التلفزيون علي المدى الطويل، حيث توصل الباحثون إلي أن تأثيراته تراكمية وان مشاهدته المستمرة يمكن أن تغرس إطارا فكريا لدي المشاهدين يستخدمونه في تقسير الحقائق والأحداث اليومية. r- تتعدي نظرية الغرس التقافي المستوي الفردي للتأثير لتشمل ما تقوم به من تشكيل

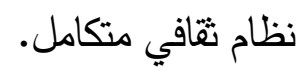

r- تشكل المضامين التي يقدمها التلفزيون وجهة نظر تختلف عن الخبرة الثخصية. ع- تعاملت نظرية الغرس مع مصطلح الغرس بدلا من التأثير مما يؤكد أن هذه العملية

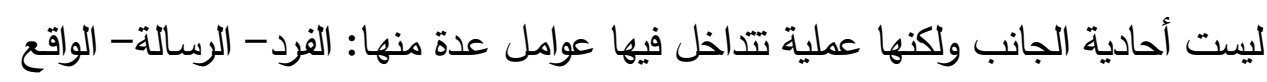
الاجتماعي نفسه.

0- أكدت نظرية الغرس أن مصطلح الغرس ينتج عن المشاهدة العفوية غير الانتقائية.

\section{الإطار الإنمُجي الددراسة:}

'- ميرفت الطرابيثي، عبد العزيز السيد، نظريات الاتصال، دار النهضة العربية، القاهرة، ج × . Y، ص

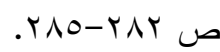

ז- أماني السيد فهمي، الاتجاهات الحديثة لنظرية التأثير في الراديو وإلتلفزيون، المجلة العلمية لبحوث الإعلام،

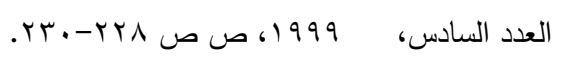


الهدف الرئيسي: التعرف علي دور الإعلانات التلفزيونية في نثر الخرافات الطبية. وينقسم إلي مجموعة من الأهداف الفرعية: 1- التعرف علي الآليات الفنية التي يلجأ إليها القائمين علي الإعلانات التلفزيونية في نثر الخرافات الطبية (من حيث الثكل والمضمون). r- التعرف علي نوعية المنتجات الطبية الخرافية التي تقدم عبر هذه الإعلانات، والفئة المستهفة منها. r- التعرف علي هوية القنوات التلفزيونية التي تبث الإعلانات المروجة لهذه الخرافات الطبية. ـ - التعرف علي مدي استجابة المشاهدين لما يقدم عبر هذه الإعلانات من منتجات طبية خرافية. وسعت الدراسة لتحقيق أهدافها من خلال حزمة من التساؤلات، التي تضمنت مجموعة

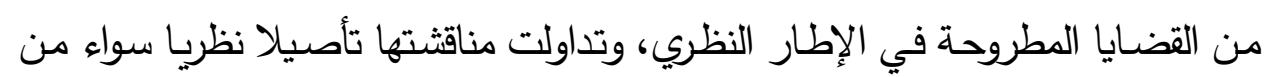
خلا الدراسات السابقة أو الدفاهيم والاقتراب النظري للدراسة. وقد حدن الطيار الدراسة تساؤلا رئيسيا يتبعه مجموعة من التساؤلات الفرعية.

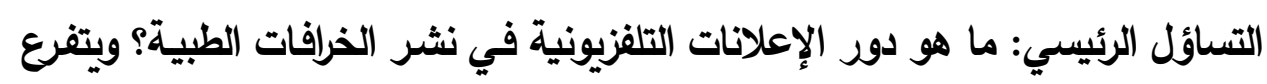
من هذا التساؤل عدد من التساؤلات الفرعية:

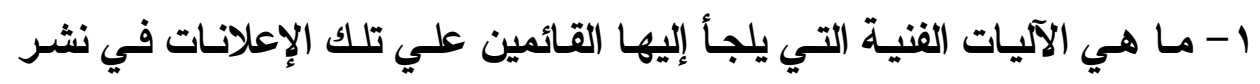
الخرافات الطبية من حيث الثكل والمضمون ؟ ويتفرع منه عدد من التساؤلات الفرعية منها: ا- ما هي سمات المادة الإعلانية الناشرة للخرافة الطبية؟

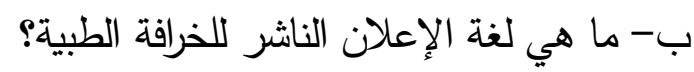

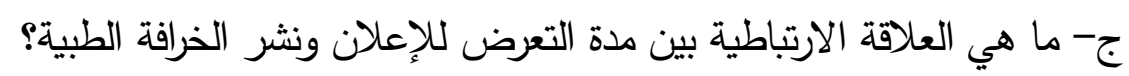

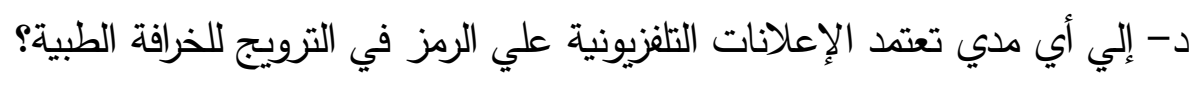


هـ- ما هي نوعية الثخصيات الظاهرة في الإعلان، وأهم سماتها، ودور هذه السمات في الترويج للخرافات الطبية؟ ץ- ما هي نوعية المنتجات الطبية الخرافية التي تقدم عبر هذه الإعلانـات، وما هي الفئة المستهدفة منها؟

ץ- ما هي هوية القنوات التلفزيونية التي تبث الإعلانات المروجة للخرافات الطبية؟

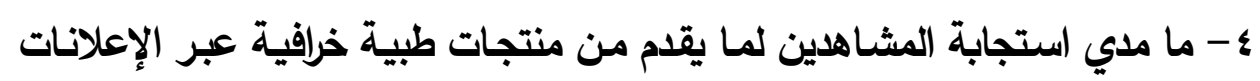
التلفزيونية؟ ويتفرع منه عدد من التساؤلات الفرعية منها: أ- إلي أي مدي تلعب حاجة الأفراد للتمتع بحالة من الكمال الجسدي دوراً في استخدام تلك المنتجات الطبية الخرافية التي تقدم عبر الإعلانات التلفزيونية؟ لإبه ب- إلي أي مدي تلعب حاجة الأفراد للتمتع بحياة صحية أفضل دوراً في استخدام تلك الإعل المنتجات الطبية الخرافية التي تقدم عبر الإعلانات التلفزيونية؟ ج- إلي أي مدي تلعب حاجة الأفراد للتمتع بحالة جنسية مثالية دوراً في استخدام تلك الإكلان المنتجات الطبية الخرافية التي تقدم عبر الإعلانات التلفزيونية؟

\section{الإجمراكات المنهمية اللدراسة:}

اعتمد الباحث في تحليل وتفسير إثـالية الدراسـة الراهنـة علي عدة خطوات لمحاولـة تحقيق أهداف دراسته. أولا استخدم الباحث منهج تحليل المضمون لعدد من الإعلانات

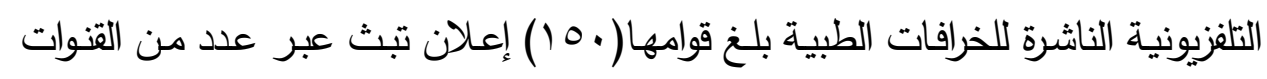

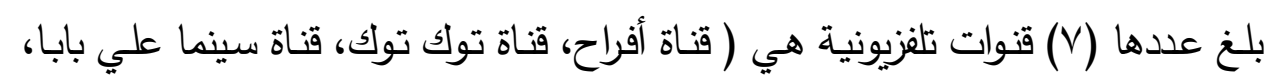
قناة سينما تيوب، قناة جي دراما، قناة شعبيات، قناة تتح). واتبع الباحث الخطوات التالية في تحليل مضمون هذه الإعلانات: أولا: اختيار مادة التحليل:واشتمل علي تحليل محتوي الإعلانات التلفزيونية التي تروج للخرافات الطبية عبر V قنوات تلفزيونية بإجمالي ، 10 إعلان تلفزيوني. 
ثانيا: عينة مادة التحليل:واشتملت علي المساحة الزمنية الذي يستغرقه كل إعلان من

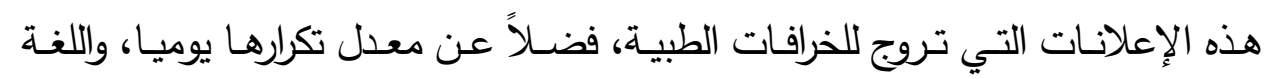
المستخدمة في الترويج لمثل تلك الخرافات. ثالثا: وحدات تحليل المضمون وتثمل: 1- وحدة الكلمة: حيث تم تحليل مجموعة الرموز التي تعتمد عليها تلك الإعلانات في الترويج للمنتجات ذات الطبيعة الطبية الخرافية. ץ- وحدة المضمون: حيث تم تحليل الأفكار التي اعتمدت عليها الإعلانات في الترويج للمنتجات ذات الطبيعة الطبية الخرافية، من حيث هل هي أفكار عاطفية تخاطب قضايا ملحـة لدي المشـاهدين (مثل قضـايا الأمومـة، الأبـوة، الصـحة، الجمـال) أم إنها أفكـار تخويفية تعتمد في الترويج للمنتج علي عنصري الندرة والمحدودية، آم إنها أفكار عقلية

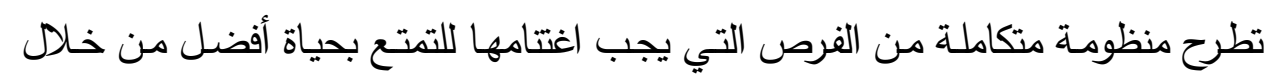
استخدام المنتج المعلن عنه.

\section{رابعا:فئات تحليل المضمون:}

وهنا حاول الباحث أن يجيب عن سؤال ماذا قيل داخل الإعلان؟ وفقا للعناصر التالية:

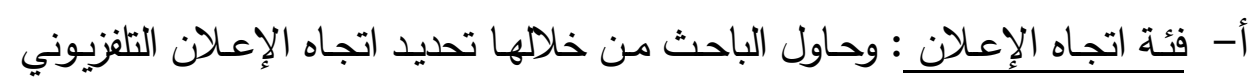
المروج للمنتجات الطبية الخرافية، من حيث هل يساعد علي الكف عن سلوكيات معينة، آم يحرض علي سلوك ما، آم يساعد علي تثبيت وتعزيز نمط محدد من السلوكيات.

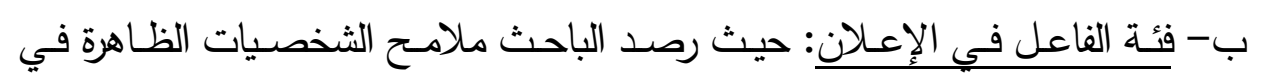
الإعـلان، مـن حيث السـن والجنس والمهنـة وبعض الخصـائص الاخري، مثل توافر الصحة والجمال في شخصية المعلن. ج- فئة موضـوع الإعـلان: حيث رصد الباحث مـا يقدم من منتجات تروج للخرافـات الطبية مثل الأدوية- الأجهزة الطبية- المستحضرات- الأعشاب.

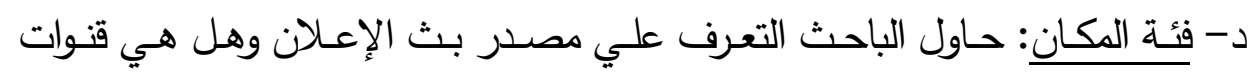
تلفزيونية حكومية آم خاصة آم الاثثين معا. 
هـ - فئة القيم التي يبثها الإعلان: وهل هي قيم جمالية- جنسية- صحية.

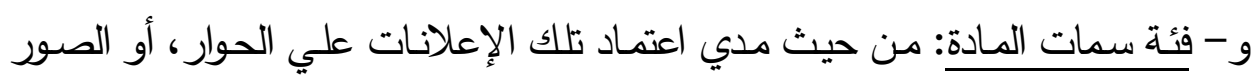

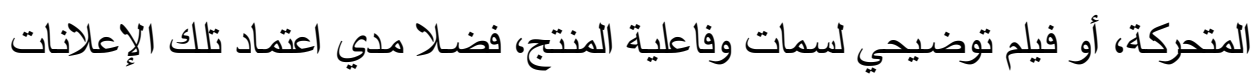

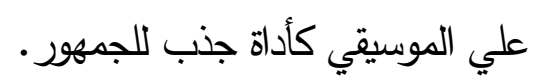

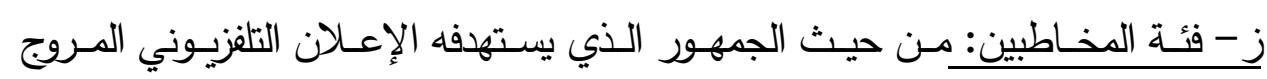
للخرافات الطبية من حيث كونهم أطفال - شباب- كبار السن - المتروجين.

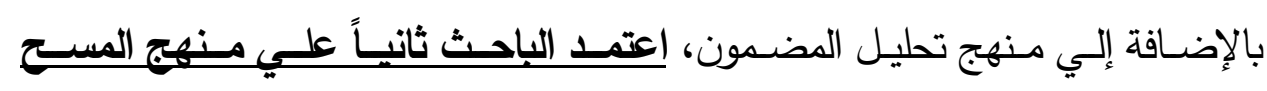

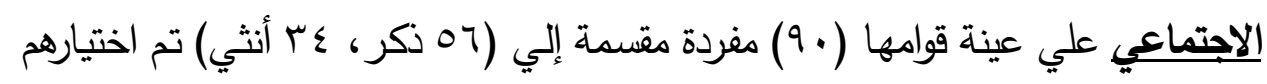

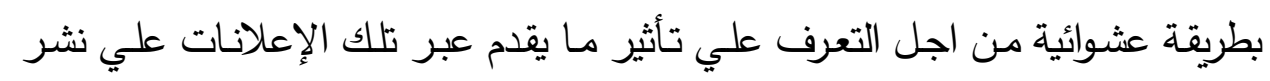

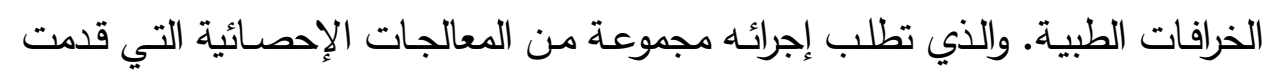

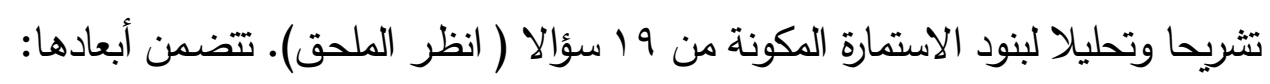

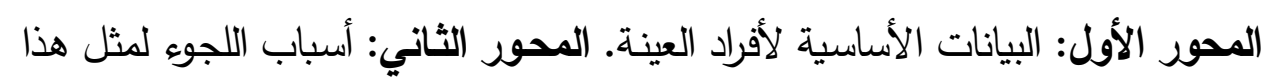

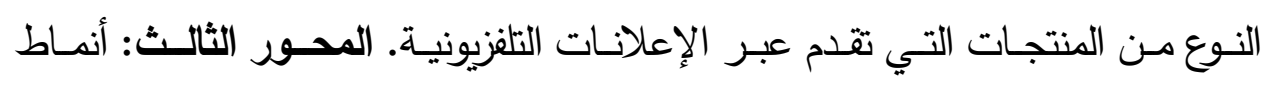

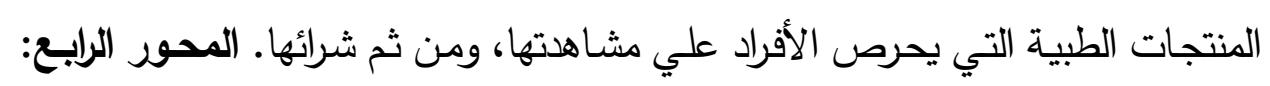

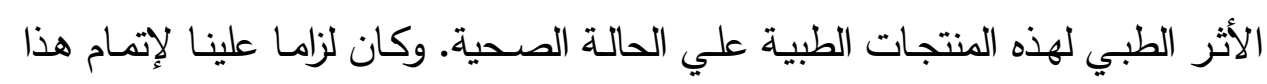

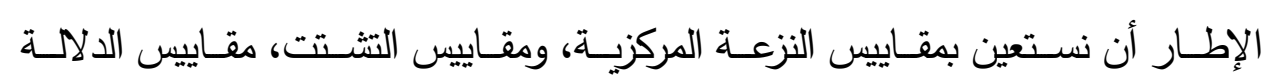
الإحصائية، وقد تتاوبت تلك العمليات الإحصائية علي بنود الاستمارة من خلال مفرداتها

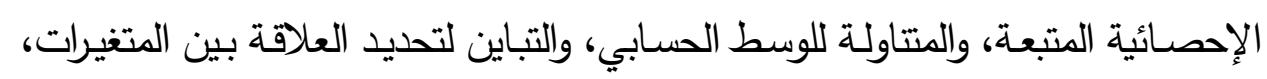
إلي جانب استخدام مقياس (كآT) و اختبار (T) للمقارنة بين الذكور / والإناث.

\section{أداة الدراسة:}


اعتمد الباحث في دراسته علي أداتين: أولا "استمارة تحليل المضمون" لتحليل مضمون الاعلانـات التي تروج للمنتجات الطبية الخرافية والتي تبث علي التئي السبع قنوات محل الدراسة الراهنة. كما اعتمد الباحث ثانيا علي "أداة الاستيان" لرصد استجابات الأفراد نحو ما يقدم عبر الإن

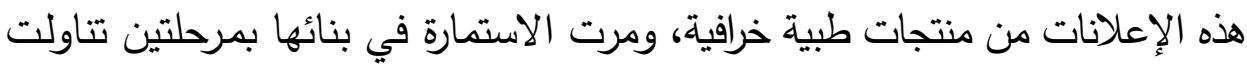

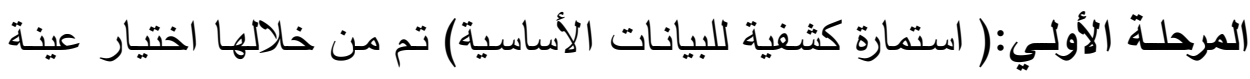

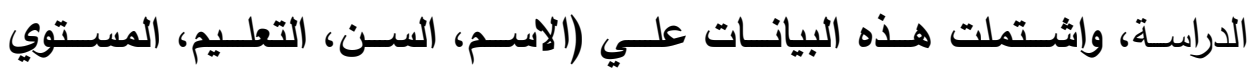

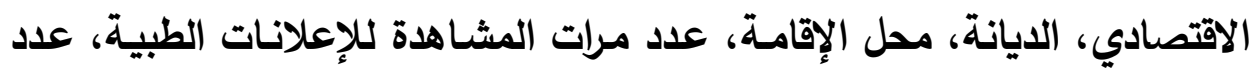

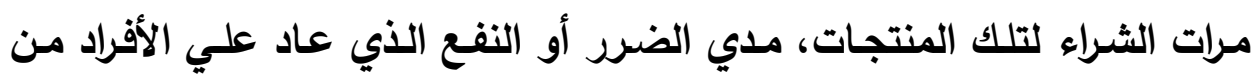

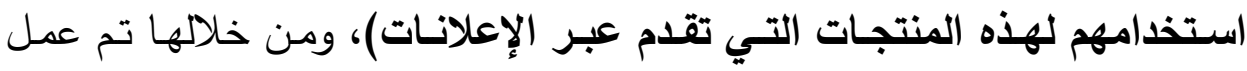

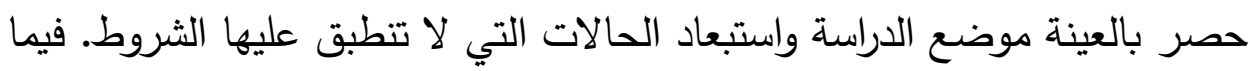

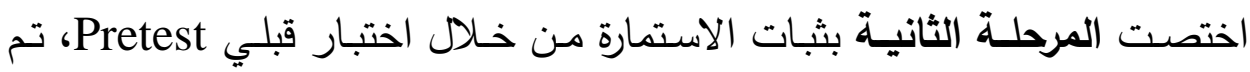

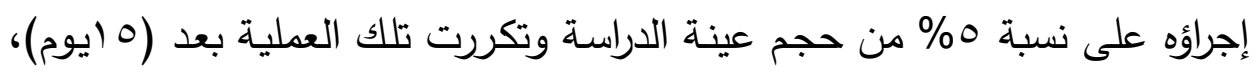

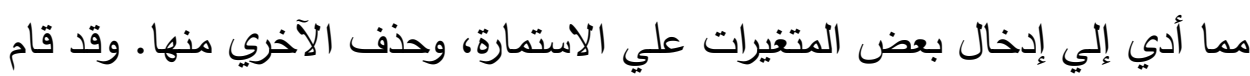

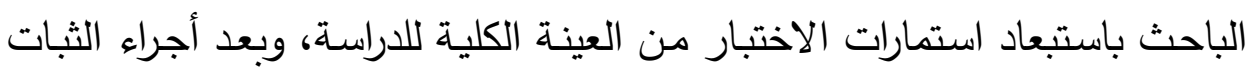

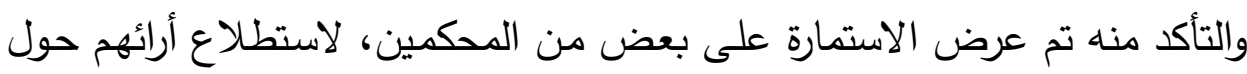
المطروح بها من قضايا، وتم موافقتهم عليها.

\section{مينة الدراسة:}

واختار البامث في الدراسة الراهنة عينتين ووضسع همبموعة هـن المعايير

الموضوعية الخاصة بافتيار كل عينة:

أولا: أسباب تقعلق بعينة الإعلانات:

1- حرص الباحث علي اختيار الإعلانات الطبية ذات المعدل التكراري المرتفع) أي التي تتميز بالكثافة الإعلانية). 
ץ- حرص الباحث علي اختيار الإعلانات التلفزيونية التي تروج لخرافات طبية ذات مضامين مختلفة. ז- حرص الباحث علـي اختيار الإعلانـات التي تخاطب شـرائح متتوعـة مـن - الجمهور

\section{ثانيا: أسباب تتعلق بالعينة البشرية :}

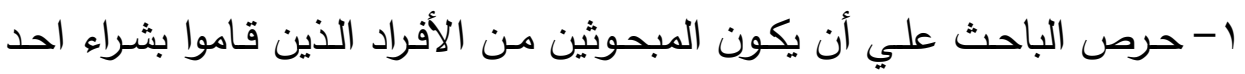

المنتجات الطبية التي تقدم عبر الإعلانات التلفزيونية.

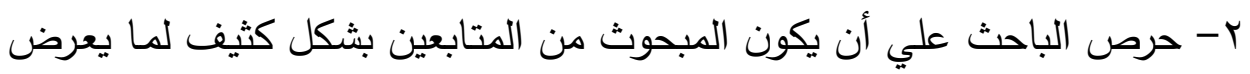
من منتجات طبية عبر الإعلانات التلفزيونية.

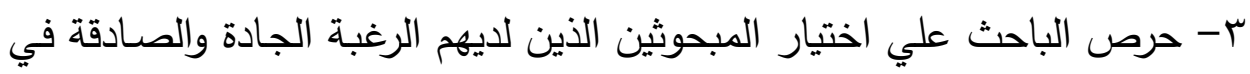
المشاركة حتى يدلون بإجابات صادقة وبعيدة عن المغالطة.

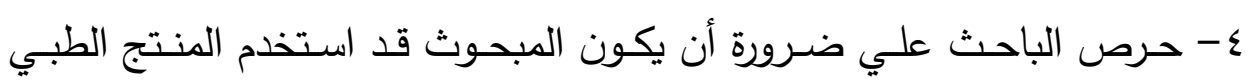
المعلن عنه، واكتثف الأثر الطبي الناتج عن استخدامه.

\section{خمانص العينة: 1- خصائص العينة الإملانية:}

تكونت العينة الإعلانية من عدد من الإعلانات بلخ قوامها ـ 10 إعلان تم اختيارها بثكل عددي بناءا علي اختصاصها في نشر الخرافات الطبية، وتتوعت تلك الإعلانات

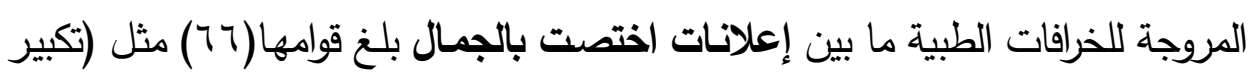

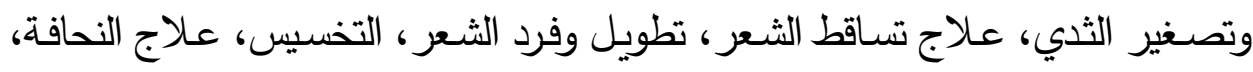

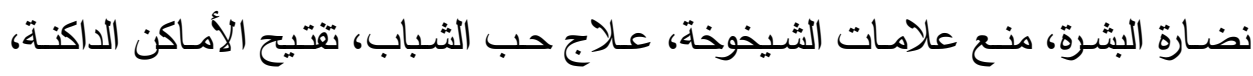

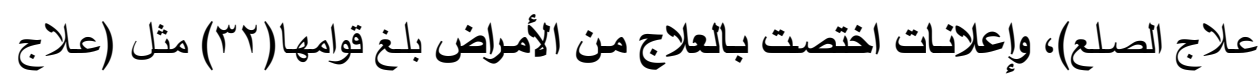

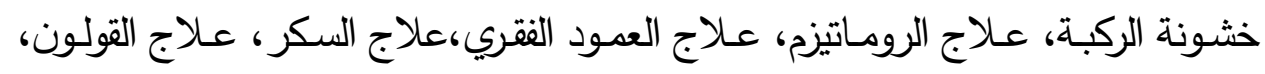

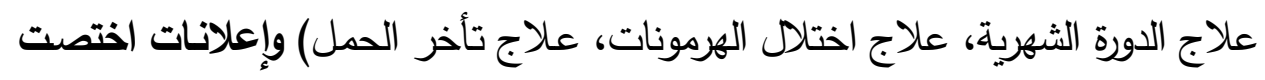




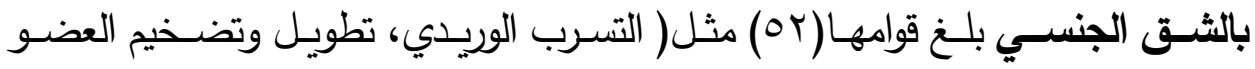
الذكري، علاج ضعف الانتصاب، علاج سرعة القذف، منتجات الإثارة الجنسية). r- خمائم العينة البشئية. تكونت العينـة من و مفردة( 07 ذكر +ع أنثي) تم اختيارهم بطريقة عشوائية. وتم اختيارهم بنسبة بلغت r \%\% للذكور مقابل ^ץ\% للإناث. واختص القطاع الريفي منها

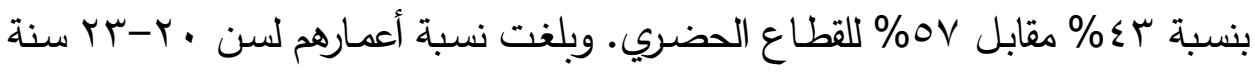

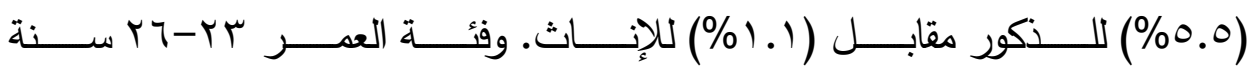

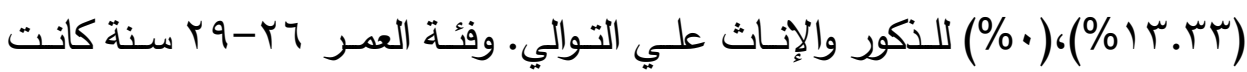

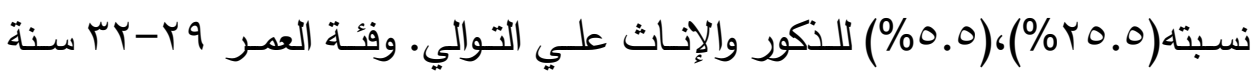

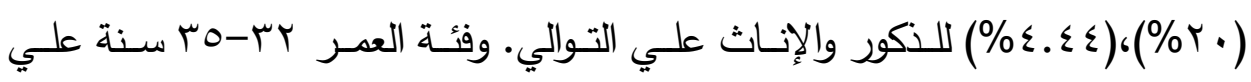

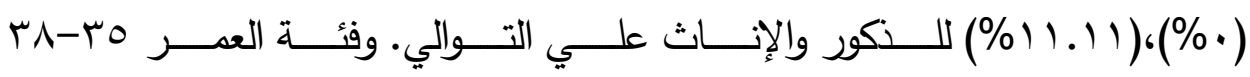

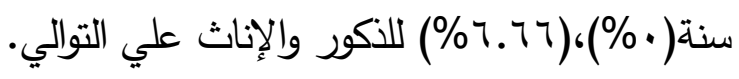

\section{أَ- الديانة:}

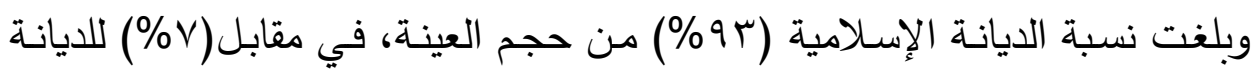
المسيحية. وتثير تلك النسب إلي أن الدين لم يعد يشكل أي عائق في قبول الأفراد لتلك الخرافات الطبية التي تبث عبر شاشات التلفزيون. بل يري الباحث أنهم نظروا

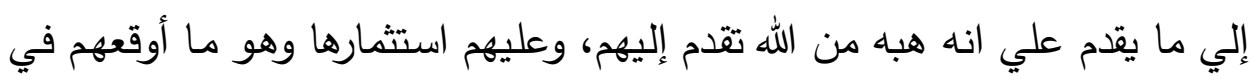
فخ الخرافة.

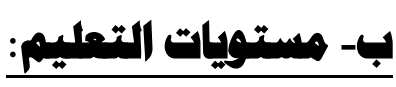

مستويات التعليم لأفراد العينـة أوضحت ارتفاع المستوي التعليمي لكل من الذكور

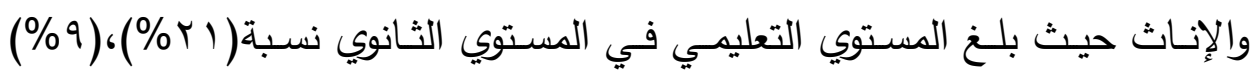
للذكور والإنـاث علي التوالي، في حين بلـخ المستوي الجامعي نسبة ( بr\%)،

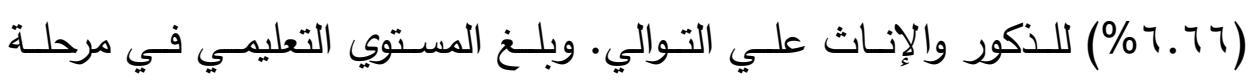




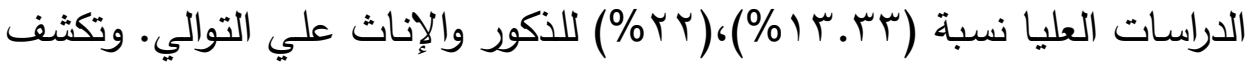
تلك النسـب عـن مـدي التــاقض بـين ارتفـاع المستوي التعليمي والوقوع في فـخ الخرافة، والذي يري الباحث انهه قد يرجع إلي سعي أفراد العينـة الحثيث نحو رفع

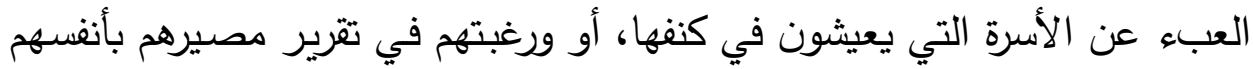
بعيدا عن النموذج الطبي التقليدي الذي يضعه الأطباء.

\section{ج- كثانة المشاهدة ومالاقتمها بنسب الثشراك:}

كثـفتت نتـائج الدراســة عـن احـتلال متغيـر مشــاهدة الإعــلان مــرة واحـــة

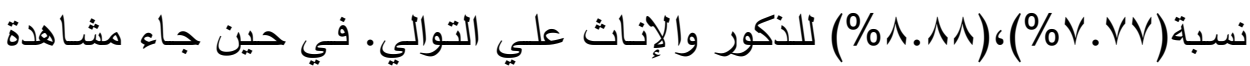
الإعلانات مرتين يومياً نسبة(؟ ؟ ـ ( \%)،؛( • \%) للذكور والإناث علي التوالي. في حين جاء مشاهدة الإعلانات ثلاث مرات يوميا نسبة(0.0 \% \%)،(ب ( \%) للذكور

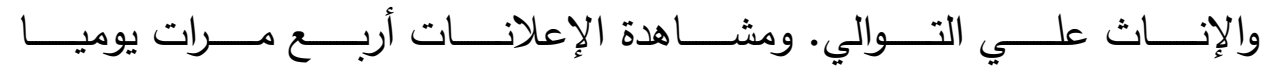
نسبة(؟ ــ \%)،( • (\%) للذكور والإنـاث علي التوالي.وأخيرا مشـاهدة الإعلانـات خمس مرات فأكثر نسبة( • (\%)،(7 7. \% \%) للذكور والإناث علي التوالي. وتكثـف تلك النسـب عـن حجم الأغـراء والتحفيز الذي يمارسـه القـائمين علي الإعلانات في جذب انتباه الأفراد نحو ما يقدم من منتجات. وهو الأمر الذي تظهر نتائجه بصورة جليه في عدد مرات الشراء حيث بلغت نسبة شراء المنتج مرة واحدة

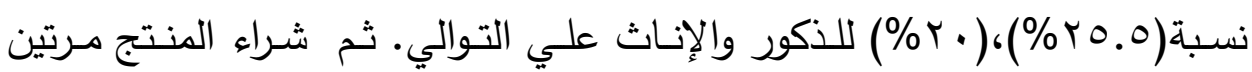

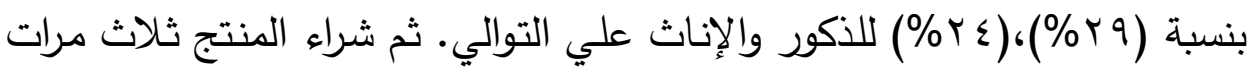

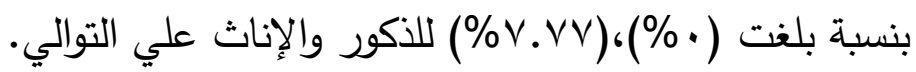

\section{المجال الجغرافي:}

اشتمل المجال الجغرافي لعينة البحث علي مجالين جغرافيين هما: مجال العينة الإعلانية حيث تم تطبيق الدراسة علي V قنوات تلفزيونية هي( قناة أفراح، قناة توك توك، قناة سينما علي بابا، قناة سينما تيوب، قناة جي دراما، قناة تتح، قناة شعبيات)، وتم 
منها استخراج الإعلانات التلفزيونية ذات الصبغة الطبية الخرافية والمحملة باتجاهات مختلفة ما بين علاجية وجنسية وجمالية. ومجال العينة البشرية حيث تم إجراء الدراسة في مركز ابشواي باعتباره يمثل القطاع الريفي، ومدينة الفيوم باعتبارها تمثل القطاع الحضري.

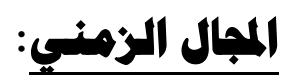
استغرقت فترة المتابعة لما يعرض من اعلانات تلفزيونية تروج للخرافات الطبية علي

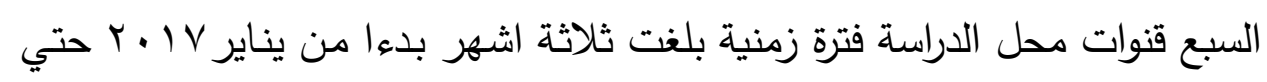

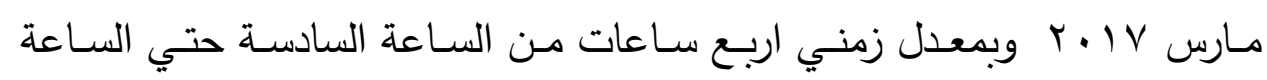

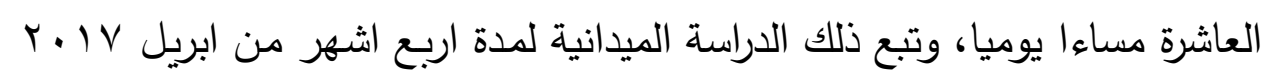

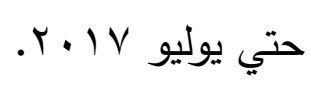

\section{نتائه الدراسة:}

نستعرض فيما يلي نتائج الدراسة مشتملة علي تحليل مضمون الإعلانات التلفزيونية

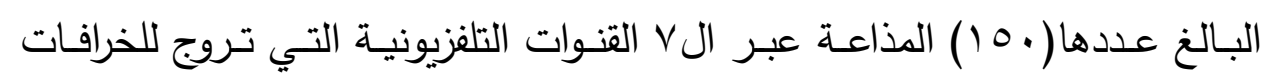
الطبية، ثم الانتقال لعرض نتائج المسح الاجتماعي علي عينة الدراسة. المحور الأول: الآليـات الفنيـة التي يلجـأ إليهـا القـائمين علـي تلك الإعلانـات التلفزيونية في نشر الخرافات الطبية

جدول رقم (1)

يوضح سمات المادة الإعلانية الناشرة للخرافة الطبية

\begin{tabular}{|c|c|c|c|c|c|c|c|c|c|c|}
\hline \multicolumn{9}{|c|}{ عدد الإعلانات } & \multirow[b]{2}{*}{ المؤشرا } & \multirow[b]{2}{*}{ المحو } \\
\hline$\%$ & ع المجو & شعبيا & ت & سبند & تينوب & تو & درام & أفرا & & \\
\hline IT.rT & $r$. & $\varepsilon$ & r & 1 & $\wedge$ & 1 & 1 & $r$ & شخصيات & 3 \\
\hline
\end{tabular}




\begin{tabular}{|c|c|c|c|c|c|c|c|c|c|}
\hline$\%$ & & & & & & & & & تتحدث عن \\
\hline$\% \leq \varepsilon$ & 77 & 14 & $r$ & $\varepsilon$ & iv & 9 & Ir & V & توضيحي \\
\hline $\begin{array}{c}\text { IV.r } \\
\%\end{array}$ & rq & $\Lambda$ & - & $r$ & V & $r$ & 0 & 1 & عن منحركة المنتج \\
\hline$\% . .74$ & 1 & - & - & - & 1 & - & & - & شوار بين \\
\hline $\begin{array}{c}Y \leq . T V \\
\%\end{array}$ & $r v$ & V & $r$ & 1 & 11 & V & V & $r$ & توضيحية \\
\hline $1 \ldots$ & 10. & rr & $V$ & $\wedge$ & $\leqslant \varepsilon$ & $r$. & rq & ir & المجموع \\
\hline
\end{tabular}

أوضحت مؤشرات جدول رقم (1) اعتمـاد الإعلانـات التلفزيونية علي آلية الفيديو التوضـيحي في ترويجها للخرافات الطبيـة، حيث جـاءت هذه الآليـة في المرتبـة الأولي بنسبة ؟ ٪\%، وفي المرتبـة الثانية جاءت تقنية الرسوم التوضيحية بتقنية

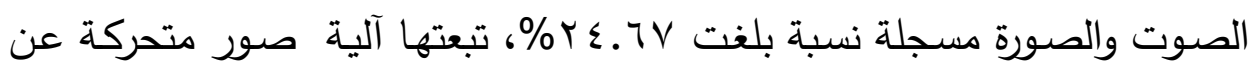

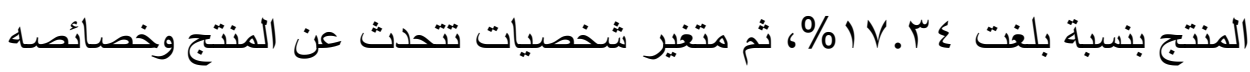
ودوره في الثفاء من الأمراض بنسبة سـ.ب ا \% وأخيرا في المرتبة الخامسة جاءت

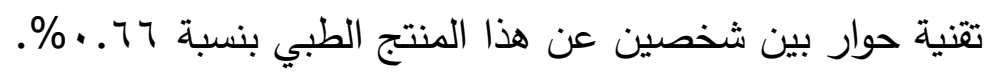


وتؤكد النسب السابقة علي تتوع الميكانزمات التي تعتمد عليها الإعلانات في نشر خرافاتها الطبية، ومن هذه الميكانزمات:

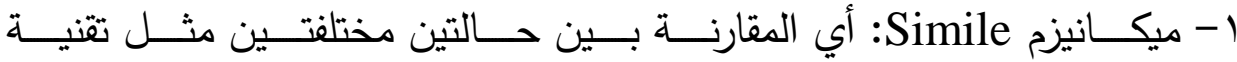
"Befor\&After" حيث يري المستهلك أن النتائج متسقة بشكل كلي مع الواقع وقابلة للتنبؤ. r- ميكانيزم Like: أي إبراز الثبيه للجمهور لتحديد موقعه من هذا الثبياه. r- ميكانيزم As: أي اعتماد الإعلان علي ألفاظ أو كلمات واضحة في ذاتها مثل مئل استخدام ستجعلك مثل الحصان - الأسد - ملكة جمال. ع- ميكانيزم Simple: أي استخدام بعض الرموز أو العلامات الإعلانية. 0- ميكانيزم Data: أي إعطاء بيانات كاملة عن المنتج. 7- ميكانيزم Personification: أي الاعتماد علي التجسيد في الإعلان باعتباره

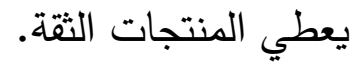
V- ميكانيزم Metaphor: بمعني استخدام الاستعارات في الإعـلان أي استخدام

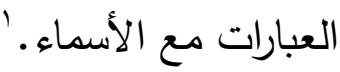
ويرجع الاعتماد علي تلك الميكانزمات إلي اقتناع القائمين علي تلك الإعلانات التلفزيونية المروجة للخرافات الطبية، إلي حاجة المشاهدين إلي نوعين مختلفين من الاستـلال حتى تصل لهم الرسالة كاملة، النـوع الأول: لغوي قائم علي إيضـاح هيكل ومواصفات المنتج الإعلاني، أما النوع الثاني: فهو استدلال عملي بمعني أن

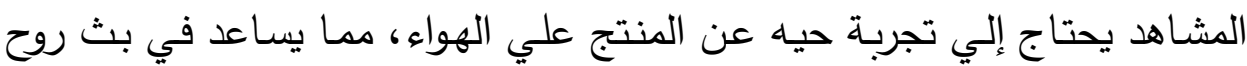

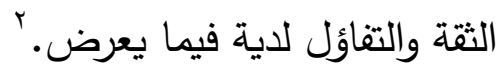

1 - Barnalis, Chetia." Rhetorical Devices in English Advertisement Texts in India: A descriptive Study', International Journal of Social Science and Humanity, Vol,5,No.11,2015,P:P980-981.

2 - Nancy, Ikaria." Mains Discourse of Advertising: Reference of Kiswahili and English Adverts in Kenyan Media", International Journal of Science and Research,Vol,3.Issue.11,2114,P:1564. 
وربمـا يرجـع هذا التـوع انطلاقاً مـن انـه كلهـا تتوعت الآليات التي تعتمد عليها الإعلانـات في الترويج لمنتجاتهـا، كلمـا زادت عدد الحـواس التي يمكن للمتلقي استخدامها في تلقي الفكرة التي تروج لها الإعلانات، وهو مـا يؤدي إلي دعمها وتقويتها وتثبيتها في ذهن المتلقي. ' وكأنتـا أمسام نـوع مـن الحـوار الغير مباشـر بين القـائمين علـي المنتج أو الرسـالة الإعلانية وبين المشاهد، ويتم هذا الحوار وفقا لرؤية كل منهما، فالقائم علي الرسالة

$$
\text { الإعلانية يبدأ حواره بالاتي: }
$$

ا- مرحلة الوصف التفصيلي للمنتج: وهي المرحلة التي تثمل وصف خصائلة خصائص

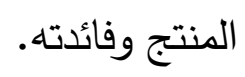

ץ- مرحلـة الإطـار الفني للمنتج: حيث يعتمــ الإعـلان هنـا علي إبـراز العلامـة

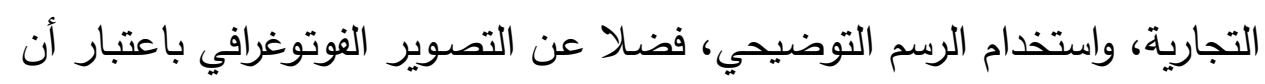
التمثيل البصري يعطي الفرصة لشرح إمكانيات المنتج ومعناه.

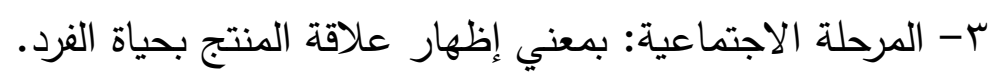

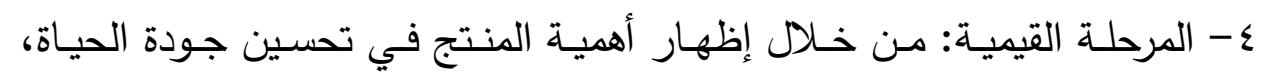

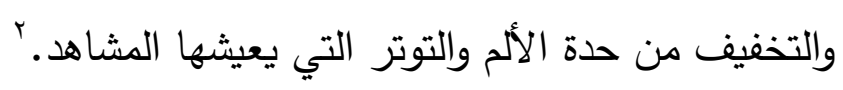

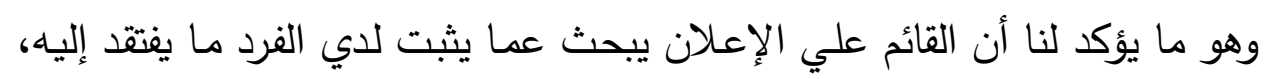

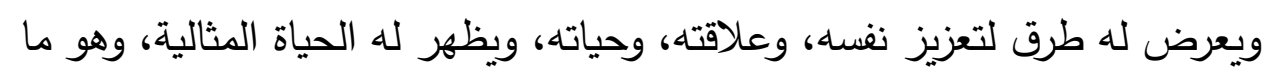
يكشف عن الهدف الرئيس للقائم علي الإعلان وهو تشكيل هوية المشاهد. تلك الهوية التي يطلق عليها "بهوية ما بعد الحداثـة أو الهويـة بالاختيار"، القائمة الإنة علي استحداث معان جديدة بدلا من المعاني التقليدية، مما يسفر عن إيجاد علاقة

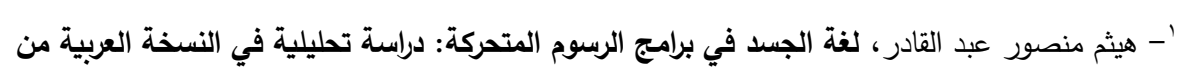

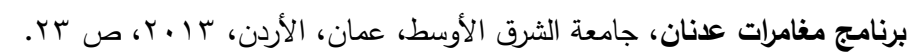
2 - Biook,Behna.Jafar,Zamanian "Gender and The Discourse of Advertising in English and Persian Magazine Advertisements" ,International Journal of Academic Research in Business and Social Science, Vol4, No.11,2014,P:7. 
بين الثقافة التي تبث وتشكيل وجدان المستهلك بما يتوافق مع الملمح الجديد لهذه

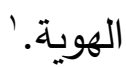

وإذا كان ما سبق يمثل لغة حوار القائمين علي الإعلانات، فان لغة حوار المتلقي

تتم وفقا للخطوات التالية:

1- قراءة الإعلان بصفة عامة( أي تكوين انطباع عام عن المنتج).

r- معرفة ماذا يهدف إليه الإعلان.

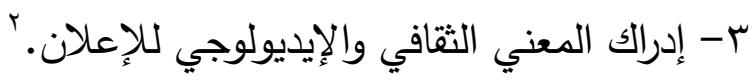

وكأن المتلقي هنا يقوم بنوع من التكيف مع المنتج، من خلال تغيير منظومة أفكاره

ومعتقداته التقليدية.

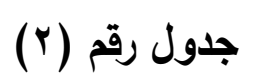

يوضح اللغة التي يقدم بها الإعلان التلفزيوني الناشر للخرافة الطبية

\begin{tabular}{|c|c|c|c|c|c|c|c|c|c|c|}
\hline \multicolumn{9}{|c|}{ عدد الإعلانات } & \multirow[b]{2}{*}{ المؤشرا } & \multirow[b]{2}{*}{ الألوح } \\
\hline$\%$ & ع المجمو & شعبيا & $\tau$ & سبنم & سينم & تو & دراد & أفرا & & \\
\hline 91 & $1 \leqslant V$ & rr & $\mathrm{v}$ & $\mathrm{v}$ & $\leq \varepsilon$ & $r$. & $r \varepsilon$ & Ir & العربية أو & 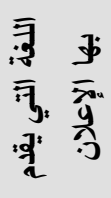 \\
\hline
\end{tabular}

'- احمد مجدي حجازي، علم الاجتماع الأسس والقضايا والمشكلات، القاهرة،99919 19 ص

$.1 \% 7$

2 - Nagwa,Elgazzar. "Reading Culture in Arab Television Advertising: A content Analysis of

Egyptian Advertising", Faculty of Mass Communication, MISR International University Cairo-

Egypt,2014,P:7. 


\begin{tabular}{|c|c|c|c|c|c|c|c|c|c|}
\hline- & - & - & - & - & - & - & - & - & الألغنبية \\
\hline$\% r$ & $\mu$ & - & - & 1 & - & - & r & - & الاثنين \\
\hline $1 \ldots$ & 10. & rr & V & $\wedge$ & $\leq \varepsilon$ & $r$. & Y & $1 \%$ & المجموع \\
\hline
\end{tabular}

وتشير مؤشرات جدول رقم(r) إلي اعتماد الإعلانات التلفزيونية علي اللغة العربية

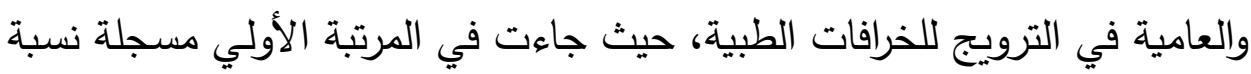

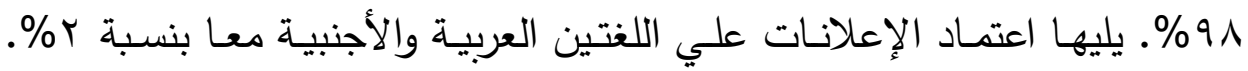
وأخيرا اعتمادها علي اللغة الأجنبية فقط في المرتبة الأخيرة بنسبة • \% وربما يرجع اعتماد القائمين علي الإعلانات علي اللغة العربية والعامية، لما لها من دور بارز في جذب انتباه المشاهدين نحو المنتج، لأنه من المعروف انه لكي يصل الرعل الإعلان إلي المستهلك، لابد أن يتسم بالوضوح والاكتمال والتتظيم، ويقاس الوضوح من خلال خلو الإعلان من العقبات والعوائق التي تحول دون وصوله للمستهلك، واهم هذه العوائق هي البعد عن المصطلحات الغير معروفة والغير مألوفة.' ويرجع تركيز القائمين علي الإعلانات علي اللغة لما لها من دور في تغيير إرادة الجمهور وأرائه ومواقفه، وهو ما يجعل منها ذات طابع موجه وفقا لتعبير "اديموند ليتش".

هذا الطابع نلاحظه في اعتمـاد الإعلانات محل الدراسـة الناشرة للخرافات الطبية علي ثلاث أنماط من الخطابات الموجهة أولها:هي الخطابات المحفزة: وفيها يقوم الإعـلان بتوجيـه النصـيحة للجمهور باستخدام هذا النمط من المنتجـات، ثانيها:

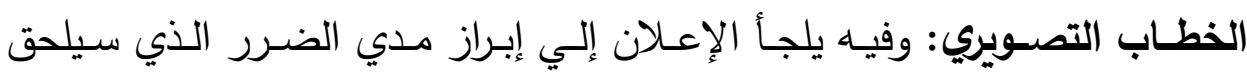

1 - Hosney, M, Eldaly." Towards an Understanding of The Discourse of Advertising: Review of Research with Special Reference to The Egyptian Media", African Neblo, Issue, 3,2011,P:33.

2 - Diplomova, Prace. Jana, Lapsanska." Adverting with The Concentration on The Linguistic Means and The Analysis of Advertising Slogans", Datum obhajoby, Bratislava, 2006, p:26. 
بالثخص في حالة التأخر عن استخدام المنتج، مستعيناً بعبارات تضمن التهويل

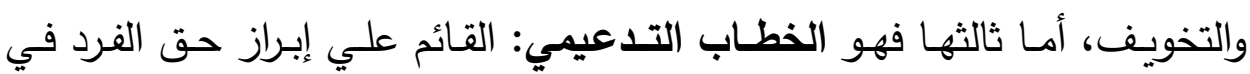
الحصول علي المنتج للعيش بثكل داعم في المجتمع.

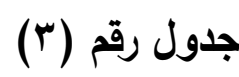

يوضح الفاصل الزمني بين الإعلانات الناشرة للخرافات الطبية

\begin{tabular}{|c|c|c|c|c|c|c|c|c|c|c|}
\hline \multicolumn{9}{|c|}{ عدد الإعلانات } & \multirow[b]{2}{*}{ ت } & \multirow[b]{2}{*}{ الألر } \\
\hline$\%$ & ع الجمو & تعبيا & $\begin{array}{l}\text { ت } \\
\tau\end{array}$ & سيند & سينم & تو تو تو & | دراه & أفرا & & \\
\hline $\begin{array}{c}01 . r T \\
\%\end{array}$ & vv & $r$. & $r$ & $r$ & r & 9 & ir & $\wedge$ & دقيتين & \\
\hline $\begin{array}{c}r . .9 v \\
\%\end{array}$ & $\Leftrightarrow$ & 11 & $r$ & r & 9 & • & v & $r$ & دقائق & 哥 \\
\hline$\% \wedge .7 \vee$ & it & - & - & 1 & $\wedge$ & 1 & r & 1 & دائقي & $\overline{3}$ \\
\hline$\% \wedge .4 \vee$ & it & 1 & r & r & $r$ & 1 & $r$ & 1 & خمسئق & $\frac{73}{30}$ \\
\hline$\% \varphi$ & $r$ & - & - & - & - & 1 & r & - & دقائق & 奇 \\
\hline- & - & - & - & - & - & - & - & - & دقائق & 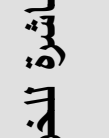 \\
\hline$\% .14$ & 1 & - & - & - & - & 1 & - & - & ثقائق & $\begin{array}{l}\frac{\cdot \vec{G}}{3} \\
\bar{y}\end{array}$ \\
\hline$\% .44$ & 1 & - & - & - & - & 1 & - & - & دقائق & : 3 \\
\hline$\% 1 . r 4$ & $r$ & - & - & - & 1 & 1 & - & - & عشر & \\
\hline
\end{tabular}




\begin{tabular}{|c|c|c|c|c|c|c|c|c|c|}
\hline & & & & & & & & & دقائق \\
\hline $1 \ldots$ & 10. & $r r$ & V & $\wedge$ & $\{\xi$ & r & Y & ir & المجموع \\
\hline
\end{tabular}

تكثف مؤشرات جدول رقم (r) عن كثافة إعلانية غير مسبوقة للإعلانات التي تـروج للخرافـات الطبيـة، حيـث تـراوح الفاصـل الزمني لتكرار نفس الإعـلان مـدة

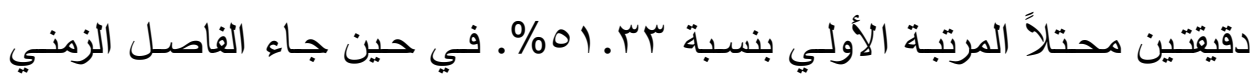

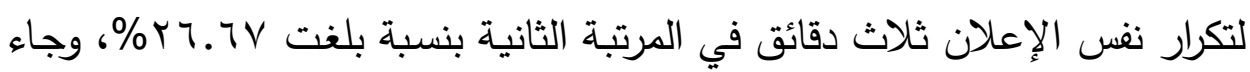

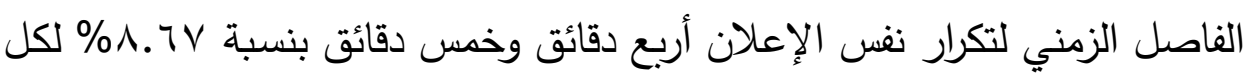
منهما. في حين سجلت متغيرات ست دقائق، وسبع دقائق، وثماني دقائق، وتسع

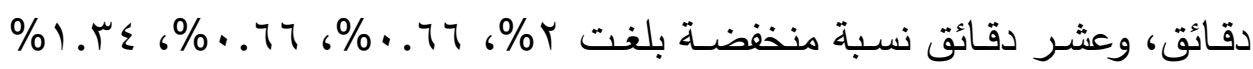

$$
\text { علي التوالي. }
$$

وتكثف تلك النسب عن رغبة القائمين علي الإعلانات الناشرة للخرافات الطبية في زيـادة الجرعـة الإعلانيـة عن نفس المنتج لعدة مرات يوميا بفواصل زمنية قصيرة جدا، مـن اجل تدعيم وتثبيت الرسـالة الإعلانيـة في ذهـن المتلقي، ممـا يـفعهم تدريجيا لقبول المنتج المعلن عند.

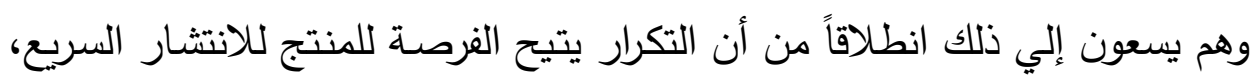
وبالتالي مشاهدته واستخدامه من قبل اكبر قطاع في المجتمع، وهو مـا يتفق مـع

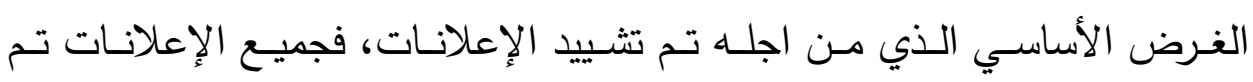
تصميمها لتكون ذات طبيعة تطفلية

\section{جدول رقم (ء)}

يوضح الرموز التي يستخدمها القائمين علي الإعلانات في نشر الخرافات الطبية 


\begin{tabular}{|c|c|c|c|c|c|c|c|c|c|c|}
\hline \multicolumn{9}{|c|}{ عدد الإعلانات } & \multirow[b]{2}{*}{ المؤشرا } & \multirow[b]{2}{*}{ الألور } \\
\hline$\%$ & ألجمو & شعبيا & $\tau$ & سبنم & تيني & تو & دراد & أفرا & & \\
\hline$\% 04$ & $\wedge \varepsilon$ & 17 & $r$ & 0 & rr & 9 & IV & 11 & الموسيقي & \\
\hline $\begin{array}{c}\text { r.TV } \\
\%\end{array}$ & $\Leftrightarrow$. & 9 & $\varepsilon$ & r & Ir & $\wedge$ & $\varepsilon$ & 1 & الصور & \\
\hline $\begin{array}{c}\text { IV.rr } \\
\%\end{array}$ & ri & $v$ & - & 1 & 9 & $r$ & 0 & 1 & اللغة & \\
\hline $1 \cdots$ & 10. & rr & v & $\wedge$ & « & $r$. & צ & IT & المجموع & \\
\hline
\end{tabular}

ويكثف جدول رقم (ع) عن احتلال الموسيقي المرتبة الأولي كأحد الرموز التي اعتمد عليها القائمين علي الإعلانات في الترويج للخرافات الطبية، وجاء ذلك بنسبة

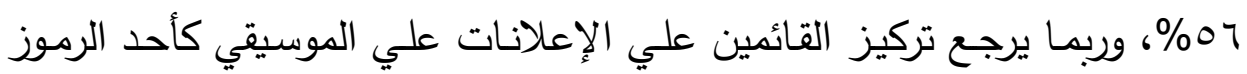
الصسوتية، بسبب أن استخدام الموسيقي يسـاعد علي تأكيد الفعل وإضـفاء المـزاج النغسي لاستقبال المنتج.' وهو ما يتفق مسع ما ذهب إليه "كلاينز" من أن الموسيقي والانفعال يرتبطان معا بطريقة بيولوجية معينة مبرمجة مسبقا في المخ، بحيث انه بمجرد سماع الموسيقي،

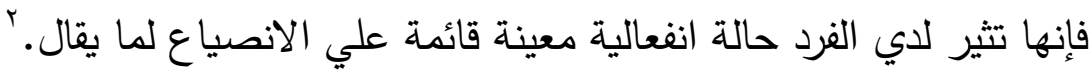
فالصوت يحتفظ بأهمية كبيرة وفقا "لرولان بارث"، حيث يؤدي وظيفتين هامتين " هما: ' - رانيا صادق مدوح، الإعلان التلفزيوني: التصميم والإنتاج، دار أسامة للنشر والتوزيع، عمان، الأردن، r . بr، ص ص

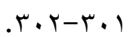
r بل جلين ويسلون، سيكولوجية فنون الأداء، ترجمة: شاكر عبد الحميد، المجلة الوطنية للثقافة والفنون والآداب،

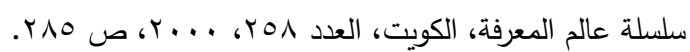

3 - Roland, Barthes." Rethorique de Image", in Communication, Vol,4,1964,P:43. 
ا- الترسيخ: حيث تقوم بتوجيه المشاهد نحو مدلول معين ونوع من المعني، لا تستطيع الصورة أن تبلغه بمفردها. r- وظيفة المناوبة: وتقوم علي إعانة الصورة في إنتاج معني يتكون من مستوي اعلي من مستوي الخطاب. علي الجانب الأخر كثفت النتائج عن احتلال الصور المرتبة الثانية كأحد الرموز التي اعتمد عليها القائمين علي الإعلانات في الترويج للخرافات الطبية، وجاء ذلك

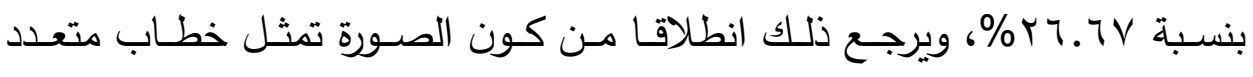
المعاني، حيث تقدم دعما لتجميل ما يعرض، كما إنها تضفي قدرا من المصداقية

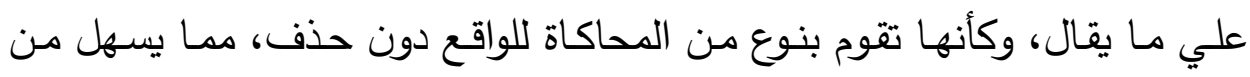
عملية الإقناع وبالتالي قبول المنتج.'

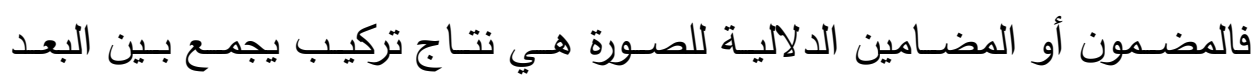
الايقوني( التمثيل البصري الذي يعتمد علي المحاكاة فينقل المشـاهد إلي الصـورة

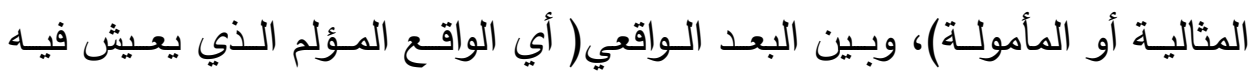

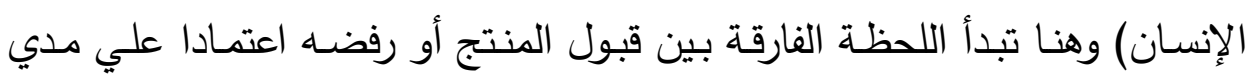
قدرته علي إقناع المشاهد بإمكانية نقل الواقع الايقوني في حياته. خلاصة الأمر أن الاعتماد علي الرموز من قبل القائمين علي الإعلانات يتفق مع الإنى ما ذهب إليه "سكوت" من أن الثعارات أو الرموز تخلق لدي الجمهور دوافع نفسية الإني

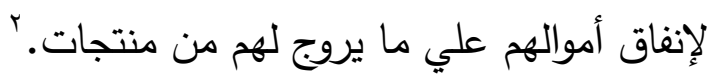

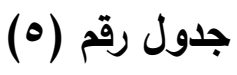

يوضـح نمط الثخصيات التي تعتمد عليها الإعلانـات التلفزيونية في الترويج للخرافات الطبية

'- إبراهيم محمد سليمان، مدخل إلي مفهوم سيمائية الصورة، المجلة الجامعة، العدد السادس عشر ، المجلد الثاني، ـ ا بr، ص

.171

2 - Scptt, Walter,D." The Psychology of Advertising: A simple Exposition of The Principle of Psychology in Their Relation to Successful Advertising", Boston, Small, Toronto, 1910,P:P 8485. 


\begin{tabular}{|c|c|c|c|c|c|c|c|c|c|c|}
\hline \multicolumn{9}{|c|}{ عدد الإعلانات } & \multirow[b]{2}{*}{ المؤشرات } & \multirow[b]{2}{*}{ الأححور } \\
\hline$\%$ & المجموع & شعبيات & تتح & سينما & تيوب & توك & جي & أفراح & & \\
\hline$\% r$ & $r$ & 1 & - & 1 & - & - & 1 & - & شخصيات & \multirow{4}{*}{ 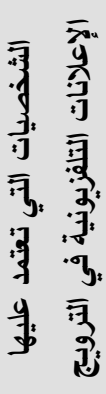 } \\
\hline$\% \wedge \wedge$ & ITr & rA & $v$ & $v$ & $r q$ & 11 & rI & ir & شخصيات غير & \\
\hline$\% 1$. & 10 & $r$ & - & - & 0 & r & $\varepsilon$ & 1 & الأطباء & \\
\hline $1 \ldots$ & 10. & rr & $v$ & $\wedge$ & \& & r. & YY & ir & المجموع & \\
\hline
\end{tabular}

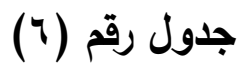

يوضح سمات الثخصيات التي تعتمد عليها الإعلانات في الترويج للخرافات

\begin{tabular}{|c|c|c|c|c|c|c|c|c|c|c|}
\hline \multicolumn{9}{|c|}{ عدد الإعلانات } & \multirow[b]{2}{*}{ المؤشرات } & \multirow[b]{2}{*}{ الأول } \\
\hline$\%$ & المجموع & شعبيات & تتح & سينما & تيوب & توك & جي & أفراح & & \\
\hline$\% \leq 0 . \mu \leq$ & $7 \wedge$ & iv & 1 & r & ir & 9 & Yl & 0 & فئة عمرية & \multirow{4}{*}{ 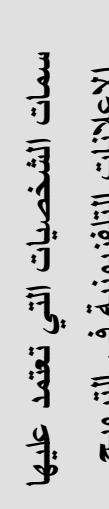 } \\
\hline \% \% & $r \cdot$ & v & $r$ & r & 0 & - & $r$ & - & بالجمال & \\
\hline \% & gr & $\wedge$ & $r$ & $\varepsilon$ & Y & 11 & r & $\wedge$ & بالنثاط & \\
\hline $1 \ldots$ & 10. & rr & $v$ & $\Lambda$ & $\varepsilon \varepsilon$ & $r$. & Y & ir & المجموع & \\
\hline
\end{tabular}

كثفت نتائج جدول رقم(0) عن اعتماد الإعلانات التلفزيونية في الترويج للخرافات

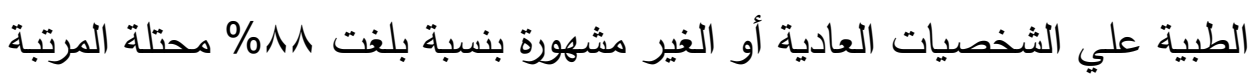
الأولي، في حين جـاء اعتمـاد الإعلانـات التلفزيونيـة علي الأطباء في الترويج 
لمنتجاتهم ذات الطبيعة الطبية الخرافية في المرتبة الثانية بنسبة بلغت • (1\%، وجاء الاعتماد علي الثخصيات المشهورة في المرتبة الثالثة والأخيرة بنسبة بـ\%ة. وجاء جدول رقم(؟) ليوضح لنا سمات تلك الثخصيات حيث جاء متغير كون الشخصية التي تعلن عن المنتجات ذات الطبيعة الطبية الخرافية تنتمي إلي الفئة الثابة بنسبة

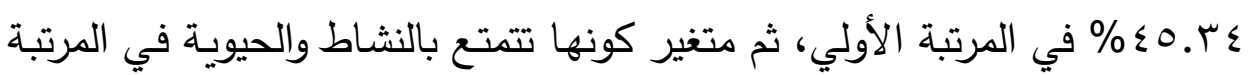
الثانية بنسبة سب. (؟ \%)، وأخيرا كونها تتمتع بالجمال في المرتبة الأخيرة بنسبة r.r.

وبالنظر لتلك النتائج نجد أن اعتماد الإعلانات علي الثخصيات العادية، يساعد علي تحقيق التطابق بين الجمهور المستهدف للإعـلان والرسالة الإعلانية، حيث يشعر المعلن إليه بان ما يقدم لـه عبر الإعلان يتطابق ويتفق مع محيطه الواقعي

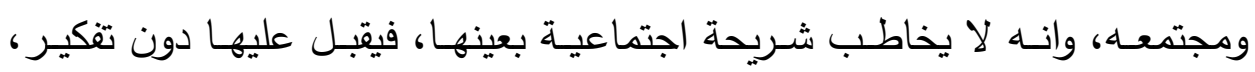

ويطلق علي هذا التطابق "محتوي الرؤيـة". ومن هنا يمكن القول بأنـه كلما كانت الدرجة أو الطريقة التي يعبر بها الإعلان

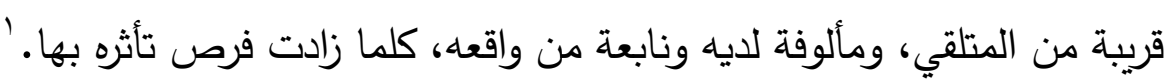
كما أن اعتماد الإعلانات علي الفئات الثابة في الترويج للمنتج الخرافي، يضمن له له

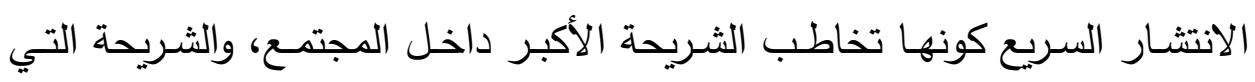
لديها الرغبة في خوض غمار التجربة مع كل ما هو جديد، لمجرد انه مختلف، أملاً في الثعور بالنرجسية البيولوجية المفقودة لديهم. كما أن تمتع تلك الثخصيات المعلنة عن المنتج بالحيوية والنشـاط، يعطي أمساً للمشاهد في محاكاة النموذج المعلن عنه، وفي إمكانية علاج الاختلالات البيولوجية التي يعاني منها، ومن ثم الانتقال إلي حالة من التوافق الفيزيقي المرغوب، كما

'- مني سعيد الحديدي، سلوى إمام، الإعلان في التلفزيون المصري، مركز الجامعة، القاهرة، بV7 ا،

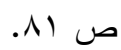


تعطي رسالة مصداقية وثقة للمتلقي مفادها، أن ما يعرض هو العلاج والتشخيص السليم للمرض، وهو ما يعطي الإعلان صفة الشرعية.

المحور الثـاني: نوعيـة المنتجـات الطبيـة الخرافيـة التي تقدم عبر الإعلانـات التلفزيونية

$$
\text { جدول رقم (v) }
$$

يوضح المنتجات الطبية الخرافية ذات الثق الجمالي التي تروج لها الإعلانات

التلفزيونية

\begin{tabular}{|c|c|c|c|c|c|c|c|}
\hline \multicolumn{6}{|c|}{ الإعلانات } & \multirow[b]{2}{*}{ المؤشرات } & \multirow{2}{*}{ الثدور } \\
\hline$\%$ & المجموع & أفراح & توك & دراما & سيني & & \\
\hline$\% 4 . .7$ & $\varepsilon$ & - & 1 & 1 & r & الثعر منتــات عـلاج تســـــ & \\
\hline$\%$ Ir.lr & $\wedge$ & r & r & r & r & الثعر منتجــات تطويــل وفــرد & 牙 \\
\hline$\% 19 . \vee$. & ir & - & 1 & $r$ & $\varepsilon$ & الثدي منتــات تكبيـر وتصـغير & 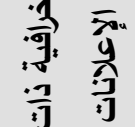 \\
\hline$\% \vee .01$ & 0 & r & - & 1 & r & منتجات التخسيس & 武哥 \\
\hline$\% \vee . \diamond \wedge$ & $\bullet$ & 1 & 1 & - & $r$ & منتجات علاج النحافة & द. \\
\hline$\% 1.01$ & 1 & - & - & - & 1 & منتجات نضارة البشرة & $\overline{3}$ \\
\hline$\%$ r..r & r & 1 & - & - & 1 & منتجات علاج الشيخوخة & 3 \\
\hline$\% r . . r$ & r & - & - & 1 & 1 & منتجات علاج حب الثباب & ని \\
\hline$\% \vee . \diamond \wedge$ & • & - & 1 & $r$ & 1 & منتجات علاج الصلع & \\
\hline
\end{tabular}




\begin{tabular}{|c|c|c|c|c|c|c|}
\hline$\%$ \%l. & r & r & $\varepsilon$ & 7 & 9 & منتجــات تفتـيح الأمـــاكن \\
\hline $1 \ldots$ & 79 & $1 T$ & 1. & iv & rq & المجموع \\
\hline
\end{tabular}

كثفت مؤشرات جدول رقم(V) عن احتلال منتجات تفتيح الأماكن الداكنة المرتبة

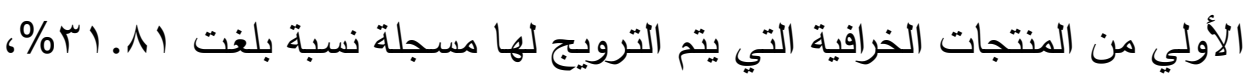

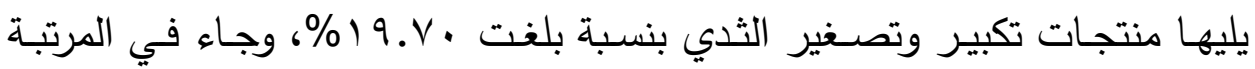

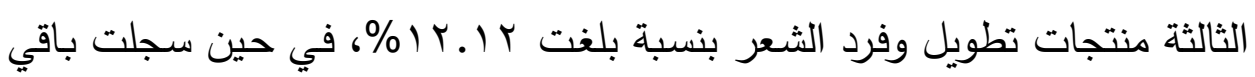
المنتجات المسئولة عن التخسيس، وعلاج النحافة، وعلاج الصلع، نسب متساوية

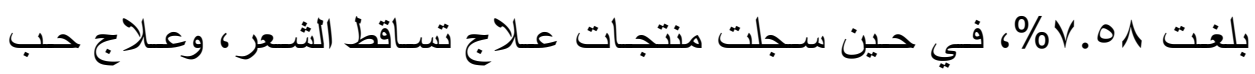
الثباب، وعـلاج علامـات الثيخوخة، ورطوبـة البشرة نسب متقاربـة إلي حد كبير

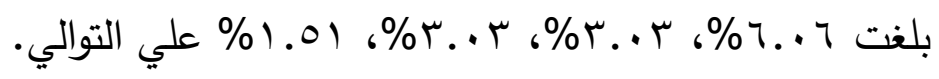

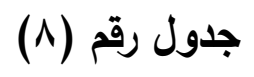

يوضح المنتجات الطبية الخرافية ذات الثق العلاجي التي تروج لها الإعلانات

التلفزيونية

\begin{tabular}{|c|c|c|c|c|c|c|}
\hline \multicolumn{5}{|c|}{ الإعلانات } & \multirow[b]{2}{*}{ المؤشرات } & \multirow{2}{*}{ الثحاني } \\
\hline$\%$ & المجموع & توك & جي & تيوب & & \\
\hline
\end{tabular}




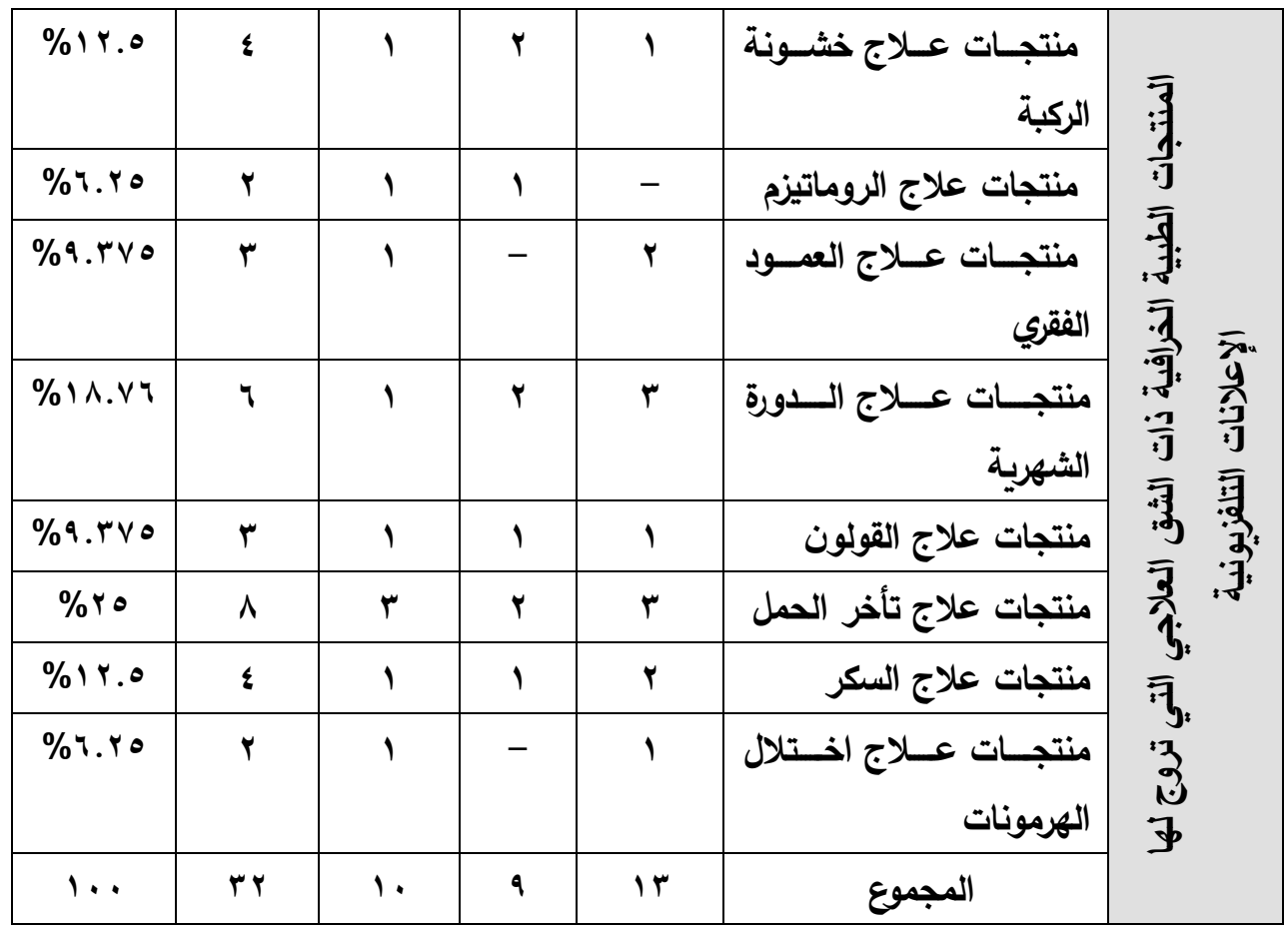

وجاءت نتائج جدول رقم(^) لتكثف عن احتلال منتجات علاج تأخر الحمل المرتبة الأولي من المنتجات الخرافية التي يتم الترويج لها وجاء ذلك بنسبة

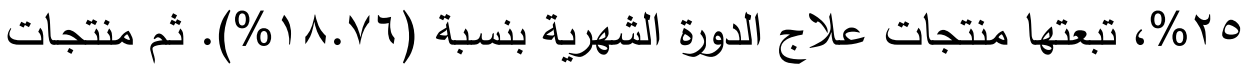
عـلاج السكر ، وعـلاج خشـونة الركبة بنسب متسـاوية بلغت (بـ ( \% \%)، ثم منتجـات عـلاج العــود الفقـري، ومنتجـات عـلاج القولـون بنسـب متسـاوية بلغت(9vor.9)، وأخيرا منتجات علاج الروماتيزم، واختلال الهرمونات بنسب

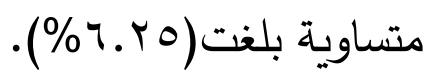

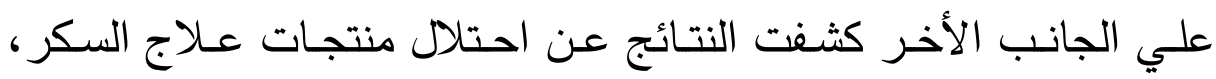
ومنتجـات عـلاج خشـونة الركبـة نسـب متسـاوية بلغـت (ب. ( ا \%)، تبعتها منتجات علاج الروماتيزم، ومنتجات علاج اختلال الهرمونات بنسب متساوية بلغت (0. . . \%)، كما سجلت منتجات عـلاج القولون، ومنتجات عـلاج الآم العمود الفقري نسب متساوية بلغت (rv.9\%). 
جدول رقم (9)

يوضـح الخرافات الطبية ذات الثنق الجنسي التي تروج لها الإعلانات

التلفزيونية

\begin{tabular}{|c|c|c|c|c|c|c|c|}
\hline \multicolumn{6}{|c|}{ علد الإعلانات } & \multirow[b]{2}{*}{ المؤشرات } & \multirow[b]{2}{*}{ الثحور } \\
\hline$\%$ & المجموع & 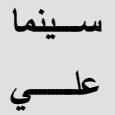 & 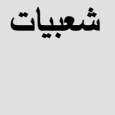 & تتح & تيوب & & \\
\hline$\%$ rr... v & ir & r & $\wedge$ & 1 & 1 & منتجــات عــلاج التســرب & . \\
\hline$\% \backslash r . \varepsilon 7$ & v & r & $\varepsilon$ & - & 1 & منتجـات زيـادة حجم العضو & 寻: 刍 \\
\hline$\% \varepsilon \cdot . r q$ & Yl & $r$ & Ir & $r$ & $r$ & منتجات ضعف الانتصاب & \\
\hline$\% 10 . r q$ & $\wedge$ & 1 & 0 & r & - & منتجات علاج سرعة القذف & \\
\hline$\% \vee .79$ & $\varepsilon$ & - & $r$ & 1 & - & منتجات الإثارة الجنسية & \\
\hline $1 \cdots$ & or & $\wedge$ & rr & v & 0 & المجموع & \\
\hline
\end{tabular}

وتكثـف نتائج جدول رقـم(9) عـن نشـر مجموعـة مـن المنتجـات الطبيـة الخرافيـة المتعقة بهذا الجانب الجنسي، وهو ما ظهر جليا في احتلال منتجات علاج ضعف الانتصاب المرتبة الأولي بنسبة وب . ـ \%، تليه منتجات علاج التسرب الوريدي في المرتبة الثانية بنسبة V . . r \% \%، تليه منتجات علاج سرعة القذف في المرتبة الثالثة بنسبة وس.0 10 وفي المرتبة الرابعـة جاءت منتجات زيـادة حجم العضـو الذكري 


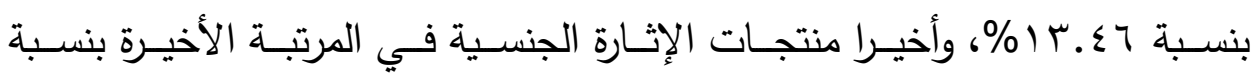
.$\% \vee .79$

المحـور الثالث: هويـة القنـوات التلفزيونيـة التي تبـث الإعلانـات التـي تـروج للخرافات الطبية

كثفت نتائج تحليل المضمون عن أن السبع قنوات التي تبث الإعلانات التلفزيونية الناشرة للخرافات الطبية هي قنوات خاصـة، وهو مـا يكثف عن حجم الدور الذي لـاتي تلعبه ثقافة الرأسمالية في عملية التغيير والتبديل والإحـال لثقافـة الأفراد. فالتلاقح الحضـاري الذي ولّده انتقال المعلومـة عبر شاشـات التلفزيون، قد رسـخ قيم وثقافـة المصدِر للمعلومة، وهو ما يترتب عليه جعل المتلقي في حالة من الارتباك غير قادر في إطارها علي تحديد الحقيقي من الخرافي. وهو ما يتقق مع ما ذهب إليه عالم الاجتماع " ميلز" في تأكيده علي خطورة وسائل الإعلام وكيفية تأثيرها في صياغة، وتثكيل أفكار الأفراد، وتكوين وعيهم، حيث قال

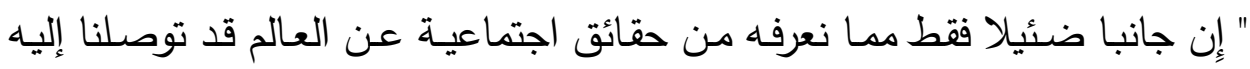
بأنفسنا، والجانب الأكبر عن طريق وسائل الإعلام، والاتصال الجماهيري".'

المحور الرابع: مدي استجابة المشاهدين لما يقدم عبر الإعلانات من منتحات طبية خرافية

$$
\text { جدول رقم (·) (1) - (1) - (1) }
$$

يوضح دلالة الفروق بين أفراد العينة حول أسباب استخدام تلك المنتجات الطبية الخرافية تبعا للفروق الريفية/ الحضرية، النوعية ابلية النولية

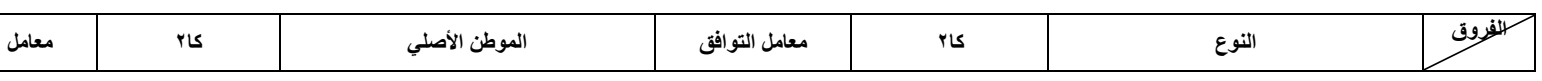

${ }^{1}$ - Wright,C, Mills." The Power Elite", Oxford University: London, 1969,P:311. 


\begin{tabular}{|c|c|c|c|c|c|c|c|c|c|c|c|c|c|c|c|}
\hline \multirow{2}{*}{ القيمة } & \multirow{2}{*}{ الدلالة } & \multirow{2}{*}{ القيمة } & \multicolumn{2}{|c|}{ الحضر } & \multicolumn{2}{|c|}{ الريف } & \multirow{2}{*}{ الدالة } & \multirow{2}{*}{ القيمة } & \multirow{2}{*}{ 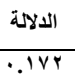 } & \multirow{2}{*}{ القيمة } & \multicolumn{2}{|c|}{ الإناث } & \multicolumn{2}{|c|}{ الذكور } & \\
\hline & & & $\%$ & $ت$ & $\%$ & 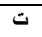 & & & & & $\%$ & ت & $\%$ & $ت$ & تغيركة \\
\hline & & & $\% ৭ . \wedge$. & 0 & $\%$ & - & & & & & $\%$ & . & $\% \%^{\wedge} . .^{9}$ & 0 & في تلجربة \\
\hline & & & $\%$ \%q.\&। & 10 & $\%$ & $r \varepsilon$ & & & & & $\%^{0}$. & IV & $\% \div 1 . \vee V$ & Tr & الأمراض من ألة \\
\hline & & & $\% 0.9$. & $r$ & $\%$ \% & ir & & & & & \%rr.Or & $\Lambda$ & $\% 1 \leqslant .{ }^{9}$ & $\Lambda$ & وصفات \\
\hline & & & $\%$ \% .१\& & TV & $\% 0.1 Y$ & $r$ & & & & & $\%$ \%४.\&V & 9 & $\%$ ro.vr & $r$. & التن حدة \\
\hline & & & $1 \ldots$ & 01 & $1 \cdots$ & r9 & & & & & $1 \ldots$ & $r \varepsilon$ & $1 \cdots$ & 07 & المجموع \\
\hline
\end{tabular}

\section{جدول رقم (1)}

يوضح دلالة الفروق بين أفراد العينة حول أسباب الثقة في المنتجات الطبية التي تعرض عبر الإعلانات للفروق الريفية/ الحضرية، النوعية

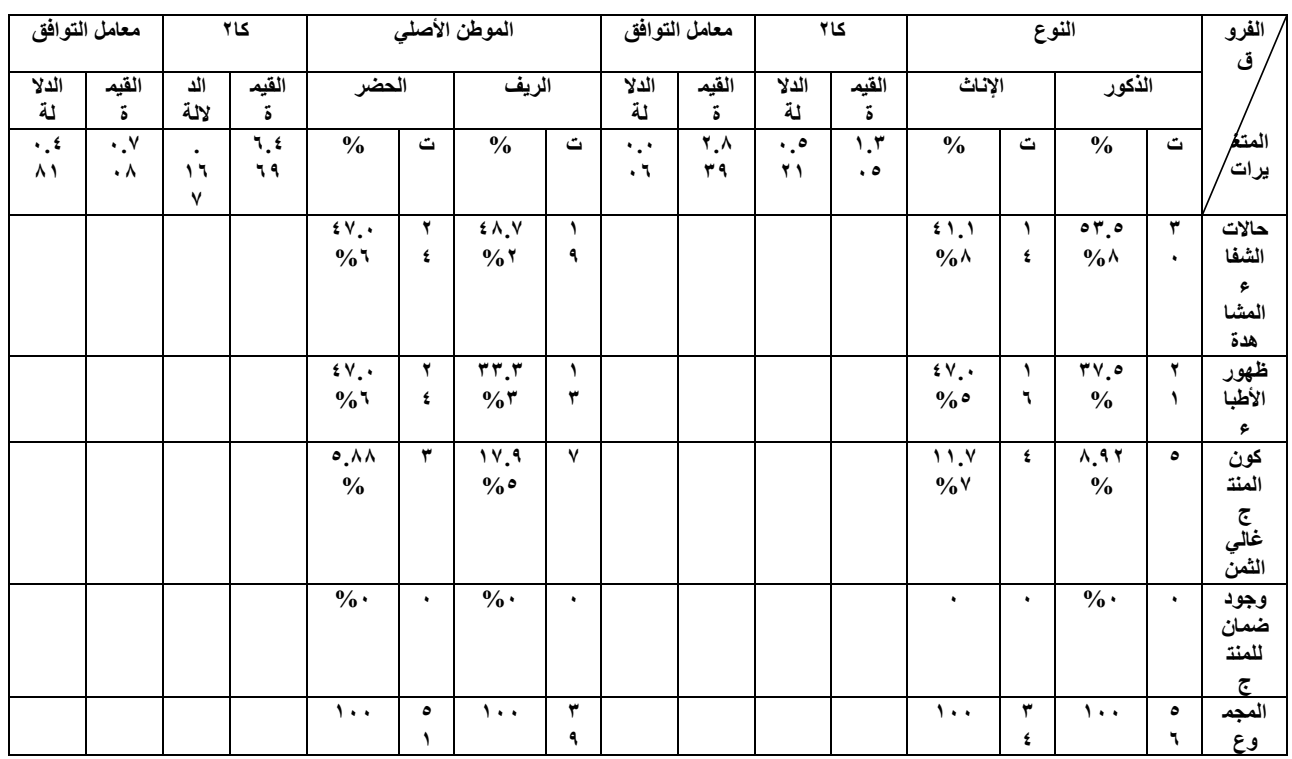

كثفت نتائج الدراسـة عن احتلال متغير الثفاء من الأمراض المرتبة الأولي في استخدام المشـاهدين للمنتجات الطبية الخرافيـة التي تروج لها الإعلانـات مسجلا

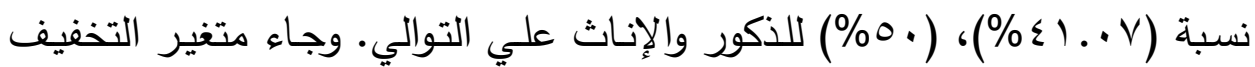

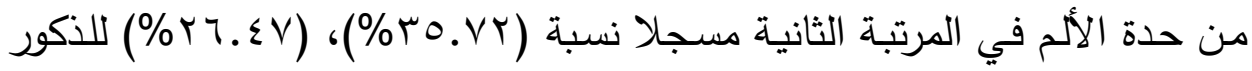
والإنـاث علي التوالي. وأخيـرا متغيـر فثـل وصـفات الأطبـاء في المرتبـة الثالثة 


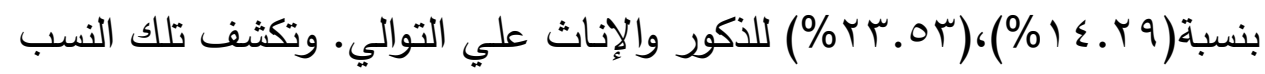
عن ارتباط استخدام الأفراد للمنتجات الطبية التي تروج لها الإعلانات التلفزيونية بحجم الأمسل والطموح الذي يسيطر عقولهم ومشـاعرهم، رغبـة منهم في تجـاوز

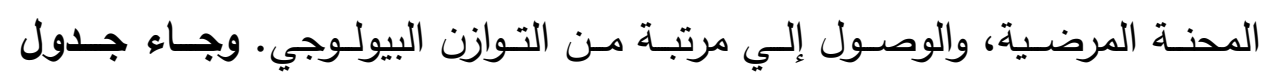

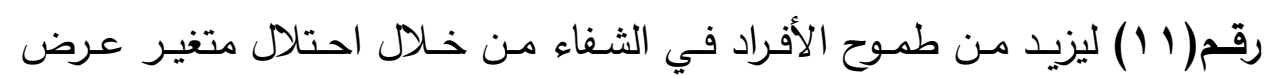

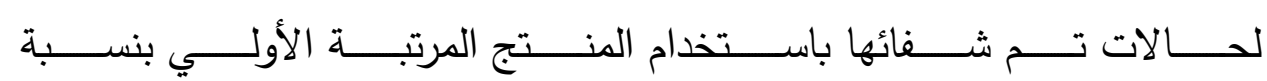

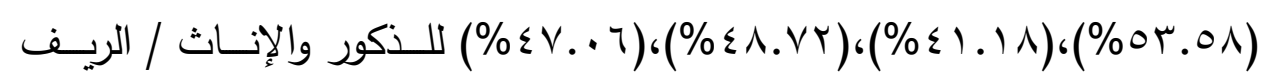
والحضر علي التوالي.

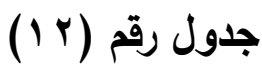

يوضح دلالة الفروق بين أفراد العينة حول نوعية المنتجات الجمالية الخرافية التي يقبلون علي شرائها تبعا للفروق الريفية/ الحضرية، النوعية لونه

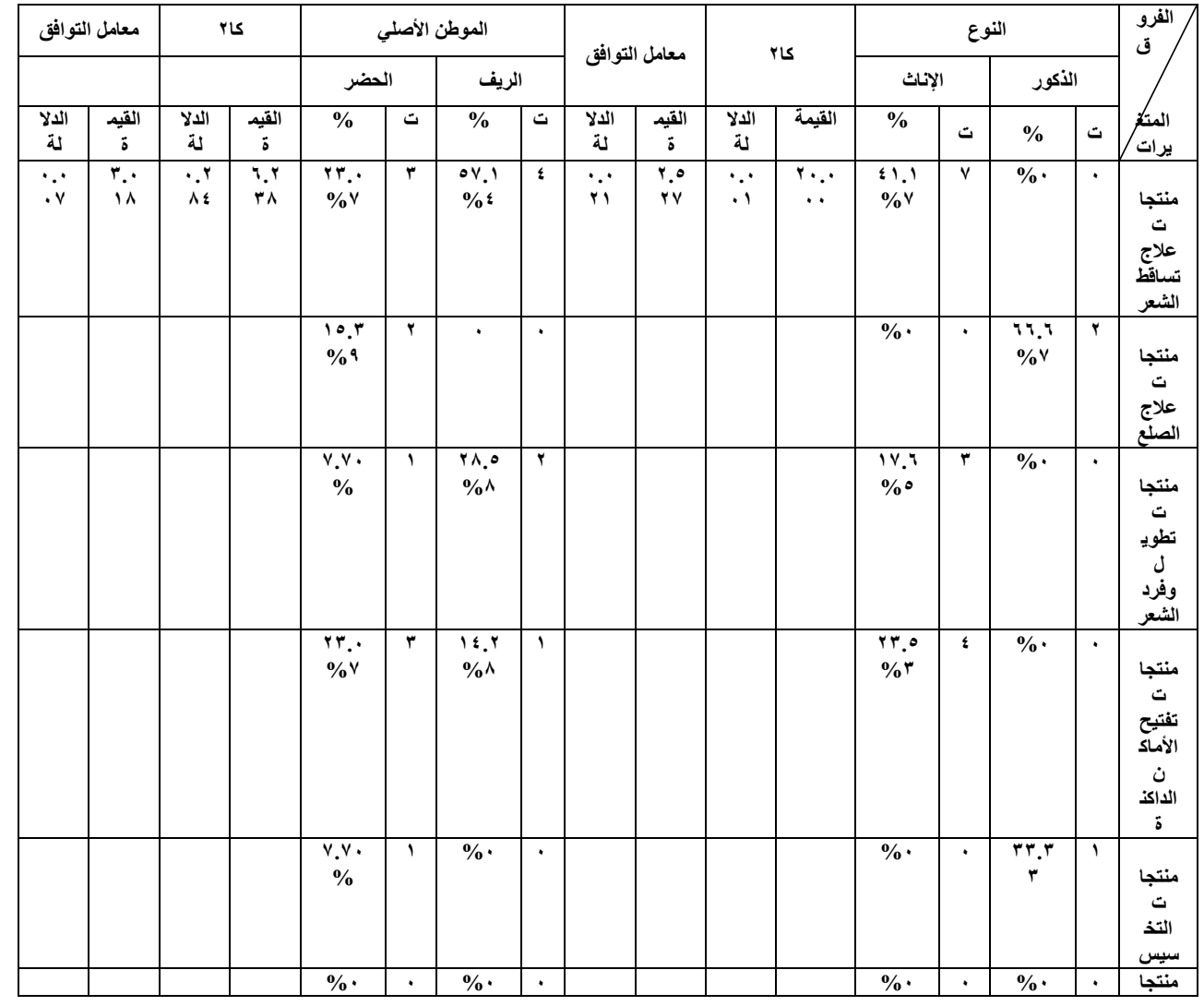




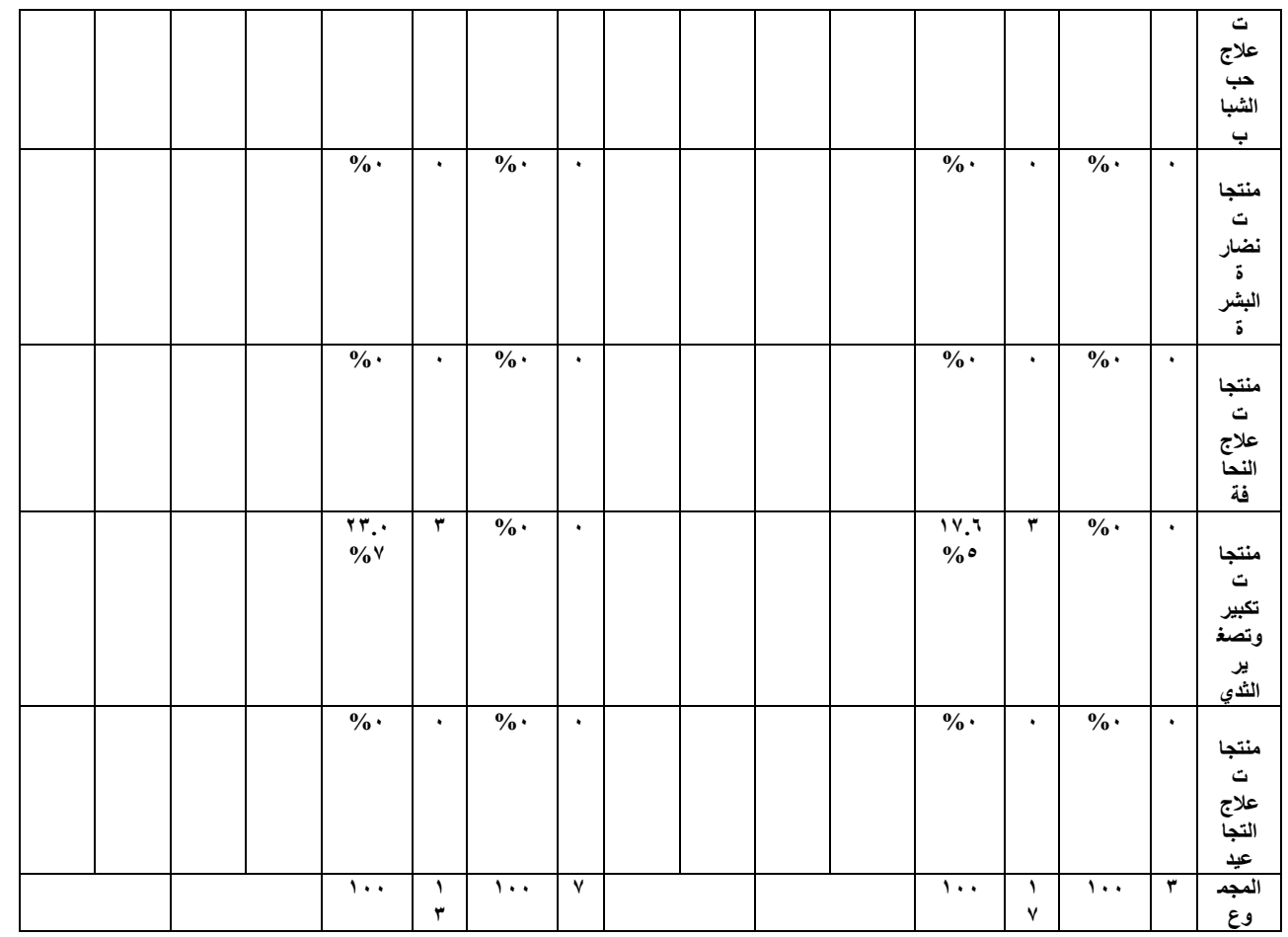

وجاءت نتائج جدول رقم(Y ( ) متسقة بشكل كبير مع نتائج جدول رقم(V) من حيث احتلال منتجات علاج تساقط الثعر ، وتطويل وفرد الثعر ، وتفتيح الأماكن الدكنة، وتكبير وتصغير الثدي اعلي مستوي دلالة معنوية عند نسبة احتمال( ( ....) علي مستوي الفروق النوعية، حيث سجلت منتجات عـلاج تساقط الثـعر نسبة بلغت

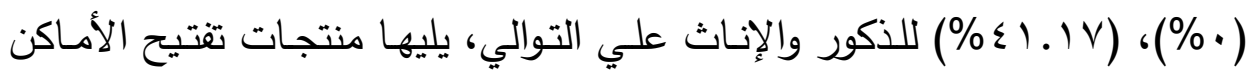

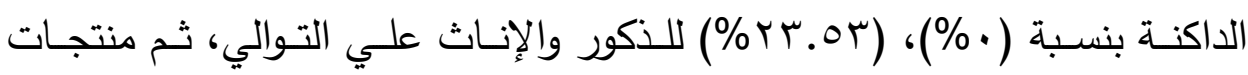

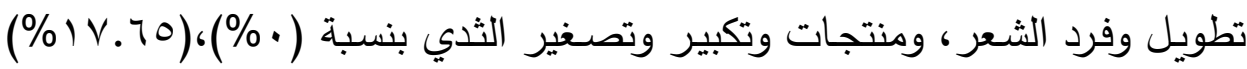
للذكور والإناث علي التوالي. ولم تختلف النتائج علي مستوي الريف/ الحضر حيث سجلت استجابات المبحوثين فروق جوهريـة ذات دلالمة معنويـة عند مستوي دلالـة

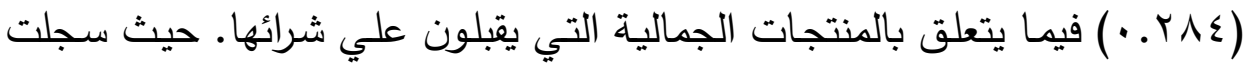

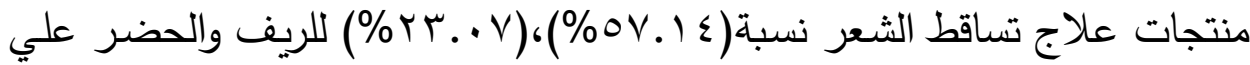

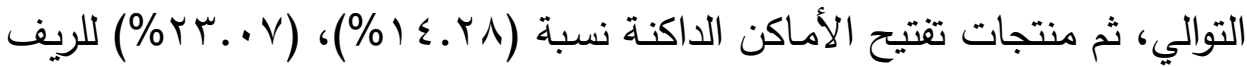




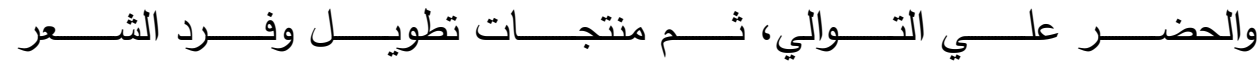

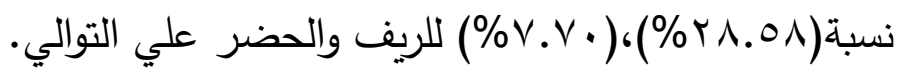
وتكثف النسب السابقة عن الإقبال المتزايد من قبل الإناث علي المنتجات الخرافية التي تقدم عبر الإعلانات التلفزيونية والمتعلقة بالجمال الجسدي، انطلاقاً من أن الن النيال الجسـ لـم يعد رمـزا للهويـة وحدها، ولكنـهـ أصسبح سـلعة يمكن تحديثها باستمرار

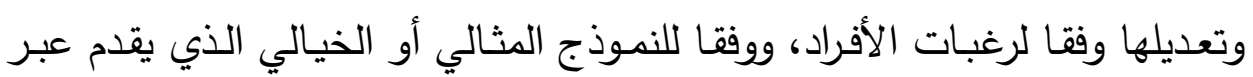

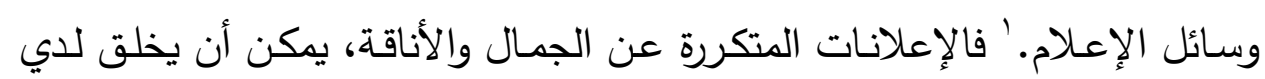
النسـاء حالـة يطلق عليها "بكراهيـة الجســ"، حيـث تبـدأ النسـاء في النظر إلـي

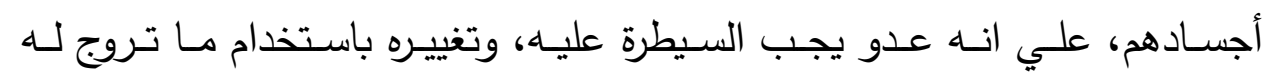
الإعلانات. إنمات

وهو الأمر الذي لم يقوض فقط من قيمة الذات للمرأة، ولكنه مارس عليها نوع من الضـغوط، لكي تتوافق وتتلاءم مـع ممارسـات الجمال الخياليـة، في محاولـة منهـا لمحاكاة الصورة المثالية للمرأة المقدمة عبر الرسالة الإعلانية، وكأننا أمام أسطورة جديدة ترغب المرأة في الوصول إليها وهي أسطورة "المرأة السوبر".

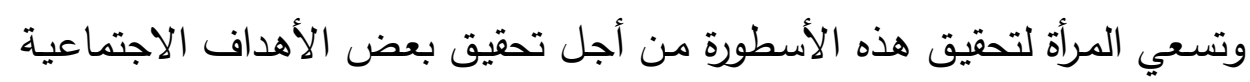
والشخصية، حيث يشعرن بأنهن في ادني شريحة من منظومة الشرائح الجمالية في

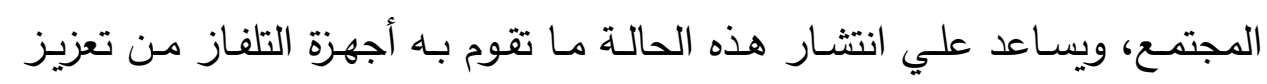

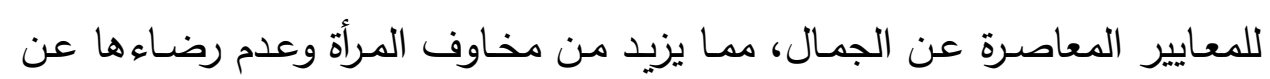
جسدها، مما يدفعها بحالة من اللاوعي إلي استخدام المنتجات التي يتم الترويج

1 - Gimlin,D,L." Body: Beauty and Self Image in American Culture",

California, University of California Press,2002,P:78. 
لهـا، ' مـن اجل الوصـول إلي نمط الجسـ الملائم أو مـا يعرف بالجسـم المثالي

r."Meso Morophic"

هذا النموذج الذي يدفع الإناث بدون تفكير نحو الاستثار في كميات كبيرة من الوقت، والطاقة، والحالة العاطفية، لكي يتوافقوا مـع المثل العليا للجسد، جنبا إلي

$$
\text { جنب مع الهواجس والخوف من الثيخوخة. }
$$

ويعكس ما سبق انتقال النساء من مرحلة المراقبة والملاحظة لكل ما يبث عبر الإعلانات التلفزيونية، إلي مرحلة الفعل من خلال البدء في رسم مخططات جسدها، وبما يتوافق مع رغباتها وحاجاته الفعلية.

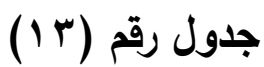

يوضتح دلالة الفروق بين أفراد العينة حول نوعية المنتجات العلاجية الخرافية التي يقبلون علي شرائها تبعا للفروق الريفية/ الحضرية، النوعية.

\begin{tabular}{|c|c|c|c|c|c|c|c|c|c|c|c|c|c|c|c|c|}
\hline \multicolumn{2}{|c|}{ معامل التوافق } & \multicolumn{2}{|c|}{ كاr } & \multicolumn{4}{|c|}{ الموطن الأصلي } & \multirow{2}{*}{\multicolumn{2}{|c|}{ معامل التوافق }} & \multirow{2}{*}{\multicolumn{2}{|c|}{ SLr }} & \multicolumn{4}{|c|}{ النوع } & /الفرو \\
\hline & & & & \multicolumn{2}{|c|}{ الحضر } & \multicolumn{2}{|c|}{ الريف } & & & & & \multicolumn{2}{|c|}{ الإناث } & \multicolumn{2}{|c|}{ الذكور } & \\
\hline الدةلا & القيه & لالة الا & القيمة & $\%$ & ت & $\%$ & ت & الدلا & القيه & للة الدا & القيمة & $\%$ & ت & $\%$ & $ت$ & يرات/ \\
\hline$\ddot{v}$. & $\begin{array}{l}\ddot{A} \\
\hat{\mu}\end{array}$ & $\ddot{i v}$ & $\begin{array}{l}10 . \\
0 \% .\end{array}$ & $\begin{array}{l}r 4.7 \\
\% v\end{array}$ & $\varepsilon$ & $\begin{array}{l}\text { or } \\
\% \\
\%\end{array}$ & $\wedge$ & $\because$ & $\begin{array}{l}4 \\
81\end{array}$ & $\ddot{r}$ & $\begin{array}{l}\text { IT. } \\
\text { IV }\end{array}$ & $\begin{array}{l}18.7 \\
\% 0^{7}\end{array}$ & $r$ & $\begin{array}{l}71.0 \\
\%\end{array}$ & $\wedge$ & عنلتج \\
\hline & & & & $\% r$. & $r$ & $\begin{array}{l}7.7 \mathrm{~V} \\
\%\end{array}$ & 1 & & & & & $\begin{array}{l}18.7 \\
\% 0^{7}\end{array}$ & $r$ & $\begin{array}{c}\text { v.v. } \\
\%\end{array}$ & 1 & علتجا ت القولو \\
\hline & & & & $\begin{array}{l}1+r \\
\% r\end{array}$ & $r$ & $\begin{array}{l}1 \% \cdot r \\
\% r\end{array}$ & r & & & & & $\begin{array}{l}11 . v \\
\% 4\end{array}$ & $r$ & $\begin{array}{l}r r . \\
\% \dot{ }\end{array}$ & $r$ & علاتج \\
\hline & & & & $\%$. & . & $\%$. & . & & & & & $\%$. & . & $\%$ & . & علتجا \\
\hline
\end{tabular}

1 - Maria,Martinez ,Lirola. Jan, Chovanec." The Dream of Perfect Body Come True: Multimodality in Cosmetic Surgery Advertising", Journal of Discourse and Society, Vol,23,No,5,2012,P:490.

2 - Michelle, Leigh, Grose." Individual Body Satisfaction and Perception: The Effect of Medias Ideal Body Image on Female College Students", Baylor University, in Partial Fulfillment of The Requirement for Degree of Master of Arts,2009,P:11.

3 - Forbes, G, B. Et al." Sexism Hostility Toward Women and Endorsement of Beauty Ideals and Practices: Are Beauty Ideals Associated with Oppressive Beliefs?", Journal of Sex Roles, Vol,56, 2007,P:r ro. 


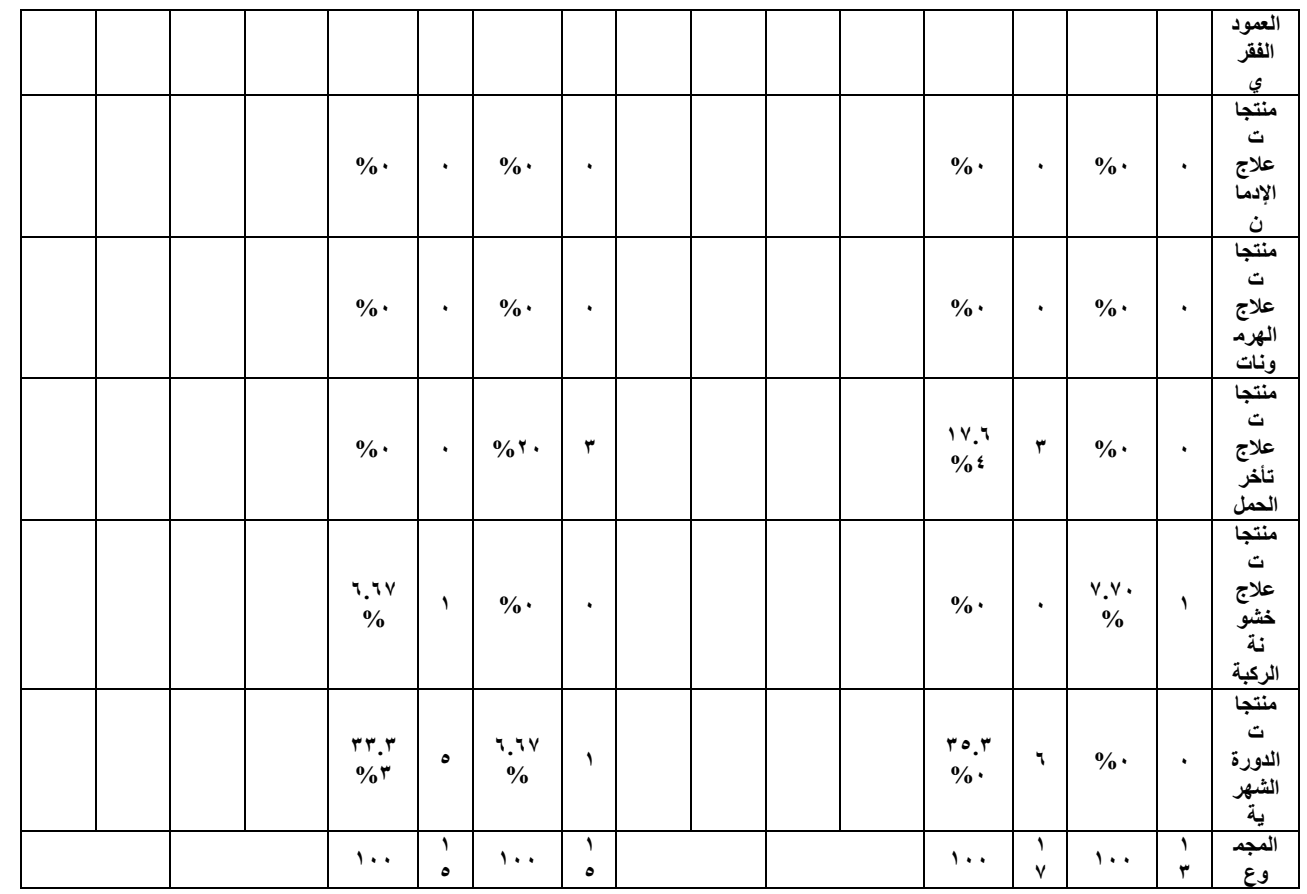

أوضـحت مؤشرات جدول رقم(ب I) تعاظم نسبة أفراد العينة تبعا لفروقها النوعية، الحضـرية/ الريفيـة، لاختيـار منتجات عـلاج اضطرابات الدورة الثـهرية، ومنتجـات علاج تأخر الحمل، وقد سجلت النسبة علي مستوي الفروق النوعية تقرببا ( •\%)،

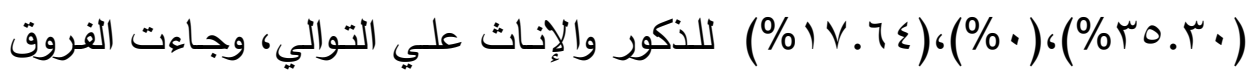

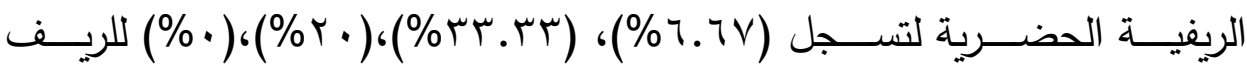
والحضر علي التوالي. وتكثف النسب السابقة عن أن إقبال النساء علي المنتجات الخرافية المتعلقة بالحمل واضطرابات الدورة الثهريـة، ربما يرجح لما يمثله الإنجاب من قضية محوريـة في حياتهـا، كمـا انـه عامـل مسن عوامـل اسـتقرار الكيـان الأسـري، وبالتالي فان أي عائق يمنع تحقيق هذا الحلم يجعلها تبحث بشكل حثيث عن أي وسيلة تساعدها في تجاوز هذه المحنة حتى ولو كانت هذه الوسيلة غير علمية. 
انطلاقـاً مـن أن تجربـة العقم وعدم الإنجـاب، غالبـا مـا تعـد تجربـة مسـجلة بعلامـات القلق والخوف والضـوط الاجتماعية والوصمة الاجتماعية، فضـلا عن تهديد للهوية الاجتماعية للزوجة ومكانتها.' فالرغبة في إنجاب طفل هو جزء أساسي من مشروع الحياة الزوجية، وينظر إلية باعتباره خطوة ضرورية للوصول إلي مرحلة النضج والحفاظ علي الجنس البشري، بالإضافة إلي الحصول علي الدعم الاجتماعي اللازم من قبل أفراد المجتمع.

فالزوجة تنظر إلي نفسها باعتبارها كائن كاملا ولها وجودها فقط، عندما تنتقل إلي مرحلـة الوالديـة، أي إثبات خصـوبتها، وبالتـالي الثـعور بالأمسان علي بـي زواجها، فالإنجاب يعكس مدي عمق العلاقة الزوجية، ويجعلها يشعر وكانها أنجزت ما كان من المفترض أن تفعله أي امرأة راشدة.

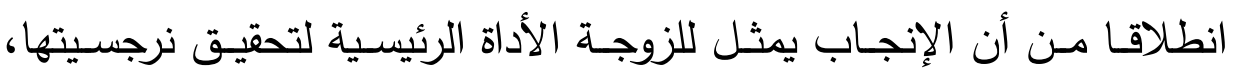
فضلا عن جلب القوة، وتثكيل نوع من السلطة التي تمكنها من التفاوض في وقت الأزمات داخل الأسرة، كما انه يمثل للرجل الآلية لإثبات رجولته. ؛ علي الجانب الأخر غابت الفروق النوعية، والريفية/ الحضرية بالنسبة لمنتجات علاج السكر ، والقولون، والروماتيزم حيث سجلت نسب قريبة إلي حد كبير بلغت (\% (\%).0r)

${ }^{1}$ - Rowland,R." A child at Any Price?", An Over View of Issue in The Studies in The New Reproductive Technologies and The Threat to Women", Women Studies International Fop am, Vol. 8, 1985,p:p 539-546.

2 - Daniluk, J." Infertility: Intrapersonal and Interpersonal Impact", Journal of Fertility and Sterility, Vol,49,Issue,6,1988,P:P 982-990.

3 - Widge,A." Socio culture Attitudes Toward Infertility and Assisted Reproduction in India", in VAYENA, E. et al( editor), " Current Practices and Controversies in Assisted Reproduction: "Medical, Ethical and Social Aspects of Assisted Reproduction" WHO Headquarters in Geneva, Switzerland, 2011, p:62.

4 - Ibid, P: 61. 


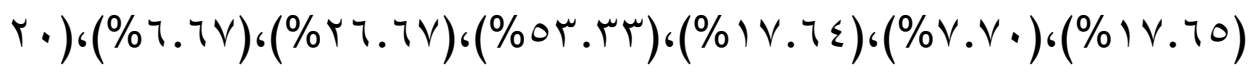

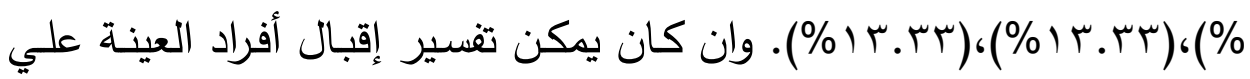
مثل تلك المنتجات الطبية الخرافية لكونها تتعلق بعلاج عدد من الأمـراض ذات التأثير المباشر علي كافة أنشطتهم الحياتية. خلاصة الأمر : نجد انه في ظل هذه الإعلانات التلفزيونية المروجة للخرافات الطبية التي تمثل احد أوجه ثقافة العولمة يتم اقتحام فكر المستقبل ووجدانهـ لصياغة طموحاته تبعا لأهداف المركز الرأسمالي المعولم( القائمين علي تلك القنوات)، بما يحقق إعاقة الفكر لدي المتلقي، مما يسهم في تغيير المنظومة

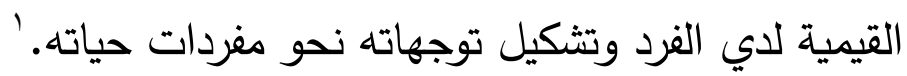

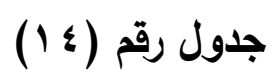

يوضـح أنـواع المنتجـات الجنسـية الخرافيـة التي يقبـل عليها الأفراد بسبب

\begin{tabular}{|c|c|c|}
\hline النسبة & التكرار & المتغيرات \\
\hline$\%$ \%r.o & r & منتجات تطويل العضو الذكري \\
\hline$\%$ r. & ir & منتجات تأخير القذف \\
\hline$\% r$. & $\wedge$ & منتجات علاج ضعف الانتصاب \\
\hline$\%$. & · & منتجات تحقيق النشوة \\
\hline$\% \backslash \vee .0$ & $\checkmark$ & منتجات علاج التسرب الوريدي \\
\hline$\%$. & - & منتجات علاج البرود الجنسي \\
\hline $1 \ldots$ & $\varepsilon$. & المجموع \\
\hline
\end{tabular}

جدول رقم (10) - (1) - (1)

1 - James, Wilson. Stan Leroy, Wilson." Mass Media and Mass Culture: An Introduction", Mc Graw- Hill Inc, U.S.A,1998,P:P 270-276. 
يوضح أنواع المنتجات الجنسية الخرافية التي يقبل عليها الأفراد بسبب الإعلانات موزعة طبقاً للريف والحضر .

\begin{tabular}{|c|c|c|c|c|}
\hline النسبة & 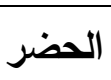 & النسبة & الريف & المتغيرات \\
\hline$\%$ \%..ค & 7 & $\% \leq 1.1 v$ & $v$ & منتجات تطويل العضو الذكري \\
\hline$\% \circ$ Y.IV & ir & $\%$. & . & منتجات تأخير القذف \\
\hline$\%$ Y.Vr & 0 & $\% \backslash$ \%. & $r$ & منتجات علاج ضعف الانتصاب \\
\hline$\%$. & - & $\%$ & . & منتجات تحقيق النشوة \\
\hline$\%$. & - & $\% \leq 1.1 \mathrm{~V}$ & $\checkmark$ & منتجات علاج التسرب الوريدي \\
\hline$\%$. & - & $\%$. & - & منتجات علاج البرود الجنسي \\
\hline $1 \ldots$ & rr & $1 \ldots$ & iv & المجموع \\
\hline
\end{tabular}

وكثفت نتائج جدول رقم(ء () عن اتجـاه الذكور نحو استخدام المنتجـات الطبيـة الخرافية ذات الشق الجنسي، وظهر ذلك جلياً في احتلال منتجات تطويل العضو

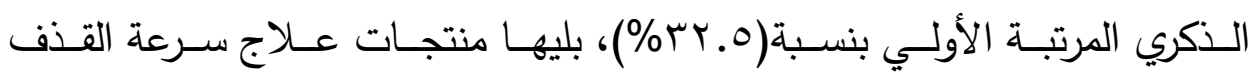

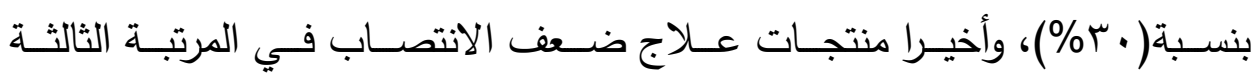
بنسبة(·r\%). وجـاء جدول رقم(0) (10) ليكثف لنـا عن فروق جوهريـة بين الريـف والحضـر فيمـا يتعلق بالإقبال علي تلك المنتجات الجنسية حيث سـلت منتجات تطويـل العضـو الذكري، ومنتجـات عـلاج سـرعة القذف، ومنتجـات عـلاج ضـعف لإنف

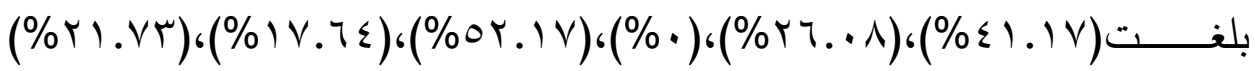
للريف والحضر علي التوالي. وربما يرجع حجم الإقبال المتزايد من قبل الرجال علي تلك المنتجات الطبية الجنسية نظرا لقيمة الجنس في حياة الرجال، من حيث كونـه

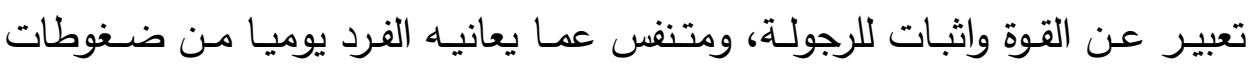


اجتماعيـة ونفسية، فضـلا عن كونـه يمثل شـريان الحياة الذي يمكن الزوجين من تعزيز حاجاتهم في الأخذ والعطاء والمودة والمحبة والرعاية والحنان، '

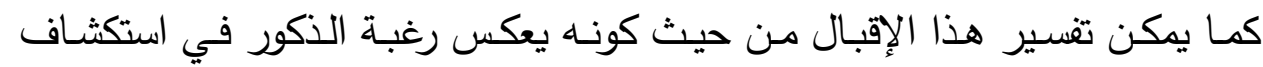
الطـرق المؤديـة إلـي المتعـة الجنسية، ورغبتهـه في ممارسـة شكل مـن أشكال الحكم

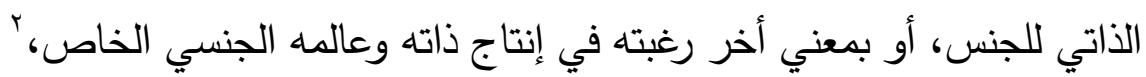

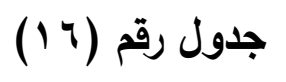

يوضح دلالة الفروق بين أفراد العينة حول مدي التحسن الطبي جراء استخدام

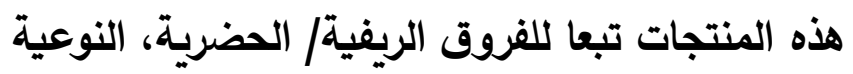

\begin{tabular}{|c|c|c|c|c|c|c|c|c|c|c|c|c|c|c|c|c|}
\hline \multicolumn{2}{|c|}{ معامل التوافق } & \multicolumn{2}{|c|}{ SLI } & \multicolumn{4}{|c|}{ الموطن الأصلي } & \multicolumn{2}{|c|}{ معامل التوافق } & \multicolumn{2}{|c|}{ SL } & \multicolumn{4}{|c|}{ النوع } & / الفرو \\
\hline للة اللا & القيّ & الدة الأ & القيم & \multicolumn{2}{|c|}{ الحضر } & \multicolumn{2}{|c|}{ الريف } & اللة & القيه & للة اللا & القيم & \multicolumn{2}{|c|}{ الإناث } & \multicolumn{2}{|c|}{ الذكور } & \\
\hline$\ddot{\imath \wedge}$ & $\because$ & $\begin{array}{l}\because \wedge \\
. v\end{array}$ & 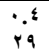 & & & & & $\because$ & $\begin{array}{l}0.1 \\
\varepsilon v\end{array}$ & $\begin{array}{l}\cdot 1 \\
v \varepsilon\end{array}$ & $\begin{array}{l}1 . \wedge \\
0 .\end{array}$ & $\%$ & $\Xi$ & $\%$ & 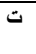 & \\
\hline & & & & $\begin{array}{l}\text { ro. } \\
\% 9\end{array}$ & $\begin{array}{l}1 \\
1\end{array}$ & $\begin{array}{l}r Y . \dot{ } \\
\% v\end{array}$ & 9 & & & & & $\begin{array}{l}r Y . r \\
\% 0^{\prime}\end{array}$ & 1 & $\begin{array}{l}19.7 \\
\% \leq\end{array}$ & $\begin{array}{l}1 \\
1\end{array}$ & نعم \\
\hline & & & & $\begin{array}{l}V \leqslant 0 \\
\% 1\end{array}$ & $\begin{array}{l}\Gamma \\
\Lambda \\
\end{array}$ & $\begin{array}{l}17.9 \\
\%{ }^{4}\end{array}$ & 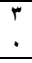 & & & & & $\begin{array}{l}\text { TV. } \\
\% 0^{\circ}\end{array}$ & $\begin{array}{l}r \\
r\end{array}$ & $\begin{array}{l}\lambda \cdot{ }^{\top}{ }^{\top} \\
\end{array}$ & $\begin{array}{l}\varepsilon \\
\end{array}$ & $\bar{y}$ \\
\hline & & & & $1 \cdots$ & $i$ & $1 \ldots$ & $\begin{array}{l}4 \\
\end{array}$ & & & & & $1 \ldots$ & $\begin{array}{l}\Gamma \\
\end{array}$ & $1 \cdots$ & $\begin{array}{l}0 \\
\end{array}$ & وأمجم \\
\hline
\end{tabular}

جدول رقم (Iv)

يوضح دلالة الفروق بين أفراد العينة حول حجم الانتكاسة الصحية نتيجة استخدام تلك المنتجات تبعا للفروق الريفية/ الحضرية، النوعية

\begin{tabular}{|c|c|c|c|c|c|c|c|c|c|c|c|c|c|c|c|c|}
\hline \multicolumn{2}{|c|}{ معامل التوافق } & \multicolumn{2}{|c|}{ كاץ } & \multicolumn{4}{|c|}{ الموطن الأصلي } & \multirow{2}{*}{\multicolumn{2}{|c|}{ معامل التوافق }} & \multirow{2}{*}{\multicolumn{2}{|c|}{ كاי }} & \multicolumn{4}{|c|}{ النوع } & \\
\hline & & & & \multicolumn{2}{|c|}{ الحضر } & \multicolumn{2}{|c|}{ الريف } & & & & & \multicolumn{2}{|c|}{ الإناث } & \multicolumn{2}{|c|}{ الذكور } & \\
\hline للة الالا & أقيد & للة الدلا & أقيد & $\%$ & ت & $\%$ & $ت$ & للة الالا & القيه & لة الدا & أقيم & $\%$ & ت & $\%$ & ت & \\
\hline$\cdots \Lambda$ & $\because r$ & $\cdots 1$ & ४. & M.A & 1 & ז.זי & 1 & $\cdots$ & r.A & $\cdots$ & 9.7 & $\Gamma \varepsilon . V$ & $\wedge$ & 00.0 & $r$ & تدهو \\
\hline$r \varepsilon$ & rT & $v_{1}$ & .0 & $\%$ ؛ & $\varepsilon$ & $\% r$ & 9 & $\cdots$ & r. & $\cdot 1$ & va & $\% \wedge$ & & $\% 4$ & . & J \\
\hline & & & & ri.o & 1 & 17.7 & 0 & & & & & $\leq \vee . \wedge$ & 1 & Ir.r & 7 & توقف \\
\hline
\end{tabular}

1 - Esther,Perel.M.A,Lmft." Erotic Fantasy Reconsidered: From Tragedy to Triumph', Spring,Vol,7,2011,P:13.

2 - Lynee,Jamieson ."Intimacy Transformed: critical Look At The Pure Revolution", The Journal Of Sociology,Vol,33,No.3,1999.P:478. 


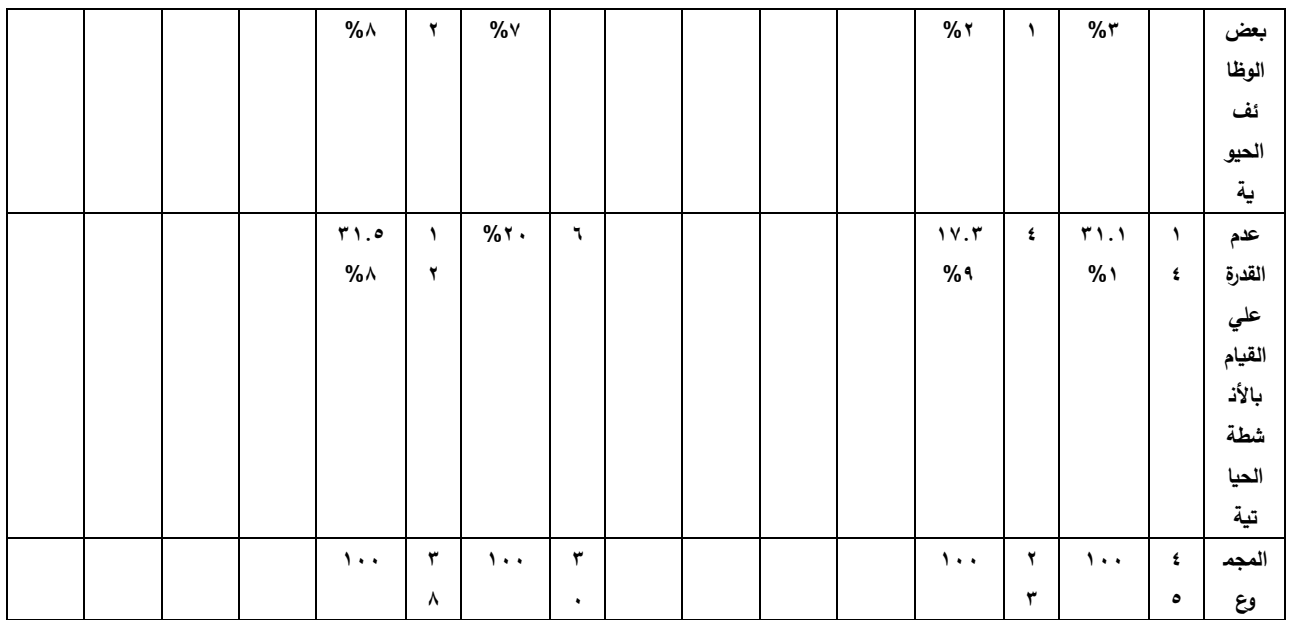

وينتقل بنا جدول رقم(7 (1) ليكثف عن حجم الانتكاسة الصحية التي أصابت الأفراد نتيجة استخدامهم لهذه المنتجات الطبية التي تروج لها الإعلانات التلفزيونية، حيث أظهرت نتائجه فروق ذات دلالة معنوية عند نسبة احتمال( ( . ... للفروق النوعية

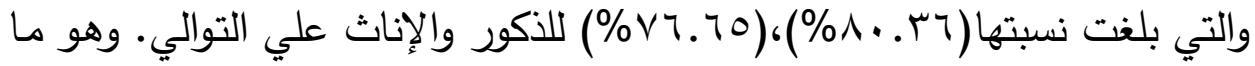
يكثف عن حجم الخداع الذي مارسه القائمين علي تلك الإعلانات في تزييف الواقع الصحي، ومحاولة تحقيق نوع من الثراء وكسب المال حتى ولو علي صحة الأفراد، وهو ما ظهر بشكل واضـح في جدول رقم(V) الذي اظهر احتلال متغير تدهور الحالة الصحية المرتبة الأولي في الأثر الطبي لاستخدام تلك المنتجات بنسبة بلغت

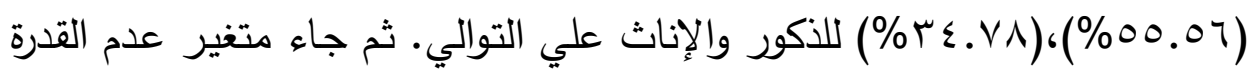

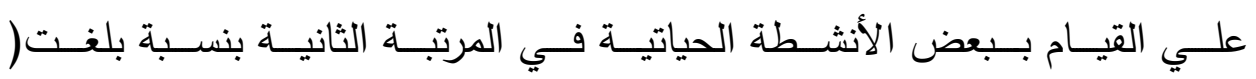

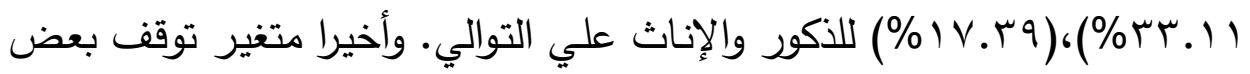

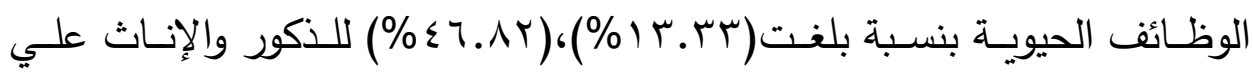
التوالي.

قضابيا واستخلاصات عامة 1- الفكر اللاتنموي( الطابع التجاري) للإعلانات التلفزيونية 
كثفت نتائج الدراسة عن اتخاذ الإعلانات التلفزيونية منعرج بعيدا جدا عن الفكر

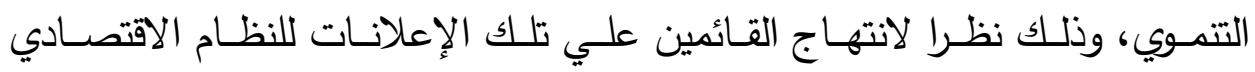

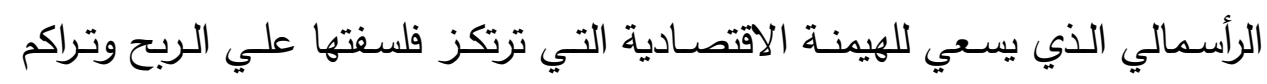

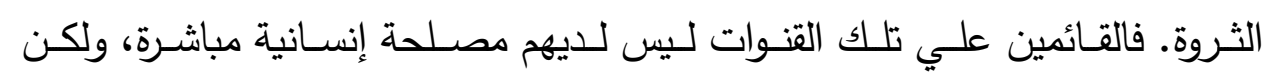

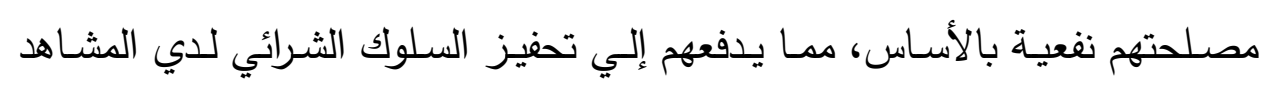

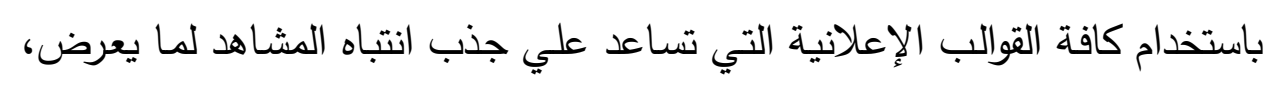

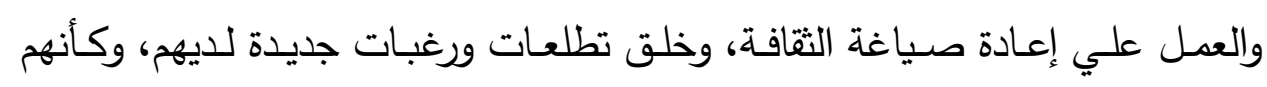

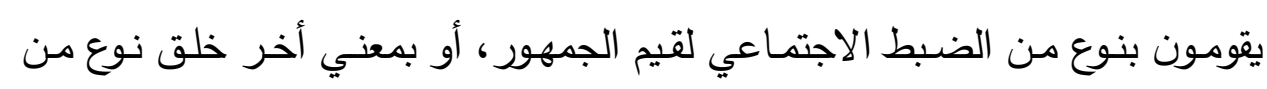

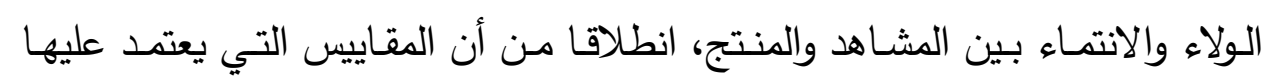

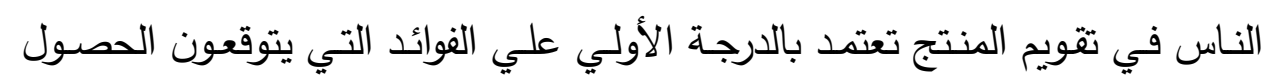
عليها من استهلاكهم لهذه المنتجات.

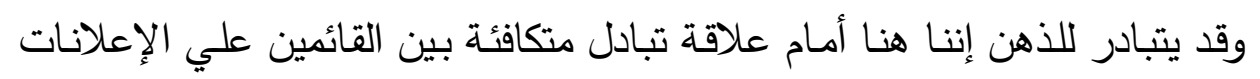

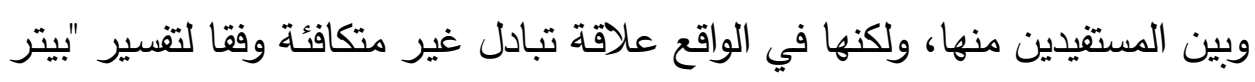

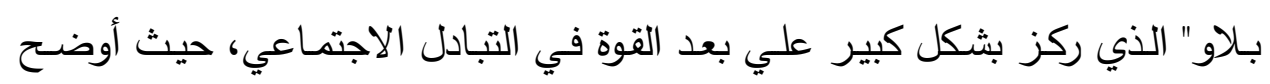

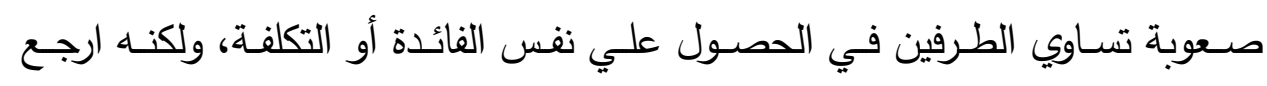

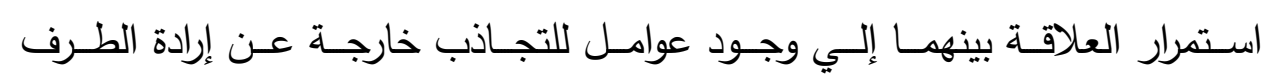

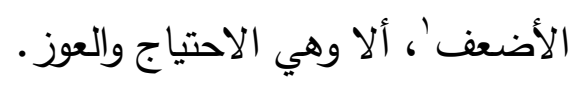
ب - الإعلانات التلفزيونية واستلاب الوعي الإعي

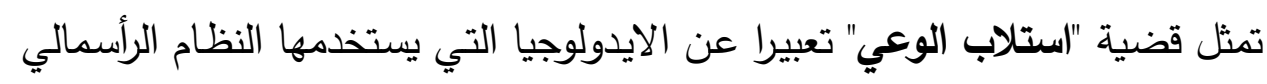

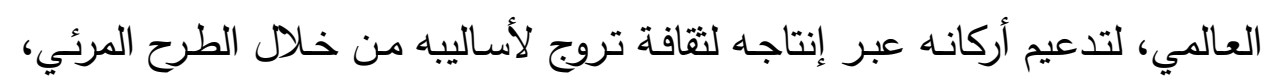

'- محمد علي محا، تاريخ الاجتماع: الرواد والاتجاهات المعاصرة، دار المعرفة الجامعية، الإسكندرية، إ 
مستخدما فيها تـويب التناقضـات، وهـي احدي الآليـات التي تستخدمها الأنظمـة

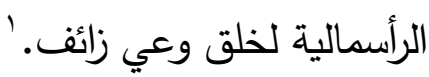
أو بمعني أخر خلق وعي مصنوع في رؤوس الأفراد، من خلال تغيير الطريقة التي رئ يفكرون بها، ويدركون بها أمور حياتهم، كما إنها ترسم الصورة الذهنية لديهم عن واقع خيالي يتعلق بحياة صحية مثالية، وتجعلهم يرون الرفاه الوهمي ويصدقونه،

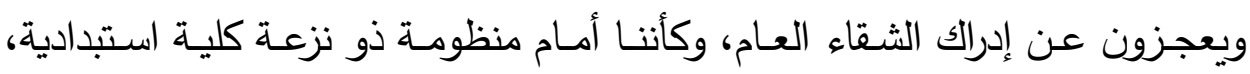
تبحث عادة عن آليات للهيمنة والسيطرة علي عقول الأفراد، من خلال تفريخ ذاكرة الأفراد من كل العناصر الرافضة لما يتم تثكيله الآن، ومتى تحقق ذلك أصبح ذهن الفرد طيعا وملائما، لتثبيت أي أفكار خيالية أو خادعة، وهو ما تقوم به الإعلانات في ترويجها للخرافات الطبية. حيث تقدم كما كبيرا من المنتجات التي يعتقد الفرد إنها

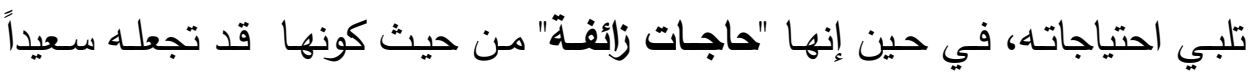
للحظة، ولكنها تترك أثثارها السلبية عليه علي المدى البعيد. في كل الأحوال الاستلاب هنا لا يعبر بدرجة كبيرة عن الهيمنـة الفكريـة للقائمين

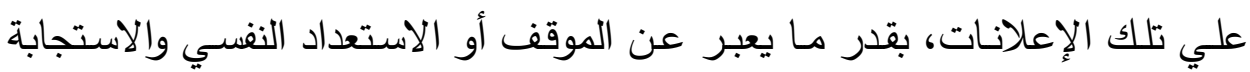
الطوعية للمشاهد، الذي عاني لفترات طويلة من الحرمان والضـفف والفقر مما جعله فريسة سهلة لما يقدم له.

\section{r- منتجات طبية خرافية مدعمة عبر الصورة النمطية}

كشفت نتائج الدراسة عن اعتماد الإعلانات التلفزيونية في ترويجها للخرافات الطبية علي ما يسمي بالصورة النمطية، من خلال نشر حقائق مبالغ فيها عن الأدويـة أو الو المنتجـات الطبيـة، فضـلا عـن مخاطبتهـا للمشـاعر الذاتيـة والاحتياجـات البيولوجيـة للأفراد، حيث تعمل هذه الصورة النمطية علي تغليف الواقع الموضوعي بواقع بديل،

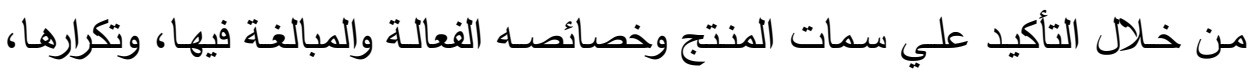

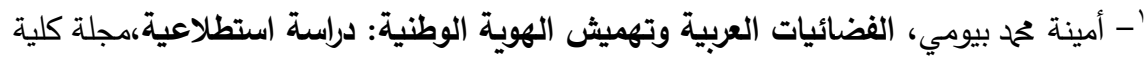

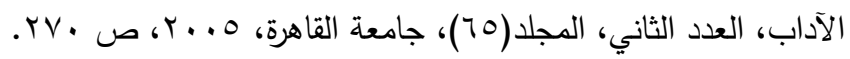


وتوضيحها، وترسيخها، كما يقوم القائمين علي القنوات التلفزيونية بالبحث عن أي شواهد، أو أحداث أو ممارسـات، مهما كانت نـادرة، لتأكيد الصسورة النمطية السلبية

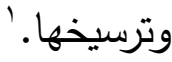

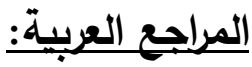

1. إبراهيم محمد سليمان، مدخل إلي مفهوم سيمائية الصورة، المجلة الجامعة، العدد السادس

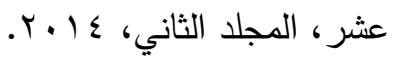
r. أحمد زكي بدوي، معجم مصطلحات الإعلام، دار الكتاب اللبناني، بيروت، الطبعة الأولي، $.199 \varepsilon$

r. أحمد مجدي حجازي، العولمـة بين التفكيك وإعادة التركيب: دراسات في تحديات النظام

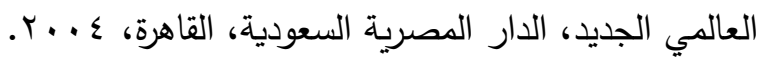

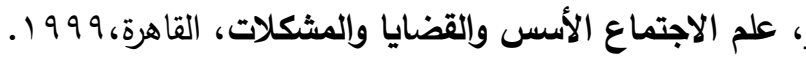
.$\varepsilon$

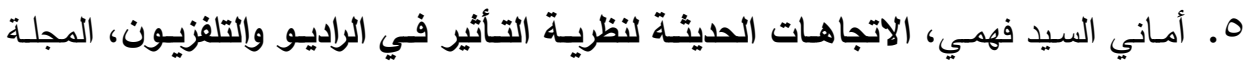
العلمية لبحوث الإعلام، العدد الساد،، 1999.

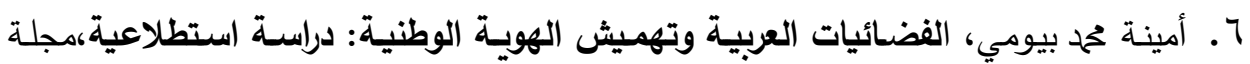

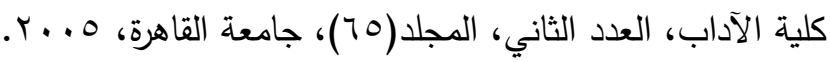

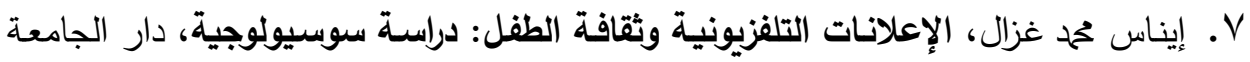

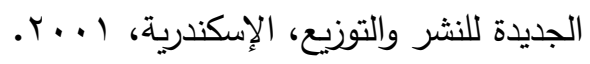
^. بير بورديو، التلفزيـون واليـات التلاعب بـالعقول، ترجمة وتقديم: درويش الحلوجي، دار

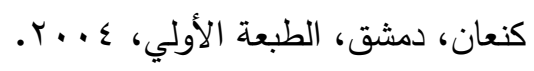
9. جلين ويسلون، سيكولوجية فنون الأداء، ترجمة: شاكر عبد الحميد، المجلة الوطنية للثقافة

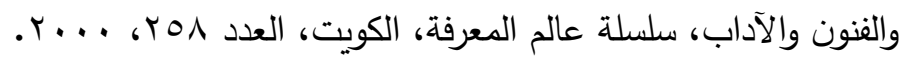

'- فهر عبد الرحمن الثميمري، التربية الإعلامية: كيف نتعامل مع الأعلام، مكتبة الملك فهر الوطنية

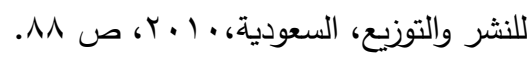


• ا • جمال حمح عبد الحي، مـذخل تـاريخي لنشـأة وتطور التلفـاز، مجلـة الأكاديميـة الأمريكية العربية للعلوم والتكنولوجيا، المجلد الثالث، العدد السابع، ب ا ـ ب.

ا ا. حسن عمـاد المكاوي، ليلي حسين السيد، الاتصـال ونظرياتـه المعاصـرة، الدار المصرية

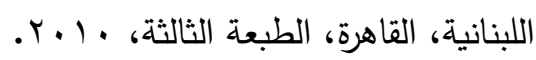

ץ ا.رانيا صـادق ممدوح، الإعـلان التلفزيـوني: التصـيم والإنتـاج، دار أسـامة للنشر والتوزيـ، عمـان،

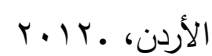

س ا. فهد عبد الرحمن الثميمري، التربية الإعلامية: كيف نتعامل مع الأعلام، مكتبة الملك فهد الوطنية

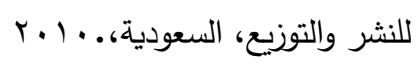

ع ا ـ مححد علي محح، تاريخ الاجتماع: الرواد والاتجاهـات المعاصرة، دار المعرفة الجامعية، الإسكندرية، $19 \wedge r$.

ه ا. مني سعيد الحديدي، سلوى إمام، الإعلان في التلفزيون المصري، مركز الجامعة، القاهرة، $19 \vee 7$.

ד ا ـ ميرفت الطرابيثـي، عبد العزيز السيد، نظريـات الاتصـال، دار النهضــة العربية، القـاهرة، Y.. T.

V V ا. هيثم منصسور عبد القادر، لغـة الجسـ في برامج الرسـوم المتحركـة: دراسـة تحليليـة في النسخة العربية من برنامج مغامرات عدنان، جامعة الشرق الأوسط، عمان، الأردن، با ـ.ץ.

\section{المراجع الأجنيية:}

1. Barnalis, Chetia." Rhetorical Devices in English Advertisement Texts in India: A descriptive Study', International Journal of Social Science and Humanity, Vol,5,No.11,2015.

2. Biook,Behna.Jafar, Zamanian "Gender and The Discourse of Advertising in English and Persian Magazine Advertisements" ,International Journal of Academic Research in Business and Social Science, Vol4, No.11,2014.

3. Black, J.Champion,D.;“' Methods and Issues in Social Research', John Wiley and Sons, New York,Inc,1976.

4. Daniluk, J." Infertility: Intrapersonal and Interpersonal Impact", Journal of Fertility and Sterility, Vol,49,Issue,6,1988.

5. David, R, Vinson." Superstitions In Medicine: Bad Luck Or Bad Logic?: Annals Of Emergency Medicine", Madigan Army Medical Center University of Washington Tacoma, WA,Vol,31, Issue,5,1998. 
6. Diplomova, Prace. Jana, Lapsanska." Adverting with The Concentration on The Linguistic Means and The Analysis of Advertising Slogans", Datum obhajoby, Bratislava, 2006.

7. Dominin, Umohi ."Superstition and Syncretism: Set Backs To Authentic Christian Practice in Africa", International Journal of Humanities and Social Science Invention, Vol,2, Issue, 7,2013.

8. Eman, Mosharafa." All You Need To Know About The Cultivation Theory", Global Journal Of Human Social Science: Arts and HumanitiesPsychology,Vol,15,Issue.8,2015.

9. Esther,Perel.M.A,Lmft." Erotic Fantasy Reconsidered: From Tragedy to Triumph', Spring,Vol,7,2011.

10. Fils, Henwood, Et al.."Turned On Or Turned Off?: Accessing health information on the Internet", Scandinavian Journal of Information Systems, Vol,14,Issue, 2,2002.

11. Forbes, G, B. Et al." Sexism Hostility Toward Women and Endorsement of Beauty Ideals and Practices: Are Beauty Ideals Associated with Oppressive Beliefs?", Journal of Sex Roles, Vol,56, 2007.

12. George, Gerbner. Et all." Living With Television: The Dynamic Of The Cultivation Process", in "Perspective on Media Effects",Jennings,Bryant. Dolfzillmann,Hillsdale( Edit), Journal Of Advertisting,Vol,16,Issue,3,1987.

13. George, W,Kisker. "The Disorganized Personality", University Of Cincinnati, Third Edition, 1983.

14. Gimlin,D,L." Body: Beauty and Self Image in American Culture", California, University of California Press,2002.

15. Hosney, M, Eldaly." Towards an Understanding of The Discourse of Advertising: Review of Research with Special Reference to The Egyptian Media", African Neblo, Issue,3,2011.

16. Hugo, Magnus." Superstition in Medicine", Translation By: Julius,L. Salinger, Punk., Wagnalls Company, New York and London,1908.

17. James, Shanahan. Michael, Morgan." Television and Its Viewers: Cultivation Theory and Research", The Press Syndicate Of The University Of Cambridge, 1999.

18. James, Wilson. Stan Leroy, Wilson." Mass Media and Mass Culture: An Introduction", Mc Graw- Hill Inc, U.S.A,1998.

19. Jane, L, Risen. "Believing What We Do Not Believe: Acquiescence To Superstitions Beliefs and Other Powerful Intuitions', American Psychological Association Journal, Vol,123,No,1.2016.

20. Jannifer, Reiling." Superstition in Medicine", American Association, Jama, Vol,295, No,1,2006.

21. Josefine, Bengtsson." The Power Of The Ideal Man: Exploring The Effects Of Using Him In Media", Springer, 2012.

22. Julia,Swannell." The Little Oxford Dictionary Of Current English", $6^{\text {Th }}$ Ed, Oxford, Oxford University Press, 1988.

23. Kaptan,S,S. "Advertising: New Concepts,", New Delhi, Sarup and Sons, 2002.

24. Katherine, Miller." Communication Theories: Perspectives Processes and Contexts", USA: McGraw- Hill INC,2002.

25. Kotler, Philip. Keller, Kevin. "Marketing Management", New Jersey, Person Prentice- Hall,2009. 
26. Lynee,Jamieson ."Intimacy Transformed: critical Look At The Pure Revolution", The Journal Of Sociology,Vol,33,No.3,1999.

27. Maria,Martinez ,Lirola. Jan, Chovanec." The Dream of Perfect Body Come True: Multimodality in Cosmetic Surgery Advertising", Journal of Discourse and Society, Vol,23,No,5,2012.

28. Michel, Morgan." Cultivation Analysis and Media Effects" In The Sage Hand Book Of Media Processes and Effects", Robin,L,Nabi.Mary, Beth.(Edit), Sage Publication,2009.

29. Michelle, Leigh, Grose." Individual Body Satisfaction and Perception: The Effect of Medias Ideal Body Image on Female College Students", Baylor University, in Partial Fulfillment of The Requirement for Degree of Master of Arts, 2009.

30. Micheal, Hardey." Doctor In The House: The Internet As A source Of Lay Health Knowledge and The Challenge To Expertise", Sociology Of Health and Illness', Vol,21, No,6,1999.

31. Nagwa, Elgazzar. "Reading Culture in Arab Television Advertising: A content Analysis of Egyptian Advertising", Faculty of Mass Communication, MISR International University Cairo- Egypt,2014.

32. Nancy, Ikaria." Mains Discourse of Advertising: Reference of Kiswahili and English Adverts in Kenyan Media", International Journal of Science and Research,Vol,3.Issue.11,2114.

33. Omer,Ozeri. "Cultivation Theory and Hegemony: A research From Turkey On Cultivation Role Of Television", The Journal Of Informatol44,Vol,3,2011.

34. Paual, Chambers" Television Medical Advertising", Journal Of Proc. Roy. Soc. Med, Vol,62,1969.

35. Reber,Bryan.Yahmim,Change" Assessing Cultivation Theory and Public Health Model For Crime Reporting, New Paper Research Journal,Vol,21, 2001.

36. Roland, Barthes." Rethorique de Image", in Communication, Vol,4,1964.

37. Running, Head ."Cultivation Theory: Growth Or Phenomenon?: Cultivation Theory since its Inception ", Sharany alakshmi Sudhakar, Word Press.

38. Rowland,R." A child at Any Price?", An Over View of Issue in The Studies in The New Reproductive Technologies and The Threat to Women", Women Studies International Fop am, Vol. 8, 1985.

39. Sarah, Tayer." Instagram: What Makes You Post?", Pepperdine Journal Of Communication Research, Vol,4, Issue,14,2016.

40. Scptt, Walter,D." The Psychology of Advertising: A simple Exposition of The Principle of Psychology in Their Relation to Successful Advertising", Boston, Small, Toronto, 1910.

41. Silbel, Akova." The Relationship Between Superstitions, Metaphors and Advertising", Journal Of Academic Marketing Mysticism,Vol,3,No,9,2011.

42. Shinichi,Saito "Television and The Cultivation Of G ender- Role Attitude In Japan :Dose Television Contribute To The Maintenance Of The Status Quo? Journal Of Communcation, Vol,57,2007.

43. Shrum,L,J." A process Model Of Consumer Cultivation: The Role Of Television is A function Of The Type Of Judgment", Journal Of Communcation, Vol,29, No,20.2004. 
44. Walim,James,Potter." Critical Analysis Of Cultivation Theory", Journal Of Communication, Vol,64,Issue,6,2014.

45. Widge,A." Socio culture Attitudes Toward Infertility and Assisted Reproduction in India", in VAYENA, E. et al( editor), " Current Practices and Controversies in Assisted Reproduction: "Medical, Ethical and Social Aspects of Assisted Reproduction" WHO Headquarters in Geneva, Switzerland, 2011.

46. Wright,C, Mills." The Power Elite", Oxford University: London, 1969. 


\section{ملحق الدراسة}

استـمارة استبيان

ن

دور الإعلانات التلفزيونية في نشر الخرافات الطبية

إعداد

د. هممد كمال احمد حسن

بيانات هذه الاستمارة سرية ولن تستذام إلا في أغراض البحث العلمي 
المحور الأول: البيانات الأساسية:

$$
\text { 1- الاسم (اختيارى): . }
$$

أنثى ） ( )

$$
\begin{aligned}
& \text { ذكر ( ) } \\
& \text { r- النوع: }
\end{aligned}
$$

………............

مسيحي

( )

مسلم

r- السن: .

(
ابتائي
يقرأ ويكتب ( )
ه- المستوي التعليمي:
ثانوي ( )
إعدادي ( )
دراسات عليا ( )
جامعي ( )
( ) لاعمل
اعمل ( )
צ- الحالة المهنية:
حضر ( ) ( )
ريف ( )
V- الموطن الأصلي:

^- كم عدد مرات شرائك لهذه المنتجات الطبية المقدمة من خلال هذه الإعلانات:

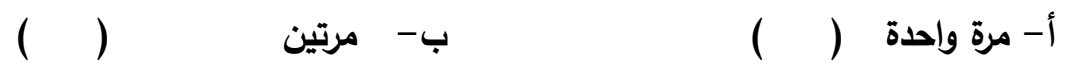

$$
\begin{aligned}
& \text { د أربع مرات } \\
& \text { ج- ثلاث مرات ( ( ) ( ) }
\end{aligned}
$$

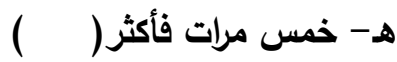

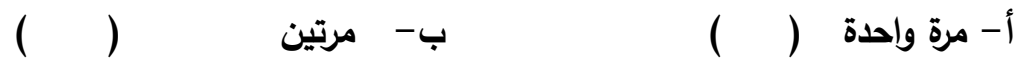

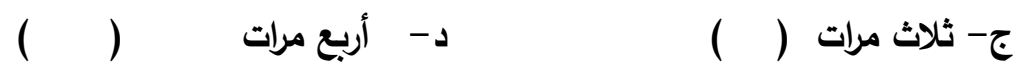

المحور الثاني: أسباب استخام هذا النوع من المنتجات:

ـ - لماذا تستخدم هذا النوع من المنتجات؟

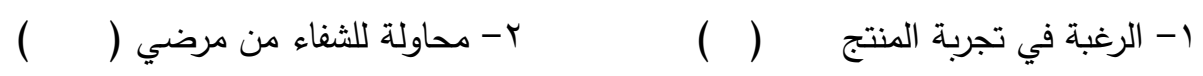


ع- التخفيف من حدة الألم

ب- فثل أدوية الأطباء ( )

o - أخري تذكر

1 - ما هو أكثر شيء قدم في الإعلان جعلك تعتقد في مصداقيته؟ r- (الأطباء التي تعلن عن

1- حالات الثفاء التي تقدم في الإعلان ( ) ( )

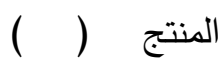

ع - وجود ضمان للمنتج ( )

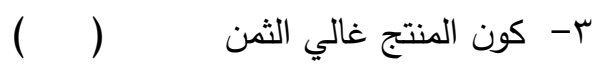

ه- أخري تذكر

المحور الثالث: أنماط المنتجات الطبية المستخدمة: r ا - ما هي أكثر المنتجات الطبية التي قت بثرائها تأثرا بما قدم عبر الإعلانات

التلفزيونية؟

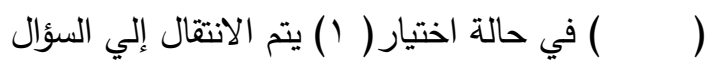

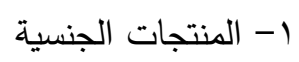

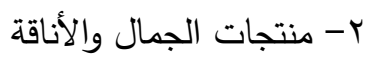

رقم (T) - (1) - (1).

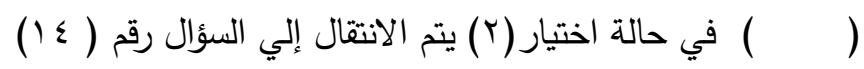

r- منتجات العلاج من الأمراض في حالة اختيار (r) يتم الانتقال إلي السؤال

$$
\text { رقم(10) - (10). }
$$

ع- أخري تذكر

rا - ما هي أهم هذه المنتجات الجنسية؟

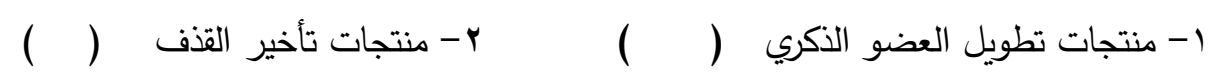

ع - منتجات زيادة النشوة

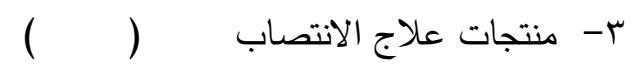

الجنسية ( ) ( )

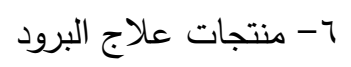

ه- منتجات علاج التسرب الوريدي ( ) ( )

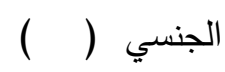

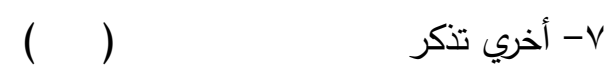


؛ ا - ما هي أهم منتجات الجمال التي قمت بشرائها؟

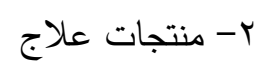

1- منتجات علاج تساقط الثعر ( )

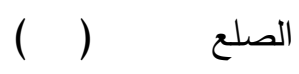

ـ - منتجات تفنيح الأماكن

r- منتجات تطويل وفرد الثعر ( ) ( )

الداكنة ( )

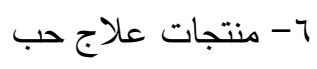

0- منتجات التخسيس ( ) ( )

الثباب ( )

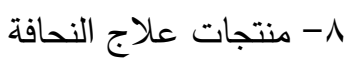

V- منتجات نضارة البشرة ( ) ( )

( )

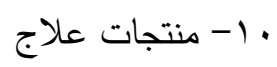

9- منتجات تكبير وتصغير الثذي ( )

( ) التجاعيد

( ) أخري تذكر

10

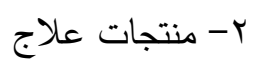

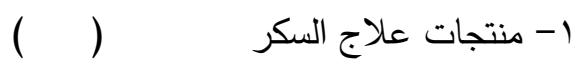

القولون ( ) ( )

ع - منتجات علاج العمود

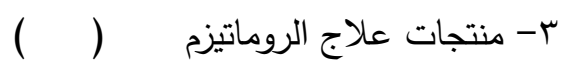

الفقري ( )

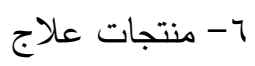

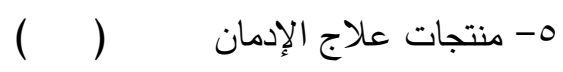

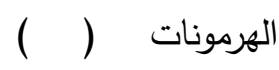

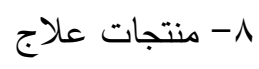

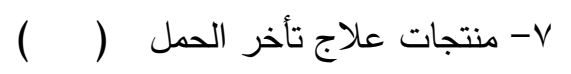

خشونة الركبة ( ) منتجات علاج

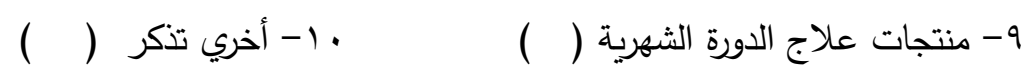

المحور الرابع: الأثر الطبي الناتج عن استخدام تلك المنتجات:

11 - هل شعرت بتحسن بعد استخد/مك المنتج؟ 


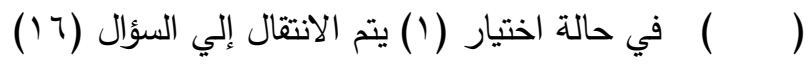

ن-1

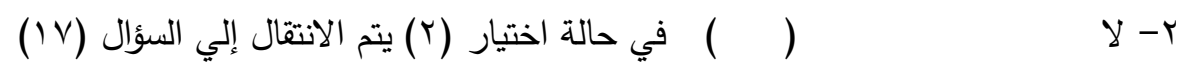

IV

r- تم الشفاء من المرض

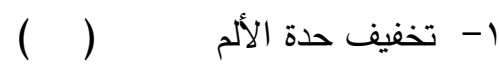

$(\quad)$

ع- أخري تذكر

r- الحد من تدهور الحالة ( ) ( )

$($ )

1 ا - ما هي أهم مظاهر الانتكاسة؟

r- توقف بعض الوظائف

1- تدهور الحالة الصحية ( ) ( )

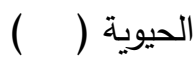

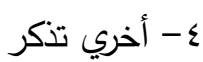

r- عدم القدرة علي القيام بالأنشطة الحياتية ( )

( )

9 ا 19

$\gamma-r$

( )

- 1- نعم 


\title{
Lexical Analysis of Obama's and Hillary Clinton's Political Speeches about the Arab Spring
}

\author{
By \\ Mai Ashraf Hussein Sayed \\ A researcher, Faculty of Arts, Fayoum \\ University
}




\section{$\underline{\text { Abstract }}$}

This study aims at highlighting the major role played by lexical analysis in conveying certain ideological messages in the political speeches of Obama and Hillary Clinton about the Arab Spring. The sample consists of five political speeches, three belong to Obama and two belong to Clinton. The speeches were collected from the period (February-November, 2011). Relying on Van Dijk's socio-cognitive approach which gives particular significance to lexical analysis, the study is to look into the use of metaphor and metonymy in the selected speeches. The findings of this study revealed that both Obama and Hillary Clinton have used the two selected linguistic devices in order to achieve their ideological goals and convince the listeners of their thoughts. The most important ideas which they try to stress, through the use of these devices, are that America is the hero who has made a great effort and has cooperated with other partners to secure the Arab citizens from the atrocities of their leaders and that the Arab leaders are dictators. Also, they want to confirm that America is the leader and hence all the Arab countries should follow it.

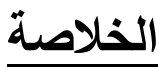

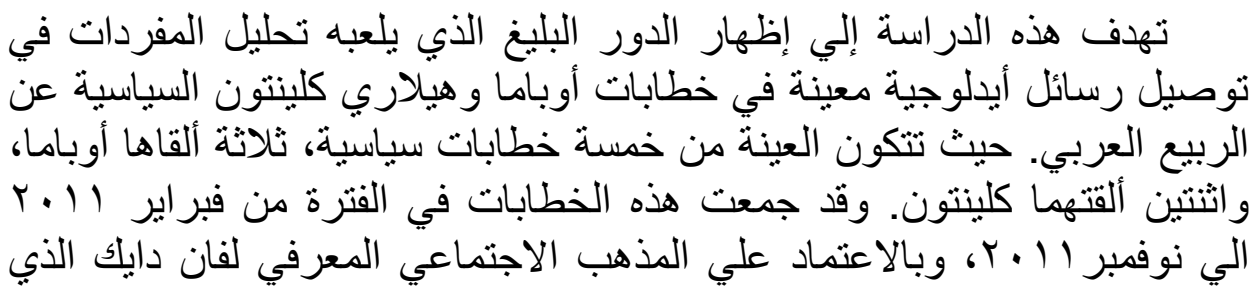


يهنم اهتماما كبير ا بتحليل المفردات تفحص هذه الدراسة استخدام الاستعارة

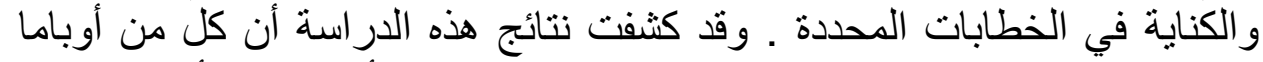

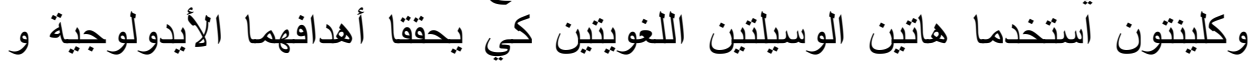

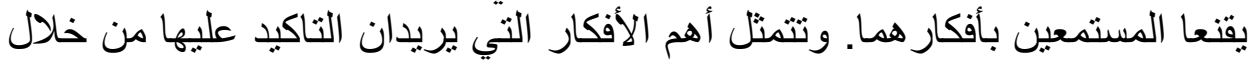

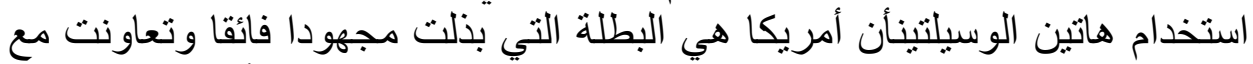

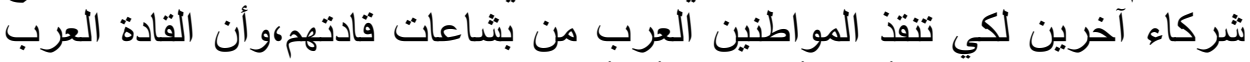

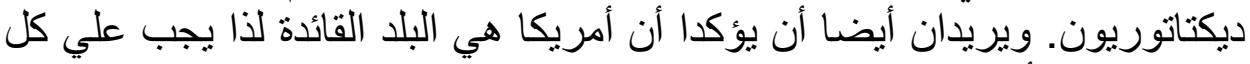

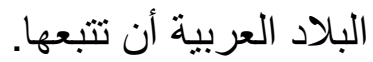

\section{Introduction}

This paper starts by theoretically introducing lexical analysis; its definition, its importance, and the names of some rhetorical devices which this analysis can be applied through. Then, it highlights the two devices that have been chosen for the analysis. Each device is accompanied by a theoretical overview which presents the definition, the significance, and general examples. This overview is followed by some examples from Obama and Hillary Clinton's political speeches. After the examples, there is a quantitative account of the purposes of the selected rhetorical devices. Finally, there is a conclusion of the two linguistic devices chosen for the analysis.

Lexical analysis can be defined, according to Patrick Hanks (2013), as a wide examination of word use and meaning in a text. Hanks (2013) argues that words have "meaning potentials" (p.73), and "these potentials are activated when the words are used" (p.73). He adds that the meaning of a word is determined by its context. As for the importance of lexical analysis, Hanks (2013) suggests that lexical analysis helps people "better understand how words go together in collocational constructions to make meanings" (p.7). Thus, lexical analysis plays a central role in distinguishing one text from the other one. In addition, according 
to Sayed (2009), what makes the study of lexical items quiet essential is the fact that it is through words that a speaker is able to convey his own messages which are the aim of a given discourse. Thus, the researcher found it essential to handle this linguistic phenomenon.

There are some figures of speech which are most relevant to the lexical analysis of a text. These figures are metaphor, simile, hyperbole, irony and metonymy (Hanks, 2013).Metaphor and metonymy have been chosen for the analysis.

\section{Metaphor: A Theoretical Overview}

Metaphor can be defined as figure of speech which involves making an implicit comparison between two unrelated things but they share some common characteristics (Ferraro\& Briody, 2017). Developing a comparison in a metaphor does not include using 'like' or 'as' (Corbett, 2013). For example, 'Ahmed is a lion'. The word 'lion' which is applied to an animal is here attributed to a person. What is meant here is that the characteristics of the lion which include strength, bravery and control are attributed to Ahmed. George Lakoff and Mark Johnson (1980) define metaphor in a simpler way and point out that "the essence of metaphor is understanding and experiencing one kind of thing in terms of another." (p.5). Thompson (2004) gives a clear example of metaphor in which the words 'crippled' and 'burden' are used metaphorically: "The north is crippled with the burden of the industrial revolution to an extent that the south hardly begins to understand." (p.220). The literal meaning of the word 'crippled' is 'disabled' like, for example, ' a crippled child' whereas 'burden' literally means 'something heavy'. Therefore, the interpretation of the sentence above into a metaphorical language might be: " The north is in a difficult situation because of the effects of the 
industrial revolution." (p. 221). Consequently, metaphor involves two meanings: literal and figurative. The literal meaning is imperfect, but the figurative one creates a beautiful image and provides us with the intended meaning and the effect which the speaker desires. Livingstone and Harrison (1981) see that metaphors "serve the dual purpose of remedying some temporary imperfection of literal language and providing imaginative and entertaining verbal puzzles" (p.95)

Lesz (2011) views that metaphor is inevitable when we speak about our emotions, experiences, and beliefs. Moreover, Lakoff\& Johnson (1980) assert that metaphor pervades everyday language. This means that it is present in most texts like newspapers, conversations and political speeches. They contend that:

Metaphor is pervasive in everyday life, not just in language but in thought and action ... Our concepts structure what we perceive, how we get around in the world, and how we relate to other people (p.3).

Using metaphor in political speeches is of a great importance for the political speaker. Charteris-Black (2004) argues that "metaphors are chosen by speakers to achieve particular communication goals within particular contexts rather than being predetermined by bodily experience" (p.247). In other words, political speakers use metaphor in political speeches to legitimate their policies and agendas in front of their listeners. In his works written in 1991 and 2003, Lakoff wants to stress the idea that political figures use metaphors to justify what they say in order to win the public consensus. This idea accounts for the use of metaphor in Obama's and Clinton's speeches where they try to justify their policies in front of the Arab citizens in order to influence the citizens' opinions and thoughts. 
Lakoff (1991) states some metaphor systems which are used to understand international politics. The first system is called 'The State-as-Person System' in which a state is conceptualized as a human being "engaging in social relations within a world community ... It lives in a neighborhood, and has neighbors, friends and enemies ... Well-being is wealth ... Strength for a state is military strength" (p.3).This system was introduced by Lakoff during the first Gulf war to analyze the role of metaphor in political discourse. He indicates that the idea of personifying the State-as-Person has the advantage of linking the ordinary citizen's well-being and economic state with those of the State. This connection makes the citizen need to strengthen his ties with the State in order to preserve his needs.

It is worthy of note that the researcher started with this system and found that it was able to convey all the important messages in the speeches of Obama and Clinton, so there is no need to study other systems of metaphor.

\section{Examples of the Use of The State-as-Person System of Metaphor from Obama's Political Speeches:}

Obama makes use of the State-as-Person system in order to personify America to stir the emotions of his listeners. To reassure the listeners that America respects the Tunisian citizens and supports the transition to democracy in Tunisia, the President personifies America in his remarks on the Middle East and North Africa on $19^{\text {th }}$ May, 2011:

We have the chance to show that America values the dignity of the street vendor in Tunisia more than the raw power of the dictator. There must be no doubt that the United States of America welcomes change 
that advances self-determination and opportunity (the second speech of Obama, para.20).

In the above quotation, Obama represents America as a person who has the ability to value the dignity of the people and who welcomes change in Tunisia. This personification conveys the intended message of this quotation which is praising America's democratic regime. Personifying America in this way has a profound psychological effect on the Tunisian listeners as they find themselves love America, appreciate it and accept whatever it does. In addition, the Tunisian people feel that they have supporters represented in America and that America encourages the Tunisian revolution. That metaphor also means that American people have sympathy for Tunisian people as if they are one entity.

In the same speech, he personifies America as a person who is interested in solving the Arab world's problems represented in stopping terrorism and securing the Arab citizens from violence to show America's leading role. This metaphor aims at showing the key role of America:

For decades, the United States has pursued a set of core interests in the region: countering terrorism... and safe-guarding the security of the region... We will continue to do these things, with the firm belief that America's interests are not hostile to people's hopes; they're essential to them (the second speech of Obama, para.16).

In addition, the President makes use of metaphor, in the same speech, by depicting America as a person who respects the rights of the Arab citizens in order to praise America's democratic regime. This is the main aim of this quotationand it also shows 
America's preference for getting rights and its respect to people who seek to get their rights in a peaceful way:

Let me be clear, America respects the right of all peaceful and law-abiding voices to be heard, even if we disagree with them (the second speech of Obama, para.40).

Obama again confirms America's support for democracy in the Arab countries in the same speech by personifying America as a person who supports democracy and wants to achieve it in the Arab region so as to show America's central role. This is the purpose of this quotation and it shows indirectly to what extent America is a democratic country:

America's support for democracy will therefore be based on ensuring financial stability, promoting reform, and integrating competitive markets with each other and the global economy. And we're going to start with Tunisia and Egypt (the second speech of Obama, para.47).

In addition, he stresses the idea of supporting nations that seek democracy by using the same metaphor in the same speech to assert America's fundamental role:

Moreover, the United States will continue to support those nations that transition to democracy — with greater trade and investment - so that freedom is followed by opportunity (the third speech of Obama, para.28).

Another example out of the various examples of metaphor in which Obama personifies The United States of America is in his address to the United Nations General Assembly on $21^{\text {st }}$ September, 2011. In the next quotation, the President embodies America as a person who is pleased with the freedom of Libya from the tyranny 
of Gaddafi. Thus, America is reopening its embassy in Tripoli. This metaphor illustrates that America supports political relationships between itself and Libya. The main purpose of this metaphor is to show America's significant role:

From Tripoli to Misurata to Benghazi - today, Libya is free. Yesterday, the leaders of a new Libya took their rightful place beside us, and this week, the United States is reopening our embassy in Tripoli (the third speech of Obama, para.19).

Moreover, in the subsequent quotation, the President depicts The United States of America as a person who has the ability to impose sanctions on Syria's leaders and has some allies to cooperate with in the hard effort. In addition, it supports the Syrian people. Personifying America in this way has a deep psychological effect on the Syrian people as they find themselves trust America and its effort to rescue them from Bashar Al-Asad. This quotation aims at encouraging people to continue the revolution in addition to showing America's role. The message here is that America does its best for the sake of Syria and that it has the ability as well as the authority to impose sanctions on Syria's leaders. Therefore, America has a unique ability and it is the leader of all countries. Furthermore, the United Nations Security Council is personified as a person who can sanction the Syrian regime and support the Syrian people:

Already, the United States has imposed strong sanctions on Syria's leaders. We supported a transfer of power that is responsive to the Syrian people. And many of our allies have joined in this effort. But for the sake of Syria - and the peace and security of the world - we must speak with one voice. There's no excuse for inaction. Now is the time for the United 
Nations Security Council to sanction the Syrian regime, and to stand with the Syrian people (the third speech of Obama, para.24).

Also, Obama asserts the idea that America has some allies and partners to cooperate with in his speech about Libya on $28^{\text {th }}$ March, 2011. This metaphor shows that America has strong relationships with the other countries and it plays an essentialrole:

In this effort, the United States has not acted alone. Instead, we have been joined by a strong and growing coalition. This includes our closest allies - nations like the United Kingdom, France, Canada, Denmark, Norway, Italy, Spain, Greece, and Turkey - all of whom have fought by our side for decades (the first speech of Obama, para.14).

In the same speech, the President shows America's social relationships in addition to its role:

To summarize, then: in just one month, the United States has worked with our international partners to mobilize a broad coalition, secure an international mandate to protect civilians, stop an advancing army, prevent a massacre, and establish a No Fly Zone with our allies and partners (the first speech of Obama, para.15).

In the subsequent quotation, Obama uses the system of the State-as-Person to personify America to stir the emotions of his listeners. The main purpose of this quotation is to encourage people to work or to continue the revolutions in addition to showing America's positive role:

Throughout the region, we will have to respond to the calls for change. In Yemen, men, women and children gather by the thousands in towns and city squares every day with the hope that their determination and spilled blood will prevail over a 
corrupt system. America supports those aspirations. We must work with Yemen's neighbors and our partners around the world to seek a path that allows for a peaceful transition of power from President Saleh, and a movement to free and fair elections as soon as possible (the third speech of Obama, para.25).

In the above quotation, Obama reassures the listeners that America will respond to the call of the Arab citizens for defending them and protecting them from violence and cruelty of their leaders. This shows that America is a democratic country which supports the weak citizens and it is against unjust leaders. In addition, Obama confirms America's support to the Yemen people's aspirations by personifying America as a person who has partners to work with for achieving the Yemen people's dreams represented in getting rid of corruption, President Saleh, and a movement to free and fair elections.

Furthermore, Obama, in the subsequent quotation, embodies America as a person who has friends among whom is Bahrain. He describes America as a devoted friend who helps her friends in their difficult situations and behaves for the sake of those friends. This personification has a deep effect on Bahrainis as it persuades them that America stands with them in their revolution. This metaphor also illustrates the idea that America seeks peace, not war, and likes making friendships. The main purpose of this quotation is to show America's strong relationships in addition to its role:

America is a close friend of Bahrain, and we will continue to call on the government and the main opposition bloc — the Wifaq — to pursue a meaningful dialogue that brings peaceful change that 
is responsive to the people (the third speech of Obama, para.26).

The President again depicts the United States of America as a friend to nations who seek freedom in his speech about Libya on 28 March, 2011. The following metaphor also shows that America allows its citizens to have freedom. The main purpose of this quotation is to praise America's democratic regime:

Because wherever people long to be free, they will find a friend in the United States. Ultimately, it is that faith - those ideals - that are the true measure of American leadership (the first speech of Obama, para.41).

In addition, he represents America as a leader who has responsibility towards nations that suffer from the atrocities of their leaders. This metaphor shows that America is the leader and the Arab countries are the ones that follow her. It also shows America's crucial role:

To brush aside America's responsibility as a leader and - more profoundly - our responsibilities to our fellow human beings under such circumstances would have been a betrayal of who we are (the first speech of Obama, para.25).

\section{Examples of the Use of The State-as-Person System of} Metaphor from Clinton's Political Speeches:

It is notable that Hillary Clinton goes on the same line taken by Obama where she tries to make use of the system of the Stateas-Person. Shepersonifies America by attributing such human description like having friends and partners, having interests, helping the others and so on. Therefore, in her Keynote Address at the National Democratic Institute's 2011 Democracy Awards Dinner on $7^{\text {th }}$ November, 2011, she 
embodies America as a person who helps the Syrian people to get their rights. The main purpose of this quotation is to praise the American citizens represented in the ambassador in order to show how far they suffered for the sake of the Syrian people:

When our Ambassador to Syria was mobbed, assaulted, and threatened, just for meeting with peaceful protestors, he put his personal safety on the line to let the Syrian people know that America stands with them (the second speech of Clinton, para.6).

Also, in the following quotation, she describes America as a person that people call for help to solve their problems and a person who has a role to play. Personifying America in this way means that it is a wise and trusted country to the extent that it has the ability to solve people's problems. This personification also means that America is an indispensable country in the days of the Arab revolutions as it is the one that can help the Arab citizens solve their problems. The main purpose of this quotation is to praise America:

I've heard people asking America to solve all their problems and others wondering whether we have any role to play at all (the second speech of Clinton, para.7).

Furthermore, in the subsequent quotation, the Secretary of State personifies America so as to stir the emotions of the listeners and show America's leading role:

Now, America did push for reform, but often not hard enough or publicly enough. And today, we recognize that the real choice is between reform and unrest (the second speech of Clinton, para.12).

In the above quotation, Clinton represents America as a person who works for and supports reform in the Arab countries and 
hence refuses instability. Thus, America is the country of reform and it seeks reform by action not just saying.

Moreover, in the next quotation, she describes America as a person who has complex interests and has a friend. This metaphor shows America's friendly relationships in addition to its role:

As a country with many complex interests, we'll always have to walk and chew gum at the same time. That is our challenge in a country like Bahrain, which has been America's close friend and partner for decades (the second speech of Clinton, para.21).

Furthermore, using the adjective 'complex' as well as the phrase ' walk and chew gum' in the above quotation, means that America has a great task to do. Furthermore, by using metaphor to personify America as a person who has a friend, Clinton repeats Obama's metaphor which is mentioned before.

Also, she confirms the idea that America has partners whomit motivates to achieve reform in the Arab region. Furthermore, the Secretary of State indicates that the past leaders were better than the present ones and hence she dispraises indirectly the present leaders of the Arab countries. This metaphor aims at encouraging partners to reform in addition to showing America's role:

Fundamentally, there is a right side of history. And we want to be on it. And-without exception-we want our partners in the region to reform so that they are on it as well (the second speech of Clinton, para.23).

Moreover, she uses the same metaphor that was used by Obama in which she personifies America as a person who respects the rights of the others and prefers democracy as well 
as freedom, so it works for achieving them. In addition, she indicates the idea that America likes good and hates evil. This personification makes the Tunisian listeners respect America.Thus, metaphor is employed by politicians to achieve their ideological goals. This quotation shows America's friendly relationships with Tunisia in addition to America's vital role:

In Tunisia, an Islamist party has just won a plurality of the votes in an open, competitive election. Its leaders have promised to embrace freedom of religion and full rights for women. To write a constitution and govern, they will have to persuade secular parties to work with them.

And as they do, America will work with them, too, because we share the desire to see a Tunisian democracy emerge that delivers for its citizens and because America respects the right of the Tunisian people to choose their own leaders (the second speech of Clinton, para.28).

In addition, Clinton uses metaphor, in her remarks about Internet Rights and Wrongs: Choices \& Challenges in a Networked World on $15^{\text {th }}$ February, 2011, to personify America as a person who motivates other nations to exercise the freedom of connecting. Personifying America in this way aims at representing America in a favorable picture as it is the country which supports freedom and wants other nations to enjoy it. Moreover, she confirms the idea that America keeps up with modern technology represented in the internet and calls for using it throughout the Arab region. The main purpose of this quotation is to show America's role:

Together, the freedoms of expression, assembly, and association online comprise what I've called the freedom to connect. The United States supports this freedom for people 
everywhere, and we have called on other nations to do the same (the first speech of Clinton, para.13).

Moreover, in the same speech, she uses metaphor to personify America as a brave, strong person who has the ability to deter criminals and terrorists online. This personification also represents America in a remarkable picture and illustrates that it refuses terrorism and it plays a major role to stop it online. Consequently, the purpose of this quotation is to show America's key role:

The United States is aggressively tracking and deterring criminals and terrorists online (the first speech of Clinton, para.21).

To stress the positive image of America, Clinton embodies it as a person who helps other nations to apply laws in order to be stable so as to show America's leadingrole. By using this metaphor, the secretary of State confirms Obama's idea that America is superior to the Arab countries and the whole world and it does them a favor:

The United States Government invests in helping other nations build their own law enforcement capacity (the first speech of Clinton, para.21).

She also adds that America intends to get rid of all criminal activities online and offline and it respects laws and values. The main purpose of this quotation is to show America's role:

The United States is determined to stop terrorism and criminal activity online and offline, and in both spheres we are committed to pursuing these goals in accordance with our laws and values (the first speech of Clinton, para.22).

\section{A Quantitative Account of the purposes of using metaphor in the selected speeches \\ Table 1}




\begin{tabular}{|l|l|l|l|l|}
\hline The purposes of using & \multicolumn{2}{|l|}{ Obama's Speeches } & \multicolumn{2}{l|}{ Clinton's Speeches } \\
\cline { 2 - 5 } metaphor & Frequency & Percentage & Frequency & Percentage \\
\hline $\begin{array}{l}\text { 1-showing America's } \\
\text { vital role }\end{array}$ & 5 & 38.4 & 5 & 50 \\
\hline $\begin{array}{l}\text { 2-showing America's } \\
\text { strong relationships in } \\
\text { addition to its role }\end{array}$ & 3 & 23.1 & 2 & 20 \\
\hline $\begin{array}{l}\text { 3-encouraging } \\
\text { peopletocontinue the } \\
\text { revolutions and } \\
\text { emphasizing } \\
\text { America's role }\end{array}$ & 2 & 15.4 & 1 & 10 \\
\hline $\begin{array}{l}\text { 4-praising America's } \\
\text { democratic regime or } \\
\text { the American citizens }\end{array}$ & 3 & 23.1 & 2 & 20 \\
\hline
\end{tabular}

From table 1, it is obvious that the total number of the examples of metaphor taken from Obama's speeches are thirteen, five out of them are used to show America's important role and three examples are used to show America's good relationships in addition to its role while two examples are used to encourage people to continue the revolutions. Finally, only three examples are used to praise America's democratic regime.

On the other hand, the total number of examples of metaphor taken from Clinton's speeches are ten, five out of them are used to show America's vital role while two examples are used to show America's social relationships in addition to its role, one example is used to encourage people to continue the revolutions, but two examples are used to praise America or the American citizens.

Thus, it can be concluded that both Obama and Clinton used metaphor for the purpose of showing America's key role for the sake of the Arab citizens during the days of the Arab Spring more than the other purposes. The purpose of showing 
America's crucial role had the first rank with $38.4 \%$ and 50\% while the purposes of showing America's good relations in addition to its role and praising America's democratic regime had the second rank with $23.1 \%$ and $20 \%$. The purpose of encouraging people to work had the third rank with $15.4 \%$ and $10 \%$.

To conclude, both Obama and Clinton want to confirm that America is the leader of the Arab countries and the whole world. It is the one who has the authority to impose sanctions and the one who can help the other countries. Moreover, it is a strong country which did the Arab countries a favor during the revolutions. Also, it is a democratic country and it has strong relationships with the other countries, so it is a good example which should be followed.

\section{2- Metonymy: A Theoretical Overview}

Metonymy can be defined, according to Hanks (2013), as "a figure of speech in which, instead of using a word, a speaker uses a word that denotes something associated with the thing meant" (p.226). It is obvious from this definition that the basic concepts of metonymy are 'substitution' and 'association'. For Gunter Radden\& Klaus-Uwe Panther (1999), metonymy includes "the substitution of the name of one thing for that of another thing" (p.17). In other words, we use metonymy when an idea or a concept is replaced by a single word or feature that is connected to it. Lakoff\& Johnson (1980) see that metonymy, like metaphor, is an important part of our everyday life as it is present in our thoughts and actions. They give an example of metonymy which is "She's just a pretty face" (p.18). In this 
sentence, we drive the basic information about a girl or a woman from her face. According to Panther\& Radden (1999), this sentence is "assumed to mean 'she is just a pretty woman', but this sentence does not mean that she is pretty 'all over'. It suggests that, most importantly, she has a pretty face" (p. 18). They argue that "metonymy does not simply substitute one entity for another entity, but interrelates them to form a new meaning" (p.19).

Actually, in our culture, we get the basic information about what the person is like when we look at his/her face. Lakoff\& Johnson(1980) stress this point and suggest that when we look at a person's picture, the most important part in the picture is the person's face. This is because through the face we can see what he looks like. However, when we see the picture of the body without the face, this sounds strange. Thus, metonymy is an essential way of thinking about people.

As for the importance of metonymy in political discourse, Van Dijk (1997) contends that metonymy and metaphor are used in political language in order to "follow the overall goals of positive self-presentation and negative other-presentation' (p.36). This strategy is based on the idea that our people and actions are described in positive associations whereas our political opponents are described in negative ones. The example which Van Dijk gives concerning this strategy is the characterization of our soldiers or politicians as good animals such as lions or tigers while representing the others as dirty animals like rats or dogs.

It is worthy of note that the metonymic strategy which the researcher has used is what Panther\& Radden (1999) called 
"salient characteristic for person" (P. 215). The idea of this strategy is that we refer to the person by mentioning some of his qualities to draw the audience attention to them. This strategy is suitable in this study as Obama and Clinton refer to the Arab leaders through some noun phrases that refer to their characteristics.

\section{Examples of the Use of Metonymy from Obama's Political}

\section{Speeches}

Obamamakes use of the rhetorical strategy of metonymy to present other people in a negative image. He tries to blacken the Arab leaders and their regime by attributing an ugly picture to them. He uses the linguistic device of metonymy, in his remarks to the United Nations General Assembly on $21^{\text {st }}$ September, 2011, to reinforce the picture of the Arab leaders as 'dictators' who used violence against their people and suppressed their people' hopes. He describes the leaders of the Arab countries and their regime by using the words 'corruption', 'tyranny', dictators', and 'dictatorship' to reveal their atrocities. These words served as metonymies for the bad rule of the Arab leaders and to what extent the Arab citizens suffered from injustice and violence of their leaders. They also refer to Obama's refusal of the Arab leaders' atrocities. The main purpose of the subsequent quotation is to blacken the Arab leaders' reputation and expose their drawbacks:

The humiliating grip of corruption and tyranny is being pried open. Dictators are on notice. Technology is putting power into the hands of the people. The youth are delivering a powerful rebuke to dictatorship, and rejecting the lie that 
some races, some peoples, some religions, some ethnicities do not desire democracy (the third speech of Obama, para.21).

Obama also refers to the president of Tunisia in the same speech by using the phrase ' the rule of an iron fist' to refer to injustice and suppression. Also, this quotation aims at showing America's sympathy with the Arab citizens:

One year ago, the hopes of the people of Tunisia were suppressed. But they chose the dignity of peaceful protest over the rule of an iron fist (the third speech of Obama, para. 16).

In the same speech, he makes use of the metonymies 'dictator' and 'tyranny' instead of the President's name to refer to the President of Libya as well as its dictatorship. So, the main purpose of this quotation is to blacken the Arab leaders' reputation and reveal their inhumanity:

One year ago, the people of Libya were ruled by the world's longest-serving dictator (the third speech of Obama, para.18).

Obama praises the Libyan people's determination to fulfill their revolution and get rid of their presidentin the same speech:

In the months that followed, the will of the coalition proved unbreakable, and the will of the Libyan people could not be denied. Forty-two years of tyranny was ended in six months (the third speech of Obama, para.19).

He makes use of metonymy to attribute such inhuman description like 'The humiliating grip of corruption and tyranny/ dictators/ dictatorship/ the rule of an iron fist/ the world's longest-serving dictator/Forty-two years of tyranny' to the Arab leaders. 
Furthermore, in his speech about Libya on $28^{\text {th }}$ March, 2011, the President refers to Moammar Gaddafi by using the noun 'dictator'. However, the main purpose of this quotation is to show America's essential role and its effective turn:

Because while our military mission is narrowly focused on saving lives, we continue to pursue the broader goal of a Libya that belongs not to a dictator, but to its people (the first speech of Obama, para.21).

Also, in the same speech about Libya, Obama mentions one Libyan's reference to Gaddafi by using the metonymy 'nightmare'. It is a metonymy for social, economic and political injustice and suppression. Therefore, the main purpose of this quotation is to blacken the Libyan President's reputation and reveal his brutality:

As one Libyan said, "For the first time we finally have hope that our nightmare of 40 years will soon be over." (the first speech of Obama, para.6)

Moreover, in his remarks on the Middle East and North Africa on $19^{\text {th }}$ May, 2011, Obama makes use of the metonymy 'dictator' to refer to the President of Tunisia. The main purpose of this quotation is to praise the Arab citizens' determination:

Hundreds of protesters took to the streets, then thousands. And in the face of batons and sometimes bullets, they refused to go home -- day after day, week after week -- until a dictator of more than two decades finally left power (the second speech of Obama, para.8).

Again, he refers to the Tunisian president in the next quotation. However,its main purpose is to show America's central role: 
We have the chance to show that America values the dignity of the street vendor in Tunisia more than the raw power of the dictator (the second speech of Obama, para.20).

In the same speech, he uses the noun 'tyranny' to refer to the Arab leaders as well as their atrocities and hence blacken their reputation and expose their atrocities:

It's the same kind of humiliation that takes place every day in many parts of the world -- the relentless tyranny of governments that deny their citizens dignity (the second speech of Obama, para.7).

Furthermore, the president in the same speech makes use of metonymy to refer to the Arab leaders and their brutality. Also, he wants to show America's feeling sympathy for the Arab citizens:

Across the region, those rights that we take for granted are being claimed with joy by those who are prying loose the grip of an iron fist (the second speech of Obama, para.67).

Examples of the Use of Metonymy from Clinton's Political

\section{Speeches}

Clinton utilizes the same device of metonymy that is employed by Obama in order to blacken the Arab leaders and their regime by attributing an inhuman description to them. Therefore, in herKeynote Address at the National Democratic Institute's 2011 Democracy Awards Dinner on $7^{\text {th }}$ November, she reinforces the picture of the Arab Presidents as 'dictators' and 'autocrats' who oblige their citizens to accept their rule. Thus, this quotation aims at exposing the Arab leaders' atrocities: 
We begin by rejecting the false choice between progress and stability. For years, dictators told their people they had to accept the autocrats they knew to avoid the extremists they feared (the second speech of Clinton, para.12).

In addition, in the following quotation, she refers to the Arab citizens by the phrase ' the demand for change' and also to the Arab leaders by the phrase ' the refusal to change'. She wants to assert the idea that the reason for the revolutions in the region is the Arab leaders themselves and their cruel regime and also that the Arab citizens just demand their rights. Using the noun phrase 'the demand' is a metonymy for the legitimacy of the Arab revolutions as the Arab citizens just demand their legitimate rights. However, using the noun 'the refusal' is a metonymy for the Arab leaders' stubbornness. So, this quotation aims at defending the Arab citizens:

The truth is that the greatest single source of instability in today's Middle East is not the demand for change. It is the refusal to change (the second speech of Clinton, para.14).

In the same speech, she shows America's sympathy with the Arab citizens:

Free, fair, and meaningful elections are essential-but they are not enough if they bring new autocrats to power or disenfranchise minorities (the second speech of Clinton, para. 18).

In the above quotation, Clinton refers to the Arab leaders by the noun 'autocrats', but she refers to the Arab citizens by using the noun phrase ' disenfranchise minorities'. Using these metonymies summarizes the conditions in the Arab world, that is, the Arab leaders are unjust and tyrant, but the citizens of the Arab countries are helpless in front of the tyranny of their leaders. 
Again, she refers to the Arab leaders and their crackdown by using the noun 'autocrats'. Using this noun summarizes all the Arab Presidents' atrocities. In addition, using that noun is a metonymy for injustice and Clinton's hate of the Arab leaders' regime. Therefore, this quotation aims at exposing the Arab leaders' inhumanity:

But in part, the pushback comes from autocrats around the world wondering if the next Tahrir Square will be their capital square, and some are cracking down when they should be opening up (the second speech of Clinton, para.35).

She also blackens the Arab leaders' reputation in the next quotation:

When autocrats tell us the transition to democracy will take time, we answer, "Well, then let's get started." (the second speech of Clinton, para. 39).

Furthermore, the Secretary of States refers to the Arab revolutions by using the noun 'journey'. He also personifies America as a person who helps make these revolutions successful ones to show America's vital role and stress the idea that thanks to America, theses revolutions succeeded. Using the metonymy 'journey' indicates that the revolutions took much time and they inevitably were full of a lot of hardships and suffering:

And on this journey that they have begun, the United States will be their partner. And of the many tools at our disposal the National Endowment and NDI and all of the family of organizations that were created three decades ago to help people make this journey successfully - will be right there (the second speech of Clinton, para.48). 
Also, in her remarks about Internet Rights and Wrongs: Choices \& Challenges in a Networked World on $15^{\text {th }}$ February, 2011, Clinton refers to the Arab leaders by using the noun 'dictator' in order to blacken their reputation':

We believe that governments who have erected barriers to internet freedom... will eventually find themselves boxed in. They will face a dictator's dilemma and will have to choose between letting the walls fall or paying the price to keep them standing (the first speech of Clinton, para.46).

\section{A Quantitative Account of the purposes of using metonymy in the selected speeches}

Table 2

\begin{tabular}{|l|l|l|l|l|}
\hline The purposes of $\begin{array}{ll}|l| \\
\text { using metonymy }\end{array}$ & Obama's Speeches & \multicolumn{2}{l|}{ Clinton's Speeches } \\
\cline { 2 - 5 } & Frequency & Percentage & Frequency & Percentage \\
\hline $\begin{array}{l}\text { 1-blacken the Arab } \\
\text { leadersand expose } \\
\text { their atrocities }\end{array}$ & 4 & 40 & 4 & 57.1 \\
\hline $\begin{array}{l}\text { 2-show America's } \\
\text { sympathy with the } \\
\text { Arab citizens }\end{array}$ & 2 & 20 & 1 & 14.3 \\
\hline $\begin{array}{l}\text { 3- defend the Arab } \\
\text { citizens or praise } \\
\text { their determination }\end{array}$ & 2 & 20 & 1 & 14.3 \\
\hline $\begin{array}{l}\text { 4-show America's } \\
\text { crucial role }\end{array}$ & 2 & 20 & 1 & 14.3 \\
\hline
\end{tabular}

From table 2, it is notable that the total number of the examples of metonymy taken from Obama's speeches are ten, four out of them are used to blackenthe Arab leaders and expose their atrocities while two of them are used to show America's sympathy with the Arab citizens. Two examples are used to defend the Arab countries and two examples are used to show America's significant role. 
On the other hand, the total number of metonymies taken from Clinton's speeches are seven, four out of them are used to blackenthe Arab leaders as well as exposing their atrocities while one example is used to show America's sympathy with the Arab citizens, one example is used to defend the Arab countries and also one example is used to show America's central role.

Therefore, it can be concluded that both Obama and Clinton used metonymy for the purpose of blackening the Arab leaders and exposing their atrocitiesmore than the other purposes. That purpose had the first rank with $40 \%$ and $57.1 \%$ while all the other purposes had the second rank with $20 \%$ and $14.3 \%$.

To sum up, both Obama and Clinton want to stress the idea that American leaders are always strong, brave and able to achieve democracy in their country and so there are not any revolutions in America. On the other hand, the Arab leaders are weak and dictators. So, they have failed to achieve freedom as well as democracy in their countries. Consequently, there were revolutions against their regime. In addition, they indicate that they share the sorrow of the Arab citizens in their difficult situation and they are against the Arab leaders' injustice and suppression.

\section{$\underline{\text { Conclusion }}$}

After analyzing the use of metaphor and metonymy in the political speeches of Obama and Clinton, it can be concluded that both of them have used the two linguistic devices for achieving almost the same goals. For instance, there are two purposes which have been repeated in the selected devices. The first one is showing America's key role. 
The second one is praising the Arab citizens' determination or courage so as to encourage them to continue their revolutions. However, there are two purposes which have been mentioned in just metaphor. They are showing America's strong relationships with the other countries and praising America's democratic regime. Also, there are two purposes that have been mentioned in just metonymy. They are blackening the Arab leaders' reputation as well as exposing their atrocities and showing America's sympathy with the Arab citizens.

To conclude, both Obama and Clinton used the two rhetorical devices in order to confirm some ideas. First, America put a great deal of effort and has cooperated with some allies and partners to defend the Arab people and secure them from the tyranny of their leaders. Second, America is a devoted country which feels pity for the Arab citizens and supports them in their difficult situation. Third, America is a democratic country which calls for peace and freedom. Fourth, the Arab leaders are unjust. Therefore, using the rhetorical devices of metaphor and metonymy were essential.

\section{References}

Charteris-Black, J. (2004).Corpus approaches to critical metaphor analysis .Basingstoke: Palgrave Macmillan.

Clinton, H.R. (2011, February, $16^{\text {th }}$ ). Internet Rights and Wrongs: Choices\& Challengesin a Networked World. Attached as the first speech of Clinton. Retrieved from https ://www .indexoncensorship .org/2011/02/internet-rights-and-wrongs-choiceschallenges-in-a-networked-world/ 
(2011, November $\left.9^{\text {th }}\right)$. Keynote Address at the National Democratic Institute's 2011 Democracy Awards Dinner. Attached as the second speech of Clinton. Retrieved fromhttp :// www .scoop . co.nz / stories / WO1111/S00205 / keynote -address -at -the - national-democratic -institute.htm

Corbett, P. (2001). How to Teach Fiction Writing at Key Stage 2. Britain: David Fulton.

Ferraro, G.P.,\& Briody, E.K. (2016). The cultural dimension of Global Business ( $8^{\text {th }}$ ed.). New York: Routledge.

Hanks, P. (2013). Lexical analysis: Norms and exploitations. Cambridge Mass: The MIT Press.

Lakoff, G. (1991). Metaphor and War: The Metaphor System Used to Justify War in the Gulf. In: Viet Nam Generation Journal\& Newsletter, 3(3).

------- (2003). Metaphor and war, again. Retrieved Febuary 20, 2008 from http://www.alternet.org/story/15414.

\& Johnson, M. (1980). Metaphors We Live By.

Chicago: The University of Chicago Press.

Lesz, B. (2011). To Shape the World for the Better:An Analysis of Metaphors in the Speeches of Barack Obama (Master's thesis, Tromso University).

Retrievedfromhttps://munin.uit.no/bitstream/handle/10037/354 $0 /$ thesis.pdf?sequence $=1$

Livingstone, D. N. \& Harrison, R.T. (1981). Meaning through Metaphor: analogy as Epistemology. Annals of the Association of American Geographers, 71(1), 95-107. 
Obama, B.H. (2011, March $\left.28^{\text {th }}\right)$. Remarks by the President in Address to the Nation on Libya. Attached as the first speech of Obama. Retrieved from

https://obamawhitehouse.archives.gov/the-press-

office/2011/03/28/remarks-president-address-nation-libya

- (2011, May $\left.19^{\text {th }}\right)$. Remarks by the President on

the Middle East and North Africa. Attached as the second speech of Obama. Retrieved

fromhttps://obamawhitehouse.archives.gov/the-press-

office/2011/05/19/remarks - president-middle-east-and-north$\underline{\text { africa }}$

------ $\left(2011\right.$, September, $\left.21^{\text {st }}\right)$. Remarks by the

President in Address to the United Nations General Assembly.

Attached as the third speech of Obama. Retrieved

fromhttps://obamawhitehouse.archives.gov/the-press-

office/2011/09/21/remarks-president-obama-address-united-

nations-general-assembly

Panther, K.U. \& Radden, G. (1999). Metonymy in language and thought. Amsterdam: John Benjamins.

Sayed,Y. H. (2009). George W. Bush Versus Saddam Hussein: A Critical Discourse Analysis (UnPublished Master's thesis). Ain Shams University, Cairo.

Thompson, G. (2004). Introducing Functional Grammar. London: Oxford University Press. 
Van Dijk, T. A. (1997). What is Political Discourse Analysis?In J. Blommaert\& C. Bulcean (Eds.), Political Linguistics (pp. 11-52).Amsterdam: John Benjamins. 